\title{
The Electric Energy Savings from New Technologies
}

R. J. Moe, Project Manager

B. J. Harrer

M. A. Kellogg

A. J. Lyke

K. L. Imhoff

Z. J. Fisher

September 1986

Prepared for the U.S. Department of Energy under Contract DE-AC06-76RLO 1830

Pacific Northwest Laboratory Operated for the U.S. Department of Energy by Battelle Memorial Institute 


\title{
DISCLAIMER
}

This report was prepared as an account of work sponsored by an agency of the United States Government. Neither the United States Government nor any agency thereof, nor any of their employees, makes any warranty, express or implied, or assumes any legal liability or responsibility for the accuracy, completeness, or usefulness of any information, apparatus, product, or process disclosed, or represents that its use would not infringe privately owned rights. Reference herein to any specific commercial product, process, or service by trade name, trademark, manufacturer, or otherwise, does not necessarily constitute or imply its endorsement, recommendation, or favoring by the United States Government or any agency thereof. The views and opinions of authors expressed herein do not necessarily state or reflect those of the United States Government or any agency thereof.

\author{
PACIFIC NORTHWEST LABORATORY \\ operated by \\ BATTELLE \\ for the \\ UNITED STATES DEPARTMENT OF ENERGY \\ under Contract DE-AC06-76RLO 1830
}

\begin{tabular}{|c|c|}
\hline \multirow{2}{*}{\multicolumn{2}{|c|}{ Printed in the United States of America }} \\
\hline & \\
\hline \multicolumn{2}{|c|}{$\begin{array}{l}\text { Available from } \\
\text { National Technical Information Service }\end{array}$} \\
\hline \multirow{3}{*}{\multicolumn{2}{|c|}{$\begin{array}{l}\text { United States Department of Commerce } \\
\text { S285 Port Royal Road } \\
\text { Springfield, Virginia } 22161\end{array}$}} \\
\hline & \\
\hline & \\
\hline \multirow{2}{*}{\multicolumn{2}{|c|}{$\begin{array}{l}\text { NTIS Price Codes } \\
\text { Microfiche } A 01\end{array}$}} \\
\hline & \\
\hline \multicolumn{2}{|c|}{ Printed Copy } \\
\hline & Price \\
\hline Pages & Codes \\
\hline $001-025$ & $\mathrm{~A} 02$ \\
\hline 026-050 & $\mathrm{A} 03$ \\
\hline $051-075$ & A04 \\
\hline $076-100$ & $A 05$ \\
\hline $101-125$ & $A 06$ \\
\hline $126-150$ & $A 07$ \\
\hline $157-175$ & $A 06$ \\
\hline $176-200$ & A09 \\
\hline $201-225$ & A010 \\
\hline $226-250$ & A011 \\
\hline $251-275$ & A012 \\
\hline $276-300$ & $A 013$ \\
\hline
\end{tabular}


THE ELECTRIC ENERGY SAVINGS

FROM NEW TECHNOLOGIES

R. J. Moe, Project Manager

B. J. Harrer

M. A. Kellogg

A. J. Lyke

K. L. Imhoff

Z. J. Fisher

Seotember 1986

Prepared for the U.S. Department of Energy under Contract DE-AC06-76RLO 1830

Pacific Northwest Laboratory Richland, Washington 99352 


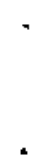




\section{ABSTRACT}

This report was prepared by Pacific Northwest Laboratory for the Office of Coal and Electricity Policy (OCEP), U.S. Department of Energy. The purpose of the report is to provide information about the electricity-saving potential of new technologies to OCEP that it can use in developing alternative long-term projections of U.S. electricity consumption. Low-, base-, and high-case scenarios of the electricity savings for 10 technologies were prepared. The total projected annual savings for the year 2000 for all 10 technologies were 137 billion kilowatt hours (BkWh), $279 \mathrm{BkWh}$, and $470 \mathrm{BkWh}$, respectively, for the three cases. The magnitude of these savings projections can be gauged by comparing them to the Department's reference case projection for the 1985 National Energy Policy Plan. In the Department's reference case, total consumption in 2000 is projected to be $3319 \mathrm{BkWh}$. Because approximately 75 percent of the base-case estimate of savings are already incorporated into the reference projection, only 25 percent of the savings estimated here should be subtracted from the reference projection for analysis purposes. 


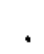

. 


\section{EXECUTIVE SUMMARY}

This report was prepared by Pacific Northwest Laboratory (PNL) for the Office of Coal and Electricity Policy (OCEP), U.S. Department of Energy. The purpose of the study was to provide information about new electricity-saving technologies to the OCEP that it can use in the development of alternative projections of U.S. electricity consumption for the fifth National Energy Policy Plan (NEPP). More specifically the goals of the project were to:

- Collect information about characteristics and costs of 10 new technologies for saving electricity.

- Provide estimates of the potential future market, market penetration rate, and impact on aggregate U.S. electricity use for the 10 technologies. Estimate impacts for low, base and high scenarios.

- Estimate the levelized cost/kwh saved for each technology and compare these estimates to published estimates of the cost of constructing new capacity.

We approached the project by defining three major tasks: 1) select 10 technologies, 2) develop a method of projecting market potential, market penetration rate and electricity savings for the selected technologies, and 3) generate results, i.e., estimate the energy savings and other parameters for the technologies.

\section{TECHNOLOGY SELECTION}

We selected the 10 technologies from a list of 27 new technologies. Twenty of these candidate technologies were suggested by Amory Lovins. Seven technologies came from a review of the literature and conversations with other experts. Criteria were established for selecting 10 technologies from the list of 27 . The first criteria was the electricity-saving potential based on previous estimates from the literature. The top five technologies in savings potential for the residential, commercial and industrial sectors were selected providing a list of 15 technologies. The next criteria applied was that the technology either be commercially available right now, or be expected to be 
available in the near future. In addition, the technology should not already have a high market penetration because most of the electric energy savings available from the technology would then already be accounted for in present consurption.

Four technologies from the residential sector and three each from the industrial and commercial sectors were selected. The 10 technologies selected were:

- Residential

- advanced heat pumps

- advanced thermal insulation and anti-infiltration devices

- solar water heaters

- high-efficiency appliances

- Commercial

- advanced lighting

- glazings and other window technologies

- heat and cool storage

- Industrial

- adjustable-speed motors

- high-efficiency motors

- advanced electrolytic techniques.

Not all available conservation technologies could be analyzed in this study. However, according to estimates from previous studies, the 10 selected technologies should comprise a significant proportion of the future energy savings likely to be obtained from all conservation measures.

\section{METHODOLOGY}

The second task was to develop a methodology for projecting the electricity savings of each of the 10 technologies. This method is similar to methods used to project sales of products under development. The method can be divided into six steps: 
1. Estimate the potential market. The potential market is the total possible market adjusted due to limitations on the use of the technology. The total potential market is estimated for new, normal replacement, and retrofit/accelerated replacement applications. (a)

2. Compare the cost of the energy saving technology to conventional technology in new, replacement and retrofit/accelerated replacement cases. The basis for this comparison is the payback period for the energy saving technology calculated as a function of its incremental capital costs and annual energy cost savings.

3. Project the maximum market penetration based on published estimates of market penetration as a function of estimated payback period.

4. Estimate the year-by-year penetration rate using an S-curve function.

5. Compute projected annual sales for the technology. The potential market, computed in Step 1 , is multiplied by the year-by-year penetration rates, Step 4 , to estimate annual sales.

6. Project the total electricity savings. The accumulated sales in any given year is multiplied by the per-unit electricity savings to estimate total electricity savings.

Methodologies for projecting low-case and high-case scenarios were developed. For the low-case projections two modifications to the base-case were made. The maximum market penetration rates were divided by two and the $S$-curve was adjusted so that the maximum rate was approached more slowly. For the high-case projections, the maximum penetration was doubled (up to a maximum of 90 percent) and the $S$-curve was adjusted to accelerate the approach to the maximum penetration rate.

(a) For purposes of this study, a new application of a technology represents the use of a technology in a situation where the stock of the technology has increased, normal replacement represents its use in a situation where the useful 1 ife of an existing technology is ended and retrofit/accelerated replacement represents its use where a technology is replaced before its useful life is ended. 
Estimates of the cost/kWh saved for each technology were also computed so that comparisons could be made between the cost of new generating capacity and the cost of each conservation technology. These estimates were computed based on the estimated incremental, levelized costs and the estimated annual energy savings for the technologies.

RESULTS

Tables ES.1 through ES.4 sumarize the quantitative findings of this study. Tables ES.1, ES.2, and ES.3 display the base-case, low-case, and highcase projections of electricity savings for each technology respectively, for each of the years 1985, 1990, 1995, and 2000. Total projected savings in the base case increase from 21 BkWh in 1985 to 63 BkWh in 1990, 162 BkWh in 1995, and $279 \mathrm{BkWh}$ in 2000. The projected savings in 2000 equal the expected output of approximately 51 one-gigawatt electrical generating units. (a) The three commercial technologies account for approximately half of these projected savings, with the major portion of that contribution coming from advanced lighting technologies. Advanced heat pumps are the largest electricity saver in the residential sector, and adjustable speed drive (ASD) motors are the largest saver in the industrial sector.

In the low-case scenario, total projected savings in 2000 are 137 BkWh (equal to approximately 25 one-gigawatt units). Advanced lighting, ASD motors, and heat pumps remain the largest contributors to this total. In the high-case scenario, total projected savings in 2000 are 470 BkWh (i.e., about 85 onegigawatt units). Glazings, ASD motors, lighting, and heat pumps account for 84 percent of these total savings. The low, base and high scenario results are believed to encompass the likely range of future energy savings that will result from the 10 technologies. However, the wide variance in estimated savings, associated with the use of differing assumptions, suggests that the projections should be used cautiously.

(a) For purposes of comparison, it was assumed that a one-gigawatt electrical generating unit would produce approximately 5.5 billion kWh annually. 
TABLE ES.1. Base-Case Projections of Electricity Savings (BkWh) (a)

Residential

$\underline{1985} \quad \underline{1990} \quad \underline{1995} \quad \underline{2000}$

Advanced Heat Pumps

$1 \quad 7 \quad 28 \quad 61$

Advanced Thermal Insulation and Anti-Infiltration Devices

Solar Water Heaters

$\begin{array}{rrrr}2 & 5 & 13 & 16 \\ 1 & 2 & 3 & 4 \\ =- & -- & -1 & -5 \\ 4 & 14 & 45 & 86\end{array}$

Commercial

Glazings and Other Window

Technologies

$\begin{array}{llll}5 & 16 & 35 & 49\end{array}$

Advanced Lighting Technologies

$\begin{array}{llll}2 & 13 & 40 & 79\end{array}$

Heat and Cool Storage

$=\frac{2}{31} \quad \frac{4}{79} \quad-\frac{8}{136}$

Industrial

High-Efficiency Motors

$\begin{array}{llll}- & 2 & 4 & 6\end{array}$

Adjustable-Speed-Drive Motors

$\begin{array}{llll}9 & 17 & 34 & 51\end{array}$

Advanced Electrolytic Techniques

Total

Subtotal $\frac{9}{21} \quad \frac{19}{63} \quad \frac{38}{162} \quad \frac{58}{\frac{2}{279}}(\mathrm{~b})$

(a) Columns may not add due to rounding.

(b) Total in the year 2000 is approximately equivalent to 51 onegigawatt plants. 
TABLE ES.2. Low-Case Projections of Electricity Savings (BkWh)

Residential

Advanced Heat Pumps

Advanced Thermal Insulation and Anti-Infiltration Devices

Solar Water Heaters

High-Efficiency Appliances

Subtotal $\underline{1985} \quad \underline{1990} \quad \underline{1995} \quad \underline{2000}$

$\begin{array}{llll}1 & 4 & 14 & 30\end{array}$

$\begin{array}{llll}1 & 2 & 4 & 6\end{array}$

$\begin{array}{llll}- & 1 & 1 & 2\end{array}$

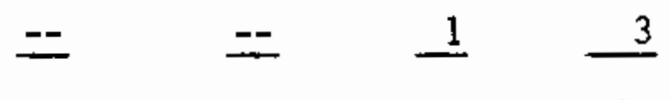

3

20

Commercial

Glazings and other window

Technologies

$\begin{array}{rrrr}4 & 8 & 13 & 19 \\ 1 & 7 & 19 & 36 \\ -- & 1 & 2 & 4 \\ 5 & 16 & 34 & 59\end{array}$

Industrial

High-Efficiency Motors

$\begin{array}{llll}- & 1 & 2 & 3\end{array}$

Adjustable-Speed-Drive Motors

7

13

20

35

Advanced Electrolytic Techniques

Tota)

$\begin{array}{lllll}\text { Subtotal } & \frac{-}{\frac{8}{2}} & \frac{14}{16} & \frac{22}{36} & \frac{38}{\frac{3}{137}}\end{array}$

(a) Columns may not add due to rounding.

(b) Total in the year 2000 is approximately equivalent to 25 onegigawatt plants. 
TABLE ES.3. High-Case Projections of Electricity Savings

Residential

$\underline{1985} \quad \underline{1990} \quad \underline{1995} \quad \underline{2000}$

Advanced Heat Pump

$\begin{array}{llll}2 & 11 & 41 & 78\end{array}$

Advanced Thermal Insulation and Anti-Infiltration Devices

Solar Water Heaters

High-Efficiency Appliance

Subtotal

$\begin{array}{rrrr}3 & 16 & 31 & 32 \\ 1 & 4 & 8 & 9 \\ =- & -- & -3 & \frac{11}{130}\end{array}$

Commercial

Glazings and Other Window

Technologies

$\begin{array}{llll}6 & 38 & 99 & 116\end{array}$

Advanced Lighting Technologies

$\begin{array}{llll}2 & 14 & 49 & 96\end{array}$

Heat and Cool Storage

$=\frac{2}{8} \quad \frac{5}{153} \quad \frac{9}{220}$

Industrial

High-Efficiency Motors

$\begin{array}{llll}-- & 2 & 7 & 12\end{array}$

Adjustable-Speed-Drive Motors

Advanced Electrolytic Techniques

Total

\begin{tabular}{|c|c|c|c|c|}
\hline \multirow{3}{*}{ Subtotal } & 0 & - & - & 1 \\
\hline & 9 & 32 & 90 & 121 \\
\hline & $\overline{23}$ & 118 & 325 & $\overrightarrow{470^{(b}}$ \\
\hline
\end{tabular}

(a) Columns may not add due to rounding.

(b) Total in the year 2000 is approximately equivalent to 85 onegi gawatt plants. 
TABLE ES.4. Comparison of Estimated Minima1 Levelized Cost/kWh for Conservation Technologies and National Average Projected Cost/kWh from New Generating Capacity

Conservation Technology

Residential

Advanced Heat Pump

Advanced Thermal Insulation and Anti-Infiltration Devices

Solar Water Heaters

High-Efficiency Appliances

Commercial

Glazings and Other Window Technologies.

Advanced Lighting Technologies

Heat and Cool Storage

Industrial

High-Efficiency Motors

Adjustable-Speed-Orive Motors

Advanced Electrolytic Technologies
Relative Cost Comparison Retrofit7

New/ Accelerated Replacement Replacement Applications Applications

Lower Higher

Lower Lower

Higher NA

Lower (a) Higher

Lower Lower

Lower Lower

Lower NA

Lower NA

Lower (b) Lower (b)

NA Lower

(a) Three appliances were analyzed. One had lower cost.

(b) ASD motors were divided into five categories, based on horsepower. Only the largest two categories representing motors over 50 hp had costs lower than the cost of new generating capacity.

Table ES.4 summarizes the findings regarding the estimated levelized cost per $k$ Wh saved of the various technologies. According to recent Energy Information Administration publications, the median projected cost for new coal generating capacity among 10 DOE regions in 1995 is $5.21 \$ / \mathrm{kWh}$. Table ES.4 exhibits which technologies have a lower estimated minimal levelized cost than this 
median generating cost in 1) new and normal replacement applications and 2) retrofit/accelerated replacenent applications. The table shows that nearly all of the technologies have an estimated minimal levelized cost $/ \mathrm{kWh}$ saved that is less than the national average cost of electricity from new generating capacity, in both types of applications. The estimates of the levelized costs for the kWh savings are termed "minimal" estimates because they are significantly affected by the assumed cost of capital. The 8 percent real rate used in this study represents an approximation of the cost of capital to utilities. Most electricity users would probably require some higher rate of interest.

In addition to the quantitative results summarized in Tables ES.1 through ES.4, the reader is referred to individual report chapters for discussions of the technology-specific findings. The most important general finding is that only a few of the 10 technologies selected for detailed analysis are new enough and radically different enough from existing technologies already in use that their availability is not reflected in the models used to generate the NEPP projections. (a) These technologies are advanced heat pumps (water-to-air and natural gas-fired heat pumps), heat and cool storage in commercial buildings, and new electrolytic techniques in the aluminum industry.

The base-case projection of the year 2000 electricity savings associated with the three technologies not included in NEPP models is approximately $69 \mathrm{BkWh}$, or 25 percent of the corresponding total projection for all 10 technologies. This estimate is approximately equal to the output of 13 onegigawatt generating units. A comparative analysis(a) indicates that the other seven technologies examined are either 1) technologies that have been available for a long enough period of time that their energy savings are reflected in the NEPP models; or 2) are refinements, extensions, or enhancements of existing technologies whose availability is also reflected in the models.

The findings of this study are subject to several caveats, resulting from the inherent uncertainty in such projections, as well as from time and resource

(a) For a more detailed discussion, see Electricity-Conserving Technologies in the NEPP Projections. Applied Energy Services, Inc., Arlington, Virginia Torthcoming 1986). 
constraints. The market-penetration estimates are based solely on economic factors without considering sociological, psychological and institutional factors that may influence purchasing behavior. The methodology employed is based on a small number of case studies and does not vary from technology to technology. The only cost savings of the new technologies incorporated in the estimates were due to reduced electricity consumption and not to other operating cost savings. It was also assumed throughout the base case that the maximum market penetration rate was achieved in the year 2000 .

The analysis was performed at the national, not the regional, level. National electricity prices and estimates of consumption by end use were used. Estimates of the savings for those technologies whose adoption may vary significantly across regions (such as solar water heaters) may therefore be inaccurate.

In the analysis of each technology a large number of other assumptions were necessary. Estimates of future electricity prices in each sector were required, as were estimates of future residential and comercial building stocks (and their characteristics), the future stock of electric motors (by horsepower class), and future U.S. production of aluminum. The associated data needed to develop these estimates were readily available but data specific to many of the technologies were more difficult to identify. In most cases where published estimates were unavailable, assumptions were made so that the resulting base case energy savings estimates would be on the high end of the likely range. The low-case estimates provide a lower bound, while the high-case estimates provide an upper bound.

Finally, the impacts of the 10 technologies on load shapes were not considered. Because the economic value to utilities of energy savings depends on the season and time of day that the savings occur, this analysis does not directly yield estimates of the value of the estimated energy savings to utilities.

Because of these caveats listed above, the electricity savings estimates developed in this study should be interpreted as first-cut or approximate estimates that provide information about the potential magnitudes of the actual 
savings and also point to further areas of investigation. For purposes other than the development of alternative forecasts of electricity consumption, the savings estimates should be used with caution. 



\section{CONTENTS}

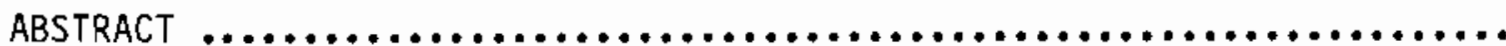

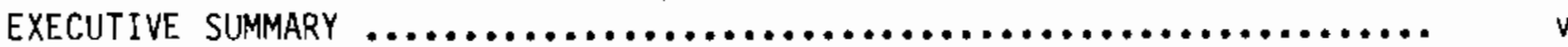

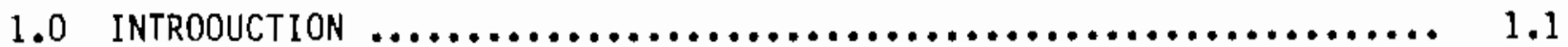

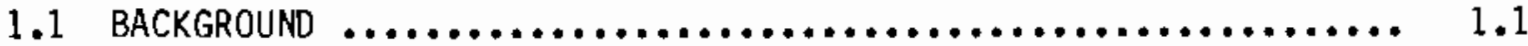

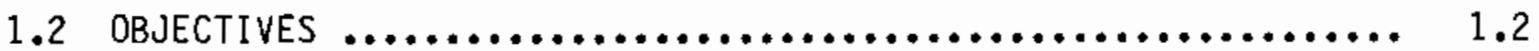

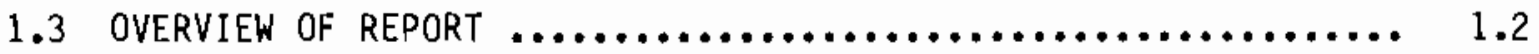

2.0 CONCLUSIONS $\ldots \ldots \ldots \ldots \ldots \ldots \ldots \ldots \ldots \ldots \ldots \ldots \ldots \ldots \ldots \ldots \ldots \ldots \ldots \ldots \ldots \ldots \ldots$

3.0 SELECTION OF CONSERVATION TECHNOLOGIES FOR OETAILED MARKET

ANALYSES. ........................................... 3.1

3.1 Electricity CONSERVATION TECHnOLOgiES ................. 3.1

3.2 SELECTION CRITERIA............................. 3.3

3.3 RESidential TECHNOLOGY EVAluations $\ldots \ldots \ldots \ldots \ldots \ldots \ldots \ldots \ldots \ldots \ldots$

3.3.1 Present Residential Electricity Consumption

by End Use ................................. 3.8

3.3.2 Selected Residential Technologies ................. 3.9

3.3.3 Residential Technologies Considered but Not

Selected ...................................... 3.12

3.4 COMMERCIAL TECHNOLOGY EVALUATIONS $\ldots \ldots \ldots \ldots \ldots \ldots \ldots \ldots \ldots \ldots \ldots \ldots$

3.4.1 Present Comercial Electricity Consumption

by End Use ................................... 3.20

3.4.2 Selected Commercial Technologies ................. 3.20

3.4.3 Commercial Technologies Considered but Not

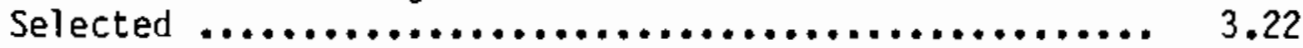

3.5 INDUSTRIAL TECHNOLDGY EVALUATIONS $\ldots \ldots \ldots \ldots \ldots \ldots \ldots \ldots \ldots \ldots \ldots \ldots$

3.5 .1 Present Industrial Electricity Consumption
by End Use $\ldots \ldots \ldots \ldots \ldots \ldots \ldots \ldots \ldots \ldots \ldots \ldots \ldots \ldots \ldots \ldots \ldots \ldots$

3.5.2 Selected Industrial Technologies ............... 3.26 


\subsubsection{Industrial Technologies Considered but Not}

Selected

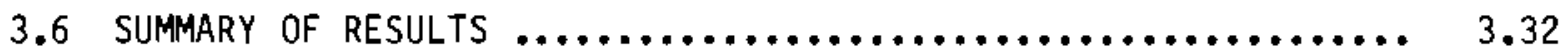

3.7 References for Chapter $3.0 \ldots \ldots \ldots \ldots \ldots \ldots \ldots \ldots \ldots \ldots \ldots . . \ldots \ldots . . . \ldots \ldots$

4.0 MARKET PENETRATION AND ENERGY SAVINGS ESTIMATION METHOOOLOGY $\ldots \ldots . .4 .1$

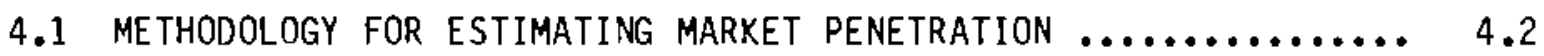

4.1.1 Estimating the Maximum Potential Market

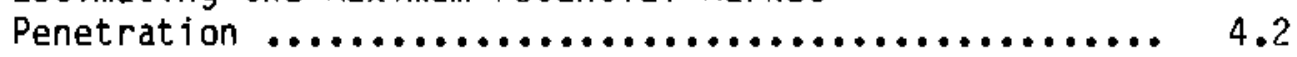

4.1.2 Estimation of Market Adoption Rates ............... 4.8

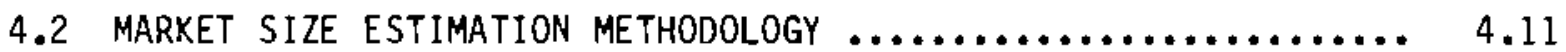

4.2.1 Existing Stock Estimation ...................... 4.11

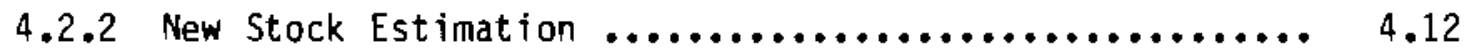

4.2.3 Retirement Stock Estimation $\ldots \ldots \ldots \ldots \ldots \ldots \ldots \ldots \ldots \ldots, 4.12$

4.2.4 Forecasting the Number of Units of the
New Technology ............................... 4.13

4.3 ENERGY SAVINGS ESTIMATION METHODOLOGY $\ldots \ldots \ldots \ldots \ldots \ldots \ldots \ldots . . \ldots . . \ldots$

4.4 SENSITIVITY ANALYSIS OF ESTIMATED ENERGY SAVINGS $\ldots \ldots \ldots \ldots \ldots .4 .15$

4.5 INPUT ASSUMPTIONS AND DATA SOURCES $\ldots \ldots \ldots \ldots \ldots \ldots \ldots \ldots \ldots, 4.16$

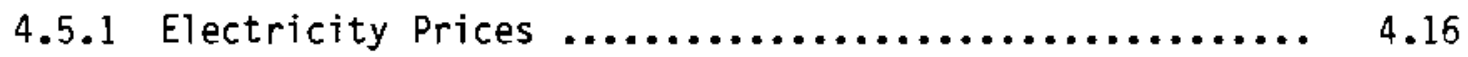

4.5.2 Residential Sector Assumptions $\ldots \ldots \ldots \ldots \ldots \ldots \ldots \ldots . . . \ldots .17$

4.5.3 Commercial Sector Assumptions .................. 4.18

4.5.4 Industrial Sector Assumptions $\ldots \ldots \ldots \ldots \ldots \ldots \ldots \ldots . . .6 .18$

4.6 ENERGY COST ESTIMATION METHODOLOGY $\ldots \ldots \ldots \ldots \ldots \ldots \ldots \ldots \ldots .4 .19$

4.6.1 Cost/kWh of New Electricity Generating Capacity ...... 4.19

4.6.2 Cost $/$ kWh of New Conservation Technologies .......... 4.21

4.6.3 Cost Comparisons: New Generation Capacity versus Conservation Measures 


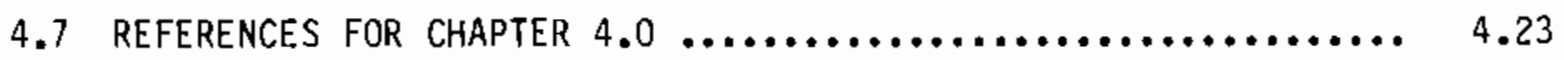

5.0 ADVANCED HEAT PUMP TECHNOLOGIES $\ldots \ldots \ldots \ldots \ldots \ldots \ldots \ldots \ldots \ldots \ldots \ldots, 5.1$

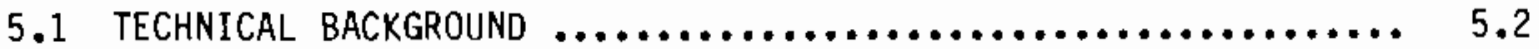

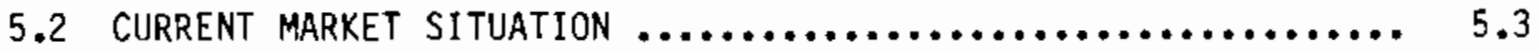

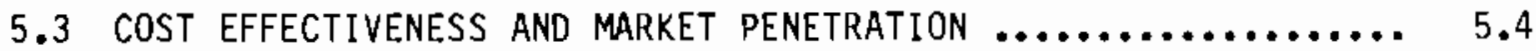

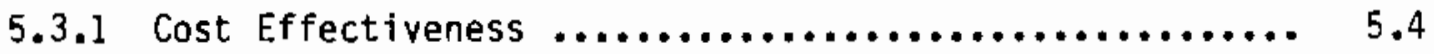

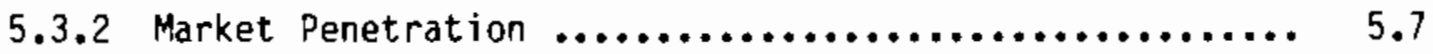

5.4 HOUSING STOCK PROJECTIONS AND MARKET SHARE ESTIMATES $\ldots \ldots \ldots .5 .10$

5.5 ENERGY SAVINGS COMPUTATIONS AND RESULTS $\ldots \ldots \ldots \ldots \ldots \ldots \ldots \ldots . . \ldots .10$

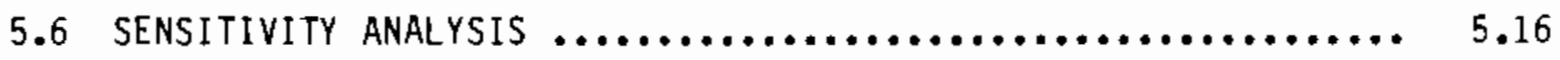

5.6.1 Low Market-Penetration Scenarios .................. 5.17

5.6.2 High Market Penetration Scenarios ................. 5.22

5.7 COST/KWh OF ENERGY SAVED CALCULATIONS AND COMPARISONS

TO THE CDST/kWh OF PRODUCING NEW GENERATING CAPACITY ........ 5.22

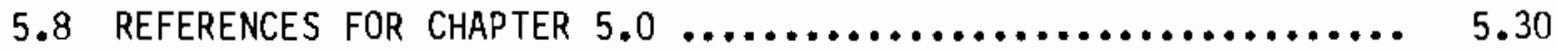

6.0 ADVANCED THERMAL INSULATION AND ANTI-INFILTRATION TECHNIQUES $\ldots . . .6 .1$

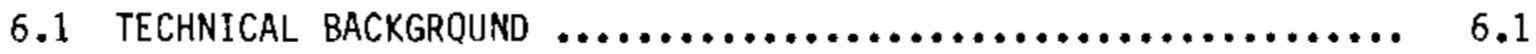

6.2 CURRENT MARKET SITUATION $\ldots \ldots \ldots \ldots \ldots \ldots \ldots \ldots \ldots \ldots \ldots \ldots, 6.3$

6.3 COSt EfFECtivenesS AND MaRKET PENETRATION $\ldots \ldots \ldots \ldots \ldots \ldots \ldots, 6.6$

6.3 .1 Cost Effectiveness $\ldots \ldots \ldots \ldots \ldots \ldots \ldots \ldots \ldots \ldots \ldots \ldots, 6.6$

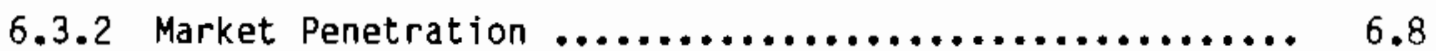

6.4 HQUSING STOCK PROJECTIONS AND MARKET SHARE ESTIMATES $\ldots \ldots \ldots . .6 .8$

6.5 ENERGY SAVINGS COMPUTATIONS AND RESULTS $\ldots \ldots \ldots \ldots \ldots \ldots \ldots \ldots . .12$

6.5.1 Electrical Energy Savings Computations ............... 6.12

6.5.2 Aggregate Electrical Energy Savings Results ......... 6.12

6.6 SENSITIVITY ANALYSIS $\ldots \ldots \ldots \ldots \ldots \ldots \ldots \ldots \ldots \ldots \ldots \ldots . \ldots . \ldots . \ldots \ldots$ 
6.6.1 Low Market -Penetration Scenario ................. 6.13

6.6.2 High Market-Penetration Scenarios .................. 6.14

6.7 COST/KWh OF ENERGY SAVED CALCULATIONS AND COMPARISONS TO

THE COST/KWh OF CONSTRUCTING AND OPERATING NEW

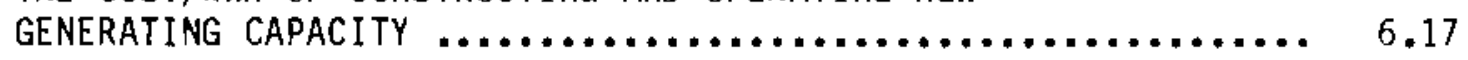

6.8 REFERENCES FOR CHAPTER $6.0 \ldots \ldots \ldots \ldots \ldots \ldots \ldots \ldots \ldots \ldots \ldots .6 .22$

7.0 SOLAR WATER HEATERS $\ldots \ldots \ldots \ldots \ldots \ldots \ldots \ldots \ldots \ldots \ldots \ldots \ldots \ldots \ldots \ldots \ldots \ldots \ldots \ldots \ldots, 7.1$

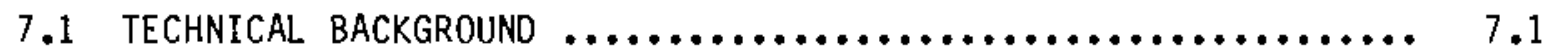

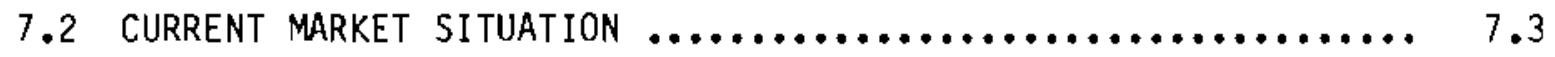

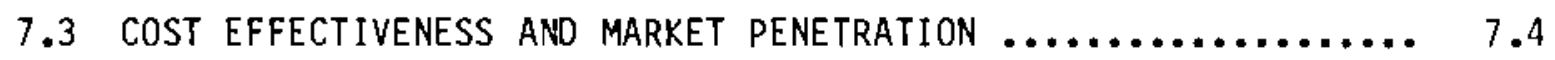

7.3.1 Cost Effectiveness of Representative Product ........ 7.5

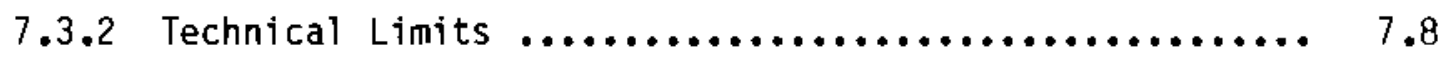

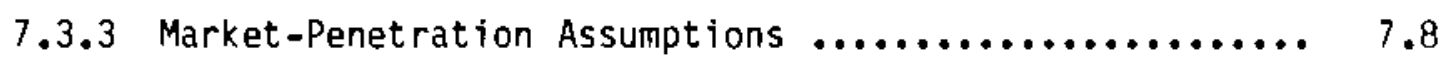

7.4 HOUSING STOCK PROJECTIONS AND MARKET ShARE ESTIMATES $\ldots \ldots \ldots . .7 .9$

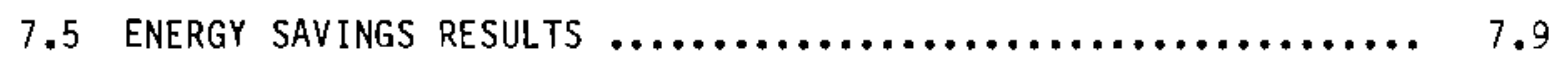

7.6 SENSITIVITY OF ANALYSIS TO MARKET-PENETRATION

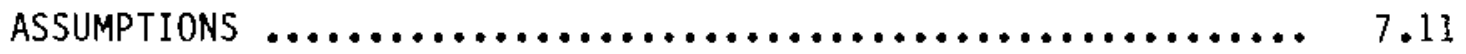

7.6.1 Low Market-Penetration Scenario .................. 7.12

7.6.2 High Market-Penetration Scenario ................. 7.12

7.7 COMPARISON OF COSTS: NEW GENERATING CAPACITY VERSUS

ENERGY CDNSERVATION WITH SOLAR WATER HEATERS $\ldots \ldots \ldots \ldots \ldots \ldots \ldots, 7.12$

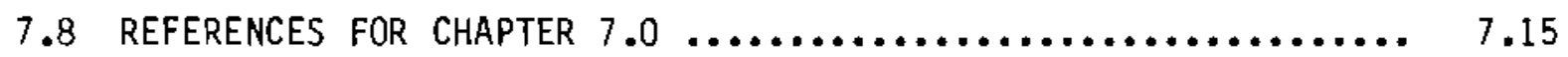

8.0 High EFfiCienCy APPliances $\ldots \ldots \ldots \ldots \ldots \ldots \ldots \ldots \ldots \ldots \ldots \ldots \ldots, 8.1$

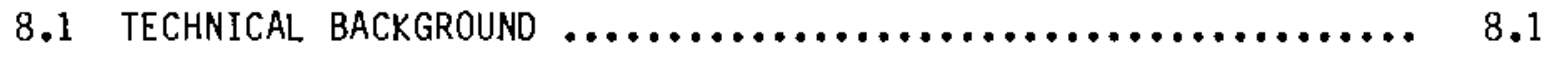

8.1 .1 Product Definitions $\ldots \ldots \ldots \ldots \ldots \ldots \ldots \ldots \ldots \ldots \ldots \ldots \ldots \ldots \ldots \ldots . .2$

8.1 .2 Measures to Improve Efficiency $\ldots \ldots \ldots \ldots \ldots \ldots \ldots \ldots . .6 .3$

8.1.3 Efficiency Measures in Standard Product Design ........ 8.9 
8.2 CURRENT MARKET SITUATION $\ldots \ldots \ldots \ldots \ldots \ldots \ldots \ldots \ldots \ldots \ldots \ldots \ldots, 8.11$

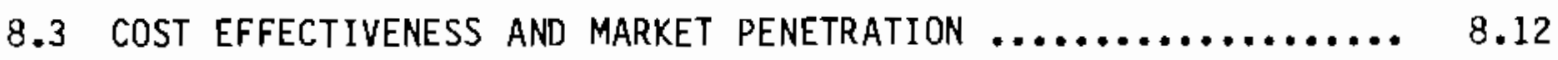

8.3.1 Cost Effectiveness of More Efficient Product:

Three Scenarios................................. 8.13

8.3 .2 Technical Limits $\ldots \ldots \ldots \ldots \ldots \ldots \ldots \ldots \ldots \ldots \ldots \ldots \ldots . . .6 .16$

8.3.3 Market-Penetration Assumptions .................. 8.17

8.4 HOUSING STOCK PROJECTIONS AND MARKET SHARE ESTIMATES $\ldots \ldots \ldots . .8 .17$

8.5 ENERGY SAVINGS RESULTS $\ldots \ldots \ldots \ldots \ldots \ldots \ldots \ldots \ldots \ldots \ldots \ldots \ldots . \ldots \ldots . \ldots \ldots \ldots$

8.6 SENSITIVITY OF ANALYSTS TO MARKET-PENETRATION
ASSUMPTIONS $\ldots \ldots \ldots \ldots \ldots \ldots \ldots \ldots \ldots \ldots \ldots \ldots \ldots \ldots \ldots \ldots \ldots \ldots \ldots \ldots \ldots \ldots \ldots \ldots \ldots$

8.6.1 Low Market-Penetration Scenarios ................. 8.22

8.6.2 High Market-Penetration Scenarios ................. 8.24

8.7 COMPARATIVE COSTS: NEW GENERATING CAPACITY VERSUS

HIGH-EFFICIENCY REFRIGERATORS AND FREEZERS $\ldots \ldots \ldots \ldots \ldots \ldots \ldots, 8.31$

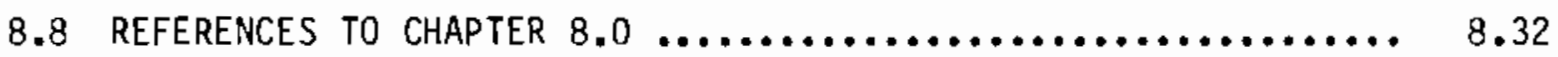

9.0 GLAZING AND OTHER WINDOW TECHNOLOGIES $\ldots \ldots \ldots \ldots \ldots \ldots \ldots \ldots \ldots . . . .1$

9.1 TECHNICAL 8ACXGROUND $\ldots \ldots \ldots \ldots \ldots \ldots \ldots \ldots \ldots \ldots \ldots \ldots . \ldots . \ldots . \ldots . \ldots . \ldots$

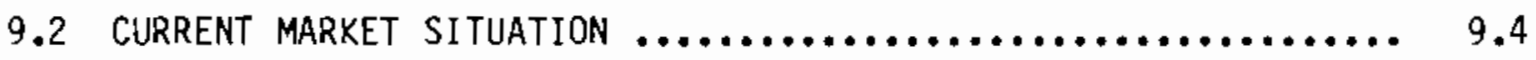

9.3 COST EFFECTIVENESS, TECHNICAL LIMITS AND MARKET
PENETRATION $\ldots \ldots \ldots \ldots \ldots \ldots \ldots \ldots . \ldots \ldots \ldots \ldots \ldots \ldots$

9.3.1 Payback Periods and Representative Energy Saving ...... 9.6

9.3 .2 Technical Limits ................................ 9.10

9.3.3 Market-Penetration Assumptions ................... 9.12

9.4 COMMERCIAL BUILDING STOCK AND MARXET SHARE PROJECTIONS $\ldots \ldots \ldots .9 .13$

9.5 ELECTRICITY SAVINGS RESULTS $\ldots \ldots \ldots \ldots \ldots \ldots \ldots \ldots \ldots \ldots \ldots, 9.16$

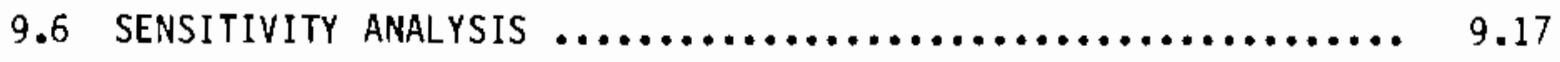

9.6.1 Low Market-Penetration Scenario ................. 9.17 
9.6.2 National Annual Electrical Energy Savings

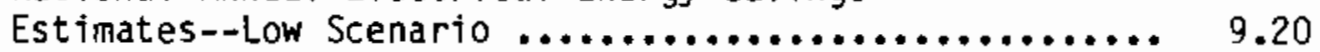

9.6.3 High Market-Penetration Scenario .................. 9.20

9.6.4 National Annual Electrical Energy Savings

Estimates--High Scenario ....................... 9.21

$9.7 \mathrm{COST} / \mathrm{kWh}$ OF ENERGY SAVED CALCULATIONS AND COMPARISONS

TO THE COST/KWh OF PRODUCING NEW GENERATION CAPACITY ........ 9.21

9.8 REFERENCES FOR CHAPTER $9.0 \ldots \ldots \ldots \ldots \ldots \ldots \ldots \ldots \ldots \ldots \ldots ., 9.26$

10.0 AdVANCEd Lighting TeChnOLOGIES $\ldots \ldots \ldots \ldots \ldots \ldots \ldots \ldots \ldots \ldots \ldots \ldots \ldots \ldots . \ldots \ldots$

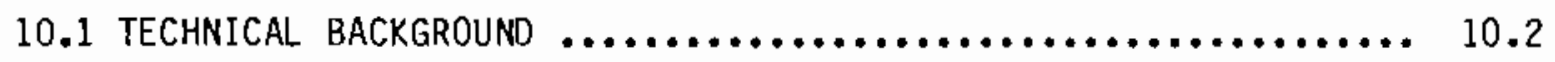

10.1.1 The Electronic Ballast ....................... 10.2

10.1.2 Energy-Saving Fluorescent Lamps $\ldots \ldots \ldots \ldots \ldots \ldots \ldots . . . .10 .3$

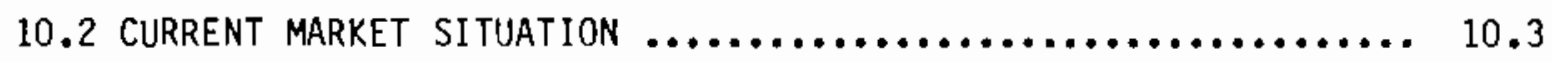

10.2.1 The Fluorescent Ballast Market $\ldots \ldots \ldots \ldots \ldots \ldots \ldots \ldots . . .10 .3$

10.2.2 The Fluorescent Lamp Market .................... 10.5

1D.2.3 Competition from Other Technologies .............. 10.6

10.3 COSt EFFECTIVEnESS AND MARKET PENETRATION $\ldots \ldots \ldots \ldots \ldots \ldots \ldots, 10.7$

10.3.1 Cost Effectiveness of Electronic Ballasts .......... 10.7

10.3.2 Electronic Ballast Market Penetration ............. 10.9

10.3.3 Cost Effectiveness of Energy-Saving Fluorescent Lamps ......................................... 10.10

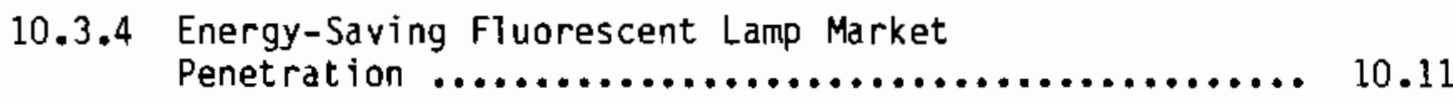

10.4 COMMERCIAL BUILDING AND MARKET SHARE PROPERTIES $\ldots \ldots \ldots \ldots \ldots 10.12$

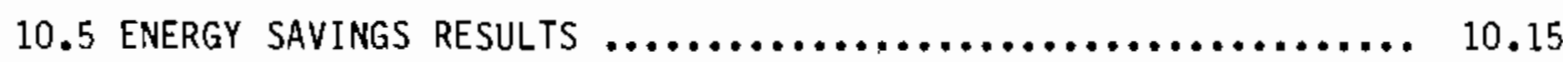

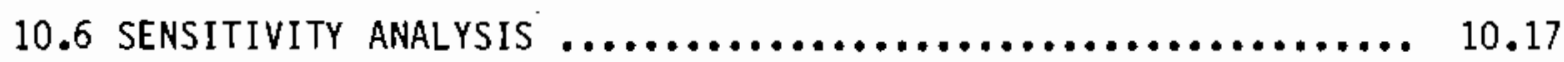

10.6.1 Low Market-Penetration Scenario .................. 10.17 
10.6.2 National Annual Electrical Energy Savings

Estimates--Low Scenario ....................... 10.18

10.6.3 High Market-Penetration Scenarios ................ 10.18

10.6.4 National Annual Electrical Energy Savings

Estimates--High Scenario ....................... 10.21

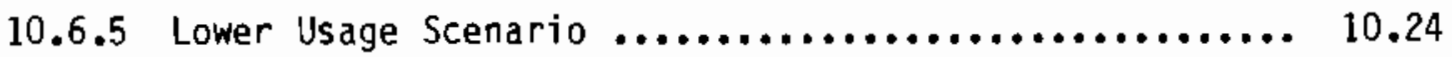

10.6.6 National Annual Electrical Energy Savings

Estimates--Lower Usage Scenario .................. 10.25

10.7 COST/KWh OF ENERGY SAVED CALCULATIONS AND COMPARISONS

TO THE COST/KWh OF PROOUCTION NEW GENERATING

CAPACITY

10.25

10.8 REFERENCES FOR CHAPTER $10.0 \ldots \ldots \ldots \ldots \ldots \ldots \ldots \ldots \ldots \ldots \ldots . \ldots \ldots . \ldots \ldots$

11.0 HEAT AND COOL STORAGE IN COMMERCIAL BUILOINGS $\ldots \ldots \ldots \ldots \ldots \ldots \ldots . .11$

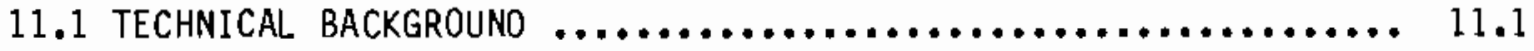

11.2 CURRENT MARKET SITUATION $\ldots \ldots \ldots \ldots \ldots \ldots \ldots \ldots \ldots \ldots \ldots \ldots, 11.6$

11.3 COST EFFECTIVENESS AND MARKET PENETRATION $\ldots \ldots \ldots \ldots \ldots \ldots \ldots, 11.7$

11.3.1 Cost Effectiveness $\ldots \ldots \ldots \ldots \ldots \ldots \ldots \ldots \ldots \ldots \ldots \ldots, 11.7$

11.3.2 Market Penetration $. . \ldots \ldots \ldots \ldots \ldots \ldots \ldots \ldots \ldots \ldots \ldots \ldots \ldots \ldots, 11.9$

11.4 COMMERCIAL BUILOING STOCK ANO MARXET SHARE PROJECTIONS $\ldots \ldots \ldots 11.10$

11.5 NATIONAL ENERGY SAVINGS $\ldots \ldots \ldots \ldots \ldots \ldots \ldots \ldots \ldots \ldots \ldots \ldots, 11.10$

11.6 SENSITIVITY ANALYSIS $\ldots \ldots \ldots \ldots \ldots \ldots \ldots \ldots \ldots \ldots \ldots \ldots \ldots \ldots, 11.15$

11.6.1 Low Market-Penetration Scenario .................. 11.15

11.6.2 National Annual Electrical Energy Savings
Estimates - Low Scenario ....................... 11.16

11.6.3 High Market-Penetration Scenarios ............... 11.16

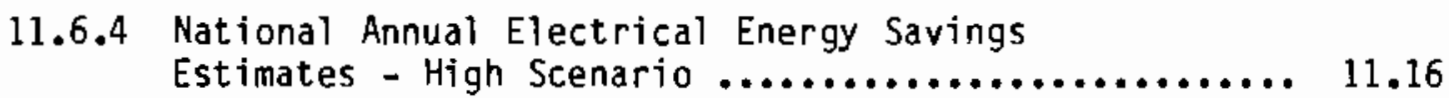

11.7 COST/KWh OF ENERGY SAVED CALCULATIONS AND

COMPARISONS TO THE COST/KWh OF PRODUCING

NEW GENERATION CAPACITY 
11.8 REFERENCES FOR CHAPTER $11.0 \ldots \ldots \ldots \ldots \ldots \ldots \ldots \ldots \ldots \ldots \ldots, 11.23$

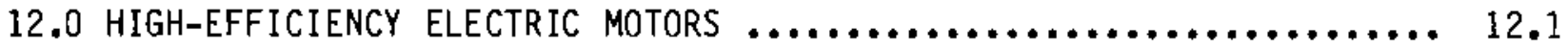

12.1 TECHNOLOGY OESCRIPTION $\ldots \ldots \ldots \ldots \ldots \ldots \ldots \ldots \ldots \ldots \ldots \ldots \ldots \ldots \ldots \ldots \ldots \ldots \ldots, 12.1$

12.2 CURRENT MARKET SITUATION $\ldots \ldots \ldots \ldots \ldots \ldots \ldots \ldots \ldots \ldots \ldots \ldots \ldots \ldots \ldots \ldots, 12.4$

12.3 COST EFFECTIVENESS AND MARKET PENETRATION $\ldots \ldots \ldots \ldots \ldots \ldots \ldots .12 .5$

12.3.1 Cost Effectiveness of High-Efficiency Motors ........ 12.5

12.3.2 Technical Limits on the Use of High-Efficiency Motors....................................... 12.10

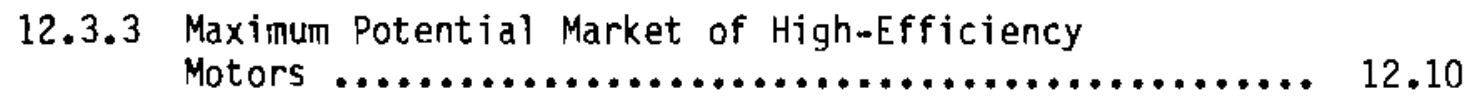

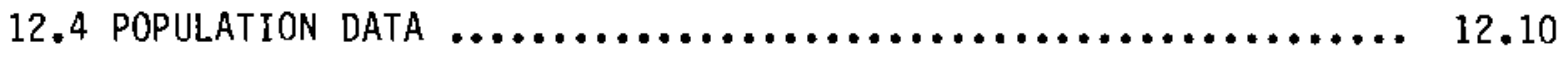

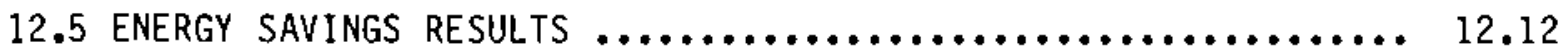

12.6 SENSITIVITY ANALYSIS $\ldots \ldots \ldots \ldots \ldots \ldots \ldots \ldots \ldots \ldots \ldots \ldots \ldots \ldots \ldots \ldots, 12.18$

12.6.1. Low Market-Penetration Scenario .................. 12.18

12.6.2 High Market-Penetration Scenario .................. 12.19

12.7 COST/KWh OF ENERGY SAVED CALCULATIONS AND COMPARISONS TO

THE COST/kWh OF PRODUCING NEW GENERATING CAPACITY $\ldots \ldots \ldots \ldots \ldots . .25$

12.8 REFERENCES FOR CHAPTER $12.0 \ldots \ldots \ldots \ldots \ldots \ldots \ldots \ldots \ldots \ldots \ldots, 12.32$

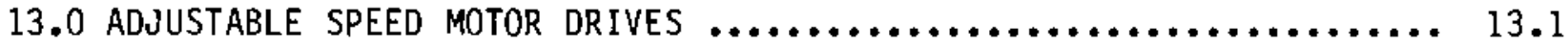

13.1 TECHNOLOGY DESCRIPTION $\ldots \ldots \ldots \ldots \ldots \ldots \ldots \ldots \ldots \ldots \ldots \ldots \ldots \ldots \ldots \ldots, 13.1$

13.2 CURRENT MARkEt SITUATION $\ldots \ldots \ldots \ldots \ldots \ldots \ldots \ldots \ldots \ldots \ldots \ldots, 13.3$

13.3 COSt Effectiveness And MaRket Penetration $\ldots \ldots \ldots \ldots \ldots \ldots \ldots, 13.4$

13.3.1 Cost Effectiveness of Adjustable Speed Drives ....... 13.4

13.3.2 Technical Limits on the Use of ASOs ............... 13.10

13.3.3 Maximum Potential Market Penetration of ASOs ......... 13.10

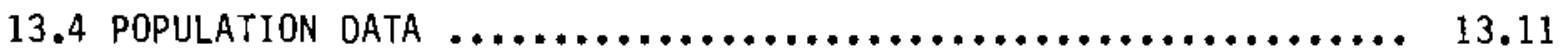

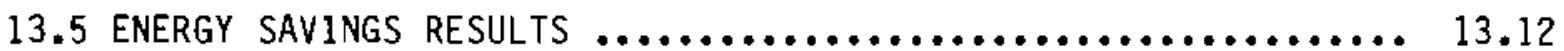




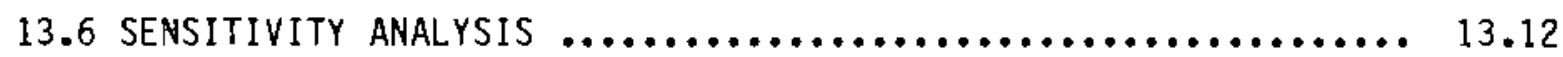

13.6.1 Low Market-Penetration Scenario ................. 13.12

13.6.2 High Market Penetration Scenario ................. 13.15

13.7 COST/KWh OF ENERGY SAVED CALCULATIONS AND

COMPARISONS TO THE COST/KWh OF PROOUCING

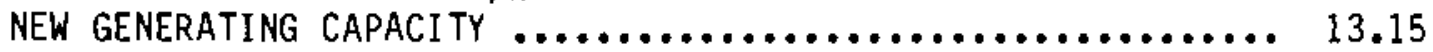

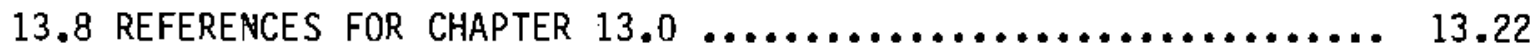

14.0 ElECTROLYTIC PROCESSES: THE CASE OF ALUMINUM $\ldots \ldots \ldots \ldots \ldots \ldots \ldots . . \ldots \ldots$

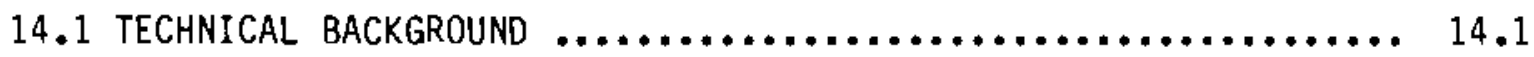

14.2 CURRENT MARKET SITUATION $\ldots \ldots \ldots \ldots \ldots \ldots \ldots \ldots \ldots \ldots \ldots \ldots \ldots \ldots \ldots, 14.4$

14.3 COSt EFfectiveness and Market PENETRATION $\ldots \ldots \ldots \ldots \ldots \ldots \ldots, 14.6$

14.3.1 Simple Payback of Alcoa Process, for New Plants

and Titanium Diboride $\left(\mathrm{TiB}_{2}\right)$ Coating for

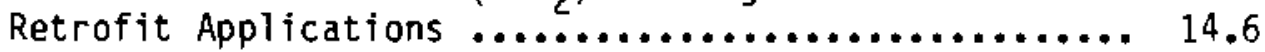

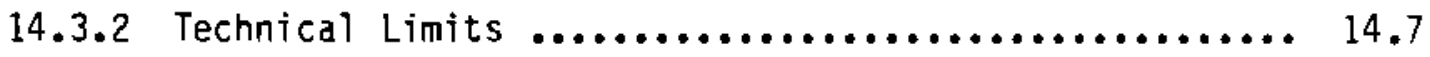

14.3.3 Market Penetration Assumptions $. \ldots \ldots \ldots \ldots \ldots \ldots \ldots, 14.8$

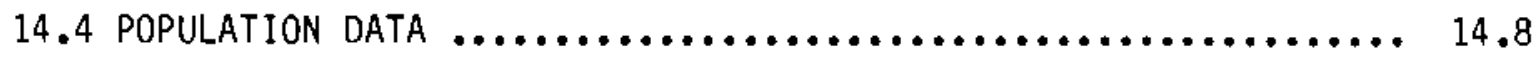

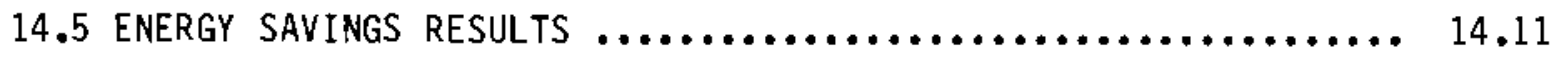

14.6 SENSITIVITY OF ENERGY SAVINGS RESULTS TO MARKET-

PENETRATION ASSUMPTIONS $. \ldots \ldots \ldots \ldots \ldots \ldots \ldots \ldots \ldots \ldots \ldots, 14.12$

14.6.1 Low Market-Penetration Scenario .................. 14.12

14.6.2 High Market-Penetration Scenario ................ 14.12

14.7 ESTIMATED COST/KWh FOR ENERGY CONSERVED WITH

SPECIAL TITANIUM DIBORIDE CATHODE COATING IN

PRIMARY ALUMINUM PRODUCTION $\ldots \ldots \ldots \ldots \ldots \ldots \ldots \ldots \ldots \ldots \ldots, 14.14$

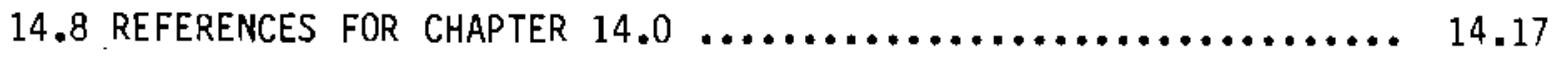




\section{FIGURES}

4.1 Flow Diagram of Electrical Savings Estimation Methodology Employed in this Study $. . \ldots \ldots \ldots \ldots \ldots \ldots \ldots \ldots \ldots \ldots \ldots \ldots \ldots, 4.1$

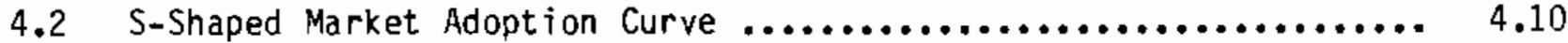

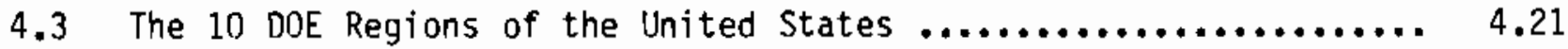

6.1 Air Leakage Spots in Conventionat Construction $\ldots . . \ldots \ldots \ldots \ldots . .6 .2$

6.2 Air Leakage Test Results for Average Home of 1,780 Sq. Ft. ...... 6.2

7.1 Pumped Heat Exchange Domestic Hot Water System........... .7 7.3

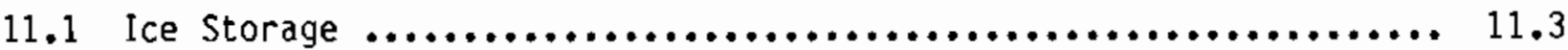

11.2 Chilled Water Storage $\ldots \ldots \ldots \ldots \ldots \ldots \ldots \ldots \ldots \ldots \ldots \ldots \ldots \ldots \ldots, 11.4$

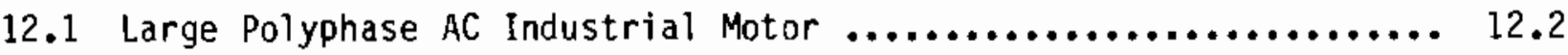

13.1 Illustration of a Potential Application of an Adjustable

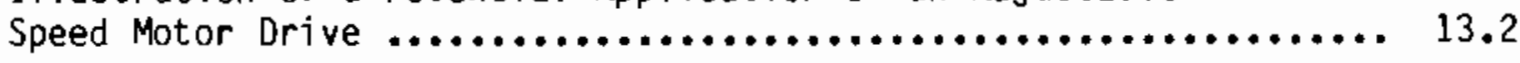




\section{TABLES}

ES.1 Base-Case Projections of Electricity Savings ................. ix

ES.2 Low-Case Projections of Electricity Savings ................. $x$

ES.3 High-Case Projections of Electricity Savings $\ldots \ldots \ldots \ldots \ldots \ldots \ldots \ldots$

ES.4 Comparison of Estimated Minimal Levelized Cost/kWh for

Conservation Technologies and National Average Projected

Cost/kwh from New Generating Capacity

3.1 List of Electricity Conservation Technologies ............... 3.2

3.2 Criteria Used in Selecting Conservation Technologies .......... 3.4

3.3 Evaluation of Residential Electricity Conservation

Technologies .......................................... 3.7

3.4 Evaluation of Commercial Electricity Conservation

Technologies

3.5 Evaluation of Industrial Electricity Conservation

Technologies

3.6 Conservation Technologies Selected for Market Analyses ......... 3.33

4.1 Maximum Potential Market Penetration of Residential

Conservation Technologies Estimated as a Function of

Simple Payback

4.6

4.2 Maximum Potential Market Penetration of Comercial and Indus-

trial Conservation Technologies Estimated as a Function of

Incremental First Cost and Simple Payback

4.3 Common Input Assumptions $\ldots \ldots \ldots \ldots \ldots \ldots \ldots \ldots \ldots \ldots \ldots \ldots \ldots \ldots \ldots \ldots \ldots . . \ldots 4 . \ldots \ldots$

4.4 Regional Costs of New Coal Capacity Power .................... 4.20

5.1 Heat Pump Space Conditioner Simple Pay-Back Calculations ........ 5.8

5.2 Housing Stock Projections and Electric Water-to-Air Heat

Pump Market Share Estimates for Electrically Heated and Cooled

Residences

5.3 Housing Stock Projections and Electric Water-to-Air Heat

Pump Market Share Estimates for Electrically Cooled Only

Residences 
5.4 Housing Stock Projects and Gas-Fired Heat Pump Market Share Estimates for Electrically Heated and Cooled Residences

5.5 Housing Stock Projections and Gas-Fired Heat Pump Market Share Estimates for Electricaliy Cooled Only Residences .......... 5.14

5.6 Estimated National Annual Electrical Savings from New Heat

Pump Technologies BkWh ....................................... 5.16

5.7 Electric Water-to-Air Heat Pump Low Market-Penetration

Scenario for Electrically Heated and Cooled Residences ........... 5.18

5.8 Electric Water-to-Air Heat Pump Low Market-Penetration

Scenario for Electrically Cooled Only Residences ................ 5.19

5.9 Gas-Fired Heat Pump Low Market-Penetration Scenario for Electrically Heated and Cooled Residences ..................... 5.20

5.10 Gas-Fired Heat Pump Low Market-Penetration Scenario for

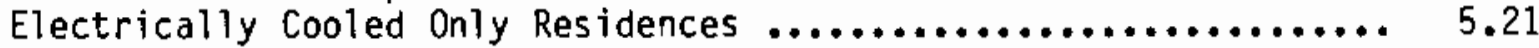

5.11 National Annual Electrical Savings Estimates From the Low Market-Penetration Scenario for the New Heat Pump Technologies

5.12 Electric Water-to-Air Heat Pump High Market-Penetration Scenario for Electrically Heated and Cooled Residences

5.13 Electric Water-to-Air Heat Pump High Market-Penetration Scenario for Electrically Cooled Oniy Residences ............... 5.24

5.14 Gas-Fired Heat Pump High Market-Penetration Scenario for Electrically Heated and Cooled Residences ................. 5.25

5.15 Gas-Fired Heat Pump High Market-Penetration Scenario for Electrically Cooled Only Residences

5.16 National Annual Electrical Savings Estimates from the High Market-Penetration Scenarios for the New Heat

Pump Technologies ...................................... 5.27

5.17 Cost/kWh Saved Calculations for Electric Water-to-Air

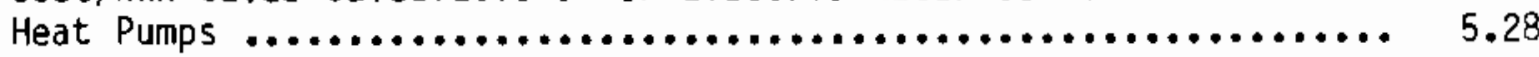

5.18 Cost/kwh Saved Calculations for Gas-Fired Heat Pumps ........... 5.29

6.1 Single-Family Homes with Selected Types of Insulation 1978 and 1980-1982 
6.2 Single-Family Homes Making Conservation Improvements $1978-1982$.............................................. 6.4

6.3 Insulation and Anti-Infiltration Improvements for Residential

Homes Base Case and Efficient Home Assumptions ................ 6.5

6.4 Insulation and Anti-Infiltration Space Conditioning Simple Pay-Back Calculations .................................... 6..9

6.5 Housing Stock Projections and Market Share Estimates of Thermal Efficiency Measures for Electrically Heated Residences -.........

6.6 Housing Stock Projections and Market Share Estimates of Thermal Efficiency Measures for Electrically Cooled Residences .......... 6.11

6.7 Estimated National Annual Electrical Savings from Improved Thermal Efficiency Measures

6.8 Housing Stock Projections and Low Market Share Scenario of Thermal Efficiency Measures for Electrically Heating Residences

6.9 Housing Stock Projections and Low Market Share Scenario of Thermal Efficiency Measures for Electrically Cooled Residences

6.10 National Annual Electrical Savings Estimates from the Low Market-Penetration Scenario for Advanced Thermal

Efficiency Measures

6.11 Housing Stock Projections and High Market Share Scenario of Thermal Efficiency Measures for Electrically Heated Residences

6.12 Housing Stock Projections and High Market Share Scenario of Thermal Efficiency Measures for Electrically Cooled Residences

6.13 National Annual Electrical Savings Estimates from the High Market-Penetration Scenario for Advanced Thermal Efficiency Measures

6.14 Cost/kWh Calculations for Advanced Thermal Insulation and Ant $i$-Infiltration Techniques

7.1 Payback Period of Representative Solar Water Heater 
7.2 Housing Stock Projections, Annual Market Share, and

Electricity Savings for Solar Water Heaters with

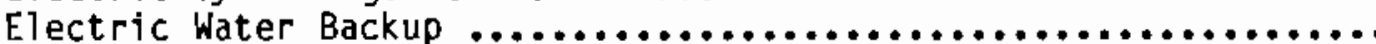

7.3 Projections of Energy Savings with Market Penetration

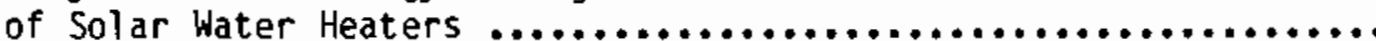

7.4 Low Market Scenario Housing Stock Projections, Annual

Market Share, and Electricity Savings for Solar Water

Heaters with Electric Water Backup

7.5 High Market Scenario Housing Stock Projections, Annual

Market Share, and Electricity Savings for Solar Water

Heaters with Electric Water Backup

7.6 Cost/kWh Calculation for Representative Solar

Water Heater

8.1 Product Features and Their Impact on Appliance Energy Use ....... 8.4

8.2 Summary of Measures to Improve Efficiency in Refrigerators,

Refrigerator-Freezers and Freezers

8.3 Products Selected for Payback Analysis ....................... 8.14

8.4 Payback Period of More Efficient $13 \mathrm{ft}^{3}$ Upright

Freezer-Manual Defrost

8.5 Payback Period of More Efficient $18 \mathrm{ft}^{3}$ Top-Freezer

Refrigerator--Automatic Defrost: Actual Anerican Mode1 ........ 8.16

8.6 Payback Period of More Efficient $18 \mathrm{ft}^{3}$ Top-Freezer

Refrigerator--Automatic Defrost: Hypothetical Japanese

Model

8.7 Annual Market Share Projections--More Efficient Freezers ........ 8.18

8.8 Annual Market Share Projections--More Efficient Refrigerators

Based on Payback Period of American Model

8.9 Annual Market Share Projections--More Efficient Refrigerators

Based on Payback Period of Hypothetical Japanese Model

8.10 Annual Energy Savings Projections for More Efficient Freezers, More Efficient American Refrigerator Freezers, and Japanese

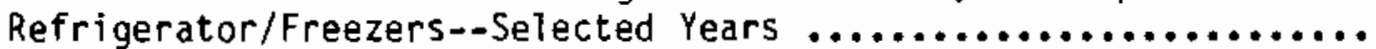

8.11 Low Market-Penetration Scenario and Annual Savings of Delivered Electricity--More Efficient Freezers 
8.12 Low Market-Penetration Scenario and Annual Savings of Delivered Electricity--More Efficient Refrigerators

Based on Payback of American Model

8.13 Low Market-Penetration Scenario and Annual Savings of Delivered Electricity--More Efficient Refrigerators

Based on Payback Period of Hypothetical Japanese Model

8.14 Low Market-Penetration Scenario: Energy Savings Projections

for High-Efficiency Freezers and Refrigerator-Freezers ...........

8.15 High Market-Penetration Scenario and Annual Savings of

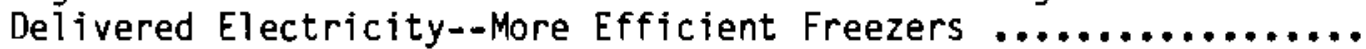

8.16 High Market-Penetration Scenario and Annual Savings and

Delivered Electricity--More Efficient Refrigerators

Based on Payback Period of American Model

8.17 High Market-Penetration Scenario and Annual Savings and

Delivered Electricity--More Efficient Refrigerators

Based on Payback of Hypothetical Japanese Model

8.18 High Market-Penetration Scenario: Energy Savings Projections

for High-Efficiency Freezers and Refrigerator-Freezers ...........

8.19 Cost/kWh Calculation for More Efficient Freezers and

Refrigerator-Freezers

9.1 Technical Performance of Conventional and Energy-Conserving

Windows

9.2 Cost Effectiveness of Heat Mirror ${ }^{m} 55$ Equipped Double Glass Versus Tinted Double Glass on a New Two-Floor Commercial Building of $21,000 \mathrm{ft}^{2}$ in Dallas, Texas. CALPAS computer simulation; $1,760 \mathrm{ft}^{2}$ feet of windows

9.3 Cost Effectiveness for Retrofitting a 6-Story Commercial Building of $40,000 \mathrm{ft}^{2}$ in Evanston, Illinois with Solar Film and Thermal Windows for $1,233 \mathrm{ft}^{2}$ of Windows

9.4 Potential Commercial Building Energy Savings Due to

Assorted Building Conservation and Redesign Measures

9.5 Potential Reductions in Annual Energy Use/ $\mathrm{ft}^{2}$ for

Commercial Buildings Due to Window Redesign

9.6 First Costs and Paybacks for Heat Mirrorm on New Commercial

Buildings, and for Thermal Windows and Solar Film on an

Existing Commercial Building 
9.7 Sumary of Values Assumed for Market Share, Energy Savings and Technical Limits .............................. 9..13

9.8 Commercial Floorspace Projections and Market Share Estimates for Window Conservation Technologies on Electrically Heated and Cooled Buildings ..................... 9.14

9.9 Commercial Floorspace Projections and Market Share Estimates for Window Conservation Technologies on Electrically Cooled Buildings ........................................... 9.15

9.10 Estimated National Annual Electricity Savings from Window Conservation Technologies on Commercial Buildings ............. 9.16

9.11 Commercial Floorspace Projections and Low Scenario Market Share Estimates for Window Conservation Technologies on Electrically Heated and Cooled Buildings

9.12 Commercial Floorspace Projections and Low Scenario Market Share Estimates for Window Conservation Technologies on Electrically Heated and Cooled Buildings

9.13 Estimated National Annual Electricity Savings from Window Conservation Technologies on Commercial Buildings, Low

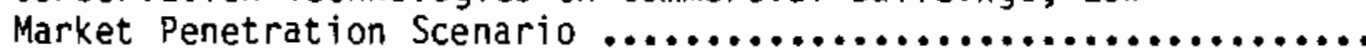

9.14 Commercial Floorspace Projections and High Scenario Market Share Estimates for Window Conservation Technologies on Electrically Heated and Cooled Buildings

9.15 Commercial Floorspace Projections and High Scenario Market Share Estimates for Window Conservation Technologies on Electrically Heated and Cooled Buildings ................. 9.23

9.16 Estimated National Annual Electricity Savings from Window Conservation Technologies on Commercial Buildings, High Market Penetration Scenario

9.17 Cost/kWh Calculations for Energy-Efficient Windows, as a Retrofit Measure for Existing Commercial Buildings ........... 9.24

10.1 Electronic Ballast Manufacturers ......................... 10.4

10.2 Standard and Energy Efficient 48-Inch Fluorescent Bulbs ........ 10.6

10.3 Market Share Estimates for Electronic Ballasts ............... 10.10

10.4 Market Share Estimates for Energy Saving Fluorescent Lamps ..... 10.12 
10.5 Annual Market Share and Energy Savings Projections for Electronic Ballasts .................................... 10.13

10.6 Annual Market Share and Energy Savings Projections for Energy-Efficient Fluorescent Lamps ......................... 10.14

10.7 Energy Savings Results: Electronic Ballasts and High Efficiency Fluorescent Lamps ........................... 10.16

10.8 Low Scenario Market Share Penetration Estimates for Energy Saving Fluorescent Lamps and Electronic Ballasts .............. 10.18

10.9 Low Scenario Annual Market Share and Energy Savings Projections for Electronic Ballasts .......................... 10.19

10.10 Low Scenario Annual Market Share and Energy Savings Projections for Energy-Efficient Fluorescent Bulbs ............ 10.20

10.11 Low Market-Penetration Scenario Energy Savings Results:

Electronic Ballasts and High Efficiency Fluorescent Lamps ....... 10.21

10.12 High Scenario Market Share Estimates for Energy Saving Fluorescent Lamps and Electronic Ballasts ................... 10.21

10.13 High Scenario Annual Market Share and Energy Savings Projections for Electronic Ballasts ..................... 10.22

10.14 High Scenario Annual Market Share and Energy Savings Projections for Energy-Efficient Fluorescent Lamps

10.15 High Market-Penetration Scenario Energy Savings Results ........ 10.24

10.16 Lower Scenario Market-Penetration Estimates for Energy Saving Fluorescent Lamps and Electronic Ballasts .............. 10.25

10.17 Low Usage Scenario Annual Market Share and Energy Savings Projections for Electronic Ballasts 10.26

10.18 Low Usage Scenario Annual Market Share and Energy Savings Projections for Fluorescent Lamps ....................... 10.27

10.19 Lower Usage Scenario Energy Savings Results ................. 10.28

10.20 Cost $/ k$ Wh for Electronic Ballasts and Energy Efficient Fluorescent Lamps in New and Retirement Situations ............ 10.28

11.1 Payback Calculations of a Thermal Storage System for a 100,000 Square Foot Commercial Building 
11.2 Commercial Floorspace Projections and Thermal Storage Market

Share Estimates for Electrically Heated and Cooled Buildings ..... 11.12

11.3 Comercial Floorspace Projections and Thermal Storage Market

Share Estimates for Electrically Cooled Buildings ............. 11.13

11.4 Estimated National Annual Electrical Savings from New

Commercial Thermal Storage Installations .................... 11.14

11.5 Commercial Floorspace Projections and Low Market Share

Scenario of Thermal Storage Systems for Electrically

Heated and Cooled Buildings

11.17

11.6 Commercial Floorspace Projections and Low Market Share

Scenario of Thermal Storage Systems for Electrically

Cooled Buildings

11.18

11.7 Estimated National Arnual Electrical Savings from New

Commercial Thermal Storage Installations - Low Market -

Penetration Scenario

11.19

11.8 Commercial Floorspace Projections and High Market Share Scenario of Thermal Storage Systems for Electrically

Heated and Cooled Buildings

11.9 Commercial Floorspace Projections and High Market Share

Scenarios of Thermal Storage Systems for Electrically

Cooled Buildings

11.21

11.10 Estimated National Annual Electrical Savings from New

Comercial Thermal Storage Installations - High Market-

Penetration Scenario

11.22

11.11 Cost/kWh Calculations of a Thermal Storage System ............ 11.22

12.1 Representative Costs for High-Efficiency Electric Motors ....... 12.6

12.2 Representative Efficiency Improvements for High Efficiency

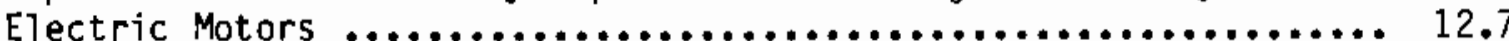

12.3 Representative Electricity Use Per Motor for Conventional

Electric Motors Calculated from a Baseline Electricity

Use for Industrial Motor Drives of 632.7 Billion kWh ............ 12.9

12.4 Representative Payback Periods for High-Efficiency Electric

Motors

12.10

12.5 Estimates of the Maximum Market-Penetration Potential of High-Efficiency Electric Motors in New and Retirement

Applications

12.11

$x x x i v$ 
12.6 Current Electric Motor Populations, Growth Rates and

Ret i rement Rates Employed in This Study .................... 12.12

12.7 Motor Stock Projections and High-Efficiency Motor Market

Share Estimates for 1 to 5 Horsepower Motors ................. 12.13

12.8 Motor Stock Projections and High-Efficiency Motor Market

Share Estimates for 5 to 20 Horsepower Motors ................ 12.14

12.9 Motor Stock Projections and High-Efficiency Motor Market

Share Estimates for 20 to 50 Horsepower Motors ................ 12.15

12.10 Motor Stock Projections and High-Efficiency Motor Market

Share Estimates for 50 to 125 Horsepower Motors ................ 12.16

12.11 Motor Stock Projections and High-Efficiency Motor Market

Share Estimates for $>125$ Horsepower Motors .................. 12.17

12.12 Projections of Energy Savings from the Use of

High-Efficiency Electricity Motors ...................... 12.18

12.13 Low Scenario Maximum Market Penetration Potentials and

Market Penetrations Assumed to be Reached in $2000, \ldots . . . \ldots . . . . .12 .19$

12.14 Low-Scenario Motor Stock Projections and High-Efficiency

Motor Market Share Estimates for 1 to 5 Horsepower Motors ....... 12.20

12.15 Low-Scenario Motor Stock Projections and High-Efficiency

Motor Market Share Estimates for 5 to 20 Horsepower Motors ...... 12.21

12.16 Low-Scenario Motor Stock Projections and High-Efficiency

Motor Market Share Estimates for 20 to 50 Horsepower Motors ..... 12.22

12.17 Low-Scenario Motor Stock Projections and High-Efficiency

Motor Market Share Estimates for 50 to 125 Horsepower Motors ..... 12.23

12.18 Low-Scenario Motor Stock Projections and High-Efficiency

Motor Market Share Estimates for >125 Horsepower Motors ......... 12.24

12.19 Low-Scenario Estimates of Electricity Savings from the Use of Electric Motors ................................. 12.25

12.20 High-Scenario Maximum Market Potentials Assumed to be

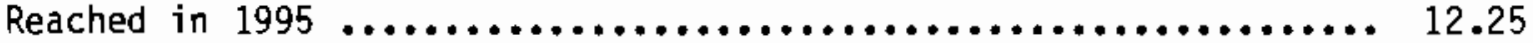

12.21 High-Scenario Motor Stock Projections and High-Efficiency Motor Market Share Estimates for 1 to 5 Horsepower Motors ....... 12.26

12.22 High-Scenario Motor Stock Projections and High-Efficiency Motor Market Share Estimates for 5 to 20 Horsepower Motors ...... 12.27 
12.23 High-Scenario Motor Stock Projections and High-Efficiency Motor Market Share Estimates for 20 to 50 Horsepower Motors ...... 12.28

12.24 High-Scenario Motor Stock Projections and High-Efficiency Motor Market Share Estimates for 50 to 125 Horsepower Motors ..... 12.29

12.25 High-Scenario Motor Stock Projections and High-Efficiency Motor Market Share Estimates for $>125$ Horsepower Motors ......... 12.30

12.26 High-Scenario Estimates of Electricity Savings from the Use of High-Efficiency Electric Motors $. . . \ldots \ldots \ldots \ldots \ldots \ldots \ldots . . .12 .31$

12.27 Cost/kWh Saved Calculations for High-Efficiency

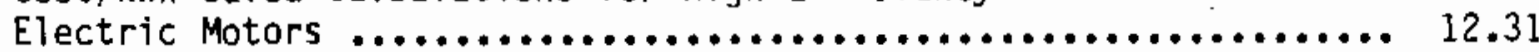

13.1 Representative Estimates of Adjustable Speed Drive Costs,

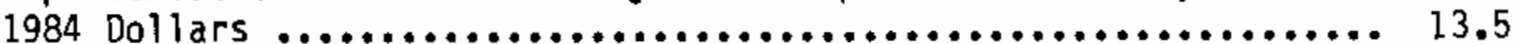

13.2 Representative Electricity Use per Motor for Conventional Electric Motors Calculated from a Baseline Electricity Use for Industrial Motor Drives of 632.7 billion kwh $\ldots \ldots \ldots \ldots \ldots 13.7$

13.3 Representative Payback Periods for Adjustable Speed Drives on Electric Motors in New Applications ....................... 13.9

13.4 Representative Payback Periods for Adjustable Speed Drives on Electric Motors in Retirement/Retrofit Applications .......... 13.9

13.5 Estimates of the Maximum Market-Penetration Potential of Adjustable Speed Drives in New and Retirement/Retrofit Applications

13.6 Current Electric Motor Populations, Growth Rates and Retirement Rates Employed in This Study

13.7 Annual Market Share Projections - Adjustable Speed Drives on Industrial Electric Motors of 50 to $125 \mathrm{HP}$

13.8 Annual Market Share Projections - Adjustable Speed Drives on Industrial Electric Motors Greater than $125 \mathrm{HP}$

13.9 Estimated Energy Savings (BKWh) and Number of Units Projected to Be Installed for Adjustable Speed Drives on Industrial Electric Motors ......................... 13.15

13.10 Low Scenario Annual Market Share Projections - Adjustable Speed Drives on Industrial Electric Motors of 50 to 125 HP ....... 13.16 
13.11 Low Scenario Annual Market Share Projections - Adjustable Speed Drives on Industrial Electric Motors Greater than 125 HP

13.12 Low Scenario Estimated Energy Savings and Number of Units Projected to Be Installed for Adjustable Speed Drives on Industrial Electric Motors

13.13 High Scenario Annual Market Share Projections - Adjustable Speed Drives on Industrial Electric Motors of 50 to 125 HP

13.14 High Scenario Annual Market Share Projections - Adjustable Speed Drives on Industrial Electric Motors Greater than $125 \mathrm{HP}$

13.15 High Scenario Estimated Energy Savings and Number of Units Projected to Be Installed for Adjustable Speed Drives on Industrial Electric Motors

13.16 Cost/kWh Saved Calculations for Adjustable Speed Drives on Electric Motors in New and Retirement Applications

13.17 Cost/kWh Saved Calculations for Adjustable Speed Drives on Electric Motors in Retrofit Applications

14.1 Simple Payback of Titanium Diboride Cathode Coating for Retrofits of $\mathrm{Hall}$-Heroult Cells

14.2 Estimates of 1983 Capacity Utilization and Primary Aluminum Production, with Assumptions Regarding Capacity and Utilization in 2000

14.3 Estimates for Cathode Retrofits of Hall Reduction Cells Using a $\mathrm{TiB}_{2}$ Coating

14.4 Primary Aluminum Industry in the United States: Projected Capacity, $\mathrm{TiB}_{2}$ Retrofits, and Energy Savings by Year, $1985-2000$

14.5 Estimates and Projections of Annual Energy Savings in Primary Aluminum Due to Declining Production and Adoption of a Special Cathode Coating

14.6 Low Market-Penetration Scenario Estimates of Annual Market Share and Energy Savings for $\mathrm{TiB}_{2}$ Cathode Coating Retrofit Measure 
14.7 Estimated National Annual Electricity Savings in

Primary Aluminum Production Due to Capacity

Retirement and $\mathrm{TiB}_{2}$ Retrofit--Low Market-

Penetration Scenario ................................... 14.14

14.8 High Market-Penetration Scenario Estimates of Annual

Market Share and Energy Savings to $\mathrm{TiB}_{2}$ Cathode

Coating Retrofit Measure ................................ 14.15

14.9 Estimated National Annual Electricity Savings in Primary

Aluminum Production Due to Capacity Retirement and

$\mathrm{TiB}_{2}$ Retrofit--High Market-Penetration Scenario

14.10 Cost/kWh Calculations for Titanium Diboride Cathode

Coatings, as a Retrofit Measure for Existing U.S.

Aluminum Smeiters

14.16 


\subsection{INTRODUCTION}

This research was performed by Pacific Northwest Laboratory (PNL) for the Office of Coal and Electricity Policy (OCEP), U.S. Department of Energy. The focus of the project was on new technologies that may reduce the consumption of electricity in the future.

\subsection{BACKGROUND}

In the base case forecasts of the Fourth National Energy Policy Plan (NEPP-IV), aggregate U.S. electricity consumption was forecast to grow during the next 20 years at approximately the same rate as the real gross national product (GNP). Recent aggregate trends support this association between electricity consumption and economic growth, and it is likely that the NEPP-V base case forecasts of electricity demand and GNP currently being prepared will be similarly related.

However, several phenomena that have not yet begun to affect aggregate U.S. electricity consumption, and thus are not yet part of the recent trends upon which these forecasts are based, may break or at least weaken the relationship between future electricity consumption growth and GNP growth. In particular, several conservation technologies and/or products that may replace more electricity-intensive technologies have been developed and commercialized in the past 5 to 10 years, and many more can be expected to become commercially available in the next 5 to 10 years. Some analysts believe that these technologies will significantly reduce future U.S. electricity consumption, and,

therefore, indirectly weaken the relationship between growth in consumption and GNP. Amory Lovins, for example, has suggested in his publications, correspondence, and public testimony that such technologies could potentially reduce future electricity consumption to 25 percent of its current value, which would result in an annual savings of more than 1700 billion kilowatt hours (BkWh).

Because some of these technologies may not yet have been adequately incorporated into the models used to generate the NEPP electricity consumption projections, the resulting projections may overpredict future U.S. electricity 
consumption. The OCEP initiated this study to help ensure that its projections of U.S. electricity consumption reflect the availability of the most important of these new technologies.

\subsection{OBJECTIVES}

The objectives of this study are three-fold:

- to collect information about the technical characteristics and costs of new electricity saving technologies

- to estimate base, low, and high scenarios of the future potential markets, market penetration rates, and impacts on aggregate electricity consumption of 10 of these technologies

- to estimate a minimal, national average levelized cost/kWh saved by each of the 10 technologies.

\subsection{OVERVIEW OF REPORT}

To achieve these objectives, three tasks were performed:

- selection of 10 technologies for detailed analysis

- development of a methodology for estimating the potential market, market penetration electricity savings, and levelized cost of each technology

- assessment of the characteristics and estimation of the potential market, market penetration, electricity savings, and levelized cost/kWh saved for each technology.

The remainder of this report is divided into 13 chapters. Chapter 2.0 presents the conclusions and recommendations generated from performing these three tasks. Chapter 3.0 describes the methods and results of the technology selection task. Chapter 4.0 discusses the methodology developed for estimating the future potential market, market penetration, electricity savings, and minimal levelized cost/xWh saved of each technology. Chapters 5.0 through 14.0 present detailed analyses of each of the 10 technologies. Each analysis includes a description of the technology; base-, low-, and high-scenario projections of 
the future potential market, market penetration rate, and electricity consumption impacts of the technology; and an estimate of the levelized cost/kWh saved by the technology. Chapters 5.0-8.0 cover technologies affecting the residential sector; Chapters 9.0-11.0, the commercial sector; and Chapters 12.0-14.0 the industrial sector. 



\subsection{CONCLUSIONS}

In brief, the study yielded the following conclusions:

- More than 25 technologies or products developed in the past 5 to 10 years or expected to be developed in the next 5 to 10 years are discussed in the open literature as having the potential to significantly reduce future U.S. electricity consumption. Amory Lovins has stated that these and other emerging products could reduce future consumption by more than 1700 billion kilowatt hours (BkWh) annually. Ten of these technologies were selected for more detailed analysis. Previously published estimates of the potential electricity savings associated with these 10 technologies suggest that they could save approximately 725 Bkwh of electricity, or about 40 percent of Lovins' total estimate of potential savings.

- A relatively simple, straightforward methodology for projecting future potential markets and market-penetration rates based on capital and operating costs exists in the literature and can be used to generate approximate, first-cut estimates of these parameters.

- Of the 10 technologies selected for detailed analysis, several are new enough and different enough from technologies currently in use that their commercial availability is probably not reflected in the models used to generate the National Energy Policy Plan (NEPP) projections. These technologies include water-to-air and natural gasfired heat pumps, heat and cool storage in commercial buildings, and new electrolytic techniques in the aluminum industry. Base-case projections of the year 2000 electricity savings associated with these technologies are approximately $69 \mathrm{BkWh}$, which is about equal to the output of 13 one-gigawatt generating units. The other technologies examined are either technologies that have been available for a long enough period of time that they are appropriately represented in the NEPP models or are refinements of existing technologies whose availability is reflected in the models. Included in the former category are solar water heaters, American-made high-efficiency freezers and 
refrigerators, and electronic adjustable-speed-drive motors. Included in the latter category are thermal insulation and antiinfiltration devices, glazings and other window technologies, highefficiency fluorescent light bulbs and ballasts, and high-efficiency electric motors, (a)

- High-, base-, and low-case projections of the electricity savings associated with the 10 technologies are (in BkWh):

$\begin{array}{lcccc}\text { High Case } & \frac{1985}{23} & \frac{1990}{118} & \frac{1995}{325} & \frac{2000}{470} \\ \text { Base Case } & 21 & 63 & 162 & 279 \\ \text { Low Case } & 16 & 36 & 76 & 137\end{array}$

- 8ase-case projections of electricity savings for the year 2000 are (in BkWh):

- Residential, 86

- heat pumps, 61

- Thermal insulation and anti-infiltration devices, 16

- Solar water heaters, 4

- High-efficiency appliances, 5

- Commercial, 136

- Glazings and other window technologies, 49

- Lighting technologies, 79

- Heat and cool storage, 8

- Industrial, 58

- High-efficiency motors, 6

- Adjustable-speed-drive motors, 51

- Electrolytic techniques, 0.3

(a) For a more detailed discussion of the treatment of the technologies in the models used for NEPP, see Electricity Conserving Technologies in the NEPP Projections, Applied Energy Services, Inc., Artington, Virginia (ín press). 
- The estimated minimal levelized cost/kWh saved of most of the 10 technologies analyzed is less than the projected average cost $/ \mathrm{kWh}$ of new generating capacity. Utilities facing capacity constraints and considering building new generating capacity may therefore wish to consider facilitating the penetration of one or more of these technologies instead, since they may reduce future costs by doing so.

- The projections generated in this study are subject to several important caveats due to the inherent uncertainties in such projections and to the time and resource constraints of the study. The base-case projections tend to be overestimates of the likely savings, as an attempt was made to be "conservative" in making assumptions. The low-scenario projections, however, probably bound the actual estimates from below. The projections are based almost solely on information in the open literature, as original data collection on such items as consumer acceptance of each technology was beyond the scope of the study. The methodology employed in the study, al though used by a number of Federal agencies is based on a small number of case studies and has not been empirically validated. In applying this methodology to each technology, a number of simplifying assumptions had to be made. For example, the projections are based entirely on average economic and climatic characteristics of the nation, because a region-by-region analysis was beyond the scope of the study. Because of these and other limitations of the analysis, we believe the projections should be interpreted as first-cut or approximate estimates that provide information about the potential magnitudes of the savings associated with the technologies, and not as precise estimates of the actual savings. 



\subsection{SELECTION OF CONSERVATION TECHNOLOGIES FOR DETAILED MARKET ANALYSES}

Many conservation technologies could produce future electrical energy savings. The first task in this analysis was to develop a list of the conservation technologies that could be implemented in the residential, commercial, and industrial sectors. The initial list was too large to permit detailed analyses of the market penetration and energy-savings potential of all of them with the resources available. Accordingly, a decision was made to select and focus upon 10 that appeared especially promising or important. To complete this task, selection criteria were developed. Data were collected on each technology on the list, and each technology was evaluated to determine how well it met the criteria. If a technology did not meet a specified criterion to some degree, it was rejected until the 10 technologies that best fit all of the specified criteria were identified.

In this chapter, the criteria used in the selection process are described. Evaluations of the degree to which each of the conservation technologies in the residential, commercial, and industrial sectors meet the selection criteria are also presented. The chapter concludes with a summary of the results of the selection process.

\subsection{ELECTRICITY CONSERVATION TECHNOLOGIES}

There are many new and newly developing electrical energy savings technologies that could be used in different applications in the near future. Thus, the first step in this analysis was to identify those technologies that have the potential to be major contributors to future electrical energy savings. An initial list of these potentially "major contributors" is presented in Table 3.1. This list is primarily a modification and extension of a similar listing that had been suggested by Amory Lovins. (a) Lovins' list was generally complete but it did not include some important measures. The technologies added to his list were:

(a) Unpublished letter from Amory Lovins, Director of Research, Rocky Mountain Institute, Snowmass, Colorado, to David Meyer, Office of Coal and Electricity Policy, U.S. Department of Energy, Washington, D.C. 


\section{TABLE 3.1. List of Electricity Conservation Technologies}

\begin{tabular}{|c|c|c|c|}
\hline & Technology Name & Sector (s) & End Use \\
\hline 1. & $\begin{array}{l}\text { Advanced thermal insulation and } \\
\text { anti-Infiltration }\end{array}$ & residentlal/commerclal & space conditloning \\
\hline 2. & Advanced heat pump technologies & residentlal/comnerciol & space cond $1+$ loning \\
\hline 3. & Hybrid passive spece heoting & residential/commercial & space heating \\
\hline 4. & Passive space heating & residential/commerclal & spece neotIng \\
\hline 5. & Hybrid passive space cooling & res Idential/commerclal & space cooling \\
\hline 6. & Passive space cooling & resldentlal/commerclal & space coollng \\
\hline 7. & Alr-to-alr heat exchangers & residentiol/commerclal & space conditioning \\
\hline 8. & Energy monagement control systems & residentlal/commercial/Industrial & general use \\
\hline 9. & Evaporative cooling & resldentiol/commerclol & spoce cooling \\
\hline 10. & $\begin{array}{l}\text { Desiccont dehumldificztion and } \\
\text { cooling }\end{array}$ & residentlal/commerclol & space cooling \\
\hline 11. & $\begin{array}{l}\text { Window qlazings and other } \\
\text { window technologies }\end{array}$ & residential/commerclal & space conditioning \\
\hline 12. & Solar water heaters & residentlal & water heatling \\
\hline 13. & Heat pump water neaters & residentlal & water heating \\
\hline 14. & HIgh-effliciency electrical appltances & residentiol & opp liances \\
\hline 15. & High-efficlency gas appllances & residentlal & appl lances \\
\hline 16. & Advanced lighting technologles & resident Iol/commerclal/Industrial & lignting \\
\hline 17. & Doylighting tochnologies & residentlal/commercial/industrial & I Ighting \\
\hline 18. & Heat/cool storage in floor slabs & conmerctol & space condltioning \\
\hline 19. & HIgh-efflciency office equlpment & commerclol & office operation \\
\hline 20. & Varlable-speed motor controllers & Industrial & motor drive \\
\hline 21. & High-etflelency motors & Industrlal & motor drlve \\
\hline 22. & $\begin{array}{l}\text { Motor resizing, clutched flywheels, } \\
\text { etc. }\end{array}$ & Industrial & motor drive \\
\hline 23. & $\begin{array}{l}\text { Hydraulic/direct industrlal drive } \\
\text { to replace electric drlve }\end{array}$ & Industrlal & motor drive \\
\hline 24. & High-efficlency electrolyt le process & Industrial & electrolysis \\
\hline 25. & $\begin{array}{l}\text { Displacement of steel and aluminum } \\
\text { with graphite flbers }\end{array}$ & Industrlal & $\begin{array}{l}\text { electrolysis/process } \\
\text { hesting }\end{array}$ \\
\hline 26. & Increase cherging of steel serop & Industrial & process heating \\
\hline 27. & Fluidized-bed heat treatment & industrlal & process heating \\
\hline
\end{tabular}


- energy control management systems

- air-to-air heat pumps

- water-to-air heat pumps

- variable-speed motor drives

- heat-pump water heaters

- heat/cool storage for commercial buildings

- energy-efficient motors.

\subsection{SELECTION CRITERIA}

The objective of developing selection criteria for use in this study was to provide a methodology for selecting 10 conservation technologies for detailed study that could be consistently applied across all the technologies listed in Table 3.1. The criteria were formulated so that the 10 technologies that are readily identifiable as being the most likely to have a significant impact upon future electricity demands would be selected from among those listed. The criteria were exclusionary in the sense that, if a technology did not fulfill each of the selection criteria to at least a moderate degree, it was excluded from the selected technology set, until only those 10 technologies that fit all of the selection criteria remained.

The first selection criterion is that the selected technologies should represent a cross-section of those available in the residential, industrial, and commercial sectors. The residential sector appeared to offer more potential for electrical energy savings than the other sectors because of a larger number of available conservation technologies and greater electrical energy use (DOE 1984). Four technologies were therefore selected from the residential sector and three each from the comercial and the industrial sectors.

Additional criteria were then specified for selecting technologies from among those available within each sector. A summary of the specified criteria is presented in Table 3.2 .

The first criterion listed in Table 3.2 is that the technology be among the top five in its sector in terms of potential electricity savings. It is the most important criterion, and most of the available technologies were 
TABLE 3.2. Criteria Used in Selecting Conservation Technologies

1. The technology is among the top five in terms of estimated potential electricity savings from among those available in each of the electricityconsuming sectors (residential, commercial and industrial).

2. The technology is comercially available or is likely to become commercially available in the near future.

3. The technology has not reached high levels of market penetration that would preclude the potential for obtaining additional market share in the future.

4. Unbiased experts and published literature indicate that the potential for growth in the use of the technology is promising.

5. The technology is clearly identifiable as a relatively distinct technology that will allow for projections of its market penetration and energysavings potentials to be developed.

6. Penetration of the technology will not require radical changes in existing modes of operation.

7. The technology appears, on the basis of published information, to be cost effective.

excluded or included in the selected technology set based on this criterion. If a technology did not appear to have a large potential for producing electrical energy savings relative to other available technologies in its sector, it was excluded from further analyses. For some technologies, published estimates of the potential energy savings were available. In other cases, estimates of potential energy savings for the technologies were derived using published data on the amount of electricity used in a particular sector's end use (1ighting, heating, etc.) and assumptions about the percentage reduction in energy use that a particular conservation technology would produce in this end use. In many cases, the relative amount of electricity used for a given end use was so small that the technologies that might impact upon this end use could be excluded on this basis alone from the selected set of technologies.

The second criterion is that the technology be comercially available or expected to soon become commercially available. It was used to eliminate technologies that are in the basic research and development stage. For such technologies, analyzing the potential energy savings and market penetration of the 
technologies would be extremely speculative. Very few of the listed technologies were eliminated from further consideration using this criterion.

The third criterion, that the technology has not yet attained a high degree of market penetration (significantly above 10 percent), was used to exclude technologies for which future increases in market penetration and energy savings possibilities are limited. This criterion was employed for two reasons. First, a high degree of current market penetration reduces the possibility for large future increases in penetration. Consequently, the potential for significant additional energy savings would be modest. Second, the energy savings from high current penetration would also have been (implicitly) accounted for in present energy forecast models. Several technologies from each sector were excluded from further analysis on the basis of this criterion.

The fourth criterion was used to eliminate technologies that conservation experts contacted at Pacific Northwest Laboratory and elsewhere felt had littie potential for market-penetration growth. In addition, those technologies for which little or no information was identified in the published literature available to us were eliminated. If available expert opinion and published literature are currently unable to provide a positive assessment of a conservation technology, it was assumed to be unlikely that the technology will be implemented on a widespread basis in the future.

The fifth criterion is that the technology be relatively distinct. This criterion was used to el iminate technologies for which the definition of the technology is so broad that analyzing the market-penetration and energy-saving potential of it would be almost impossible. For example, a passive solar cooling technology can include anything from shade trees to window glazing. The definition of a passive solar technology is not distinct enough to allow for a market analysis to be performed. Several other examples of technologies that were not clearly identifiable were noted.

The sixth criterion was used to eliminate technologies that require radical changes in existing operations and behavior. Such technologies are less likely to be implemented than technologies that do not require behavioral changes. In addition, the energy savings of technologies that require behavior changes are more uncertain, because the changes in behavior may be short 
lived. Only a small number of the available technologies appeared to require radical changes in existing behavior and modes of operation, but these were eliminated from further consideration.

The seventh criterion, that the technology appears to be cost effective, was used to eliminate technologies only when they were obviously too expensive to be cost effective. Relatively few technologies fell into this category.

After having clearly specified the criteria for the technology-selection process, the necessary data to evaluate the technologies according to the criteria were collected and the selection process was performed. The data collected for the evaluation were obtained from various sources, including articles and papers from Arthur D. Little, InC. (ADL), the Alliance to Save Energy (ASE), the U.S. Department of Energy (DOE), the Electric Power Research Institute (EPRI), the Lawrence Berkeley Laboratory (LBL), the Office of Technology Assessment (OTA), and others. A great deal of emphasis was placed on verifying that data used were consistent with Fifth National Energy Policy Plan (NEPP-V) data and projections. As a backup, consistency was further checked using the estimated sectoral end-use data of the Energy Conservation Multi-Year Plan, FY 1986-FY 1990 (DOE 1984a).

The technology-selection process was performed by evaluating each measure according to how well the measure met the specified selection criteria. Whenever it was determined that a technology did not meet any one of the criteria to at least a moderate degree, that technology was evaluated as not suitable for selection. In most cases, the estimated potential electricity savings of each technology was stressed as the most critical criterion. Evaluations of each of the technologies listed in Table 3.1 are presented by sector in the next three sections of this chapter.

\subsection{RESIDENTIAL TECHNOLOGY EVALUATIONS}

In this section, 17 residential electricity conservation technologies for different end uses-are evaluated as to how well they meet the selection criteria. Table 3.3 provides an overview of the results of the selection and evaluation analysis. Note from Table 3.3 that the technologies of thermal insulation and anti-infiltration devices, advanced heat pumps, solar water 
TABLE 3.3. Evaluation of Residential Electricity Conservation Technologies

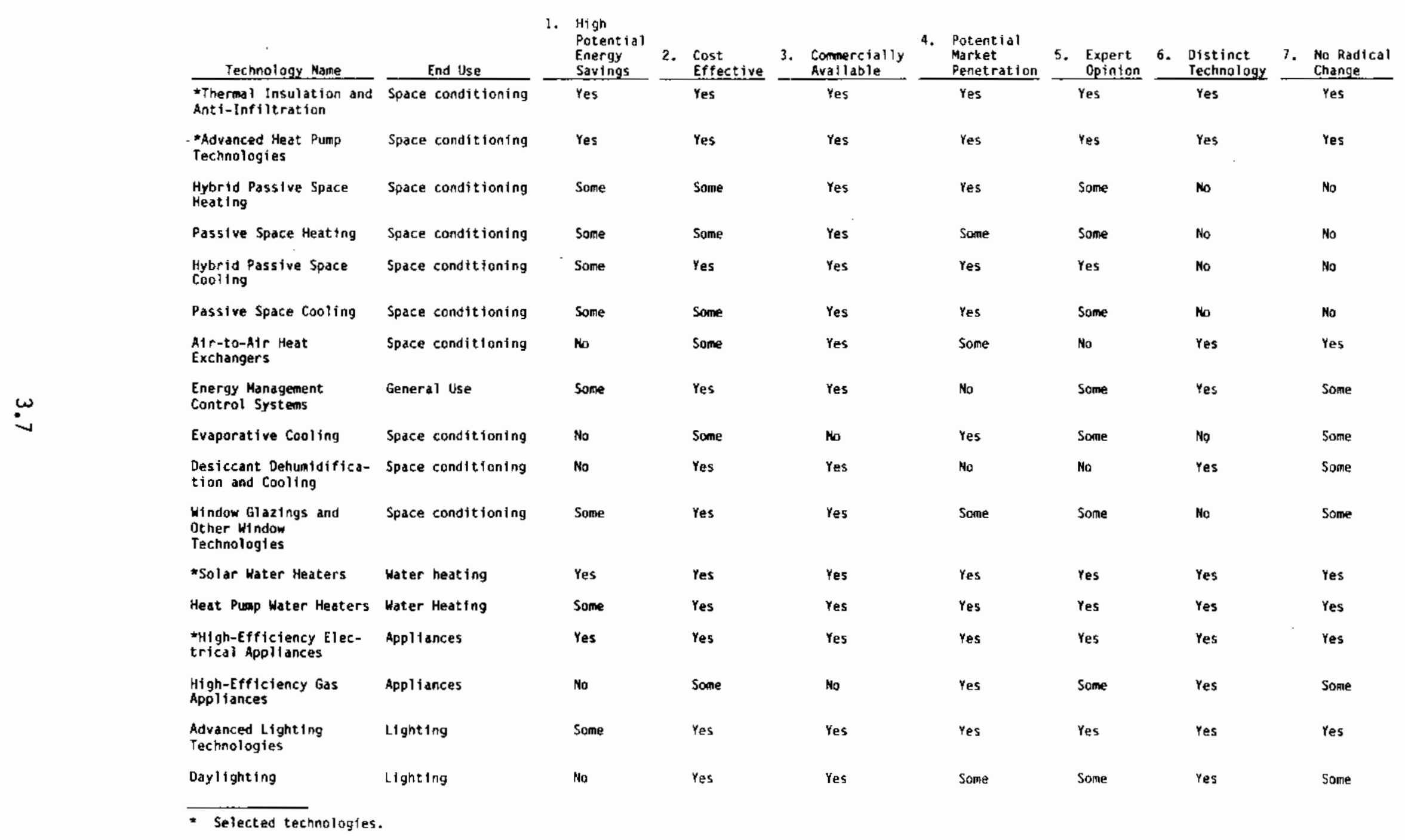


heaters, and high-efficiency electric appliances were evaluated as meeting all of the selection criteria and, thus, were selected to be included in the final technology set.

The remainder of this section presents a description of the evaluation process for the residential sector conservation technologies. The evaluation begins (in Section 3.3.1) with a brief sumary of the present levels of electricity consumption for different end uses in the residential sector. This information is important because the potential for future electrical energy savings from each technology is directly related to present consumption. Section 3.3.2 presents brief descriptions of the four residential technologies that were selected for more detailed analysis while Section 3.3.3 provides information about the residential technologies listed in Table 3.1 that were not selected.

\subsubsection{Present Residential Electricity Consumption by End Use}

Space conditioning is the single largest end use of electricity in the residential sector. In 1984, approximately 117 billion kilowatt hours (Bkwh) out of a total of $780 \mathrm{BkWh}$ of residentially consumed electricity was used for the purpose of space heating. In addition, residential space cooling consumed an estimated 167 BKWh (DOE 1985). Because more than one-third of the total residential electrical energy consumption is used for space conditioning, reductions in electricity consumed for this purpose have the potential to produce relatively large electricity savings.

In 1983, electrical consumption for refrigeration was estimated to be in the range of $111 \mathrm{BKWh}$ (DOE 1985). When refrigerators are considered in combination with freezers (41 BKWh), cooking and drying equipment (50 BkWh), and "other" appliances such as washers, toasters, etc. (126 BkWh), it becomes apparent that the potential for future electrical savings from more efficient appliances is also large.

Water heating is the third largest use of electricity consumption in the residential sector. In 1984, residential use of electricity for water heating was an estimated 85 BkWh of electrical consumption, which was approximately 11 percent of total residential electrical consumption (DOE 1985). Residential 
electricity use for lighting was approximately 80 BkWh in 1984. This was approximately 10 percent of total residential electricity consumption.

\subsubsection{Selected Residential Technologies}

The technologies selected for the residential sector have the potential to impact upon the electricity consumed in all of the major end uses listed above. Evaluations of each of the selected technologies are presented below.

Advanced Thermal Insulation and Anti-Infiltration Technologies

Thermal insulation reduces the amount of thermal transmission through walls, ceilings and floors and, thus, can reduce the energy used in both heating and cooling buildings. Anti-infiltration technologies (such as vapor barriers) reduce the amount of air exchange in buildings, thereby resulting in decreased heating and cooling energy usage and reduced moisture infiltration.

These measures clearly remain among the most important technologies in terms of their untapped potential for additional and significant electrical energy savings. New, technologically superior, safer, and more cost-effective insulation retrofit measures in combination with newly developed and developing anti-infiltration retrofit devices have the potential to reduce electricity use for space heating in existing homes by as much as 50 percent (OTA 1969). Furthermore, these measures also have the potential to further reduce electrical consumption for space cooling in existing homes by more than 10 percent (OTA 1969). Even greater energy savings could be attained if new high insulation and low infiltration building practices become more common for new residential structures. Based on the current amount of electricity used for space conditioning in the residential sector, achieving these potential reductions could reduce residential electricity consumption by $75 \mathrm{BkWh}$. Because of their high savings potential and because these technologies appeared to meet all the other selection criteria, they were selected for more detailed analysis.

Advanced Heat Pump Technologies

Heat pumps are devices that can, under many conditions, heat and cool buildings more efficiently than conventional HVAC systems. When heating, a 
heat pump's refrigerant takes available heat from outside air or water, compresses it, and distributes it throughout a building through a forced air system. When cooling, the cycle is reversed. Several different types of heat pumps, including electric air-to-air and water-to-air models and gas models, fit within the general category of heat pump technologies.

The air-to-air electric heat pump has made significant gains in the residential space-conditioning market during the past several years. However, future market growth for heat pumps is likely to be comprised primarily of the expanded use of electric water-to-air models and gas models.

Several gas-fired heat pump technologies are currently receiving large expenditures for development and, if they are perfected and aggressively marketed, they could be commercially available and competitive by the late 1980s or early 1990s. The gas-fired motors now being developed are likely to be significantly improved over existing models. This technical advance, in combination with the fact that gas power is less expensive per unit of power output than electricity, suggests that the gas-fired heat pump is likely to become an important space heating technology. Specifically, the anticipated market potential for gas-fired heat pump systems ranges from a competitive share to a complete domination of the market (Itteilag and Swanson 1984).

Because the energy efficiency of water-to-air heat pumps is significantly higher than that of either electric HVAC systems or the more conventional airto-air electric heat pumps, they also have considerable potential to reduce electrical use for space conditioning. In combination with gas heat pumps, water-to-air heat pumps form a category that deserves to be considered among the most promising of the new residential energy savings technologies.

Every gas-fired heat pump that penetrates the electric space-conditioning market obviously displaces 100 percent of the electrical alternative's electrical consumption with gas consumption. Assuming that water-to-air heat pumps compete for a market share only with other electric HVAC systems, each of these systems will also contribute to a reduction in electricity demand. For example, depending on the climate conditions of the installation, water-to-air heat pumps can reduce electrical consumption compared to air-to-air heat pumps by as much as 25 percent (McGuigan 1982). Hence, the potential exists for 
additional reductions in electrical energy use, beyond those that have been achieved using air-to-air heat pumps, through the use of advanced heat pump technologies. Because of the remaining large potential for energy savings from the use of advanced heat pump technologies and because they appeared to meet all of the other selection criteria, they were selected for intensive study. High-Efficiency Electrical Appliances

The potential electrical savings of advanced insulation for appliances has been reported to be in the range of 32 BkWh by the year 2000 (D0E 1984C). For refrigerators and freezers alone the savings could be in the range of 23 BkWh by the year 2000 , depending on the degree of market penetration of these technologically advanced appliances. In addition, high-efficiency electrical appliances generally are out of the research and development stage, would not require major changes in behavior, and appear to be cost effective. Because high-efficiency appliances appeared to meet all of the selection criteria, they were selected for intensive study.

Solar Water Heaters

Mechanically, solar water heaters for the home are not very different from gas or electric water heaters. Solar collectors absorb solar radiation and convert it to usable heat. Solar energy actually serves to preheat the household hot water and must typically be used in combination with a conventional gas or electric water heater. The reduction in household electricity use for water heating attributable to use of a solar water heater depends on the climate, the site, and the surface area of solar panels that are installed.

Solar water heaters now appear to be economically competitive with electric water heaters in many parts of the country. In addition, solar water heaters appear to have a relatively large energy-savings potential. Depending on the location and the number of square feet of solar panels installed, 30 percent to 75 percent of a household's energy demand for water heating can be met by a solar water heater (HUD/DOE 19BO). Assuming that an energy savings of 50 percent is a representative average, the potential electricity savings of solar hot water heaters could be as great as 42 BkWh. Solar water heaters appear to have great potential for significant future penetration in the market 
for water heaters. In summary, this technology appeared to meet all of the selection criteria, and was therefore selected for intensive study.

\subsubsection{Residential Technologies Considered but Not Selected}

Each of the technologies discussed in this section failed to adequately meet at least one of the specified selection criteria.

Hybrid Passive Space Heating

Hybrid passive heating applications include the heating of building areas with only minimal use of low-power fans or pumps. Primary methods include employing external structural devices to capture heat from sunilight and to diffuse that heat to the building proper by means of radiance, convection, conduction, fan, or pump. Specific systems include the trombe wall, the stagnating trombe wall, the water wall, the sunspace or greenhouse, roof pond systems, and the thermosiphon.

Although the future electrical energy savings of this technology are potentially substantial, it has a relatively high initial installation cost with a consequent long pay-back period. As such, it is likely to remain a less desirable alternative than the insulating and/or heat pump technologies. This technology was not included in our final selected set of technologies because:

1. It would, to be widely effective, require extensive refitting of existing homes and/or radical changes in the manner in which new houses are designed and built, so its cost effectiveness and consumer acceptability are uncertain.

2. It is not clear that, as a system, it could be readily analyzed as a distinct technology.

\section{Passive Space Heating}

Passive space heating is, the heating of building areas without the use of any mechanical or external storage/collection devices. Primary methods include allowing sunlight to warm building areas through south-facing windows and allowing the natural distribution of that warmth by means of convection, conduction, or radiation from south-facing solar-warmed walls next to living space. 
The potential electrical energy savings of this technology are moderate as compared to the insulating and heat pump technologies. Passive space heating is primarily limited to improvements in the architectural design of new buildings because effective savings from the implementation of these systems into existing buildings can only be gained at a relatively high cost. Specifically, this technology was not recommended for further study because:

1. Its contribution to future electrical energy savings is likely to be only moderate in comparison to the potential contributions of other conservation measures.

2. It has a probable rate of market penetration that is strongly dependent upon the number of new houses that are built, because it is generally not applicable to existing buildings.

3. It is not clear that, as a system, it could be readily analyzed as a distinct technology.

Hybrid Passive Space Cooling

Hybrid passive space cooling is the cooling of building areas with only minimal use of mechanical or external devices. Primary methods include cooling by evaporation, ventilation, dehumidification, convection, conduction, and/or radiation reduction. Examples include air-wash evaporative cooling devices, low-power ventilation fans or pumps, dehumidifiers, and mechanized venetiantype blinds that automatically adjust the solar radiation permitted to enter the work space to the most desirable level.

The electrical energy savings of these measures are potentially substantial. However, hybrid passive space cooling is not a single technology but rather a family of related technologies, some of which would require significant behavioral adjustments by the users. As such, this technology did not meet the selection criteria of being a distinct technology nor that of requiring no radical changes in behavior.

Passive Space Cooling

Passive space cooling is the cooling of building areas without the use of any mechanical or external storage/collection devices. Primary methods include 
shading of building areas from exposure to the sumer sun and allowing ventilation to reduce internal heat and humidity. Examples include external shading from trees, awnings, and overhangs; window glazings and/or venetian-type blinds; earth sheltering; and daytime/nighttime "modulated" ventilation procedures.

The potential electrical energy savings of these measures is low to moderate, depending on the climate where they are applied. This category is also better described as a family of related technologies and depends heavily upon significant behavioral adjustments to be most effective. For these reasons, passive space cooling was not included in the group of technologies selected for intensive study.

\section{Air-to-Air Heat Exchangers}

An air-to-air heat exchanger is a device for mitigating reductions in indoor air quality resulting from building tightening. Air-to-air heat exchangers mix the heat of outgoing indoor air with incoming outdoor air to result in less heat loss than would occur if air were allowed to be exchanged through walls, windows, and other parts of a building. Thus, the exchangers allow for acceptable levels of indoor air quality to be achieved while at the same time preserving much of the energy-conserving potential of the building.

Further analysis of this technology was not recommended because:

1. It compares unfavorably with other residential technological systems in terms of its potential for significantly affecting the future consumption of electrical energy. In fact, this technology by itself does not save energy but rather contributes to the energy savings of other technologies by reducing heat loss while alleviating an undesirable air-quality side effect that typically occurs with high levels of insulation and tightening.

2. It has a probable rate of market penetration that is strongly dependent on the degree to which the irsulating and anti-infiltration technologies are adopted. 


\section{Energy Management Control Systeins}

In recent years, a variety of control systems have been developed to more efficiently manage the energy use of a building. Examples of these controls include night setback thermostats, automated lighting controls, and electric demand data recording systems. These controls either provide automated control of energy-consuming systems or provide data to residents that allow them to better manage their consumption of energy.

This technology has already achieved a relatively high level of market penetration. Therefore, al though such systems have saved a significant amount of electrical energy to date, it seems likely that future savings attributable to these systems have already been accounted for in projections of residential sector demand. Accordingly, they are not included in the selected technology set.

Evaporative Space Cooling

Evaporative cooling occurs when heat energy in the air or on a roof is "consumed" or converted into water vapor by evaporation. Although the creation of water vapor increases the ambient humidity, in dry climates that increase combines with the coinciding reduction in air temperature to provide greater comfort. Primary methods include the addition of bodies of water (pools or fountains) or of moisture (atriums) to cool the living/working space or, alternatively, the spraying of roof tops with water to cool the ceiling surface below. Some other methods include employing mechanical evaporative devices to pre-cool air before it enters various types of conventional air coolers to reduce the energy demand of those systems.

Applications of the evaporative cooling methodologies are only reasonably effective in hot/arid climates where water for cooling is plentiful. In less arid regions, use of evaporative space-cooling methods is less beneficial because these systems tend to produce an undesirable increase in the ambient humidity. Most importantly, in almost all applications, the potential electrical energy savings of these systems is relatively small. As such, they would have to be used in combination with alternative cooling equipment to ensure reasonable occupant comfort. Finally, the more advanced system designs 
of this technology are still in the basic research and development stage. Because of the above factors, this technology is not selected for further study.

Desiccant Dehumidification and Cooling

Desiccant cooling is the drying of very humid air, which helps to promote natural cooling (by evaporation of sweat) and to reduce the formation of frost and condensation on refrigeration units (allowing them to work more efficiently). In climates that experience high humidity levels, the dehumidification effectively reduces electrical demand for air conditioning and refrigeration. The use of desiccant salts (which absorb moisture from air), solar dehumidification systems, or mechanical dehumidifiers are all methods of desiccant cooling. Desiccant salts eventually become saturated with moisture and require (solar or gas) energy for drying out; specific systems have been and continue to be developed for this purpose.

This technology is not recommended for inclusion in the final technology set primarily because its contribution to potential future electrical energy savings is not likely to be large. Most forms of this technology have been around a long time and are only effective in climatic regions that experience high levels of humidity or in typically humid buildings such as those that are passively cooled. In addition, desiccant salt solar systems are still in the development stage and remain a technological challenge.

\section{Window Glazings and Other Window Technologies}

Glazings are materials that are either translucent or transparent to solar radiation. By regulating the intensity of sunlight allowed to pass through a glazed surface, the natural warming and lighting effects of sunlight can be either permitted or inhibited. Glazings also have the quality of increasing the insulation R-value of treated windows. Other window technologies include various types of window shades or energy-efficient venetian blinds that automatically adjust to regulate the solar radiation permitted to enter the living/working space.

The potential contribution to future electrical energy savings of this technology in the residential sector is only moderate. Therefore, it is not 
recommended for inclusion in the selected set of residential conservation technologies. However, the contribution to commercial sector electrical savings is potentially quite large for these technologies, and they will be selected for further analysis in that application.

Heat Pump Water Heating Systems

Heat-pump water heaters incorporate the general principles of heat pump technology in heating water. Heat is drawn from the air, condensed, and then transferred to water. The ideal location for a heat-pump water heater is in a partially conditioned location where the air temperature is normally between $45^{\circ} \mathrm{F}$ and $95^{\circ} \mathrm{F}$. In summer, a water heat pump located indoors can reduce cooling loads by transferring heat from indoor air. However, in winter the same heat pump could increase space heating demands. For this reason and others, it is normally recommended that heat-pump water heaters be placed in areas that are normally unoccupied.

Water heating heat pumps are estimated to be about 50 percent more energy efficient than electric resistance water heaters (EPRI 1984) but, depending on the climate, typically less energy efficient than solar water heaters. In addition, determining the potential energy savings of heat pump water heaters is difficult because their effectiveness is dependent upon their location within a residence. If they are located inside a residence that uses electric space heating or outside a residence located in a cold climate, their energy-savings potential is marginal. Thus, even though the capital costs of heat pump water heaters are generally lower than solar water heaters, they were not included in the selected technology set because of lower potential energy savings considerations.

High-Efficiency Light Bulbs

High-Efficiency light bulbs are simply light bulbs that perform the same function as conventional light bulbs while using less energy. Estimates of the potential savings in future electrical consumption from highly efficient lighting technologies in the residential sector were not identified during this study. However, it appeared that a very high percentage efficiency improvement would be necessary in order for these light bulbs to be competitive with the 
selected technologies in tems of their expected electricity savings, and they were not included in the selected technology set on this basis.

Daylighting

Daylighting is a technology whereby buildings are designed to capture natural light for internal building use by using proper window spacing, window angles, and other techniques. The use of natural light will obviously reduce the amount of electricity used in providing artificial light. However, properly designed daylighting systems can also reduce cooling electrical demands because of the lower heat content of natural light compared to artificial light.

The potential energy savings of daylighting in the residential sector appear to be very small because the technology will generally be cost effective only on new buildings, and even in these buildings the savings of the increased use of natural light in residences are likely to be relatively smal1. Based on these considerations, daylighting was not included among the selected set of technologies.

High Efficiency Gas Appliances

High efficiency gas appliances include gas refrigeration and air conditioning. At present high efficiency products employing these technologies are not being produced in significant numbers and have achieved only negligible market penetration. Although this is an area of keen interest on the part of both the American Gas Association and the Gas Research Institute, our preliminary findings indicate that products employing this technology would be configured so differently from standard appliances that their adoption and use would require substantial changes in consumer behavior. Thus, this technology was not selected for further study.

\subsection{COMMERCIAL TECHNOLOGY EVALUATIONS}

Evaluations of the degree to which 15 commercial electricity conservation technologies meet the specified selection criteria are discussed in this section. A sumary of the results of these evaluations is shown in Table 3.4. Again, in that table a "Yes" implies that a conservation technology fully met 


\section{TABLE 3.4. Evaluation of Commercial Electricity Conservation Technologies}

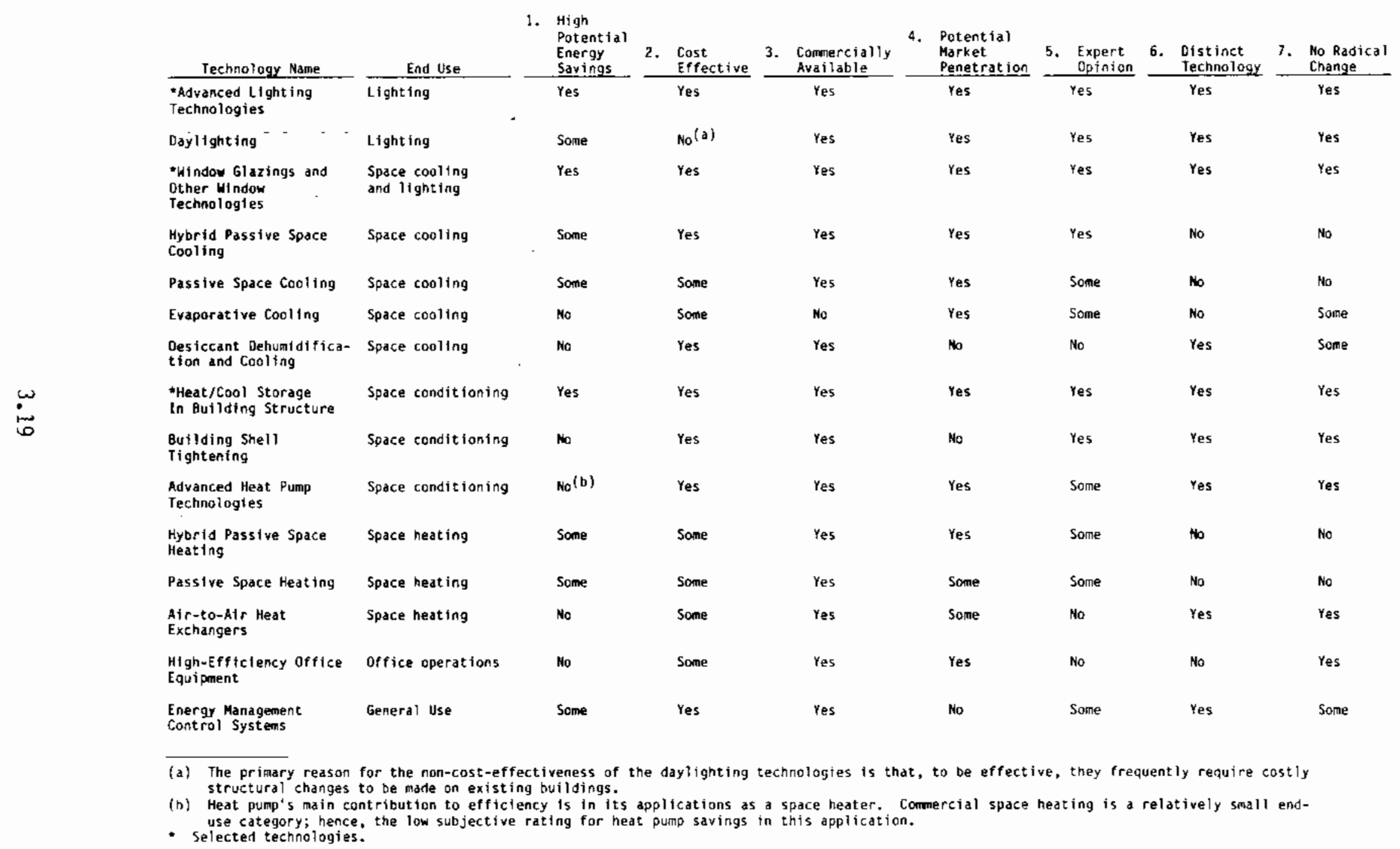


the corresponding selection criterion; a "Some" implies that a technology at least moderately met the corresponding selection criterion; a "No" implies that a technology did not meet the corresponding selection criterion. Note that the selected technologies (i.e., those identified in Table 3.4 by an asterisk) of advanced lighting systems, window glazings and other window technologies, and heat/cool storage in building structures were evaluated as fully meeting all of the selection criteria.

\subsubsection{Present Commercial Electricity Consumption by End Use}

The lighting of commercial buildings is by far the largest of the electricity consuming end-use categories in the commercial sector. In 1984, an estimated 237.38 BkWh out of a total $656.5 \mathrm{BkWh}$ of commercial electricity use was consumed for lighting purposes in the commercial sector (DOE 1985). Consequently, improvements over present lighting technologies could dramatically affect total future electrical consumption.

Space cooling is the second largest electrical energy user of the commercial end-use categories. In 1984, an estimated 193.4 BkWh was used for the purpose of commercial sector space cooling (DOE 1985). Potential future reductions in electricity used for this purpose would significantly contribute toward influencing total electrical energy savings by the year 2000 .

The electrical requirement for heating in commercial buildings is, at most, only one-quarter of that required for cooling. In 1984, an estimated 43.9 BkWh of electricity was consumed commercially for space heating (DOE 1985). Ouring the week, the working space of a commercial building is warmed by the heat produced from the operation of lights, office machines, and from body heat. Therefore, commercial buildings typically produce an excess of heat during the work week. However, over the weekends during the colder months the internal activities of the building can not meet the heating requirements and the heating system must typically be turned on.

\subsubsection{Selected Commercial Technologies}

The selected technologies of advanced lighting systems, window glazings and other window technologies, and heat and cool storage in the building mass could have significant impacts upon the electricity used in the three major 
end-use categories of the commercial sector. In addition, they were determined to have fully met all of the selection criteria. An explanation of why each of these technologies was selected for further analysis is presented below.

\section{Advanced Lighting Systems}

Ballasts are devices for starting voltage and limiting lamp current in all gas-discharge lamps. High-frequency ballasts perform these functions more efficiently. The lower power input requirements of high-frequency ballasts reduce the heat retention in a light fixture. Thus, both lighting and cooling eiectricity demands can be reduced by using high-frequency ballasts. SL/PL bulbs are simply light bulbs that require less electricity input to produce light output than the standard incandescent bulbs in widespread use today.

High-frequency ballasts, more efficient fluorescent tubes, and more efficient light bulbs all have significant potential for reducing future electrical energy consumption. It has been estimated that approximately 68.8 Bkwh of electricity could be saved annually by the year 2000 by using more efficient lighting technologies (DOE 1984b). These technologies are commercially available, to a limited degree, and should not require major changes in existing behavior. Advanced lighting technologies have the potential to produce large energy savings and also appeared to fulfill the other selection criteria. Thus, it was included in the selected set of technologies.

Window Glazings and Other Window Technologies

Glazings and other window technologies were described in Section 3.3. However, the potential electrical energy savings of implementing these technologies are significantly greater in the commercial sector than they are in the residential sector.

Replacing clear glass office windows with windows that are properly glazed, or installing light filtering film over existing windows, could reduce commercial electrical consumption for cooling by up to 22 percent, which equates to a potential savings of about 44 BkWh. Glazings also have the ability to increase the insulation R-value of treated windows, and they allow for more widespread use of daylighting technologies. Additional energy savings can be gained by further regulating the solar radiation that enters the work space 
with various window shades and energy-efficient venetian blinds. This technology appeared to fulfill all of the technology selection criteria and, thus, was included in the selected technology set.

Heat and Cool Storage in the Building Structure

HVAC units, regardless of type, work far more efficiently when they are used for cooling pre-cooled air. Because night air, depending on the location, is typically much cooler than mid-day air, HVAC systems operating at night can save up to 30 percent on their energy intake (Anderson et al. 1979). Therefore, if night-time cool air can be stored in the building structure and released when needed during the heat of the day, substantial energy savings can be realized.

Furthemore, during the winter months, commercial buildings typically have to he heated only on Monday mornings for a few hours or until the activities that take place within the buildings are well underway. This is because, even during the winter months, commercial buildings typically acquire substantial heat from the operation of lights, office machines, and from body heat. When this heat is directed into the building's structure rather than discarded to the outside, it can be released again as needed over the weekend to help maintain building temperature without turning up the furnace. It has been estimated that up to 50 percent of a commercial building's demand for heat can be met by employing this method (Anderson et al. 1979).

The combined heating and cooling savings that could be realized by more widespread application of these methods appeared large, and the technology appeared to fulfill all of the other selection criteria. Thus, it was retained for more in-depth analysis.

\subsubsection{Commercial Technologies Considered but Not Selected}

The following sections provide explanations for not selecting other technologies for further study. Note that if these technologies have already been described for residential sector applications, they are not described again below. 


\section{Daylighting}

This technology is likely to significantly reduce commercial lighting demand for electricity in new commercial buildings. However, its application to existing buildings is, in most cases, not cost effective. The potential electrical energy savings directly attributable to daylighting technologies have been estimated to be only about one-fourth of the potential savings attributable to advanced lighting technologies (DOE 1984b). Because of the apparent lack of cost effectiveness of daylighting on existing buildings and its low potential for savings relative to advanced iighting technologies, it was not selected for intensive study.

Hybrid Passive Cooling

This technology is not a single technology but rather a family of related technologies, some of which are likely to be major contributors to future electrical savings and some of which will have a much smaller impact on those savings. The major contributors (i.e., window glazings and blinds, and heat and cool storage in floor slabs) will be treated in this analysis as two distinct technologies. The remaining contribution of other hybrid passive cooling technologies to electrical savings is not large enough to warrant detailed analysis.

\section{Passive Cooling}

The anticipated future electrical savings of this technology are moderate when the impact of window glazings is treated as a separate technology. Other forms of passive cooling either are not cost effective or would require significant behavioral adjustments in their application. For these reasons, passive cooling was not selected for additional research.

Evaporative Cooling

Applications of the evaporative cooling methodologies are cost effective and have a large impact on electrical consumption only in hot/arid climates where water for cooling is plentiful. In humid climates, these systems are inappropriate because they elevate the level of humidity, which is, of course, undesirable. The potential for electrical energy savings of these systems is relatively small, and they were not selected for further study. 
Desiccant Dehumidification and Cooling

The likely contribution of these methodologies to reduce future electrical energy demand is modest. For the most part, this is not a new technology, but newer systems are being developed (e.g., desiccant salt solar systems). In almost all applications, these systems would have to be used in combination with other cooling measures to ensure reasonable comfort. Finally, these systems are only applicable to humid climates or to structures that are typically humid, such as those that are passively cooled.

Advanced Insulation and Anti-Infiltration Technologies

Most of the more modern commercial buildings are already fairly well constructed in terms of levels of insulation and anti-infiltration measures. Because of this and because heating is not nearly as large a commercial eiectrical end use as either lighting or space-cooling, the potential for substantial future electrical savings from building-shell tightening is comparatively sma11. Hence, this technology was not selected for further study.

Advanced Heat Pump Technologies

In terms of electrical energy savings, the main contribution of advanced heat pumps is in space heating. Since the commercial end use of space heating is small relative to lighting and space-cooling, the anticipated future electrical savings due to the application of heat pump technologies in the commercial sector are comparatively small. This technology was not selected for further study.

Hybrid Passive Heating

Hybrid passive heating is actually not a single technology but rather is several different technologies under a broad heading. The more important of these specific hybrid passive heating technologies are treated independently. The combined contribution to future electrical savings of the lesser hybrid passive technologies is likely to be modest. 


\section{Passive Heating}

Like the other passive technologies, this alternative has major and minor specific technologies which are better considered individually. The anticipated future electrical savings of the minor passive heating technologies are not likely to significantly contribute to future electrical energy savings. In addition, many of them do not appear to be cost effective or would require adjustments in behavior. This technology was not selected for further study.

Air-to-Air Heat Exchangers

This technology compares unfavorably with other comanercial alternatives in terms of its potential for significant contributions to future electricity consumption reductions. The system's primary contribution is that it reduces heat loss while bringing in fresh air for ventilation. It only saves energy when used in concert with building tightening measures and was not selected for further analysis.

High-Efficiency Office Equipment

Besides lighting and space conditioning, all other end uses of electricity combined in the commercial sector utilize only 92 BKWh, or 14 percent, of total commercial electricity use (DOE 1984a). Because of the relatively small electrical consumption of commercial office equipment, the potential savings resulting from major technological improvements in their efficiency is likely to be small compared to those from lighting and space-cooling conservation technologies. Therefore, this category was not selected for further analysis.

Energy Management Control Systems

These systems have been commercially available for several years and are already widely used in the commercial sector. A recent survey conducted by the association of energy engineers found that 62 percent of commercial firms are currently using energy management systems and that an additional 32 percent are planning to install such systems in the near future (Association of Energy Engineers 1984). Therefore, although this technology has saved large amounts of electricity to date, it seems likely that future savings from these systems will be relatively small. Therefore, it was not selected for further analysis. 


\subsection{INDUSTRIAL TECHNOLOGY EVALUATIONS}

Evaluations and discussions of 11 industrial electricity-saving technologies are presented in this section. As before, a summary of the basic results of these evaluations (presented in Table 3.5) precedes the more detailed discussions. Note that the selected technologies of variable-speed motor controllers, high-efficiency motors, and high-efficiency electrolytic processes (identified in Table 3.5 by an asterisk) were evaluated as having met all of the selection criteria to at least a moderate degree.

\subsubsection{Present Industrial Electricity Consumption by End Use}

In 1984, approximately 899 BkWh of electricity was consumed in the industrial sector, according to a recent estimate (DOE 1985). The major end-use applications for this electricity were for motor drives and electrolytic processes.

Electric motors account for by far the largest share of total electrical energy use in the industrial sector. In 1984, 656 BkWh was consumed for motordrive end uses (DOE 1985). This comprised 68 percent of industrial electricity end usage. Obviously, if even small percentage changes in electrical energy use in this sector are achieved, the total savings could be relatively large.

Electrolytic processes are the second largest end use of electricity in the industrial sector, consuming about $114 \mathrm{BkWh}$ in 1984 (DOE 1985). Almost 70 percent of this electricity is consumed in the primary metals industry, and most of the other 30 percent is used in the chemical and allied products industry.

\subsubsection{Selected Industrial Technologies}

The three technologies selected for further study could have major impacts on the electric energy used by motor drives and electrolytic processes. These selected technologies have the combined potential to annually save in excess of an estimated 197 BKWh of electricity by the year 2000. Discussions of these technologies are presented below. 
TABLE 3.5. Evaluation of Industrial Electricity Conservation Technologies

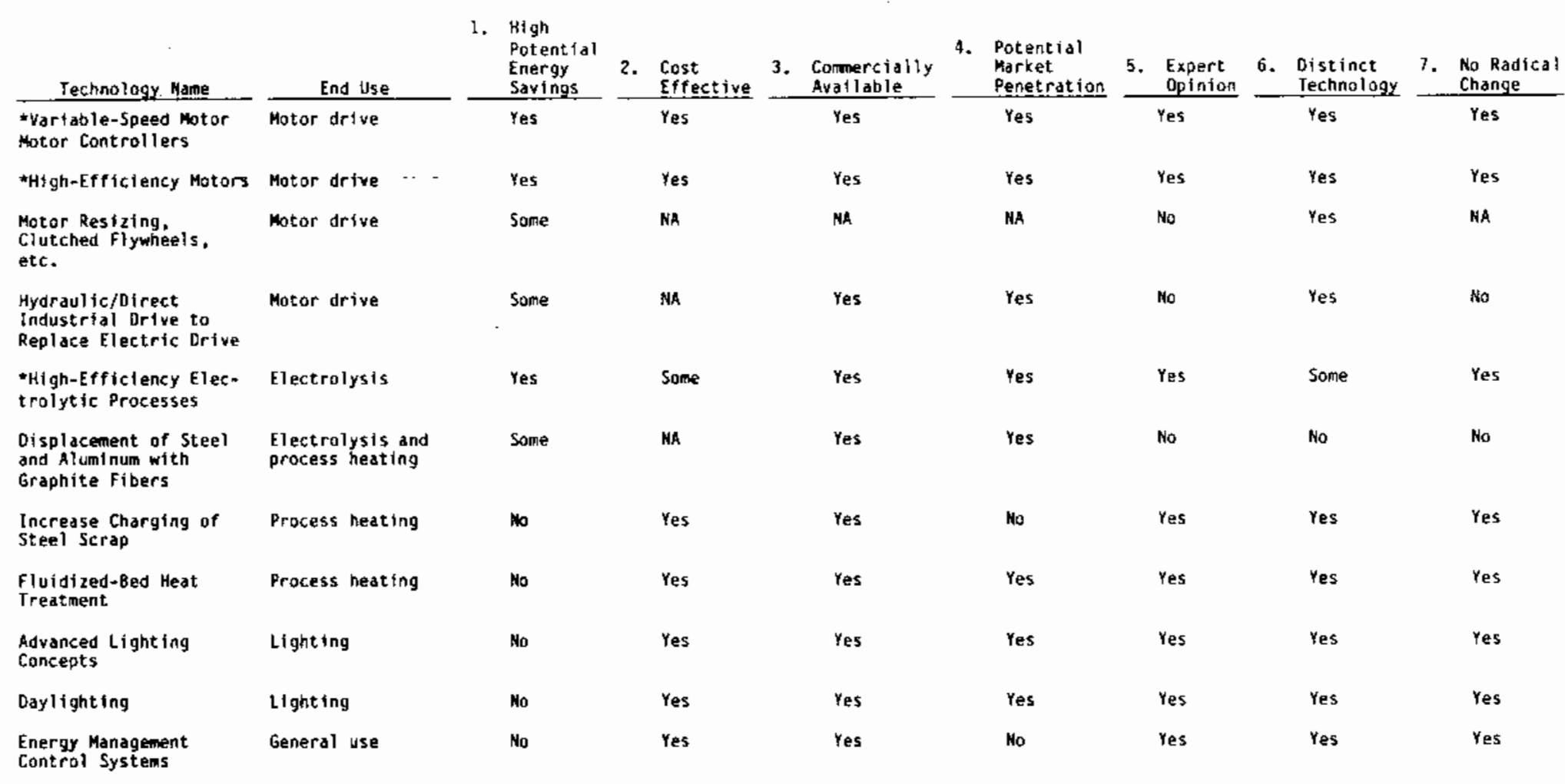

- Selected technologies. 
Variable-Speed Motor Controllers

Variable-speed drives allow electric motors to operate at varied speeds so as to match varying load requirements. The resulting closer match of motor output and load requirements reduces the electricity used in powering electric motors. Variable-speed drives are seeing increasing use in industries in which processes require speed control, where load requirements vary substantially over time and where soft-starting may reduce wear and tear on components. Several different types of power semiconductors and circuits may be used to accomplish variable-speed control, but the most common technique is to use variable-frequency controllers.

Variable-speed motor controllers can save energy by reducing the throttling losses associated with varying motor load requirements. The typical net energy savings that can be expected from the use of variable-speed motor controllers are on the order of 25-30 percent (Hane et al. 1983). Thus, the potential energy savings of variable-speed motors could be as high as $139 \mathrm{BkWh}$.

Variable-speed motor controllers are comnercially available and are generally regarded as being cost-effective in many industrial applications. The Electric Power Research Institute (EPRI) believes the potential for variable speed electric motor controllers to capture a significant part of the future industrial electric motor drive market is so great that they have initiated a research program to study the technology. In addition, the technology is distinct and readily identifiable. In summary, it appears that the technology of variable-speed electric motor controllers meets all of the criteria and consequentiy it was selected for further study.

\section{High-Efficiency Electric Motors}

Energy-efficient electric motors are motors designed to minimize internal motor losses from such sources as stator winding resistance, rotor slip, bearing friction and stray load losses. The technology of energy-efficient motors incorporates only internal motor design changes that reduce internal motor energy losses. The reduction in electricity use that will result from the use of energy-efficient motors will depend upon the size of the motor. In general, 
the greatest reductions will occur in motor sizes from 5 to 50 horsepower, while the smallest reductions will occur in motors greater than 125 horsepower.

High-efficiency electric motors can be used in association with either variable-speed or constant-speed motor drives. The energy savings of more efficient electric motors will generally range from 5 to 12 percent (ADL 1976). According to one estimate, the likely level of savings for energy-efficient motors by the year 2000 is approximately 35 BkWh (ADL 1976). Energy-efficient electric motors are commercially available and, in many cases may be more cost effective than variable-speed controllers. In addition, energy-efficient motors are a distinct technology. In summary, energy-efficient motors seem to meet all of the selection criteria, and this technology was selected for further study.

High-Efficiency Electrolytic Processes

An electrolytic process is basically a purification process that involves the application of an electric current to a substance to separate it into relatively pure components (i.e., into a pure gas or a pure solid deposit).

Several technologies are currently available for producing improvements in the energy efficiency of electrolytic processes. For example, efficiency improvements of 2D percent are achievable in existing aluminum plants using currently available technology (Alliance to Save Energy 1983).

The sources of improvements are numerous and include:

- improved cell design

- improved carbon electrodes

- changes in the chemical bath in which reduction takes place.

A 20 percent decrease in the electricity used in electrolytic processes could result in potential electricity savings of about $22 \mathrm{BkWh}$. Although these savings are relatively small compared to the potential savings in electric motors, they are relatively large compared to the potential savings in other industrial electricity end uses, such as process heating. In addition, the Department of Energy is currently sponsoring research to improve the efficiency of electrolytic processes that has the potential to produce even greater savings (DOE 1984a). 
More efficient electrolytic processes will not require major changes in current industrial modes of operation. Because more efficient electrolytic processes appeared to meet all of the selection criteria, this technology was selected for further study.

\subsubsection{Industrial Technologies Considered but Not Selected}

Explanations of why several other industrial conservation technologies were not selected for further study are presented below.

Industrial Motor Resizing, Clutched Flywheels, Torque Converters, ACS Chips

The technologies of industrial motor resizing and ACS chips save energy by more closely matching motor output to load requirements. They therefore compete with variable-speed motor controllers, and much of the electrical energy savings that may be available from these technologies may already be captured by analyzing variable-speed motor controllers. Clutched flywheels and torque converters do not compete directly with variable-speed motor controllers. However, contacts with available experts and a review of available literature did not provide any information on these technologies. This indicates that their potential energy savings are likely to be relatively small. Because some of the above technologies compete with variable-speed motor controllers and because the level of their potential energy savings appeared to be small, they were not selected for further study.

\section{Hydraulic or Direct Industrial Drive to Replace Electric Drive}

This technology also competes directly with variable-speed electric motors at the end-use application level. However, because the use of this technology would involve significantly greater changes in industrial modes of operation than would the use of variable-speed drives, it appears that variable-speed drives offer greater market penetration potential. In addition, some experts $^{(a)}$ question whether the energy-savings potential of hydraulic drive

(a) Personal communication with Ray Watts, mechanical engineer with Pacific Northwest Laboratory, October 1984. 
motors would be significant. One available study indicated that for the specific application of powered hand tools, the energy consumption of hydraulically powered hand tools could actually be greater than that of electrically powered hand tools (DOE 1977). In sumary, it appears that the potential energy savings levels and market potential of hydraulic and direct industrial drives are too small relative to variable-speed motor controllers to be included in the 10 technologies selected for further study.

Displacement of Steel and Aluminum by Composites Containing Graphite Fibers

The production of graphite fibers is likely to require less electrical energy than the production of steel and aluminum. Thus, if graphite fibers can replace steel and aluminum, the amount of electricity used in the industrial sector will be reduced. However, replacement of steel and aluminum with graphite would likely require significant changes in existing industrial and commercial modes of operation. For this reason, this technology was not selected for further study.

Fluidized-Bed and Other Advanced Heat Treatment of Metal Parts

Use of a fluidized bed of chemicals in the heat treating of metal parts can reduce the amount of electricity used in this industrial process by facilitating more efficient heat transfer. However, because the total electricity used in the heat treating of metal parts is only 26 BkWh (DOE 1985), it appears that the potential energy savings of fluidized-bed heat treating processes are relatively small. Even if fluidized-bed furnaces reduced electrical heat treating usage by 50 percent, the savings would be small relative to those that could be obtained for electric motor and electrolytic process end uses. Accordingly, this technology was not selected for further analysis.

Advanced Lighting Technologies for the Industrial Sector

Lighting, space conditioning and other end uses of electricity in the industrial sector combined consumed approximately 77 BkWh of electricity (DOE 1985). This total is only 17 percent of the industrial electric use for motor drives and 75 percent of the electricity used in electrolytic processes. Obviously, very large improvements in the efficiency of these end uses would be 
necessary before the total electricity savings would compare to small improvements in the efficiency of motor drives and electrolytic processes.

Advanced lighting technologies such as high-frequency ballasts and more efficient fluorescent tubes, were discussed in detail in Section 3.4. Lighting technologies were not selected for more detailed study here because of their small potential for electricity savings in this sector.

Daylighting

Daylighting, which involves the replacement of artificial light with natural light, could potentially be used to reduce energy use for lighting in the industrial sector. However, as discussed previously, the electric energy used for lighting in the industrial sector is relatively small. Thus, the potential energy savings from daylighting are likely to be small. The potential savings from daylighting are also limited by the fact that it is likely to be cost effective only on new industrial structures. For these reasons, daylighting was not selected for further study.

\section{Energy Management Control Systems}

Energy management control systems have the potential to save electrical energy in all industrial end uses by improving the efficiency and coordination of energy-consuming industrial processes. However, additional future energy savings from the use of energy management control systems are likely to be relatively small because such control systems are already widely used. Therefore, the potential for future significant additions to the market penetration of energy management control systems is relatively small.

\subsection{SUMMARY DF RESULTS}

The 10 technologies selected for a more extensive market analysis are summarized in Table 3.6. Only technologies that were evaluated positively for each of the criteria were selected. Over the long term, the total potential electricity savings, annually, for the 10 selected technologies is 727 Bkh according to previous estimates. 
TABLE 3.6. Conservation Technologies Selected for Market Analyses

\begin{tabular}{|c|c|c|}
\hline $\begin{array}{c}\text { Electricity } \\
\text { Consumption Sector } \\
\end{array}$ & Selected Technology & $\begin{array}{c}\text { Estimated } \\
\text { Maximum } \\
\text { Potential } \\
\text { Electricjty } \\
\text { Savings } \\
\text { (BkWh) in } 2000 \\
\end{array}$ \\
\hline Residential & $\begin{array}{l}\text { Advanced heat pumps } \\
\text { Advanced insulation and anti-infiltration } \\
\text { devices } \\
\text { Solar water heaters } \\
\text { High-Efficiency appliances }\end{array}$ & $\begin{array}{r}152 \\
96 \\
57 \\
32\end{array}$ \\
\hline Commercial & $\begin{array}{l}\text { Advanced lighting } \\
\text { Glazings/blinds } \\
\text { Storage of heat and cool in the building } \\
\text { structure }\end{array}$ & $\begin{array}{l}69 \\
44 \\
80\end{array}$ \\
\hline Industrial & $\begin{array}{l}\text { Variable-speed motor controllers } \\
\text { High-Efficiency electric motors } \\
\text { High-Efficiency electrolytic processes }\end{array}$ & $\begin{array}{r}139 \\
35 \\
23\end{array}$ \\
\hline $\begin{array}{l}\text { Total Estimated } \\
\text { Electricity } \\
\text { Savings }\end{array}$ & 10 selected technologies & 727 \\
\hline
\end{tabular}

(a) Estimates provided in literature obtained from various sources including DOE 1984b) and (EPRI 1984).

By comparison, Amory Lovins has estimated that over several decades, U.S. electricity consumption could potentially be reduced to one quarter of its present level through the full use of presentiy available, cost-effective energy-saving technologies (Lovins 1984). At current consumption levels, these potential savings exceed $1700 \mathrm{BkWh}$. Thus, the previously estimated potential electricity savings for the 10 selected technologies of $727 \mathrm{BkWh}$ could provide over 40 percent of the potential savings estimated by Lovins.

\subsection{REFERENCES FOR CHAPTER 3.0}

Alliance to Save Energy. 1983. Industrial Investment in Energy Efficiency: Opportunities, Management Practices, and Tax Incentives. July. 
Anderson, L. 0., K. G. Bernander, E. Isfalt, and A. H. Rosenfeld. 1979. Storage of Heat and Cool in Hollow-Core Concrete Slabs. Swedish Experience, and Application to Large, American-Style Buildings. LBL-8913. Lawrence Berkeley Laboratory, Livermore, California.

ADL. 1976. Energy Efficiency and Electric Motors. PB-259-129, Arthur D. Little, Incorporated, Cambridge, Massachusetts.

Association of Energy Engineers. 1984. Congress Advance. Newsletter published by the Association of Energy Engineers, Atlanta, Georgia.

EPRI. 1984. Industrial Electro-Technologies and Electrification (IEE) Program Plan. Electric Power Research Institute, Palo Alto, California.

Hane, G. L., et al. 1983. Industrial Conservation. Volume III of Assessment of Electric Power Conservation and Supply Resources in the Pacific Northwest. Prepared for the Pacific Northwest Electric Power and Conservation Planning Council, Portland, Oregon, by Battelle, Pacific Northwest Laboratories.

Itteilag, R. L., and C. A. Swanson. 1984. "A Life-Cycle Cost Analysis of Residential Gas-Fired Heat Pumps." Public Utilities Fortnightly. May 10, 1984.

Lovins, Amory B. 1984. Investigation of PSNH Financing Plan to Complete Construction of Seabrook Unit No. 1, Docket No. 34-200, Di rect Testimony of Amory B. Lovins--Least-Cost Reliable Electrical Services as an Alternative to Seabrook. The State of New Yampshire before the Public Utilities Commission, October, 1984.

McGuigan, Dermot, with Amanda McGuigan. 1982. Heat Pumps - An Efficient Heating and Cooling Alternative. Garden Way Publishing, Charlotte, Vermont.

0TA. 1969. Residential Energy Conservation. Office of Technology Assessment, Washington, D.C.

U.S. HUD and DOE. 1980. Is Solar Water Heating Right For You? HUD-401. Prepared by the Department of Housing and Urban Development in cooperation with the U.S. Department of Energy, Washington, D.C.

U.5. DOE. 1984a. Energy Conservation Multi-Year Plan, FY 1986 - FY 1990. Department of Energy, Office of Conservation, Washington, D.C.

U.S. DOE. 1984b. Project Appraisal Input for FY86 Documentation of DE R and Technology Program Plan. Prepared for the U.S. Department of Energy, Office of Bulldings Energy Research and Development, by Pacific Northwest Laboratory, Richland, Washington. 
U.S. DOE. 1977. Comparative Study of the Energy Characteristics of Powered Hand Tools. SAN-1731-T2. Prepared for the U.S. Department of Energy, Office of Industrial Programs, by Varigas Research, Inc., Timonium, Maryland.

U.S. DOE. 1985. National Energy Policy Plan-V. Department of Energy, Office of Policy, Planning, and Analysis, Washington, D.C. 


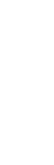

. 


\subsection{MARKET PENETRATION AND ENERGY SAVINGS ESTIMATION METHODOLOGY}

This chapter describes the methodology used in the study to 1) estimate the likely energy savings associated with each of the 10 technologies selected for further analysis and 2) compare the cost per kilowatt hour saved by each technology to the cost of new electrical generating plants.

An overview of the methodology for estimating future energy savings is provided in Figure 4.1. The four elements of Figure 4.1 are described in Sections $4.1-4.4$.

In Section 4.1 , the methodology used in the study for estimating the maximum market-penetration potential of conservation technologies is described. The general methodology for estimating the market sizes of the various conservation technologies is described in Section 4.2 . Section 4.3 describes the

Step 1 - Estimate maximum market-penetration potential of conservation technologies as a function of their payback period, their incremental first cost, and any technical factors that may limit their market-penetration potential

Step 2 - Estimate likely market penetration of conservation technologies in future years as a function of their maximum marketpenetration potential and their market adoption rates

Step 3 - Estimate the size of the markets where the conservation technologies could potentially be used and combine these estimates with the likely market-penetration estimates derived in Step 2 to forecast the number of applications where the technologies would be applied

Step 4 - Forecast electricity savings that will result from the use of the conservation technologies as a function of the number of applications where the technologies are likely to be applied under different market-penetration assumptions and differences in electricity use between the conservation technologies and the conventional technologies they are replacing

FIGURE 4.1. Flow Diagram of Electrical Savings Estimation Methodology Employed in this Study 
method used to derive estimates of the energy saving potential of the various technologies. Section 4.4 describes the elements of a sensitivity analysis of the impacts of a low market-penetration scenario and a high market-penetration scenario on conservation technology energy savings. Section 4.5 discusses assumptions and data sources used in the market analysis. The chapter concludes (in Section 4.6) with a discussion of the methodology used to compare the costs of energy savings from the various conservation technologies to the energy costs of new electrical generating plants. Note that the analysis considers only energy savings; because the load shape impacts of the technologies are not addressed in this study, we are not able to estimate the value of these savings to utilities.

\subsection{METHODOLOGY FOR ESTIMATING MARKET PENETRATION}

As illustrated in Figure 4.1, the market-penetration rates of the conservation technologies analyzed in this study are estimated as a function of their maximum market-penetration potential and their likely rates of market adoption (i.e., the rate at which they reach the maximum). This section describes how the "most likety" market-penetration rates are derived; the methods used to derive the low and high market-penetration estimates are presented in Section 4.4. A number of assumptions were necessary to derive estimates of the market-penetration rates and some of these assumptions are described in this section. However, the specific data assumptions used in the study for each of the conservation technologies are described later in the report.

\subsubsection{Estimating the Maximum Potential Market Penetration}

The maximum potential market penetration of a technology represents the highest percentage of the total market a technology is likely to achieve. Thus, as defined in this study, maximum potential market penetration estimates do not incorporate a time dimension. Most studies of the potential market penetration of a technology in a given application have found that the most important factor determining this potential is the cost-effectiveness of the technology (e.g. Mansfield 1961; Fliegal and Kivlin 1966). There are various methods of measuring this cost-effectiveness, including net present value, internal rate of return, simple payback and incremental first cost. 
Although discounted cash flow methods, such as net present value, are preferable in a theoretical sense, many studies have shown that a majority of potential purchasers of conservation technologies still use simple payback to determine whether they will undertake a conservation investment (Moore 1983 and Kastovich et al. 1982). In reference to conservation technologies, simple payback is the length of time required for the technologies to return capital investment through energy cost savings. Many potential investors will not purchase conservation technologies unless the payback period on their investment is less than three years (Moore 1983).

Various studies have shown that incremental first cost, as well as payback period, are important in determining the potential market for conservation technologies in the commercial and industrial sectors (Alliance To Save Energy 1984 and DOE/BERD 1984). Incremental first cost can be interpreted as the percentage increase in initial capital costs required for the purchase of a conservation technology rather than a conventional technology. Decision makers in the commercial and industrial sectors often indicate that, as a method of capital rationing, they will not purchase a conservation technology with significantly higher first costs than a conventional technology (Garrett-Price 1985).

In this study, the potential market penetration of the various conservation technologies are determined as a function of the payback period for each residential sector technology and percentage incremental first cost and payback period for each commercial and industrial sector technology. The equations used to calculate the payback period and incremental first cost for the conservation technologies were the following:

$$
\begin{gathered}
C A P=(C V-C N) / C N \\
P B=(C V-C N) /(P E S \times A E U \times E P)
\end{gathered}
$$

where

$$
\begin{aligned}
C A P= & \text { Percentage incremental capital cost (including installation costs) } \\
& \text { of the conservation technology compared to the existing technology } \\
C V= & \text { Capital cost of the conservation technology }
\end{aligned}
$$




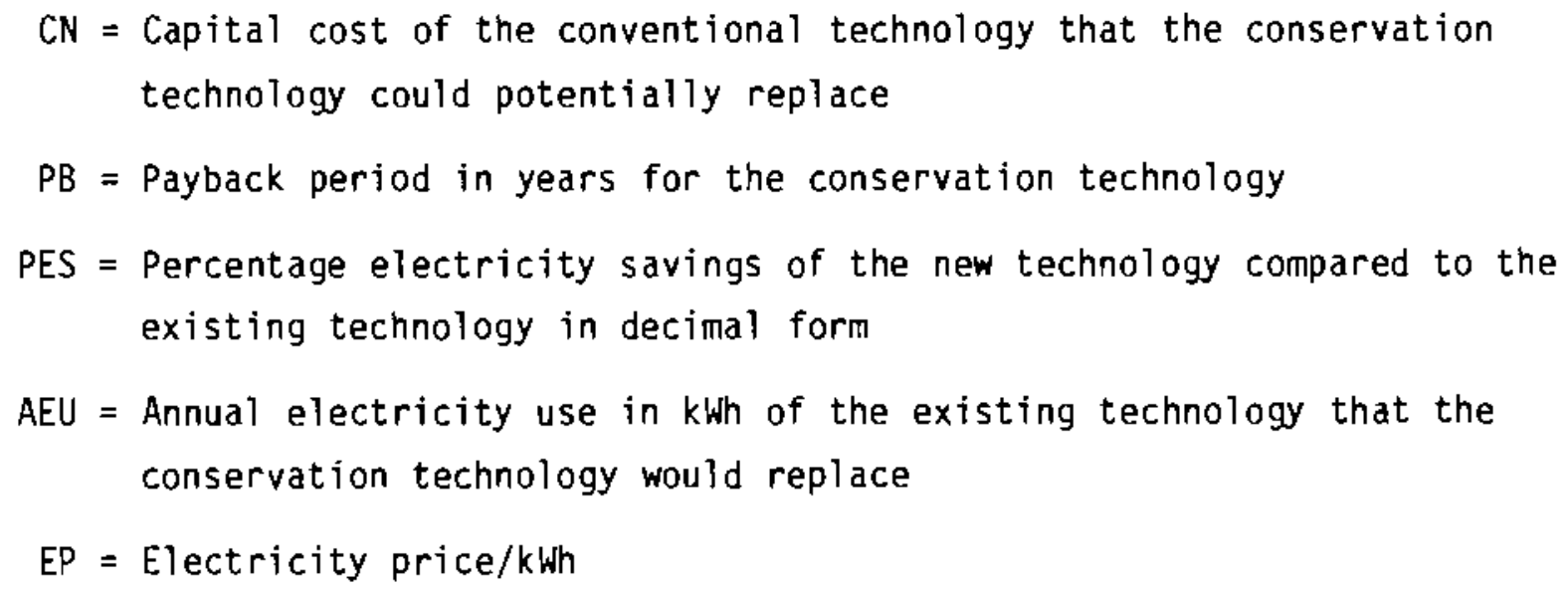

The numerator in both of the equations described above is the incremental capital cost of the conservation technology. This numerator will vary depending on whether the conservation technology is used in a new application, a retirement application, or a retrofit application. The differences between these applications are briefly described below.

For purposes of this study, a new application of a conservation technology is defined as an addition to the existing stock of the technology, while a retirement application represents a replacement of an existing technology that no longer operates properly. For example, an addition to the residential housing stock creates a potential new application of an advanced heat pump technology, while the replacement of a conventional HVAC system that no longer operates properly is a potential retirement application. The replacement of a conventional technology that is still operating properly with a conservation technology is a retrofit application.

In both new and retirement applications of a technology, it is assumed that the choice faced by a potential purchaser of a conservation technology is whether to purchase a conservation technology or purchase a conventionat technology. Thus, the payback period estimate for both new and retirement applications is based on the difference in capital costs between the two technologies. For example, if a conservation technology has an initial capital cost of $\$ 500$ and the conventional technology has an initial capital cost of $\$ 300$, then the numerator in the payback period and incremental first cost equations for new and retirement applications of the conservation technology would be $\$ 200$. 
In retrofit applications, calculation of the payback period is based on an assumption that the initial cost of the conventional technology is zero because it is a cost that has already been incurred. Thus, the numerator of the payback period and incremental first cost equations is equal to the total initial capital cost of the conservation technology. In the example described above, the numerator would be $\$ 500$ for all retrofit applications of the conservation technology. Note that because $\mathrm{CN}$ is zero in retrofit applications, it is not possible to calculate incremental capital cost using Equation 4.1 . In the chapters that follow, where retrofitting is technically possible, we substituted an estimate of incremental capital cost for new/retirement applications for this incalculable variable.

The denominator for all of the potential applications of the conservation technology is the estimated annual energy cost saving in dollars. Thus, because the numerator used in calculating payback period and incremental first cost for new and retirement applications is smaller than that used for retrofit applications, the payback period for retrofit applications will be longer.

This study will rely on the results of an empirical study that identified residential consumer payback period requirements (Kastovich et al. 1982) as the basis for deriving maximum potential market-penetration estinates. In Kastovich's study, several hundred residential home builders and owners were interviewed concerning whether they would purchase a conservation technology if the technology had a payback period equal to a specified number of years.

The interview results were compiled and percentages of builders and owners who stated they would purchase a conservation technology at various payback periods were calculated (e.g., 90 percent of home owners said they would purchase a heat pump if the payback period were one year or less). These percentages were used to represent a maximum potential market penetration that a conservation technology could achieve.

The market-penetration results obtained in Kastovich's study are shown in Table 4.1. These results are used directly in estimating the baseline maximum potential market penetration that the four residential conservation technologies selected for analysis in this study are likely to achieve. To account for 
TABLE 4.1. Maximum Potential Market Penetration of Residential Conservation Technologies Estimated as a Function
of Simple Payback

\begin{tabular}{|c|c|c|c|}
\hline \multirow[b]{2}{*}{ Simple } & \multirow[b]{2}{*}{ Payback, Years } & \multicolumn{2}{|c|}{ Penetration (b) } \\
\hline & & $\begin{array}{l}\text { Maximum Potential Market } \\
\text { New Installations (\%) }\end{array}$ & $\begin{array}{l}\text { Retrofit/Retirement } \\
\text { Installations \% } \\
\end{array}$ \\
\hline & 1 & 70 & 90 \\
\hline & 2 & 40 & 75 \\
\hline & 3 & 10 & 60 \\
\hline & 4 & & 45 \\
\hline & 5 & & 30 \\
\hline & 6 & & 20 \\
\hline & 7 & & 15 \\
\hline & 8 & & 10 \\
\hline & 9 & & 7.5 \\
\hline & 10 & & 7.5 \\
\hline & $>10$ & & 5 \\
\hline
\end{tabular}

(a) Source: Calculated directly from results of interviews of home builders and homeowners (Kastovich et al. 1982).

(b) Example interpretation of table is that if a residential conservation technology has a sample payback period of one year in new and retirement applications and three years in retrofit applications, its maximum potential market penetration will be 70 percent in new applications, 90 percent in retirement applications, and 60 percent in retrofit applications.

potential variance around the baseline estimates shown in Table 4.1 , a sensitivity analysis of the impacts was performed. The major elements of the sensitivity analysis are described in Section 4.4 .

The results shown in the second column of Table 4.1 are based upon the minimum payback requirements of new home builders. Thus, they are only applied to new applications of residential conservation technologies. The results shown in the third column of Table 4.1 are based on the minimum payback period requirements of existing home owners. Therefore, these results are applied to both retirement and retrofit applications of the conservation technologies. For example, if the calculated payback period for a residential technology is 
one year in new and retirement applications and three years in retrofit applications, then the maximum potential market penetration the technology woutd ever achieve is 70 percent in new applications, 90 percent in retirement applications and 60 percent in retrofit applications.

As stated above, empirical evidence suggests that incremental first cost, as well as payback period, are important in determining the potential market for conservation technologies in the commercial and industrial sectors. In a study performed for DOE/BERD, estimates of the interaction between incremental first cost and payback period in determining maximum potential market penetration were presented (DOE 1984a). These estimates are shown in Table 4.2. The estimates are used directly in specifying the baseline maximum potential market penetration of the commercial and industrial conservation technologies analyzed in this study. For example, if the percentage incremental first cost of a commercial conservation technology is 10 percent and the payback period is one year in new and retirement applications, then the maximum potential market

TABLE 4.2. Maximum Potential Market Penetration of Commercial and Industrial Conservation Technologies Estimated as a Function of Incremental First Cost and Simple Payback(b)

First Cost Percentage Increase (\%)

10

20

30

40

50
Simple Payback, Years

\begin{tabular}{|c|c|c|c|c|}
\hline$I$ & 2 & 3 & 4 & 5 \\
\hline $75 \%$ & $65 \%$ & $50 \%$ & $45 \%$ & $20 \%$ \\
\hline $50 \%$ & $45 \%$ & $40 \%$ & $30 \%$ & $10 \%$ \\
\hline $35 \%$ & $30 \%$ & $25 \%$ & $20 \%$ & $5 \%$ \\
\hline $30 \%$ & $25 \%$ & $15 \%$ & $10 \%$ & $0 \%$ \\
\hline $25 \%$ & $15 \%$ & $10 \%$ & $5 \%$ & $0 \%$ \\
\hline
\end{tabular}

(a) Source: Taken directly from results presented by DOE/BERD 1984.

(b) Example interpretation of table is that if a commercial or industrial conservation technology has a first cost percentage increase of 10 percent and a simple payback of one year, then its maximum potential market penetration will be 75 percent in both new and retirement installations. 
penetration of the technology in these applications is 75 percent. In the sensitivity analysis, the maximum potential market penetration of technologies in the industrial and commercial sectors was varied to evaluate the impacts on energy savings. The major elements of this analysis are described in Section 4.4 .

The estimates presented in Tables 4.1 and 4.2 are based on the payback of incremental costs, without regard for technical limitations that may preclude certain applications of a technology. For example, storage of heating and cooling in commercial building masses is only feasible in buildings with hollow-core construction; commercial buildings without hollow-core construction should be excluded from the population of buildings that could potentially use this conservation technology.

The maximum potential market penetration for each conservation technology was estimated in this study using the following equation:

$$
\text { MAXP = MPEN } \times(1-T L)
$$

where

$$
\begin{aligned}
\text { MAXP = } & \text { Maximum market penetration of each technology } \\
\text { MPEN = } & \text { Maximum market penetration (in decimal form) obtained from } \\
& \text { Tables } 4.1 \text { and } 4.2 \text { as a function of payback period and (for the } \\
& \text { commercial and industrial sectors) incremental first cost. } \\
\mathrm{TL}= & \text { Percentage of applications (in decimal form) where the use of a } \\
& \text { conservation technology would be technically infeasible }
\end{aligned}
$$

Only in cases where there was a strong basis for applying technical limits were such limits applied. Thus, the technical limits parameter (TL) was zero for many of the conservation technologies.

\subsubsection{Estimation of Market Adoption Rates}

The market penetration of a conservation technology is a time dependent parameter. No conservation technology is likely to reach its maximum potential 
market penetration in a period as short as one year. The speed at which a conservation technology reaches its maximum market penetration can be defined as its market adoption rate, and this rate is dependent upon many factors.

E. M. Rogers, a rural sociologist, hypothesized that the rate of market adoption of a new technology is dependent upon: 1) its relative advantage compared to a conventional technology, 2) its compatibility with existing methods, 3) its divisibility into small units, 4) its ease of communication, and 5) its complexity (Rogers 1962). Economists, including Mansfield (1961) and Griliches (1958), have identified several variables likely to influence the rate of market adoption including: 1) profitability, 2) costs relative to other alternatives, 3) risk (both economic and technical), and 4) size of initial investment relative to the average value of assets of firms in the industry.

It was not possible within the scope of this study to evaluate how the factors listed above might apply to the rate of market adoption of the various conservation technologies, except in a subjective fashion. However, it was possible to make use of empirical studies that demonstrate that an S-shaped curve will generally reflect the rate of market adoption of a conservation technology more accurately than other functions (Blackman 1972). An illustration of such an S-shaped curve is shown in Figure 4.2.

In this study, the market adoption rates for the various technologies will be assumed to reflect an S-shaped curve. Thus, the fastest growth in market penetration is assumed to occur in the middle years between the point of technology introduction and maximum market potential. In the early years of product introduction and in the later years when the maximum penetration is approached, market adoption is assumed to occur at a slower rate.

It is also assumed in the baseline analysis of this study that all of the conservation technologies will reach their maximum potential market penetration within 16 years, so that a technology that is currently available will reach its maximum potential market penetration by 2000. This assumption is consistent with several empirical studies of the rates of market adoption for various technologies (Blackman 1972). It is also consistent with assumptions used by DOE/BERD in forecasting the energy savings that will result from the use of 


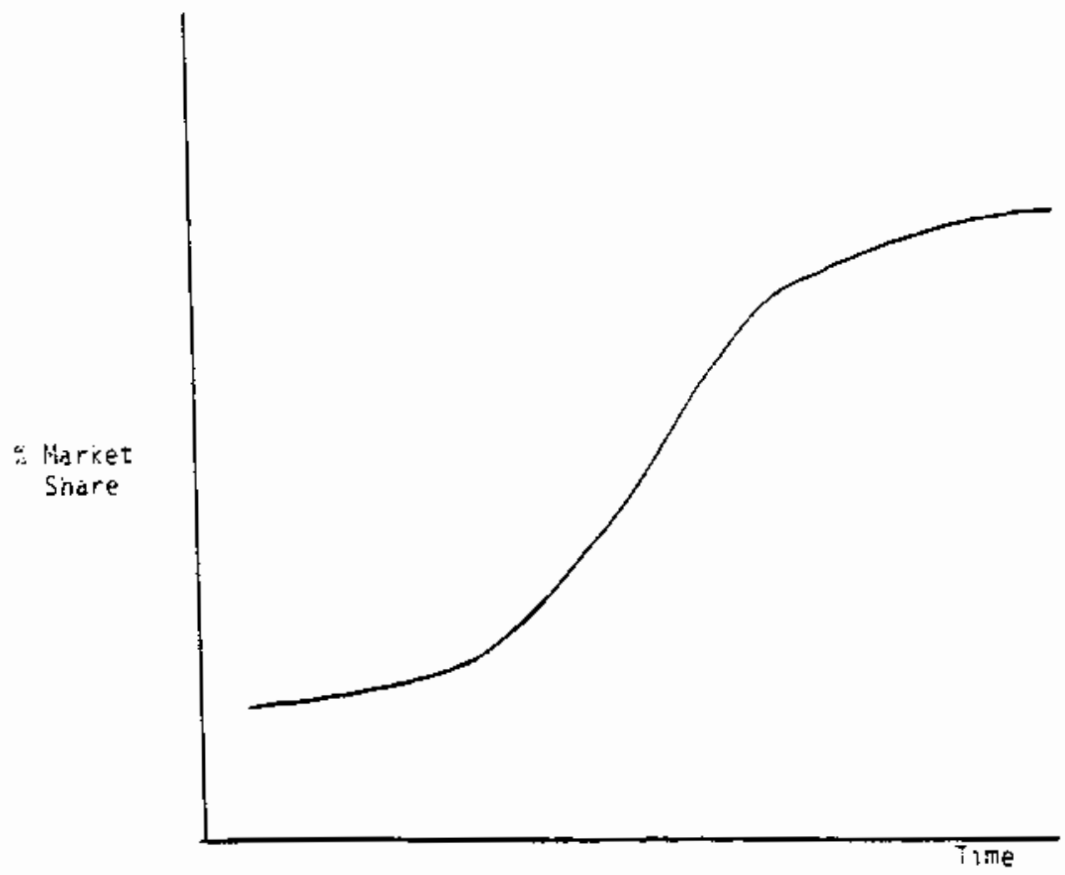

FIGURE 4.2. S-Shaped Market Adoption Curve

conservation technologies (DOE 1984a). However, to account for potential variations in the rates of market adoption of conservation technologies, a sensitivity analysis (described in Section 4.4) of the impacts on technology energy savings of varying these rates was performed.

Using the empirically based assumption of an S-shaped market adoption curve and the baseline analysis assumption that the maximum potential market penetration would be reached by the year 2000, the usage of conservation technologies was phased in over time. This procedure was performed by interpolating, using an S-shaped function similar to the one illustrated in Figure 4.2, between the estimated level of the current market penetration of a conservation technology and the maximum-potential market penetration estimated from Equation 4.3. For example, suppose the current market penetration of a conservation technology is estimated to be 1 percent and its maximum market penetration was estimated from Equation 4.3 to be 5 percent. The penetration rate would therefore increase 4 percent between 1984 and 2000. The market penetration of the technology could then be assumed to grow at a rate of 0.2 percent a year during the first five years (to 2.0 percent in 1989), 0.3 percent a year during 
the next nine years (to 4.7 percent in 1995), and 0.15 percent during the last two years (to 5.0 percent in 2000). The specific levels of market penetration assumed for the conservation technologies in all years of the forecast period (1984 to 2000) are presented in tables in each of the chapters of this report.

\subsection{MARKET SIZE ESTIMATION METHODOLOGY}

Estimation of the size of the market in which each of the conservation technologies would be applied was performed using estimates of the existing stock, forecasts of the future stock, and assumed retirement rates for the conventional technology. Each of these elements are described in this section.

\subsubsection{Existing Stock Estimation}

In this study, existing stocks of conventional electricity consuming technologies are calculated using published estimates of the number of units of the conventional technology that currently exist and estimates of the percentages of these units that use electricity. Thus, the equation used to derive estimates of the existing stock of the conventional technology was the following:

$$
E X S=P O P \times P E
$$

where

$$
\begin{aligned}
\text { EXS = } & \text { Existing stock of conventional technology that uses electricity } \\
P O P= & \text { Published estimate of the total number of existing units of the } \\
& \text { conventional technology } \\
P E= & \text { Percentage of the total number of units of the conventional } \\
& \text { technology that use electricity }
\end{aligned}
$$

An example of an estimate used to represent the total number of units of a conventional technology $(P O P)$ is the number of single-family residences. This estimate is used to represent the variable POP for all of the residential conservation technologies. An example of an estimate used to represent the percentage of the total number of units that use electricity (PE) is the percentage of single-family residences that use electric water heaters. Because 
the estimates used in Equation 4.4 vary from one conservation technology to another, they are discussed in detajl in the chapters pertaining to each of the individual technologies.

\subsubsection{New Stock Estimation}

New stocks of the conventional electricity consuming technology are also derived from published estimates. Estimation of new stocks of the conventional technology was performed using the following equation:

$$
N W S_{i}=F O R_{i} \times P E
$$

where

$$
\begin{aligned}
\text { NWS }_{i}= & \text { New stock of conventional technology that uses electricity in } \\
& \text { year } i \text {, where } i=1985 \text { to } 2000 \\
\text { FOR }_{i}= & \text { Published forecast of the total number of additions to the stock } \\
& \text { on the conventional technology in year } i
\end{aligned}
$$

An example of the variable $\mathrm{FOR}_{j}$ is a published estimate of additions to the residential housing stock in 1985. Note that the variable PE in Equation 4.5 is the same one used in Equation 4.4. Thus, in this study, it is assumed that the percentages of the total forecast number of new conventional technologies that used electricity are fixed at current estimated levels.

\subsubsection{Retirement Stock Estimation}

Retirement stocks are estimated as a function of the total number of existing units of a conventional technology, the percentage of these units that use electricity, and the expected lifetime of the conservation technology. The equation to calculate retirement stocks is the following:

$$
R S_{i}=(E X S / E L) \times P E
$$


where

$\mathrm{RS}_{j}=$ Number of units of the conventional technology that use electricity retired in year $i$, where $i=1984-2000$

$E L=$ Expected life of the conventional technology obtained from published studies

For conservation technologies that represent an add-on rather that a replacement of a conventional technology (i.e. solar water heating systems), the retirement of the conventional technology should not affect the rate of usage of the conservation technology. Thus, for add-on technologies, the net retirements of the conventional technology were assumed to be zero. 4.2.4 Forecasting the Number of Units of the New Technology

In this study, forecasts of the number of units of the new technology that will be in use in future years are obtained by integrating the likely market penetration rates for the new technology with estimates of the stocks of the conventional technology. The following three equations were used to develop these forecasts:

$$
\begin{aligned}
& \mathrm{ANU}_{n}=\sum_{i=1984}^{n} \mathrm{NWS}_{i} \times \mathrm{MPN}_{i} \\
& \mathrm{ARU}_{n}=\sum_{i=1984}^{n} \mathrm{RS}_{i} \times \mathrm{MPR}_{i} \\
& \mathrm{EU}_{n}=\left(E S-\mathrm{ARU}_{n}\right) \times \mathrm{MPE}_{i}
\end{aligned}
$$

where

$$
\begin{aligned}
\mathrm{ANU}_{\mathrm{n}}= & \text { Aggregate number of units of a conservation technology that will be } \\
& \text { installed in new applications in forecast year } n \text {, where } n=1985, \\
& 1990,1995, \text { and } 2000 \\
M^{\prime}= & \text { Likely level of market penetration of a conservation technology in } \\
& \text { new applications in year } i \text {, where } i=1984 \text { to } 2000
\end{aligned}
$$




$$
\begin{aligned}
\text { ARU }_{n}= & \text { Aggregate number of units of a conservation technology that will be } \\
& \text { installed in retirement applications in forecast year } n \text {, where } n= \\
& 1985,1990,1995 \text { and } 2000 \\
M_{i}= & \text { Likely level of market penetration of a conservation technology in } \\
& \text { retirement applications in year } i \text {, where } i=1984 \text { to } 2000 \\
E U_{n}= & \text { Number of units of a conservation technology that will be installed } \\
& \text { in retrofit applications in forecast year } n \text {, where } n=1985,1990, \\
& 1995 \text { and } 2000 \\
& \text { MPE } i= \\
& \text { Likely level of market penetration of a conservation technology in } \\
& \text { applications in year } i \text {, where } i=1984 \text { to } 2000
\end{aligned}
$$

The market penetration variables used in the above equations obtained by integrating the results derived from Equation 4.3 with information about the likely rate of market adoption for each of the conservation technologies. Note that because the number of new and retirement applications are changing every year, it is necessary to aggregate the annual unit estimates to obtain an estimate of the total number of units that will use the technology in new and retirement applications between the beginning of the current year and the selected forecast years.

When an existing unit of a conventional technology is assumed to be retired because it is no longer operable, it is subtracted from the existing stock of the technology and added to the retirement stock. This does not change the total number of applications where the conservation technology could potentially be applied. However, it does allow for the rate of market penetration to change depending on whether the existing conventional technology is retired or whether retrofitting is being considered for reasons of energy cost savings alone.

\subsection{ENERGY SAVINGS ESTIMATION METHODOLOGY}

Once forecasts of the number of units that would use the conservation technologies in the various forecast years were obtained, the energy savings potentials of the technologies were calculated using the following equation: 


$$
E S V_{n}=\left(A N U_{n}+A R U_{n}+E U_{n}\right) \times(P E S \times A E U)
$$

where

$$
\begin{aligned}
E S V_{n}= & \text { Forecast energy savings for a conservation technology in forecast } \\
& \text { year } n, n=1985,1990,1995 \text { and } 2000 \\
\text { PES = } & \text { Percentage electricity savings of the new technology compared to } \\
& \text { the existing technology in decimal form } \\
A E U= & \text { Annual electricity use in kWh of the existing technology that the } \\
& \text { conservation technology would replace }
\end{aligned}
$$

A number of assumptions were necessary to forecast energy savings potential using the Equations 4.1 to 4.10 . These assumptions are described as part of the individual market analyses of the conservation technologies.

\subsection{SENSITIVITY ANALYSIS OF ESTIMATED ENERGY SAVINGS}

As previously indicated, a number of factors will influence the electrical energy savings that are likely to be obtained from the use of conservation technologies. Among these factors are the capital and operating costs of the technologies, their energy savings abilities, the maximum market penetration they will achieve, and the rate at which they will reach their maximum market penetration. All of the factors that could influence the energy savings of the various conservation technologies are subject to significant uncertainty. Two of the most important and most uncertain factors appear to be the level of the maximum market penetration the technologies will achieve and the rate at which this maximum is reached. Thus, these two factors were incorporated into a sensitivity analysis of the estimated energy savings for the various conservation technologies.

The major elements of the sensitivity analysis performed on the various conservation technologies were the following:

- a low scenario was implemented, which assumed that the maximum potential market penetration of each conservation technology was half of 
the value obtained from Table 4.1 or 4.2 and that a slower rate of market adoption would result in only 75 percent of the maximum potential market penetration being reached by 2000 ;

- a high scenario was implemented, which assumed that the maximum potential market penetration of each conservation technology was twice as large as the value obtained from Table 4.1 or 4.2 and that a faster rate of market adoption would result in the maximum potential market penetration being reached by 1995.

For some of the conservation technologies, the elements of the sensitivity analysis were modified from those listed above to account for such factors as technical limitations to the widespread use of a technology, the late introduction of the technology several years into the forecast period, and maximum potential market penetration rates that when doubled would exceed 100 percent. These modifications are described in more detail in the chapters of this report that present the results of the sensitivity analysis for each of the selected conservation technologies.

\subsection{INPUT ASSUMPTIONS AND DATA SOURCES}

In order to estimate likely energy savings attributable to technologies addressed in this study, it was necessary to make assumptions about several key inputs. This section discusses general input assumptions used along with their sources and reasons they were chosen. More specific input assumptions, relevant to only ore or two conservation technologies, are not included here, but are discussed in the individual market analysis of each technology. Table 4.3 summarizes the common input assumptions and their sources.

\subsubsection{Electricity Prices}

For most people, the principle motivating factor for the adoption and installation of energy conservation technologies is to save money. The level of expected cost savings is a key factor in an end user's decision on whether or not to invest in a conservation technology. As the level of savings is directly related to the price of the energy saved, it was important to choose representative electricity prices. 
TABLE 4.3. Common Input Assumptions

\begin{tabular}{|c|c|c|}
\hline As sumption & Source & Comments \\
\hline Electricity Price & $\frac{\frac{\text { Annual Energy }}{\text { Review 1983 }}}{\text { (D0E 1984) }}$ & $\begin{array}{l}\text { Residential } 7.18 \$ / \mathrm{kWh} \\
\text { Commercial } 7.01 \$ / \mathrm{kWh} \\
\text { Industrial } 4.9 \$ / \mathrm{kWh}\end{array}$ \\
\hline Housing Stock & $\frac{\text { Energy Projections }}{\text { to the Year } 2000}$ & $\begin{array}{l}\text { Estimates provided for } \\
1985,1990,1995 \text { and } 2000 . \\
\text { Estimates derived using assumed } \\
2 \% \text { annual growth rate. }\end{array}$ \\
\hline $\begin{array}{l}\text { Commercial } \\
\text { Floorspace }\end{array}$ & $\frac{\frac{\text { Annual Energy }}{\text { Out look } 1983}}{\text { (D0E } 1984)}$ & $\begin{array}{l}\text { Floorspace estimate in } \\
\text { square footage provided for } \\
1983-1990 \text { and for } 1995 \text {. Estimates } \\
\text { for other years derived using } \\
\text { an assumed } 2 \% \text { annual growth rate. }\end{array}$ \\
\hline Motor Populations & $\begin{array}{l}\text { Classification and } \\
\text { Evaluation of } \\
\text { Electric Motors }\end{array}$ & $\begin{array}{l}\text { Estimates presented for } 1978 \text {. } \\
\text { Estimates for study time frame } \\
\text { derived assuming constant } \\
\text { annual motor additions and } \\
\text { retirement. }\end{array}$ \\
\hline
\end{tabular}

Prices of $7.84 \% / \mathrm{kWh}$ for the residential sector, $7.01 \% / \mathrm{kWh}$ for the commercial sector, and $4.97 \% / \mathrm{kWh}$ for the industrial sector from the Annual Energy Review 1983 (OOE 1984) were chosen as being the most reliable. These represent the average price of electricity sold by the electric utility industry for 1983. Prices for 1983 were used since they were the most current during the time this study was undertaken.

Real prices for electricity are assumed to remain constant for the 19842000 timeframe. This is consistent with the projections DOE/EIA published in the Annual Energy Out look for 1984 (DOE 1985), which indicate that real electricity prices are expected to remain stable or decline slightly throughout the forecast period. Except as noted, all prices other than those for electricity quoted in this study are in 1984 dollars.

\subsubsection{Residential Sector Assumptions}

A good indication of future residential energy use activity is projected housing stock. Estimates of residential housing stock are based on NEPP data published in Energy Projections to the Year 2010 (OOE 1983). Based on the 
point estimates given for the years 1985, 1990, 1995 and 2000, projections were interpolated for other years within the study timeframe using the 2 percent annual housing growth rate cited in that report.

Within our analysis, new housing is assumed to be equivalent to the incremental difference between the current year's housing stock and the previous year's housing stock. There is assumed to be no housing stock retirement.

Estimates of household fuel shares for specific uses and percentages of households employing certain appliances were derived from the 1982 Residential Energy Consumption Survey (DOE 1983). The estimates derived from the survey are further assumed to remain constant through the year 2000.

\subsubsection{Commercial Sector Assumptions}

Due to the great variance in the size and type of commercial buildings, actual population figures alone may not be sufficient to give a clear indication of the level of comercial activity. Subsequently a better indication of commercial activity, total commercial floorspace, was chosen. Projections of total commercial floorspace are based on estimates reported in the Annual Energy Outlook 1983 (DOE 1984). Using the estimates provided for the years 1983-1990 and 1995, estimates were interpolated for 1991-1994 and extrapolated to 2000 assuming a 2 percent annual growth rate. New commercial floorspace is estimated as the incremental difference between estimates for consecutive years. Floorspace retirement is assumed to be zero.

\subsubsection{Industrial Sector Assumptions}

Population estimates for electric motors used in analysis of high efficiency motors and alternate speed motor drives were taken from data prepared by Argonne National Laboratory (ANL) for DOE in 1980. These estimates are based on motor populations for 1978. In our analysis we assume that there has been no growth between the 1978 and 1984 motor populations and that for the years 1985 and 2000, new additions and unit retirements occur at a fixed annual amount.

Detailed information on input assumptions and data sources used for our market analysis of electrolytic processes is presented in the chapter devoted to that topic. 


\subsection{ENERGY COST ESTIMATION METHODOLOGY}

The demand for electrical energy is expected to grow in the future. To meet that growth demand, there are two primary utility investment alternatives that have been receiving consideration. One alternative is for utilities to invest in new electricity-generating capacity. The other alternative is for utilities to invest in (i.e., subsidize the installation of) conservation measures so as to make better use of the electricity-generating capacity that al ready exists. This section is a description of the methodology used to compare these alternatives on the basis of their respective levelized cost/kwh of electricity either produced or saved.

\subsubsection{Cost/kWh of New Electricity Generating Capacity}

The principal types of new electricity-generating units scheduled to become operational over the next 10 years are nuclear and coal-fired power plants (Smolen et al. 1983). The estimated regional costs to the consumer of the electricity produced by coal power plants is presented in Table 4.4, and the $10 \mathrm{OOE}$ regions are shown in Figure 4.3. In general, these costs are calculated by estimating the levelized (i.e., discounted) annual capital costs associated with the power plants, adding these costs to the estimated annual variable costs of the power plants (i.e., fuel, labor, etc.) and dividing the sum of the two costs by the expected annual kWh production of the plants. For purposes of the comparisons performed in this study, we chose to use the weighted national average cost for new coal generation of $5.21 \% / \mathrm{kWh}$. The nationwide average for new nuclear generating capacity on a per kwh basis is estimated to be a much higher $6.58 \% / \mathrm{kWh}^{(\mathrm{a})}$. In comparing the cost of each of the 10 technologies to the cost of building new generating capacity, we chose to use the estimated average cost for coal capacity. This was done because present conditions indicate that capacity additions in the timeframe of this study are more likely to be coal-fired than nuclear-fired.

(a) The estimated cost of new nuclear powered generating capacity was calculated using a number of EIA models. These costs include fuel at $0.71 \$ / \mathrm{kWh}$ from the levelized Nuclear Fuel Cycle cost model, decomissioning costs at $0.04 \$ / \mathrm{kWh}$, operating and maintenance at $0.63 \$ / \mathrm{kWh}$ from the OMCOST Model, and capital costs of $4.70 \% / \mathrm{kWh}$ estimated by the CONCEPT Model. T\&0 costs are assumed to be $0.5 \$ / \mathrm{kWh}$, the same for coal generated capacity. 
TA8LE 4.4. Regional Costs of New Coal Capacity ( $\$ / \mathrm{kWh}$, constant 1984 dollars)

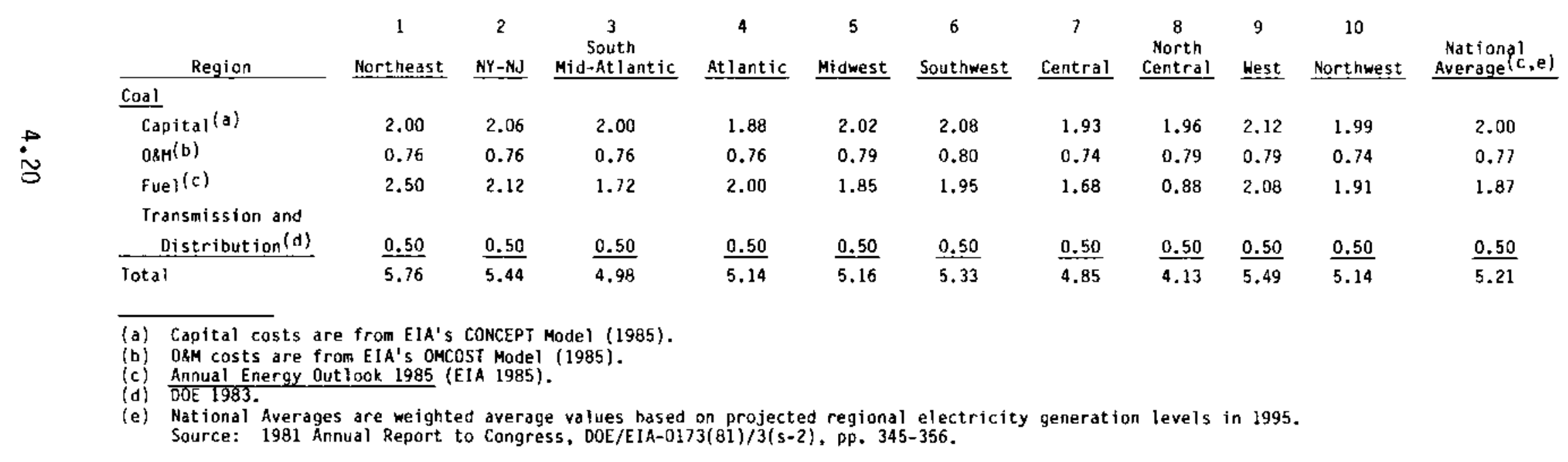




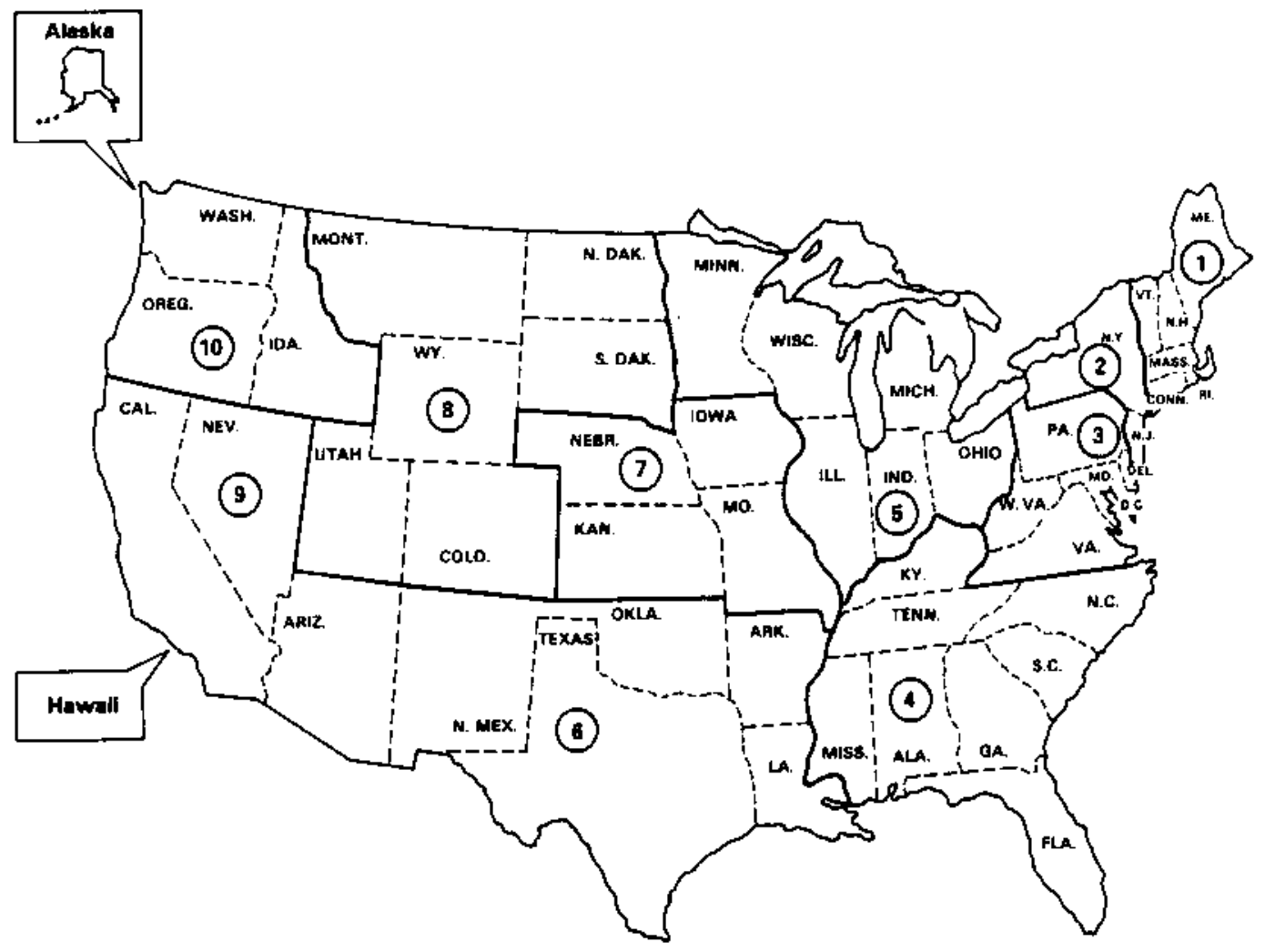

FIGURE 4.3. The 10 DOE Regions of the United States

\subsubsection{Cost/kwh of New Conservation Technologies}

Each of the 10 conservation technologies discussed in Chapters 5.0 through 14.0 is an investment in reducing future electricity consumption. Therefore, it is possible to estimate the levelized cost per kWh of electricity saved by such investments. To do this, the incremental capital cost of each technology is converted to a discounted annual cost and then divided by the annual kWh savings expected to be obtained from the technology.

$$
C_{j}=\left[\left(C V_{j}-C N_{j}\right)\left(\frac{d(1+d)^{n}}{(1+d)^{n}-1}\right)\right] \quad E S A_{j}
$$

where

$$
\begin{aligned}
C C_{j}= & \text { the levelized cost per } k \text { Wh saved for the conservation technology } j \\
C V_{j}= & \text { the capital cost of the conservation technology } j \\
C N_{i}= & \text { the capital cost of the conventional technology } i \text { that the conser }- \\
& \text { vation technology } j \text { would replace }
\end{aligned}
$$




$$
\begin{aligned}
E S S A_{j}= & \text { the electricity saved annually by conservation technology } j \\
d= & \text { the real discount rate used to levelize the incremental capital } \\
& \text { costs of conservation technology } j \\
n= & \text { the useful lifetime in years of conservation technology } j ;
\end{aligned}
$$

The term in brackets in the equation presented above is a method for converting the present value of the incremental capital costs of the conservation technologies to a discounted stream of annual payments. In principle, these payments can be regarded as being similar to equal mortgage payments that are used to amortize the debt on a home or other type of property. Use of the above equation allows for the cost/kwh saved by conservation technologies and the costs/kWh produced by new generating plants to be compared on a consistent basis.

Estimates of the discounted, levelized cost/kWh saved for the various conservation technologies were calculated using an eight percent real discount rate. This rate was selected as an approximation of the real cost of capital to utilities, and it yields estimates that may be regarded as "minimal" or floor estimates. In many cases, electricity users would supply some or all of the capital required, at some higher real rate of interest. The 8 percent rate was calculated by subtracting an average future inflation rate of 5 percent from a representative long-term utility bond interest rate of 13 percent (Wall Street Journal, 1985).

4.6.3 Cost Comparisons: New Generation Capacity versus Conservation Measures

Following estimation of the cost/kWh saved for each technology, a direct comparison can be made between those costs and either the projected regional costs or the projected national average cost/kWh of new coal fired generating capacity. For conservation technologies that, on either a regional or national basis, are less costly than new power plants, it is feasible for utilities to invest in the technologies to save power rather than investing in power plants to produce electricity. Note, however, that an estimate of a conservation technology's nationally representative cost/k wh saved may be significantly different from an estimate of the cost/kWh saved in a utility service area. Such differences are especially likely for residential and commercial space heating 
and cooling technologies because energy loads for heating and cooling vary considerably from region to region. Much analysis at the utility level is required to identify an economically optimal portfolio of utility investments.

The estimated cost per $k$ Wh saved should serve as a general guide. Actual costs/kWh saved for the technologies in specific applications could vary considerably from the values estimated.

\subsection{REFERENCES FOR CHAPTER 4.0}

Alliance to Save Energy. 1984. Industrial Investment in Energy Efficiency: Opportunities, Management Practices, and Tax Incentives. Alliance to Save Energy, Washington, D.C.

Blackman, A. Wade Jr. 1972. "A Mathematical Model for Trend Forecasts." Technological Forecasting and Social Change. Volume 3, Number 4.

Fliegal, F. C., and J. E. Kivlin. 1966. "Attributes of Innovations as Factors in Diffusion." The American Journal of Sociology. 72:235-248.

Garrett-Price, B. A. 1985. Potential for Energy Conservation in the Cement Industry. PNL -5330. Pacific Northwest Laboratory, Richland Washington.

Griliches, 2. 1958. "Research Costs and Social Returns: Hybrid Corn and Related Innovations." Journal of Political Economy. 5:419-431.

Kastovich, J. E., R. R. Lawrence, R. R. Hoffman, and C. Pavlak. 1982. Advanced Electric Heat Pump Market and Business Analysis. ORNL/Sub/79-24712/1. Report prepared by Westinghouse Electric Corporation for Oak Ridge National Laboratory, Oak Ridge, Tennessee.

Mansfield, E. 1961. "Technical Change and the Rate of Imitation." Econometrica. 29:741-766.

Moore, N. L. 1983. State-of-the Art of Furnace Recuperation in the Primary Metals Industry: Technical Briefing Report. PNL-4803. Pacific Northwest Laboratory, Richland, Washington.

Rogers, E. M. 1962. Diffusion of Innovations. The Free Press, New York.

Smolen, G. R. et al. 1983. Regional Projections of Nuclear and Fossil Electric Power Generation Costs. ORNL/TM-8958. Oak Ridge National Laboratory, Oak Ridge, Tennessee.

U.S. 00E. 1982. 1981 Annual Report to Congress. Department of Energy, Washington, $0 . C$. 
U.S. O0E. 1984a. Project Appraisal for Office of Buildings Energy Research Development. Department of Energy, Office of Buildings Energy Research and 


\subsection{ADVANCED HEAT PUMP TECHNOLOGIES}

In this chapter we estimate the potential national savings of electricity for the years 1985 to 2000 due to recent improvements in heat pump (HP) systems for residential space conditioning. Of specific interest are the potential savings from the new high efficiency, electric water-to-air and gas-fired heat pump systems.

In terms of their efficiency and cost-effectiveness, these advanced heat pumps (AHPS) have emerged as a reasonable alternative in the residential heating, ventilating, and air conditioning (HVAC) market. They typically use 50 to 75 percent less electrical energy than conventional electric resistance (ER) HVAC systems use to produce the same heating and cooling services. In addition, purchase and installation costs are considered low enough to make AHPs economically viable alternatives in the residential HVAC market. Hence, to the degree that these advanced HPS capture some share of the future HVAC market they will conserve electrical energy.

This analysis begins with a brief review of the technical background of heat pump systems in Section 5.1. Section 5.2 describes the present and the expected future conditions of the residential HVAC market. Section 5.3 deals with the issues of cost-effectiveness and of estimating the potential for new heat pump systems to penetrate the HVAC market. In Section 5.4., the estimates of market penetration of Section 5.3 are applied to housing stock data and forecasts to obtain estimates of future yearly installations of new-technology heat pumps. Section 5.5 presents the estimates of the maximum potential for annual savings of electrical energy due to the new residential heat pump technologies by the years 1990, 1995, and 2000, along with a brief discussion of those results. Section 5.6 is an analysis of the sensitivity of the results to changes in the market-penetration scenarios. Finally, Section 5.7 presents the estimated cost/kwh saved by the new heat pumps and discusses how those costs compare with the cost/kwh of new electrical generating capacity. 


\subsection{TECHNICAL BACKGROUND}

The history of heat pump technology begins in 1850 with an Irishman by the name of Lord Kelvin. By combining and applying several different but related physical principles he developed what he was to call a "heat multiplier." That system was to become the forerunner of the heat pump systems of today.

To understand how heat pump systems work to save energy one must first understand those same basic physical principles put to use by Lord Kelvin. Those principles are 1) some heat exists in any matter until it reaches the ultimate low temperature of $-460^{\circ} \mathrm{F}$ or $-273^{\circ} \mathrm{C}$, 2) heat aiways flows from a warmer element to a cooler element, 3) compressing a gas causes its temperature to rise while expanding it causes it to cool, 4) heat is absorbed when a liquid evaporates and is released again when the vapor condenses, and 5) both temperature and pressure influence whether a refrigerant (i.e., a liquid that boils at a low temperature) is in its liquid or gas phase. (a)

Modern heat pump systems work by circulating a refrigerant continuously in a closed cycle while alternately and strategically compressing and expanding it. The expanded and cooled refrigerant picks up heat from a source (typically air or water) via an evaporator and then, when compressed, releases that captured heat to a more desired location via a condenser. The only energy input for heat pump systems is that which is used to operate a motor driven fan and a compressor. The compressor both propels the refrigerant through the system and creates pressure changes to either enhance the evaporation (heat absorption) or the condensation (heat release) of the refrigerant. Such systems are reversible so that heat can be pumped indoors during winter or outdoors during summer.

At present, the most common heat pump HVAC system is the electric air-toair system. Such systems are now capturing about 50 percent of the market for new electric installations and have al ready captured up to 25 percent of the total residential electric HVAC market (DOE 1984 and Cairns 1984).

(a) See McGuigan 1982, Nesbit 1984, and OECD 1982. 
The new water-to-air heat pump models are about 25 percent more efficient than the air-to-air units (McGuigan 1982) because a water source (i.e., a well, lake, river, ocean, or municipal water system) usually has a higher temperature than winter air and a lower temperature than summer air, so it can better serve as a source or receptor of heat. In short, with the new water-to-air heat pump more heat can be pumped with less system effort.

Gas heat pump models, driven by a gas-fired motor, are currently under development. Such systems, although less efficient then electric systems, are expected to be cheaper to operate because gas is about one-third the cost of electricity per unit of equivalent energy. (a)

\subsection{CURRENT MARKET SITUATION}

By the mid 1960s, it became apparent that first generation HPs, introduced over the previous decade, were plagued with problems and design flaws. Thus, the electric resistance HVAC systems captured the major market share. By the mid-1970s, the design flaws of the earlier HP models had been remedied and the energy saving potential of HP systems became more important in the marketplace. Consequently, electric air-to-air HPs have made significant gains in the residential space conditioning market in recent years.

Of the new generation electric water-to-air and the gas-fired HP models, only the electric water-to-air systems are presently being actively marketed. An estimated 115,000 water-to-air type systems are currently in use, which is less than one percent of the residential electric HVAC market. (b) However, these advanced HP systems are becoming more popular. (c)

(a) The present national average price for natural gas is about $63 \$ /$ therm of energy (DOE 1984) which when converted into an energy equivalent number of $\mathrm{kWhs}$, is comparable to about $2.4 \$ / \mathrm{kWh}$. This compares to the current national average residential electricity price of $7.18 \% / \mathrm{kWh}$.

(b) Estimates were obtained via a phone conversation with a representative of the Air-Conditioning Research Institute.

(c) See McGuigan, 1982 and according to phone conversations with representatives of the Singer Company - Climate Control Division and others. 
Gas-fired heat pumps are not currently comnercially available in the United States, but are receiving large expenditures for development. (a) They could be comercially available and competitive by the late 1980s or early 1990s. Specifically, the anticipated market potential for gas-fired heat pump systems ranges from a moderate market share to a near domination of the market by the year 2000 (GRIO 1983).

\subsection{COST EFFECTIVENESS AND MARKET PENETRATION}

In this section, the cost-effectiveness of the new electric water-to-air and gas-fired heat pump technologies are estimated. As an extension of the cost-effectiveness analysis, a projection of the likely market share of each alternative at a given point in time can be obtained (see Chapter 4).

\subsubsection{Cost Effectiveness}

The primary competitors of the new HP technologies are electric resistance (ER) HVAC systems and electric air-to-air (ATA) HP systems. At present, the existing electric HVAC stock (i.e., in existing homes) is about 75 percent ERtype systems and about 25 percent ATA heat pump systems. The new installation electric HVAC markat mix is about 50 percent ER systems and 50 percent ATA heat pump systems. The ATA heat pump systems typically have a somewhat higher initial capital cost and a somewhat lower cost of operation than ER systems. Appropriate consideration must be given to these facts when a representative scenario of initial capital and operation cost figures are selected for a base case "conventional" HVAC unit. In light of this, a representative figure for the installed capital cost of a base case conventional HVAC unit is assumed to be $\$ 2900$. Likewise, the installed capital cost figures representative of the electric water-to-air (with an available water supply) and the gas-fired heat pump systems were, respectively, $\$ 4100$ and $\$ 4200$. (b)

(a) See Chan 1984, Hlawiczka 1984, Kawamoto 1984, Nakatani 1984, and Tanaka 1984.

(b) The figures for the conventional HVAC unit and for the electric water-toair heat pump were obtained from (McGuigan 1982). The acceptability of those figures was confirmed via several informal telephone conversations with relevant market vendors. The figure for the gas-fired heat pump unit was obtained from Itteilag and Swanson (1984). 
The efficiency gain achievable by employing the new technology can be determined by comparing the "seasonal performance factor" (SPF) of the new technology to that of the conventional technology. The SPF is a measure specifically designed for such direct comparisons. That is, because comparisons of HVAC energy efficiency are typically made against a standard conventional HVAC system, the SPF was defined to equal 1.0 for those systems. Hence, if an alternative system had a SPF of 2.0, that syster would use just half of the energy required by a conventional unit to produce the same output of heating or cooling services.

The SPF measure employs the word "seasonal" because HVAC efficiencies vary from season to season as well as from region to region. Accounting for all such variations in efficiency levels is beyond the scope of the present analysis, so that it will be assumed that there is only one average or representative national SPF for each of the technologies. The national SPF value selected to be representative of electric water-to-air heat pump systems is 3.0 in both heating and cooling modes of their application. This value was chosen based on the approximate average of values reported by major U.S. manufacturers. (a) For the gas-fired heat pumps, that figure is 1.5 for heating and 1.0 for cooling (but recall that gas provides the same energy input at one-third the cost of electricity at present prices).(b)

The consumption of electricity for home heating and cooling purposes varies greatly from region to region. Attempting to account for all such variations in this analysis would be prohibitively costly. Again, representative national average figures were employed here for analytical simplicity. Specifically, it will be assumed that the average electrically heated home uses approximately $5900 \mathrm{kWh} / \mathrm{yr}$ for heating and that the average electrically cooled home uses approximately $2300 \mathrm{kWh} / \mathrm{yr}$ for cooling. (c) Using these figures and the national average price of electricity for 1983 of $7.18 \$ / \mathrm{kWh}$ (DOE 1984), the

(a) See the "Manufacturers Index" of McGuigan (1982).

(b) For the SPF estimates of a representative gas-fired heat pump system, see the "intermediate case" in Itteilag and Swanson (1984).

(c) The rounded figures very closely approximate an average figure computed from residential energy consumption information found in DOE/EIA (1984). 
average electrically space-conditioned household which uses the conventional HVAC technology would (on average) spend approximately $\$ 420 / y r$ on electricity for heating and about $\$ 165 / y r$ on electricity for cooling.

In a new house or for the replacement of a worn-out HVAC system (i.e., in a retirement application), the installation of an electric water-to-air heat pump system in lieu of a conventional HVAC will initially cost the purchaser an additional $\$ 1200$. (a) However, a water-to-air heat pump uses only about onethird as much electricity as a conventional HVAC system. Because of its greater efficiency, the water-to-air heat pump system would save approximately $\$ 280 / y r$ in electrical heating costs and approximately $\$ 110 / y r$ in electrical cooling costs for an average annual electricity cost savings of approximately $\$ 390$. Therefore, the estimated payback period for installing an electric water-to-air heat pump system in a new house, assuming free access to an existing water supply is a little more than 3 years. (b)

If a consumer was to consider the benefits of retrofitting an existing conventional HVAC system (i.e., one that still has its original value and service-producing potential) with an electric water-to-air heat pump system, the incremental capital cost would be $\$ 4100$. This implies that the consumer could expect the system to pay for itself in approximately 10.5 years (i.e., $\$ 4100$ divided by $\$ 390 / y r)$.

The actual number of properties with nearly free access to a water supply is unknown but clearly it would be significantly less in both the new and the existing home markets than the total number of homes. That is, in some (unknown) number of cases, a new well may have to be dug at an additional cost of $\$ 3,000$ to $\$ 4,000$, or the water to be used in the system may have to be purchased from a municipal supply system at some additional cost to the consumer. Water-use costs such as these would be expected to be highly variable from municipality to municipality and therefore would be difficult to quantify in a representative fashion. Because of this and because the number of such cases is unknown, these cases were not differentiated from the base-case (i.e.,

(a) $\$ 4100$ minus $\$ 2900$.

(b) $\$ 1200$ divided by $\$ 390 / y r$. 
free access to water) set of cost assumptions. Hence, the base-case scenario is optimistic in its cost assumptions and, consequentiy, in its marketpenetration potential.

The installation of a gas-fired heat pump system in a new house or for the replacement of a broken or worn-out system will initially cost the purchaser approximately $\$ 1300$ more than a conventional HVAC system. However, because the assumed representative SPF in the heating phase of a gas-fired heat pump syster is 1.5, that implies that they are about 33 percent more energy efficient for heating. As mentioned above gas is about 70 percent less expensive to use per unit of output than electricity. Hence, the average annual savings on the typical fuel bill for heating for a gas-fired heat pump would be approximately $\$ 335 /$ yr.

For cooling, a gas-fired heat pump system would likely not be any more energy efficient than the conventional electrical HVAC system but the fuel cost for gas power is much less than that for electricity. Because of this priceof-power differential, the fuel cost for cooling the average household would be approximately $\$ 115 / y$ r less for the gas-fired heat pump than for the conventional alternative.

The annual cost savings for the average household would be approximately $\$ 450 / y r$ for heating and cooling with a representative gas-fired heat pump. These savings imply a simple payback period of less than 3 years in a new housing installation ( $\$ 1300$ incremental capital cost divided by $\$ 450 / y r$ in savings) and of a little more than 9 years if purchased as a retrofit system $(\$ 4200$ divided by $\$ 450 / y r)$. These results are summarized in Table 5.1.

\subsubsection{Market Penetration}

The estimated rate of market penetration of each of the new heat pump technologies depends on many factors. Among the most important of these factors are 1) the initial incremental capital costs of the new technology, 2) the simple payback period, 3) whether the technology is being considered as a new installation or as a retrofit installation, 4) the size of the new and the retrofit markets, and 5) whatever technical limitations there may be to the effective implementation of the technology. The capital costs and the payback 
TABLE 5.1. Heat Pump Space Conditioner Simple Pay-Back Calculations

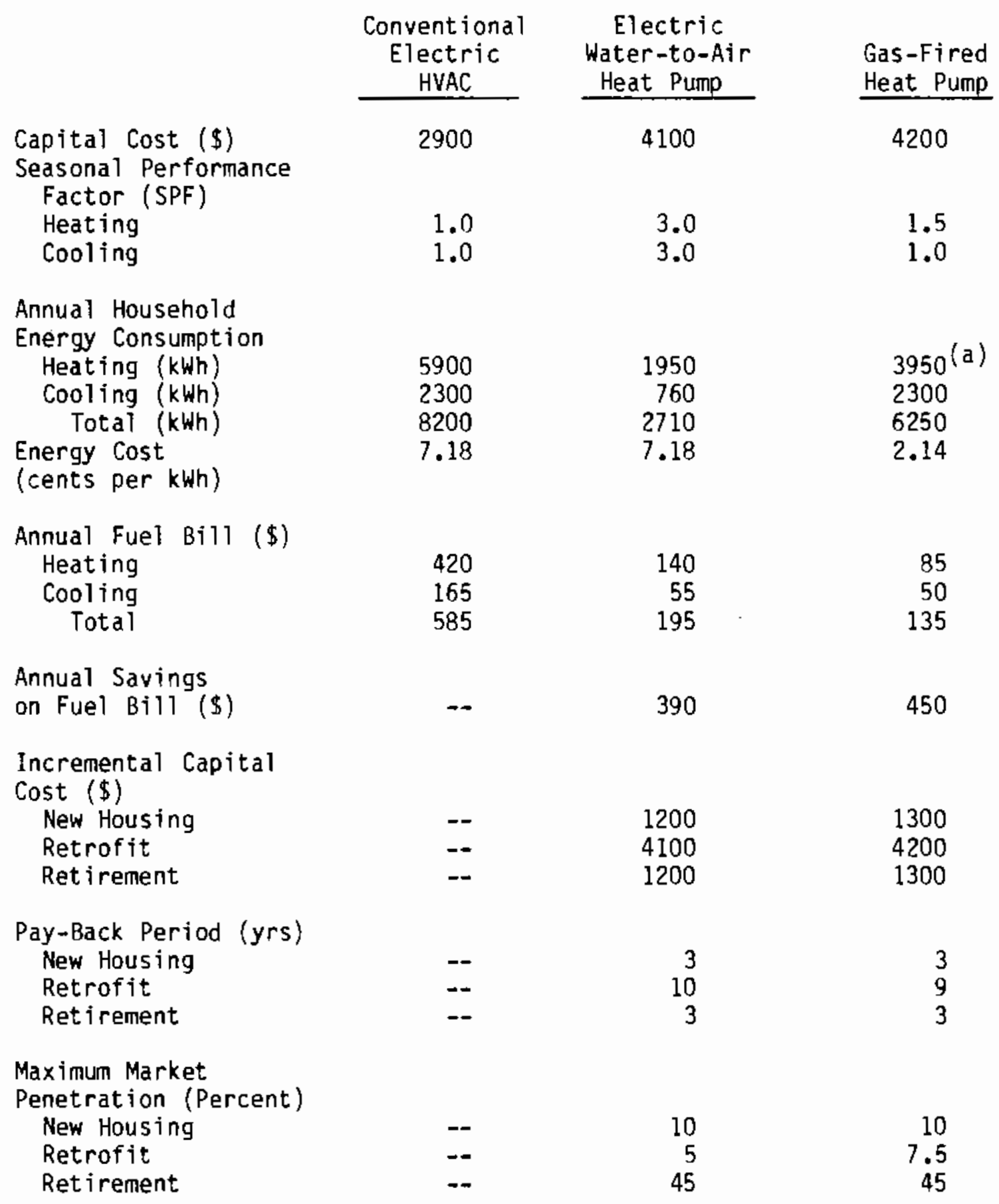

(a) kWh are energy equivalents. 
periods are reported in Table 5.1. Note that our estimated payback periods are for residences that are both heated and cooled electrically. We have not estimated separate payback periods (and thus market penetrations) for electrically cooled only and electrically heated and cooled residences, although it is clear that the payback period for residences that are electrically cooled only would be longer than for those both heated and cooled electrically.

The market-penetration analys is is further complicated by the likelihood that the two new-technology HP systems will, in fact, be competing against each other for HVAC market share as well as against the conventional technology. To the degree that this occurs, the market-penetration estimates presented below could be overstated, because we do not account for this in our analysis.

There are some technical constraints to implementing the new heat pump technologies. For example, the choice of the water-to-air heat pump system depends upon low-cost access to a sufficient water supply (i.e., a lake, river, or well). In fact, about 11.5 million homes have access to their own well, about 60 percent of which have sufficient flow capacity to accommodate the return flow of a water-to-air heat pump. (a) More importantly, properties with low-cost access to an alternative water source would be expected to be numerous since many communities are located close to either a lake or river. However, some (unknown number of) properties do not have low cost access to water. Those properties could still buy water from a municipal source, drill a new well, or install a technically advanced "closed-loop" type water system but only at considerably higher operation or installation cost. Hence, in those instances electric water-to-air HP systems are likely to be considered uneconomical and as such they are not explicitly considered in this analysis. To the degree that the housing stock figures used in this analysis include properties inappropriate for the technology, our results overstate the potential market penetration of water-to-air HP systems.

The most apparent drawback to the immediate implementation of the gasfired heat pump systems is that they are not likely to be actively marketed in

(a) This information was obtained via a telephone conversation with John Voztek, National Water Well Association, November 2l, 1984. 
the United States until about 1990. Another important consideration regarding the likelihood of their implementation would be the degree of availability and the relative per-unit energy cost of gas relative to electricity across the nation.

Mindful of these limitations, the reader is referred to Table 4.1, which relates the simple payback period for new and for retrofit installations to the percent rate of market penetration. From that table we see that the estimated market penetration of the electric water-to-air HP systems into the electric HVAC market is 10 percent (due to an estimated 3 year payback) of the new housing market, 45 percent ( 3 year payback) of the retired units market, and 5 percent (10 year payback) of the retrofit market. The estimates for gas-fired HP systems are 10 percent ( 3 year payback) of the new housing market, 45 percent ( 3 year payback) of the retired units market, and 7.5 percent ( 9 year payback) of the retrofit market. These results are summarized at the bottom of Table 5.1.

\subsection{HOUSING STOCK PROJECTIONS AND MARKET SHARE ESTIMATES}

Tables 5.2 through 5.5 present projections of housing stock and market share percentages at yearly intervals to the year 2000. The housing stock projections are based on estimates used by the DOE for computations in the National Energy Policy Plan (DOE 1983). The percentage of houses that use electricity for both heating and cooling purposes and for cooling only are calculated from estimates published in the 1982 Residential Energy Consumption Survey (DOE 1984b). The market share estimates are derived as described in Chapter 4.0 and are based on the payback period and market-penetration estimates presented in Table 5.1 .

\subsection{ENERGY SAVINGS COMPITATIONS AND RESULTS}

In this section, expected savings of electricity nationwide from the new heat pump technologies are estimated for the years 1990, 1995, and 2000. These estimates are based on the average annual electrical energy savings in a representative electrically space-conditioned home and the expected rate of market 
TABLE 5.2. Housing Stock Projections and Electric Water-to-Air Heat Pump Market Share Estimates for Electrically Heated and Cooled Residences

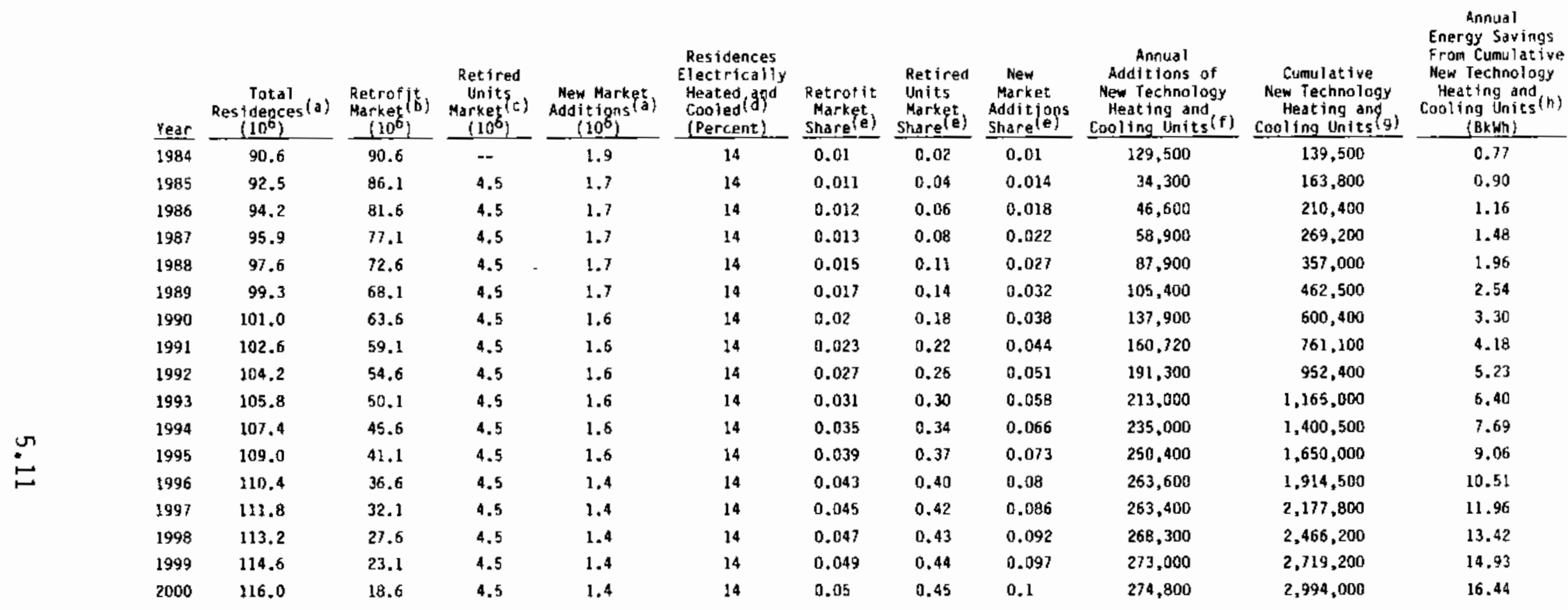

(a) Source: MEpp Forecasts.

(c) Source: BPA 1981 .

(d) Percentage based on estimates from the 1982 Resident1al Energy Consumption Survey (DOE/EIA 1984).

(f) Calculated by:

[(Retfofit Market in Year 1) $\times$ (Percent Electric) $\times$ (Retrofit Share in Year 1) + (Retired Untts Harket in Year i) $x$

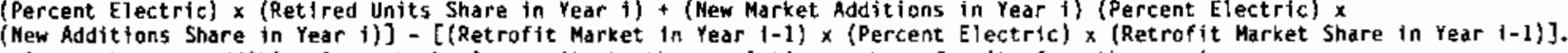

(h) Calculated by suming each years additional new technology units to the cumulative number of units from the previous year. 
TABLE 5.3. Housing Stock Projections and Electric Water-to-Air Heat Pump Market Share Estimates for Electrically Cooled Oniy Residences

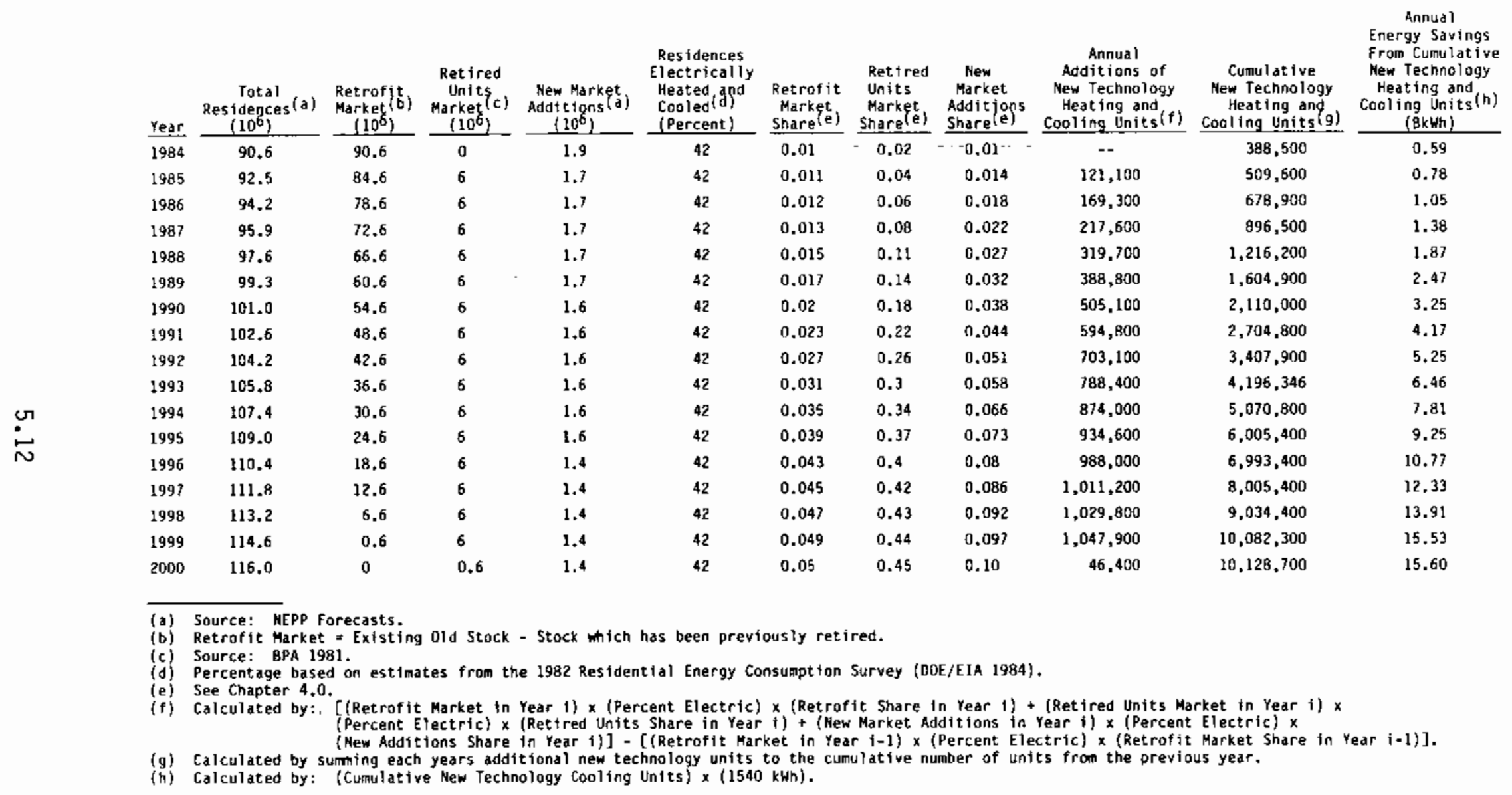


TABLE 5.4. Housing Stock Projects and Gas-Fired Heat Pump Market Share Estimates for Electrically Heated and Cooled Residences

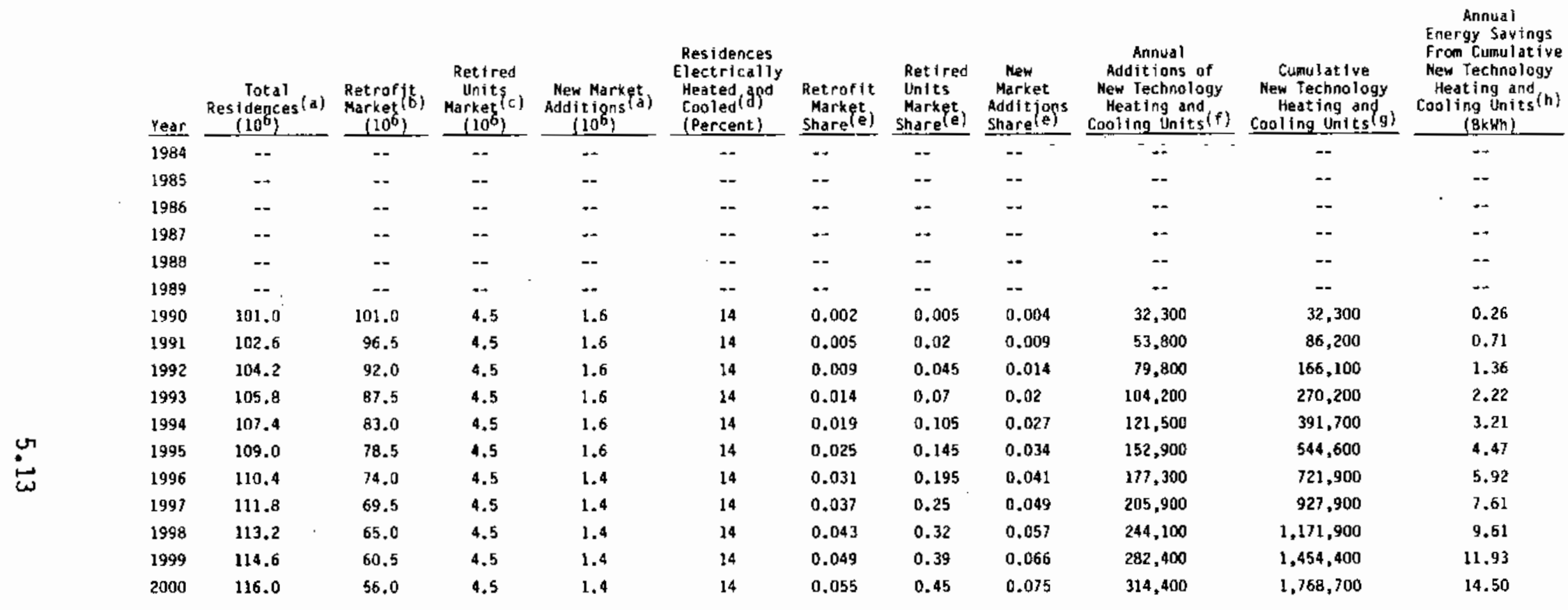

(a) Source: NEPP Forecasts.

b) Retrofit Market = Existing 01d Stock - Stock which is retited.

(c) Source: BPA 1981 .

estimates from the 1982 Residential Energy Consumption Survey (OOE/EIA 1984).

(e) See Chapter 4.0.

[(Retrofit Market in Year 1) $\times$ (Percent Electric) $\times$ (Retrofit Share in Year i) + (Retired Units Market in Year i) (

calculated by

(h) Calculated by: (Cumulative New Technology Heating and Cooling Units) $x$ (B200 kivh) number of units from the previous year. 
TABLE 5.5. Housing Stock Projections and Gas-Fired Heat Pump Market Share Estimates for Electrically Cooled Only Residences

\begin{tabular}{|c|c|c|c|c|c|c|c|c|c|c|c|}
\hline Year & [. Residences $(a)$ & $\begin{array}{l}\text { Retrofjt } \\
\text { Market } \\
\left(10^{6}\right) \\
\end{array}$ & $\begin{array}{c}\text { Retíred } \\
\text { Init } \\
\text { Market } \\
\left(10^{6}\right) \\
\end{array}$ & $\begin{array}{l}\text { New Market } \\
\text { Additions } \\
\left(10^{6}\right) \\
\end{array}$ & $\begin{array}{l}\text { Residences } \\
\text { Electrically } \\
\text { Heated (dgd } \\
\text { Cooled (d) } \\
\text { (Percent) } \\
\end{array}$ & $\begin{array}{l}\text { Retrofit } \\
\text { Market } \\
\text { Share }\end{array}$ & $\begin{array}{l}\text { Retired } \\
\text { Units } \\
\text { Market } \\
\text { Share (e) } \\
\end{array}$ & $\begin{array}{l}\text { New } \\
\text { Market } \\
\text { Additjogs } \\
\text { Share }(\mathrm{e}) \\
\end{array}$ & $\begin{array}{c}\text { Annual } \\
\text { Additions of } \\
\text { Mew Technology } \\
\text { Heating and } \\
\text { Cooling Units }(f)\end{array}$ & $\begin{array}{c}\text { Cumul at ive } \\
\text { New Technolagy } \\
\text { Heat ing and } \\
\text { Cooling Units (g) }\end{array}$ & $\begin{array}{c}\text { Annual } \\
\text { Energy Sayings } \\
\text { From Cumulative } \\
\text { New Technology } \\
\text { Heating and } \\
\text { Cooling Units }(h) \\
\text { (BkWh) }\end{array}$ \\
\hline 1984 & -- & -- & -- & $\leadsto$ & -- & -- & -- & -- & $\because$ & - & -- \\
\hline 1985 & -- & -- & -. & $\cdots$ & .. & - & $=$ & -- & -- & -- & -- \\
\hline 1986 & - & + & -- & -. & $\cdots$ & - & -- & -- & -- & -- & $\cdots$ \\
\hline 1987 & -- & -- & -- & -- & -- & -- & -- & -- & -- & -- & -- \\
\hline 1988 & -- & -- & -- & -- & -- & -- & -- & -- & $\cdots$ & -- & -. \\
\hline 1989 & -- & -- & -- & -- & -- & -- & -- & -- & -- & $\cdots$ & -- \\
\hline 1990 & 101 & 101 & 6 & 1.6 & 42 & 0.002 & 0.005 & 0.004 & 100,100 & 100,200 & 0.23 \\
\hline 1991 & 102.6 & 95 & 6 & 1.6 & 42 & 0.005 & 0.02 & 0.009 & 171,100 & 271,200 & 0.62 \\
\hline 1992 & 104.2 & 89 & 6 & 1.6 & 42 & 0.009 & 0.045 & 0.014 & 259,700 & 530,900 & 1.22 \\
\hline 1993 & 105.8 & 83 & 6 & 1.6 & 42 & 0.014 & 0.07 & 0.02 & 341,500 & 872,400 & 2.01 \\
\hline 1994 & 107.4 & 77 & 6 & 1.6 & 42 & 0.019 & 0.105 & 0.027 & 409.200 & $1,281,600$ & 2.95 \\
\hline 1995 & 109 & 72 & 6 & 1.6 & 42 & 0.025 & 0.145 & 0.034 & 519,300 & $1,800,900$ & 4.14 \\
\hline 1996 & 110.4 & 65 & 6 & 1.4 & 42 & 0.031 & 0.195 & 0.041 & 616,300 & $2,417,200$ & 5.56 \\
\hline 1997 & 111.8 & 59 & 6 & 1.4 & 42 & 0.037 & 0.25 & 0.049 & 729.400 & $3,146,600$ & 7.24 \\
\hline 1998 & 113.2 & 53 & 6 & 1.4 & 42 & 0.043 & 0.32 & 0.057 & 880,200 & $4,026,800$ & 9.26 \\
\hline 1999 & 114.6 & 47 & 6 & 1.4 & 42 & 0.049 & 0.39 & 0.066 & $1,031,700$ & $5,058,500$ & 11.63 \\
\hline 2000 & 116 & 41 & 6 & 1.4 & 42 & 0.055 & 0.45 & 0.075 & $1,157,900$ & $6,216,400$ & 14.30 \\
\hline $\begin{array}{l}\text { (a) } \\
\text { (b) } \\
\text { (c) } \\
\text { (e) } \\
\text { (c) }\end{array}$ & \multicolumn{11}{|l|}{$\begin{array}{l}\text { Source: MEPP For } \\
\text { Retrof ft Market } \\
\text { Source: BPA } 198 \\
\text { Percentage based } \\
\text { See Chapter } 4.0 \text {. } \\
\text { Calculated by: } \\
\text { Calculated by sur } \\
\text { Calculated by: }\end{array}$} \\
\hline
\end{tabular}


penetration of the new heat pump technologies. To use these representative savings and market-penetration estimates to obtain a national savings estimate, they are applied to the data and forecasts presented in Tables 5.2 through 5.5 that characterize the size, composition, and expected changes over time of the space conditioning market.

The representative household that chooses to install an electric water-toair heat pump over a conventional electric HVAC system will save an estimated $3950 \mathrm{kWh} / \mathrm{yr}$ for heating and $1540 \mathrm{kWh} / \mathrm{yr}$ for cooling.(a) The total annual savings are therefore estimated to be $5490 \mathrm{kWh}$ for a home that is both electrically heated and cooled.

The gas-fired heat pump system uses gas to circulate the refrigerant and to power the compressor but it also uses some electricity to power a fan. To simplify the analysis it will be assumed that the fan uses a negligible amount of electricity. Therefore, every gas-fired heat pump that is installed in lieu of a conventional electric HVAC system will save virtually all of the electricity that system would have otherwise consumed. As indicated in Table 5.1, that has been estimated to be $8200 \mathrm{kWh}$ for homes that are both heated and cooled electrically. Savings for cooling only would be an estimated $2300 \mathrm{kWh}$.

The final savings were calculated by taking the estimated number of new technology units (found in Tables 5.2 through 5.5 above) installed by a given year and multiplying those estimates by the above described estimates of the per unit annual electrical energy savings (in kWh's). The resulting estimates of electricity savings appear in the final column of each of those four tables. A summary of these savings estimates is presented in Table 5.6 .

Most of the information necessary to perform this analysis was found to be readily available from related sources in the literature as well as from market agents. However, the reader should be aware that portions of the analysis were

(a) See the "Annual Household Energy Consumption" estimates that are presented in Table 5.1 and subtract the electric water-to-air heat pumps estimated consumption from that of the conventional HVAC system to obtain these per representative household annual energy savings estimates. 


\section{TABLE 5.6. Estimated National Annual Electrical Savings}

from New Heat Pump Technologies BkWh

\begin{tabular}{|c|c|c|c|c|c|}
\hline Year & $\begin{array}{c}\text { Electric } \\
\text { Water-to-Air } \\
\text { Heating } \\
\text { and Cooling } \\
\end{array}$ & $\begin{array}{c}\text { Electric } \\
\text { Water-to-Air } \\
\text { Cooling } \\
\text { Only } \\
\end{array}$ & $\begin{array}{l}\text { Gas-Fired } \\
\text { Heating and } \\
\text { Cooling } \\
\end{array}$ & $\begin{array}{c}\text { Gas-Fired } \\
\text { Cooling } \\
\text { Only } \\
\end{array}$ & $\begin{array}{c}\text { Tota } \\
\text { Savings } \\
\end{array}$ \\
\hline 1985 & 0.90 & 0.78 & 0 & 0 & 1.69 \\
\hline 1990 & 3.30 & 3.25 & 0.26 & 0.62 & 7.43 \\
\hline 1995 & 9.06 & 9.25 & 4.47 & 5.56 & 28.34 \\
\hline 2000 & 16.48 & 15.60 & 15.50 & 14.30 & 60.84 \\
\hline
\end{tabular}

treated in a highly simplistic fashion for the sake of analytical convenience. More specifically, these results depend critically on a specific scenario of assumed future prices, market penetration rates, housing stock changes, and "representative technology units." Such assumptions, forecasts, and other simplifications, no matter how well represented, should be interpreted as only approximate estimates. The results of this analysis should therefore be regarded in a similar fashion.

Table 5.6 shows that the two technologies considered in this chapter could save an estimated $61 \mathrm{BkWh}$ in the year 2000. Current (1984) electricity use for space conditioning is approximately $284 \mathrm{BkWh}$. Although this latter figure is forecast to grow between now and 2000 , the savings estimated here are a sizable portion of projected future electricity use for space conditioning. Hence, to the degree that the energy savings potential of these new heat pump technologies has not been accounted for in the most recent electricity consumption forecasts, those forecasts could be overstating the electrical energy demand for residential space conditioning by up to approximately 20 percent.

\subsection{SENSITIVITY ANALYSIS}

This section is an analysis of the sensitivity of the aggregate energy savings results presented in Section 5.5 to alterations in the marketpenetration scenario. The analysis may serve to indicate a maximum/minimum range within which the actual energy savings could be expected to occur. 
Alternatively, the analysis may be helpful as an indicator of the potential benefit from programs to increase the use of the new energy saving technologies.

\subsubsection{Low Market-Penetration Scenarios}

It is possible that the new heat pump technologies will not penetrate the residential HVAC market as quickly or completely as indicated in Tables 5.2 through 5.5. For example, if the future cost of electricity to the consumer is perceived to be low relative to the cost of the new technologies, then the consumer's incentive to invest in such conservation technologies will not be strong. Alternatively, if technical limitations become a serious constraint to a new technology's acceptance by the consumer, then the technology's rate of market penetration will be dampened, resulting in low market penetration.

The low market-penetration scenarios for the new electric water-to-air heat pump technology assume that the maximum level of market penetration reaches only half that of our previous estimates for all three markets. The maximum market-penetration rates were therefore estimated to be 2.5 percent in the retrofit market, 22.5 percent in the retirement market, and 5 percent in the new market. Furthermore, we lowered the entire S-curve (see Figure 4.1), assuming that only 75 percent of that new maximum penetration potential will be achieved by the year 2000 .

The low market-penetration scenarios for the new gas-fired heat pump technology assume that the penetration reaches only half of what the year 2000 base case was for all three markets. Due to the late market entry date of these systems, further limitations on their penetration were not assumed. The details of the analysis for the low market-penetration scenarios are presented in Tables 5.7 through 5.10. A summary of national annual electrical energy savings estimates for the low market-penetration scenario of the new heat pump technologies is presented in Table 5.11. These results could be interpreted as being indicative of a reasonable minimum for the expected electrical energy savings from the new heat pump technologies. 
TABLE 5.7. Electric Water-to-Air Heat Pump Low Market-Penetration Scenario for Electrically Heated and Cooled Residences

\begin{tabular}{|c|c|c|c|c|c|c|c|c|c|c|c|}
\hline Year & {$\left[\begin{array}{c}\begin{array}{c}\text { Total } \\
\text { Residenges }(a) \\
\left(10^{6}\right)\end{array} \\
\end{array}\right.$} & $\begin{array}{l}\text { Retrofjt } \\
\text { Market }(b) \\
\left(10^{6}\right) \\
\end{array}$ & $\begin{array}{c}\text { Retired } \\
\text { Units } \\
\text { Market } \\
\left(10^{6}\right) \\
\end{array}$ & $\begin{array}{l}\text { New Market } \\
\text { Additigns(a) } \\
\left(10^{6}\right) \\
\end{array}$ & $\begin{array}{c}\text { Residences } \\
\text { Electrically } \\
\text { Heated (gnd } \\
\text { Cooled } \\
\text { (Percent) } \\
\end{array}$ & $\begin{array}{c}\text { Retrofit } \\
\text { Market. } \\
\text { Share(e) } \\
\end{array}$ & $\begin{array}{l}\text { Retired } \\
\text { Units } \\
\text { Market } \\
\text { Share(e) } \\
\end{array}$ & $\begin{array}{c}\text { New } \\
\text { Market } \\
\text { Addityons } \\
\text { Share (e) } \\
\end{array}$ & $\begin{array}{c}\text { Annual } \\
\text { Additions of } \\
\text { New Technology } \\
\text { Heating and } \\
\text { Cooling Units }(f) \\
\end{array}$ & $\begin{array}{c}\text { Cumblative } \\
\text { Mew Iectinalogy } \\
\text { Heat ing and } \\
\text { Cooling Units (g) } \\
\end{array}$ & $\begin{array}{c}\text { Annual } \\
\text { Energy Savings } \\
\text { From Cumulative } \\
\text { Hew Technology } \\
\text { Heat ing and } \\
\text { Cooling inits }(h) \\
\text { (Bkwh) }\end{array}$ \\
\hline 1984 & 90.6 & 90.6 & -- & 1.9 & 14 & 0.005 & 0.02 & 0.01 & 65,100 & 66,100 & 0.36 \\
\hline 1985 & 92.5 & 86.1 & 4.5 & 1.7 & 14 & 0.0055 & 0.025 & 0.011 & 21.200 & 87,400 & 0.48 \\
\hline 1986 & 94.2 & 81.6 & 4.5 & 1.7 & 14 & 0.006 & 0.03 & 0.012 & 24,000 & 111,300 & 0.61 \\
\hline 1987 & 95.9 & 77.1 & 4.5 & 1.7 & 14 & 0.0065 & 0.04 & 0.013 & 29,900 & 141,200 & 0.78 \\
\hline 1988 & 97.6 & 72.6 & 4.5 & 1.7 & 14 & 0.007 & 0.05 & 0.015 & 36,000 & 177,300 & 0.97 \\
\hline 1989 & 99.3 & 68.1 & 4.5 & 1.7 & 14 & 0.008 & 0.065 & 0.017 & 50,100 & 227,400 & 1.25 \\
\hline 1990 & 101 & 63.6 & 4.5 & 1.6 & 14 & 0.009 & 0.08 & 0.019 & 58,500 & 285.900 & 1.57 \\
\hline 1991 & 102.6 & 59.1 & 4.5 & 1.6 & 14 & 0.011 & 0.1 & 0.022 & 78,800 & 364,700 & 2.00 \\
\hline 1992 & 104.2 & 54.6 & 4.5 & 1.5 & 14 & 0.013 & 0.12 & 0.025 & 89,600 & 454,300 & 2.49 \\
\hline 1993 & 105.8 & 50.1 & 4.5 & 1.6 & 14 & 0.014 & 0.13 & 0.027 & 86.700 & 541,072 & 2.97 \\
\hline 1994 & 107.4 & 45.6 & 4.5 & 1.6 & 14 & 0.015 & 0.14 & 0.029 & 92,300 & 633,300 & 3.48 \\
\hline 1995 & 109 & 41.1 & 4.5 & 1.6 & 14 & 0.016 & 0.148 & 0.031 & 96.500 & 729,800 & 4.01 \\
\hline 1996 & 110.4 & 36.6 & 4.5 & 1.4 & 14 & 0.017 & 0.155 & 0.0325 & 98,000 & 827.800 & 4.54 \\
\hline 1997 & 111.8 & 32.1 & 4.5 & 1.4 & 14 & 0.018 & 0.16 & 0.034 & 100.000 & 927,800 & 5.09 \\
\hline 1998 & 113.2 & 27.6 & 4.5 & 1,4 & 14 & 0.018 & 0.164 & 0.0355 & 101,200 & $1,029,400$ & 5.65 \\
\hline 1999 & 114.6 & 23.1 & 4.5 & 1.4 & 14 & 0.019 & 0.167 & 0.0365 & 102,500 & $1,131,700$ & 6.21 \\
\hline 2000 & 116 & 18.6 & 4.5 & 1.4 & 14 & 0.019 & 0.169 & 0.0375 & 102,900 & $1,234,700$ & 6.78 \\
\hline $\begin{array}{l}\text { (a) } \\
\text { (b) } \\
\text { (c) } \\
\text { (d) } \\
\text { (e) } \\
\text { (f) }\end{array}$ & \multicolumn{11}{|l|}{$\begin{array}{l}\text { Source: MEPP Fo } \\
\text { Retrofit Market } \\
\text { Source: BPA } 19 \\
\text { Percentage based } \\
\text { See Chapter } 4.0 \\
\text { Calculated by: } \\
\text { Calculated by sh } \\
\text { Calculated by: }\end{array}$} \\
\hline
\end{tabular}


IABLE 5.8. Electric Water-to-Air Heat Pump Low Market-Penetration Scenario for Electrically Cooled Only Residences

\begin{tabular}{|c|c|c|c|c|c|c|c|c|c|c|c|c|}
\hline & Year & $\begin{array}{c}\text { Total } \\
\text { Residerces }(0) \\
\left(10^{6}\right) \\
\end{array}$ & $\begin{array}{l}\text { Retrof } j t \\
\text { Market }(b) \\
\left(10^{6}\right) \\
\end{array}$ & $\begin{array}{c}\text { Retired } \\
\text { Units } \\
\text { Market }\{c\} \\
\left(10^{6}\right\} \\
\end{array}$ & $\begin{array}{r}\text { New Market } \\
\text { Additigns } \\
\left(10^{6}\right) \\
\end{array}$ & $\begin{array}{l}\text { Residences } \\
\text { Electrically } \\
\text { Heated god } \\
\text { Cooled } \\
\text { (Percent) } \\
\end{array}$ & $\begin{array}{l}\text { Retrofit } \\
\text { Market } \\
\text { Share } \\
\end{array}$ & $\begin{array}{l}\text { Retired } \\
\text { Units } \\
\text { Market } \\
\text { Share(e) } \\
\end{array}$ & $\begin{array}{l}\text { Mew } \\
\text { Market } \\
\text { Additjons } \\
\text { Sharele) } \\
\end{array}$ & $\begin{array}{c}\text { Annual } \\
\text { Additions of } \\
\text { New Technology } \\
\text { Heating and } \\
\text { Cool } f \text { ng Units } f \text { ) } \\
\end{array}$ & $\begin{array}{c}\text { Cumwlative } \\
\text { New Technalogy } \\
\text { Heating and } \\
\text { Cooling Units gl } \\
\end{array}$ & $\begin{array}{c}\text { Annual } \\
\text { Enerqy Savings } \\
\text { From Cumulaty } \\
\text { Hew Technolagy } \\
\text { Heating and } \\
\text { Cooling Units (h) } \\
\text { (Bkwh) } \\
\end{array}$ \\
\hline & 1984 & 90.6 & 90.6 & 0 & 1.9 & 42 & 0.005 & 0.02 & 0.01 & 198,200 & 198,200 & 0.31 \\
\hline & 1985 & 92.5 & 84.6 & 6 & 1.7 & 42 & 0.0055 & 0.025 & 0.011 & 76,000 & 274,300 & 0.42 \\
\hline & 1986 & 94.2 & 78.6 & 6 & 1.7 & 42 & 0.006 & 0.03 & 0.012 & 86,800 & 361,000 & 0.55 \\
\hline & 1987 & 95.9 & 72.6 & 6 & 1.7 & 42 & 0.0065 & 0.04 & 0.013 & 110,200 & 471,300 & 0.73 \\
\hline & 1988 & 97.6 & 66.6 & 6 & 1.7 & 42 & 0.007 & 0.05 & 0.015 & 134,300 & 605,600 & 0.93 \\
\hline & 1989 & 99.3 & 60.6 & 6 & 1.7 & 42 & 0.008 & 0.065 & 0.017 & 183,800 & 789,300 & 1.22 \\
\hline & 1990 & 101.0 & 54.6 & 6 & 1.6 & 42 & 0.009 & 0.08 & 0.019 & 217,100 & $2,006,500$ & 1.55 \\
\hline & 1991 & 102.6 & 48.6 & 6 & 1.6 & 42 & 0.011 & 0.1 & 0.022 & 284,900 & $1,291,400$ & 1.99 \\
\hline & 1992 & 104.2 & 42.6 & 6 & 1.5 & 42 & 0.013 & 0.12 & 0.025 & 327,200 & $1,618,700$ & 2.49 \\
\hline & 1993 & 105.8 & 36.6 & 6 & 1.6 & 42 & 0.014 & 0.13 & 0.027 & 328,380 & $1.947,000$ & 2.99 \\
\hline & 1994 & 107.4 & 30.6 & 6 & 1.6 & 42 & 0.015 & 0.14 & 0.029 & 349,800 & $2,296,900$ & 3.54 \\
\hline & 1995 & 109.0 & 24.6 & 6 & 1.6 & 42 & 0.016 & 0.148 & 0.031 & 366,300 & $2,663,200$ & 4.10 \\
\hline 6 & 1996 & 110.4 & 18.6 & 6 & 1.4 & 42 & 0.0168 & 0.15 & 0.0325 & 363,000 & $3,026,300$ & 4.66 \\
\hline & 1997 & 111.8 & 12.6 & 6 & 1.4 & 42 & 0.0175 & 0.16 & 0.034 & 384,600 & $3,410,800$ & 5.25 \\
\hline & 1998 & 113.2 & 6.6 & 6 & 1.4 & 42 & 0.018 & 0.164 & 0.0355 & 391,400 & $3,802,300$ & 5.86 \\
\hline & 1999 & 114.6 & 0.6 & 6 & 1.4 & 42 & 0.0185 & 0.167 & 0.0365 & 397,000 & $4,199,300$ & 6.47 \\
\hline & 2000 & 116.0 & 0.0 & 0.6 & 1.4 & 42 & 0.0188 & 0.169 & 0.0375 & 17,400 & $4,216,700$ & 6.49 \\
\hline & $\begin{array}{l}\text { (a) } \\
\text { (b) } \\
\text { (c) } \\
\text { (d) } \\
\text { (e) } \\
\text { (f) }\end{array}$ & \multicolumn{11}{|c|}{ 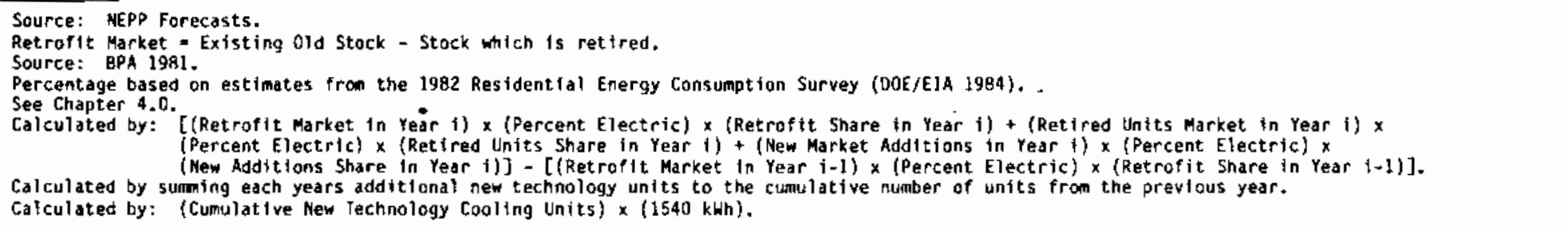 } \\
\hline
\end{tabular}


TABLE 5.9. Gas-Fired Heat Pump Low Market-Penetration Scenario for Electrically Heated and Cooled Residences

\begin{tabular}{|c|c|c|c|c|c|c|c|c|c|c|c|}
\hline Year & $r \quad \begin{array}{c}\text { Total } \\
\text { Residences } \\
\left(10^{6}\right)\end{array}$ & $\begin{array}{l}\text { Retrofjt } \\
\text { Market } \\
\left(10^{5}\right) \\
\end{array}$ & $\begin{array}{c}\text { Ret 1red } \\
\text { Units } \\
\text { Market }(c) \\
\left(10^{\mathrm{G}}\right) \\
\end{array}$ & $\begin{array}{c}\text { New Market } \\
\text { Addit 1gns? } \\
\left(10^{b}\right) \\
\end{array}$ & $\begin{array}{l}\text { Residences } \\
\text { Electrically } \\
\text { Heated }(g)^{d} \\
\text { Cooled }(\mathrm{d}) \\
\text { (Percent) } \\
\end{array}$ & $\begin{array}{c}\text { Retrofit } \\
\text { Market } \\
\text { Share (e) } \\
\end{array}$ & $\begin{array}{r}\text { Retired } \\
\text { Units } \\
\text { Market } \\
\text { Share (e) } \\
\end{array}$ & $\begin{array}{l}\text { New } \\
\text { Market. } \\
\text { Addityons } \\
\text { Share } \\
\end{array}$ & $\begin{array}{c}\text { Annual } \\
\text { Additions of } \\
\text { New Technology } \\
\text { Heating and } \\
\text { Cooling Units }(f) \\
\end{array}$ & $\begin{array}{c}\text { Cumulative } \\
\text { New Technology } \\
\text { Heat Ing and } \\
\text { Cooling Units }(g) \\
\end{array}$ & $\begin{array}{c}\text { Annud) } \\
\text { Energy Sdvings } \\
\text { From Cumul at ive } \\
\text { New Technol ogy } \\
\text { Heating and } \\
\text { Cooling Units }(h) \\
\text { (Bkwh) } \\
\end{array}$ \\
\hline 1984 & -- & -- & -- & -- & -- & -- & -- & -- & $\cdots$ & $\cdots$ & $\cdots$ \\
\hline 1985 & -- & $\ldots$ & 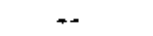 & $\because$ & -- & -- & -- & -- & -- & -- & -- \\
\hline 1986 & -- & -- & -- & -- & - & $\rightarrow$ & + & $\cdots$ & +- & -- & - \\
\hline 1987 & - & $\cdots$ & - & -- & -- & -- & -- & -- & -- & -- & -- \\
\hline 1988 & -- & -- & -- & - & -- & -- & -- & -- & -- & -- & -- \\
\hline 1989 & - & -- & -- & -- & -- & -- & -- & -- & - & -- & -- \\
\hline 1990 & 101.0 & 101.0 & 4.5 & 2.6 & 14 & 0.002 & 0.005 & 0.004 & 32,300 & 32,300 & 0.26 \\
\hline 1991 & 102.6 & 96.5 & 4.5 & 1.6 & 14 & 0.003 & 0.015 & 0.006 & 23,000 & 55,400 & 0.45 \\
\hline 1992 & 104.2 & 92.0 & 4.5 & 1.6 & 14 & 0.005 & 0.03 & 0.008 & 44,600 & 99,900 & 0.82 \\
\hline 1993 & 205.8 & 87.5 & 4.5 & 1.6 & 14 & 0.008 & 0.05 & 0.011 & 67,500 & 167,500 & 1.37 \\
\hline 1994 & 107.4 & 83.0 & 4.5 & 1.6 & 14 & 0.012 & 0.08 & 0.015 & 45,200 & 282,700 & 2.15 \\
\hline 1995 & 109.0 & 78.5 & 4.5 & 1.6 & 14 & 0.016 & 0.115 & 0.02 & 113,300 & 375,000 & 3.08 \\
\hline 1996 & 110.4 & 74.0 & 4.5 & 1.4 & 14 & 0.019 & 0.145 & 0.025 & 117,300 & 493,300 & 4.05 \\
\hline 1997 & 111.8 & 69.5 & 4.5 & 1.4 & 14 & 0.022 & 0.17 & 0.029 & 130,000 & 232,800 & 1.91 \\
\hline 1998 & 113.2 & 65.0 & 4.5 & 1.4 & 14 & 0.024 & 0.19 & 0.032 & 130,300 & 535,900 & 4.39 \\
\hline 1999 & 114.6 & 60.5 & 4.5 & 1.4 & 14 & 0.026 & 0.21 & 0.036 & 141,200 & 947,700 & 7.77 \\
\hline 2000 & $\$ 16.0$ & 56.0 & 4.5 & 1.4 & 14 & 0.028 & 0.225 & $0.03 B$ & 148,500 & $1,043,300$ & 8.56 \\
\hline $\begin{array}{l}(a) \\
(b) \\
(c) \\
(d) \\
(f) \\
(f) \\
(g) \\
(h)\end{array}$ & \multicolumn{11}{|l|}{$\begin{array}{l}\text { Source: NEPP Fo } \\
\text { Retrofit Market } \\
\text { Source: BPA } 198 \\
\text { Percentage based } \\
\text { See Chapter } 4.0 \text {. } \\
\text { Calcuiated by: } \\
\text { Calculated by su } \\
\text { Calculated by: }\end{array}$} \\
\hline
\end{tabular}


TABLE 5.10. Gas-Fired Heat Pump Low Market-Penetration Scenario for Electrically Cooled Oniy Residences

\begin{tabular}{|c|c|c|c|c|c|c|c|c|c|c|c|}
\hline Year & 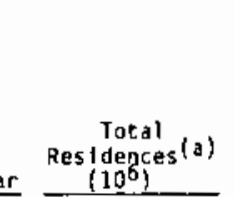 & $\begin{array}{l}\text { Retrof }) \text { (5) } \\
\text { Market } \\
\left(10^{6}\right) \\
\end{array}$ & $\begin{array}{c}\text { Retired } \\
\text { Unit } \\
\text { Market } \\
\left(10^{6}\right) \\
\end{array}$ & $\begin{array}{l}\text { New Market } \\
\text { Additions(d) } \\
\left(10^{6}\right\} \\
\end{array}$ & $\begin{array}{l}\text { Residences } \\
\text { Electrically } \\
\text { Heated god } \\
\text { Cooled (g) } \\
\text { (Percent) } \\
\end{array}$ & $\begin{array}{l}\text { Retrofit } \\
\text { Markęt } \\
\text { Shargiel } \\
\end{array}$ & $\begin{array}{l}\text { Retired } \\
\text { Units } \\
\text { Market } \\
\text { Share? } \\
\end{array}$ & $\begin{array}{l}\text { Hew } \\
\text { Market } \\
\text { Additjons } \\
\text { Share }\end{array}$ & $\begin{array}{c}\text { Annual } \\
\text { Additions of } \\
\text { New Technology } \\
\text { Heating and } \\
\text { Cogling units }(f) \\
\end{array}$ & $\begin{array}{l}\text { Cumulative } \\
\text { New Technology } \\
\text { Heating and } \\
\text { Cooling Units }(g) \\
\end{array}$ & $\begin{array}{c}\text { Annual } \\
\text { Energy Savings } \\
\text { From Cumulative } \\
\text { New Technology } \\
\text { Heating and } \\
\text { Cooling Units (h) } \\
\text { (Bkwh) } \\
\end{array}$ \\
\hline 1984 & $\ldots$ & -- & -- & -. & - & 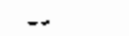 & -- & -- & -- & -. & .. \\
\hline $1985^{\circ}$ & -- & -- & -- & .. & -. & -- & -- & -- & -- & $\cdots$ & 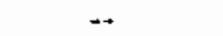 \\
\hline 1986 & -- & - & - & -- & -- & -- & -- & $-\infty$ & .. & -- & -- \\
\hline 1987 & - & -- & -- & .- & + & -- & -- & -- & -- & -- &. \\
\hline 1988 & -- & - & $\cdots$ & -- & -- & -- & 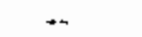 & -- & -- & -- & -- \\
\hline 1989 & - & -- & -- & -- & -- & - & -- & -- & - & -- & -- \\
\hline 1990 & 101.0 & 201 & 6 & 1.6 & 42 & 0.002 & 0.005 & 0.004 & 100,200 & 100.100 & 0.23 \\
\hline 1991 & 102.6 & 95 & 6 & 1.6 & 42 & 0.003 & 0.015 & 0.006 & 76,700 & 176,800 & 0.41 \\
\hline 1992 & 104.2 & 89 & 6 & 1.6 & 42 & 0.005 & 0.03 & 0.008 & 148,200 & 325,000 & 0.75 \\
\hline 1993 & 105.8 & 83 & 6 & 1.6 & 42 & 0.008 & 0.05 & 0.011 & 225,400 & 550,400 & 1.27 \\
\hline 1994 & 107.4 & 77 & 6 & 1.6 & 42 & 0.012 & 0.08 & 0.015 & 320,700 & 871,250 & 2.00 \\
\hline 1995 & 109.0 & 71 & 6 & 1.6 & 42 & 0.016 & 0.115 & 0.02 & 392,300 & $1,263,500$ & 2.91 \\
\hline 1996 & 110.4 & 65 & 6 & 1.4 & 42 & 0.019 & 0.145 & 0.025 & 421,700 & $1,685,200$ & 3.88 \\
\hline 1997 & 111.8 & 59 & 6 & 1.4 & 42 & 0.022 & 0.17 & 0.029 & 471,900 & $2,157,100$ & 4,96 \\
\hline 1998 & 113.2 & 53 & 6 & 1.4 & 42 & 0.024 & 0.19 & 0.032 & 486,700 & $2,643,800$ & 6.08 \\
\hline 1999 & 114.6 & 47 & 6 & 1.4 & 42 & 0.026 & 0.21 & 0.036 & 529,400 & $3,173,200$ & 7.30 \\
\hline 2000 & 116.0 & 41 & 6 & 1.4 & 42 & 0.028 & 0.225 & 0.038 & 558,300 & $3,731,450$ & 8.58 \\
\hline $\begin{array}{l}\text { (a) } \\
\text { (b) } \\
\text { (c) } \\
\text { (d) } \\
\text { (e) }\end{array}$ & \multicolumn{11}{|c|}{ 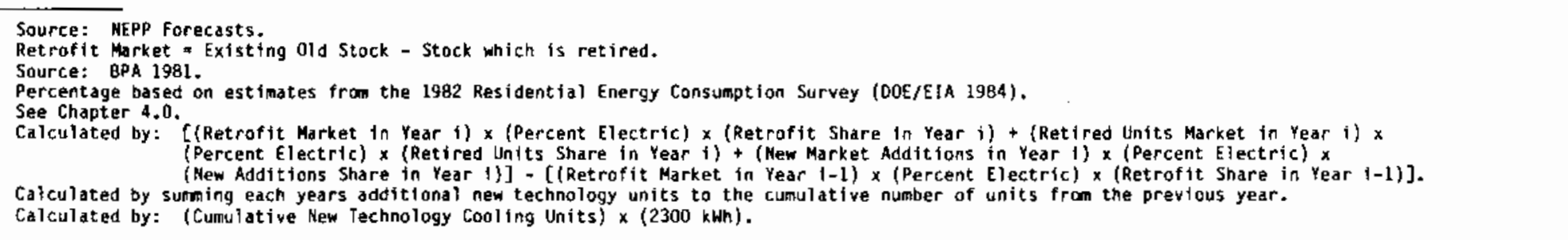 } \\
\hline
\end{tabular}


Table 5.11. National Annual Electrical Savings Estimates From the Low MarketPenetration Scenario for the New Heat Pump Technologies (BkWh)

\begin{tabular}{|c|c|c|c|c|c|}
\hline Year & $\begin{array}{l}\text { Water-to-Air } \\
\text { Heating } \\
\text { and Cooling } \\
\end{array}$ & $\begin{array}{c}\text { Water-to-Air } \\
\text { Cooling } \\
\text { Only } \\
\end{array}$ & $\begin{array}{c}\text { Gas-Fired } \\
\text { Heating and } \\
\text { Cooling } \\
\end{array}$ & $\begin{array}{c}\text { Gas-Fired } \\
\text { Cooling } \\
\text { Only } \\
\end{array}$ & $\begin{array}{c}\text { Total } \\
\text { Savings } \\
\end{array}$ \\
\hline 1985 & 0.48 & 0.42 & 0 & 0 & 0.90 \\
\hline 1990 & 1.57 & 1.55 & 0.26 & 0.23 & 3.61 \\
\hline 1995 & 4.01 & 4.10 & 3.08 & 2.91 & 14.10 \\
\hline 2000 & 6.78 & 6.49 & 8.56 & 8.58 & 30.41 \\
\hline
\end{tabular}

\subsubsection{High Market-Penetration Scenarios}

The high market-penetration scenarios for the new electric water-to-air heat pump technology assumes a doubling for the new installation and the retrofit markets. The maximum level of penetration in the retirement market is assumed to remain the same but it is to be achieved in 1995 rather than in 2000 .

The high market-penetration scenarios for the gas-fired heat pump assumes a doubling of the penetration achieved in the base case by the year 2000 for the new installation and the retrofit markets. Due to the relatively high penetration in the base case retirement market (i.e., 45 percent) and due to the late market entry date of this technology, the assumed penetration for that market does not change from the base case. The specifics of the high marketpenetration scenarios are detailed in Tables 5.12 through 5.15. A summary of the national annual electrical energy savings for the high market-penetration scenario of the advanced heat pump systems are displayed in Table 5.16. These estimates represent a reasonable maximum for the expected electrical energy savings from the advanced heat pump technologies.

\subsection{COST/kWh OF ENERGY SAVED CALCULATIONS AND COMPARISONS TO THE COST/kWh OF PRODUCING NEW GENERATING CAPACITY}

The new heat pump technologies may be considered as investments that have a return to the investor in the form of future reductions in the amount of energy that must be purchased for space conditioning. To the degree that the 
TABLE 5.12. Electric Water-to-Air Heat Pump High Market-Penetration Scenario for Electrically Heated and Cooled Residences

\begin{tabular}{|c|c|c|c|c|c|c|c|c|c|c|c|c|}
\hline & Year & $\begin{array}{c}\text { Total } \\
\text { Residences (a) } \\
\left(10^{6}\right) \\
\end{array}$ & $\begin{array}{l}\text { Retrofjt } \\
\text { Market }(5) \\
\quad\left(10^{6}\right) \\
\end{array}$ & $\begin{array}{c}\text { Retíred } \\
\text { Hnits } \\
\text { Market }(c) \\
\left(10^{6}\right) \\
\end{array}$ & $\begin{array}{l}\text { New Market } \\
\text { Additions? } \\
\left(10^{b}\right) \\
\end{array}$ & $\begin{array}{l}\text { Residences } \\
\text { Electrically } \\
\text { Heated gad } \\
\text { Cooled }(\mathrm{g}) \\
\text { (Percent) } \\
\end{array}$ & $\begin{array}{l}\text { Retrofit } \\
\text { Market } \\
\text { Share (e) }\end{array}$ & $\begin{array}{l}\text { Retired } \\
\text { Units } \\
\text { Market } \\
\text { Share (e) } \\
\end{array}$ & $\begin{array}{l}\text { New } \\
\text { Market } \\
\text { Addit jops } \\
\text { Share (e) } \\
\end{array}$ & $\begin{array}{c}\text { Annud } \\
\text { Addittons of } \\
\text { New Iechnology } \\
\text { Keating and } \\
\text { Cooling Units } f) \\
\end{array}$ & $\begin{array}{l}\text { Cumulative } \\
\text { Newechnology } \\
\text { Heat ing and } \\
\text { Cooling Units (g) }\end{array}$ & $\begin{array}{c}\text { Annual } \\
\text { Energy Savings } \\
\text { Fron Cumulative } \\
\text { New Technology } \\
\text { Heating and } \\
\text { Coaling Units (h) } \\
\text { (BkWh) } \\
\end{array}$ \\
\hline & 1984 & 90.6 & 90.6 & -- & 1.9 & 14 & 0.01 & 0.02 & 0.01 & 129.500 & 129,500 & 0.56 \\
\hline & 1985 & 92.5 & 86.1 & 4.5 & 1.7 & 14 & 0.013 & 0.04 & 0.015 & 58,600 & 188,100 & 1.03 \\
\hline & 1986 & 94.2 & 81.6 & 4.5 & 1.7 & 14 & 0.017 & 0.07 & 0.023 & 87,100 & 275,200 & 1.51 \\
\hline & 1987 & 95.9 & 77.1 & 4.5 & 1.7 & 14 & 0.022 & 0.1 & 0.033 & 114,100 & 389,300 & 2.14 \\
\hline & 1988 & 97.6 & 72.6 & 4.5 & 1.7 & 14 & 0.03 & 0.14 & 0.05 & 167,500 & 556,900 & 3.06 \\
\hline & 1989 & 99.3 & 68.1 & 4.5 & 1.7 & 14 & 0.04 & 0.2 & 0.07 & 219,100 & 775,000 & 4.25 \\
\hline & 1990 & 101,0 & 63.6 & 4.5 & 1.6 & 14 & 0.05 & 0.27 & 0.1 & 256,300 & $1,032,300$ & 5.67 \\
\hline & 1991 & 102.6 & 59.1 & 4.5 & 1.6 & 14 & 0.065 & 0.35 & 0.13 & 342,200 & $1,374,600$ & 7.55 \\
\hline & 1992 & 104.2 & 54.6 & 4.5 & 1.6 & 14 & 0.077 & 0.4 & 0.16 & 338,600 & $1,713,200$ & 9.41 \\
\hline & 1993 & 105.8 & 50.1 & 4.5 & 1.6 & 14 & 0.087 & 0.43 & 0.18 & 328,900 & $2,046,000$ & 11.23 \\
\hline & 1994 & 107.4 & 45.6 & 4.5 & 1.6 & 14 & 0.095 & 0.44 & 0.19 & 316,000 & $2,362,038$ & 12.97 \\
\hline & 1995 & 109.0 & 41.1 & 4.5 & 1.6 & 14 & 0.1 & 0.45 & 0.2 & 297.200 & $2,659,258$ & 14.60 \\
\hline & 1996 & 110.4 & 36.6 & 4.5 & 1.4 & 14 & 0.1 & 0.45 & 0.2 & 259,700 & $2.918,000$ & 16.03 \\
\hline & 1997 & 111.8 & 32.1 & 4.5 & 1.4 & 14 & 0.1 & 0.45 & 0.2 & 259,700 & $3,178,700$ & 17.45 \\
\hline & 1998 & 113.2 & 27.6 & 4.5 & 1.4 & 14 & 0.1 & 0.45 & 0.2 & 259,700 & $3,438,400$ & 18.88 \\
\hline & 1999 & 114.6 & 23.1 & 4.5 & 1.4 & 14 & 0.1 & 0.45 & 0.2 & 259.700 & $3,698,100$ & 20.30 \\
\hline & 2000 & 116.0 & 18.6 & 4.5 & 1.4 & 14 & 0.1 & 0.45 & 0.2 & 259,700 & $3,957,800$ & 21.73 \\
\hline & $\begin{array}{l}\text { (a) } \\
\text { (b) } \\
\text { (c) } \\
\text { (d) } \\
\text { (e) } \\
\text { (f) }\end{array}$ & \multicolumn{11}{|l|}{$\begin{array}{l}\text { Source: MEPP Fo } \\
\text { Retrofit Market } \\
\text { Source: BPA } 198 \\
\text { Percentage based } \\
\text { See Chapter } 4.0 \text {. } \\
\text { Calculated by: } \\
\text { Calculated by su } \\
\text { Calculated by: }\end{array}$} \\
\hline
\end{tabular}


TABLE 5.13. Electric Water-to-Air Heat Pump High Market-Penetration Scenario for Electrically Cooled Only Residences

\begin{tabular}{|c|c|c|c|c|c|c|c|c|c|c|c|}
\hline Year & ar $\begin{array}{c}\text { Total } \\
\text { Res1degces }(a) \\
\left(10^{6}\right)\end{array}$ & $\begin{array}{l}\text { Retrof }\{t \\
\text { Market }(t) \\
\left(10^{6}\right) \\
\end{array}$ & $\begin{array}{c}\text { Retired } \\
\text { Units } \\
\text { Market (c) } \\
\left(10^{5}\right) \\
\end{array}$ & $\begin{array}{l}\text { New Market } \\
\text { Additíns }(\mathrm{d}) \\
\left(10^{6}\right) \\
\end{array}$ & $\begin{array}{l}\text { Residences } \\
\text { Electrically } \\
\text { Heated (and } \\
\text { Cooled }(\mathrm{g}) \\
\text { (Percent) } \\
\end{array}$ & $\begin{array}{l}\text { Retrofit } \\
\text { Market } \\
\text { Share }\end{array}$ & $\begin{array}{l}\text { Retired } \\
\text { Untts } \\
\text { Market } \\
\text { Share } \\
\end{array}$ & $\begin{array}{c}\text { New } \\
\text { Market } \\
\text { Additjons } \\
\text { Sharele) } \\
\end{array}$ & $\begin{array}{l}\text { Annual } \\
\text { Addittions of } \\
\text { New Technology } \\
\text { Heating and } \\
\text { Cooling Units }(f) \\
\end{array}$ & $\begin{array}{l}\text { Cumulative } \\
\text { Mew Technology } \\
\text { Heating and } \\
\text { Cooling Units } \\
\end{array}$ & $\begin{array}{c}\text { Annual } \\
\text { Energy Savings } \\
\text { From Cumulattve } \\
\text { New Technology } \\
\text { Heating and } \\
\text { Cool ing Units }(h) \\
\text { (Bkwh) } \\
\end{array}$ \\
\hline 1984 & 90.6 & 90.6 & 0 & 1.9 & 42 & 0.01 & 0.02 & 0.01 & 388,500 & 388,500 & 0.60 \\
\hline 1985 & 92.5 & 84.6 & 6 & 1.7 & 42 & 0.013 & 0.04 & 0.015 & 192,900 & 581,400 & 0.89 \\
\hline 1986 & 94.2 & 78.6 & 6 & 1.7 & 42 & 0.017 & 0.07 & 0.023 & 292,100 & 873,500 & 1.35 \\
\hline 1987 & 95.9 & 72.6 & 6 & 1.7 & 42 & 0.022 & 0.1 & 0.033 & 385,200 & $1,258,700$ & 1.94 \\
\hline 1988 & 97.6 & 66.6 & 6 & 1.7 & 42 & 0.03 & 0.14 & 0.05 & 556,800 & $1,815,500$ & 2.79 \\
\hline 1989 & 99.3 & 60.6 & 6 & 1.7 & 42 & 0.04 & 0.2 & 0.07 & 732,900 & $2,548,400$ & 3.92 \\
\hline 1990 & 101.0 & 54.6 & 5 & 1.6 & 42 & 0.05 & 0.27 & 0.1 & 876,100 & $3,424,600$ & 5.27 \\
\hline 1991 & 102.6 & 48.6 & 6 & 1.6 & 42 & 0.065 & 0.35 & 0.13 & $1,150,500$ & $4,578,400$ & 7.04 \\
\hline 1992 & 104.2 & 42.6 & 6 & 1.6 & 42 & 0.077 & 0.4 & 0.16 & $1,166,400$ & $5,740,500$ & 8.84 \\
\hline 1993 & 105.8 & 36.6 & 6 & 1.6 & 42 & 0.087 & 0.43 & 0.18 & $1,164,200$ & $6,904,800$ & 10.63 \\
\hline 1994 & 107.4 & 30.6 & 5 & 1.6 & 42 & 0.095 & 0.44 & 0.19 & $1,120,100$ & $8,024,800$ & 12.36 \\
\hline 1995 & 109.0 & 24.6 & 6 & 1.6 & 42 & 0.1 & 0.45 & 0.2 & $1,080,700$ & $9,105,500$ & 14.02 \\
\hline 1996 & 110.4 & 18.6 & 6 & 1.4 & 42 & 0.1 & 0.45 & 0.2 & 999,700 & $10,105,100$ & 15.56 \\
\hline 1997 & 111.8 & 12.6 & 6 & 1.4 & 42 & 0.1 & 0.45 & 0.2 & 999,700 & $11,104,700$ & 17.10 \\
\hline 1998 & 113.2 & 6.6 & 6 & 1.4 & 42 & 0.1 & 0.45 & 0.2 & 999,700 & $12,104,300$ & 18.64 \\
\hline 1999 & 114.6 & 0.6 & 6 & 1.4 & 42 & 0.1 & 0.45 & 0.2 & 999,700 & $13,103,900$ & 20.18 \\
\hline 2000 & 116.0 & 0 & 0.6 & 1.4 & 42 & 0.1 & 0.45 & 0.2 & 92,400 & $13,196,300$ & 20.32 \\
\hline $\begin{array}{l}\text { (a) } 5 \\
\text { (b) } \\
\text { (c) } \\
\text { (d) } \\
\text { (e) } \\
\text { (f) } \\
\text { (g) } \\
\text { (h) }\end{array}$ & \multicolumn{11}{|c|}{$\begin{array}{l}\text { Source: MEPP Forec } \\
\text { Retrof 1t Market = } \\
\text { Source: BPA 1981. } \\
\text { Percentage based } \\
\text { See Chapter 4.0. } \\
\text { Calculated by: }\end{array}$} \\
\hline
\end{tabular}


TABLE 5.14. Gas-Fired Heat Pump High Market-Penetration Scenario for Electrically Heated and Cooled Residences

\begin{tabular}{|c|c|c|c|c|c|c|c|c|c|c|c|}
\hline Year & r Residegces $(a)$ & $\begin{array}{l}\text { Retrofjit) } \\
\text { Market }(b) \\
\left(10^{6}\right) \\
\end{array}$ & $\begin{array}{c}\text { Ret ired } \\
\text { Units } \\
\text { Market }(c) \\
\left(10^{6}\right) \\
\end{array}$ & $\begin{array}{c}\text { New Market } \\
\text { Additigns(a) } \\
\left(10^{\delta}\right) \\
\end{array}$ & $\begin{array}{l}\text { Residences } \\
\text { Electrically } \\
\text { Heated agd } \\
\text { Cooled } \\
\text { (Percent) } \\
\end{array}$ & $\begin{array}{l}\text { Retrofit } \\
\text { Market } \\
\text { Share e } \\
\end{array}$ & $\begin{array}{l}\text { Retired } \\
\text { Units } \\
\text { Market } \\
\text { Share? } \\
\end{array}$ & $\begin{array}{c}\text { New } \\
\text { Market } \\
\text { Additjans } \\
\text { Share (e) } \\
\end{array}$ & $\begin{array}{l}\text { Annual } \\
\text { Addttions of } \\
\text { New Technology } \\
\text { Heating and } \\
\text { Coolfing Units } f \text { ) } \\
\end{array}$ & $\begin{array}{c}\text { Cumulative } \\
\text { New Technology } \\
\text { Heating and } \\
\text { Cooltng Units }(g) \\
\end{array}$ & $\begin{array}{c}\text { Annual } \\
\text { Energy Savings } \\
\text { From Cumulative } \\
\text { New Technology } \\
\text { Heating and } \\
\text { Cooling Jnits (h) } \\
\text { (BkWh) } \\
\end{array}$ \\
\hline 1984 & -- & -- & $\because$. & -- &.- & -- & -- & -- & + & -- & -- \\
\hline 1985 & -- & 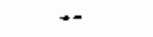 & -- & -- & -- & - & -- & $\rightarrow$ & -- & -- & 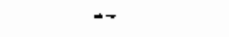 \\
\hline $19 R 6$ & -- & -- & - & -- & $\cdots$ & -- & $\cdots$ & -- & -- & -- & -- \\
\hline 1987 & -- & -- & -- & $\cdots$ & -- & -. & -- & $\omega$ & -- & -- & $\cdots$ \\
\hline 1988 & -- & -- & -- & -- & -- & -- & $\rightarrow$ & -- & -- & $\because$ & -- \\
\hline 1989 & -- & -- & $\cdots$ & -- & -- & -- & -- & -- & -- & -- & -- \\
\hline 1990 & 101.0 & 101.0 & 4.5 & 1.6 & 14 & 0.002 & 0.005 & 0.004 & 32,300 & 32,300 & 0.26 \\
\hline 1991 & 102.6 & 96.5 & 4.5 & 1.6 & 14 & 0.006 & 0.02 & 0.01 & 67,600 & 100,000 & 0.82 \\
\hline 1992 & 104.2 & 92.0 & 4.5 & 1.6 & 14 & 0.011 & 0.045 & 0.018 & 93,000 & 193,000 & 1.58 \\
\hline 1993 & 105.8 & 87.5 & 4.5 & 1.6 & 14 & 0.018 & 0.07 & 0.027 & 128,000 & 322,200 & 2.64 \\
\hline 1994 & 107.4 & 83.0 & 4.5 & 1.6 & 14 & 0.03 & 0.105 & 0.037 & 202,500 & 524,500 & 4.30 \\
\hline 1995 & 109.0 & 78.5 & 4.5 & 1.6 & 14 & 0.045 & 0.145 & 0.05 & 248,500 & 773,000 & 6.34 \\
\hline 1996 & 110.4 & 74.0 & 4.5 & 1.4 & 14 & 0.065 & 0.195 & 0.07 & 315,400 & $1,088,400$ & 8.92 \\
\hline 1997 & 111.8 & 69.5 & 4.5 & 1.4 & 14 & 0.085 & 0.25 & 0.09 & 328,800 & $1,417,200$ & 11.62 \\
\hline 1998 & 113.2 & 65.0 & 4.5 & 1.4 & 14 & 0.095 & 0.32 & 0.115 & 261,600 & $1,678,800$ & 13.77 \\
\hline 1999 & 114.6 & 60.5 & 4.5 & 1.4 & 14 & 0.105 & 0.39 & 0.135 & 297,000 & $1,975,800$ & 16.20 \\
\hline 2000 & 116.0 & 56.0 & 4.5 & 1.4 & 14 & 0.11 & 0.45 & 8.15 & $285,0.00$ & $2,261,700$ & 18.55 \\
\hline $\begin{array}{l}\text { (a) } \\
\text { (b) } \\
\text { (c) } \\
\text { (d) } \\
\text { (e) } \\
\text { (f) }\end{array}$ & \multicolumn{11}{|c|}{ 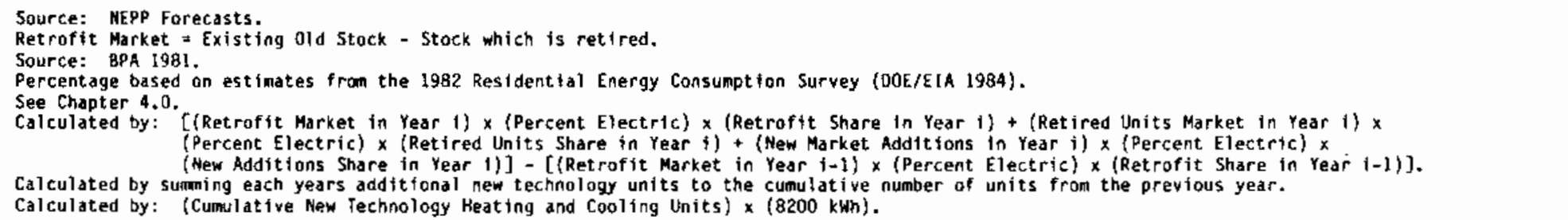 } \\
\hline
\end{tabular}


TABLE 5.15. Gas-Fired Heat Pump High Market-Penetration Scenario for Electrically Cooled Oniy Residences

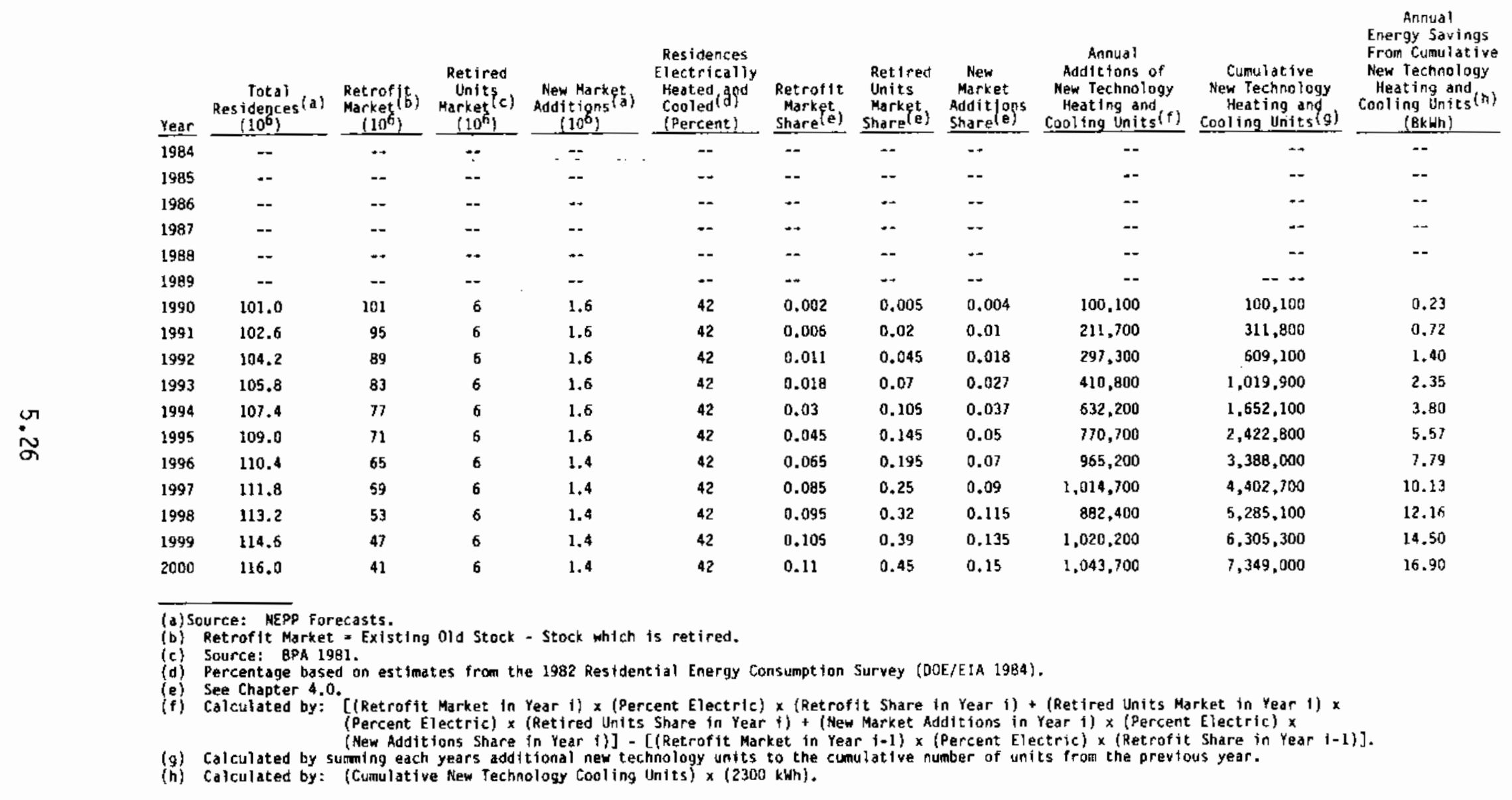


TABLE 5.16. National Annual Electrical Savings Estimates from the High MarketPenetration Scenarios for the New Heat Pump Technologies (Bkwh)

\begin{tabular}{|c|c|c|c|c|c|}
\hline Year & $\begin{array}{c}\text { Electric } \\
\text { Water-to-Air } \\
\text { Heating } \\
\text { and Cooling } \\
\end{array}$ & $\begin{array}{c}\text { Electric } \\
\text { Water-to-Air } \\
\text { Cooling } \\
\text { Onty } \\
\end{array}$ & $\begin{array}{c}\text { Gas-Fired } \\
\text { Heating and } \\
\text { Cooling } \\
\end{array}$ & $\begin{array}{c}\text { Gas-Fired } \\
\text { Cooling } \\
\text { Only } \\
\end{array}$ & $\begin{array}{c}\text { Total } \\
\text { Savings } \\
\end{array}$ \\
\hline 1985 & 1.03 & 0.89 & 0 & 0 & 1.92 \\
\hline 1990 & 5.67 & 5.27 & 0.26 & 0.23 & 11.43 \\
\hline 1995 & 14.60 & 14.02 & 6.34 & 5.57 & 40.53 \\
\hline 2000 & 21.13 & 20.32 & 18.55 & 16.90 & 77.50 \\
\hline
\end{tabular}

cost/kWh of those energy savings is less than the cost/kwh of producing that power utilities may choose to invest in technologies instead of new generating capacity.

In that regard, the cost/kWh saved calculations for each space conditioning application of the new heat pump technologies are displayed in Tables 5.17 and 5.18 and compared with estimated national average cost/kWh of new power from a new coal-fired generating plant of about $5.21 \$ / \mathrm{kWh}$.

The results of this analysis indicate that the costs/kWh saved for new and retirement market installations of both the electric water-to-air $(2.55 \$ / \mathrm{kWh})$ and the gas-fired HPS $(1.85 \$ / \mathrm{kWh})$ are significantly less than the estimated $5.21 \% / \mathrm{kWh}$ cost of new power. On the other hand, the analys is indicates that the $8.73 \$ / \mathrm{kWh}$ cost for energy saved by replacing existing conventional electric HVACs with electric water-to-air type systems would not be a good investment for utilities and the cost of replacing an existing HVAC with a gas-fired HP system $(5.98 \$ / \mathrm{kWh})$ would, at best, be only slightly more expensive than the cost of generating new power.

These estimates are based on the assumption that the typical residence is both heated and cooled with electricity. The analysis also provides estimates of costs/kWh saved for heating only and for cooling only applications even though the typical HP system is designed to be used in both applications. For residences that are only cooled electrically, the cost of both water-to-air heat pumps $(9.1 \$ / \mathrm{kWh})$ and gas heat pumps $(6.6 \$ / \mathrm{kWh})$ exceed the national average cost of new generating plant additions (both for new and retirement markets). 
TABLE 5.17. Cost/kWh Saved Calculations for Electric Water-to-Air Heat Pumps

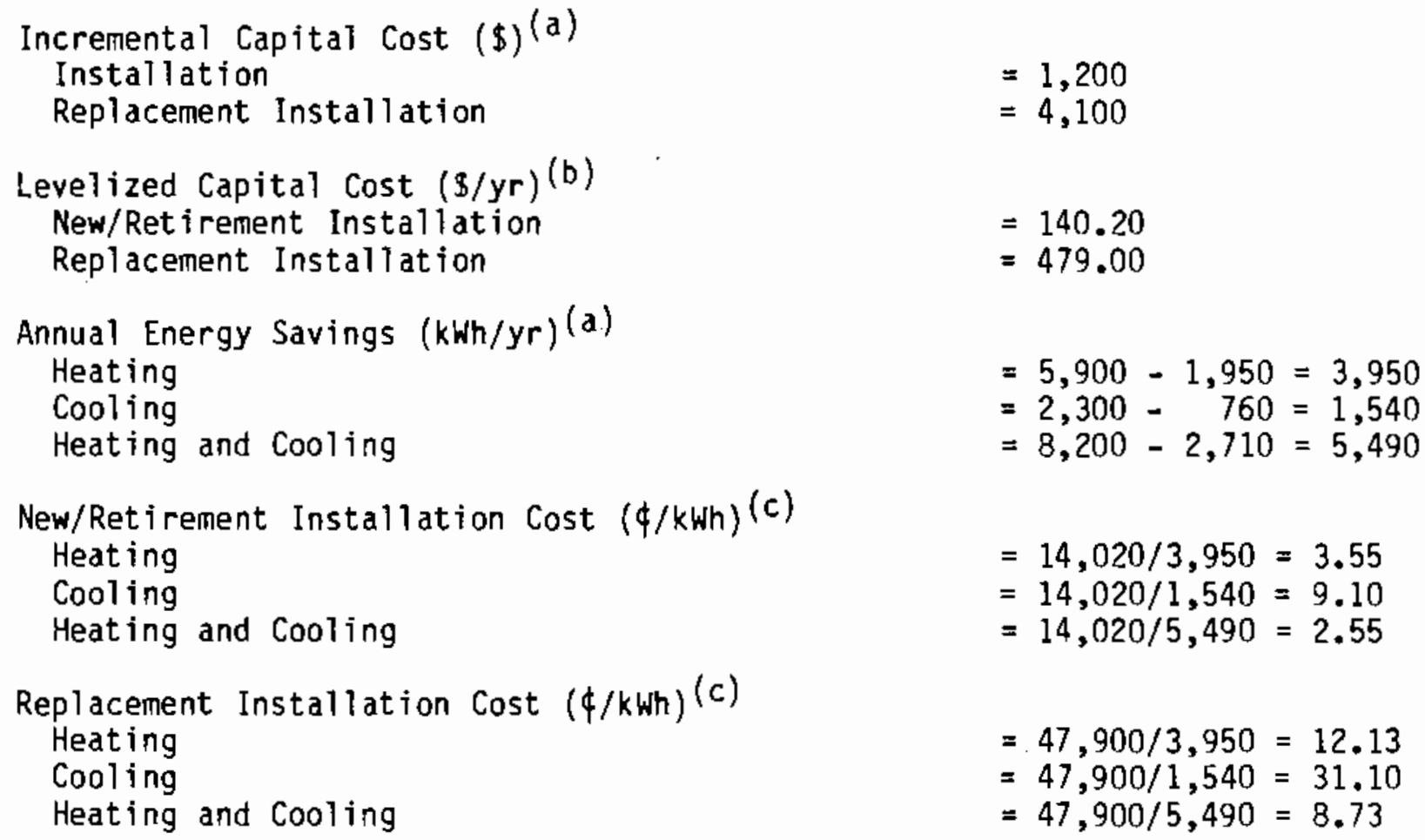

Replacement Installation Cost $(\$ / k w h)(c)$ Heating Cooling Heating and Cooling 
TABLE 5.18. Cost/kWh Saved Calculations for Gas-Fired Heat Pumps

\begin{tabular}{|c|c|}
\hline $\begin{array}{l}\text { Incremental Capital Cost }(\$)^{(a)} \\
\text { Installation } \\
\text { Replacement Installation }\end{array}$ & $\begin{array}{l}=1,300 \\
=4,200\end{array}$ \\
\hline $\begin{array}{l}\text { Levelized Capital Cost }(\$ / y r) \\
\text { New/Retirement Installation } \\
\text { Replacement Installation }\end{array}$ & $\begin{array}{l}=151.88 \\
=490.68\end{array}$ \\
\hline $\begin{array}{l}\text { Annual Energy Savings }(\mathrm{kWh} / \mathrm{yr})^{(\mathrm{a})} \\
\text { Heating } \\
\text { Cooling } \\
\text { Heating and Cooling }\end{array}$ & $\begin{array}{l}=5,900 \\
=2,300 \\
=8,200\end{array}$ \\
\hline $\begin{array}{l}\text { New/Retirement Installation Cost }(\$ / \mathrm{kWh})^{(\mathrm{c})} \\
\text { Heating } \\
\text { Cooling } \\
\text { Heating and Cooling }\end{array}$ & $\begin{array}{l}=15,188 / 5,900=2.57 \\
=15,188 / 2,300=6.60 \\
=15,188 / 8,200=1.85\end{array}$ \\
\hline $\begin{array}{l}\text { Replacement Installation Cost }(\$ / \mathrm{kWh})(\mathrm{C}) \\
\text { Heating } \\
\text { Cooling } \\
\text { Heating and Cooling }\end{array}$ & $\begin{array}{l}=49,068 / 5,900=8.32 \\
=49,068 / 2,300=21.33 \\
=49,068 / 8,200=5.98\end{array}$ \\
\hline
\end{tabular}

\footnotetext{
(a) See Table 5.1 .

(b) The level stream of annual payments the present value of which would equal the investment's incremental capital cost. Assumes a 15 year useful lifetime of the investment and an 8 percent rate of interest compounded annually. See Equation 4.11 above.

(c) Levelized Capital Cost (x 100/\$)/Annual Energy Savings.
}

\subsection{REFERENCES FOR CHAPTER 5.0}

8PA. 1981. Technical Review of the Oak Ridge National Laboratory Engineering/Economic Model of Residential Energy Use. 8onneville Power Administration, Portland, Oregon.

Cairns, E. J. 1984. "Heat Pump Market Penetration." Presentation at the DOE/BERD Annual Review of the Energy Efficient Buildings Program (EEB) and Energy Analysis Program (EA), September 17 and 18, 1984. U.S. Department of Energy, Washington, D.C.

Chan, T. S. with R. S. Beier and W. S. Chin. 1984. "Technical and Economic Feasibility of Stirling Cycle Industrial Heat Pumps." In Proceedings of the 19th Intersociety Energy Conversion Engineering Conference (IECEC) 1984. Volume 3. p. 1962-1967. 
Gas Research Institute Digest (GRID). 1983. "GRI's Gas-Fired Heat Pump Program: An Update." GRID. 6(1):1, 4-6, January/February 1983.

Hiawiczka, H. 1984. "The Funding of Heat Pumps Within the German Energy R\&D Program in the Sector of End-Use Technologies... Results, Experiences, Evaluations, Future Prospects," Presented at the IEA Heat Pump Conference, May 22-25, 1984. Gray, Austria.

Itteilag, R. L., and C. A. Swanson. 1984. "A Life-Cycle Cost Analysis of Residential Gas-Fired Heat Pumps." Public Utilities Fortnightly. May 10, 1984.

Kawamoto, H., Y. Takata, K. Shibuya. 1984. "Development of a Gas Engine Heat Pump for Domestic and Commercial Use." In Proceedings of the 1984 International Gas Research Conference. Gas Research Institute, Chicago, IIlinois.

McGuigan, D. with A. McGuigan. 1982. Heat Pumps - An Efficient Heating and Cooling Alternative. Gordon Way Publishing, Charlotte, Vermont.

Moynihan, T. M. and R. A. Ackermann. 1984. "Test Results for a StirlingEngine-Driven Heat-Actuated Heat Pump Breadboard System." In Proceedings of the 19th Intersociety Energy Conversion Engineering Conference (IECEC) 1984. Volume 3. p. 1819-1822.

Nakatani, Y. and H. Moni with Y. Narimatsu and T. Watanabe. 1984. "Stirling Engine Development Project in Japan." In Proceedings of the 19th Intersociety Energy Conversion Engineering Conference (IECEC) 1984. Volume $3 . ~ p$. 2055-2057.

Nesbit, W. 1984. "Pumping Heat into Cold Water." EPRI Journal, January/February 1984, pp. 16-21. Electric Power Research Institute, Palo Alto, California.

OECD. 1982. "Heat Pump Systems." Organization for Economic Cooperation and Development, International Energy Agency, Washington, D.C.

Tanaka, K. and E. Miura. 1984. "Heat Pumps in Japan 1975-1990." Presented at the IEA Heat Pump Conference, May 22-25, 1984. Gray, Austria.

U.S. DOE. 1984a. Annual Energy Outlook 1983: With Projections to 1995. DOE/EIA-0383(83), Department of Energy, Energy Information Administration, Washington, D.C.

U.S. DOE * 1984b. RECS: Housing Characteristics 1982, D0E/EIA-0314(82), Department of Energy, Energy Information Administration, Washington, D.C.

U.S. D0E. 1984C. Energy Conservation Multi-Year Plan. FY 1986-FY 1990. Department of Energy, Office of Conservation, Washington, D.C. 
U.S. DOE. 1983. Energy Projections to the Year 2010. DOE/PE-0029/2, Department of Energy, Office of Policy, Planning, and Analysis, Washington, D.C.

U.S. DOE. 1978. "Heat Pump Technology: A Survey of Technical Development Market Prospects." Department of Energy, Washington, D.C. 


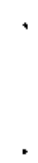




\subsection{ADVANCED THERMAL INSULATION AND ANTI-INFILTRATION TECHNIQUES}

This chapter we estimated the potential electrical energy savings in the U.S. for the years 1990, 1995, and 2000 from improvements in the thermal efficiency of residential structures by key conservation measures. Among the most important of these measures are ceiling, wall, and floor insulation and antiinfiltration (tightening) techniques to reduce air leakage.

Section 6.1 is a technical review of insulation and anti-infiltration methods and of how those methods contribute to household energy savings. Typical insulation levels in new and existing homes and recent trends in those levels are discussed in Section 6.2. Section 6.3 describes estimates of the purchase and installation costs, the energy savings, and the market penetration of specific insulation improvements. In Section 6.4 the market penetration estimates of Section 6.3 are applied to housing stock data and to housing stock forecasts to obtain an annual estimates of future insulation and anti-infiltration installations. Section 6.5 presents of the results of the analysis. Section 6.6 is an analysis of the sensitivity of the energy savings results to

changes in the market-penetration scenarios. Finally, Section 6.7 presents the estimated cost/kWh saved by improved thermal efficiency measures and discusses how those costs compare with the cost/kWh of new electrical generating capacity.

\subsection{TECHNICAL BACKGROUND}

Insulation's ability to reduce the loss (gain) of heat by conduction is expressed in terms of thermal resistance or R-value. The higher the R-value of the application, the lower the heat flow through the insulating material. Insulation materials are sold by volume (i.e., number of inches deep over a specified area of ceiling, wall, or floor) typically in the form of blankets or loose-fill that can be blown into spaces.

Measures to reduce air infiltration contribute toward more energy efficient buildings by reducing direct air flows between the inside and the outside of buildings. The major areas of air leakage through the building are between the soleplate and the foundation, through or around electrical wall outlets, 
ventilation duct systems, exterior windows and doors, and up various ceiling vents and fireplace chimneys (see Figures 6.1 and 6.2). Some anti-infiltration measures include caulking, weatherstripping, new air-tight window and door

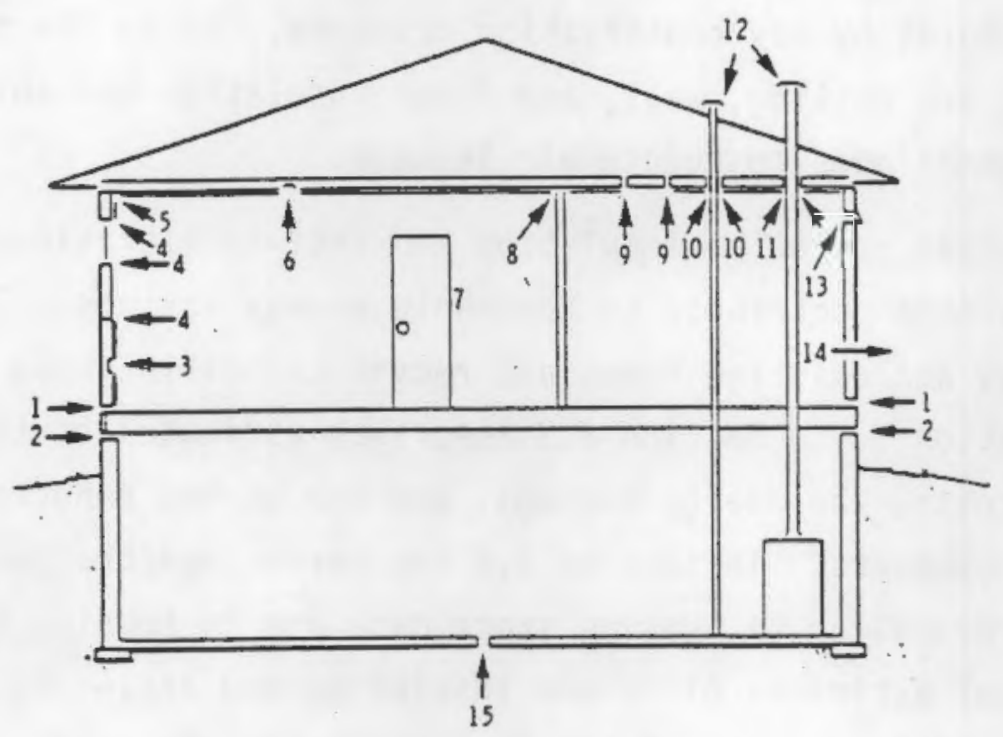

Joint between sill and floor

2. Joint between poists and basement

3. Eler"-ical boxes

4. Joints at wincows

5. Joints between wall and ceiling

6. Ceiling light fixture

7. Cracks at doors

8. Joints at interior partitions

9. Joints at attic haich

10. Plumbing stack Denetration

11 Chimney penetration of cering

12. Chimner leaks ait from nouse contunuously

13. Vents from bathroom and kitchen

14 Holes through vapor barrier tears

15. Floor drain fart enters via

weeping (Ile)

\section{FIGURE 6.1. Air Leakage Spots in Conventional Construction} Source: PNL, 1981, p. 8.

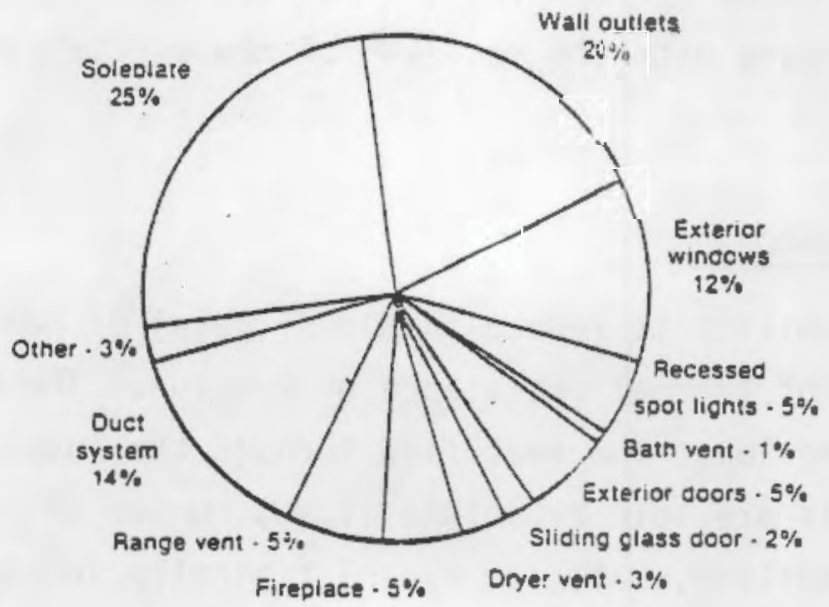

FIGURE 6.2. Air Leakage Test Results for Average Home of 1,780 Sq. Ft. Source: Texas Power and Light Company, Residential Air Infiltration. November 1977. 
sills, fireplace doors and inserts, closeable shutters, special plastic coverings over wall outlets, and tighter building practices.

Infiltration is measured in terms of "air changes per hour" (ach). The lower the ach, the more air-tight and energy efficient the building is. Factors affecting a building's ach include air-tightness of the building, wind speed and the differential between indoor and outdoor temperatures.

\subsection{CURRENT MARKET SITUATION}

The source used for estimating the insulation of existing homes is the Residential Energy Consumption Survey: Housing Characteristics 1982 (D0E/EIA 1984). That publication reports on the number/percent of homes with various types of insulation, but not how much insulation is in existing homes. Table 6.1 summarizes the information that is available on the insulation of ceilings and walls of existing residential buildings, while Table 6.2 summarizes recent trends in insulation and home tightening. The information in these tables was used along with a set of regional estimates (NPPC 1983) and

TABLE 6.1. Single-family Homes with Selected Types of Insulation 1978 and 1980-1982 (Percent)

\begin{tabular}{|c|c|c|c|c|}
\hline Type of Insulation & $\underline{1978}$ & $\underline{1980}$ & 1981 & $\underline{1982}$ \\
\hline Roof/Ceiling Insulation & & & & \\
\hline Yes & 75.6 & 76.8 & 77.6 & 79.0 \\
\hline No & 17.2 & 14.5 & 13.8 & 13.3 \\
\hline Unknown & 7.2 & 8.7 & 8.6 & 7.7 \\
\hline Wall Insulation & & & & \\
\hline Yes & 53.2 & 64.4 & 61.4 & \\
\hline All Walls & NA & 52.6 & 51.3 & 50.7 \\
\hline Some walls & NA & 11.8 & 10.1 & 10.6 \\
\hline & 28.7 & 20.5 & 21.6 & 2 \\
\hline Unknown & 18.1 & 15.1 & 17.0 & \\
\hline
\end{tabular}

NA $=$ not asked.

Note: For 1979, not asked.

Source: Energy Information Administration, 1978 through 1982 Residential Energy Consumption Surveys. 
TABLE 6.2. Single-Family Homes Making Conservation Improvements 1978-1982 (Percent)

\begin{tabular}{|c|c|c|c|c|c|}
\hline $\begin{array}{l}\text { Conservation } \\
\text { Improvements }\end{array}$ & $\underline{1978}$ & 1979 & $\underline{1980}$ & 1981 & 1982 \\
\hline Caulking & 18.6 & (a) & 19.1 & 10.8 & 10.7 \\
\hline Weatherstripping & 7.6 & (a) & 13.6 & 6.1 & 5.8 \\
\hline $\begin{array}{l}\text { Closeable Shutters, } \\
\text { Reflective Film, } \\
\text { Plastic Coverings, or } \\
\text { Insulating Drapes (b) }\end{array}$ & 8.3 & (a) & 9.6 & 4.3 & 5.0 \\
\hline $\begin{array}{l}\text { Roof/Ceiling } \\
\text { Insulation }\end{array}$ & 5.1 & 5.8 & 6.1 & 3.9 & 2.6 \\
\hline Storm Doors & 4.4 & $6.3^{(c)}$ & 5.8 & 4.0 & 3.8 \\
\hline Storm Windows & 4.3 & (c) & 4.3 & 3.1 & 3.0 \\
\hline Wall Insulation & 2.6 & 2.9 & 3.5 & 2.3 & 1.7 \\
\hline Basement/Crawl & 2.1 & (a) & 1.6 & 0.9 & 0.9 \\
\hline
\end{tabular}

(a) Not asked.

(b) This category did not inciude film or drapes in 1978 or film in 1980.

(c) Storm doors and storm windows were combined into one category in the 1979 survey.

Note: The 1979 Screener Survey collected very limited data on conservation improvements.

Source: Energy Information Administration, 1978 through 1982 Residential Energy Consumption Surveys.

expert opinion(a) to construct a set of assumptions about insulation and antiinfiltration levels, in a prototypical home used to represent the national average. These existing-home base-case assumptions are presented in the first column of Table 6.3. As the reader will note, they are RI9 for ceilings, R11 for walls, R7 for floors, and 0.6 ach for infiltration.

(a) Personal communication on December 7, 1984 with Arthur Johnson of the National Association of Home Builders (NAHB) Research Foundation, Inc., Rockville, Maryland. 
TABLE 6.3. Insulation and Anti-Infiltration Improvements for Residential Homes Base Case and Efficient Home Assumptions

\begin{tabular}{|c|c|c|c|c|c|}
\hline & $\begin{array}{c}\text { Base Case } \\
\text { Assumptions } \\
\end{array}$ & 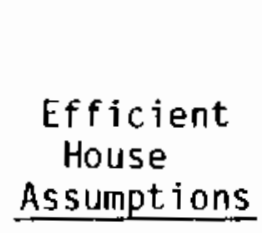 & $\begin{array}{c}\text { Purchase and } \\
\text { Installation } \\
\text { Cost } \\
\text { Assumptions (a) } \\
(1984 \$)\end{array}$ & $\begin{array}{c}\text { Heating } \\
\text { Percent } \\
\text { Savings (b) } \\
\text { Assumptions } \\
\end{array}$ & $\begin{array}{c}\text { Cooling } \\
\text { Percent } \\
\text { Savings } \\
\text { Assumptions (c) } \\
\end{array}$ \\
\hline \multicolumn{6}{|c|}{ Existing Homes } \\
\hline Ceiling & R19 & $\mathrm{R} 38$ & 500 & $7.7 \%$ & $0.1 \%$ \\
\hline Walls & R11 & R11 & (d) & $0.0 \%$ & $0.0 \%$ \\
\hline Floors & R7 & R19 & 500 & $9.7 \%$ & $0.1 \%$ \\
\hline Infiltration & $0.6 \mathrm{ach}$ & $0.4 \mathrm{ach}$ & 550 & $30.0 \%$ & $30.0 \%$ \\
\hline Totals & & & 1550 & $47.4 \%$ & $30.2 \%$ \\
\hline \multicolumn{6}{|l|}{ New Homes } \\
\hline $\begin{array}{l}\text { Ceiling } \\
\text { Walls } \\
\text { Floors } \\
\text { Infiltration }\end{array}$ & $\begin{array}{c}\text { R30 } \\
\text { R11 } \\
\text { R11 } \\
0.6 \text { ach }\end{array}$ & $\begin{array}{c}\mathrm{R} 49 \\
\mathrm{R} 31 \\
\mathrm{R} 30 \\
0.4 \mathrm{ach}\end{array}$ & $\begin{array}{r}400 \\
1000 \\
575 \\
550 \\
\end{array}$ & $\begin{array}{r}2.9 \% \\
35.0 \% \\
5.2 \% \\
30.0 \% \\
\end{array}$ & $\begin{array}{r}0.1 \% \\
13.0 \% \\
0.1 \% \\
30.0 \% \\
\end{array}$ \\
\hline Totals & & & 2525 & $73.1 \%$ & $43.2 \%$ \\
\hline
\end{tabular}

(a) Based on information gathered from the following sources: 1) NPPC 1983, p. K-32 through K-12, 2) Palmiter $1984, p, 6,3)$ Personal Communication with several unnamed market vendors over the week of December 3-7, 1984.

(b) NPPC 1983, p. K-3 through K-12.

(c) PNL, 1981, P. 8.4 through B.9.

(d) Assumed too costly to retrofit. 
The information for new housing insulation levels was obtained from recent surveys performed by the National Association of Home Builders (NAHB). Accord. ing to that source(a), the national averages for R-value insulation levels in new residential buildings for 1982 were R25.3 for ceilings, R11.9 for walls, and R7.8 for floors. Unfortunately, the typical air change rate for new homes was not available from the NAHB. However, a commonly used figure in alternative studies (Palmiter 1984) estimates that value to be approximately 0.6 ach. Again, the reader will note that the assumed base case values for new homes, also presented in the first column of Table 6.3 , have been rounded to more "standard" values.

\subsection{COST EFFECTIVENESS AND MARKET PENETRATION}

In this section, the assumed costs, expected energy and dollar savings, and consequent cost-effectiveness of higher levels of insulation/anti-infiltration measures are presented and discussed. These results are then used to estimate the degree to which such measures will be implemented in the housing market between the present year and the year 2000.

\subsubsection{Cost Effectiveness}

In order to make the task of obtaining cost estimates more manageable, it was necessary to explicitly define a specific set of "thermally efficient house" assumptions for existing and new residential homes. (b) These assumptions are presented in the second column in Table 6.3. The assumed "efficient" scenarios of R-values and ach levels presented here were selected not so much because they represent "ideal" improvements but rather because, given the published costs and energy savings estimates for various sets of specific home improvements (NPPC 1983 and Paimiter 1984), they are representative alternatives to present standards. The R-values and the infiltration rates for the

(a) Personal communication on December 7, 1984 with Arthur Johnson of the NAHB Research Foundation, Inc., Rockville, Maryland.

(b) The critical dimensions of such a home are; ceiling space requiring insulation equaling approximately $1200 \mathrm{sq}$. ft., wall space to the outside equaling approximately $2000 \mathrm{sq}$. ft., floor space requiring insulation equaling approximately $1200 \mathrm{sq}$. ft., with "average numbers" of doors, window, electrical outlets, etc. 
"thermally efficient" existing home differ from those of the "thermally efficient" new home primarily because it is usually far more costiy to install higher levels of insulation in older homes. This is because older homes were rarely constructed with energy efficiency in mind and typically have less space, especially between the inside and outside walls, to fill with insulation. To make more space for insulation, such homes would have to be remodeled with a $2^{\prime \prime} \times 6$ " outer wall frame to replace the less spacious and more prevalent $2^{\prime \prime} \times 4^{\prime \prime}$ type outer wall frame. Obviously, such remodeling would be far more costly than simply filling a pre-existing space with insulation. On the other hand, building a new home with a $2 \times 6$ outer wall frame with special insulation siding material is not nearly as costly and can provide substantial energy savings.

Estimates of average national costs of increasing R-values and decreasing infiltration rates from the "base case" to the "efficient house" levels could not be found. Therefore, the purchase and installation cost assumptions presented in the third column of Table 6.3 are based on regional approximations (NPPC 1983 and Palmiter 1984) and substantiated by personal communication with market vendors.

The percent heating and cooling energy savings assumptions presented in columns four and five of Table 6.3 were also difficult to quantify on a national level. Such figures are typically climate specific and climates vary considerably from region to region. Therefore, the sources (PNL 1981, NPPC 1983, and Palmiter 1984) which reported such energy savings estimates did so only for specific insulation level changes in specific regions. Because of this regional variation, the energy savings assumptions listed in Table 6.3 are only potentialiy "representative" for the nation as a whole.

Note that the percent heating savings assumptions exceed those for cooling for the same improvement in insulation. This is primarily because the rate of loss of heat or cooling by conduction through ceilings, walls, and floors to the buildings exterior depends on the indoor-outdoor temperature differential. The greater the indoor-outdoor temperature differential, the higher the 
rate of heat transfer. Hence, because the indoor-outdoor temperature differential is typically greater (both in terms of size and of duration) during the heating season, there is a greater potential for energy savings for heating as compared to cooling.

\subsubsection{Market Penetration}

The degree to which higher levels of insulation are likely to be installed depends on several factors. Some of the more important factors are: 1) the initial incremental capital cost of the "thermal efficiency" measures, 2) the simple payback period, 3) whether the efficiency measures are being applied to new or to previously existing homes, 4) the number of existing homes and the number of new hories being built each year, and 5) technical limitations that may exist to the effective installation of such measures. The capital costs and the payback periods are reported in Table 6.4, as are the expected maximum market penetration rates.

The only readily apparent technical limitations to the implementation of these efficiency measures is the problem of retrofitting existing buildings, as well as problems of reduced indoor air quality. As infiltration is reduced below 0.2 ach there may be a significant deterioration of interior air conditions. These conditions can be remedied by installing an air-to-air heat exchanger which can provide ventilation while losing less than 15 percent of the heat that would otherwise be lost through ordinary infiltration (PNL 1981). In the present case, such devices would not be required because the infiltration rate is assumed to be higher than 0.2 ach (i.e., 0.4 ach).

\subsection{HOUSING STOCK PROJECTIONS AND MARKET SHARE ESTIMATES}

Tables 6.5 and 6.6 present scenarios of housing stock projections and market share percentages at yearly intervals up to the year 2000. The housing stock projections are based on estimates used by the DOE for computations in The National Energy Policy Plan (DOE 1983). The percentage of houses that use 1984). Note that separate calculations were performed for electrically cooled homes, although the payback periods and maximum market penetration rates were 
TABLE 6.4. Insulation and Anti-Infiltration Space Conditioning Simple Pay-Back Calculations

\begin{tabular}{|c|c|c|c|c|}
\hline & $\begin{array}{l}\text { Existing } \\
\text { Home } \\
\text { Base Case } \\
\end{array}$ & $\begin{array}{l}\text { Efficient } \\
\text { Existing } \\
\text { Home } \\
\end{array}$ & $\begin{array}{l}\text { New Home } \\
\text { Base } \\
\text { Case } \\
\end{array}$ & $\begin{array}{l}\text { Ef ficient } \\
\text { New Home }\end{array}$ \\
\hline Incremental Capital Cost $(\$)^{(a)}$ & -- & 1550 & - & 2525 \\
\hline $\begin{array}{l}\text { Percent Savings }(a) \\
\text { Heating -- } \\
\text { Cooling -- }\end{array}$ & $\begin{array}{l}47.4 \\
30.2\end{array}$ & -- & $\begin{array}{l}73.1 \\
43.2\end{array}$ & \\
\hline $\begin{array}{l}\text { Annual Househgld Energy } \\
\text { Consumption (b) } \\
\text { Heating (kWh) } \\
\text { Cooling (kWh) }\end{array}$ & $\begin{array}{l}5900 \\
2300 \\
\end{array}$ & $\begin{array}{l}3103 \\
1605 \\
\end{array}$ & $\begin{array}{l}5600 \\
2275 \\
\end{array}$ & $\begin{array}{l}1506 \\
1292 \\
\end{array}$ \\
\hline Total Heating and Cooling ( $\mathrm{kwh}$ ) & 8200 & 4708 & 7875 & 2798 \\
\hline Energy Cost (cents per kWh) ${ }^{(b)}$ & 7.18 & 7.18 & 7.18 & 7.18 \\
\hline $\begin{array}{l}\text { Annual Fuel Bill }(\$)^{(C)} \\
\text { Heating }(\$) \\
\text { Cooling }(\$)\end{array}$ & $\begin{array}{l}420 \\
165 \\
\end{array}$ & $\begin{array}{l}223 \\
115 \\
\end{array}$ & $\begin{array}{l}402 \\
163 \\
\end{array}$ & $\begin{array}{r}108 \\
93 \\
\end{array}$ \\
\hline Total Heating and Cooling (\$) & 585 & 338 & 565 & 201 \\
\hline Annual Savings on Fuel Bill $(\$)^{(d)}$ & -- & 247 & -- & 364 \\
\hline Simple Pay-Back Period $(y r s)^{(e)}$ & -- & 6 & -- & 7 \\
\hline $\begin{array}{l}\text { Maximum Market Penetration } \\
\text { (percent) }\end{array}$ & & 20 & & 10 \\
\hline
\end{tabular}

(a) Based on information gathered from the following sources: 1) NPPC 1983, p. K-3 through $\mathrm{K}-12$, 2) Palmiter 1984 , p. 6,3 ) personal communication with several unnamed market vendors over the week of December 3-7, 1984.

(b) These rounded figures very closely approximate and average figure computed from residential energy consumption information found in the Residential Energy Consumption Survey: Housing Characteristics 1982 (DOE/EIA 1984).

(c) Calculated at $\$ 7.18 \$ / \mathrm{kwh}$.

(d) Calculated by subtracting the total annual base case fuel bills from their respective total annual "efficient" home fuel bills.

(e) Calculated by dividing the incremental capital costs of the home improvements by the calculated annual dollar savings on the "efficient" homes fuel bill.

(f) See Chapter 4.0 and Table 4.1 above for a description of the methodology used to calculate these maximum market penetration rates from the above calculated simple payback period. 
TABLE 6.5. Housing Stock Projections and Market Share Estimates of Thermal Efficiency Measures for Electrically Heated Residences

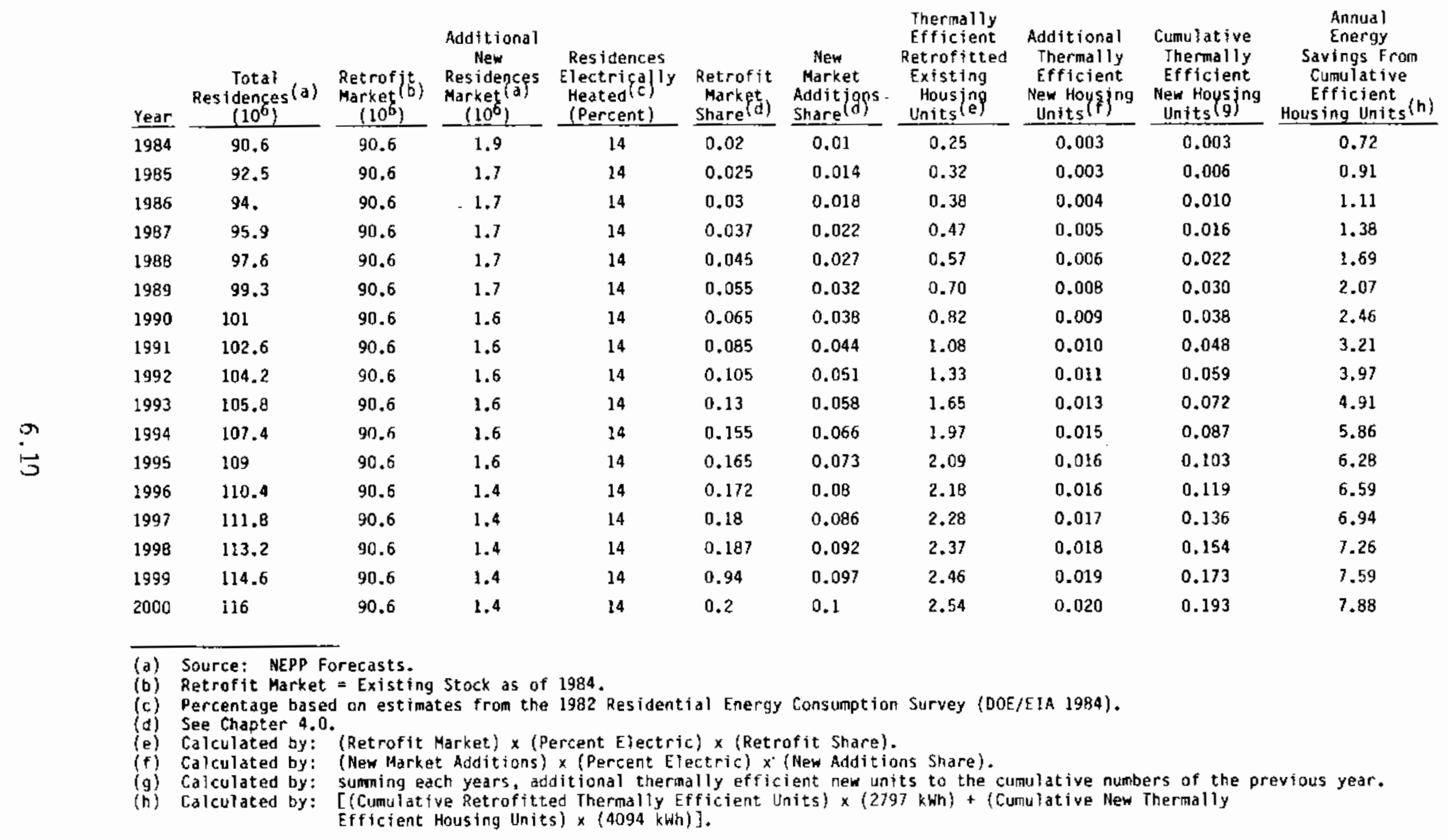


TABLE 6.6. Housing Stock Projections and Market Share Estimates of Thermal Efficiency Measures for Electrically Cooled Residences

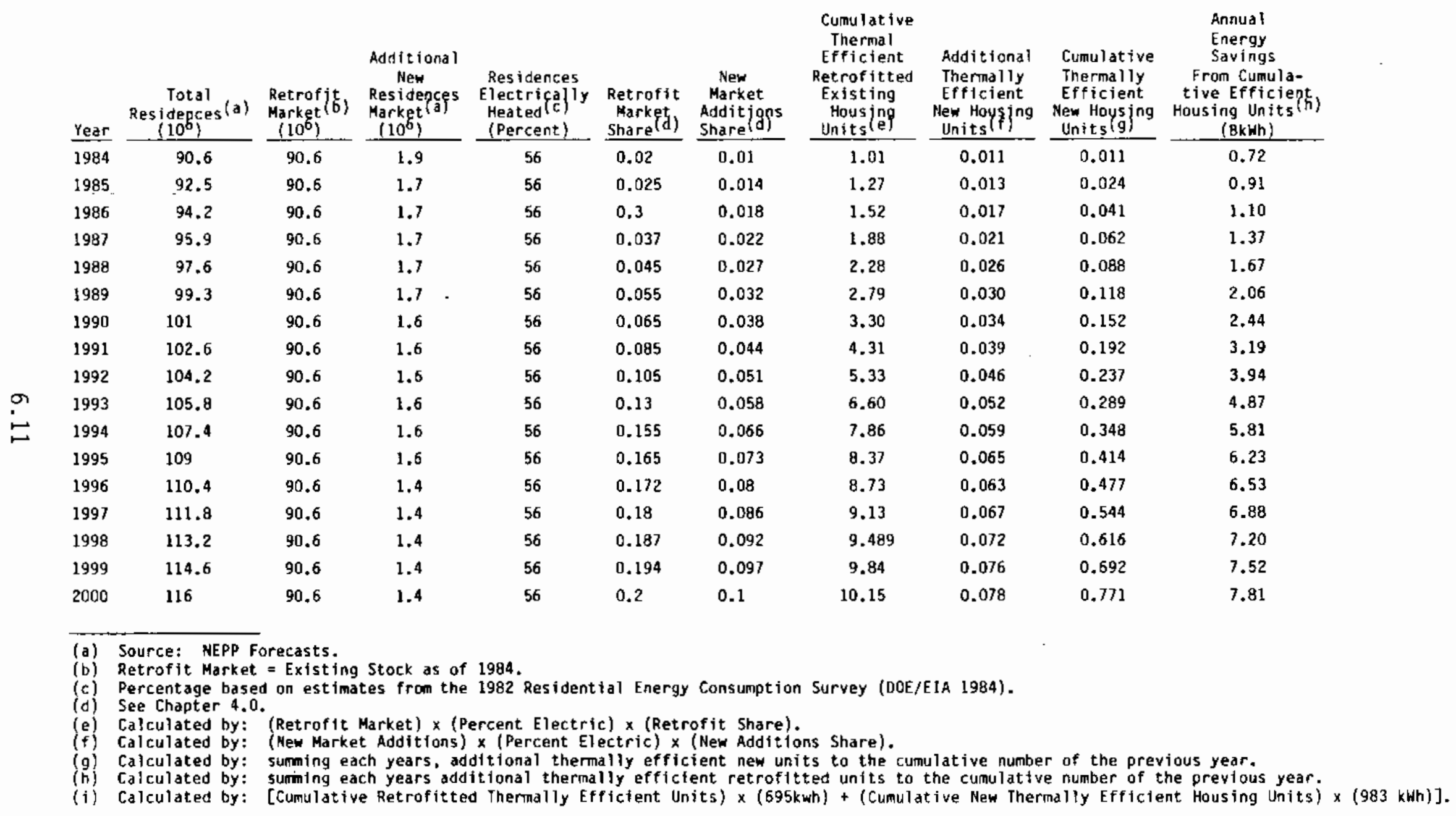


calculated for a "typical" residence that is both heated and cooled electrically. Varying these assumptions was not performed in the analysis due to the time and budget constraints. The percentage of market share estimates are derived as described in Chapter 4.0 and are based on the payback period and market penetration estimates presented in Table 6.4 .

\subsection{ENERGY SAVINGS COMPUTATIONS AND RESULTS}

Tables 6.5 and 6.6 also present estimates of the expected national electrical energy savings from improvements in the thermal efficiency of residential buildings for the years 1984-2000. These estimates are based on the average annual electrical energy savings in a representative electrically space conditioned home and the expected rate of market penetration of the thermal efficiency measures. To use these savings and market penetration estimates to obtain a national savings estimate, they are applied to the data and forecasts presented in Tables 6.5 and 6.6 that characterize the size, composition, and expected changes over time of the insulation/anti-infiltration markets.

\subsubsection{Electrical Energy Savings Computations}

The representative existing households that choose to install the selected set of thermal efficiency measures could save an estimated $2797 \mathrm{kWh} / \mathrm{yr} / \mathrm{resi-}$ dence for heating and $695 \mathrm{kWh} / \mathrm{yr} / \mathrm{residence}$ for cooling. (a) For new housing, the selected set of thermal efficiency measures could save an estimated $4094 \mathrm{kWh} /$ $\mathrm{yr} /$ residence for heating and $983 \mathrm{kWh} / \mathrm{yr} /$ residence for cooling.

\subsubsection{Aggregate Electrical Energy Savings Results}

The results of the foregoing analysis are sumarized in Table 6.7 . The table shows that adoption of new insulation and anti-infiltration technologies in residential sector between 1984 and 2000 will reduce residential space conditioning electricity use by an estimated 15.7 BkWh in 2000 .

(a) See the "Annual Household Energy Consumption" estimates that are presented in Table 6.1 and subtract the estimated consumption of the thermaliy efficient home from that of the base case home to obtain these per representative household annual energy savings estimates. 
TABLE 6.7. Estimated National Annual Electrical Savings from Improved Thermal Efficiency Measures (BkWh)

\begin{tabular}{|c|c|c|c|c|c|}
\hline Year & $\begin{array}{l}\text { Existing } \\
\text { Home } \\
\text { Heating }\end{array}$ & $\begin{array}{l}\text { Existing } \\
\text { Home } \\
\text { Cooling }\end{array}$ & $\begin{array}{l}\text { New } \\
\text { Home } \\
\text { Heat ing }\end{array}$ & $\begin{array}{l}\text { New } \\
\text { Home } \\
\text { Cooling }\end{array}$ & $\begin{array}{c}\text { Total } \\
\text { Savings } \\
\end{array}$ \\
\hline $\begin{array}{l}1985 \\
1990 \\
1995 \\
2000\end{array}$ & $\begin{array}{l}0.89 \\
2.31 \\
5.86 \\
7.10\end{array}$ & $\begin{array}{l}0.89 \\
2.29 \\
5.82 \\
7.06\end{array}$ & $\begin{array}{l}.02 \\
.15 \\
.42 \\
.79\end{array}$ & $\begin{array}{l}.02 \\
.15 \\
.41 \\
.75\end{array}$ & $\begin{array}{r}1.82 \\
4.90 \\
12.51 \\
15.69\end{array}$ \\
\hline
\end{tabular}

The reader should be aware that portions of the analysis were treated in a somewhat simplistic fashion for the sake of analytical convenience. More specifically, these results depend critically on a specific scenario of assumed future prices, market penetration rates, housing stock changes, and "representative technology units." Such assumptions, forecasts, and other necessary simplifications, no matter how well represented, will still be imperfect approximations. It is therefore appropriate to assess the sensitivity of these results to changes in the scenario of assumptions.

\subsection{SENSITIVITY ANALYSIS}

This section is an analysis of the sensitivity of the aggregate energy savings results presented in Section 6.5 to alterations in the marketpenetration scenario. Low and high market-penetration scenarios are presented that imply a minimum/maximum range within which future energy savings are likely to occur. Also, the high penetration scenario implies what the maximum potential for national energy savings might be if programs or policies designed to increase the private use of the new energy saving measures were instituted.

\subsubsection{Low Market-Penetration Scenario}

The advanced thermal efficiency measures may not penetrate the residential market as quickly or as completely, as indicated in Tables 6.5 and 6.6. Hence, it would be appropriate to investigate the implications of that possibility.

The specific low market-penetration scenario investigated here assumes that the maximum potential level of penetration is only half of what it was 
estimated to be in both markets of the base case scenario. That is, the maximum market share was reduced from a 0.2 market share to a 0.1 market share for the retrofit market and from a 0.1 market share to a 0.05 market share for the new housing market. It is also assumed that only 75 percent of that new maximum market share potential will be achieved by the year 2000 . Tables 6.8 and 6.9 combine that scenario with a housing stock forecast to obtain a low penetration estimate of the future number of thermally efficient retrofit and new housing units.

The national estimate of annual electrical energy savings estimates for the low market-penetration scenario of the advanced thermal efficiency measures are presented in the last columns of Tables 6.8 and 6.9 and summarized in Table 6.10. The estimates were obtained by multiplying the year's estimated number of new "thermally efficient" housing units from the scenario times the estimates of the per unit annual electrical energy savings. These results could be interpreted as being indicative of a reasonable minimum of the expected electrical energy savings from the new thermal efficiency measures.

\subsubsection{High Market-Penetration Scenarios}

Under certain conditions, the advanced thermal efficiency measures may penetrate the market more rapidly than Tables 6.5 and 6.6 indicate. For example, if the government or certain utilities should decide that it would be a good investment to subsidize the installation of such measures, then the probable number of such installations would be increased. Hence, it is proper that the implications of that possibility be further investigated.

Specifically, the high market-penetration scenario assumes that the maximum potential level of penetration is twice what it was estimated to be in both markets of the base use case scenario. To that effect, the maximum market share was increased from 0.2 for the new housing market. It is further assumed that the new maximum market share is achieved by 1995 . Tables 6.11 and 6.12 combine that scenario with a housing stock forecast to arrive at high penetration estimates of the future number of thermally efficient retrofit and new housing units. 
TABLE 6.8. Housing Stock Projections and Low Market Share Scenario of Thermal Efficiency Measures for Electrically Heating Residences

\begin{tabular}{|c|c|c|c|c|c|c|c|c|c|c|}
\hline Year & $\begin{array}{c}\begin{array}{c}\text { Total } \\
\text { Residegces (a) } \\
\left(10^{6}\right)\end{array} \\
\end{array}$ & $\begin{array}{l}\text { Retrof }) \text { (b) } \\
\text { Market } \\
\left(10^{6}\right) \\
\end{array}$ & $\begin{array}{l}\text { Additional } \\
\text { New } \\
\text { Residepcess } \\
\text { Market }(a) \\
\left(10^{6}\right) \\
\end{array}$ & $\begin{array}{c}\text { Residences } \\
\text { Electrica)ly } \\
\text { Heated }(c)^{1 y} \\
\text { (Percent) } \\
\end{array}$ & $\begin{array}{l}\text { Retrofit } \\
\text { Market } \\
\text { Share (d) } \\
\end{array}$ & 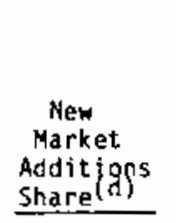 & $\begin{array}{l}\text { Cumulative } \\
\text { Thermal } \\
\text { Efficient } \\
\text { Retrofitted } \\
\text { Existing } \\
\text { Housing } \\
\text { Unfts (e) } \\
\end{array}$ & $\begin{array}{l}\text { Additional } \\
\text { Thermally } \\
\text { Eff icient } \\
\text { New Housing } \\
\text { Units }(f) \\
\end{array}$ & $\begin{array}{l}\text { Cumulative } \\
\text { Thermally } \\
\text { Efficient } \\
\text { New Housigg } \\
\text { Units }(g) \\
\end{array}$ & $\begin{array}{c}\text { Annual } \\
\text { Energy } \\
\text { Savings } \\
\text { From Cumbula- } \\
\text { tive Efficiept } \\
\text { Housing Units }(h) \\
\text { (BkWh) } \\
\end{array}$ \\
\hline 1984 & 90.6 & 90.6 & 1.9 & 14 & 0.02 & 0.01 & 0.25 & 0.003 & 0.003 & 0.72 \\
\hline 1985 & 92.5 & 90.6 & 1.7 & 14 & 0.02 & 0.011 & 0.25 & 0.002 & 0.005 & 0.73 \\
\hline-1986 & 94.2 & 90.6 & 1.7 & 14 & 0.0225 & 0.012 & 0.29 & 0.003 & 0.008 & 0.83 \\
\hline 1987 & 95.9 & 90.6 & 1.7 & 14 & 0.025 & 0.013 & 0.32 & 0.003 & 0.011 & 0.93 \\
\hline 1988 & 97.6 & 90.6 & 1.7 & 14 & 0.0275 & 0.014 & 0.35 & 0.003 & 0.014 & 1.03 \\
\hline 1989 & 99.3 & 90.6 & 1.7 & 14 & 0.03 & 0.015 & 0.38 & 0.004 & 0.018 & 1.14 \\
\hline 1990 & 101 & 90.6 & $1.6^{\circ}$ & 14 & 0.0325 & 0.0165 & 0.41 & 0.004 & 0.021 & 1.24 \\
\hline 1991 & 102.6 & 90.6 & 1.6 & 14 & 0.035 & 0.018 & 0.44 & 0.004 & 0.025 & 1.34 \\
\hline 1992 & 104.2 & 90.6 & 1.6 & 14 & 0.04 & 0.02 & 0.51 & 0.004 & 0.030 & 1.54 \\
\hline 1993 & 105.8 & 90.6 & 1.6 & 14 & 0.045 & 0.022 & 0.57 & 0.005 & 0.035 & 1.74 \\
\hline 1994 & 107.4 & 90.6 & 1.6 & 14 & 0.05 & 0.025 & 0.63 & 0.006 & 0.040 & 1.94 \\
\hline 1995 & 109 & 90.6 & 1.6 & 14 & 0.06 & 0.0275 & 0.76 & 0.007 & 0.047 & 2.32 \\
\hline 1996 & 110.4 & 90.6 & 1.4 & 14 & 0.065 & 0.03 & 0.82 & 0.006 & 0.053 & 2.52 \\
\hline 1997 & 111.8 & 90.6 & 1.4 & 14 & 0.0675 & 0.032 & 0.86 & 0.007 & 0.060 & 2.64 \\
\hline 1998 & 113.2 & 90.6 & 1.4 & 14 & 0.07 & 0.034 & 0.89 & 0.007 & 0.067 & 2.76 \\
\hline 1999 & 114.6 & 90.6 & 1.4 & 14 & 0.0725 & 0.036 & 0.92 & 0.007 & 0.074 & 2.87 \\
\hline 2000 & 116 & 90.6 & 1.4 & 14 & 0.075 & 0.0375 & 0.95 & 0.007 & 0.081 & 2.99 \\
\hline $\begin{array}{l}\text { (a) } \\
\text { (b) } \\
\text { (c) } \\
\text { (d) } \\
\text { (e) } \\
\text { (f) } \\
\text { (a) } \\
(\mathrm{h})\end{array}$ & \multicolumn{10}{|l|}{$\begin{array}{l}\text { Source: NEPP For } \\
\text { Retrofit Market = } \\
\text { Percentage based } \\
\text { See Chapter } 4.0 . \\
\text { Calculated by: } \\
\text { Calculated by: } \\
\text { Calculated by: } \\
\text { Calculated by: } \\
\text { Calculated by: }\end{array}$} \\
\hline
\end{tabular}


TABLE 6.9. Housing Stock Projections and Low Market Share Scenario of Thermal Efficiency Measures for Electrically Cooled Residences

\begin{tabular}{|c|c|c|c|c|c|c|c|c|c|c|c|}
\hline & Year & $\begin{array}{c}\text { Total } \\
\text { Residences }(a) \\
\left(10^{6}\right) \\
\end{array}$ & $\begin{array}{l}\text { Retrof jt } \\
\text { Market } \\
\left(10^{6}\right) \\
\end{array}$ & $\begin{array}{l}\text { Additional } \\
\text { New } \\
\text { Residences } \\
\text { Market } \\
\left(10^{6}\right) \\
\end{array}$ & $\begin{array}{l}\text { Residences } \\
\text { Electricafly } \\
\text { Heated }(c) \\
\text { (Percent) } \\
\end{array}$ & $\begin{array}{l}\text { Retrofit } \\
\text { Market } \\
\text { Share d) } \\
\end{array}$ & $\begin{array}{l}\text { New } \\
\text { Market } \\
\text { Additjggs } \\
\text { Share }\end{array}$ & $\begin{array}{l}\text { Cumulative } \\
\text { Thermal } \\
\text { Efficient } \\
\text { Retrafitted } \\
\text { Existing } \\
\text { Housing } \\
\text { Units (e) } \\
\end{array}$ & $\begin{array}{l}\text { Additional } \\
\text { Thermally } \\
\text { Efficient } \\
\text { New Housing } \\
\text { Units }\end{array}$ & $\begin{array}{l}\text { Cumulative } \\
\text { Thermally } \\
\text { Efficient } \\
\text { New Housigg } \\
\text { Units }(g) \\
\end{array}$ & $\begin{array}{c}\text { Annual } \\
\text { Energy } \\
\text { Savings } \\
\text { From Cumula- } \\
\text { tive Efficient } \\
\text { Housing Units }(h) \\
\text { (BKwh) } \\
\end{array}$ \\
\hline & 1984 & 90.6 & 90.6 & 1.9 & 56 & 0.02 & 0.01 & 1.01 & 0.011 & 0.011 & 0.72 \\
\hline & 1985 & 92.5 & 90.6 & 1.7 & 56 & 0.02 & 0.011 & 1.01 & 0.010 & 0.020 & 0.73 \\
\hline & 1986 & 94.2 & 90.6 & 1.7 & 56 & 0.0225 & 0.012 & 1.14 & 0.011 & 0.031 & 0.82 \\
\hline & 1987 & 95.9 & 90.6 & 1.7 & 56 & 0.025 & 0.013 & 1.27 & 0.012 & 0.043 & 0.92 \\
\hline & 1988 & 97.6 & 90.6 & 1.7 & 56 & 0.0275 & 0.014 & 1.40 & 0.013 & 0.056 & 1.02 \\
\hline & 1989 & 99.3 & 90.6 & 1.7 & 56 & 0.03 & 0.015 & 1.52 & 0.014 & 0.070 & 1.13 \\
\hline & 1990 & 101 & 90.6 & 1.6 & 56 & 0.0325 & 0.165 & 1.65 & 0.015 & 0.085 & 1.23 \\
\hline & 1991 & 102.6 & 90.6 & 1.6 & 56 & 0.035 & 0.018 & 1.78 & 0.016 & 0.100 & 1.33 \\
\hline & 1992 & 104.2 & 90.6 & 1.6 & 56 & 0.04 & 0.02 & 2.03 & 0.018 & 0.118 & 1.53 \\
\hline$a$ & 1993 & 105.8 & 90.6 & 1.6 & 56 & 0.045 & 0.022 & 2.28 & 0.020 & 0.138 & 1.72 \\
\hline 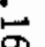 & 1994 & 107.4 & 90.6 & 1.6 & 56 & 0.05 & 0.025 & 2.54 & 0.022 & 0.161 & 1.92 \\
\hline & 1995 & 109 & 90.6 & 1.6 & 56 & 0.06 & 0.0275 & 3.04 & 0.027 & 0.188 & 2.30 \\
\hline & 1996 & 110.4 & 90.6 & 1.4 & 56 & 0.065 & 0.03 & 3.30 & 0.025 & 0.213 & 2.50 \\
\hline & 1997 & 111.8 & 90.6 & 1.4 & 56 & 0.0675 & 0.032 & 3.42 & 0.026 & 0.240 & 2.62 \\
\hline & 1998 & 113.2 & 90.6 & 1.4 & 56 & 0.07 & 0.034 & 3.55 & 0.027 & 0.267 & 2.73 \\
\hline & 1999 & 114.6 & 90.6 & 1.4 & 56 & 0.0725 & 0.036 & 3.68 & 0.028 & 0.296 & 2.85 \\
\hline & 2000 & 116 & 90.6 & 1.4 & 56 & 0.075 & 0.0375 & 3.81 & 0.029 & 0.325 & 2.96 \\
\hline & $\begin{array}{l}\text { (a) } \\
\text { (b) } \\
\text { (c) } \\
\text { (d) } \\
\text { (e) } \\
(\mathrm{f}) \\
(\mathrm{g}) \\
(\mathrm{h}) \\
(\mathrm{i})\end{array}$ & \multicolumn{10}{|l|}{$\begin{array}{l}\text { Source: NEPP For } \\
\text { Retrofit Market = } \\
\text { Percentage based } \\
\text { See Chapter } 4.0 . \\
\text { Calculated by: } \\
\text { Calculated by: } \\
\text { Calculated by: } \\
\text { Calculated by: } \\
\text { Calculated by: }\end{array}$} \\
\hline
\end{tabular}


TABLE 6.10. National Annual Electrical Savings Estimates from the Low Market-Penetration Scenario for Advanced Thermal

Efficiency Measures (BkWh)

\begin{tabular}{|c|c|c|c|c|c|}
\hline Year & $\begin{array}{l}\text { Existing } \\
\text { Home } \\
\text { Heating }\end{array}$ & $\begin{array}{l}\text { Existing } \\
\text { Home } \\
\text { Cooling }\end{array}$ & $\begin{array}{l}\text { New } \\
\text { Home } \\
\text { Heating }\end{array}$ & $\begin{array}{l}\text { New } \\
\text { Home } \\
\text { Cooling }\end{array}$ & $\begin{array}{c}\text { Total } \\
\text { Savings } \\
\end{array}$ \\
\hline $\begin{array}{l}1985 \\
1990 \\
1995 \\
2000\end{array}$ & $\begin{array}{l}.71 \\
1.15 \\
2.13 \\
2.56\end{array}$ & $\begin{array}{l}.71 \\
1.15 \\
2.12 \\
2.55\end{array}$ & $\begin{array}{l}.02 \\
.09 \\
.19 \\
.43\end{array}$ & $\begin{array}{l}.02 \\
.08 \\
.18 \\
.41\end{array}$ & $\begin{array}{l}1.48 \\
2.48 \\
3.70 \\
5.95\end{array}$ \\
\hline
\end{tabular}

The national estimate of annual electricity savings estimates for the high market-penetration scenario of the advanced thermal efficiency measures are presented in the last columns of Tables 6.11 and 6.12 , respectively, and summarized in Table 6.13. These estimates were derived by multiplying the year's estimated number of new "thermally efficient" housing units from the high scenario by the estimates of the per unit annual electrical energy savings from the new thermal efficiency measures. The estimates are representative of a plausible maximum for the expected future electrical energy savings from the advanced thermal efficiency measures.

\subsection{COST $/ \mathrm{kWh}$ OF ENERGY SAVED CALCULATIONS AND COMPARISONS TO THE COST/kWh OF CONSTRUCTING AND OPERATING NEW GENERATING CAPACITY}

The advanced thermal efficiency measures may be considered as potential investments for utilities to include in their generating portfolio. If the cost/kWh of these electricity savings produced by these investments is less than the cost/kWh of producing that power, then undertaking such investments would be cost-effective for the utility.

The calculations of the cost/kWh saved for heating, cooling, and heating and cooling combined due to the advanced thermal efficiency measures are presented in Table 6.14. These estimates may be compared to the national estimated average cost of about $5.21 \$ / k$ Wh for producing new generating capacity from a new coal-fired generating plant (see Table 4.3). 
IABLE 6.11. Housing Stock Projections and High Market Share Scenario of Thermal Efficiency Measures for Electrically Heated Residences

\begin{tabular}{|c|c|c|c|c|c|c|c|c|c|c|c|}
\hline & Year & $\begin{array}{c}\text { Total } \\
\text { Residences (a) } \\
\left(10^{6}\right)\end{array}$ & 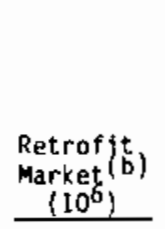 & $\begin{array}{l}\text { Additional } \\
\text { New } \\
\text { Residences } \\
\text { Market (a) } \\
\left(10^{6}\right) \\
\end{array}$ & $\begin{array}{l}\text { Residences } \\
\text { Electricaly } \\
\text { Heated }(c) \\
\text { (Percent) }\end{array}$ & $\begin{array}{l}\text { Retrofit } \\
\text { Market } \\
\text { Share d) } \\
\end{array}$ & $\begin{array}{c}\text { New } \\
\text { Market } \\
\text { Additjons } \\
\text { Share }\end{array}$ & $\begin{array}{l}\text { Cumulative } \\
\text { Thermal } \\
\text { Efficient } \\
\text { Retrofitted } \\
\text { Existing } \\
\text { Housing } \\
\text { Units (e) } \\
\end{array}$ & $\begin{array}{l}\text { Additional } \\
\text { Thermally } \\
\text { Efficient } \\
\text { New Housing } \\
\text { Units } f(f) \\
\end{array}$ & $\begin{array}{c}\text { Cumutative } \\
\text { Thermally } \\
\text { Efficient } \\
\text { New Kousing } \\
\text { Units }(g) \\
\end{array}$ & $\begin{array}{c}\text { Annual } \\
\text { Energy } \\
\text { Savings } \\
\text { From Cumuld- } \\
\text { tive Efficiept } \\
\text { Housing Inits } \\
\text { (BkHh) } \\
\end{array}$ \\
\hline & 1984 & 90.6 & 90.6 & 1.9 & 14 & 0.02 & 0.01 & 0.25 & 0.003 & 0.003 & 0.72 \\
\hline & 1985 & 92.5 & 90.6 & 1.7 & 14 & 0.04 & 0.02 & 0.51 & 0.005 & 0.007 & 1.45 \\
\hline & 1986 & 94.2 & 90.6 & 1.7 & 14 & -0.065 & 0.04 & 0.82 & 0.008 & 0.015 & 2.37 \\
\hline & 1987 & 95.9 & 90.6 & 1.7 & 14 & 0.095 & 0.06 & 1.20 & 0.011 & 0.026 & 3.48 \\
\hline & 1988 & 97.6 & 90.6 & 1.7 & 14 & 0.13 & 0.085 & 1.65 & 0.015 & 0.042 & 4.78 \\
\hline & 1989 & 99.3 & 90.6 & 1.7 & 14 & 0.17 & 0.115 & 2.16 & 0.020 & 0.062 & 6.29 \\
\hline & 1990 & 101 & 90.6 & 1.6 & 14 & 0.22 & 0.145 & 2.79 & 0.025 & 0.087 & 8.16 \\
\hline & 1991 & 102.6 & 90.6 & 1.6 & 14 & 0.28 & 0.165 & 3.55 & 0.031 & 0.118 & 10.42 \\
\hline & 1992 & 104.2 & 90.6 & 1.6 & 14 & 0.34 & 0.18 & 4.31 & 0.038 & 0.156 & 12.70 \\
\hline . & 1993 & 105.8 & 90.6 & 1.6 & 14 & 0.37 & 0.19 & 4.69 & 0.041 & 0.198 & 13.94 \\
\hline$\infty$ & 1994 & 107.4 & 90.6 & 1.6 & 14 & 0.39 & 0.195 & 4.95 & 0.044 & 0.241 & 14.82 \\
\hline & 1995 & 109 & 90.6 & 1.6 & 14 & 0.4 & 0.2 & 5.07 & 0.044 & 0.286 & 15.36 \\
\hline & 1996 & 110.4 & 90.6 & 1.4 & 14 & 0.4 & 0.2 & 5.07 & 0.045 & 0.325 & 15.52 \\
\hline & 1997 & 111.8 & 90.6 & 1.4 & 14 & 0.4 & 0.2 & 5.07 & 0.039 & 0.365 & 15.68 \\
\hline & 1998 & 113.2 & 90.6 & 1.4 & 24 & 0.4 & 0.2 & 5.07 & 0.039 & 0.404 & 15.84 \\
\hline & 1999 & 114.6 & 90.6 & 1.4 & 14 & 0.4 & 0.2 & 5.07 & 0.039 & 0.443 & 16.00 \\
\hline & 2000 & 116 & 90.6 & 1.4 & 14 & 0.4 & 0.2 & 5.07 & 0.039 & 0.482 & 16.16 \\
\hline & $\begin{array}{l}(a) \\
(b) \\
(c) \\
(d) \\
(e) \\
(f) \\
(g) \\
(h) \\
(i)\end{array}$ & \multicolumn{10}{|l|}{$\begin{array}{l}\text { Source: NEPP Fo } \\
\text { Retrofit Market } \\
\text { Percentage based } \\
\text { See Chaptef } 4.0 \text {. } \\
\text { Calculated by: } \\
\text { Calculated by: } \\
\text { Calculated by: } \\
\text { Caiculated by: } \\
\text { Calculated by: }\end{array}$} \\
\hline
\end{tabular}


TABLE 6.12. Housing Stock Projections and High Market Share Scenario of Thermal Efficiency Measures for Electrically Cooled Residences

\begin{tabular}{|c|c|c|c|c|c|c|c|c|c|c|c|}
\hline & Year & $\begin{array}{c}\text { Tota } i \\
\text { Residegces (a) } \\
\left(10^{6}\right)\end{array}$ & $\begin{array}{l}\text { Retrof })^{t} \\
\text { Market } \\
\left(10^{6}\right) \\
\end{array}$ & $\begin{array}{l}\text { Additional } \\
\text { New } \\
\text { Residences } \\
\text { Market (a) } \\
\left(10^{6}\right) \\
\end{array}$ & $\begin{array}{c}\text { Residences } \\
\text { Electricaly } \\
\text { Heated })^{1 y} \\
\text { (Percent) } \\
\end{array}$ & $\begin{array}{l}\text { Retrofit } \\
\text { Market } \\
\text { Share }(d) \\
\end{array}$ & $\begin{array}{c}\text { New } \\
\text { Market } \\
\text { Addit tons } \\
\text { Share } \\
\end{array}$ & $\begin{array}{l}\text { Cumulative } \\
\text { Thermal } \\
\text { Efficient } \\
\text { Retrofitted } \\
\text { Exist tng } \\
\text { Housing } \\
\text { Units(e) } \\
\end{array}$ & $\begin{array}{l}\text { Additional } \\
\text { Thermally } \\
\text { Efficient } \\
\text { New Housing } \\
\text { Units }(f)^{-} \\
\end{array}$ & $\begin{array}{l}\text { Cumulative } \\
\text { Thermally } \\
\text { Efficient } \\
\text { New Housing } \\
\text { Units }(g)^{\circ} \\
\end{array}$ & $\begin{array}{c}\text { Annual } \\
\text { Energy } \\
\text { Savings } \\
\text { From Cumula- } \\
\text { tive Efficient } \\
\text { Housing Units (h) } \\
\text { (BkWh) } \\
\end{array}$ \\
\hline & 1984 & 90.6 & 90.6 & 1.9 & 56 & 0.02 & 0.01 & 1,01 & 0.011 & 0.011 & 0.72 \\
\hline & 1985 & 92.5 & 90.6 & 1.7 & 56 & 0.04 & 0.02 & 2.03 & 0.019 & 0.030 & 1.44 \\
\hline & 1986 & 94.2 & 90.6 & 1.7 & 56 & 0.065 & 0.04 & 3.30 & 0.031 & 0.061 & 2.35 \\
\hline & 1987 & 95.9 & 90.6 & 1.7 & 56 & 0.095 & 0.06 & 4.82 & 0.045 & 0.106 & 3.45 \\
\hline & 1988 & 97.6 & 90.6 & 1.7 & 56 & 0.13 & 0.085 & 6.60 & 0.062 & 0.168 & 4.75 \\
\hline & 1989 & 99.3 & 90.6 & 1.7 & 56 & 0.17 & 0.115 & 8.63 & 0.081 & 0.249 & 6.24 \\
\hline & 1990 & 101 & 90.6 & 1.6 & 56 & 0.22 & 0.145 & 11.16 & 0.099 & 0.347 & 8.10 \\
\hline & 1991 & 102.6 & 90.6 & 1.6 & 56 & 0.28 & 0.165 & 14.21 & 0.125 & 0.473 & 10.34 \\
\hline & 1992 & 104.2 & 90.6 & 1.6 & 56 & 0.34 & 0.18 & 17.25 & 0.152 & 0.625 & 12.60 \\
\hline " & 1993 & 105.8 & 90.6 & 1.6 & 56 & 0.37 & 0.19 & 18.77 & 0.166 & 0.791 & 13.82 \\
\hline $\overrightarrow{6}$ & 1994 & 107.4 & 90.6 & 1.6 & 56 & 0.39 & 0.195 & 19.79 & 0.175 & 0.965 & 14.70 \\
\hline & 1995 & 109 & 90.6 & 1.6 & 56 & 0.4 & 0.2 & 20.29 & 0.179 & 1.145 & 15.23 \\
\hline & 1996 & 110.4 & 90.6 & 1.4 & 56 & 0.4 & 0.2 & 20.29 & 0.157 & 1.301 & 15.38 \\
\hline & 1997 & 111.8 & 90.6 & 1.4 & 56 & 0.4 & 0.2 & 20.29 & 0.157 & 1.458 & 15.54 \\
\hline & 1998 & 113.2 & 90.6 & 1.4 & 56 & 0.4 & 0.2 & 20.29 & 0.157 & 1.615 & 15.69 \\
\hline & 1999 & 114.6 & 90.6 & 1.4 & 56 & 0.4 & 0.2 & 20.29 & 0.157 & 1.772 & 15.85 \\
\hline & 2000 & 116 & 90.6 & 1.4 & 56 & 0.4 & 0.2 & 20.29 & D. 157 & 1.929 & 16.00 \\
\hline & $\begin{array}{l}\text { (a) } \\
\text { (b) } \\
\text { (c) } \\
\text { (d) } \\
\text { (e) } \\
(f) \\
(g) \\
(h) \\
(i)\end{array}$ & \multicolumn{10}{|c|}{ 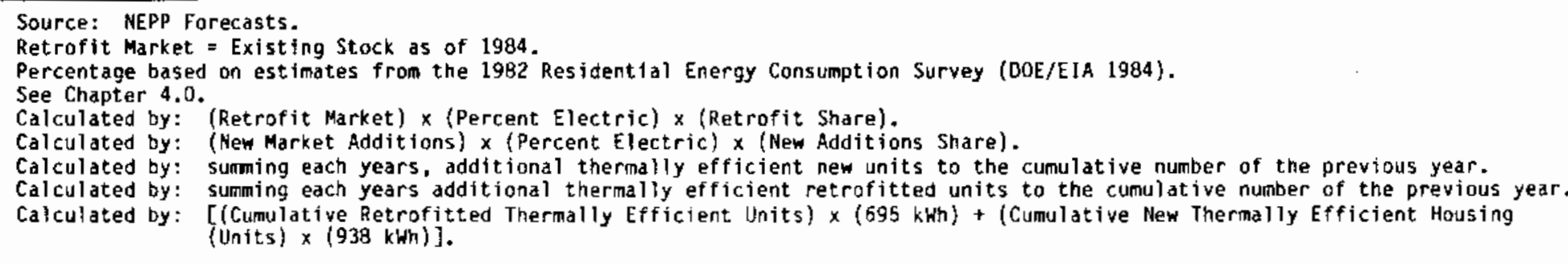 } \\
\hline
\end{tabular}


TABLE 6.13. National Annual Electrical Savings Estimates from the High Market-Penetration Scenario for Advanced Thermal Efficiency Measures (BkWh)

\begin{tabular}{|c|c|c|c|c|c|}
\hline Year & $\begin{array}{c}\text { Existing } \\
\text { Home } \\
\text { Heating }\end{array}$ & $\begin{array}{c}\text { Existing } \\
\text { Home } \\
\text { Cooling } \\
\end{array}$ & $\begin{array}{l}\text { New } \\
\text { Home } \\
\text { Heat ing }\end{array}$ & $\begin{array}{l}\text { New } \\
\text { Home } \\
\text { Cooling }\end{array}$ & $\begin{array}{c}\text { Total } \\
\text { Savings } \\
\end{array}$ \\
\hline 1985 & 1.42 & 1.41 & .03 & .03 & 2.89 \\
\hline 1990 & 7.81 & 7.77 & .35 & .33 & 16.26 \\
\hline 1995 & 14.24 & 14.12 & 1.12 & 1.11 & 30.59 \\
\hline 2000 & 14.26 & 14.13 & 1.90 & 1.82 & 32.16 \\
\hline
\end{tabular}

The specific indications are that new and retrofit thermal efficiency installations are less costly than new power for heating and cooling combined and, in retrofit installations, for heating only. On the other hand, thermal efficiency measures would be a relatively poor investment for locations which have large power demands for cooling relative to the demands for heating. In general, however, it appears that the advanced thermal efficiency measures are good investments and deserve further consideration at the regional level. 
TABLE 6.14. Cost/kWh Calculations for Advanced Thermal Insulation and Anti-Infiltration Techniques

Incremental Capital Cost $(\$)^{(a)}$

New Installation $\quad=2525$

Retrofit Installation $\quad=1550$

Levelized Capital cost $(\$ / y r)(b)$

New Installation

$=224.29$

Retrofit Installation

$=137.68$

New Installation
Annual Energy Savings (kWh/yr)

Heating

$=5,600-1,506=4,094$

Cooling

$=2,275-1,292=983$

Heating and Cooling

$=7,875-2,798=5,077$

Retrofit Installation
Annual Energy Savings (kwh/yr) $(c)$

Heating

Cooling

Heating and Cooling

$=5,900-3,103=2,797$

$=2,300-1,605=695$

$=8,200-4,708=3,492$

New Installation Cost $(\$ / k W h)^{(d)}$

Heating

Cooling

Heating and Cooling

$=22,429 / 4,094=5.48$

$=22,429 / \quad 983=22.82$

$=22,429 / 5,077=4.42$

Retrofit Installation Cost $(\$ / \mathrm{kWh})^{(\mathrm{d})}$

Heating

Cooling

Heating and Cooling

$=13,768 / 2,797=4.92$

$=13,768 / 695=19.81$

$=13,769 / 3,492=3.94$

(a) See Table 6.3 f for the new and the retrofit scenario assumptions and see Table 6.4 for the incremental capital cost figure.

(b) The level stream of annual payments the present value of which would equal the investment's incremental capital cost. Assumes a 30 year useful lifetime of the investment and an 8 percent rate of interest compounded annually. See Formula 4.11.

(c) See Table 6.4.

(d) Levelized Capital Cost (x 100\$/\$)/Annual Energy Savings. 


\subsection{REFERENCES FOR CHAPTER 6.0}

The American Society of Heating, Refrigerating, and Air-Conditioning Engineers, Inc., (ASHRAE) and Illuminating Engineering Society of North America. 1980. "ASHRAE Standard: Energy Conservation In New Building Design." ASHRAE Circulation Sales Department, 345 East 47th Street, New York.

Northwest Power Planning Council (NPPC). 1983. 1983 Northwest Conservation and Electric Power Plan. Volume II. Portland, Oregon.

Pacific Northwest Laboratory (PNL). 1981. Energy Conservation Manual for Builders in the Mid-Columbia Basin Area. Prepared for the U.S. Department of Energy by Pacific Northwest Laboratory, Richland, Washington.

Palmiter, L., M. J. DeLaitant, and J. Hanford. 1984. "Optimal Conservation for Twenty Three Northwest Climates." Prepared for the Northwest Power Planning Council by ECOTYPE, 2812 East Madison, Seattle, Washington.

U.S. DOE/EIA. 1984. Annual Energy Outlook 1983: With Projections to 1995. DOE/EIA-0383(83), Department of Energy, Energy Information Administration. Washington, $0 . C$.

U.S. 00E. 1984. Energy Conservation Multi-Year Plan. FY 1986-FY 1990. Department of Energy, Office of Conservation, Washington, $0 . C$.

U.S. DOE. 1983. Energy Projections to the Year 2010. D0E/PE-0029/2, Department of Energy, Office of Policy, Planning, and Analysis, Washington, D.C.

U.S. DOE. 1984. RECS: Housing Characteristics 1982. D0E/EIA-0314(82), Department of Energy, Energy Information Administration, Washington, D.C. 


\subsection{SOLAR WATER HEATERS}

This chapter presents forecasts of the future electricity savings associated with adoption of solar water heaters. A technical description of this technology is provided in Section 7.1. Market availability is discussed in Section 7.2. The cost-effectiveness of a typical system is calculated in Section 7.3. Expected market penetration based on typical cost-effectiveness and the methodology of Chapter 4.0 is also provided in Section 7.3. In Section 7.4, these market penetration estimates are applied to housing stock data and forecasts in order to project numbers of solar water heaters in place in 1990, 1995 and 2000. Energy savings results and assumptions are presented in Section 7.5. Section 7.6 is an analysis of the sensitivity of the energy savings results to changes in the market penetration scenarios. Section 7.7 compares the estimated cost/kWh saved from solar water heaters with the estimated cost/kWh of new electrical generating capacity.

\subsection{TECHNICAL BACKGROUND}

Solar water heaters decrease the energy requirements for conventional water heaters by providing a source of preheated tap water. Solar water heaters supplement conventional water heaters and ordinarily do not replace them. All systems require collectors in a sunny location, a storage tank for the warmed water, and a back-up water heater (generally gas or electric). Solar water heaters typically preheat water to $110^{\circ} \mathrm{F}$ or more (McMillan 1981), and in sunny conditions can often provide all of a household's hot water. With a well-insulated hot water tank, some solar heat may be retained through night time hours and cloudy periods as well.

There are three basic types of solar water heaters: integral collector/ storage systems, passive (or thermosiphon) systems, and pumped systems. Integral collector/storage systems use the same unit for heat collection and water storage; i.e. the storage tank absorbs solar energy directly. Thermosiphon systems have separate collectors and storage tanks; fluid circulates heat between these components without use of a pump or moving parts. Heated fluids tend to rise and stratify in a given volume, with the hottest fluid on top. In 
a thermosiphon water heating system, the fluid heated in the collector rises and circulates through the water storage tank. As the fluid travels, it cools down. The cooled fluid falls and returns to the bottom of the collector. Control valves may be necessary to prevent reverse siphon at night. Proper circulation in a thermosiphon system may require locating the storage tank at a higher elevation than the collector; this requirement can make use of a rooftop collector unworkable. Pumped solar water heaters have separate collectors and storage tanks. The solar water heater tank is installed next to a conventional water heater and feeds preheated water to it. Fluid is pumped from the solar system water tank to a collector, where it becomes warm. It circulates back through the solar water tank and loses its heat to this cooler reservoir. Cooled fluid is then pumped back up to the collector and the cycle is repeated.

A simple schematic of a pumped system is shown in figure 7.1. The system shown in the diagram is known as a pumped heat exchange solar water heater and is typically used in regions where freezing occurs on a regular basis. A fluid that will not readily freeze at outside temperatures (such as a solution of ethylene glycol) is circulated through tubes connecting the solar water tank and collector components and passing through them. A flat plate collector is shown in Figure 7.1. Sunlight striking the cover of the collector plate transfers heat to the fluid-carrying tubing in the lower layer. The warmed fluid circulates to the water storage unit where it warms the stored water. The heat exchange fluid is then pumped back through the collector.

Pumped systems can circulate potable (i.e., drinkable) water instead of an anti-freeze solution. Such systems may save on capital costs and are appropriate in regions of the country where freezing is rare. However, they have greater failure potential than heat exchange systems.

The sizing of a solar water heater system depends on climate and family size. A solar system's tank should be sized to hold enough hot water for a day; on average, each person in a household uses approximately 20 gallons of hot water per day (Wright 1978). The necessary collector area may vary between regions of the country, but is unlikely that a unit providing 60 to 90 gallons a day will exceed $100 \mathrm{ft}^{2}$. A typical range of sizes is 30 to $80 \mathrm{ft}^{2}$. 


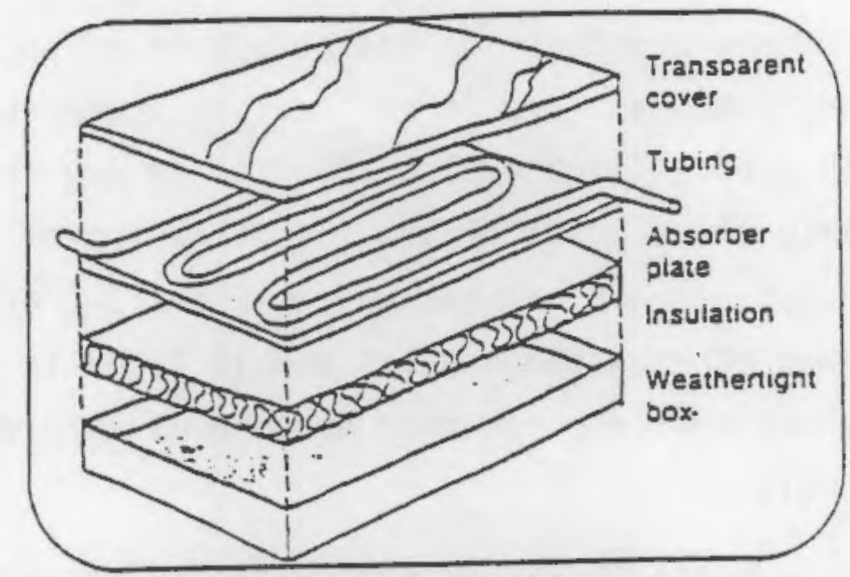

Explooed view of flat-plate cellector.

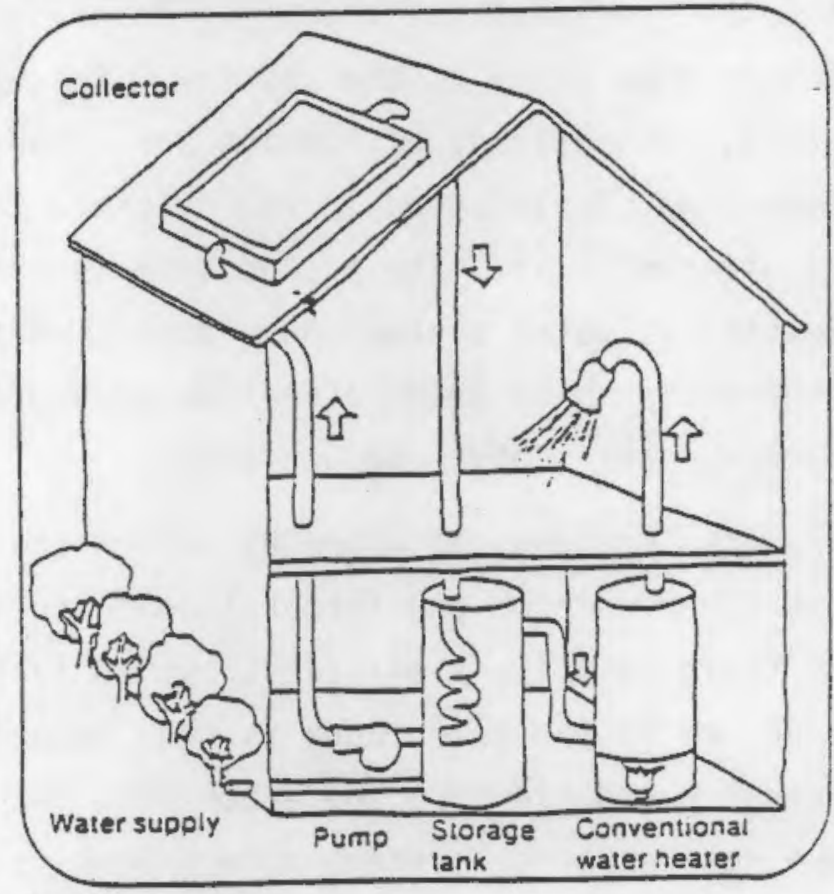

Two-tank sysiem.

FIGURE 7.1. Pumped Heat Exchange Domestic Hot Water System Source: U.S. Department of Housing and Urban Development 1980a

\subsection{CURRENT MARKET SITUATION}

No published estimates of current national penetration of solar water heaters were located. In California, some counties require builders to consider the feasibility and benefits of solar water heating in new construction; 
perhaps 30 percent of new construction has some form of solar water heater. (a) In areas of the country where there is no local or state support, market penetration may approach zero. Climate also affects the degree of market penetration. A 1984 estimate shows overall market penetration of water heaters using neither electric resistance nor natural gas at 2 percent of households (Nesbit 1984). 0i1, solar and other water heaters are included in this approximation, but the figure does not indicate how many households supplement conventional water heaters with solar.

Solar water heaters are available from numerous manufacturers and are distributed by dealers in all parts of the country. Interest in solar water heaters is increasing in some areas of the country. For example, a program designed according to U.S. Department of Housing and Urban Development (HUD) "Solarbank" requirements was implemented in Pennsylvania this year and seems to have helped sales significantly. (b) The product mix is changing, however. Active (pumped) domestic hot water systems have dominated the market in the past, but passive (thermosiphon or integral collector/storage) systems are now gaining ground (SolarAge staff report, August 1983).

Prices of solar water heaters vary more by region than by type of system. Passive systems (thermosiphon and integral collectors/storage) typically cost less because of their relative simplicity, but in fact the more expensive passive systems are priced in the same range as many pumped systems. Heat exchange systems generally require more collector area than other systems; this feature tends to make heat exchange systems more expensive.

\subsection{CDST EFFECTIVENESS AND MARKET PENETRATION}

The cost effectiveness and the likely market penetration of solar water heaters are discussed in this section. Both of these quantities vary by region, but time and budget constraints precluded following up on regional

(a) Personal communication with David Sizelove, Solar Industries, Inc. representative, November 1984.

(b) Personal communication with Stephen McDonnel1, Pennsylvania Governor's Energy Counci1, 1984. 
distinctions. Instead, a reference case is developed. The use of a generalized reference case may result in biases which are noted at appropriate stages of the analysis. To begin the analysis, the payback period for the representative product/region is calculated, with and without government support, according to procedures discussed in Chapter 4.0 of this document. Next, technical factors that might preclude the use of solar water heaters in some situations are considered. Forecasts of the number of solar water heaters in place in 1990 and 2000 follow. The forecasts set the stage for aggregated projections of electricity use in domestic water heating, with and without displacements of electricity demand due to the use of solar water heaters.

\subsubsection{Cost Effectiveness of Representative Product}

The capital cost, operating cost, and energy savings of conventional water heating versus water heating supplemented with solar energy are calculated in this subsection. The "representative" system has a payback period of 19.9 years. The assumptions and calculations are explained in the following paragraphs.

\section{Conventional Electric Resistance Water Heating.}

Electric water heaters generally store water and heat it in the same unit. Incoming water (not preheated) is usually about $55^{\circ} \mathrm{F}$ (McMillan 1981). Water may be heated up to about $210^{\circ} \mathrm{F}$ depending on the model; the temperature is usually controlled with an automatic thermostat. Tank size may range from compact to about 82 gallons. A 52 gallon size is typical for a family of four.

The installed initial cost of electric water heaters may vary from about $\$ 300$ to $\$ 600$, depending on the model and whether the installation is to a newly constructed home or is a retrofit to an existing house. (a) However, only operating costs are of concern in the present analysis because a solar water heater would always be installed with a conventional water heater, and,

(a) Sears Roebuck and Company, Pasco, Washington, and DOE personal communication with Mr. Roehl of Roehl Plumbing, Kennewick, Washington, November 1984. 
therefore, the capital costs of the conventional system can be ignored in the remainder of the analysis. Only the incremental installed cost of the solar water heater is relevant.

Energy consumption by electric water heaters varies significantly between households depending on the quantity of water used and the type of heater; samples of usage are $4515 \mathrm{kWh} / \mathrm{yr}$ for single-family homes and $2730 \mathrm{kWh} / \mathrm{yr}$ for multi-family dweltings (DOE/EIA 1984), and $4745 \mathrm{kWh} / \mathrm{yr}$ (52 gal model, General Electric 1979). Annual energy consumption for the electric water heater reference case is assumed to be $5147 \mathrm{kWh} / \mathrm{yr}$, a weighted average based on sub-metered hot water data in the Pacific Northwest (Northwest Power Planning Council 1983). This figure is similar to that used in the Oak Ridge National Laboratory Residential Energy Use Simulation Model.(a) Using an energy price of $7.18 \$ / \mathrm{kWh}$, operating costs of the reference conventional systern are $\$ 370 /$ year.

Solar Water Heating. A pumped heat exchange water heater produced by a major manufacturer (the 80-gal capacity Solar Industries Heat Exchange System 12063) is used as the solar water heater reference, and two $4 \times 8 \mathrm{ft}$ collectors (appropriate for a Portland, Oregon or New Jersey location) are assumed. The necessary collector area depends on climate; one $4 \times 10 \mathrm{ft}$ collector might suffice in southern Florida while three $3 \times 8 \mathrm{ft}$ collectors would be more appropriate in Seattle.(b)

Installed costs of standard solar water heaters actually can range from about $\$ 1600$ to $\$ 5000$. Total installed costs for a heat exchange solar system range from about $\$ 60$ to $\$ 70 / \mathrm{ft}^{2}$ of collector space, while other pumped solar systems cost from $\$ 50$ to $\$ 60 / \mathrm{ft}^{2}$. For the reference case, we assume that installed costs are approximately $\$ 60 / \mathrm{ft}^{2}$, including materials and labor; (c) with two $4 \times 8 \mathrm{ft}$ collectors (net area is $30.7 \mathrm{ft}^{2} /$ collector) the installed cost of this solar reference case is $\$ 3684$.

(a) Conversation with T. U. Secrest, Pacific Northwest Laboratory.

(b) Personal communication with David Sizelove, Solar Industries, Inc. representative, November 1984.

(c) Personal communication with David Sizelove, Solar Industries, Inc. representative, November 1984. 
Government loans and some subsidies are frequently available for solar water heaters. Every state currently participates in a federal-level (HUD) program (Solar Bank) except Alaska, Wyoming, and South Dakota. (a) To date, the solar component of this program has not been very active, but in states where the solar incentives are actively used significant loans and grants are authorized. The maximum amount of assistance for solar domestic hot water systems is $\$ 1000$ per dwelling unit or 40 percent of their cost, whichever is less, for one- to four-family residential buildings (Solar Energy and Energy Conservation Bank 1984). A variety of other incentives may exist at state and local levels, including income and property tax credits and utility rebates. As of April 10, 1984, 29 states had income tax credits for solar purchases in place (Malloy 1984). Nonmarket support appears to be common, but is not included in the reference system's cost since one cannot predict whether it will continue during the projection period.

Operating Cost Savings. A solar water heater reduces water heating electricity consumption from 30 to 50 percent in northern locations, and 50 to 75 percent in southern locations (HUD, 1979; conversation with Tom Shea, Heliotherm, November 1984). Assuming 50 percent annual savings on energy costs, $5147 \mathrm{kWh} / \mathrm{yr}$ on conventionally-operated hot water heaters and $7.18 \$ / \mathrm{kWh}$, cost savings from a solar water heater installation amount to $\$ 185 / y r$.

Hot Water System Payback Period

The payback period for a representative solar water heater is calculated in Table 7.1. In the reference case, 19.9 years are required to recover the investment. A solar water heater with the same initial cost, that supplemented the same conventional water heater with the same price for electricity should have a longer payback period in cloudier and more northern climates and a shorter payback period in sunnier and more southern climates. Where electricity prices are higher, the payback period is shorter. With a government

(a) Telephone conversation with Julia Fermoile, Solar Energy and Energy Conservation Bank, November 16, 1984. 
TABLE 7.1. Payback Period of Representative

Solar Water Heater

Initial Installed Cost of New System: $\$ 3684$

Operating Cost Savings: $\$ 185.00 / \mathrm{yr}^{(\mathrm{a})}$

Payback Period:

(Initial Cost $\div$ Annual Savings) $\quad 19.9$ yr

(a) Based on 50 percent displacement of hot water heating by solar system and $\$ 370$ annual electricity bill with no solar water heater supplement.

subsidy of $\$ 1000$, an amount that is not uncoman, the payback period for the representative solar water heater would be 14.5 years.

\subsubsection{Technical Limits}

Technical limits are defined as those limitations that preclude use of the technology at any cost. A hypothetical example would be the use of a solar water heating system without freeze protection in Minnesota. Solar water heating manufacturers appear to have developed products to meet most regional needs. Although lower savings and higher capital costs may occur in unfavorable climates, these conditions do not prohibit the use of solar water heaters for technical reasons. No quantifiable technical limits were found, and the remainder of this analysis proceeds on the assumption that any household with a conventional water heater is a potential candidate for supplemental solar water heating.

\subsubsection{Market-Penetration Assumptions}

Market penetration is assumed to be a function of payback period, as described in the methodology chapter (refer to Table 4.1). Based upon a representative payback period of 19.9 years, the probable maximum market penetration of solar water heaters on existing units using electric resistance water heating is 5 percent. Maximum consumer acceptance in new markets may be lower; nevertheless, 5 percent is used for both energy savings calculations. As 
explained in Chapter 4.0, this market penetration figure implies that sales of the conservation technology, solar water heaters, in the year 2000 amount to 5 percent of the sales of the conventional technology, electric water heaters. It also implies that 5 percent of the existing 1984 stock will have been retrofitted with solar water heaters by the year 2000 . Section 7.6 discusses the impacts on the analysis of higher and lower assumed market penetration.

\subsection{HOUSING STOCK PROJECTIONS AND MARKET SHARE ESTIMATES}

Stock data (existing number of residential electric water heaters, expected rate of growth, and expected additions of solar water heaters) are discussed in this section. Table 7.2 shows projections of housing stock, electric water heaters and solar water heaters at yearly intervals from 1984 to 2000. Housing projections are based on projections supporting the National Energy Policy Plan (DOE 1983). The percentage of houses using electricity for water heating ( 31.8 percent) is extracted from the 1981 Residential Energy Consumption Survey (DOE/EIA 1984). (a) Market shares for solar water heaters are estimated as described in Chapter 4.0 and are based on a payback period exceeding 10 years.

\subsection{ENERGY SAVINGS RESULTS}

Energy savings of $2574 \mathrm{kWh} / \mathrm{yr}$ are assumed to be typical for solar water heaters with electric resistance domestic hot water backup. In this section, expected energy savings for the nation as a whole are projected, based on perunit savings and expected market penetration. The final column of Table 7.2 shows projections of energy savings from supplementation of electric water heating by solar water heating in the residential sector. Projected annual energy savings are $4.27 \mathrm{BKWh}$ by the year 2000 . These projections are summarized in Table 7.3 .

\footnotetext{
(a) According to J. B. Hoyt, Manager of Forecasting and Market Analysis, Whirlpool Corporation, the 1980 Census of Housing shows a split on water heating of 57.5 percent gas, 33.5 percent electric, 8 percent fuel oil and the remainder, other sources (personal communication, November (1984).
} 
TABLE 1.2. Housing Stock Projections, Annual Market Share, and Electricity Savings for Solar Water Heaters with Electric Water Backup

\begin{tabular}{|c|c|c|c|c|c|c|c|c|}
\hline Year & $\begin{array}{l}\text { Annual New } \\
\text { Housing Additions }(a) \\
\left(10^{6}\right)\end{array}$ & $\begin{array}{c}\text { Residences } \\
\text { With Electric } \\
\text { Water Heating }(b) \\
\text { (Percent) } \\
\end{array}$ & $\begin{array}{l}\text { Market Share } \\
\text { for New } \\
\text { and Retrofit } \\
\text { Applications (c) } \\
\end{array}$ & 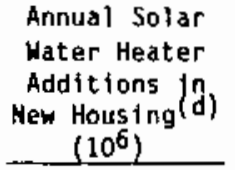 & 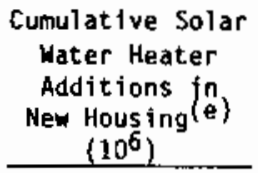 & $\begin{array}{c}\text { Cumulative } \\
\text { Retrofit Solar } \\
\text { Water Heater } \\
\text { Additions }(f) \\
\left(10^{6}\right) \\
\end{array}$ & $\begin{array}{c}\text { Cumulative New } \\
\text { and Retrofit } \\
\text { Solar Water Heater } \\
\text { Additions }(9) \\
\left(10^{6}\right) \\
\end{array}$ & $\begin{array}{c}\text { Cumulative } \\
\text { Annual Energy } \\
\text { Savings } \\
\text { Bkwh } \\
\end{array}$ \\
\hline 1984 & 1.9 & 0.318 & 0.010 & 0.006 & 0.006 & 0.29 & 0.29 & 0.76 \\
\hline 1985 & 1.7 & 0.318 & 0.011 & 0.006 & 0.012 & 0.32 & 0.33 & 0.85 \\
\hline 1986 & 1.7 & 0.318 & 0.012 & 0.006 & 0.018 & 0.35 & 0.36 & 0.94 \\
\hline 1987 & 1.7 & 0.318 & 0.013 & 0.007 & 0.025 & 0.37 & 0.40 & 1.03 \\
\hline 1988 & 1.7 & 0.318 & 0.015 & 0.008 & 0.032 & 0.43 & 0.46 & 1.19 \\
\hline 1989 & 1.7 & 0.318 & 0.017 & 0.009 & 0.040 & 0.49 & 0.53 & 1.36 \\
\hline 1990 & 1.6 & 0.318 & 0.020 & 0.010 & 0.049 & 0.58 & 0.63 & 1.61 \\
\hline 1991 & 1.6 & 0.318 & 0.023 & 0.012 & 0.059 & 0.66 & 0.72 & 1.86 \\
\hline 1992 & 1.6 & 0.318 & 0.027 & 0.014 & 0.071 & 0.78 & 0.85 & 2.18 \\
\hline 1993 & 1.6 & 0.318 & 0.031 & 0.016 & 0.084 & 0.89 & 0.98 & 2.52 \\
\hline 1994 & 1.6 & 0.318 & 0.035 & 1.018 & 0.100 & 1.01 & 1.11 & 2.85 \\
\hline 1995 & 1.6 & 0.318 & 0.039 & 1.020 & 0.118 & 1.12 & 1.24 & 3.20 \\
\hline 1996 & 1.4 & 0.318 & 0.043 & 1.019 & 0.138 & 1.24 & 1.38 & 3.54 \\
\hline 1997 & 1.4 & 0.318 & 0.045 & 1.020 & 0.157 & 1.30 & 1.45 & 3.74 \\
\hline 1998 & 1.4 & 0.318 & 0.047 & 1.021 & 0.177 & 1.35 & 1.53 & 3.94 \\
\hline 1999 & 1.4 & 0.318 & 0.049 & 1.022 & 0.198 & 1.41 & 1.61 & 4.14 \\
\hline 2000 & 1.4 & 0.318 & 0.050 & 1.022 & 0.220 & 1.44 & 1.66 & 4.27 \\
\hline
\end{tabular}

\footnotetext{
(a) Source: NEPP Forecasts.

(b) Percentage is based on estimates from the 1982 Residential Energy Consumption Survey (DOE/EIA 1984).

(c) See Chapter 4.0.

(d) Calculated by: (Annual housing additions) $x$ (market share).

(e) Calculated by: Current years additions + previous years cumulat 1 ve additions.

(f) Calculated by: Total 1984 housing $(90,6 \mathrm{million}) \times$ market share for retrofit applications. Assumes that there is no retirement of housing stock.

(g) Calculated by: Cumulative additions to New housing + Cumulative retrofitted additions.

(h) Calculated by: (Cumulative additions of solar water heaters) $\times(2574 \mathrm{kWh} /$ year $)$.
} 
TABLE 7.3. Projections of Energy Savings with Market

Penetration of Solar Water Heaters

\begin{tabular}{cc} 
Year & $\begin{array}{c}\text { Energy Savings } \\
\text { (BKWh) }\end{array}$ \\
\hline 1985 & 0.85 \\
1990 & 1.61 \\
1995 & 3.20 \\
2000 & 4.27
\end{tabular}

The above projections of energy savings are subject to several limitations. Regional differences are not accounted for in the cost-effectiveness calculation, which was used to project market shares of solar water heaters. In addition, projected market shares were based only on a payback criterion and did not account for other factors, such as uncertain future electricity rates, which may also be significant in consumer purchase decisions. (a) Finally, the analysis does not extend to technologies other than solar water heating, such as heat pump water heaters, which may also displace electric water heating in future years.

\subsection{SENSITIVITY OF ANALYSIS TO MARKET-PENETRATION ASSUMPTIONS}

This section summarizes two variations of the scenario discussed in Sections $7.3,7.4$ and 7.5. The first variation assumes the same per unit energy savings but reduces the assumed maximum market penetration by 50 percent; additionally, maximum market penetration is assumed to occur more slowly than in the base case. Thus, fewer units are installed and less energy is saved. Section 7.6.1 summarizes the low market-penetration scenario. The second variation also assumes the same per unit energy savings, but the assumed maximum market penetration is doubled. In addition, maximum market penetration is assumed to occur more quickly than in the base case. Thus, more units are installed and energy savings are larger. Section 7.6.2 summarizes the high market-penetration scenario.

(a) Conversation with William Dokas, Sun Solector Corporation, 11/21/84. 


\subsubsection{Low Market-Penetration Scenario}

The maximum market penetration assumed in previous sections is, at 5 percent, already very low. If it were reduced by 50 percent, and if by the year 2000 only 75 percent of the units that might eventually be installed had been installed, 640,000 solar water heaters with electric back-up are projected for residential use at the turn of the century. Assuming energy savings of $2573.5 \mathrm{kWh} / \mathrm{yr} / \mathrm{unit}$, annual electricity savings for solar water heaters would be less than $1.64 \mathrm{BkWh}$ in the year 2000. Annual market share assumptions and projected energy savings are presented in Table 7.4.

\subsubsection{High Market-Penetration Scenario}

In the scenario of this section, maximum market penetration is assumed to reach 10 percent by the year 1995 . This is double the maximum assumed in Sections 7.3,7.4, and 7.5. Both the faster rate of adoption and the higher maximum seem reasonable given the numbers of solar water heaters al ready purchased despite long payback periods. For example, a 1979 report indicated that 11,000 solar domestic hot water systems were already installed in California alone, and that California installations account for about one-third of installations nationwide (HUD 1980b). The high market-penetration scenario assumes 360,000 units nationwide in 1985 and more than 3 million units by 1995 . Electricity savings would reach 8.67 BkWh annually by the year 1995 . Table 7.5 presents annual market share assumptions and projected energy savings for the high market penetration scenario.

\subsection{COMPARISON OF COSTS: NEW GENERATING CAPACITY VERSUS ENERGY CONSERVATION WITH SOLAR WATER HEATERS}

The estimated cost of conserving electricity with solar water heating does not compare favorably with the cost of generating new power using the assumptions of this analysis. The cost/kWh conserved with solar water heating is calculated in Table 7.6. The cost/kWh saved (approximately 15\$) is much higher than the cost/kwh of new coal powered generation cited in Table 4.3. 
TABLE 7.4. Low Market Scenario Housing Stock Projections, Annual Market Share, and Electricity Savings for Solar Water Heaters with Electric Water Backup

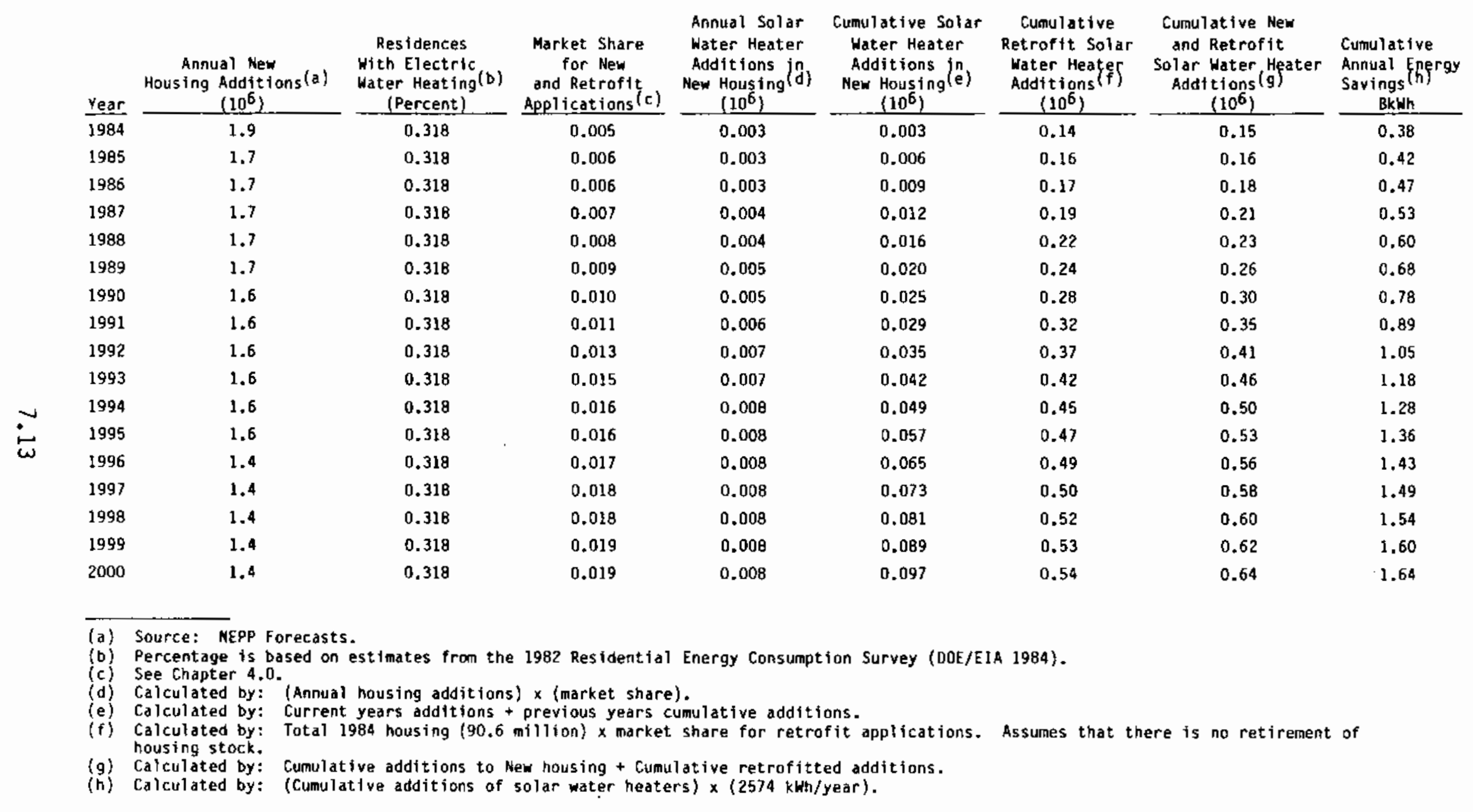


TABLE 7.5. High Market Scenario Housing Stock Projections, Annual Market Share, and Electricity Savings for Solar Water Heaters with Electric Water Backup

\begin{tabular}{|c|c|c|c|c|c|c|c|c|}
\hline Year & $\begin{array}{c}\text { Annual New } \\
\text { Housing Additions(a) } \\
\left(10^{6}\right)\end{array}$ & $\begin{array}{l}\text { Resfidences } \\
\text { With Electric } \\
\text { Water Heating }(b) \\
\text { (Percent) } \\
\end{array}$ & $\begin{array}{l}\text { Market Share } \\
\text { for New } \\
\text { and Retrofit } \\
\text { Agplications (c) } \\
\end{array}$ & $\begin{array}{l}\text { Annual Solar } \\
\text { Water Heater } \\
\text { Additions in } \\
\text { New Hous }(n g(d) \\
\left(10^{6}\right) \\
\end{array}$ & 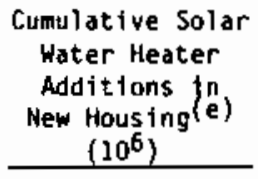 & $\begin{array}{l}\text { Cumulative } \\
\text { Retrofit Solar } \\
\text { Water Heater } \\
\text { Additions } \\
\left(10^{6}\right) \\
\end{array}$ & $\begin{array}{l}\text { Cumulative New } \\
\text { and Retrof it } \\
\text { Solar Water Heater } \\
\text { Additions (g) } \\
\left(10^{6}\right)\end{array}$ & $\begin{array}{c}\text { Cumulative } \\
\text { Annual Energy } \\
\text { Savings } \\
\text { BkWh } \\
\end{array}$ \\
\hline$\overline{1984}$ & 1.9 & 0.318 & 0.010 & 0.006 & 0.006 & 0.29 & 0.29 & 0.76 \\
\hline 1985 & 1.7 & 0.318 & 0.012 & 0.006 & 0.012 & 0.35 & 0.36 & 0.92 \\
\hline 1986 & 1.7 & 0.318 & 0.015 & 0.008 & 0.019 & 0.43 & 0.45 & 1.16 \\
\hline 1987 & 1.7 & 0.318 & 0.020 & 0.011 & 0.027 & 0.58 & 0.60 & 1.55 \\
\hline 1988 & 1.7 & 0.318 & 0.028 & 0.015 & 0.037 & 0.81 & 0.84 & 2.17 \\
\hline 1989 & 1.7 & 0.318 & 0.038 & 0.021 & 0.053 & 1.09 & 1.15 & 2.95 \\
\hline 1990 & 1.6 & 0.318 & 0.050 & 0.025 & 0.073 & 1.44 & 1.51 & 3.90 \\
\hline 1991 & 1.6 & 0.318 & 0.065 & 0.033 & 0.099 & 1.87 & 1.97 & 5.07 \\
\hline 1992 & 1.6 & 0.318 & 0.075 & 0.038 & 0.132 & 2.16 & 2.29 & 5.90 \\
\hline 1993 & 1.6 & 0.318 & 0.084 & 0.043 & 0.170 & 2.42 & 2.59 & 6.67 \\
\hline 1994 & 1.6 & 0.318 & 0.093 & 0.047 & 0.213 & 2.68 & 2.89 & 7.44 \\
\hline 1995 & 1.6 & 0.318 & 0.100 & 0.051 & 0.260 & 2.88 & 3.14 & 8.08 \\
\hline 1996 & 1.4 & 0.318 & 0.100 & 0.045 & 0.311 & 2.88 & 3.19 & 8.22 \\
\hline 1997 & 1.4 & 0.318 & 0.100 & 0.045 & 0.355 & 2.88 & 3.24 & 8.33 \\
\hline 1998 & 1.4 & 0.318 & 0.100 & 0.045 & 0.400 & 2.88 & 3.28 & 8.45 \\
\hline 1999 & 1.4 & 0.318 & 0.100 & 0.045 & 0.444 & $2 . B B$ & 3.33 & 8.56 \\
\hline 2000 & 1.4 & 0.318 & 0.100 & 0.045 & 0.489 & 2.88 & 3.37 & 8.67 \\
\hline
\end{tabular}

(a) Source: NEPP forecasts.

(b) Percentage is based on estimates from the 1982 Residential Energy Consumption Survey (DDE/EIA 1984).

c) See Chapter 4.0.

de) Calculated by: (Annual housing additions) $x$ (market share).

e) Calculated by: Current years additions + previous years cumulative additions.

(f) Calculated by: Total 1984 housing (90.6 million) x market share for retrofit applications. Assumes that there is no retirement of housing stock.

(g) Carculated by: Cumulative additions to New housing + Cumulative retrofitted additions.

(h) Calculated by: (Cumulative additions of solar water heaters) $\times(2574 \mathrm{kWh} / \mathrm{year})$. 
TABLE 7.6. Cost/kWh Calculation for Representative Solar Water Heater

\begin{tabular}{|c|c|c|c|c|}
\hline Technology & $\begin{array}{c}\text { Incremental } \\
\text { Capityal } \\
\text { Cost }(a) \\
(\$ 1984)\end{array}$ & $\begin{array}{c}\text { Level ized } \\
\text { Capital } \\
\text { Cost } \\
(\$ / y r)\end{array}$ & $\begin{array}{c}\text { Annual } \\
\text { Energy } \\
\text { Savings }(c) \\
\text { (kWh/yr) }\end{array}$ & $\begin{array}{c}\text { Cost } \\
\text { per } \\
k W h(d) \\
(\$ / k W h)\end{array}$ \\
\hline water heate & 3684 & 375 & 2574 & 14.6 \\
\hline
\end{tabular}

(a) Refer to Table 7.1.

(b) Refer to Equation 4.11. Assumes a 20-year lifetime of the investment and an 8 percent rate of interest compounded annually.

(c) Refer to discussion of operating cost savings in Section 7.3. Assumes 50 percent savings over a conventionally-operated water heater using $5147 \mathrm{kWh} / \mathrm{yr}$.

(d) Calculated by: (Levelized Capital Cost) $\div$ (Annual Energy Savings) = cost/kWh.

The initial costs of solar water heaters and the energy savings to be expected from them vary greatly by region. Thus, there may be regions of the United States where the cost of energy conserved with solar water heating compares favorably with the cost of generating new power. Nevertheless, it appears that in most regions conserving with this technology is likely to be more expensive than generating power supplies from new power plants.

\subsection{REFERENCES FOR CHAPTER 7.0}

General Electric Co. 1979. United States Energy Data Book. Energy Systems Technology Division, Sunnyvate, California.

Malloy, Molly. 1984. "The Solar Age 1984 State Tax Credit Survey." SolarAge $9(6): 24-26$.

Nesbit W. 1984. "Pumping Heat into Cold Water." EPRI Journal. $9(1): 16-22$. Electric Power Research Institute, PaTo ATto, CaTifornia.

Northwest Power Planning Council. 1983. Regional Conservation and Electric Power Plan 1983. Portland, Oregon.

Sands, J. 1983. "Big Payoff for Phase-Change Heaters?" SolarAge. $8(11) 38-44$.

SolarAge. 1984. Energy Products Specifications Guide. SolarAge Magazine, Harrisville, New Hampshire. 
SolarAge Staff Report. 1983. "Passive Water Heaters Gaining Ground." SolarAge. $8(8), \mathrm{pp} .31-35$.

Solar Energy and Energy Conservation Bank, (24 CFR Part 1800). 1984. Federal Register. 49(53) 9865-96 (March 16, 1984).

U.S. DOE. 1984. RECS: Housing Characteristics 1982, D0E/EIA-0314(82), U.S. Department of Energy, Energy information Administration, Washington, D.C.

U.S. DOE. 1983. Energy Projections to the Year 2010. Office of Policy, Planning, and AnaTysis. DOE/PE-0029/2, D.S. Department of Energy, Washington, D.C.

U.S. HUD. 1980a. Is Solar Water Heating Right for You? HUD-PDR-577, Department of Housing and Urban Development, office of Policy Development and Research, Washington, D.C.

U.S. HUD. 1980b. U.S. Solar Energy Growth and Potential Solar Factsheet. FSI06, 7th ed., February 1980. Department of Housing and Urban Developinent, office of Policy Development and Research, Washington, D.C.

U.S. HUD. 1979. Solar Factsheet FS110, 1st ed., March 1979. Department of Housing and Urban Development, Washington, D.C.

Wright, D. 1978. Natural Solar Architecture: A Passive Primer. Van Nostrand Reinhold Company, New York. 


\subsection{HIGH EFFICIENCY APPLIANCES}

This chapter addresses efficiency improvements to refrigerators and freezers in the residential sector. Due to the limited scope of this project, it was not feasible to estimate electricity savings for all home appliances. Refrigerators and freezers were selected for analysis because they account for the largest proportion of electricity use among residential appliances (DOE/BERD 1984; AHAM 1984a). Technical background is provided in Section 8.1. The current United States refrigerator/freezer market is profiled in Section 8.2; the popularity of various products is discussed and potential shifts in the market are identified. The cost-effectiveness of selected high efficiency products are calculated in Section 8.3. Cost and efficiency assumptions involved in this calculation are discussed in detail. Based on representative cost-effectiveness, market penetration is projected. In Section 8.4, the market-penetration projections are applied to appliance stock data and forecasts in order to project new sales and retrofits by 1990, 1995 and 2000. Projected electricity savings from the adoption of more efficient refrigerators and freezers are presented in Section 8.5. Section 8.6 is an analysis of the sensitivity of the energy savings results to changes in the market-penetration scenarios. Section 8.7 compares the estimated cost/kWh saved from more efficient refrigerators and freezers with the estimated cost/kWh of new capacity for electricity generation.

\subsection{TECHNICAL BACKGROUND}

A number of products, whose energy use and other features differ markedly, are classified as refrigerators and/or freezers. Subsection 8.1 .1 begins with definitions of the appliances. Typical differences in energy consumption by product type are identified. The technical bases for conservation measures are explained in Subsection 8.1.2. Measures are identified and grouped according to the subsystem of refrigeration to which they are directed. These subsystems include the heat pump, the refrigerator/freezer box, and auxiliary systems such as automatic defrost. Conservation potential from modified consumer habits is not discussed. Subsection 8.1 .3 provides an overview of the extent to which 
manufacturers have implemented various conservation measures. Salient differences between American refrigerators/freezers and corresponding Japanese products are addressed. This international comparison is warranted because the potential for Japan to market refrigerators and freezers in the United States introduces great uncertainty into future developments in United States appliance markets. Unfortunately, limits to test methods prevent good international comparison. Different test procedures are used in the United States and Japan to rate appliance use. These testing differences, as well as the use of test data rather than actual meter readings to rate energy use, prevent direct comparison of the relative energy use of American and Japanese refrigerators and freezers. These limitations are also discussed in Subsection 8.1.3.

\subsubsection{Product Definitions}

Definitions of refrigerators and freezers are standardized:

"(a) Refrigerators and refrigerator-freezers.

(1) "Electric refrigerator" means a cabinet designed for refrigerated storage of food at temperatures above $32^{\circ} \mathrm{F}$ and having a source of refrigeration requiring an electrical energy input only. It may include a compartment for the freezing and storage of food at temperatures below $32^{\circ} \mathrm{F}$ but does not provide a separate low-temperature compartment designed for the freezing of and long-term storage of food at temperatures below $8^{\circ} \mathrm{F}$. It has only one exterior door, but it may have interior doors or compartments.

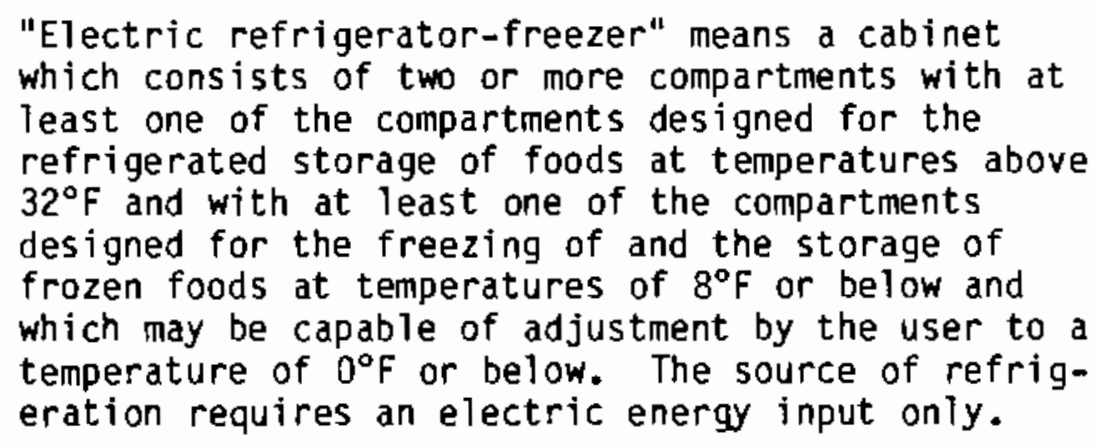
least one of the compartments designed for the refrigerated storage of foods at temperatures above $32^{\circ} \mathrm{F}$ and with at least one of the compartments designed for the freezing of and the storage of frozen foods at temperatures of $8^{\circ} \mathrm{F}$ or below and which may be capable of adjustment by the user to a temperature of $0^{\circ} \mathrm{F}$ or below. The source of refrigeration requires an electric energy input only.

(b) "Freezer" means a cabinet designed as a unit for the storage of food at temperatures of $0^{\circ} \mathrm{F}$ or below and which has the ability to freeze food. The source of refrigeration requires an electric energy input only." (Labeling and Advertising for Consumer Appliances 1984) 
In this analysis, both electric refrigerators and electric refrigeratorfreezers are referred to as refrigerators. The term "freezer' describes a separate chest or upright freezer.

Each appliance category (refrigerator, refrigerator/freezer, or freezer) encompasses several product types. The product types are differentiated by size, storage temperatures, physical arrangements and amenities. Table 8.1 summarizes how these variations affect energy use. A study that weights factors influencing customer decisions was conducted by Pacific Gas \& Electric in California and is cited by David Goldstein of the Natural Resources Defense Council (Goldstein 1983). The study shows that refrigerator/freezer energy efficiency is less important to customers than most other features, including brand, suitability, and color.

\subsubsection{Measures to Improve Efficiency}

Cold food storage has become more energy efficient in recent years and can be improved further through various design modifications. Improved heat pump systems can reduce the electricity needed to remove heat from cabinet interiors. Better refrigerator-box insulation, by doing a better job at keeping warm air out, can minimize the amount of heat that needs to be removed. Automatic defrost and other auxiliary systems can be designed with better attention to energy use, so that the same convenience features are provided for less additional electric load. In this section, conservation measures directed at these refrigeration subsystems are discussed in more detail.

Obtaining Low-Temperature Interiors: Cold temperatures are produced inside refrigerators and freezers when heat from a unit's interior is rejected to the room. The flow of heat is the reverse of what would occur naturally, since heat tends to migrate from warmer to cooler objects. In refrigerators manufactured by U.S. producers, heat removal is accomplished with a compression refrigeration system. The compression refrigerator works by circulation of a fluid that absorbs heat from the refrigerator's interior and rejects heat to the refrigerator's exterior. In addition to the refrigerant fluid, a compression refrigeration system has an evaporator (i.e., a cold coil), a condenser (i.e., a hot coil), a motor-driven pump and compressor, and a capillary tube 
TABLE 8.1. Product Features and Their Impact on Appliance Energy Use

Product Feature

Automatic Defrost

Anti-Sweat Heater

Physical Arrangement

of Refrigerator and

Freezer Compartments:

1. Side-Mounted Freezer Equal accessibility

2. Bottom-Mounted Freezer

Chest Versus Upright Freezer
Prevents condensation on cabinet exterior in humid climates
Impact on Relative Energy Use (Other Features Held Constant)

Automatic defrost uses more energy than manual defrost. Automatic defrosting requires energy to circulate dry cold air, and to melt frost when performing a defrost cycle. In addition, defrost heat adds to the heat that must be removed from the cabinet in order to keep compartment temperatures cold.

Cabinet heaters consume power directly, and they indirectly increase energy consumption by adding to the heat load of the refrigerator. of fresh and frozen stored foods

Side-mounted freezers characteristically consume more energy than top mounts because of increased door seal area, and because the freezer floor is close to the hot motor compartment.

Improved access to fresh stored foods

Suitability and customer preference
Bottom-mounted freezers require more energy than top mounts because freezer is closer to the hot motor compartment, it takes more fan power to move cold air from the freezer evaporator to the top of the fresh-food compartment, and auxiliary heat is often needed in the crisper area to prevent freezing.

For comparable model sizes, chest freezers lose less energy through gaskets and 
TABLE 8.1. (cont d)

\author{
Product Feature \\ Chest Versus Upright \\ Freezer (contd) \\ Freezer to Fresh- \\ Food Compartment \\ Volume Ratio
}

Customer needs and preferences
Allows frozen food to be stored for longer periods

Suitability

Convenience
Impact on Relative Energy Use (Other Features Held Constant)

around door openings than upright freezers. Chest freezers tend to use less energy than upright freezers.

Energy consumption is expected to go up at higher freezer to fresh-food compartment volume ratios. More heat must be extracted and kept out in order to maintain a larger volume at freezer, rather than refrigerator, temperatures.

Lower freezer compartment temperatures result in higher heat leakage to the freezer and greater total energy use.

If the product line is held constant, larger refrigerators, refrigerator/freezers and freezers tend to use more energy than smaller units. However, the energy use per unit volume tends to decrease with Targer volumes. This is because energy losses occur at surfaces, and the ratio of surface area to volume decreases as the net volume is enl arged.

Refrigerator doors containing dispenser equipment cannot be as well-insulated as doors without dispenser equipment. In addition, electric heaters may be required to prevent condensation on the dispenser hardware. Equipment with through-the-door service tends to consume more energy than equipment without it.

Sources: Arthur D. Little, Inc. 1982; Meier, Wright and Rosenfeld 1983. 
that closes the refrigerant circulation system. The evaporator, refrigerant fluid, compressor, and motor used with the compressor can all be made more efficient than common practice. The function of each of these components is described in the following paragraphs.

The evaporator, a cold coil usually installed in the freezer compartment, is where the refrigerant fluid absorbs heat from the refrigerator's interior. The fluid boils, or evaporates, because it suddenly is given room to expand (the pressure drops). A liquid will boil even at low temperatures if the pressure is low enough. When the fluid changes from its liquid to vapor state, it absorbs heat. The temperature remains constant but the heat content of the vapor is greater than the heat content of the liquid.

Two changes to the evaporator might result in lower electricity loading. First, separate evaporator coils can be installed in the refrigerator and freezer sections. Frost buildup is greatly reduced by this measure, and intervals between energy-intensive defrost cycles can be extended. One commercial model, the Amana TSC-18E, used a twin evaporator system but is no longer produced commercially (Geller 1984). A second measure to improve evaporator efficiency is to increase evaporator surface area for more rapid heat exchange (Arthur D. Little 1982).

The condenser, or hot coil, is where the refrigerant fluid parts with its heat. The refrigerant fluid condenses from vapor to liquid because of higher pressure, and it loses heat during this condensation.

The compressor is responsible for increasing the pressure so that the refrigerant fluid condenses. An electrical motor drives a pump that compresses the refrigerant while it is still a gas. The compressor, including both the motor and the pump, uses about 80 percent of the total energy of a conventional refrigerator (Goldstein 1983).

Energy use by the compressor subsystem can be reduced considerably, some analysts estimate that such measures alone could reduce a refrigerator's energy use by 29 percent (Goldstein 1983). The motor efficiency can be improved by replacement of the conventional motor core with a low-loss core and by using copper, rather than aluminum, windings in the rotating coil in the motor. The 
addition of a capacitor also improves motor efficiency; the capacitor curtails unnecessary power losses that occur when current and voltage are out of phase. A side benefit of better compressor efficiency is that a more efficient unit generates less waste heat. Waste heat from the compressor and motor adds to other heat that must be rejected from the refrigerator to the room; reducing waste heat thereby indirectly reduces the refrigerator's electricity load (Goldstein 1983).

The refrigerant fluid is chosen for its boiling temperature and pressure, and for the amount of heat it absorbs in the change from its liquid to vapor state. Properties of the refrigerant fluid affect the energy consumption of the compressor. A mixture of two refrigerant fluids might perform better in this respect than the single refrigerant fiuid conventionally used (Goldstein 1983). However, this technique has not been demonstrated commercially.

Keeping Cold Air In and Warm Air Out: Once the temperature differential between the refrigerator/freezer's interior and the room is established, it must be maintained. Heat can get into the refrigerator four ways: by convection, conduction, radiation or transfer. Conductive and radiant heat transfer occur through the cabinet box. Convective heat transfer occurs when warm air infiltrates through door cracks and when warm air rushes in an open door. Convection is minimized with good door seals, while conduction and radiation are minimized with good insulation. Heat is transferred into a refrigerator when room-temperature materials are placed in it to be chilled.

Improvements in insulation materials and increased insulation thickness are likely to continue to reduce refrigerator and refrigerator-freezer electricity consumption. Conventional American refrigerators and freezers may be insulated with a few inches of fiberglass or with polyurethane foam with R-values per inch of 0.5 and 1.2, respectively. The R-values indicate therma 1 resistance; materials with high $R$-values are better insulators than materials with low R-values. Researchers at Oak Ridge National Laboratory and Arthur D. Little, Inc. recently demonstrated feasible appliance insulations with R-values per inch as high as 3.5 (McElroy and Yarbrough 1984). Substantial energy savings could be realized if these high $R$-value materials were to replace fiberglass or polyurethane foam in refrigerator/freezer construction. Current 
American practice is to use 1.5 to 2.5 inches of insulation around the refrigerator, with slightly more around freezer sections. Increasing insulation thickness reduces conductive losses but is limited commercially by consumer needs for appliances that fit into existing spaces through existing doors. Insulation materials are becoming more effective. Improved insulation materials with greater thermal resistance is a likely technological development.

Conventional American refrigerators/freezers have a single door gasket (seal) to reduce leaks. Double gaskets can reduce convective leaks and are used in some Japanese models (Arthur D. Little 1982; Goldstein 1983).

Automatic Defrost and Anti-Sweat Heaters: Automatic defrost systems are large consumers of energy. A fan blows air past the evaporator, or cold coil; the air's humidity drops as it is cooled. The dehumidified air blows into the freezer compartment where the defrost cycle is completed. In American selfdefrosting refrigerator/freezers this cycle occurs automatically several times a day (Goldstein 1983, 1984).

Manual initiation of the defrost cycle could conserve substantial amounts of energy; such a system is used in Toshiba (a Japanese manufacturer) refrigerator/freezers. In the Toshiba models the user must press a button up to three times a year to initiate a self-defrost cycle (Goldstein 1984). Less energy would run a defrost system if there were two separate evaporators (cold coils), one in the freezer compartment and one in the refrigerator compartment. A twin evaporator system is discussed elsewhere in this report; a design developed by Arthur D. Little, Inc. was incorporated in the Amana refrigerator model used in one of the case studies in Section 8.3. Another way to modify the defrost system is to use a more efficient fan. Less waste heat is generated by more efficient fans. As a result, less waste heat must be removed from the freezer.

Refrigerators and refrigerator/freezers commonly have cabinet heaters so that condensation will not form on the cabinet exterior. The heaters use electricity directly and add to the heat that must be removed from cabinet interiors. In dry climates, condensation will not form on the cabinet's exterior in any case. Some units now have an energy-saving feature, the anti-sweat heater switch (Consumer Guide 1984). This switch enables users in dry climates to shut off the unnecessary heater. 
The energy-saving measures discussed for each refrigeration subsystem--the refrigeration cycle, the refrigerator box, and auxiliary systems--are summarized in Table 8.2 .

\subsubsection{Efficiency Measures in Standard Product Design}

The efficiency of American refrigerators and freezers has improved dramatically since the early 1970s. Refrigerators (including refrigeratorfreezers) were 66.4 percent more efficient in 1983 than in 1972 (shipmentweighted averages; AHAM 1984a). Much of this improvement is due to better insulation, with smaller contributions from more efficient motors and heat transfer systems. The rate of efficiency improvement has slowed down since the 1970s (AHAM 1984a; Geller 1984). The energy consumption per refrigerator/ freezer averaged $1726 \mathrm{kWh} / \mathrm{yr}$ for $1972 \mathrm{U.S}$. shipments and $1160 \mathrm{kWh} / \mathrm{yr}$ for 1983 shipments (AHAM 1984a). The average electricity use of refrigerators in

\section{TABLE 8.2. Summary of Measures to Improve Efficiency in Refrigerators,} Refrigerator-Freezers and Freezers

\begin{tabular}{ll}
$\begin{array}{c}\text { Refrigeration } \\
\text { Sub-System }\end{array}$ & Measures to Improve Efficiency \\
\hline Refrigeration Cycle & - use twin-evaporator \\
& - increase evaporator surface area \\
& use copper windings in the compressor \\
motor & - add a capacitor to the compressor motor \\
& - use mixture of two refrigerant fluids \\
& - use thicker insulation \\
Heat Leakage & use insulation with higher thermal \\
& resistance \\
& use double gaskets at door seals \\
Auxiliary Systems & initiate self-defrost cycle manually \\
& - install more efficient fan \\
& - use twin-evaporator
\end{tabular}


existing U.S. housing falls between these two figures; an estimated average figure of $1321 \mathrm{kWh} / \mathrm{yr}$ is used 1 ater in this report. The actual energy consumption of any unit depends on model, usage and size. It has been claimed that a refrigerator suitable for American consumers could operate at $420 \mathrm{kWh} / \mathrm{yr}$ (Goldstein 1983) but this estimate is much lower than the next lowest estimate. The most efficient American top-freezer $17-18 \mathrm{ft}^{3}$ automatic defrost models available now operate at about $900 \mathrm{kWh} / \mathrm{yr}$ (ACEEE 1984).

The efficiency of American freezers has also improved markedly--a 55.6 percent increase between 1983 and 1972 (shipment-weighted average; AHAM 1984a). The energy consumption per unit (shipment-weighted average) has dropped from $1460 \mathrm{kWh} / \mathrm{yr}$ in 1972 to $813 \mathrm{kWh} / \mathrm{yr}$ in 1983 (AHAM 1984a). An estimated average of $1536 \mathrm{kWh} / \mathrm{yr}$ for units in place is derived elsewhere in this report. The actual energy consumption of any unit varies enormousiy depending on model, usage and size.

Efficiency increases in Japanese models since 1972 appear to have been larger and less sporadic than efficiency increases for American models (Goldstein 1984). Several of the measures discussed in subsection 8.1 .2 are incorporated in Japanese models. Japanese refrigerators consume less energy than American refrigerators but some of this difference is due to the popularity of much larger appliances in America than in Japan.

The actual energy consumption of refrigerators and freezers is hard to derive from available data for either nation, and even harder to compare between nations. Metered data is extremely scarce; test methods for the manufacturer's labels are of dubious value for predicting actual energy use in the home; methods of comparing efficiency between units of different capacity seem somewhat arbitrary, and different test methods are used in Japan and the United States. Because the energy consumption by these appliances is so significant, it would be particularly helpful if more metered data were available. Because the Japanese appear to lead in the manufacture of cost-effective, low energyuse models (Goldstein 1983, 1984), metered comparisons of American and Japanese models would be very timely. 


\subsection{CURRENT MARXET SITUATION}

Although American refrigerators operate more efficiently than in the past, aggregate energy consumption by this end use has increased. Units used now are larger than in the past; the shipment-weighted average volume/unit increased from $18.16 \mathrm{ft}^{3}$ in 1972 to $20.31 \mathrm{ft}^{3}$ in 1983. Larger units tend to use more electricity. In addition, households with more than one refrigerator are increasingly common; the 1982 Residential Energy Consumption Survey indicates a saturation in residential housing of 113 percent or an average of 1.13 units per household (U.S. DOE 1984b). The high saturation is partiy attributable to households where old refrigerators are left plugged into a garage or basement outlet when a new unit is purchased. In such cases, energy consumption increases sharply when a new unit is purchased, even if the new unit is relatively efficient.

Major U.S. refrigerator and refrigerator/freezer manufacturers are General Electric (GE and Hotpoint brands), Whirlpool, Frigidaire (owned by white Consolidated Industries which includes White-Westinghouse brand) and Amana. Generat Electric and Whirlpool each have 28-30 percent of the refrigerator market; Frigidaire and White-Westinghouse share about 23 percent of the market; Amand (owned by Raytheon Corporation) has a market share of 10-12 percent. The remainder is accounted for by Admiral and other brands (market shares from Consumers Digest 1984).

The most popular refrigerator is a top-freezer, automatic defrost model with 18 to $20 \mathrm{ft}^{3}$ capacity (Consumer Reports 1983). The average Japanese refrigerator, with a volume of $8.12 \mathrm{ft}^{3}$, is less than half this size (Goldstein 1984 ).

Freezers are more efficient than in the past; they tend to be slightly smalier. The shipment-weighted capacity declined from $29.18 \mathrm{ft}^{3}$ in 1972 , to $25.28 \mathrm{ft}^{3}$ in 1983 (AHAM 1984a). The 1982 Residential Energy Consumption Survey indicates 40 percent saturation of separate freezer units in residential housing (H.S. DOE 1984b). 
Whirlpool has 30 percent of the freezer market (Consumers Digest 1984). White-Westinghouse also has a major market share. Other manufacturers include Admiral, G.E./Hotpoint, Amana and Revco (Geller 1983).

No single freezer type dominates either sales or stock (AHAM 1983b; Meier, Wright and Rosenfeld 1983). Only manual defrost models are available for chest freezers (Consumer Guide 1984). Upright models are more convenient for everyday use and take up less space than chest models.

Foreign competition could cause substantial shifts in American refrigerator and refrigerator-freezer markets. The American market will be quite vulnerable if Japanese manufacturers scale the size of their products up and market them in the United States.

\subsection{COST EFFECTIVENESS AND MARKET PENETRATION}

The cost effectiveness and likely market penetration of even higher efficiency refrigerators and freezers than typical current models are discussed in this section. Payback periods for a more efficient freezer and more efficient refrigerator-freezer are calculated in Section 8.3.1. Two scenarios, one with and one without availability of a competing Japanese product, are calculated for the refrigerator-freezer case. Technical factors that might preclude the use of high efficiency appliances are discussed in Section 8.3.2. Market penetration assumptions are discussed in Section 8.3.3.

A number of assumptions in this part of the analysis could have a Targe impact on the energy savings results (Section 8.5 ). The payback period would be much shorter if real electricity prices were assumed to increase in the 1985-2000 period, as is assumed in Geller 1983. The market penetration could be much higher if consumers accept longer payback periods for long-life appliances, such as refrigerators and freezers, than for the product analyzed in the empirical work on which our methodology is based. Furthermore, more efficient refrigerators and freezers could become readily available if international competition becomes rigorous; in such a case the price of efficient products might fall. However, the first two assumptions remain constant throughout this document, and the third involves hypotheses about products that are not commercially available in the United States. However, because alternative product 
choices could have such a large impact, a scenario based on best available information regarding Japanese products is discussed in more detail in Section 8.3.1.

It is assumed that efficiency improvements that have already taken place are incorporated into NEPP projections. If this is not the case, then the NEPP projections will overestimate energy use by residential refrigerators and freezers even if the energy saving results of this chapter are applied to the projections.

\subsubsection{Cost Effectiveness of More Efficient Product: Three Scenarios}

The cost-effectiveness of a more efficient upright freezer and a more efficient top freezer refrigerator are calculated below. Efficiency of the case study units are compared with new units of typically available efficiency for new and retirement markets, and with the efficiency of average refrigerator/freezer stock for retrofit markets. The top-freezer refrigerator model is no longer manufactured, but may still be available in stores and incorporates many of the energy savings features discussed earlier including a twin evaporator system. The reasons that this model is no longer commercially produced is the subject of a recent Pacific Northwest Laboratory Study for the DOE/BERD (Franke et al. 1985). A hypothetical case, of a more efficient top-freezer that the Japanese could possibly offer, is also considered below. Table 8.3 lists the products selected for the payback calculation. The products listed as "conventional" are typical of what is currently available but more efficient than average installed stock.

\section{Case 1: Freezer}

Table 8.4 shows the simple payback period for a new and retrofit freez-

er. Prices of $\$ 470$ for the Amana ESU-136 and $\$ 370$ for the Whirlpool EVI30 FXK are as quoted in Consumers Digest 1984. Annual energy consumption of $725 \mathrm{kWh} / \mathrm{yr}$ for the Amana and $835 \mathrm{kWh} / \mathrm{yr}$ for the Whirlpool models are based on DOE test procedures and AHAM Consumer Selection Guide 1istings (AHAM 1984b). The average energy consumption of existing freezer stock is calculated as follows: 
TABLE 8.3. Products Selected for Payback Analys is

\begin{tabular}{|c|c|c|}
\hline Scenario & Manufacturer/Model & Product \\
\hline $\begin{array}{l}\text { High-Efficiency } \\
\text { Freezer }\end{array}$ & Amana ESU-13C & $\begin{array}{l}13 \mathrm{ft}^{3} \text { Upright } \\
\text { Freezer--Manual } \\
\text { Defrost }\end{array}$ \\
\hline $\begin{array}{l}\text { Conventional } \\
\text { Freezer }\end{array}$ & Whirlpool EV130FXx & $\begin{array}{l}13 \mathrm{ft}^{3} \text { Upright } \\
\text { Freezer--Manual } \\
\text { Defrost }\end{array}$ \\
\hline $\begin{array}{l}\text { High-Efficiency } \\
\text { American } \\
\text { Refrigerator }\end{array}$ & Amana TSC-18E & $\begin{array}{l}18 \mathrm{ft}^{3} \text { Top-Freezer } \\
\text { Refrigerator-- } \\
\text { Automatic Defrost }\end{array}$ \\
\hline $\begin{array}{l}\text { High-Efficiency } \\
\text { Japanese } \\
\text { Refrigerator }\end{array}$ & Hypothetical $(a)$ & $\begin{array}{l}18 \mathrm{ft}^{3} \text { Top-Freezer } \\
\text { Refrigerator-- } \\
\text { Automatic Defrost }\end{array}$ \\
\hline $\begin{array}{l}\text { Conventional } \\
\text { Refrigerator }\end{array}$ & $\begin{array}{l}\text { White-west inghouse } \\
\text { RT188E }\end{array}$ & $\begin{array}{l}18 \mathrm{ft}^{3} \text { Top-Freezer } \\
\text { Refrigerator-- } \\
\text { Automatic Defrost }\end{array}$ \\
\hline
\end{tabular}

(a) Japanese scenario is based on published information of and phone conversations with Natural Resources Defense Council staff who have visited Japan and compared Japanese refrigerator/freezers with the refrigeration/freezers available in the U.S. These experts believe that the Japanese products are more efficiently designed than their U.S. counterparts. They also suggest that the Japanese could offer efficient units suitable for American markets at competitive prices.

TABLE 8.4. Payback Period of More Efficient $13 \mathrm{ft}^{3}$ Upright Freezer-Manual Defrost

\begin{tabular}{|c|c|c|c|}
\hline & $\begin{array}{l}\text { Capital } \\
\text { Cost }\end{array}$ & $\begin{array}{c}\text { Annual Energy } \\
\text { Use }\end{array}$ & Years to Payback \\
\hline \multicolumn{4}{|l|}{ New: } \\
\hline $\begin{array}{l}\text { Amana ESU-13C } \\
\text { Whirlpool EVI30 FXK }\end{array}$ & $\begin{array}{l}\$ 470 \\
\$ 370\end{array}$ & $\begin{array}{l}725 \mathrm{kWh} / \mathrm{yr} \\
835 \mathrm{kWh} / \mathrm{yr}\end{array}$ & $\frac{\$ 470-\$ 370}{110 \mathrm{kWh} / \mathrm{yr} \times \$ .0718 / \mathrm{kWh}}=12.7 \mathrm{yr}$ \\
\hline \multicolumn{4}{|c|}{ Accelerated Replacement: } \\
\hline $\begin{array}{l}\text { Amana ESU-13C } \\
\text { Average Stock }\end{array}$ & $\begin{array}{r}\$ 470 \\
-0-\end{array}$ & $\begin{array}{r}725 \mathrm{kWh} / \mathrm{yr} \\
1505 \mathrm{kWh} / \mathrm{yr}\end{array}$ & $\frac{\$ 470}{780 \mathrm{kWh} / \mathrm{yr} \times \$ .0718 / \mathrm{kWh}}=8$ \\
\hline
\end{tabular}


7 percent electricity use of residential sector attributable to freezers (U.S. DOE 1984C)

$\times \quad$ Total 1984 residential electricity use of 779.60 BkWh (U.S. DDE 1984a)

$\div \quad 90.6$ million households (U.S. DOE 1984a)

$\times \quad 40$ percent saturation (U.S. DOE 1984b)

$=1505 \mathrm{kWh} /$ freezer/year.

As discussed in Chapter 3.0, an electricity price of $7.18 \$ / \mathrm{kWh}$, with no real escalation is assumed throughout this analysis. Case 2: American Refrigerator

Table 8.5 shows the simple payback period for a new and accelerated replacement American refrigerator. Prices are as quoted in Consumer Reports 1983, as is energy use. The Amana TSC-18E is no longer produced but could theoretically be produced again for the same real costs and with the same efficiency. The average energy consumption of existing refrigerator stock is calculated as follows:

17 percent electricity use of residential sector attributable to refrigerators (U.S. DOE 1984C)

$\times \quad$ Total 1984 residential electricity use of 779.6 BkWh (U.S. DOE 1984a)

$\div \quad 90.6$ million households (U.S. DOE 1984a)

$\div \quad 113$ percent saturation (U.S. DOE 1984b)

$=1294 \mathrm{kWh} /$ refrigerator/year.

The long payback period for the accelerated replacement case indicates that few consumers, if any, would replace a serviceable existing refrigerator for energy savings alone.

Case 3: Japanese Refrigerator

Table 8.6 shows the simple payback period for a new and accelerated replacement Japanese refrigerator. The Japanese refrigerator is assumed to be 
TABLE 8.5. Payback Period of More Efficient $18 \mathrm{ft}^{3}$ Top-Freezer Refrigerator-Automatic Defrost: Actual American Model

Capital Annual Energy

Cost Use

Years to Payback

New:

Amana TSC-18E

$\$ 851$

White-Westinghouse

$960 \mathrm{kWh} / \mathrm{yr}$ $1200 \mathrm{kWh} / \mathrm{yr}$

$\frac{\$ 851-\$ 666}{240 \mathrm{kWh} / \mathrm{yr} \times \$ .0718 / \mathrm{kWh}}=10.7 \mathrm{yr}$ RT188E

Accelerated Replacement:

Amana TSC-18E

$\$ 851$

Average Refrigerator -D-

$960 \mathrm{kWh} / \mathrm{yr}$

$1294 \mathrm{kWh} / \mathrm{yr}$

$\frac{\$ 851}{334 \mathrm{kWh} / \mathrm{yr} \times \$ .0718 / \mathrm{kWh}}=35.5 \mathrm{yr}$

TABLE 8.6. Payback Period of More Efficient $18 \mathrm{ft}^{3}$ Top Freezer Refrigerator-Automatic Defrost: Hypothetical Japanese Model

\begin{tabular}{|c|c|c|c|}
\hline & $\begin{array}{l}\text { Capital } \\
\text { Cost } \\
\end{array}$ & $\begin{array}{l}\text { Annual Energy } \\
\text { Use } \\
\end{array}$ & Years to Payback \\
\hline \multicolumn{4}{|l|}{ New: } \\
\hline $\begin{array}{l}\text { Japanese } \\
\text { White-Westinghouse } \\
\text { RT188E }\end{array}$ & $\begin{array}{l}\$ 816 \\
\$ 666\end{array}$ & $\begin{array}{r}660 \mathrm{kWh} / \mathrm{yr} \\
1200 \mathrm{kWh} / \mathrm{yr}\end{array}$ & $\frac{\$ 150}{540 \mathrm{kWh} / \mathrm{yr} \times \$ .0718 / \mathrm{kWh}}=3.9 \mathrm{yr}$ \\
\hline \multicolumn{4}{|l|}{ Accelerated Replacement: } \\
\hline $\begin{array}{l}\text { Japanese } \\
\text { Average Refrigerator }\end{array}$ & $\begin{array}{l}\$ 816 \\
-0-\end{array}$ & $\begin{array}{r}660 \mathrm{kWh} / \mathrm{yr} \\
1294 \mathrm{kWh} / \mathrm{yr}\end{array}$ & $\frac{\$ 816}{634 \mathrm{kWh} / \mathrm{yr} \times \$ .0718 / \mathrm{kWh}}=17.9 \mathrm{yr}$ \\
\hline
\end{tabular}

45 percent more efficient than the American refrigerator (Goldstein 1984). The Japanese refrigerator is assumed to cost an incremental $\$ 150.00$, based on a conversation with staff at the Natural Resource Defense Council. The price and energy consumption for new and stock American refrigerators are as cited in Case 2.

Because of the long payback period, the accelerated replacement case is not considered in the remaining analysis.

\subsubsection{Technical Limits}

The only technical limit identified is space Timitations to insulator thickness. It is possible to indefinitely increase thickness for better thermal resistance. However, an appliance so insulated would not be suitable for 
limited kitchen spaces. No technical limits are quantified because of the mix of options available for improving appliance efficiencies. All efficiency levels used in the report could be attained by measures which do not have technical limits.

\subsubsection{Market-Penetration Assumptions}

Market penetration rates are assumed to be based on payback period as discussed in Chapter 4.0 (refer to Table 4.1). Based on a payback period of 12.7 years for a new upright freezer, maximum market penetration is assumed to be 5 percent in the new market, which includes normal replacement. 8ased on lengthy payback periods, there are assumed to be no accelerated replacements of refrigerators in any of the three scenarios. Market penetration for new markets for American models (which includes "normal" replacement) is assumed to reach 5 percent of sales by 2000, based on a payback period of more than 10 years. Based on the shorter payback period of 3.9 years in the Japanese scenario, the maximum market penetration is assumed to be 45 percent, but because the first sales will not occur until 1990, the penetration in 2000 is assumed to be only 33 percent.

\subsection{HOUSING STOCK PROJECTIONS AND MARKET SHARE ESTIMATES}

Stock data (existing numbers of refrigerators and freezers, expected rate of growth, and expected number of high-efficiency units) are discussed in this section. Table 8.7 shows market shares and stock data for more efficient freezers; Table 8.8 shows market shares for more efficient refrigerators based on the American model scenario, and Table 8.9 shows market shares and stock data for more efficient refrigerators based on the Japanese competition scenario. It is assumed that the Japanese would need five years to make the efficient refrigerator/freezer available, so it is further assumed that the first sales would occur in 1990. Housing projections are based on projections supporting the National Energy Policy Plan (DOE 1983a). Market shares for more efficient appliances are estimated according to the method described in Chapter 4.0 using the assumptions discussed in Section 8.3. We have assumed 
TABLE 8.7. Annual Market Share Projections--More Efficient Freezers

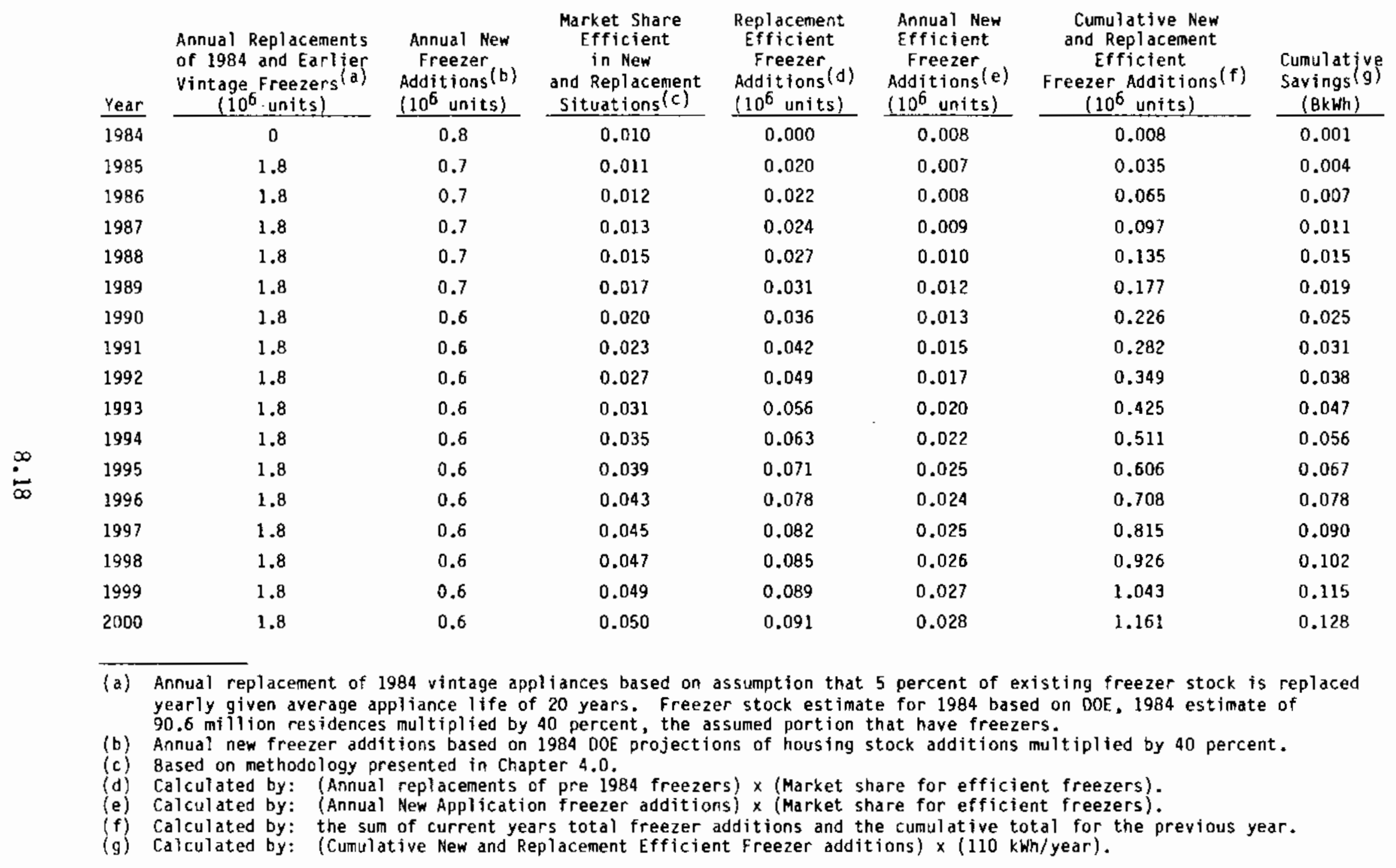


TABLE 8.8. Annual Market Share Projections--More Efficient Refrigerators Based on Payback Period of American Model

\begin{tabular}{|c|c|c|c|c|c|c|c|}
\hline Year & $\begin{array}{c}\text { Annual Replacements } \\
\text { of } 1984 \text { and Earlier } \\
\text { Vintage Refrigerators }(a) \\
\text { (1106 units) } \\
\end{array}$ & $\begin{array}{l}\text { Annual New } \\
\text { Refrigerato: } \\
\text { Additions } \\
\text { (10 } 0^{6} \text { units) } \\
\end{array}$ & $\begin{array}{c}\text { Market Share } \\
\text { Efficient } \\
\text { in New } \\
\text { and Replacement } \\
\text { Situations }(c) \\
\end{array}$ & $\begin{array}{l}\text { Replacement } \\
\text { Efficient } \\
\text { Refrigerator } \\
\text { Additions } \\
\text { (10 }) \\
\end{array}$ & $\begin{array}{l}\text { Annual New } \\
\text { Efficient } \\
\text { Refrigerator } \\
\text { Additions } \\
\text { (10 } 10^{6} \text { units) } \\
\end{array}$ & $\begin{array}{c}\text { Cumulative New } \\
\text { and Replacement } \\
\text { Efficient } \\
\text { Refrigerator Additions ( } f) \\
\left(10^{6} \text { units) }\right. \\
\end{array}$ & $\begin{array}{l}\text { Cumulatjue } \\
\text { Savings } \\
\text { (BkWh) } \\
\end{array}$ \\
\hline 1984 & 5.1 & 2.1 & 0.010 & 0.051 & 0.021 & 0.073 & 0.017 \\
\hline 1985 & 5.1 & 1.9 & 0.011 & 0.056 & 0.021 & 0.150 & 0.036 \\
\hline 1986 & 5.1 & 1.9 & 0.012 & 0.063 & 0.024 & 0.237 & 0.057 \\
\hline 1987 & 5.1 & 1.9 & 0.013 & 0.067 & 0.025 & 0.328 & 0.079 \\
\hline $198 \theta$ & 5.1 & 1.9 & 0.015 & 0.077 & 0.029 & 0.434 & 0.104 \\
\hline 1989 & 5.1 & 1.9 & 0.017 & 0.087 & 0.033 & 0.553 & 0.133 \\
\hline 1990 & 5.1 & 1.8 & 0.020 & 0.102 & 0.036 & 0.692 & 0.166 \\
\hline 1991 & 5.1 & 1.8 & 0.023 & 0.118 & 0.042 & 0.851 & 0.204 \\
\hline 1992 & 5.1 & 1.8 & 0.027 & 0.138 & 0.049 & $1.03 B$ & 0.249 \\
\hline 1993 & 5.1 & 1.8 & 0.031 & 0.159 & 0,056 & 1.253 & 0.301 \\
\hline 1994 & 5.1 & 1.8 & 0.035 & 0.179 & 0.063 & 1.496 & 0.359 \\
\hline 1995 & 5.1 & 1.8 & 0.039 & 0.200 & 0.071 & 1.766 & 0.424 \\
\hline 1996 & 5.1 & 1.6 & 0.043 & 0.220 & 0.068 & 2.054 & 0.493 \\
\hline 1997 & 5.1 & 1.6 & 0.045 & 0.230 & 0.071 & 2.355 & 0.565 \\
\hline 1998 & 5.1 & 1.6 & 0.047 & 0.241 & 0.074 & 2.670 & 0.641 \\
\hline 1999 & 5.1 & 1.6 & 0.049 & 0.251 & 0.078 & 2.999 & 0.720 \\
\hline 2000 & 5.1 & 1.6 & 0.050 & 0.256 & 0.079 & 3.334 & 0.800 \\
\hline
\end{tabular}

(a) Annual replacement of 1984 vintage appliances based on assumption that 5 percent of existing refrigerator stock is replaced yearly given average appliance life of 20 years. Refrigerator stock estimate for 1984 based on D0E, 1984 estimate of 90.5 million residences multiplied by 40 percent, the assumed portion that have refrigerators.

(b) Annual new refrigerator additions based on 1984 DOE projections of housing stock additions muitiplied by 40 percent.

(c) Based on methodology presented in Chapter 4.0 .

(e) Calculated by: (Annual New Application refrigerator additions) $x$ (Yarket share for efficient refrigerators).

(f) Calculated by: the sum of current years total refrigerator additions and the cumulative total for the previous year.

(9) Calculated by: (Cumulative New and Replacement Efficient Refrigerator additions) $x(240 \mathrm{kHh} / \mathrm{year}$ ). 
TABLE 8.9. Annual Market Share Projections--More Efficient Refrigerators Based on Payback Period of Hypothetical Japanese Model

\begin{tabular}{|c|c|c|c|c|c|c|c|}
\hline Year & $\begin{array}{c}\text { Annual Replacements } \\
\text { of } 1984 \text { and Earlier } \\
\text { Vintage Refrigerators (a) } \\
\left(10^{6} \text { units) }\right. \\
\end{array}$ & $\begin{array}{l}\text { Annual New } \\
\text { Refrigerator } \\
\text { Additions }(\mathrm{b}) \\
\left(10^{6} \text { units }\right) \\
\end{array}$ & $\begin{array}{c}\text { Harket Share } \\
\text { Efficient } \\
\text { in New } \\
\text { and Replacement } \\
\text { Situations }(c) \\
\end{array}$ & $\begin{array}{l}\text { Replacement } \\
\text { Efficient } \\
\text { Refrigerator } \\
\text { Additions (d) } \\
\left(10^{6} \text { units) }\right. \\
\end{array}$ & $\begin{array}{l}\text { Annual New } \\
\text { Efficient } \\
\text { Refrigeratoror } \\
\text { Additions (e) } \\
\left(10^{6} \text { units) }\right.\end{array}$ & $\begin{array}{c}\text { Cumulative New } \\
\text { and Replacement } \\
\text { Efficient } \\
\text { Refrigerator Additions ( } f) \\
\left(10^{6} \text { units }\right)\end{array}$ & $\begin{array}{c}\text { Cumulatjve } \\
\text { Savings } 9 \text { ) } \\
\text { (BkWh) }\end{array}$ \\
\hline 1984 & 5.1189 & 2.147 & 0.000 & 0.000 & 0.000 & 0.000 & 0.000 \\
\hline 1985 & 5.1189 & 1.921 & 0.000 & 0.000 & 0.000 & 0.000 & 0.000 \\
\hline 1986 & 5.1189 & 1.921 & 0.000 & 0.000 & 0.000 & 0.000 & 0.000 \\
\hline 1987 & 5.1189 & 1.921 & 0.000 & 0.000 & 0.000 & 0.000 & 0.000 \\
\hline 1988 & 5.1189 & 1.921 & 0.000 & 0.000 & 0.000 & 0.000 & 0.000 \\
\hline 1989 & 5.1189 & 1.921 & 0.000 & 0.000 & 0.000 & 0.000 & 0.000 \\
\hline 1990 & 5.1189 & 1.808 & 0.002 & 0.010 & 0.004 & 0.014 & 0.007 \\
\hline 1991 & 5.1189 & 1.908 & 0.005 & 0.026 & 0.009 & 0.048 & 0.026 \\
\hline 1992 & 5.1189 & 1.808 & 0.010 & 0.051 & 0.018 & 0.118 & 0.064 \\
\hline 1993 & 5.1189 & 1.808 & 0.015 & 0.077 & 0.027 & 0.222 & 0.120 \\
\hline 1994 & 5.1189 & 1.808 & 0.025 & 0.128 & 0.045 & 0.395 & 0.213 \\
\hline 1995 & 5.1189 & 1.582 & 0.045 & 0.230 & 0.081 & 0.707 & 0.382 \\
\hline 1996 & 5.1189 & 1.582 & 0.075 & 0.384 & 0.119 & 1.209 & 0.653 \\
\hline 1997 & 5.1189 & 1.582 & 0.125 & 0.640 & 0.198 & 2.047 & 1.105 \\
\hline 1998 & 5.1189 & 1.582 & 0.018 & 1.921 & 0.285 & 3.253 & 1.757 \\
\hline 1999 & 5.1189 & 1.582 & 0.250 & 1.280 & 0.396 & 4.928 & 2.661 \\
\hline 2000 & 5.1189 & 1.582 & 0.330 & 1.689 & 0.522 & 7.139 & 3.855 \\
\hline $\begin{array}{l}(\mathrm{b}) \\
(\mathrm{c}) \\
(\mathrm{d}) \\
(\mathrm{e}) \\
(\mathrm{f}) \\
(\mathrm{g})\end{array}$ & \multicolumn{7}{|c|}{$\begin{array}{l}\text { Annual replacement of } 1984 \text { vintage appliances based on assumption } \\
\text { glven average appliance } 11 \text { fe of } 20 \text { years, Refrigerator stock est } \\
\text { residences multiplied by } 40 \text { percent, the assumed port ton that hav } \\
\text { Annul new refrigerator additions based on } 1984 \text { DOE projections } 0 \\
\text { Based on methodology presented in Chapter } 4.0 \text {. } \\
\text { Calculated by: (Annual replacements of pre } 1984 \text { refrigerators) } x \\
\text { Calculated by: (Annual New Application refrigerator additions) } x \\
\text { Calculated by: the sum of current years total refrigerator addit } \\
\text { Calculated by: (Cumulative New and Replacement Efficient Refrige }\end{array}$} \\
\hline
\end{tabular}


that total market penetration of freezers remains constant at 40 percent and of refrigerators at 113 percent through 2000. The lifetime of all appliances is assumed to be 20 years.

\subsection{ENERGY SAVINGS RESULTS}

In the last column of each of Tables $8.7,8.8$ and 8.9 displays the expected energy savings projected for the three scenarios. The projections are based on per-unit energy savings and expected market penetration. To use these representative saving and market penetration estimates to obtain an aggregate savings estimate, they are applied to the market share and stock data and forecasts presented in the first six columns of Tables 8.7 through 8.9 that characterize the expected changes over time of the domestic cold storage market. Table 8.10 summarizes the projected energy savings for the three cases for selected years.

Considerable uncertainty is associated with the energy savings results. The payback period might be shorter if international competition pushes product prices down and efficiency up. The extent of such an effect is unknown, in part because current test methods do not permit good international comparison of the energy consumption of refrigerators and freezers. Some apparent efficiency differences may be caused by errors in calibration. Another factor contributing to uncertainty in the results is unknown market penetration for high efficiency appliances. Market penetration might be higher, especially with long life appliances such as refrigerators and freezers. No real escalation rate for the price of electricity is projected; this may be a false assumption

TABLE 8.10. Annual Energy Savings Projections for More Efficient Freezers, More Efficient American Refrigerator Freezers, and Japanese Refrigerator/Freezers--Selected Years (BkWh)

$\begin{array}{cccccc}\frac{\text { Year }}{1995} & \text { Freezers } & 0 & \begin{array}{c}\text { American } \\ \text { Refrigerator/Freezers }\end{array} & \begin{array}{c}\text { Japanese } \\ \text { Refrigerator/Freezers }\end{array} & \frac{0}{\text { Total }} \\ 1990 & 0.03 & 0.04 & 0.17 & 0.01 & 0.04 \\ 1995 & 0.07 & 0.42 & 0.38 & 0.21 \\ 2000 & 0.13 & 0.80 & 3.86 & 0.87\end{array}$.


that results in overestimation of payback periods, underestimation of market penetration and underestimation of energy savings.

\subsection{SENSITIVITY OF ANALYSTS TO MARKET-PENETRATION ASSUMPTIONS}

This section summarizes variations of the scenarios discussed in Sections $8.3,8.4$ and 8.5 the first set of variations assumes the same per-unit energy savings but reduces the assumed maximum market penetration by 50 percent. Additionally, for the American models, maximum market penetration is assumed to occur more slowly than in the base case. (For the Japanese models a five-year lag preceding any market penetration is already buitt into the basecase estimates.) Thus, in the low market-penetration scenario fewer highefficiency units are installed, and less energy is saved. Section 8.6.1 summarizes the low market-penetration scenarios. The second set of variations also assume the same per-unit energy savings. However, the assumed maximum market penetration is doubled, and, except in the Japanese scenario, this market penetration is assumed to occur more quickly than in the base case. Thus, more units are installed, and energy savings are larger. Section 8.6.2 summarizes the high market-penetration scenarios.

\subsubsection{Low Market-Penetration Scenarios}

Energy savings projected in the base estimates were not large. With lower market penetration, the savings are even smaller. The low market-penetration scenario for high-efficiency freezers is summarized below and is followed by summaries of the low market-penetration scenarios for refrigerator-freezers.

In the low market-penetration scenario for high-efficiency freezers, the maximum market penetration of freezers bought for new and retirement markets (i.e., for installation in new homes or to replace worn-out stock), is assumed to equal 2.5 percent with only 75 percent of the maximum achieved by the year 2000. As in the base case, no early replacement of working units occurs. Perunit energy savings for extra-high-efficiency freezers equal $110 \mathrm{kWh} / \mathrm{yr}$. Calculations are provided in Table 8.11.

In the low market-penetration scenario for American high-efficiency refrigerator-freezers, units bought for new and retirement markets (i.e., for 
TABLE 8.11. Low Market-Penetration Scenario and Annual Savings of Delivered Electricity--More Efficient Freezers

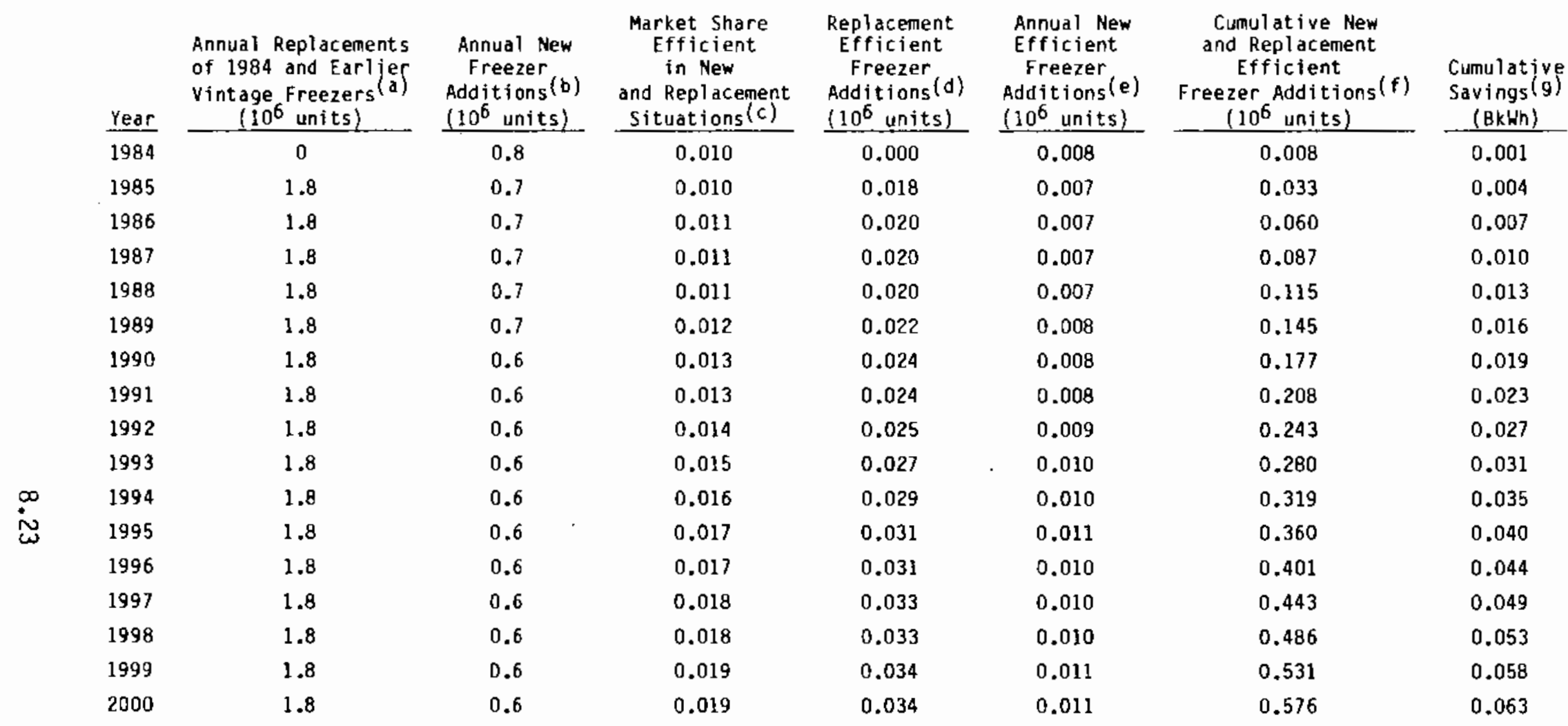

(a) Annual replacement of 1984 vintage appliances based on assumption that 5 percent of existing freezer stock is replaced yearly given average appliance life of 20 years. Freezer stock estimate for 1984 based on DOE, 1984 estimate of 90.6 million residences multiplied by 40 percent, the assumed portion that have freezers.

(b) Annual new freezer additions based on 1984 DOE projections of housing stock additions multiplied by 40 percent.

(c) Based on methodology presented in Chapter 4.0.

(d) Calculated by: (Annual replacements of pre 1984 freezers) $\times$ (Market share for efficient freezers).

(e) Calculated by: (Annual New Application freezer additions) $x$ (Market share for efficient freezers).

(f) Calculated by: the sum of current years total freezer additions and the cumulative total for the previous year.

(g) Calculated by: (Cumulative New and Replacement Efficient Freezer additions) $x$ (110 kWh/year). 
installation in new homes or to replace worn-out stock) experience maximum market penetration of 2.5 percent so slowly that only 75 percent of this maximum is realized by the year 2000. As in the base case, energy savings are insufficient to warrant early replacement of appliance in the "representative" case. The refrigerator-freezers analyzed in this scenario are assumed, on average, to use $240 \mathrm{kwh} / \mathrm{yr}$ less than other new refrigerator-freezers. Details of the market share and energy savings are provided in Table 8.12.

In the low market penetration scenario for refrigerator-freezers performing at efficiencies typical of Japanese refrigerator-freezers, but scaled upward in size for American markets, maximum market penetration reaches 16 percent by the year 2000. This is half of the market penetration in the base case. The five-year lag (assumed to occur, in the base case, before any market penetration) is retained. No early replacement of models for energy savings alone occurs. Per-unit energy savings for models installed instead of other new stock are assumed to equal $540 \mathrm{kWh} / \mathrm{yr}$. Details of the market share and energy savings are provided in Table 8.13 .

Table 8.14 summarizes energy savings results for the low market-penetration scenarios. In general, energy savings results are approximately half of the values estimated in the base-case projections.

\subsubsection{High Market-Penetration Scenarios}

High market-penetration scenarios are presented in this section to test the sensitivity of the energy savings results to the market-penetration assumptions. Maximum market penetration is doubled from the baseline assumptions. In the freezer and American refrigerator-freezer scenario, maximum market penetration occurs more quickly (by 1995). The Japanese product is assumed to be unavailable until 1990, with maximum market penetration by the year 2000 .

In the high penetration scenario for high-efficiency freezers, maximum market penetration for freezers bought for new and retirement markets (i.e., for installation in new homes or to replace worn-out stock), is assumed to equal 10 percent by 1995. Per-unit energy savings assumptions remain 
TABLE 8.12. Low Market-Penetration Scenario and Annual Savings of Delivered Electricity--More Efficient Refrigerators Based on Payback of American Model

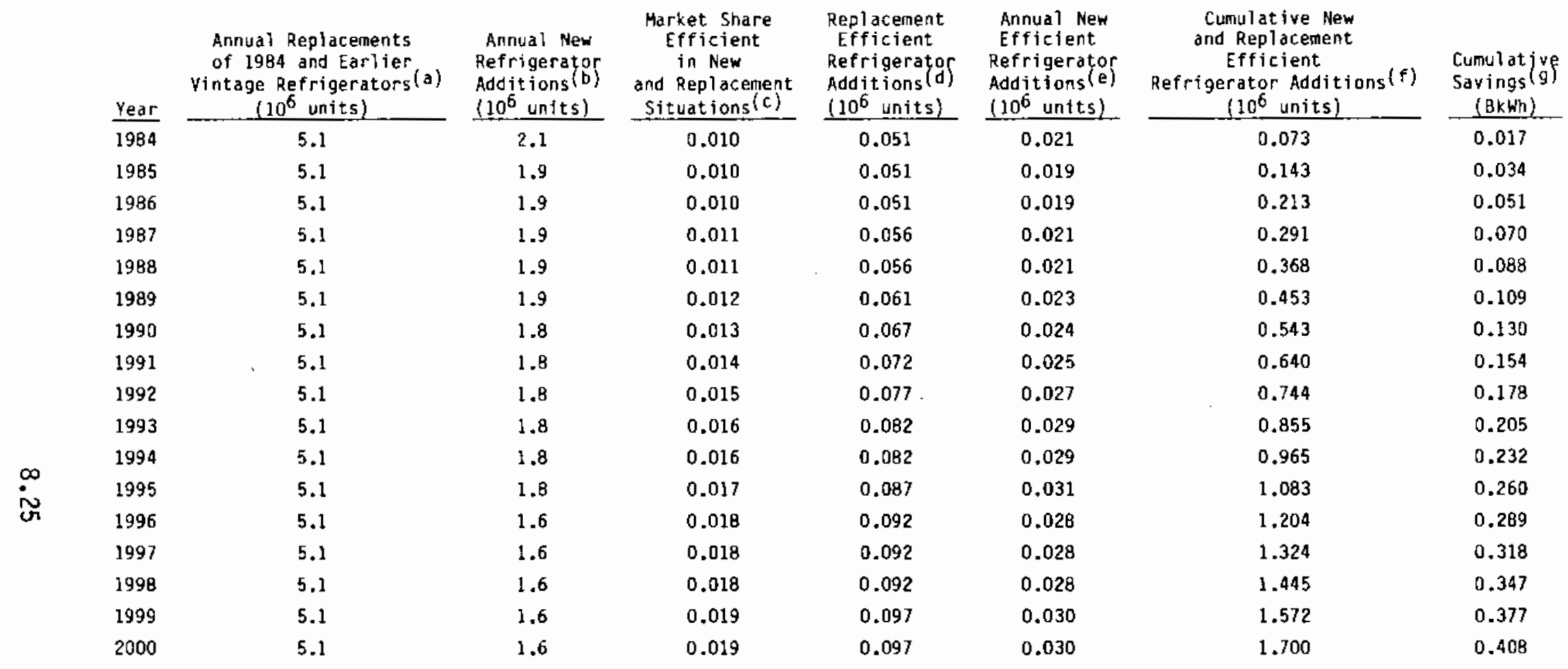

(a) Annual replacement of 1984 vintage appliances based on assumption that 5 percent of existing refrigerator stock is replaced yearly given average appliance 1 ife of 20 years. Refrigerator stock estimate for 1984 based on D0E, 1984 estimate of 90.6 milion residences multiplied by 40 percent, the assumed portion that have refrigerators.

(b) Annual new refrigerator additions based on 1984 O0E projections of housing stock additions multiplied by 40 percent.

(c) Based on methodology presented in Chapter 4.0

(d) Calcuiated by: (Annual replacements of pre 1984 refrigerators) x (Market share for efficient refrigerators).

(e) Calculated by: (Annual New Application refrigerator additions) x (Market share for efficient refrigerators).

(f) Calculated by: the sum of current years total refrigerator additions and the cumulative total for the previous year.

(g) Calculated by: (Cumulative New and Replacement Effictent Refrigerator additions) $\times(240 \mathrm{kHh} / \mathrm{year}$ ). 
TABLE 8.13. Low Market-Penetration Scenario and Annual Savings of Delivered Electricity--More Efficient Refrigerators Based on Payback Period of Hypothetical Japanese Model

\begin{tabular}{|c|c|c|c|c|c|c|c|}
\hline Year & $\begin{array}{c}\text { Annual Replacements } \\
\text { of } 1984 \text { and Earlier } \\
\text { Vintage Refrigerators (a) } \\
\left(10^{6} \text { units) }\right.\end{array}$ & $\begin{array}{l}\text { Annual New } \\
\text { Refrigerator } \\
\text { Addjtions }(b) \\
\left(10^{6} \text { units }\right) \\
\end{array}$ & $\begin{array}{c}\text { Market Share } \\
\text { Efficient } \\
\text { in New } \\
\text { and Replacement } \\
\text { Situations }(c) \\
\end{array}$ & $\begin{array}{l}\text { Replacement } \\
\text { Efficient } \\
\text { Refrigerator } \\
\text { Additions }(d) \\
\left(10^{6} \text { units }\right) \\
\end{array}$ & $\begin{array}{l}\text { Annual New } \\
\text { Efficient } \\
\text { Refrigerator } \\
\text { Additions (e) } \\
\text { (106 units) }\end{array}$ & $\begin{array}{c}\text { Cumulative New } \\
\text { and Replacement } \\
\text { Efficient } \\
\text { Refrigerator Additions }(f) \\
\left(10^{6} \text { units }\right) \\
\end{array}$ & $\begin{array}{l}\text { Cumulatjve } \\
\text { Savings } \\
\text { (BkWh) }\end{array}$ \\
\hline 1984 & 5.1 & 2.1 & 0.000 & 0.000 & 0.000 & 0.000 & 0.000 \\
\hline 1985 & 5.1 & 1.9 & 0.000 & 0.000 & 0.000 & 0.000 & 0.000 \\
\hline 1986 & 5.1 & 1.9 & 0.000 & 0.000 & 0.000 & 0.000 & 0.000 \\
\hline 1987 & 5.1 & 1.9 & 0.000 & 0.000 & 0.000 & 0.000 & 0.000 \\
\hline 1988 & 5.1 & 1.9 & 0.000 & 0.000 & 0.000 & 0.000 & 0.000 \\
\hline 1989 & 5.1 & 1.9 & 0.000 & 0.000 & 0.000 & 0.000 & 0.000 \\
\hline 1990 & 5.1 & 1.8 & 0.002 & 0.010 & 0.004 & 0.014 & 0.007 \\
\hline 1991 & 5.1 & 1.8 & 0.005 & 0.026 & 0.009 & 0.048 & 0.026 \\
\hline 1992 & 5.1 & 1.8 & 0.009 & 0.046 & 0.016 & 0.111 & 0.060 \\
\hline 1993 & 5.1 & 1.8 & 0.014 & 0.072 & 0.025 & 0.208 & 0.112 \\
\hline 1994 & 5.1 & 1.8 & 0.020 & 0.102 & 0.036 & 0.346 & 0.187 \\
\hline 1995 & 5.1 & 1.8 & 0.030 & 0.154 & 0.054 & 0.554 & 0.299 \\
\hline 1996 & 5.1 & 1.6 & 0.050 & 0.256 & 0.079 & 0.889 & 0.480 \\
\hline 1997 & 5.1 & 1.6 & 0.080 & 0.410 & 0.127 & 1.425 & 0.770 \\
\hline 1998 & 5.1 & 1.6 & 0.110 & 0.563 & 0.174 & 2.162 & 1.168 \\
\hline 1999 & 5.1 & 1.6 & 0.140 & 0.717 & 0.221 & 3.100 & 1.674 \\
\hline 2000 & 5.1 & 1.6 & 0.160 & 0.819 & 0.253 & 4.173 & 2.253 \\
\hline
\end{tabular}

(a) Annual replacement of 1984 vintage appliances based on assumption that 5 percent of existing refrigerator stack is replaced yearly given average appliance 1 ife of 20 years. Refrigerator stock estimate for 1984 based on $00 E$, 1984 estimate of 90.6 million residences multiplied by 40 percent, the assumed portion that have refrigerators.

(b) Annual new refrigerator additions based on 1984 00E project/ons of housing stock additions multiplied by 40 percent.

(c) Based on methodology presented in Chapter 4.0 .

(d) Calculated by: (Annual replacements of pre 1984 refrigerators) x (Market share for efficient refrigerators),

(e) Calculated by: (Annual New Application refrigerator additions) x (Market share for efficient refrigerators).

(f) Calculated by: the sum of current years total refrigerator additions and the cumulative total for the previous year.

(g) Calculated by: (Cumulative New and Replacement Efficient Refrigerator additions) $x$ (540 kwh/year). 
TABLE 8.14. Low Market-Penetration Scenario: Energy Savings Projections for High-Efficiency Freezers and Refrigerator-Freezers

$\begin{array}{cccccc}\frac{\text { Year }}{1985} & \text { Freezer } & 0 & \frac{\text { Refrigerator-Freezer }}{\text { American Model }} & \frac{\text { Japanese Model }}{0.03} & \frac{\text { Total }}{0.03} \\ 1990 & 0.02 & 0.13 & 0 & 0.01 & 0.16 \\ 1995 & 0.04 & 0.26 & 0.30 & 0.60 \\ 2000 & 0.06 & 0.41 & 2.25 & 2.72\end{array}$

$110 \mathrm{kWh} / \mathrm{yr}$. As in the base case, no early replacement of working units is assumed to occur. Details of the market share calculations are provided in Table 8.15.

In the high market-penetration scenario for American high-efficiency refrigerator-freezers, units bought for new and retirement markets experience maximum market penetration of 10 percent by 1995. No early replacement of working units occurs, as in the base case, for energy savings alone. The value for per-unit electricity savings is $240 \mathrm{kWh} / \mathrm{yr}$. Table B.16 provides details of the market share calculations and energy savings.

In the high market-penetration scenario for refrigerator-freezers performing at efficiencies typical of Japanese refrigerator-freezers, but scaled upward in size for American markets, maximum market penetration reaches 66 percent by the year 2000. No early replacement of existing stock for energy savings alone occurs. On average, per-unit energy savings for these highly efficient models are assumed to equal $540 \mathrm{kWh} / \mathrm{yr}$. Details of the market share and energy savings calculations are provided in Table 8.17 .

Table 8.18 summarizes energy savings results for the high market scenarios for more efficient freezers and refrigerator-freezers. Doubling the maximum market penetration and assuming more rapid market penetration more than doubled the energy savings results. 
TABLE 8.15. High Market-Penetration Scenario and Annual Savings of Delivered Electricity--More Efficient Freezers

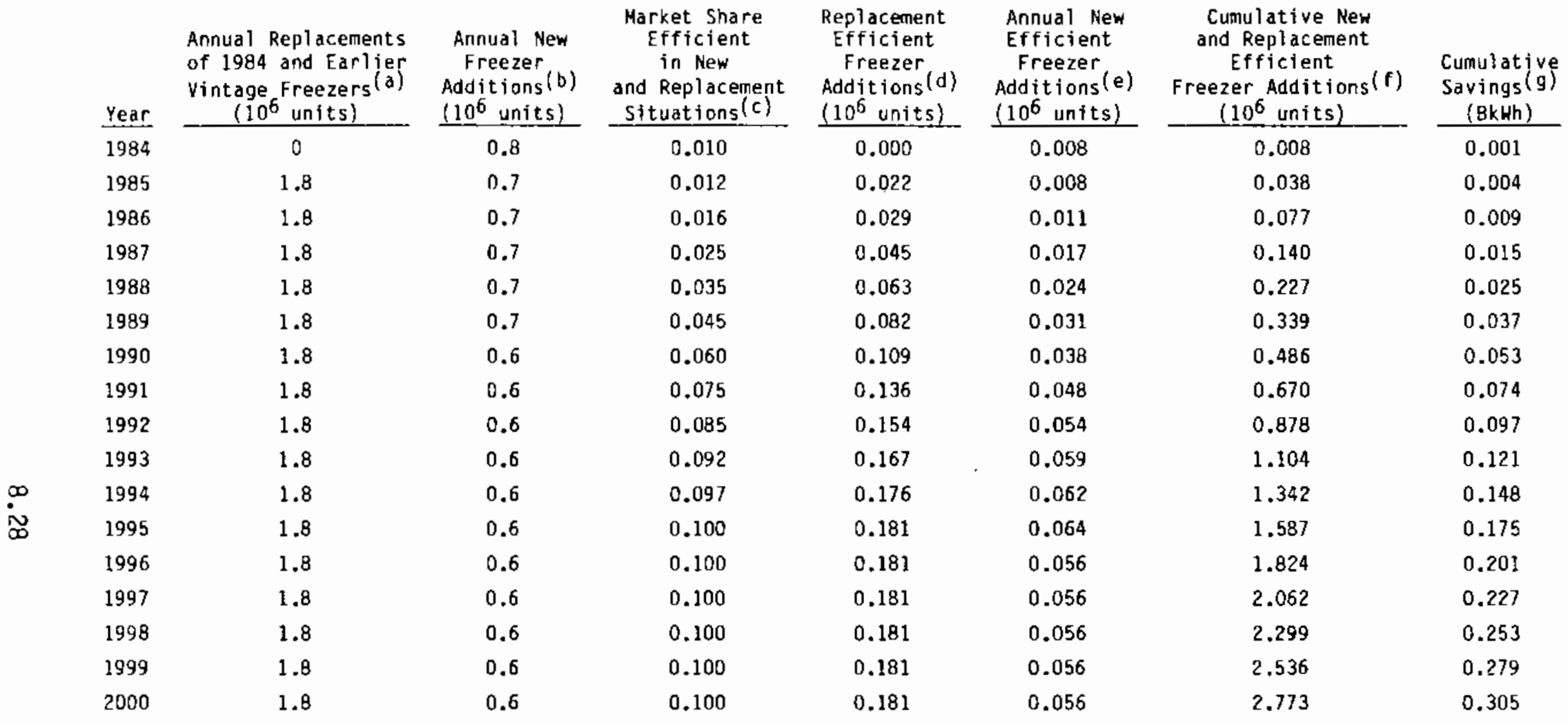

(a) Annual replacement of 1984 vintage appliances based on assumption that 5 percent of existing freezer stock is replaced yearly given average appliance life of 20 years. Freezer stock estimate for 1984 based on D0E, 1984 estimate of $90.6 \mathrm{million}$ residences multiplied by 40 percent, the assumed portion that have freezers.

(b) Annual new freezer additions based on 1984 00E projections of housing stock additions multiplied by 40 percent.

(c) Based on methodology presented in Chapter 4.0 .

(d) Calculated by: (Annual replacements of pre 1984 freezers) x (Market share for efficient freezers).

(e) Calculated by: (Annual New Application freezer additions) x (Market share for efficient freezers).

(f) Calculated by: the sum of current years total freezer additions and the cumulative total for the previous year.

(g) Calculated by: (Cumulative New and Replacement Efficient Freezer additions) $x$ (110 kWh/year). 
TABLE 8.16. High Market-Penetration Scenario and Annual Savings and Delivered Electricity--More Efficient Refrigerators Based on Payback Period of American Model

\begin{tabular}{|c|c|c|c|c|c|c|c|}
\hline Year & $\begin{array}{c}\text { Annua) Replacements } \\
\text { of } 1984 \text { and Earlier } \\
\text { Vintage Refrigerators }(a) \\
\left(10^{6} \text { units }\right) \\
\end{array}$ & $\begin{array}{l}\text { Annual New } \\
\text { Refrigerato } \\
\text { Additions }(b) \\
\left(10^{6} \text { units) }\right. \\
\end{array}$ & $\begin{array}{c}\text { Market Share } \\
\text { Efficient } \\
\text { in New } \\
\text { and Replacenent } \\
\text { Situations }(c) \\
\end{array}$ & $\begin{array}{l}\text { Replacement } \\
\text { Efficient } \\
\text { Refrigerator } \\
\text { Additions }(d) \\
\left(10^{6} \text { units }\right) \\
\end{array}$ & $\begin{array}{l}\text { Annual New } \\
\text { Efficient } \\
\text { Refrigerator } \\
\text { Additions }(\mathrm{e}) \\
\left(10^{6} \text { units }\right) \\
\end{array}$ & $\begin{array}{c}\text { Cumulative New } \\
\text { and Replacement } \\
\text { Efficient } \\
\text { Refrigerator Additions (f) } \\
\left(10^{6} \text { units) }\right.\end{array}$ & $\begin{array}{c}\text { Cumulative } \\
\text { Savings g) } \\
(B k w h)\end{array}$ \\
\hline 1984 & 5.1 & 2.1 & 0.010 & 0.051 & 0.021 & 0.073 & 0.017 \\
\hline 1985 & 5.1 & 1.9 & 0.015 & 0.077 & 0.029 & 0.178 & 0.043 \\
\hline 1986 & 5.1 & 1.9 & 0.022 & 0.113 & 0.042 & 0.333 & 0.080 \\
\hline 1987 & 5.1 & 1.9 & 0.032 & 0.164 & 0.061 & 0.558 & 0.134 \\
\hline 1988 & 5.1 & 1.9 & 0.045 & 0.230 & 0.086 & 0.875 & 0.210 \\
\hline 1989 & 5.1 & 1.9 & 0.058 & 0.297 & 0.111 & 1.284 & 0.308 \\
\hline 1990 & 5.1 & 1.8 & 0.070 & 0.358 & 0.127 & 1.768 & 0.424 \\
\hline 1991 & 5.1 & 1.8 & 0.080 & 0.410 & 0.145 & 2.323 & 0.557 \\
\hline 1992 & 5.1 & 1.8 & 0.087 & 0.445 & 0.157 & 2.925 & 0.702 \\
\hline 1993 & 5.1 & 1.8 & 0.092 & 0.471 & 0.166 & 3.562 & 0.855 \\
\hline 1994 & 5.1 & 1.8 & 0.097 & 0.497 & 0.175 & 4.234 & 1.016 \\
\hline 1995 & 5.1 & 1.8 & 0.100 & 0.512 & 0.181 & 4.927 & 1.182 \\
\hline 1996 & 5.1 & 1.6 & 0.100 & 0.512 & 0.158 & 5.597 & 1.343 \\
\hline 1997 & 5.1 & 2.6 & 0.100 & 0.512 & 0.158 & 6.267 & 1.504 \\
\hline 1998 & 5.1 & 1.6 & 0.100 & 0.512 & 0.158 & 6.937 & 1.665 \\
\hline 1999 & 5.1 & 1.6 & 0.100 & 0.512 & 0.158 & 7.607 & 1.826 \\
\hline 2000 & 5.1 & 1.6 & 0.100 & 0.512 & 0.158 & 8.278 & 1.987 \\
\hline
\end{tabular}

(a) Annual replacement of 1984 vintage appliances based on assumption that 5 percent of existing refrigerator stock is replaced yearly given average appliance life of 20 years. Refrigerator stock estimate for 1984 based on $00 E$, 1984 estimate of 90.6 million residences multiplied by 40 percent, the assumed portton that have refrigerators.

(b) Annual new refrigerator additions based on 1984 Dof projections of housing stock additions multiplied by 40 percent.

(c) Based on methodology presented in Chapter 4.0 .

(d) Calculated by: (Annual replacements of pre 1984 refrigerators) $x$ (Market share for efficient refrigerators).

(e) Calculated by: (Annual New Application refrigerator additions) x (Market share for efficient refrigerators).

(f) Calculated by: the sum of current years total refrigerator additions and the cumulative total for the previous year.

(g) Calculated by: (Cumulative New and Replacement Efficient Refrigerator additions) $x(240 \mathrm{kWh} /$ year). 
TABLE 8.17. High Market-Penetration Scenario and Annual Savings and Delivered Electricity--More Efficient Refrigerators Based on Payback of Hypothetical Japanese Model

\begin{tabular}{|c|c|c|c|c|c|c|c|}
\hline Year & $\begin{array}{c}\text { Annual Replacements } \\
\text { of } 1984 \text { and Earlier } \\
\text { Vintage Refrigerators (a) } \\
\left(10^{6} \text { units }\right) \\
\end{array}$ & $\begin{array}{l}\text { Asnual New } \\
\text { Refrigerator } \\
\text { Additions }(b) \\
\left(10^{6} \text { units }\right) \\
\end{array}$ & $\begin{array}{c}\text { Market Share } \\
\text { Efficient } \\
\text { in New } \\
\text { and Replacement } \\
\text { Situations }(c) \\
\end{array}$ & $\begin{array}{l}\text { Replacement } \\
\text { Efficient } \\
\text { Refrigerator } \\
\text { Additions(d) } \\
\left(10^{6} \text { units) }\right. \\
\end{array}$ & $\begin{array}{l}\text { Annual New } \\
\text { Efficient } \\
\text { Refrigerator } \\
\text { Additions }(e) \\
\left(10^{6} \text { units }\right) \\
\end{array}$ & $\begin{array}{c}\text { Cumulative New } \\
\text { and Replacement } \\
\text { Efficient } \\
\text { Refrigerator Additions }(f) \\
\left(10^{6} \text { units }\right)\end{array}$ & $\begin{array}{c}\text { Cumulat fve } \\
\text { Savings } g) \\
\text { (BkWh) }\end{array}$ \\
\hline 1984 & 5.1 & 2.1 & 0.000 & 0.000 & D. 000 & 0.000 & 0.000 \\
\hline 1985 & 5.1 & i. 9 & 0.000 & 0.000 & 0.000 & 0.000 & 0.000 \\
\hline 1986 & 5.1 & 1.9 & 0.000 & 0.000 & 0.000 & 0.000 & 0.000 \\
\hline 1987 & 5.1 & 1.9 & 0.000 & 0.000 & 0.000 & 0.000 & 0.000 \\
\hline 1988 & 5.1 & 1.9 & 0.000 & 0.000 & 0.000 & 0.000 & 0.000 \\
\hline 1989 & 5.1 & 1.9 & 0.000 & 0.000 & 0.000 & 0.000 & 0.000 \\
\hline 1990 & 5.1 & 1.8 & 0.002 & 0.010 & 0.004 & 0.014 & 0.007 \\
\hline 1991 & 5.1 & 1.8 & 0.010 & 0.051 & 0.018 & 0.083 & 0.045 \\
\hline 1992 & 5.1 & 1.8 & 0.020 & 0.102 . & 0.036 & 0.222 & 0.120 \\
\hline 1993 & 5.1 & 1.8 & 0.050 & D. 256 & 0.090 & 0.568 & 0.307 \\
\hline 1994 & 5.1 & 1.8 & 0.090 & 0.461 & 0.163 & 1.191 & 0.643 \\
\hline 1995 & 5.1 & 1.8 & 0.150 & 0.768 & 0.271 & 2.230 & 1.204 \\
\hline 1996 & 5.1 & 1.6 & 0.230 & 1.177 & 0.364 & 3.772 & 2.037 \\
\hline 1997 & 5.1 & 1.6 & 0.320 & 1.638 & 0.506 & 5.916 & 3.195 \\
\hline 1998 & 5.1 & 1.6 & 0.440 & 2.252 & 0.696 & 8.864 & 4.787 \\
\hline 1999 & 5.1 & 1,6 & 0.560 & 2.867 & 0.886 & 12.617 & 6.813 \\
\hline 2000 & 5.1 & 1.6 & 0.660 & 3.378 & 1.044 & 17.039 & 9.201 \\
\hline $\begin{array}{l}\text { (a) } \\
\text { (b) } \\
\text { (c) } \\
\text { (d) } \\
\text { (f) } \\
\text { (g) }\end{array}$ & \multicolumn{7}{|c|}{$\begin{array}{l}\text { Annual replacement of } 1984 \text { vintage appliances based on assumption } \\
\text { given average appliance life of } 20 \text { years. Refrigerator stock est } \\
\text { residences muttiplied by } 40 \text { percent, the assumed portion that hay } \\
\text { Annual new refrigerator additions based on } 1984 \text { coe projections } \\
\text { Based on methodology presented in Chapter } 4.0 \text {. } \\
\text { Calculated by: (Annual replacements of pre } 1984 \text { refrigerators) } \\
\text { Calculated by: (Annual New Application refrigerator additions) } \\
\text { Calculated by: the sum of current years total refrigerator addit } \\
\text { Calculated by: (Cumulative New and Replacement Efficient Refrige }\end{array}$} \\
\hline
\end{tabular}


TABLE 8.18. High Market-Penetration Scenario: Energy Savings Projections for High-Efficiency Freezers and Refrigerator-Freezers

\begin{tabular}{|c|c|c|c|c|}
\hline \multirow[b]{2}{*}{ Year } & \multicolumn{4}{|c|}{$\begin{array}{c}\text { (BkWh) } \\
\text { Refricerator-Freezer }\end{array}$} \\
\hline & Freezer & American Model & Japanese Model & Total \\
\hline 1985 & 0 & 0.04 & 0 & 0.04 \\
\hline 1990 & 0.05 & 0.42 & 0.01 & 0.48 \\
\hline 1995 & 0.18 & 1.18 & 1.20 & 2.56 \\
\hline 2000 & 0.31 & 1.99 & 9.20 & 11.50 \\
\hline
\end{tabular}

\subsection{COMPARATIVE COSTS: NEW GENERATING CAPACITY VERSUS HIGH-EFFICIENCY REFRIGERATORS AND FREEZERS}

Estimated costs/kWh conserved for the representative case studies of Section 8.3 are calculated in Table 8.19. In these case studies, costs per conserved $k$ Wh for the most efficient American models equal 8 to $9 \$ / k$ Wh when compared with an average new American model. The cost is considerably higher than the average cost of new coal powered generation cited in Table 4.3 of $5.21 \$ / \mathrm{kWh}$. The calculated costs of conserved energy are extremely sensitive to the values assumed for the costs and potential magnitude of further efficiency improvements. The scenario constructed from hypotheses about possible development of refrigerator-freezers as efficient as typical Japanese models, but scaled upward in the size for the American consumer, demonstrates this sensitivity. In the scenario that uses such assumptions, the cost of conserved energy is only $2.8 \$ / \mathrm{kWh}$. 
TABLE 8.19. Cost/kWh Calculation for More Efficient Freezers and Refrigerator-Freezers

\begin{tabular}{|c|c|c|c|c|}
\hline Technology & $\begin{array}{c}\text { Incremental } \\
\text { Capital } \\
\text { Cost } \\
(\$ 1984) \\
\end{array}$ & $\begin{array}{c}\text { Levelized }(\mathrm{d}) \\
\text { Capital } \\
\text { Cost } \\
(\$ / y r) \\
\end{array}$ & $\begin{array}{l}\text { Annual } \\
\text { Energy } \\
\text { Savings } \\
\text { (kWh/yr) } \\
\end{array}$ & $\begin{array}{c}\text { Cost }(e) \\
\text { per } \\
\text { kWh } \\
\text { (cents kWh) } \\
\end{array}$ \\
\hline $\begin{array}{l}\text { Freezer-- } \\
\text { Most Efficient Versus } \\
\text { Average New Model }\end{array}$ & $100^{(a)}$ & 10 & $110^{(a)}$ & 9.1 \\
\hline $\begin{array}{l}\text { Refrigerator-Freezer-- } \\
\text { American Scenario } \\
\text { Most Efficient Versus } \\
\text { Average New Model }\end{array}$ & $185^{(b)}$ & 19 & $240^{(b)}$ & 7.9 \\
\hline $\begin{array}{l}\text { New Refrigerator- } \\
\text { Freezer--Japanese } \\
\text { Scenario }\end{array}$ & $150^{(c)}$ & 15 & $540^{(c)}$ & 2.8 \\
\hline $\begin{array}{l}\text { (a) Refer to Table } 8.4 \\
\text { (b) Refer to Table } 8.5 \\
\text { (c) Refer to Table } 8.6 \\
\text { (d) Refer to Equation } \\
\text { interest compoundec } \\
\text { (e) Calculated on deliv } \\
\text { Energy Savings) }=\end{array}$ & $\begin{array}{l}\text { 4.11. Assumes } \\
\text { annually. } \\
\text { lered energy ba } \\
\text { cost/kWh. }\end{array}$ & $\begin{array}{l}\text { 20-year } 1 \text { ifet } i \\
\text { asis by: (Leve }\end{array}$ & $\begin{array}{l}\text { and } 8 \text { percer } \\
\text { zed Capital }\end{array}$ & $\begin{array}{l}\text { int rate of } \\
\cos t) \div(\text { annual }\end{array}$ \\
\hline
\end{tabular}

\subsection{REFERENCES FOR CHAPTER 8.0}

American Council for an Energy-Efficient Economy (ACEEE). 1984. The Most Energy-Efficient Appliances. Washington, D.C.

Arthur D. Little, Inc * 1982. Consumer Products Efficiency Standards Engineering Analysis Document. $00 E / C \vec{C}-0030$. Cambridge, Massachusetts.

Association of Home Appliance Manufacturers (AHAM). 1983a. "Communicating with Consumers About the Energy Guide Appliance Labeling Program." Chicago, llinois.

Association of Home Appliance Manufacturers (AHAM). 1983b. "Refrigeration Appliance Sales by 0istributors-States 1982." Chicago, Illinois.

Association of Home Appliance Manufacturers (AHAM). 1983c. "Saving Energy with Your Refrigerator and Freezer." Chicago, Illinois. 
Association of Home Appliance Manufacturers (AHAM). 1984b. "1984 Consumer Selection Guide for Refrigerators and Freezers." Chicago, Illinois.

Code of Federal Regulations, Part 10, Section 430(10 CFR 430). 1984. Energy Conservation Program for Consumer Products. Washington, D.C.

Code of Federal Regulations, Part 9 (15 CFR 9). 1984. "Procedures for a Voluntary Labeling Program for Household Appliances and Equipment to Effect Energy Conservation." Washington, D.C.

Code of Federal Regulations, Part 16, Section 305(16 CFR 305). 1984. "Rules for Using Energy Costs and Consumption Information Used in Labeling and Advertising for Consumer Appliances Under the Energy Policy and Conservation Act." Washington, D.C.

Consumers Digest. 1984. "Refrigerators/Freezers." 1984 Discount Buying Guide. Consumers Digest, Chicago, Illinois.

Consumer Guide. 1984. '84 8est Buys and Discount Prices. Consumer Guide Magazine 364 (April): $3 \overline{08-326 .}$

Consumer Reports. 1983. "Refrigerator/Freezers." Consumer Reports 48 (1):21-25.

Corum, Kenton R. 1984. "Interaction of Appliance Efficiency and Space Conditioning Loads: Application to Residential Energy Demand Projections." In Proceedings of ACEEE 1984 Summer Study on Energy Efficiency in Buildings, Volume E. American Council for An Energy Efficient Economy, Washington, D.C.

Fink, D. G. and H. W. Beaty, eds. 1978. Standard Handbook for Electrical Engineers, Eleventh Edition. McGraw-HilT.

Franke, J. C., et a1. 1985. Energy-Efficient Appliance Case Study. Pacific Northwest Laboratory, Richland, Washington.

Geller, Howard S. 1983. Energy Efficient Appliances. American Council for an Energy-Efficient Economy, Washington, D.C.

Geller, Howard S. 1984. "Efficient Residential Appliances and Space Conditioning Equipment: Current Savings Potential, Cost Effectiveness and Research Needs." In Proceedings of ACEEE 1984 Summer Study on Energy Efficient Buildings. American Council for an Energy-Efficient Economy, washington, $0 . \mathrm{C}$.

Goldstein, David B. 1983. "Refrigerator Reform: Guidelines for Energy Gluttons." Technology Review (February/March), pp. 36-46.

Goldstein, David 8. 1984. "Efficient Refrigerators in Japan: A Comparative Survey of American and Japanese Trends Toward Energy Conserving Refrigerators." Natural Resources Defense Council. Presented at the Third ACEEE Summer Study on Energy Efficient Buildings, Santa Cruz, California. 
McElroy, D. L., and D. W. Yarbrough. 1984. Development of Advanced Therma1 Insulation for Appliances. ORNL/CON-159. Oak Ridge National Laboratory, Oak Ridge, Tennessee.

Meier, Alan, J. Wright, and A. H. Rosenfeld. 1983. Supplying Energy Through Greater Efficiency. University of California Press, Berkeley, California.

Pacific Northwest Laboratory. 1981. Energy Conservation Manual for Builders in the Mid-Columbia Basin Area. PNL-3687. Richland, Washington.

Science Applications, Inc. 1982. Consumer Products Efficiency Standards Economic Analysis Document. DOE/CE-0029. McLean, Virginia.

U.S. Department of Commerce, 1984. Survey of Current Business. Bureau of Economic Analysis. $64(9)$.

U.S. DOE. 1982. Housing Characteristics, 1980: Residential Energy Consumption Survey. DOE/EIA-0314, U.S. Department of Energy, Energy Information Administration, Washington, D.C.

U.S. DOE. 1983a. Energy Projections to the Year 2010. U.S. Department of Energy, Office of Policy, Planning, and Analysis. U.S. Department of Energy, Washington, D.C.

U.S. D0E. 1983b. Supplement to March 1982 Consumer Products Efficiency Standards. U.S. Department of Energy, Washington, D.C.

U.S. DOE. 1984a. Annual Energy Outlook 1983. U.S. Department of Energy, Energy Information Administration, Washington, D.C.

U.S. DOE. 1984b. Housing Characteristics, 1982: Residential Energy Consumption Survey. DOETEIA-0314(82). U.S. Department of Energy, Energy Informa-

tion Administration, Washington, D.C.

U.S. DOE. 1984C. Energy Conservation Multi-Year Plan. FY 1986-FY 1990. U.S. Department of Energy, office of Conservation. Washington, D.C.

U.S. DOE/BERD. 1984. Project Appraisal Input for FY86 Documentation of CE R\&D Technology Program Plan. Prepared for the U.S. Department of Energy by

Pacific Northwest Laboratory, Richland, Washington. 


\subsection{GLAZING AND OTHER WINDOW TECHNOLOGIES}

This chapter analyzes the electricity savings potential of selected window energy conservation technologies in commercial buildings. Section 9.1 provides technical background for conventional windows and new designs. Section 9.2 describes the market situation in terms of product availability, vendors, popularity and increasing acceptance. In Section 9.3.1, costs and energy savings experienced in several building redesigns are presented. Assumptions for cost and energy savings to be used in the nationally aggregated analysis are chosen. Technical limits are discussed in Section 9.3.2; market penetration assumptions are identified in Section 9.3.3. Population estimates, i.e., commercial building space and projected market shares for the energy-conserving window applications, are shown in Section 9.4. Aggregate energy savings results, conclusions, and a summary of assumptions are presented in Section 9.5. Section 9.6 presents an analysis of the sensitivity of the energy savings results to changes in the market/penetration scenarios. Section 9.7 compares the estimated cost per $k$ wh saved with the estimated cost per $k$ wh of new electrical generating capacity.

\subsection{TECHNICAL BACKGROUND}

Windows affect building energy consumption in a number of ways. When placed without consideration for energy effects, windows can drain energy from a building. On the other hand, carefully designed windows can diminish heating or cooling loads, and supplement or replace lighting and ventilation equipment.

On a clear day in June, hourly solar heat gain through standard vertical double glazing can range from 440 British thermal units/ft ${ }^{2}$ (36 degree North latitude, windows oriented toward the north) to 1200 British thermal units $/ \mathrm{ft}^{2}$ (56 degree North latitude, windows oriented toward the east or west) (Mazria 1979). In general, summer heat gain is largest through east-and west-facing glass, but heat gain through unshaded south-facing glass may also be significant.

New window products can reduce cooling loads by controlling solar gain. Some glass products and special coatings selectively reflect thermal radiation 
to the outdoors in summer and to the indoors in winter. The effectiveness of these products is measured by their shading coefficient, which measures the ratio of solar gain through a glazing system to solar gain through a pane of double strength float glass under the same conditions. A window that has good ability to reject solar heat has a low shading coefficient. Cooling loads can also be diminished by exterior blinds that reflect solar energy before it enters the room. In addition, the extent of sumer solar gain can be controlled if only moderate glass areas face east and west.

Lighting in commercial buildings uses significant amounts of electricity during daytime hours. Conventionally, light is admitted indiscriminately through windows and may be of uneven quality or accompanied by glare. Lighting hardware at the building's perimeter and interior are often linked together, so it is not always possible to turn out lights on the building's perimeter to save electricity.

Daylighting has been used with good results in several commercial buildings (Elliott 1984; Selkowitz et al. 1983; Pansky et al. 1984). Daylighting is most likely to succeed when coordinated with architectural plans, other illumination systems, and interior design. Daylighting may then supplement or replace other light at perimeter areas, for example.

As the weakest component of a building's thermal envelope, windows significantly affect heat loss in cool weather and at night. Relative to other building materials, windows have low resistance to heat loss ( $R$ ) and high coefficients of heat transfer $(U=1 / R)$. If installation is similar, in terms of size, caulking, fit and other factors, a window material with a high $U$ value loses more heat than a window material with a lower $U$ value.

Heating requirements are reduced when windows are made more resistant to heat 10s5. Improved thermal resistance may also decrease cooling loads, but the effect is usually insignificant in comparison to cooling savings from reduced solar gain. Wooden-framed windows generally have lower $U$ values than aluminum-framed windows. It appears to be less expensive, in general, to choose aluminum over wooden windows, but for comparable thermal performance it is necessary to equip them with some type of enclosed "thermal break" that prevents rapid heat conduction to the outdoors. Double or triple glazings, 
various plastic products, and insulation products are other measures available to reduce heat loss through windows. Heating energy requirements can also be reduced by reductions in window surface area.

The product selected for payback analysis for new commercial buildings saves energy primarily by reducing cooling loads. However, it also has better insulating ability than ordinary glass. Marketed by Southwall Technologies under the trade name Heat Mirrorm, it transmits solar radiation at desirable wavelengths (i.e., visible light) but reflects it at unwanted wavelengths (i.e., near infrared that would otherwise contribute to heat gain). Three climate-specific variations of the basic product are available.

Several competing window energy conservation technologies are available. Plastic films, other glazings and exterior shading devices are available that also decrease heating requirements, cooling loads, or both. Films and glazings are generally product substitutes; exterior blinds and shading devices may complement other window technologies. The product selected for payback analysis for retrofit applications is a double-pane thermal window with solar firm.

Technical performance characteristics of Heat Mirrorm are compared with those of other windows in Table 9.1. The table shows that solar heat gain may be reduced by as much as 73 percent if a Heat Mirrorm product is used instead of clear double glazing. Winter heat loss by conduction through windows may be reduced by 62 percent.

Unfortunately, it is impossible to generalize what fraction of building energy requirements is attributable to windows. Each building must be analyzed separately, with architectural information as well as detailed knowledge of weather, geographic location and HVAC systems. In theory, a window load study could be conducted on a prototypical commercial building, but such a simulation model is outside the scope of this study. In practice, it is found in most cases that careful window design and the use of window energy-conservation technologies saves electricity during heating season and especially during cooling season. 
TABLE 9.1. Technical Performance of Conventional and Energy-Conserving Windows

\begin{tabular}{|c|c|c|c|c|}
\hline Glass Type/Thickness/Makeup & $\begin{array}{c}\text { Shadting } \\
\text { Coefficient } \\
\end{array}$ & $\begin{array}{l}\text { Relative } \\
\text { Heat GaIn(a) } \\
\text { (Btu/hr/f+2) } \\
\end{array}$ & $\begin{array}{c}\text { Summer } \\
\text { U value } \\
\text { (Btu/hr/ft/2/F) }\end{array}$ & $\begin{array}{c}\text { Winter } \\
\text { U volue } \\
\left(\theta+u / h r / f t^{2} / F\right) \\
\end{array}$ \\
\hline \multicolumn{5}{|l|}{ Clear Glass: $1 / 8 \mathrm{In}$. thick } \\
\hline Single-glazed, no alr space & 1.00 & 215 & 1.04 & 1.16 \\
\hline Doublo-glazed, i/4 In. air spaca & 0.89 & 187 & 0.61 & 0.58 \\
\hline $\begin{array}{l}\text { Triplenglazed, two } 1 / 4 \mathrm{ln} \text {. } \\
\text { air spaces }\end{array}$ & 0.85 & 176 & 0.46 & 0.39 \\
\hline \multicolumn{5}{|l|}{ Pello Windows } \\
\hline Double Glazing/Solarcool & 0.59 & $N / A$ & $N / A$ & N/A \\
\hline $\begin{array}{c}\text { Insulating Glass/Casement, } 4860 \\
f 1 x e d(5 / 8 \text { in.), total unit }\end{array}$ & $N / A$ & $N / A$ & $N / A$ & 0.52 \\
\hline Alr-Fiov Window by Ekono & $N / A$ & $N / A$ & $N / A$ & 0.06 \\
\hline \multicolumn{5}{|l|}{ Heat Mirror " Products } \\
\hline Clear & $0.39-0.70$ & $82-144$ & $0.23-0.36$ & $0.22-0.32$ \\
\hline Bronze Exterior & $0.27-0.42$ & $56-88$ & $0.23-0.36$ & $0.22-0.32$ \\
\hline Gray ExterIor & $0.23-0.36$ & $50-76$ & $0.23=0.36$ & $0.22-0.32$ \\
\hline Blue-Groen Exterlor & $0.28-0.46$ & $60-95$ & $0.23-0.36$ & $0.22-0.32$ \\
\hline
\end{tabular}

(a) Assumes Indoor/outdoor temperature difference of 14 F and ASHRAE solar heat (radlant) galn factor of 200 Btu per hour/per square foot $\left(\theta+u / h r / f t^{2}\right)$.

kkeglstered trademark of the Southwall Corporation.

N/A Data not avallable.

Source: Literature from SIGMA and indow manufacturers.

\subsection{CURRENT MARKET SITUATION}

Telephone interviews with dealers and manufacturers and a literature review confim marked progress in both the technical sophistication and market acceptance of energy-efficient windows. Numerous vendors supply a variety of energy efficient window products. Most of these products are suitable for retrofit applications but are even more effective if incorporated into original building design. The market is characterized by rapid change as research leads to practical high-efficiency products.

The popularity of energy-efficient window products is increasing. According to several manufacturers and dealers, high-performance windows are a high 
growth market. (a) Heat Mirror" windows will probably experience increasing market penetration (Aitken 1984; manufacturer 1 iterature).

The market situation in a location with high heating bills may be completely dissimilar to the market situation in a milder climate. This is because building design requirements and appropriate window technologies are extremely region-specific. State building codes, whose comprehensiveness and initial date of adoption vary greatly by state, also affect market acceptance. Despite the rapid innovation in window markets and increasing market acceptance perceived in the present study, therefore, more extensive, region-specific research would be required to characterize these markets with greater certainty.

\subsection{COST EFFECTIVENESS, TECHNICAL LIMITS AND MARKET PENETRATION}

This section appraises the cost effectiveness of the use of more efficient window technologies in the commercial sector, as typified by Heat Mirror ${ }^{m}$ for new buildings and solar film combined with thermal windows for existing buildings. Values for representative payback and energy savings are chosen in Section 9.3.1. In Section 9.3.2, technical limits are discussed. Section 9.3.3 presents projections for potential market penetration of these energy-efficient windows in commercial buildings.

\subsubsection{Payback Periods and Representative Energy Saving}

This section describes the values used in the analysis for representative payback periods and energy savings. Costs and energy savings for new commercial buildings with Heat Mirror windows are presented. The cost-effectiveness of retrofitting a commercial building with thermal windows and solar film is also described.

Heat Mirrorm on a New Commercial Building. Table 9.2 sumarizes the cost impacts of using Heat Mirror on a new commercial building in place of tinted double glass. The costs are the results of a case study published by the

(a) Conversations with Leonard Brunette, Architectural Products Manager, Belknap Industries; Wayne Shallenberer, owner, Bliss Windows; Bill Proesch, Marketing Department, Anderson Window Corporation, et al. 
TABLE 9.2. Cost Effectiveness of Heat Mirror"55 Equipped Double Glass Versus Tinted Double Glass on a New Two-Floor Commercial Building of $21,000 \mathrm{ft}^{2}$ in Dallas, Texas. CALPAS computer simulation; $1,760 \mathrm{ft}^{2}$ of windows.

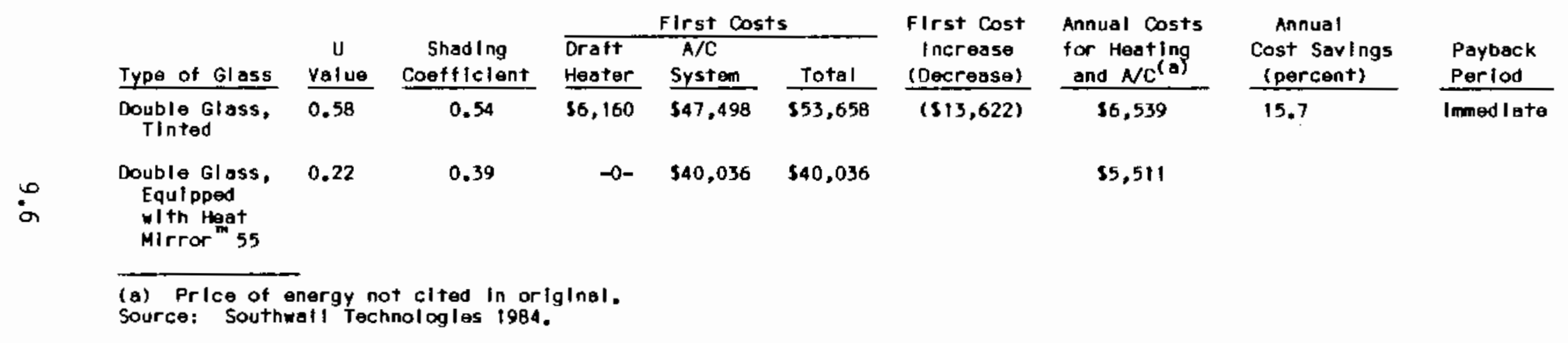


manufacturer in which a computer simulates building energy performance given $\mathrm{ft}^{2}$ of floor space, $\mathrm{ft}^{2}$ of glass, building location, window U-values and shading coefficients, costs of windows, costs of energy and other physica1 and economic data. The results are case-specific, but in general Heat Mirrorm windows pay for themselves rapidly. (a)

In the case study, the Heat Mirrorm windows increased overall building energy performance by so much that the building's design load was substantially reduced. As a result, the HVAC system for the Heat Mirror ${ }^{\text {th }}$-equipped building is smaller than the HVAC system for the building with tinted double glass. The downsizing saves more on first building costs than the incremental cost of equipping the building with Heat Mirrorm instead of tinted double glass. Thus, in the case study, the use of Heat Mirror actually reduces first costs and the payback is immediate.

First costs of the HVAC system are further reduced, in the case study, by the elimination of perimeter heaters and cooling vents. This equipment is conventionally installed near windows to eliminate drafts in winter and overheated spots in summer. These problems are eliminated with the Heat Mirrorm system so that the expensive perimeter heaters and cooling vents may be omitted.

Thermal Windows and Solar Film for a Commercial Building Retrofit. The retrofit case study is of a clothing store in Evanston, Illinois that is being converted to office space. The building will simultaneously be retrofit with energy-efficient windows. Table 9.3 compares relevant energy parameters between the original and retrofit building and shows expected initial costs, annual savings and payback. According to a representative of Scandinavian Insulating Glass of North America (SIGNA), which is supplying the basic thermal window system for the retrofit, similar projects have paid for themselves in as little time as 14 months (Galvin 1984). Solar film, made by Deposition Tech. nology, Inc., is also part of the retrofit package. Expected payback for this case study is 3.5 years (Galvin 1984).

(a) Leonard Brunette, Architectural Products Manager, Belknap Industries, personal communication. 
TABLE 9.3. Cost Effectiveness for Retrofitting a 6-Story Commercial

Building of $40,000 \mathrm{ft}^{2}$ in Evanston, Illinois with

Solar Film and Thermal Windows for $1,233 \mathrm{ft}^{2}$ of Windows

\begin{tabular}{|c|c|c|c|c|c|}
\hline Building & Type of Glass & $\begin{array}{c}\mathrm{U} \\
\text { Vatue } \\
\end{array}$ & $\begin{array}{l}\text { First Cost, } \\
\text { Inclusive } \\
\end{array}$ & $\begin{array}{c}\text { Expected Annual } \\
\text { Heating and } \\
\text { Cooling Cost } \\
\text { Savings }\end{array}$ & Payback \\
\hline Original & Single-Pane & 1.13 & -- & -- & \\
\hline Retrofit & $\begin{array}{l}\text { Double-Pane Thermal } \\
\text { with Solar Film }\end{array}$ & 0.36 & $\$ 13,000$ & $\$ 2,900-\$ 3,700$ & $3.5 \mathrm{yr}$ \\
\hline
\end{tabular}

(a) Assumed energy costs not cited in original. Source: Galvin 1984.

Representative Energy Savings. Window conservation technologies impact energy requirements for space heating, air conditioning, ventilation, and lighting. Insufficient data are available from the case studies to evaluate energy-savings potential by these end uses. Unfortunately, such subdivision is necessary for consistency with other parts of the analysis.

The approach taken in order to address this problem of insufficient data is to base the energy-savings assumptions on a larger data set available from other commercial buildings research. Table 9.4 presents energy savings, by end use, for several cases of commercial buildings redesign. Each element of this table represents the percentage energy savings for the end-use 1 isted in the first column associated with a particular set of building conservation measures (1isted in the column headings). The retrofit case is based on data collected by the California Energy Commission in extensive audits (Schultz 1984). Depending on end use and not including ventilation, average estimated potential for reductions in electricity use, through the application of various building conservation measures, ranges from 20 to 29 percent. The new building case is based on computer simulations of the response of a medium office building to various redesign measures (Pacific Northwest Laboratory 1983). The measures considered include both window and nonwindow technologies. Depending on end 
TABLE 9.4. Potential Comercial Building Energy Savings Due to Assorted Building Conservation and Redesign Measures

Electricity Savings from Building Energy Conservation Measures

\begin{tabular}{|c|c|c|c|}
\hline End Use & $\begin{array}{l}\text { Retrofit }(a) \\
\text { (percent) }\end{array}$ & $\begin{array}{l}\text { No Daylighting } \\
\text { New Building }(\mathrm{B}) \\
\text { (percent) }\end{array}$ & $\begin{array}{c}\text { Including Daylighting, } \\
\text { New Butlding } \\
\text { (percent) }\end{array}$ \\
\hline Total & Unknown & 15.4 & 22.0 \\
\hline Space Heat & 25.0 & 15.6 & 19.4 \\
\hline Cooling Energy & 19.8 & 13.7 & 21.5 \\
\hline Ventilation & 13.0 & 5.6 & 5.6 \\
\hline Lighting & 28.9 & 25.5 & 36.5 \\
\hline
\end{tabular}

(a) Schultz, California Energy Commission 1984.

(b) Pacific Northwest Laboratory 1983, average improvements over all climate areas for base case.

use, and not including ventilation, the estimates range from 14 to 26 percent energy savings (without daylighting) to 19 to 37 percent energy savings (with daylighting).

The larger data set sumarized in Table 9.4 is not ideal because contributions to overall energy savings by individual energy conservation measures are not provided. The redesigns included such conservation measures as increases in HVAC efficiencies as well as improvements in window performance. Thus, the energy savings estimates in Table 9.4 overstate the potential energy savings from window conservation measures alone.

Window conservation measures, such as selective glass orientation, therma envelope improvements and solar control, are usually significant contributors to energy savings in comercial building redesigns (Deringer, Misuriello, et a1. 1983). Referring to Table 9.4, it will be assumed that in this analysis window conservation measures accounted for three-fourths (75 percent) of the building redesign cooling and heating savings, for none of the ventilation savings, and for all of the lighting savings (in the new building case where daylighting was explicitly modeled). 
The combined estimate of energy savings potential from improvements to windows are summarized in Table 9.5. Using the estimates of potential percent reductions in energy use through adoptions of window improvements, it is possible to derive the reductions in annual $\mathrm{kWh} / \mathrm{ft}^{2}$ consumption of commercial floorspace based on DOE and EIA end use estimates. For retrofit commercial buildings, annual electricity savings are $2.63 \mathrm{kWh} / \mathrm{ft}^{2}$ for buildings using elec

tricity for both heating and cooling, and are $1.63 \mathrm{kWh} / \mathrm{ft}^{2}$ for buildings using electricity for cooling only. For new commercial buildings, annual electricity savings are $3.19 \mathrm{kWh} / \mathrm{ft}^{2}$ for butldings using electricity for both heating and cooling, and are $2.42 \mathrm{kWh} / \mathrm{ft}^{2}$ for buildings using electricity for cooling only.

This is clearly a construct chosen for purposes of developing a scenario that might indicate the order of magnitude of potential energy savings from window energy conservation technologies. It might be noted, however, that the energy savings in the case study of Heat Mirror on a new commercial building is roughly consistent with this construction. Heat Mirrorm reduced annual energy costs by 15.7 percent in the case study of a commercial building in Dallas, Texas. This percentage energy savings is higher than the value of 14.4 percent chosen to represent the energy-savings potential for an electrically heated and cooled commercial building, but is is approximately equal to the estimated cooling savings of 16.1 percent. This is probably the more appropriate comparison since a commercial building in Dallas would be dominated by cooling loads.

\subsubsection{Technical Limits}

Not all structures are suitable for window redesign. For new buildings, some construction occurs in congested areas where existing structures block the sun. In addition, architects may be limited to specific building orientations or window locations and size by the land parcel, zoning laws or interior design specifications.

In addition, some redesign attempts may fail, with energy consumption increasing over the base case instead of declining. There was a 6 percent 
TABLE 9.5. Potential Reductions in Annual Energy Use/ft ${ }^{2}$ for Commercial Buildings Due to Window Redesign

$\left(\mathrm{kwh} / \mathrm{ft}^{2}\right)$

\begin{tabular}{|c|c|c|c|c|c|c|c|c|c|}
\hline \multirow[b]{2}{*}{ Fnd Ise } & \multirow[b]{2}{*}{$\begin{array}{c}\text { Rase Case } \\
\text { Electrizicity } \\
\text { IJse/ftefal } \\
\text { kwh } \\
\end{array}$} & \multicolumn{4}{|c|}{ Buildings Electrically Heated and Cooled } & \multicolumn{4}{|c|}{ Buildings Electrically Cooled Only } \\
\hline & & $\begin{array}{l}\text { Percent } \\
\text { Decrease in } \\
\text { Energy Ilse } \\
\text { in Retrofit } \\
\text { Applications } \\
\end{array}$ & 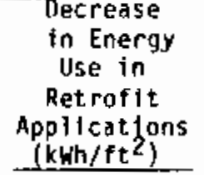 & $\begin{array}{c}\text { Percent } \\
\text { Decrease in } \\
\text { Energy Use } \\
\text { in Mew } \\
\text { Applications }\end{array}$ & $\begin{array}{l}\text { Decrease } \\
\text { in Energy } \\
\text { Isse in New } \\
\text { Apprtications } \\
\left(\mathrm{kwh} / \mathrm{ft} \mathrm{t}^{2}\right) \\
\end{array}$ & $\begin{array}{l}\text { Percent } \\
\text { necrease } \\
\text { in Energy } \\
\text { Ise in } \\
\text { Retrofit } \\
\text { Applications } \\
\end{array}$ & 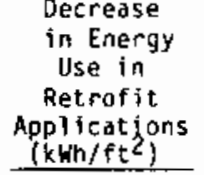 & $\begin{array}{c}\text { Percent } \\
\text { Decrease } \\
\text { in Energy } \\
\text { Use in New } \\
\text { Applications } \\
\end{array}$ & $\begin{array}{l}\text { Decrease } \\
\text { in Energy } \\
\text { Wse in New } \\
\text { Applications } \\
\left.\text { (kth } / \mathrm{ft}^{2}\right) \\
\end{array}$ \\
\hline Space Heat & 5.29 & 19.0 & 1.00 & 14.6 & .77 & .- & - & -- & -- \\
\hline Cooling & 10.97 & 14.9 & 1.63 & 16.1 & 1.77 & 14.9 & 1.63 & 16.1 & 1.77 \\
\hline Lighting & 5.94 & $\underline{0}$ & $\underline{0}$ & $\underline{11.0}$ & 0.65 & $\underline{0}$ & 0 & 11.0 & 0.65 \\
\hline Total (b) & 22.22 & & 2.63 & & 3.19 & & 1.63 & & 2.42 \\
\hline
\end{tabular}

(d) Derived from DOE/EIA 1984 and DOE 1984a.

(b) Electricity end uses potentially affected by window technologies. 
failure rate in a recent study involving the redesign of more than one hundred commercial new buildings (Deringer, Misuriello, et al. 1983). A technical limit value of 25 percent is chosen to represent these technical limits to energy savings through window redesign on new commercial buildings. This means that 25 percent of newly constructed commercial buildings are assumed to be unable to use window energy conservation measures to improve building energy performance.

For retrofits, limitations similar to those on new buildings may be encountered. The failure rate may be even higher; a DOE survey of retrofits of over 200 existing commercial buildings discovered a failure rate of about 10 percent (Deringer, Misuriello et al. 1983). In addition, existing windows may be of nonstandard sizes so that their replacement could require prohibitively expensive customization. Finally, it may not be feasible to shut down a utilized comercial building for long enough duration to perform a retrofit. A technical limit value of 40 percent is chosen to represent these technical limits to energy savings through window retrofits on existing comercial buildings. This means that 40 percent of existing commercial buildings are assumed to be unable to use window energy-conservation measures to improve building energy performance.

\subsubsection{Market-Penetration Assumptions}

Table 9.6 summarizes the first costs and payback periods calculated in Section 9.3.1. Based on these economic data and on Table 4.2, estimated maximum potential market penetration of the Heat Mirrorm conservation technology on new commercial buildings is 75 percent. The purpose of this exercise is to construct an energy conservation scenario; it is not intended to suggest any most likely case regarding the market share of Heat Mirror ${ }^{m}$ products versus market shares of competing window products. The first row of Table 4.2 is assumed to apply to the retrofit case, resulting in an assumed maximum potential market penetration for the retrofit technology of 50 percent.

Table 9.7 summarizes the values for maximum potential market share, energy savings and technical limits to be used in the remainder of the analysis for the most likely case estimates. 
TABLE 9.6 First Costs and Paybacks for Heat Mirrorm on New Commercial Buildings, and for Thermal Windows and Solar Film on an Existing Commercial Building(a)

\begin{tabular}{|c|c|c|}
\hline Measure & $\begin{array}{l}\text { First Cost } \\
\text { Increase }\end{array}$ & $\begin{array}{l}\text { Payback } \\
\text { Period }\end{array}$ \\
\hline Heat Mirrorm, New Building & 0 & Immed i ate \\
\hline Thermal Windows of Solar Film, Retrofit & $N / A^{(b)}$ & $3.5 \mathrm{yr}$ \\
\hline
\end{tabular}

(a) Assumptions stated in Section 9.3.1.

(b) First cost increase for retrofit case is not applicable to estimation of market share with Table 4.2 .

TABLE 9.7. Summary of Values Assumed for Market Share, Energy Savings and Technical Limits (Percent)

\begin{tabular}{lcc} 
Value & $\begin{array}{c}\text { New Building, } \\
\text { Heat Mirror }\end{array}$ & $\begin{array}{c}\text { Retrofit Thermal } \\
\text { Windows and } \\
\text { Solar Film }\end{array}$ \\
\cline { 2 - 3 } Technical Limit & 25 & 40 \\
Market Share: & 75 & 50 \\
1985 & 11 & 5 \\
1990 & 25 & 12 \\
1995 & 48 & 26 \\
2000 & 56 & 30 \\
& & \\
Energy Savings: & & 19 \\
Space Heat & 14.6 & 14.9 \\
Cooling Energy & 16.1 & 0 \\
Lighting & 11 &
\end{tabular}

\subsection{COMMERCIAL BUILOING STOCK ANO MARKET SHARE PROJECTIONS}

In this section, projections of future additions to total national comercial floorspace (DOE 1984a) are employed to estimate the amount of commercial building space likely to use energy-conserving window technologies by the years 1990, 1995, and 2000. Table 9.8 shows details of the population projections for more energy efficient windows on buildings that are electrically cooled and electrically heated. Table 9.9 shows details of the population projections for energy-efficient windows on buildings that are electrically cooled only. The split of 70-30 between buildings using electricity for air-conditioning only 
TABLE 9.8. Commercial Floorspace Projections and Market Share Estimates for Window Conservation Technologies on Electrically Heated and Cooled Buildings

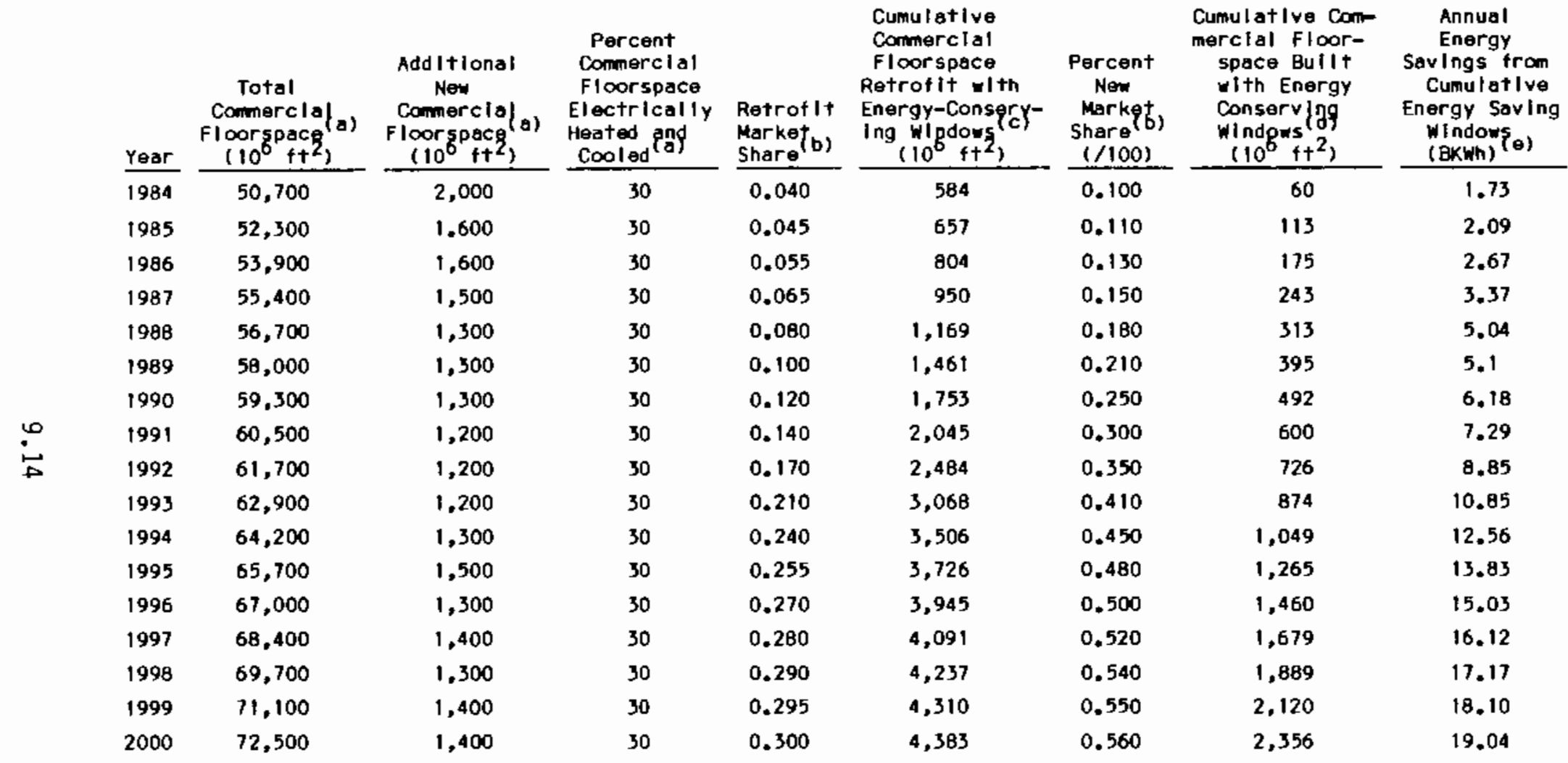

(a) DOE 1984a.

(b) See Table 13.9 and Chapter 4.0; Includes technlcel $1 \mathrm{fm} I \mathrm{ts}$.

(c) Calculated by I (Existing Comerclal Floorspace in 1984) $\times$ (\$ Electric) $x$ (Market Share for the year)l.

(d) Calculated by adding [ (Additlonal New Commerclal Floorspace) $x$ (Market Share)l for the year to the cumulative number of the previlous year.

(e) Calculated by: I (Cumulative Floorspace Retrofitted) $\times\left(2.63 \mathrm{kWh} / \mathrm{ft}^{2}\right.$ ) + (Cumulative New Floorspace) $\times$ (3.19 kWh $\left./ \mathrm{tt}^{2}\right)$ !. 
TABLE 9.9. Commercial Floorspace Projections and Market Share Estimates for Window Conservation Technologies on Electrically Cooled Buildings

\begin{tabular}{|c|c|c|c|c|c|c|c|c|}
\hline Year & $\begin{array}{c}\text { Total } \\
\text { Commerctal } \\
\text { Floorspace } \\
\left(10^{6}+t^{2}\right) \\
\end{array}$ & $\begin{array}{c}\text { Additional } \\
\text { New } \\
\text { Commerctal } \\
\text { Floorspace } \\
\left(10^{6}+t^{2}\right) \\
\end{array}$ & $\begin{array}{l}\text { Percent } \\
\text { Commerclal } \\
\text { Floorspace } \\
\text { Electrlcally } \\
\text { Heated ond } \\
\text { Cooled } \\
\end{array}$ & $\begin{array}{c}\text { Percent } \\
\text { Retrofit } \\
\text { Market } \\
\text { Share }(b) \\
(/ 100) \\
\end{array}$ & 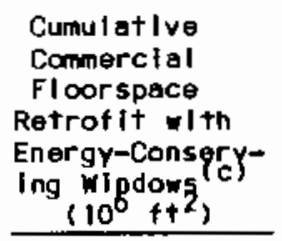 & $\begin{array}{l}\text { Percent } \\
\text { Ner } \\
\text { Market } \\
\text { Share } \\
(/ 100) \\
\end{array}$ & $\begin{array}{c}\text { Cumulative Com- } \\
\text { merclal Floor- } \\
\text { space Bullt } \\
\text { with Energy } \\
\text { Conserv }(199 \\
\text { Wndgws } \\
\left(10^{6}+t^{2}\right) \\
\end{array}$ & $\begin{array}{c}\text { Annual } \\
\text { Energy } \\
\text { Say ings from } \\
\text { CumulatI } \\
\text { Energy Saving } \\
\text { Windous } \\
\text { (BKWh) } \\
\end{array}$ \\
\hline 1984 & 50,700 & 2,000 & 70 & 0.040 & 1,364 & 0.100 & 140 & 2.56 \\
\hline 1985 & 52,300 & 1,600 & 70 & 0.045 & 1,534 & 0.110 & 263 & 3.14 \\
\hline 1986 & 53,900 & 1.600 & 70 & 0.055 & 1,875 & 0.130 & 409 & 4.05 \\
\hline 1987 & 55,400 & 1,500 & 70 & 0.065 & 2,216 & 0.150 & 566 & 4.98 \\
\hline 1988 & 56,700 & 1,300 & 70 & 0.080 & 2,727 & 0.180 & 730 & 6.22 \\
\hline 1989 & 58,000 & 1,300 & 70 & 0.100 & 3,409 & 0.210 & 921 & 7.79 \\
\hline 1990 & 59,300 & 1,300 & 70 & 0.120 & 4,091 & 0.250 & 1,149 & 9.45 \\
\hline 1991 & 60.500 & 1,200 & 70 & 0.140 & 4,773 & 0.300 & 1,401 & 11.17 \\
\hline 1992 & 61,700 & 1,200 & 70 & 0.170 & 5,795 & 0.350 & 1,695 & 13.55 \\
\hline 1993 & 62,900 & 1,200 & 70 & 0.210 & 7,159 & 0.410 & 2,039 & 16.60 \\
\hline 1995 & 65,700 & 1,500 & 70 & 0.255 & 8,693 & 0.480 & 2,953 & 21.32 \\
\hline 1996 & 67.000 & 1,300 & 70 & 0.270 & 9,204 & 0.500 & 3,408 & 23.25 \\
\hline 1997 & 68,400 & 1,400 & 70 & 0.280 & 9,545 & 0.520 & 3.917 & 25.04 \\
\hline 1998 & 69,700 & 1,500 & 70 & 0.290 & 9,886 & 0.540 & 4,409 & 26.78 \\
\hline 1999 & 71,100 & 1,400 & 70 & 0.295 & 10,057 & 0.550 & 4,948 & 28.36 \\
\hline 2000 & 72,500 & 1,400 & 70 & 0.300 & 10,227 & 0.560 & 5,496 & 29.97 \\
\hline
\end{tabular}

(a) DOE 1984a and Chapter 8.

(b) See text and Chapter 4.0; includes technical I fmits.

(c) Calcutated by [(ExIsting Comerclal Floorspace in iga4) x (\$ Electric) x (Market Share for the year)].

(d) Calculated by adding $\{$ (Additional Naw Commerclal Floorspace) $\times$ (\$ Electric) $x$ (Market Share) $\}$ for the year to the cumulative number of the prevlous year. (e) Calculated by: [(Cumulative Floorspace Retrofltted) $\times\left(1.63 \mathrm{kWh} / \mathrm{ft}^{2}\right)+($ Cumulative New Floorspace) $\times$
$\left(2.42 \mathrm{kwh} / \mathrm{ft}^{2}\right)$ ]. 
and buildings using electricity for both air-conditioning and space heating was taken from DOE/EIA (1984). All commercial buildings are assumed to use electricity for lighting.

\subsection{ELECTRICITY SAVINGS RESULTS}

Window conservation technologies that are available now are likely to find increasing use in commercial architecture. This section assesses the degree to which window conservation technologies for comercial buildings could likely reduce national electricity consumption in 1985, 1990, 1995, and 2000.

National annual electrical energy savings projections from window conservation technologies for each of the years 1984-2000 are provided in the last columns, respectively of Tables 9.8 and 9.9. These estimates are sumarized in Table 9.10 which contains projections for the years 1985, 1990, 1995, and 2000.

The estimates in Table 9.10 represent per-unit energy savings multiplied by the number of units projected to be employing energy-conserving window technologies, with units given in $\mathrm{ft}^{2}$ of comercial floorspace. Results of the analyses indicate that significant electricity savings are possible at the national level.

TABLE 9.10. Estimated National Annual Electricity Savings from Window Conservation Technologies on Commercial Buildings (Bkwh)

\begin{tabular}{|c|c|c|c|c|c|}
\hline Year & $\begin{array}{l}\text { Savings for } \\
\text { Retrofit } \\
\text { Commercial } \\
\text { Floorspace } \\
\text { Electrically } \\
\text { Heated and } \\
\text { Cooled } \\
\end{array}$ & $\begin{array}{l}\text { Savings } \\
\text { for New } \\
\text { Commercial } \\
\text { Floorspace } \\
\text { Electrically } \\
\text { Heated and } \\
\text { Cooled } \\
\end{array}$ & $\begin{array}{l}\text { Savings for } \\
\text { Retrofit } \\
\text { Commercial } \\
\text { Floorspace } \\
\text { Electrically } \\
\text { Cooled Only }\end{array}$ & $\begin{array}{l}\text { Savings } \\
\text { for New } \\
\text { Commercial } \\
\text { Floorspace } \\
\text { Electrically } \\
\text { Cooled Dnly } \\
\end{array}$ & $\begin{array}{c}\text { Total } \\
\text { Electricity } \\
\text { Savings of } \\
\text { Window } \\
\text { Conservation } \\
\text { Technologies } \\
\end{array}$ \\
\hline 1985 & 1.74 & .35 & 2.50 & .64 & 5.23 \\
\hline 1990 & 4.62 & 1.56 & 6.67 & 2.78 & 15.65 \\
\hline 1995 & 9.81 & 4.02 & 14.22 & 7.10 & 35.15 \\
\hline 2000 & 11.53 & 7.51 & 16.66 & 13.31 & 49.01 \\
\hline
\end{tabular}


This analysis could not have taken place without the use of several simplifying and limiting assumptions. The scenario is highly simplistic and the numerical energy savings results should be treated accordingly; the results demonstrate possibility rather than actuality. However, the analysis does indicate large energy conservation possibilities from energy-conscious commercial building design. Designing with the climate appears to lead to costeffective energy savings.

\subsection{SENSITIVITY ANALYSIS}

This section is an analysis of the sensitivity of the aggregate energy savings results presented in Section 9.5 to alterations in the market penetration scenario. Market share estimates and energy savings results that are lower than the Section 9.5 base case are presented in Section 9.6.1 and Section 9.6.2. Market share estimates and energy savings results that exceed the Section 9.5 base case are presented in Section 9.6.3 and Section 9.6.4.

\subsubsection{Low Market-Penetration Scenario}

A low market penetration scenario investigates the possibility that energy-efficient windows will not penetrate the commercial building market as quickly or as completely as indicated in Table 9.8 and Table 9.9. This would reduce the maximum projected energy savings potential of energy-efficient windows.

In the low market-penetration scenario, maximum market penetration of energy-efficient windows is estimated as half of the maximum of the base cases. For commercial building retrofits, this implies maximum market penetration of 15 percent. For new commercial buildings, it implies maximum market penetration of 28 percent. The rate of market penetration is assumed to slow for the low market penetration scenario. Thus, in the estimates, only 75 percent of maximum estimated penetration is achieved by the year 2000 .

Table 9.11 and Table 9.12 present market share estimates for the $10 \mathrm{w}$ market-penetration scenario for window energy conservation technologies. Market shares for window energy conservation technologies are unlikely to fall below these estimates. 
TABLE 9.11. Commercial Floorspace Projections and Low Scenario Market Share Estimates for Window Conservation Technologies on Electrically Heated and Cooled Buildings

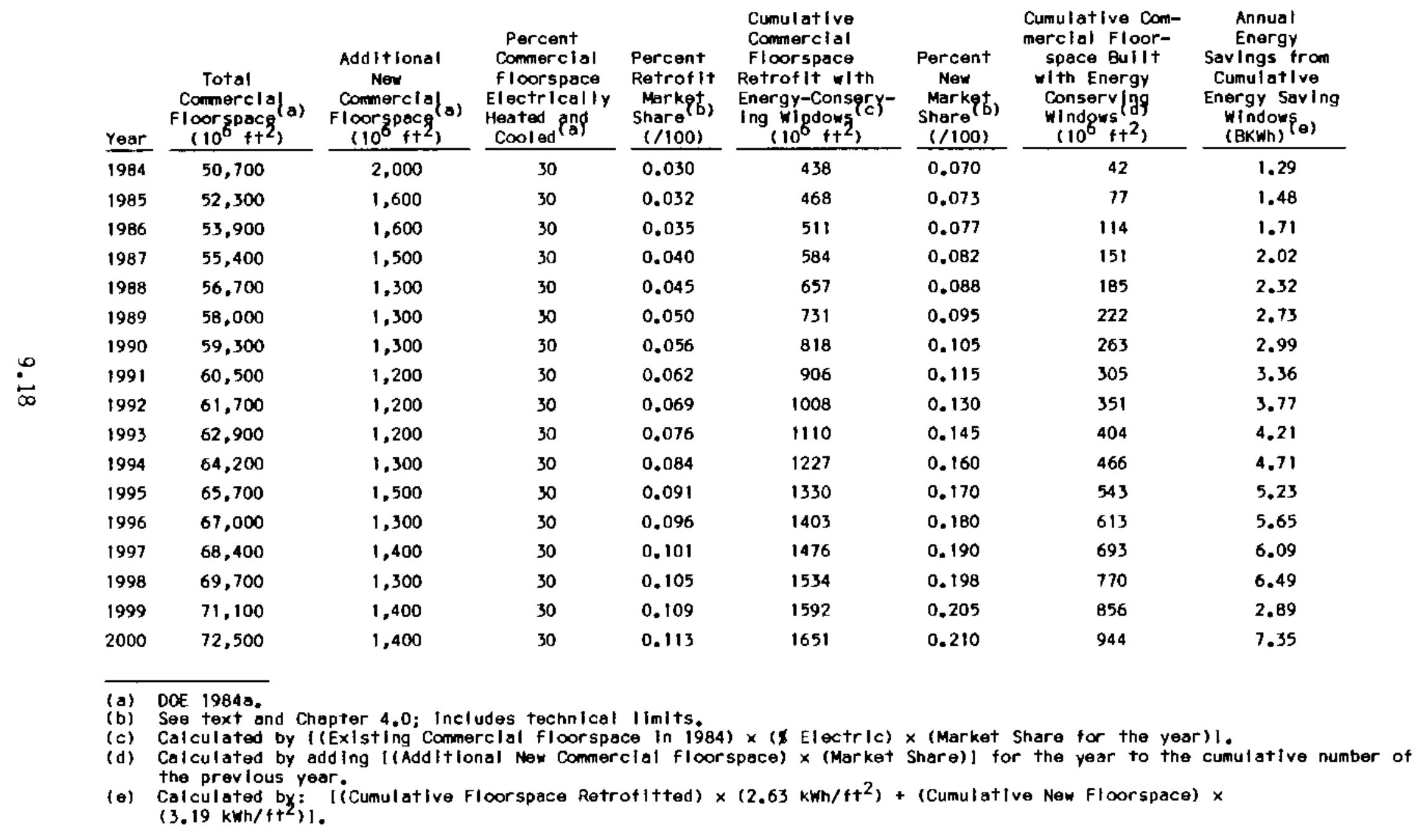


TABLE 9.12. Commercial Floorspace Projections and Low Scenario Market Share Estimates for Window Conservation Technologies on Electrically Heated and Cooled Buildings

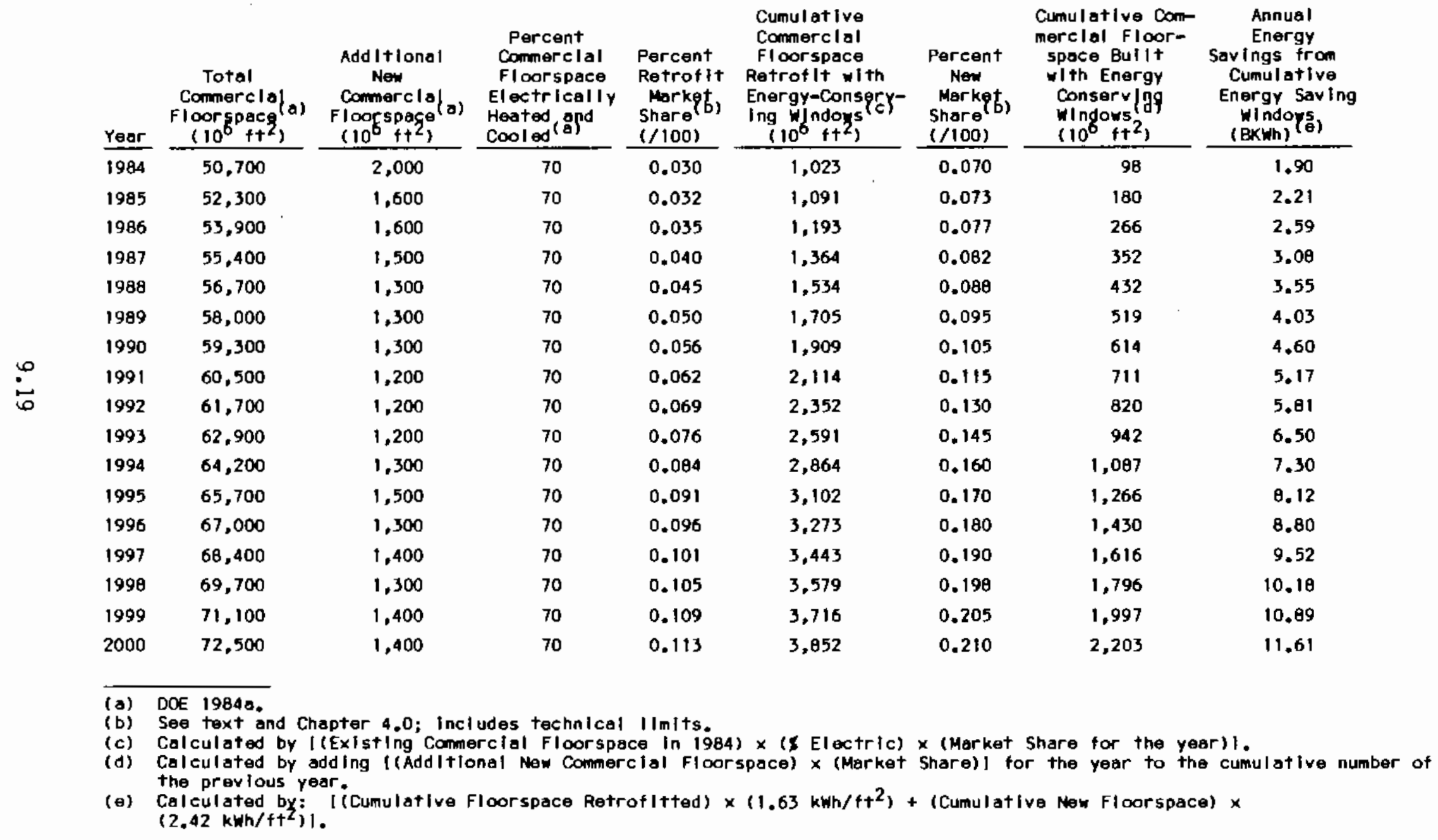




\subsubsection{National Annual Electrical Energy Savings Estimates--Low Scenario}

The national annual electricity savings estimates for the low marketpenetration scenario of energy-conserving window technologies are presented in the final columns of Tables 9.11 and 9.12, and summarized in Table 9.13. It is estimated that total annual electrical energy savings would not be less than $7.69 \mathrm{BkWh}$ by 1990 nor less than $18.96 \mathrm{BkWh}$ in 2000 .

\subsubsection{High Market-Penetration Scenario}

Window energy conservation technologies may penetrate the commercial building market more rapidly and to a greater extent than Table 9.8 and Table 9.9 indicate. This would occur, for example, if technical limits were smaller than the assumptions used in that analysis indicate. It would also occur if market acceptance were unusually rapid or complete.

In the high-market penetration scenario, maximum market penetration of energy-efficient windows is estimated to equal 60 percent of existing commercial buildings and 90 percent of new commercial structures. These maxima are estimated to be approached at a more rapid rate than in the base case and to be achieved by 1995 .

TABLE 9.13. Estimated National Annual Electricity Savings from Window Conservation Technologies on Commercial Buildings, Low Market-Penetration Scenario (BkWh)

\begin{tabular}{|c|c|c|c|c|c|}
\hline Year & $\begin{array}{l}\text { Savings for } \\
\text { Retrofit } \\
\text { Commercial } \\
\text { Floorspace } \\
\text { Electrically } \\
\text { Heated and } \\
\text { Cooled } \\
\end{array}$ & $\begin{array}{l}\text { Savings } \\
\text { for New } \\
\text { Commercial } \\
\text { Floorspace } \\
\text { Electricality } \\
\text { Heated and } \\
\text { Cooled } \\
\end{array}$ & $\begin{array}{l}\text { Savings for } \\
\text { Retrofit } \\
\text { Commercial } \\
\text { Floorspace } \\
\text { Electrically } \\
\text { Cooled Only } \\
\end{array}$ & $\begin{array}{l}\text { Savings } \\
\text { for New } \\
\text { Commercial } \\
\text { Floorspace } \\
\text { Electrically } \\
\text { Cooled Only } \\
\end{array}$ & $\begin{array}{l}\text { Total } \\
\text { Electricity } \\
\text { Savings of } \\
\text { Window } \\
\text { Conservation } \\
\text { Technologies } \\
\end{array}$ \\
\hline 1985 & 1.23 & .25 & 1.79 & .43 & 3.69 \\
\hline 1990 & 2.16 & .83 & 3.11 & 1.49 & 7.59 \\
\hline 1995 & 3.51 & 1.72 & 5.03 & 3.07 & 13.33 \\
\hline 2000 & 4.34 & 3.01 & 6.30 & 5.31 & 18.96 \\
\hline
\end{tabular}


Table 9.14 and Table 9.15 present market share estimates for the high market-penetration scenario for window energy conservation technologies. Market shares for window energy conservation technologies are unlikely to exceed these estimates.

\subsubsection{National Annual Electrical Energy Savings Estimates--High Scenario}

The national annual electricity savings estimates for the high marketpenetration scenario of energy-conserving window technologies are presented in the final columns of Tables 9.14 and 9.15, and are summarized in Table 9.16.

\subsection{COST/kWh OF ENERGY SAVED CALCULATIONS AND COMPARISONS TO THE COST/kWh OF PRDDUCING NEW GENERATION CAPACITY}

In this section, the estimated cost of electricity conserved by the use of energy-efficient windows in commercial buildings is compared with the cost of new electrical energy generating capacity. If this conserved energy is cheaper than newly generated resources, then it may make economic sense to increase the use of this conserved energy in order to supply electricity at least cost.

For new commercial construction, the case study clearly indicates that energy conservation through the use of energy-conserving window technologies is cheaper than any alternative source of energy. This is because first costs of new buildings may actually be reduced, and are reduced in the case study, by the use of energy-efficient windows. The incremental cost of the windows is smaller than the savings that result from reduced design loads and consequent downsizing of HVAC equipment.

Table 9.17 presents the calculations of the cost/kWh saved due to retrofitting commercial buildings with energy-efficient windows. The analysis indicates a large cost advantage for this energy-conservation measure. However, this result may not be representative. The effectiveness of window conservation technologies, and their cost, vary so much that it is difficult to generalize the results of the case study without introducing a potentially large error. 
TABLE 9.14. Commercial Floorspace Projections and High Scenario Market Share Estimates for Window Conservation Technologies on Electrically Heated and Cooled Buildings

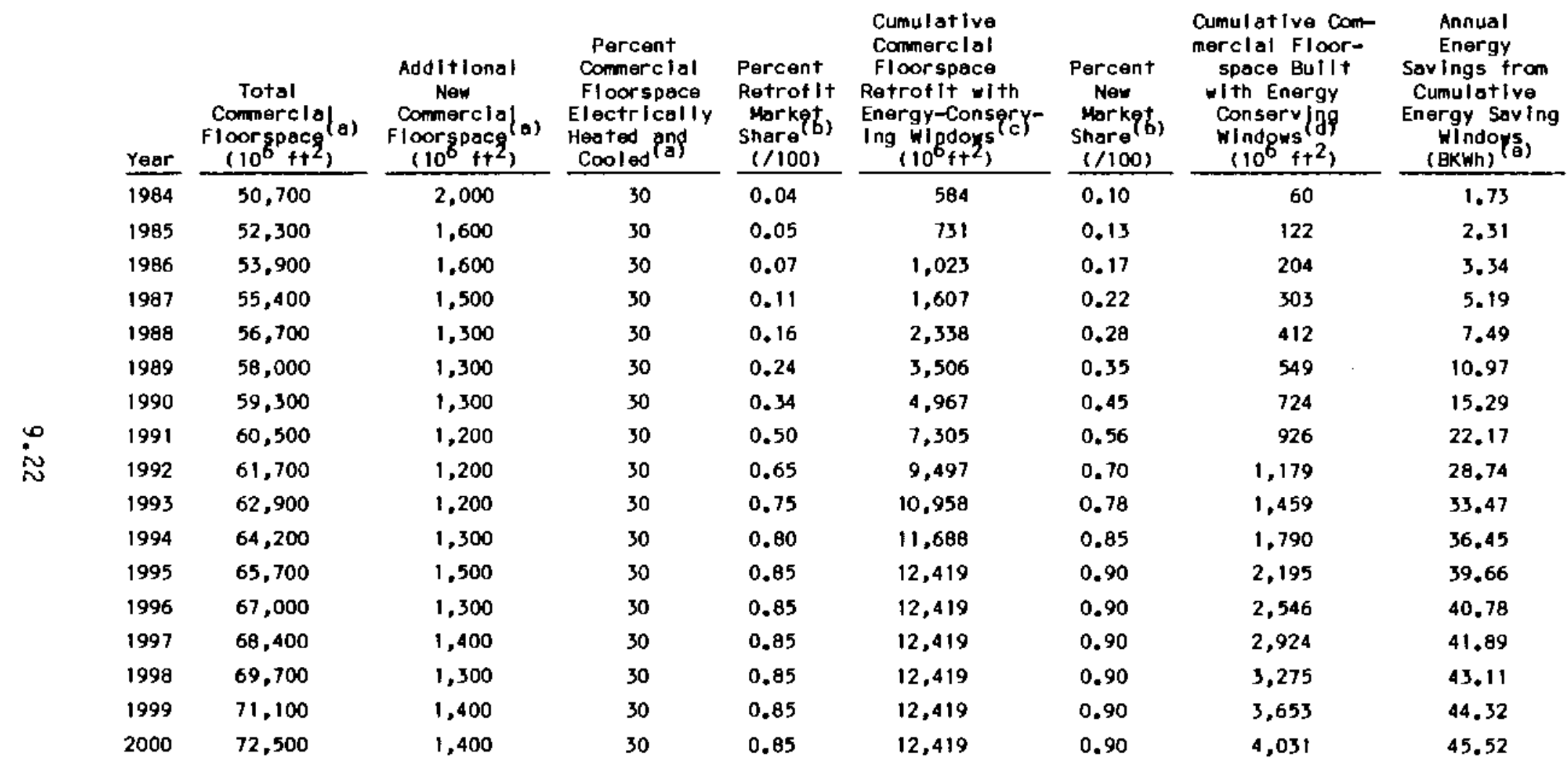

(b) DOE 1984b.

(c) Calculated by ( Exlsting Comerclal Floorspace in 1984) x (\$ Electrlc) x (Market Share for the year)l.

(d) Calculated by adding I(Additional New Comercial Floorspace) X (Market Share)l for the year to the cumulative number of the previous year.

(e) Calculated by: ( (Cumulative Floorspace Retrofltted) $\times\left(2.63 \mathrm{kWh} / \mathrm{ft}^{2}\right.$ ) + (Cumulative New Floorspace) $\times$ (3.19 k wh $\left.\left./ \mathrm{ft}^{2}\right)\right]$. 
TABLE 9.15. Commercial Floorspace Projections and High Scenario Market Share Estimates for Window Conservation Technologies on Electrically Heated and Cooled Buildings

\begin{tabular}{|c|c|c|c|c|c|c|c|c|}
\hline Year & $\begin{array}{c}\text { Total } \\
\text { Commerctal } \\
\text { F1 oorspacg } \\
\left(10^{6}+t^{2}\right) \\
\end{array}$ & $\begin{array}{c}\text { Additional } \\
\text { New } \\
\text { Commercla }(a) \\
\text { Floorgpaç } \\
\left(10^{6} \mathrm{ft}^{2}\right) \\
\end{array}$ & $\begin{array}{l}\text { Percent } \\
\text { Commerclal } \\
\text { Floorspace } \\
\text { Electrical ly } \\
\text { Heated and } \\
\text { Cooled } \\
\end{array}$ & $\begin{array}{l}\text { Percent } \\
\text { Retrofit } \\
\text { Markett } \\
\text { Share } \\
(/ 100) \\
\end{array}$ & $\begin{array}{l}\text { Cumulative } \\
\text { Commerclal } \\
\text { Floorspace } \\
\text { Retrofit Ith } \\
\text { Energy-Consery- } \\
\text { Ing Widows (c) } \\
\left(10^{6}+t^{2}\right) \\
\end{array}$ & $\begin{array}{l}\text { Percent } \\
\text { New } \\
\text { Market } \\
\text { Share } \\
(/ 100) \\
\end{array}$ & $\begin{array}{l}\text { Cumulative Com- } \\
\text { merclal floor- } \\
\text { space Bullt } \\
\text { wth Energy } \\
\text { Conservigg } \\
\text { windgus } \\
\left(10^{8} \mathrm{ft}^{2}\right) \\
\end{array}$ & $\begin{array}{c}\text { Annual } \\
\text { Energy } \\
\text { Savings from } \\
\text { Cumulative } \\
\text { Energy Saving } \\
\text { windows } \\
\text { (EKWh) } \\
\end{array}$ \\
\hline 1984 & 50,700 & 2,000 & 70 & 0.04 & 1,364 & 0.10 & 140 & 2.56 \\
\hline 1985 & 52,300 & 1,600 & 70 & 0.05 & 1,705 & 0.13 & 286 & 3.47 \\
\hline 1986 & 53,900 & 1,600 & 70 & 0.07 & 2,386 & 0.17 & 476 & 5.04 \\
\hline 1987 & 55.400 & 1,500 & 70 & 0.11 & 3,750 & 0.22 & 707 & 7.82 \\
\hline 1988 & 56,700 & 1,300 & 70 & 0.16 & 5,454 & 0.28 & 962 & 11.22 \\
\hline 1989 & 58,000 & 1,300 & 70 & 0.24 & 8,182 & 0.35 & 1,280 & 16.43 \\
\hline 1990 & 59,300 & 1,300 & 70 & 0.34 & 11,591 & 0.45 & 1,690 & 22.98 \\
\hline 1991 & 60,500 & 1,200 & 70 & 0.50 & 17,045 & 0.56 & 2,160 & 33.01 \\
\hline 1992 & 61,700 & 1,200 & 70 & 0.65 & 22,159 & 0.70 & 2,748 & 42.77 \\
\hline 1993 & 62,900 & 1,200 & 70 & 0.75 & 25,568 & 0.78 & 3,403 & 49.91 \\
\hline 1994 & 64,200 & 1,300 & 70 & 0.80 & 27,272 & 0.85 & 4,177 & 54.56 \\
\hline 1995 & 65,700 & 1,500 & 70 & 0.85 & 28,977 & 0.90 & 5,122 & 59.63 \\
\hline 1996 & 67,000 & 1,300 & 70 & 0.85 & 28,977 & 0.90 & 5,941 & 61.61 \\
\hline 1997 & 68,400 & 1,400 & 70 & 0.85 & 28,977 & 0.90 & 6,823 & 63.74 \\
\hline 1998 & 69,700 & 1,300 & 70 & 0.85 & 28,977 & 0.90 & 7,642 & 65.73 \\
\hline 1999 & 71,100 & 1,400 & 70 & 0.85 & 28,971 & 0.90 & 8,524 & 67.86 \\
\hline 2000 & 72,500 & 1,400 & 70 & 0.85 & 28,977 & 0.90 & 9,406 & 70.00 \\
\hline $\begin{array}{l}\text { (a) } \\
\text { (b) } \\
\text { (c) } \\
\text { (d) } \\
\text { (a) }\end{array}$ & \multicolumn{8}{|l|}{$\begin{array}{l}\text { DOE } 1984 \mathrm{a} \\
\text { See text and } \\
\text { Calculated by } \\
\text { Calculated by } \\
\text { the prevlous ye } \\
\text { Calculated by: } \\
\left(2.42 \mathrm{kWh} / \mathrm{tt}^{2}\right)\end{array}$} \\
\hline
\end{tabular}


TABLE 9.16 Estimated National Annual Electricity Savings from Window Conservation Technologies on Commercial Buildings, High Market-Penetration Scenario (BKWh)

\begin{tabular}{|c|c|c|c|c|c|}
\hline Year & $\begin{array}{l}\text { Savings for } \\
\text { Retrofit } \\
\text { Commercial } \\
\text { Floorspace } \\
\text { Electrically } \\
\text { Heated and } \\
\text { Cooled } \\
\end{array}$ & $\begin{array}{l}\text { Savings } \\
\text { for New } \\
\text { Commercial } \\
\text { Floorspace } \\
\text { Electrically } \\
\text { Heated and } \\
\text { Cooled } \\
\end{array}$ & $\begin{array}{l}\text { Savings for } \\
\text { Retrofit } \\
\text { Commercial } \\
\text { Floorspace } \\
\text { Electrically } \\
\text { Cooled Only } \\
\end{array}$ & $\begin{array}{l}\text { Savings } \\
\text { for New } \\
\text { Commercial } \\
\text { Floorspace } \\
\text { Electrically } \\
\text { Cooled Only } \\
\end{array}$ & $\begin{array}{c}\text { Total } \\
\text { Electricity } \\
\text { Savings of } \\
\text { Window } \\
\text { Conservation } \\
\text { Technologies } \\
\end{array}$ \\
\hline 1985 & 1.92 & 0.39 & 2.78 & 0.69 & 5.78 \\
\hline 1990 & 12.98 & 2.31 & 18.89 & 4.09 & 38.27 \\
\hline 1995 & 32.65 & 7.01 & 47.22 & 12.41 & 99.29 \\
\hline 2000 & 32.65 & 12.87 & 47.22 & 22.78 & 115.52 \\
\hline
\end{tabular}

TABLE 9.17. Cost/kWh Calculations for Energy-Efficient Windows, as a Retrofit Measure for Existing Commercial Buildings

\begin{tabular}{|c|c|}
\hline Incremental Capital Cost(a) & $33 \$ / f t^{2}$ \\
\hline Levelized Capital Cost ${ }^{(b)}$ & $2.9 \$ / \mathrm{ft}^{2}$ per year \\
\hline $\begin{array}{l}\text { Annual Electricity Savings } \\
\text { Heating and Cooling } \\
\text { Cooling Only }\end{array}$ & $\begin{array}{l}2.638 \mathrm{kWh} / \mathrm{ft}^{2} \\
1.634 \mathrm{kWh} / \mathrm{ft}^{2}\end{array}$ \\
\hline $\begin{array}{l}\text { Cost/kWh }(\mathrm{c}) \\
\text { Heating and Cooling } \\
\text { Cooling onty }\end{array}$ & $\begin{array}{l}1.1 \$ / \mathrm{kWh} \\
1.8 \$ / \mathrm{kWh}\end{array}$ \\
\hline
\end{tabular}

(a) See Table 9.3. $\$ 13,000 \div 40,000 \mathrm{ft}^{2}=33 \$ / \mathrm{ft}^{2}$.

(b) The level stream of annual payments the present value of which would equal the investment's incremental capital cost. Assumes a 30 -year useful lifetime of the investment and an 8 percent rate of interest compounded annually.

(c) Levelized capital cost divided by annual energy savings. 


\subsection{REFERENCES FOR CHAPTER 9.0}

Aitken, D. W. 1984. "Components for Window and Perimeter-Lighting Redesign to Promote the Active Use and Control of Thermal and Daylighting Energies in Existing Commercial Buildings." to be published in the Proceedings of the Conference on Building Redesign and Energy Challenges, The American Institute of Architects, Boston Massachusetts, November 15-17, 1984.

Deringer, J. J., Misuriello, H. et al. 1983. "A Baseline for Energy Oesign: The Redesign of 168 Commercial Buildings." GP0 1983 696-390. Reprints from Progressive Architecture $(4: 82,6: 82,8: 82,10: 82,12: 82,2: 83$ and 4:83), Pacific Northwest Laboratory, Richland, Washington.

Elliott, T. C. 1984. "Saving Energy in Heating/Cooling Systems: Daylighting." Power (December) special report, pp. S-1 to S-10.

Galvin, C. 1984. "Building Converts Single-Pane Windows to Double." Energy User News, Vol. 9, No. 6, February 6, 1984, p. 12.

General Electric. 1983. "Glazing with LEXAN Profiled Sheet Can Save You Energy Dollars." General Electric DTS-145(8/83)JF, Sheet Products Department, Pittsfield, Massachusetts.

Mazria, E. 1979. The Passive Solar Energy Book. Rodale Press, Emmaus, Pennsylvania.

Pacific Northwest Laboratory. 1983. Recommendations for Energy Conservation Standards and Guidelines for New Commercial Buildings: Vol. IV-B Part 2. PNL-4870-15. Richtand, Washington.

Pansky, S., et al. 1984. Automatic Daylighting Controls in Office Buildings. Transcript of meeting held September 21, 1984, as recorded by McCorkle Court Reporters, Inc., Chicago, Illinois.

Ripatti, H. and J. McDaniel. 1984. "The Economics of Air Flow Window Systems," Vol. 2, Compte Rendu, Troisiême Symposium International de L'Economie du Batiment, Consei 1 National de Recherches Canada. Reprint provided by Ekono Window Company, Bellevue, Washington.

Schultz, D. K. 1984. "End Use Consumption Patterns and Energy Conservation Savings in Commercial Buildings." Volume D of Proceedings from ACEEE 1984 Summer Study on Energy Efficiency in Buildings. American Council for an Energy-Efficient Economy, Washington, D.C.

Selkowitz, S., et al. 1983. "The Impact of Fenestration on Energy Use and Peak Loads in Daylighted Commercial Buildings." Progress in Passive Solar Energy Systems, American Solar Energy Society, Inc., PP. 187-192; or LBL BS-148, Lawrence Berkeley Laboratory, Berkeley, California. 
Southwall Technologies. 1984. Heat Mirrorm. 8.26 a/Sou. Palo Alto, California.

U.S. DOE. 1981. Non-Residential Buildings Energy Consumption Survey: Fuel Characteristics and Conservation Practices. DOE/EIA-0278, Department of Energy, Office of the Consumption Data System, June 1981.

U.S. DOE. 1983a. Energy Projections to the Year 2010. DOE/PE-0029/2, Department of Energy, Office of Policy, Planning and Analysis, Washington, D.C.

U.S. DOE. 1983b. Designing for Daylighting. Department of Energy, Building Systems Division, Washington, D.C.

U.S. DOE. 1984a. Annual Energy Outlook 1983 with Projections to 1995. DOE/EIA-0383(83), Department of Energy, Washington, D.C.

U.S. DOE. 1984b. Energy Conservation Multi-Year Plan FY 1986-FY 1990. Department of Energy, Office of Conservation, Washington, D.C., July 1984.

U.S. DOE/IEA. 1984. Model Documentation: Cormercial Sector Energy Mode1. DOE/EIA-D453, Department of Energy, Energy Information Administration, Washington, D.C., August 1984.

Wright, D. 1978. Natural Solar Architecture: A Passive Primer. Van Nostrand Reinholdt Company, New York. 


\subsection{ADVANCED LIGHTING TECHNOLOGIES}

One of the most widespread uses for electricity in the U.S. is for lighting. In all end use sectors, lighting energy is aimost totally from electric sources and the potential for energy savings exists. The most significant savings are likely to be in the commercial sector, where $237 \mathrm{BkW}$ or more than 35 percent of total electricity use was consumed in 1984 for lighting comercial buildings (DOE 1985). Several advanced technologies recently developed and marketed can reduce future electricity use in comercial sector lighting. These new technologies include electronic (solid state) ballasts, energy-saving fluorescent lamps, fluorescent dimming controls, energy-efficient fluorescent fixtures, and fluorescent lamps that operate in incandescent fixtures.

This chapter focuses on the future electricity savings that may be achieved from the use of electronic ballasts and energy-saving fluorescent lamps. Since both the new ballasts and the new lamps are perfect substitutes for their respective conventional technologies, and since approximately 70 percent of comercial sector lighting is fluorescent, these two technologies appear to have savings potential. (a) Because of resource constraints we were unable to evaluate all of the lighting technologies mentioned above. Instead we limited our analysis to those technologies that demonstrate the greatest potential in terms of maximum market penetration and aggregate energy savings.

The remainder of this chapter discusses the development, current availability, and estimated market penetration for both electronic ballasts and energy-saving fluorescent lamps. Section 10.1 contains information about the development of these two technologies, including descriptions of how each saves electricity. Section 10.2 discusses the current state of the markets for the technologies and Section 10.3 discusses their cost effectiveness and potential market penetration. Finally, Section 10.4 gives the quantitative estimates of energy savings for both electronic ballasts and energy-saving fluorescent lamps. Section 10.5 analyzes the sensitivity of the energy savings results to

(a) Based on estimates by PNL commercial buildings experts and the PG\&E survey (1981). 
changes in market penetration. Section 10.6 concludes with an estimate of the cost/kWh saved through the installation of electronic ballasts and energy efficient fluorescent bulbs.

\subsection{TECHNICAL BACKGROUND}

Electricity savings in commercial lighting really began with the introduction of the fluorescent lamp in 1939. The ability of this lamp to operate four to five times as efficiently as the incandescent lamp, plus its longer service life, resulted in its widespread use. (a) A fluorescent lamp assembly has three basic parts, each of which can contribute to electricity consumption: the ballast, the tube or lamp, and the fixture. The development of efficient ballasts and lamps is given below.

\subsubsection{The Electronic Ballast}

All gas-discharge lamps including fluorescents require ballasts to maintain stable electrical operation. The ballast provides the required starting voltage and limits the lamp current to a constant prescribed value. In normal operation, typical electromagnetic ballasts undergo energy losses amounting to 25 to 35 percent of the overall lamp/ballast system. The advent of solid state electronics provided the impetus for creating ballasts that experience much lower energy losses, and allowed lamps to operate in the 30,000 cycle range compared to the 60 cycle range of conventional units.

There are several advantages from high frequency operation. The ballasts themselves are more efficient, producing more light and less heat at a given power level. Lower levels of heat production increase ballast life and can have some impact on reducing building cooling load. The high frequencies of these ballasts do not produce an audible hum, unlike conventional electromagnetic ballasts. Lastly, electronic ballasts provide continuous dimming capabilities, which may add additional energy savings.

(a) Unpublished article on lighting standards by Stanley H. Pansky, Architect. 


\subsubsection{Energy-Saving Fluorescent Lamps}

Energy saving 1 amps have been designed to replace standard 40 watt, 48-inch fluorescent bulbs. The new lamps save energy in a variety of ways. Pressure has been increased within the bulb to increase brightness. An improved phosper coating also increases light output. Some lamps use full power to start the lamps, but have switches that reduce power levels during operation. Through these increases in efficiency, presently available energysaving lamps use 34 watts while producing the same level of illumination of standard 40 watt bulbs.

\subsection{CURRENT MARKET SITUATION}

Both electronic ballasts and energy-saving fluorescent lamps are currently available for new construction and retrofit applications. Although no published information was available on the market shares presently commanded by these technologies, sources in both industries claim that sales are growing. (a) Specific information about the two markets is discussed below.

\subsubsection{The Fluorescent Ballast Market}

The existing ballast business can be classified as a low technology mature industry. The market is dominated by Universal Manufacturing Company and Advanced Transformer Company, each of which is estimated to control about 40 percent of the magnetic ballast market (Warrock, November 12, 1984). Small profit margins, products that are near-perfect substitutes from brand to brand, and virtually identical prices for like goods characterize the ballast market. The resulting focus of marketing strategy in this industry has been on distribution, product warranties, and service to promote brand loyalty. Manufacturers of conventional ballasts are firmly entrenched in the business with relatively large investments in capital equipment and tooling, most of which has probably been fully depreciated.

(a) Personal communication with Ben Miller, GTE Sylvania (December 5, 1984); Lowell Blankenship, North America Philips (December 4, 1984); and Dr. Rudolph Verderber, Lawrence Berkeley Laboratory (November 30, 1984). 
The major vendors of electronic ballasts currently available are listed in Tabie 10.1. It is estimated that electronic ballasts currently account for 3 percent of the total ballast market. (a) General Electric Company recently announced that an electronic ballast will be added to its ballast line, but price and rated life information on it was not available for inclusion in Table 10.1. Since the commercial introduction of electronic ballasts in 1980, two manufacturers have gone out of the business: Thomas Industries, Inc. and Jefferson Electric. Although Universal Manufacturing purchased Luminoptics (one of the leaders in the development of electronic ballasts) in 1981, neither of the two dominant ballast manufacturers has developed an electronic ballast. LMP Corporation, formerly Luminoptics, brought suit against Universal Manufacturing in federal court in November 1984, alleging that both Universal and Advance Transformer have conspired in a monopolistic way to prevent the effective development of the electronic ballast market (Warrock, November 12, 1984). LMP claims that this conspiracy has kept the prices of the new ballasts higher than the prices for conventional ballasts.

\section{TABLE 10.1. Electronic Ballast Manufacturers}

\begin{tabular}{|c|c|c|c|c|c|}
\hline & Manufacturer & $\begin{array}{c}\text { Year } \\
\text { Introduced } \\
\end{array}$ & Price & $\begin{array}{l}\text { Rated } \\
\text { Life }\end{array}$ & Warranty \\
\hline 1. & $\begin{array}{l}\text { Electronic 8allast } \\
\text { Technology, Inc. }\end{array}$ & 1980 & $\$ 25-31$ & $6-10$ years + & 3 years \\
\hline 2. & General Electric & 1984 & NA & NA & 1 year \\
\hline 3. & Hunt Electronics & $\begin{array}{r}1983 \\
\text { Co. }\end{array}$ & $\$ 30-40$ & $10-20$ years & 3 years \\
\hline 4. & $\begin{array}{l}\text { Luminoptics, Div. } \\
\text { (University Mfg) }\end{array}$ & 1980 & $\$ 40-90$ & 10 years & 2 years \\
\hline 5. & Triad-Utrad & 1980 & $\$ 33-45$ & $17-20$ years & 3 years \\
\hline
\end{tabular}

Source: Energy User News, Apri1 9, 1984.

(a) Personal communication with Dr. Rudolph Verderber, Lawrence Berkeley Laboratory (November 30, 1984). 
Despite any market limitations imposed by Universal and Advance Transformer, other events suggest that the electronic ballast market will continue to grow. Probably the most significant indicator of continued sales is the recent development by General Electric and GTE Sylvania of fluorescent lamps designed specifically for use with the high-frequency, solid-state ballasts. This recognition of the electronic ballast by the major lamp manufacturers is an important market signal. In addition, General Electric announced on November 15, 1984 that an electronic ballast will be added to its ballast line. The State of Oregon, AT\&T, and several other companies have begun retrofitting with electronic ballasts (Barber, Apri1. 30, 1984; Gardner, May 7, 1984; Weaver May 23, 1983). Based on this and other information, Dr. Rudolph Verderber, Program Manager of the DOE Lighting program, predicts that the electronic ballast will dominate the ballast market by the turn of the century. (a)

10.2.2 The Fluorescent Lamp Market

The market for fluorescent lamps is similar, in many respects, to the ballast market. Several large firms dominate the market, products are substitutable and similarly priced, and marketing strategy aims at developing brand name loyalty. Unlike the ballast market, however, it is the larger manufacturers who are actively participating in the development of energy-efficient bulbs. The major energy-saving alternatives to the standard 40-watt, 48-inch fluorescent lamp along with standard lamps are listed by manufacturer in Table 10.2.

Representatives from all three manufacturers listed in Table 10.2 indicated that sales of the energy-saving lamps are growing rapidly. One representative estimated that sales of the new lamps are currently approaching 50 percent of all fluorescent sales.(b) The energy-efficient lamps are perfect substitutes for standard lamps on standard ballasts. A few of the new lamps are not recommended for use with electronic ballasts. Since the majority of lamps are compatible with either type of ballast and since the market share is

\footnotetext{
(a) Personal communication with Or. Rudolph Verderber, LBL (November 30, 1984).

(b) Personal communication with Ben Miller, GTE Sylvania (December 5, 1984).
} 
TABLE 10.2 Standard and Energy Efficient 48-Inch Fluorescent Bulbs

\begin{tabular}{|c|c|c|c|c|}
\hline Manufacturer/Model & Watts & $\begin{array}{l}\text { Rated } \\
\text { Life (hr) }\end{array}$ & Price & $\begin{array}{c}\text { Incremental } \\
\text { Price Over } \\
\text { Standard } \\
\text { Bulb }\end{array}$ \\
\hline $\begin{array}{l}\text { General Electric } \\
\text { Cool White Watt-Miser } \\
\text { Lite White Watt-Miser II } \\
\text { Lite White Deluxe Watt-Miser II } \\
\text { Optimizer } \\
\text { Watt Miser PIus }\end{array}$ & $\begin{array}{l}34 \\
34 \\
34 \\
28 \\
34\end{array}$ & $\begin{array}{l}20,000 \\
20,000 \\
20,000 \\
18,000 \\
20,000\end{array}$ & $\begin{array}{l}\$ 2.64 \\
2.91 \\
3.20 \\
\text { NA } \\
3.30\end{array}$ & $\begin{array}{l}.89 \\
1.16 \\
1.45 \\
\text { NA } \\
1.55\end{array}$ \\
\hline $\begin{array}{l}\text { GTE Sylvania } \\
\text { Cool White Super Saver I } \\
\text { Lite White Super Saver II } \\
\text { Lite White Deluxe Super Saver III } \\
\text { Cool White Super Saver Plus } \\
\text { Octron (not for retrofit) }\end{array}$ & $\begin{array}{l}34 \\
34 \\
34 \\
32 \\
32\end{array}$ & $\begin{array}{l}20,000 \\
20,000 \\
20,000 \\
20,000 \\
20,000\end{array}$ & $\begin{array}{l}2.64 \\
2.91 \\
3.20 \\
3.29 \\
3.08\end{array}$ & $\begin{array}{l}.89 \\
1.16 \\
1.45 \\
1.54 \\
1.33\end{array}$ \\
\hline $\begin{array}{l}\text { North Anerica Philips } \\
\text { Cool White Econowatt }\end{array}$ & 34 & 20,000 & 2.63 & .88 \\
\hline
\end{tabular}

(a) Incremental prices is based on the comparison of the price of energy efficient bulbs to standard bulbs produced by the three major manufacturers at $\$ 1.75$. These bulbs have the same rated 1 ife but use 40 watts.

growing rapidly, it is likely that the energy-saving fluorescent lamp will dominate the lamp industry in the future.

10.2.3 Competition from Other Technologies

Both electronic ballasts and energy-efficient lamps may face significant competition from technologies outside their narrowly defined industries. For example, the strong emergence of diming controls, which allow continuous variation in level of lighting, could affect sales of both these technologies by reducing the payback on the incremental energy savings the ballasts and lamps can add to the relatively large energy saving potential of dimmer-controlled lighting. This is particularly true for fluorescent lamps, as continuous dimming (the most efficient kind) is facilitated by the use of electronic 
ballasts. The limited information available on the trade-offs between lighting technologies, many of which are not compatible, does not allow for in-depth analys is here.

\subsection{COST EFFECTIVENESS AND MARKET PENETRATION}

The cost-effectiveness and likely market penetration of electronic ballasts and energy-saving fluorescent lamps are discussed in this section. Costeffectiveness will be measured by the estimated payback period, which is then used to estimate likely market penetration according to the methodology outlined in Chapter 4.0. Incremental capital costs will not be used directly to estimate penetration (although they are used to calculate the payback period). Using the incremental costs in this case would imply little market penetration by the year 2000 for either technology. As stated previously, information available suggests that both energy saving fluorescent lamps and electronic ballasts have already achieved some market penetration. Market penetration for these items may be much greater than factors such as incremental cost would suggest. Although the incremental cost on "big-ticket" items may be an important factor for building owners and managers, incremental cost may be ignored when it is quite small (such as $\$ 14$ for electronic ballasts or $\$ 1.25$ for energy saving fluorescent bulbs). Building owners and managers may also invest in these comparatively inexpensive measures without relying on the same methods for determining cost effectiveness that they would apply to more expensive measures.

10.3.1 Cost Effectiveness of Electronic Ballasts

To calculate the payback for an electronic ballast, representative conventional and electronic ballast and lamp units are specified as 48-inch standard fluorescent fixtures with two 40 watt lamps per fixture. To compute the payback period, the value of the annual electricity savings for a typical electronic ballast light fixture is compared to the difference in cost between a conventional ballast and an electronic ballast (see Chapter 4.0). In this analysis, only the ballast is assumed to change; no allowance is made for electronic ballasts installed with energy-saving lamps, since electronic ballast manufacturers claim ballasts are cost-efficient when retrofitted with standard 
lamps (Energy User News, July 16, 1984). For purposes of this analysis all fluorescent lighting in the commercial sector is assumed to be from reference case fixtures. It is difficult to assess the effect of this assumption on the estimates of total electricity savings generated for the new ballasts since ballasts are used with all fluorescent lights no matter how many lamps or what shape the lamps are in a fixture. The limited data available suggest that the longer the lamp tube the greater the total savings for the ballast/lamp unit (Kaufman 1981), so the results in this chapter are probably conservative.

Based on manufacturers estimates, guidelines for the IES (Illuminating Engineering Society) Handbook, and discussion with Dr. Verderber, electronic ballasts are estimated to save 19 to 32 percent of the 96 watts needed to operate a conventional ballast and lamp unit according to reference case specifications. Assuming that electricity savings with the electronic ballast are 25 percent (a reduction of approximately 8 watts in ballast consumption and losses and 16 watts in power needed to operate the lamps), use of the new ballast will result in 24 watts of electricity saved. Electronic ballast testing generally assumes $4000 \mathrm{hr} / \mathrm{yr}$ of operation (Verderber 1980), which would mean electricity savings of $96 \mathrm{kWh} / \mathrm{yr} / \mathrm{reference}$ case fixture. With commercial sector electricity prices at $7.01 \$ / \mathrm{kWh}$, the value of these electricity savings is $\$ 6.73 / y r$ for each two-lamp fixture with an electronic ballast. Throughout our analysis we have assumed $4000 \mathrm{hr} / \mathrm{yr}$ of operation. In Section 10.6, in order to test the sensitivity of our estimate of total energy savings to this assumption, we present a scenario which assumes usage of $2600 \mathrm{hr} / \mathrm{yr}$.

Representative costs for electronic ballasts are given in Table 10.1. A fairly wide range of prices is shown, with the Luminoptics ballasts priced slightly higher than the rest. Since both replacement and new construction sales of ballasts are likely to occur in large lots with discounts, these prices may be high. Mention in the media of the price paid for ballasts indicated that this was so (Duffy, September 26, 1983). Assuming some discounts are available, the price of a reference case electronic ballast is assumed to be $\$ 28.00$. Conventional ballasts generally range in price from $\$ 11.00$ for a 
basic unit to $\$ 25.00$ for an energy-efficient magnetic unit. Making the same assumption of large lot discounts, a representative price of $\$ 14.00$ is chosen for use in this analysis.

Since electronic ballasts are perfect substitutes for conventional ballasts, no incremental installation costs need to be added to the incremental capital cost calculation. Therefore, the incremental capital cost for an electronic ballast is simply the difference in cost between the new ballast $(\$ 28.00)$ and the conventional ballast $(\$ 14.00)$, or $\$ 14.00$. Dividing this increment by the value of electricity savings for one year (\$6.73) yields a payback period of 2.05 years (at 4000 hours of operation a year). This figure is consistent with manufacturers estimated paybacks, which range from one to five years (Energy User News, April 9, 1984).

Accelerated replacement of conventional ballasts by electronic ballasts does not appear to be economically possible. In addition to the incremental capital costs of $\$ 28.00$ ( $\$ 28.00$ minus zero), significant installation costs would be incurred that would likely cause the payback period associated with such accelerated replacement to be more than five years. Since the estimated penetration of investments with payback periods exceeding five years is zero (Chapter 4.0 ), such replacement is not considered in the remainder of this chapter.

\subsubsection{Electronic Ballast Market Penetration}

Market penetration of electric ballasts is assumed to be a function of the payback period (as described in Chapter 4.0), as tempered by any technical limitations. There are only two potential technical limitations that would appear to have any possible effect on market penetration. First, there are some compatibility problems between electronic ballasts and a few of the energy-saving fluorescent lamps (e.g., GTE Sylvania's Super Saver Plus and GE's Watt-Miser Pius). In fixtures where these lamps have been retrofitted, use of electronic ballasts may be precluded or at least delayed until the lamps are ready to be replaced. At that time, other lamps compatible with the new ballasts could be introduced. There are so many lamps that can be used with electronic ballasts that this problem is assumed to have no effect on market penetration. The 
second potential problem is radio frequency interference caused by the new ballasts' high frequency. Since quality engineering and manufacture appear to be able to handle this problem (no instances of occurrence could be identified), this will also be assumed to have no effect on market penetration.

The payback period of 2.05 years (at 4000 hours of operation a year) leads to an estimated maximum market penetration for electronic ballasts of 65 percent in the year 2000 as shown in Table 10.3. This penetration rate is assumed to apply to both the new construction market and the normal replacement market. This relatively high penetration rate despite high incremental capital costs, is consistent with the positive market signals discussed above, such as: the entrance of a major manufacturer (General Electric) into the market, the optimistic state of the current market, and the need for electronic ballasts in order to take advantage of the potentially large electricity savings attainable with the use of continuous diming.

\subsubsection{Cost Effectiveness of Energy-Saving Fluorescent Lamps}

The payback calculation used to assess the cost effectiveness of energy efficient fluorescent lamps is based on the selection of the 40-watt, 48-inch lamp as the representative example of a standard lamp. Standard 40-watt lamps generally consume 40 watts, while most of the energy-saving lamps consume 34 watts or less electricity for approximately the same light output (Burt Hill Kosar Rittelman Associates 1984). Using a 34-watt lamp as the representative energy-saving lamp, each energy-saving lamp saves 6 watts over the reference

TABLE 10.3. Market Share Estimates for Electronic Ballasts

\begin{tabular}{cc} 
Year & $\begin{array}{c}\text { Percent of } \\
\text { Total Annual } \\
\text { Ballast Sales }\end{array}$ \\
\cline { 2 - 2 } 1984 & 10 \\
1985 & 12 \\
1990 & 29 \\
1995 & 55 \\
2000 & 65
\end{tabular}


case standard lamp. Assuming lamp operation of 4000 hours per year, the electricity savings per year for one lamp are estimated as $24 \mathrm{kWh}$. Using the 1983 commercial sector electricity price of $7.01 \% / \mathrm{kWh}$, the value of these energy savings are $\$ 1.68 / \mathrm{yr}$ for one $1 \mathrm{amp}$.

The incremental capital cost of energy-saving lamps versus standard lamps is calculated as the difference in the cost of the lamps, since installation costs are identical for both. The range of prices for the energy-saving lamps is given in Table 10.2. A simple average of these prices gives a price of $\$ 2.98$ for the representative energy-saving lamp. The price for a standard 40-watt fluorescent lamp is $\$ 1.75$ for all three of the manufacturers listed in Table 10.2 (Energy User News, May 16, 1983), so that price will be assigned to the representative conventional lamp. The resulting incremental capital cost for energy-saving fluorescent lamps then becomes $\$ 1.23$ and with the $\$ 1.70$ worth of electricity savings implies a payback period of 0.72 years, or approximately 8.5 months. This estimate is consistent with manufacturer payback estimates which range from 8 months to 1.3 years (Energy User News, May 16, 1983).

As with electronic ballasts, accelerated replacements of conventional butbs is not considered in the remainder of this analysis because we believe the associated payback period would lead to an estimate of zero penetration. This belief is consistent with our observation that building owners do not replace working bulbs early to obtain energy savings.

\subsubsection{Energy-Saving Fluorescent Lamp Market Penetration}

Like the case for electronic ballasts, the market penetration for energysaving fluorescent lamps is assumed to be a function of the payback period and any technical limitations. No technical limitations appear to be relevant to the potential market penetration of the new lamps; even though some lamps cannot be used with an electronic ballast, there are plenty of energy-saving lamps that can be used effectively with these ballasts. Using the payback period of 8.5 months and the methodology described in Chapter 4.0, market penetration for the energy saving fluorescent lamps is estimated to reach a maximum of 75 percent by the year 2000, as shown in Table 10.4. This relatively high penetration rate actually appears conservative if industry estimates of 50 percent 
TABLE 10.4. Market Share Estimates for Energy Saving Fluorescent Lamps

\begin{tabular}{cc} 
Year & $\begin{array}{c}\text { Percent of Total } \\
\text { Annual Fluorescent } \\
\text { Lamp Sales }\end{array}$ \\
\hline 1984 & 10 \\
1985 & 13 \\
1990 & 36 \\
1995 & 65 \\
2000 & 75
\end{tabular}

penetration in today's market are accurate. This 75 percent market penetration rate is assumed to apply to both the new construction and the normal replacement markets.

\subsection{COMMERCIAL BUILDING AND MARKET SHARE PROPERTIES}

Under the resource constraints of this study no estimate of the total stock of either ballasts or lamps could be identified. The only measure of commercial activity found was commercial floorspace; unfortunately, no estimate of fluorescent fixtures $/ \mathrm{ft}^{2}$ of floorspace could be found to make the transition from energy savings per lamp or ballast/lamp unit to energy savings/ $\mathrm{ft}^{2}$ simpler. However, a commercial building survey performed by Pacific Gas and Electric Company (PG\&E 1981) provided an estimate of the commercial floorspace lighted with fluorescent fixtures as equaling approximately 70 percent of commercial floorspace. This estimate of the portion of commercial floorspace fluorescently lit was applied to estimates for commercial floorspace for 1983-1990 and 1985 obtained from DOE (DOE 1984). Yearly floorspace estimates for 19911994 were interpolated at 2 percent based on the 1990-1995 estimated growth. Estimates for 1996-2000 were derived assuming a continuation of this 2 percent annual growth in commercial floorspace. It was assumed that 70 percent of total new floorspace is lighted with fluorescent fixtures. The resulting estimates for fluorescently-lighted commercial floorspace for each of the years 1984-2000 are shown in Table 10.5 and 10.6.

Use of the new ballast and lamp technologies, particularly in the retrofit market, is also dependent on the rate at which the conventional equipment needs 
TABLE 10.5. Annual Market Share and Energy Savings Projections for Electronic Ballasts

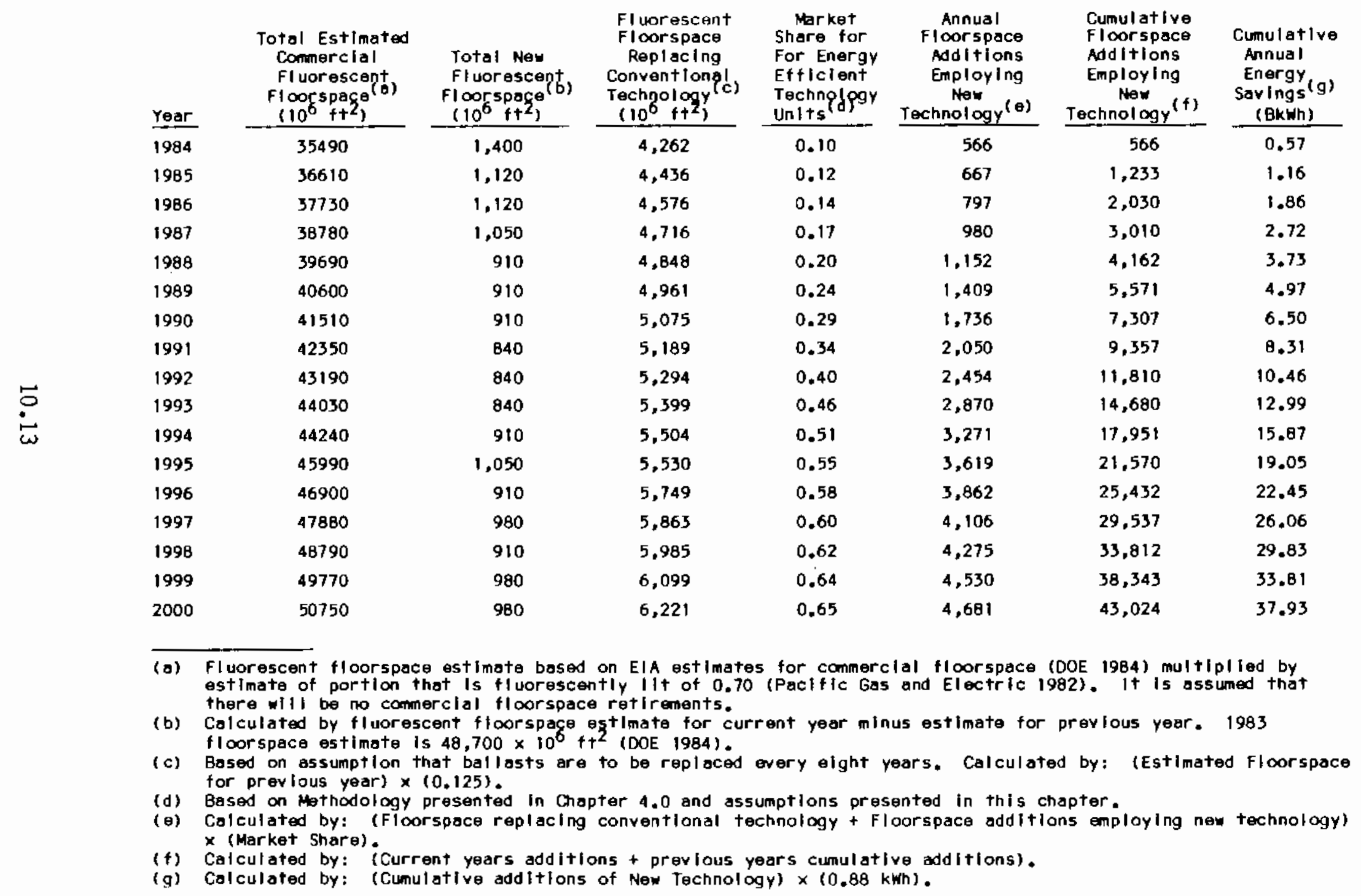


TABLE 10.6. Annual Market Share and Energy Savings Projections for Energy-Efficient Fluorescent Lamps

\begin{tabular}{|c|c|c|c|c|c|c|c|c|}
\hline & Year & $\begin{array}{c}\text { Total Estimated } \\
\text { Commerclal } \\
\text { Fluorescent } \\
\text { Floorspece } \\
\left(10^{6} t^{2}\right) \\
\end{array}$ & $\begin{array}{l}\text { Total New } \\
\text { Fluorescent } \\
\text { Floorspace }{ }^{(b)} \\
\left(10^{6} \mathrm{ft}^{2}\right) \\
\end{array}$ & $\begin{array}{c}\text { Fl uorescent } \\
\text { Floorspace } \\
\text { Replacing } \\
\text { Conventlong! } \\
\text { Technol logx (c) } \\
\left(10^{6} t^{2}\right) \\
\end{array}$ & $\begin{array}{l}\text { Market } \\
\text { Share for } \\
\text { For Energy } \\
\text { Efticlent } \\
\text { Technolggy } \\
\text { Units } \\
\end{array}$ & $\begin{array}{c}\text { Annual } \\
\text { Floorspace } \\
\text { Add it Ions } \\
\text { Employlng } \\
\text { Now } \\
\text { Technology (e) } \\
\end{array}$ & $\begin{array}{c}\text { Cunulative } \\
\text { Floorspace } \\
\text { Add l tions } \\
\text { Employing } \\
\text { New } \\
\text { Technology }(t) \\
\end{array}$ & $\begin{array}{l}\text { Cumulative } \\
\text { Annual } \\
\text { Energy } \\
\text { Savings } \\
\text { (BkWh) } \\
\end{array}$ \\
\hline & 1984 & 35,845 & 1,400 & 6,818 & 0.10 & 822 & 822 & 0.44 \\
\hline & 1985 & 36,976 & 1,120 & 7,169 & 0.13 & 1,078 & 1,900 & 1.01 \\
\hline & 1986 & 38,107 & 1,120 & 7,395 & 0.16 & 1,362 & 3,262 & 1.73 \\
\hline & 1987 & 39,168 & 1,050 & 7,621 & 0.20 & 1,734 & 4,996 & 2.65 \\
\hline & 1988 & 40,087 & 910 & 7.834 & 0.24 & 2,098 & 7,095 & 3.76 \\
\hline & 1989 & 41,006 & 910 & 8,017 & 0.30 & 2,678 & 9,773 & 5.18 \\
\hline & 1990 & 41,925 & 910 & 8,201 & 0.36 & 3,280 & 13,053 & 6.92 \\
\hline & 1991 & 42,774 & 840 & 8,385 & 0.43 & 3,967 & 17,020 & 9.02 \\
\hline & 1992 & 43,622 & 840 & 8,555 & 0.50 & 4,697 & 21,717 & 11.51 \\
\hline & 1993 & 44,470 & 840 & 8,724 & 0.56 & 5,356 & 27,075 & 14.35 \\
\hline & 1994 & 44,682 & 910 & 8,894 & 0.61 & 5,980 & 35,054 & 17.52 \\
\hline & 1995 & 46,450 & 1,050 & 8,936 & 0.65 & 6,491 & 39.545 & 20.96 \\
\hline & 1996 & 47,369 & 910 & 9,290 & 0.68 & 6,936 & 46,481 & 24.64 \\
\hline & 1997 & 48,359 & 980 & 9,474 & 0.71 & 7,422 & 53,903 & 28.57 \\
\hline & 1998 & 49,278 & 910 & 9,672 & 0.73 & 7,725 & 61,628 & 32.67 \\
\hline & 1999 & 50,268 & 980 & 9,856 & 0.74 & 8,018 & 69,646 & 36.92 \\
\hline & 2000 & 51,258 & 980 & 10,054 & 0.75 & 8,275 & 77,921 & 41.30 \\
\hline
\end{tabular}

(a) Fluorescent floorspace estImate besed on EIA estimates for commerclal floorspace (DOE 1984) multiplied by estimate of portion that is $f 1$ uorescently ilt of 0.70 (Pacific Gas and Electric 1982). It is assumed that there wll be no comm 
replacement. This retirement rate, in most cases, is directly related to the useful life of the equipment. To calculate energy savings, ballasts are assumed to be retired every eight years (a rate of 12.5 percent per year) while fluorescent lamps are assumed to be retired every five years (a rate of 20 percent per year). These retirement rates are applied directly to the commercial floorspace lighted by fluorescent fixtures.

\subsection{ENERGY SAVINGS RESULTS}

Electricity savings from electronic ballasts and energy-saving lamps for the nation as a whole are estimated below as described in Chapter 4.0. Electricity savings are presented for both the new construction and normal replacement markets.

Electronic Ballasts

Energy savings/ft ${ }^{2}$ of fluorescently-lighted comercial floorspace for electronic ballasts are based on three assumptions: 1) that fluorescent floorspace is approximately 70 percent of all comercial floorspace; 2) that the remainder of commercial floorspace is lighted primarily by incandescent sources; and 3) that incandescent sources use four times as much energy as standard fluorescent sources. The first step in the calculation is to find how much of the $237 \mathrm{BkWh}$ of electricity used for commercial lighting is used in fluorescent fixtures. Using the assumptions above, the following equation was generated:

$$
\begin{aligned}
& 237 \mathrm{BkWh}=(.30) 4 \mathrm{~F}+(.70) \mathrm{F} \\
& 124.7 \mathrm{BkWh}=\mathrm{F}
\end{aligned}
$$

where:

$F=$ electricity consumed for fluorescent lighting

Electricity consumption by fluorescent lighting currently utilizing electronic ballasts is not accounted for in this calculation. This was done for the sake of simplicity given that electronic ballasts account for less than 
1 percent of current ballast population and given that our estimates are approximations of the portion of commercial floorspace that is fluorescently lighted.

According to this calculation, 123.1 BkWh (53 percent) of all comercial lighting energy is consumed by fluorescent lighting. Since 70 percent of the 50.7 billion $\mathrm{ft}^{2}$ of commercial floorspace is assumed to be fluorescentlylighted ( 35.5 billion $\mathrm{ft}^{2}$ ), fluorescent lighting energy amounts to $3.51 \mathrm{kwh} / \mathrm{ft}^{2}$ of fluorescently-lighted floorspace not presently using electronic ballasts. The estimated 25 percent savings used to calculate the payback period implies energy savings equal to $0.88 \mathrm{kWh} / \mathrm{ft}^{2}$ annually.

Using the methodology described in Chapter 4.0, the energy savings results shown in the final column of Table 10.5 and sumarized in Table 10.7 were estimated. This suggests that in 2000 a total of 37.93 Bkwh can be saved by the electronic ballast. This is probably a conservative estimate, since some of the incandescently-lighted floorspace is expected to change to fluorescent lighting as well.

Energy-Saving Fluorescent Lamps.

Fluorescent lamp energy savings/ $\mathrm{ft}^{2}$ of fluorescently-lighted floorspace are computed using the three main assumptions and the procedure described above for electronic ballasts. Instead of a savings rate of 25 percent, however, the

TABLE 10.7. Energy Savings Results: Electronic Ballasts and High Efficiency Fluorescent Lamps

\begin{tabular}{cccc} 
Year & $\begin{array}{c}\text { Estimated Annual } \\
\text { Energy Savings } \\
\text { From Electronic Ballasts } \\
\text { (BkWh) }\end{array}$ & $\begin{array}{c}\text { Energy Savings } \\
\text { From High Efficiency } \\
\text { Fluorescent Lamps } \\
\text { (Bkwh) }\end{array}$ & $\begin{array}{c}\text { Total } \\
\text { For Both } \\
1985\end{array}$ \\
\cline { 2 - 3 } & 1.16 & 1.01 & $\frac{1}{\text { Technologies }}$ \\
1990 & 6.50 & 6.92 & 13.42 \\
1995 & 19.05 & 20.96 & 14.01 \\
2000 & 37.93 & 41.30 & 79.23
\end{tabular}


savings rate of 15 percent used in the payback calculation is used. This yields estimated energy savings of $0.53 \mathrm{kWh} / \mathrm{ft}^{2}$ of fluorescently-lighted floorspace annually for energy-saving lamps.

The last column of Table 10.6 gives the energy savings results for fluorescent lamps in both the new construction and retrofit markets. These savings are further summarized in Table 10.7. In the year 2000 energy savings in new fluorescently lighted floorspace are estimated at $41.30 \mathrm{BkWh}$. These estimates are conservative if industry estimates of 50 percent penetration rates in today's market are accurate, since the beginning penetration rate for 1984 is 10 percent in this analysis. Since no empirical data on actual penetration rates were available to confinm the industry estimates, the procedure from Chapter 4.0 was used even though the beginning market penetration rates seem to be low for energy-efficient lamps.

\subsection{SENSITIVITY ANALYSIS}

This section provides an assessment of the sensitivity of the aggregate energy savings results presented in Section 10.4 to changes in the thermal storage market penetration scenarios. Low and high market penetration scenarios are examined to determine an implied minimum/maximum range of potential future energy savings. Section 10.6.1 presents low market penetration scenario assumptions. Section 10.6.2 presents the electrical savings estimates associated with this scenario. Sections 10.6 .3 and 10.6 .4 discuss high market penetration scenario assumptions and energy savings estimates respectively. Section 10.6.5 and 10.6.6 present the assumptions and energy savings estimates for a low usage scenario in which both the high efficiency fluorescent bulbs and the electronic ballasts are assumed to have 2600 hours of usage a year.

\subsubsection{Low Market-Penetration Scenario}

Electronic ballasts and/or energy saving fluorescent lamps may not penetrate the commercial building lighting market as quickly or completely as suggested by the base-case estimates. High cost differentials and long payback periods may inhibit the market penetration of these technologies to levels below those indicated previously. 
The specific assumption for the low market-penetration scenario is that the maximum potential level of penetration is only half of what it was est $j-$ mated to be in the base case scenario. Thus the maximum potential market share was reduced from 65 percent to 32.5 percent for electronic ballasts and from 75 percent to 37.5 percent for energy saving fluorescent lamps. The assumed rate of market penetration was reduced such that only 75 percent of that new maximum potential will be reached by the year 2000. Market penetration for both electronic ballasts and energy saving fluorescent lamps are given in Table 10.8.

\subsubsection{National Annual Electrical Energy Savings Estimates--Low Scenario}

The national annual electrical energy savings estimates for the low market-penetration scenario for electronic ballasts and energy saving fluorescent bulbs are presented in Tables 10.9 and 10.10 and further summarized in Table 10.11. These estimates were obtained by multiplying the estimated new floorspace and floorspace using these technologies in retrofit capacity by the expected energy savings for each year. These results can be interpreted as being indicative of reasonable minimum expected energy savings due to these technologies.

\subsubsection{High Market-Penetration Scenarios}

It is possible that under certain circumstances, efficient lighting technologies might penetrate the market more rapidly than outlined in the base case

TABLE 10.8. Low Scenario Market Share Penetration Estimates for Energy Saving Fluorescent Lamps and Electronic Ballasts (percent of total annual sales)

\begin{tabular}{|c|c|c|}
\hline Year & $\begin{array}{c}\text { Electronic } \\
\text { Ballasts } \\
\end{array}$ & $\begin{array}{l}\text { Energy Saving } \\
\text { Fluorescent Lamps }\end{array}$ \\
\hline 1984 & 7 & 7 \\
\hline 1985 & 7.5 & 7.5 \\
\hline 1990 & 12 & 13 \\
\hline 1995 & 21 & 23.5 \\
\hline 2000 & 24.4 & 28 \\
\hline
\end{tabular}


TABLE 10.9. Low Scenario Annual Market Share and Energy Savings Projections for Electronic Ballasts

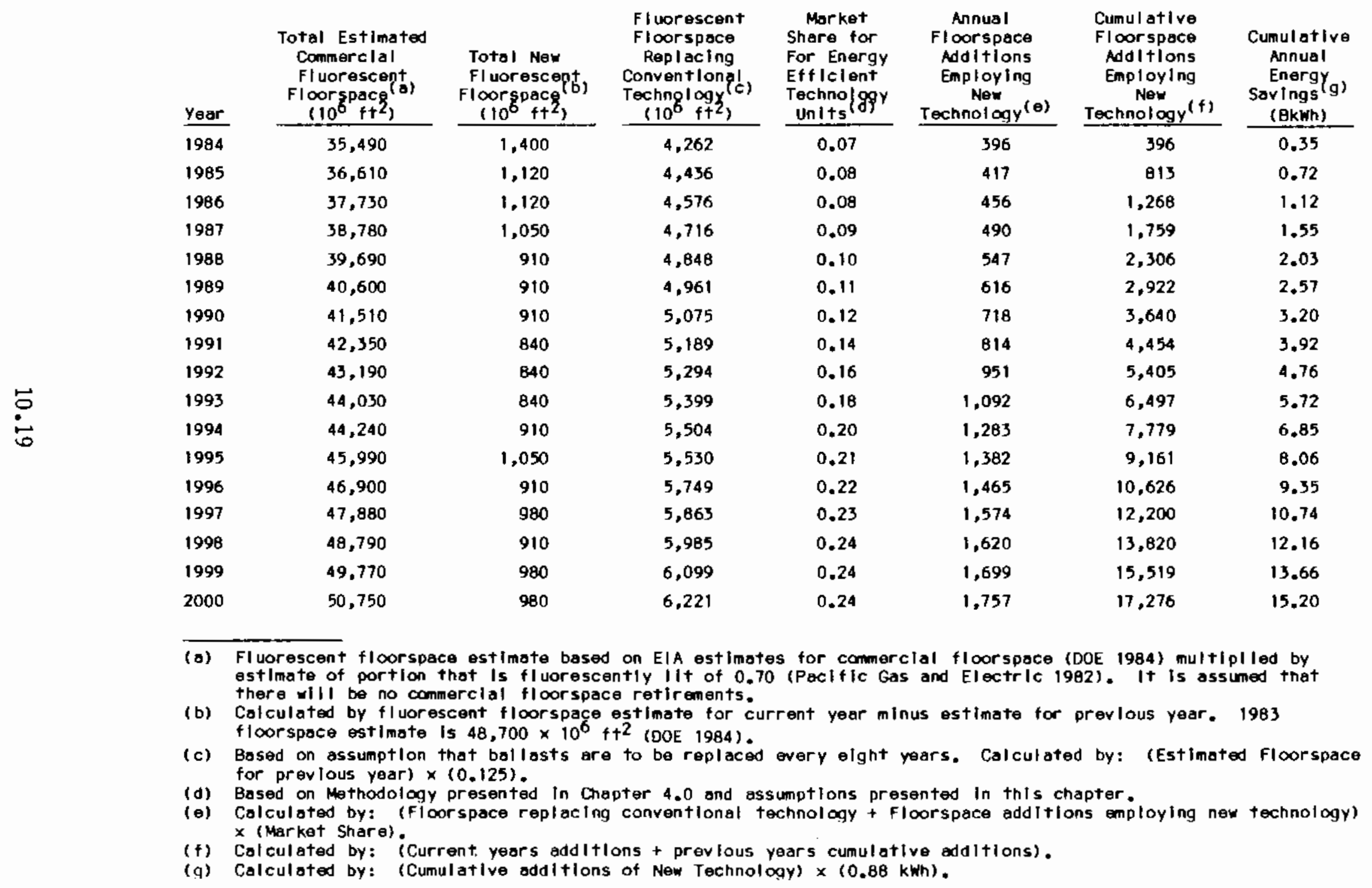


TABLE 10.10. Low Scenario Annual Market Share and Energy Savings Projections for Energy-Efficient Fluorescent Bulbs

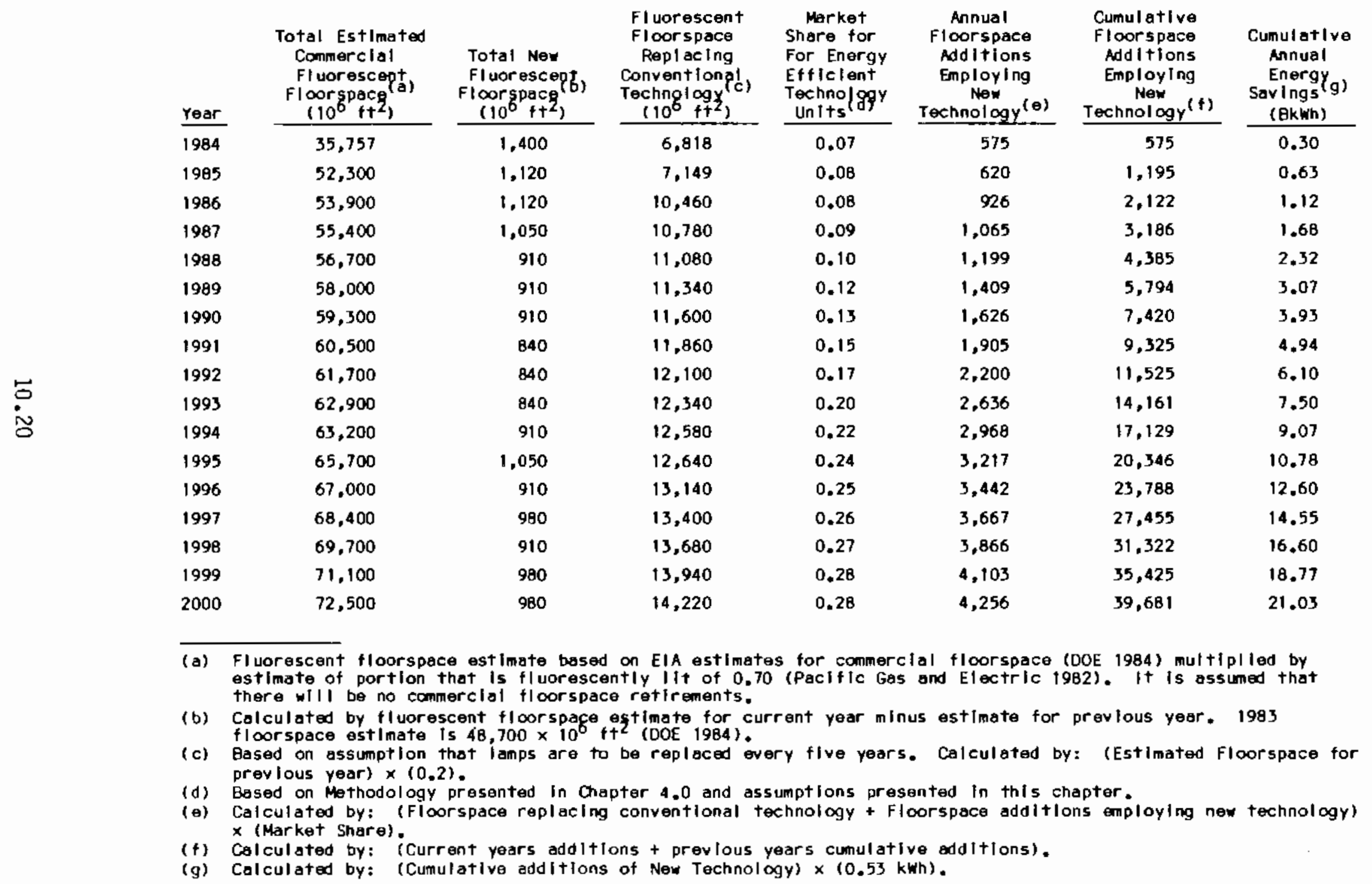


TABLE 10.11. Low Market-Penetration Scenario Energy Savings Results:

Electronic Ballasts and High Efficiency Fluorescent Lamps

\begin{tabular}{|c|c|c|c|}
\hline Year & $\begin{array}{c}\text { Estimated } \\
\text { Annual Energy } \\
\text { Savings From } \\
\text { Electronic Ballasts } \\
\text { (BkWh) } \\
\end{array}$ & $\begin{array}{c}\text { Estimated Annual } \\
\text { Energy Savings from } \\
\text { High Efficiency } \\
\text { Fluorescent Lamps } \\
\text { (BkWh) } \\
\end{array}$ & $\begin{array}{c}\text { Total } \\
\text { For Both } \\
\text { Technologies } \\
\end{array}$ \\
\hline 1985 & 0.72 & 0.63 & 1.35 \\
\hline 1990 & 3.20 & 3.93 & 7.13 \\
\hline 1995 & 8.06 & 10.78 & 18.84 \\
\hline 2000 & 15.20 & 21.03 & 36.23 \\
\hline
\end{tabular}

scenario. Possible circumstances would include government or utility subsidization of the technologies, increases in electric rates or drops in the incremental costs of the efficient technologies over their standard counterparts.

Specifically the high market-penetration scenario assumes that the maximum market share is attained by 1995 instead of 2000. Table 10.12 displays the expected market penetration for both energy saving fluorescent lamps and electronic ballasts under this scenario.

10.6.4 National Annual Electrical Energy Savings Estimates--High Scenario

The national annual electrical energy savings estimates for the high market-penetration scenario for electronic ballasts and high efficiency fluorescent bulbs are displayed in Tables 10.13 and 10.14 and further sumarized in

TABLE 10.12. High Scenario Market Share Estimates for Energy Saving Fluorescent Lamps and Electronic Ballasts (percent of total annual sales)

\begin{tabular}{ccc} 
Year & $\begin{array}{c}\text { Electronic } \\
\text { Ballasts }\end{array}$ & $\begin{array}{c}\text { Energy Saving } \\
\text { Fluorescent Lamps }\end{array}$ \\
\cline { 2 - 3 } 1984 & 10 & 10 \\
1985 & 12 & 13 \\
1990 & 42 & 48 \\
1995 & 95 & 95 \\
2000 & 95 & 95
\end{tabular}


TABLE 10.13. High Scenario Annual Market Share and Energy Savings Projections for Electronic Ballasts

\begin{tabular}{|c|c|c|c|c|c|c|c|c|}
\hline & Year & $\begin{array}{c}\text { Total Estimated } \\
\text { Commercial } \\
\text { Ff uorescent } \\
\text { Floorspace } \\
\left(10^{6}+t^{2}\right) \\
\end{array}$ & $\begin{array}{l}\text { Total New } \\
\text { Fl uorescent } \\
\text { Fl oorspace } \\
\left(10^{6} t^{2}\right) \\
\end{array}$ & $\begin{array}{l}\text { Fl worescent } \\
\text { Floorspace } \\
\text { Replacling } \\
\text { Convent longl } \\
\text { Technglogy (c) } \\
\left(10^{6} \mathrm{ft}^{2}\right) \\
\end{array}$ & $\begin{array}{l}\text { Market } \\
\text { Share for } \\
\text { For Energy } \\
\text { Eft iclent } \\
\text { Technolggy } \\
\text { Units } \\
\end{array}$ & $\begin{array}{c}\text { Annual } \\
\text { Floorspace } \\
\text { Add Itlons } \\
\text { Employling } \\
\text { New } \\
\text { Technology }(\theta) \\
\end{array}$ & $\begin{array}{c}\text { Cumulative } \\
\text { Floorspace } \\
\text { Additions } \\
\text { Employing } \\
\text { Ney } \\
\text { Technology } \\
\end{array}$ & $\begin{array}{c}\text { Cumulative } \\
\text { Annusl } \\
\text { Energy } \\
\text { Savings } \\
\text { (Bkwh) } \\
\end{array}$ \\
\hline & 1984 & 35,747 & 1,400 & 4,262 & 0.10 & 566 & 566 & 0.50 \\
\hline & 1985 & 36,875 & 1,120 & 4,468 & 0.12 & 469 & 1,035 & 0.91 \\
\hline & 1986 & 38.005 & 1,120 & 4,609 & 0.15 & 602 & 1,637 & 1.44 \\
\hline & 1987 & 39,061 & 1,050 & 4,750 & 0.20 & 812 & 2,449 & 2.16 \\
\hline & 1988 & 39,977 & 910 & 4,883 & 0.26 & 1,054 & 3,503 & 3.08 \\
\hline & 1989 & 40,894 & 910 & 4,997 & 0.33 & 1.365 & $4,86 \theta$ & 4.29 \\
\hline & 1990 & 41.811 & 910 & 5,112 & 0.42 & 1,770 & 6,638 & 5.84 \\
\hline & 1991 & 42,657 & 840 & 5,226 & 0.52 & 2,208 & 8,846 & 7.79 \\
\hline & 1992 & 43,503 & 840 & 5,332 & 0.64 & 2,765 & 11,612 & 10.22 \\
\hline & 1993 & 44,349 & 840 & 5,438 & 0.75 & 3,296 & 14,907 & 13.12 \\
\hline & 1994 & 44,560 & 910 & 5,544 & 0.05 & 3,840 & 18,747 & 16.50 \\
\hline & 1995 & 46,323 & 1,050 & 5,570 & 0.95 & 4,402 & 23,150 & 20.37 \\
\hline & 1996 & 47.240 & 910 & 5,790 & 0.95 & 4,456 & 27,605 & 24.29 \\
\hline & 1997 & 48,227 & 980 & 5,905 & 0.95 & 4,578 & 32,184 & 28.32 \\
\hline & 1998 & 49,143 & 910 & 6,028 & 0.95 & 4,614 & 36.798 & 32.38 \\
\hline & 1999 & 50,130 & 980 & 6.143 & 0.95 & 4,737 & 41,535 & 36.55 \\
\hline & 2000 & 51,118 & 980 & 6,266 & 0.95 & 4,819 & 46,353 & 40.79 \\
\hline
\end{tabular}

(a) Fluorescent floorspace estimate based on ElA estimates for commerclal floorspace (DOE 1984) multiplied by estimate of portion that is fluorescently It of 0.70 (Paclfic Gas and Electric i982). It is assumed that there wil be no comerclal floorspace retirements.

(b) Calculated by fluorescent floorspage estimate for current year minus estimate tor previous year. 1983 fl corspace estimate Is $48,700 \times 10^{6} \mathrm{ft}^{2}$ (DOE 1984).

(c) Based on assumption that ballasts are to be replaced every elght years. Calculated by: (Estimated floorspace for prevlaus year) $\times(0.125)$.

(d) Based on Methodology presented In Chapter 4.0 and assumptions presented in this chapter.

(e) Calculated by: (Floorspace replacing conventlonal technology + Floorspace additions employling new technology) $x$ (Market Share).

(f) Calculated by: (Current years additions + prevlous years cumulative additions).

(a) Calculated by: (Cumulative additlons of New Technology) $\times(0.88 \mathrm{kWh})$. 
TABLE 10.14. High Scenario Annual Market Share and Energy Savings Projections for Energy-Efficient Fluorescent Lamps

\begin{tabular}{|c|c|c|c|c|c|c|c|c|}
\hline & Year & $\begin{array}{c}\text { Total Estlmated } \\
\text { Commerclial } \\
\text { Fl uorescent' } \\
\text { Floorspace }{ }^{(a)} \\
\left(10^{6} \mathrm{ft}^{2}\right) \\
\end{array}$ & $\begin{array}{l}\text { Total New } \\
\text { Fluorescent } \\
\text { Floorspace } \\
\left(10^{6} \mathrm{ft}^{2}\right) \\
\end{array}$ & $\begin{array}{l}\text { Fl uorescent } \\
\text { Floorspace } \\
\text { Repl acting } \\
\text { Conventiongl } \\
\text { Technology (c) } \\
\left(10^{6}+t^{2}\right) \\
\end{array}$ & $\begin{array}{l}\text { Merket } \\
\text { Share for } \\
\text { For Energy } \\
\text { Efflclent } \\
\text { Technolggy } \\
\text { UnIts } \\
\end{array}$ & $\begin{array}{c}\text { Annual } \\
\text { Florspace } \\
\text { Add Itlons } \\
\text { Enploying } \\
\text { New } \\
\text { Technology }(\theta)\end{array}$ & $\begin{array}{l}\text { Cumulative } \\
\text { Floorspace } \\
\text { Additions } \\
\text { Employlng } \\
\text { New } \\
\text { Texhnology }(f) \\
\end{array}$ & $\begin{array}{c}\text { Cumulat Ive } \\
\text { Annual } \\
\text { Energy } \\
\text { Savings }(g) \\
\text { (Bkwh) } \\
\end{array}$ \\
\hline & 1984 & 35,490 & 1,400 & 6,818 & 0.10 & 822 & $B 22$ & 0.44 \\
\hline & 1985 & 36,610 & 1,120 & 7,098 & 0.13 & 1,068 & 1,890 & 1.01 \\
\hline & 1986 & 37,730 & 1,120 & 7,322 & 0.17 & 1,435 & 3,325 & 1.77 \\
\hline & 1987 & 38,780 & 1.050 & 7,546 & 0.22 & 1,891 & 5,217 & 2.77 \\
\hline & 1988 & 39,690 & 910 & 7,756 & 0.29 & 2,513 & 7,730 & 4.10 \\
\hline & 1989 & 40,600 & 910 & 7,938 & 0.38 & 3,362 & 11.092 & 5.88 \\
\hline & 1990 & 41,510 & 910 & 8,120 & 0.48 & 4,334 & 15,426 & 8.18 \\
\hline & 1991 & 42,350 & 840 & 8,302 & 0.60 & 5,485 & 20,912 & 11.09 \\
\hline & 1992 & 43,190 & 840 & 8,470 & 0.71 & 6,610 & 27,522 & 14.59 \\
\hline & 1993 & 44,030 & 840 & 8,638 & 0.81 & 7,677 & 35,199 & 18.66 \\
\hline & 1994 & 44,240 & 910 & B, 806 & 0.90 & 8,744 & 43,943 & 23.29 \\
\hline & 1995 & 45,990 & 1,050 & 8,848 & 0.95 & 9.403 & 53,346 & $28.2 B$ \\
\hline & 1996 & 46,900 & 910 & 9,198 & 0.95 & 9,603 & 62,949 & 33.37 \\
\hline & 1997 & 47,880 & 980 & 9,380 & 0.95 & 9,842 & 72,791 & 38.58 \\
\hline & 1998 & 48,790 & 910 & 9,576 & 0.95 & 9.962 & 82,753 & 43.86 \\
\hline & 1999 & 49,770 & 980 & 9,758 & 0.95 & 10,201 & 92,954 & 49.27 \\
\hline & 2000 & 50.750 & 980 & 9,954 & 0.95 & 10,387 & 103,341 & 54.78 \\
\hline & $\begin{array}{l}\text { (a) } \\
\text { (c) } \\
\text { (d) } \\
\text { (e) } \\
\text { (f) }\end{array}$ & \multicolumn{7}{|c|}{ 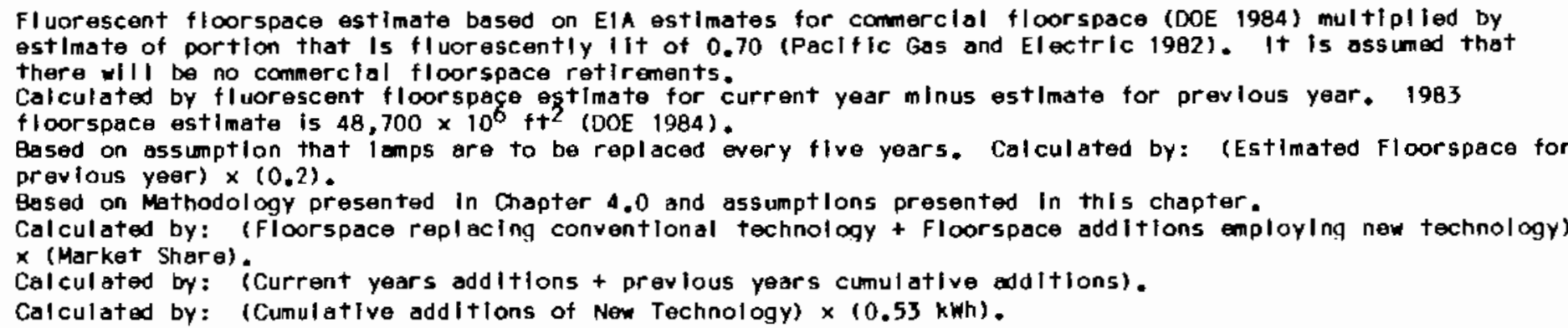 } \\
\hline
\end{tabular}


Table 10.15. These estimates were derived in the same manner as the low scenario estimates. These results can be interpreted as being indicative of reasonable maximum expected energy savings due to the adoption of these

technologies.

10.6.5 Lower Usage Scenario

Throughout our analysis we have assumed annual usage of both energy-saving fluorescent lamps and electronic ballasts at $4000 \mathrm{hr} / \mathrm{yr}$. The amount of usage either product gets would directly affect the resulting payback period of the investment in energy saving technologies. This would in turn influence the rate of market penetration. In this scenario we will assume usage of $2600 \mathrm{hr} / \mathrm{yr}$. This may more closely represent average commercial sector use that the $4000 \mathrm{hr} / \mathrm{yr}$ used previously.

For electronic ballasts, this level of usage would imply annual electricity savings of $62.9 \mathrm{kWh}$ based on the assumptions made in Section 10.3.1. With a commercial sector electricity price of $7.01 \% / \mathrm{kWh}$ the savings would equal $\$ 4.37$ a year. This implies a payback period of 3.2 years based on an incremental cost of $\$ 14$ for electronic ballasts. For energy-saving fluorescent bulbs, 2600 hours annual usage would imply annual energy saving of $15.6 \mathrm{kWh}$ equal to $\$ 1.10$ at comercial sector electricity prices of $7.01 \$ / \mathrm{kWh}$. Assuming the incremental capital cost of $\$ 1.23$ stated in Section 10.32 , the payback period would equal 1.12 years, or approximately 13 months.

TABLE 10.15. High Market-Penetration Scenario Energy Savings Results

\begin{tabular}{cccc} 
Year & $\begin{array}{c}\text { Estimated } \\
\text { Annual Energy } \\
\text { Savings from } \\
\text { Electronic Ballasts } \\
\text { (BkWh) }\end{array}$ & $\begin{array}{c}\text { Estimated Annual } \\
\text { Savings from } \\
\text { High Efficiency } \\
\text { Electronic Ballasts } \\
\text { (BkWh) }\end{array}$ & $\begin{array}{c}\text { Total } \\
\text { For Both } \\
\text { Technologies }\end{array}$ \\
\cline { 2 - 3 } & 0.91 & 1.01 & 1.92 \\
1990 & 5.84 & 8.18 & 14.02 \\
1995 & 20.37 & 28.28 & 48.65 \\
2000 & 40.79 & 54.78 & 95.57
\end{tabular}


Market penetration is assumed to be more a function of payback period than of the percentage increase in incremental cost as with the base case and low and high market-penetration scenarios.

Specifically, the lower usage scenario assumes that electronic ballasts will achieve market penetration of 50 percent by the year 2000 and energysaving fluorescent bulbs will achieve 70 percent market penetration. Table 10.16 displays the expected market penetration for both energy saving fluorescent lamps and electronic ballasts under this scenario. 10.6.6 National Annual Electrical Energy Savings Estimates--Lower Usage Scenario

The national annual electrical energy savings for the lower usage scenario for electric ballasts and high efficiency fluorescent bulbs are displayed in Tables 10.17 and 10.18 and further summarized in Table 10.19 .

\subsection{COST/kWh OF ENERGY SAVED CALCULATIONS AND COMPARISONS TO THE COST/kWh OF PRODUCTION NEW GENERATING CAPACITY}

Comparisons of the estimated levelized costs per kWh for energy efficient fluorescent lamps and electronic ballasts are presented in this section. Representative estimates of the levelized costs/kWh saved by these technologies are presented in Table 10.20. These estimates are based upon new and replacement installations. Retrofit installations would yield slightly higher

TABLE 10.16. Lower Scenario Market-Penetration Estimates for Energy Saving Fluorescent Lamps and Electronic Ballasts (percent market share)

\begin{tabular}{ccc} 
Year & $\begin{array}{c}\text { Electronic } \\
\text { Ballasts }\end{array}$ & $\begin{array}{c}\text { Energy Saving } \\
\text { Fluorescent Lamps }\end{array}$ \\
\cline { 2 - 3 } 1984 & 10 & 10 \\
1985 & 11 & 12 \\
1990 & 25 & 35 \\
1995 & 40 & 60 \\
2000 & 50 & 70
\end{tabular}


TARLE 10.17. Low Usage (2600/hr/yr) Scenario Annual Market Share and Energy Savings Projections for Electronic Ballasts

\begin{tabular}{|c|c|c|c|c|c|c|c|c|}
\hline & Year & $\begin{array}{c}\text { Total Estimated } \\
\text { Commerclal } \\
\text { Fl uorescent } \\
\text { Floorspace } \\
\left(10^{b} \mathrm{ft}^{2}\right) \\
\end{array}$ & $\begin{array}{l}\text { Total New } \\
\text { Fl uor escent } \\
\text { Floor } \text { pace }^{(\mathrm{b})} \\
\left(10^{6} \mathrm{ft}^{2}\right)\end{array}$ & $\begin{array}{c}\text { Fl uorescent } \\
\text { Floorspace } \\
\text { Repl acting } \\
\text { ConventIong: } \\
\text { Technologx } \\
\left(10^{6} \mathrm{ft}^{2}\right) \\
\end{array}$ & \begin{tabular}{l}
\multicolumn{2}{c}{ Market } \\
Share for \\
For Energy \\
Eff Iclent \\
Technolggy \\
UnIts \\
\end{tabular} & $\begin{array}{c}\text { Annual } \\
\text { Floorspace } \\
\text { Additlons } \\
\text { Employlng } \\
\text { New }(e) \\
\text { Technology } \\
\end{array}$ & $\begin{array}{c}\text { Cumul ative } \\
\text { Floorspace } \\
\text { Additlons } \\
\text { Employlng } \\
\text { Naw } \\
\text { Technology }(f) \\
\end{array}$ & $\begin{array}{l}\text { Cumulative } \\
\text { Annual } \\
\text { Energy } \\
\text { Savings } g \text { ) } \\
\text { (Bkwh) }\end{array}$ \\
\hline & 1984 & 35,490 & 1,400 & 2,727 & 0.10 & 413 & 413 & 0.36 \\
\hline & 1985 & 36,610 & 1,120 & 2,039 & 0.11 & 436 & 849 & 0.74 \\
\hline & 1986 & 37.730 & 1,120 & 2,929 & 0.13 & 526 & 1,375 & 1.21 \\
\hline & 1987 & 38,780 & 1,050 & 3.018 & 0.16 & 651 & 2.026 & 1.78 \\
\hline & 1988 & 39,690 & 910 & 3,102 & 0.18 & 722 & 2,748 & 2.41 \\
\hline & 1989 & 40,600 & 910 & 3,175 & 0.21 & 858 & 3,606 & 3.17 \\
\hline & 1990 & 41,510 & 910 & 3,248 & 0.25 & 1,040 & 4,645 & 4.08 \\
\hline & 1991 & 42,350 & 840 & 3,321 & 0.29 & 1,207 & 5,852 & 5.15 \\
\hline & 1992 & 43,190 & 840 & 3,388 & 0.33 & 1.395 & 7,247 & 6.37 \\
\hline & 1993 & 44,030 & 840 & 3,455 & 0.36 & 1,546 & 8,794 & 7.73 \\
\hline & 1994 & 44,240 & 910 & 3,522 & 0.38 & 1,684 & 10,478 & 9.22 \\
\hline & 1995 & 45,990 & 1,050 & 3,539 & 0.40 & 1,836 & 12,314 & 10.83 \\
\hline & 1996 & 46,900 & 910 & 3,679 & 0.43 & 1,973 & 14.287 & 12.57 \\
\hline & 1997 & 47,880 & 980 & 3,752 & 0.45 & 2,129 & 16,416 & 14.44 \\
\hline & 1998 & 48,790 & 910 & 3,030 & 0.47 & 2,228 & 18,644 & 16.40 \\
\hline & 1999 & 49.770 & 980 & 3,903 & 0.49 & 2,393 & 21,037 & 18.51 \\
\hline & 2000 & 50,750 & 980 & 3,982 & 0.50 & 2,481 & 23,518 & 20.69 \\
\hline & $\begin{array}{l}\text { (a) } \\
\text { (c) } \\
\text { (d) } \\
\text { (e) } \\
\text { (f) }\end{array}$ & \multicolumn{7}{|c|}{ 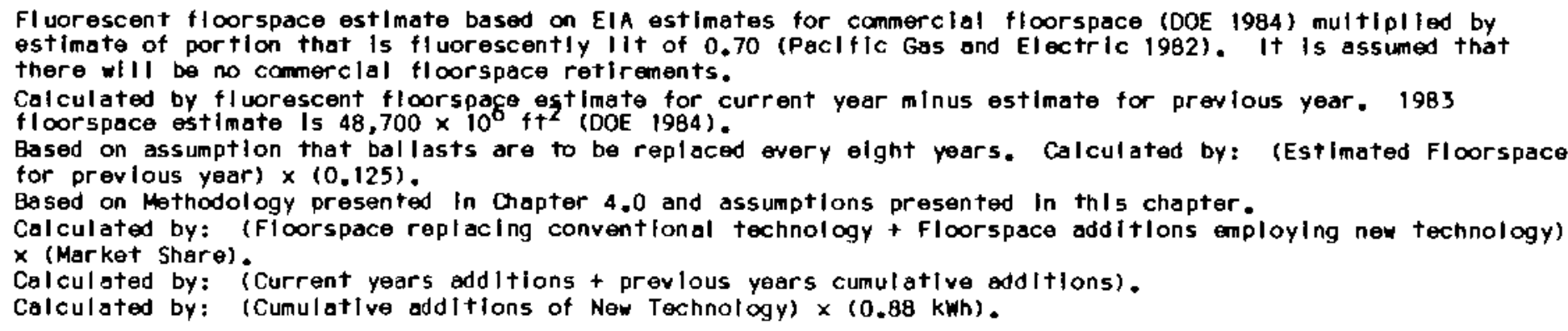 } \\
\hline
\end{tabular}


TABLE 10.18. Low Usage (2600 hr/yr) Scenario Annual Market Share and Energy Savings Projections for Fluorescent Lamps

\begin{tabular}{|c|c|c|c|c|c|c|c|}
\hline Year & $\begin{array}{c}\text { Total Estimated } \\
\text { Commerclal } \\
\text { F1 uorescent } \\
\text { Floorspace } \\
\left(10^{6}+t^{2}\right) \\
\end{array}$ & $\begin{array}{l}\text { Total New } \\
\text { FI worescent } \\
\text { FI corspace } \\
\left(10^{6} \mathrm{ft}^{2}\right) \\
\end{array}$ & $\begin{array}{l}\text { Fl vorescent } \\
\text { Floorspace } \\
\text { Repl acing } \\
\text { Convent longl } \\
\text { Techngl ogy } \\
\left(10^{6} \text { ft }\right) \\
\end{array}$ & $\begin{array}{l}\text { Narket } \\
\text { Share for } \\
\text { For Energy } \\
\text { Effliclent } \\
\text { Technolggy } \\
\text { Units } \\
\end{array}$ & $\begin{array}{c}\text { Annual } \\
\text { Floorspace } \\
\text { Additions } \\
\text { Employlng } \\
\text { Now } \\
\text { Technology } \\
\end{array}$ & $\begin{array}{c}\text { Cumul ative } \\
\text { Floorspace } \\
\text { Add ltions } \\
\text { Employlng } \\
\text { New } \\
\text { Technology } \\
\end{array}$ & $\begin{array}{l}\text { Cumuletive } \\
\text { Annual } \\
\text { Energy } \\
\text { Sovings } \\
\text { (Bkwh) } \\
\end{array}$ \\
\hline 1984 & 35,490 & 1,400 & 4,432 & 0.10 & 583 & 583 & 0.31 \\
\hline 1985 & 36,610 & 1,120 & 4,614 & 0.12 & 688 & $1,27 t$ & 0,67 \\
\hline 1986 & 37,730 & 1,120 & 4,759 & 0.15 & 882 & 2,153 & 1.14 \\
\hline 1987 & 38,780 & 1,050 & 4,905 & 0.19 & 1,131 & 3,284 & 1.74 \\
\hline 1980 & 39,690 & 910 & 5,041 & 0.24 & 1,428 & 4,713 & 2.50 \\
\hline 1989 & 40,600 & 910 & 5,160 & 0.29 & 1,760 & 6,473 & 3.43 \\
\hline 1990 & 41,510 & 910 & 5,278 & 0.35 & 2,166 & 8,639 & $4.5 B$ \\
\hline 1991 & 42,350 & 840 & 5,396 & 0.42 & 2,619 & 11,258 & 5.97 \\
\hline 1992 & 43,190 & 840 & 5,506 & 0.48 & 3,046 & 14,304 & 7.58 \\
\hline 1993 & 44,030 & 840 & 5,615 & 0.52 & 3,356 & 17,660 & 9.36 \\
\hline 1994 & 44,240 & 910 & 5,724 & 0.56 & 3,715 & 21,375 & 11.33 \\
\hline 1995 & 45,990 & 1,050 & 5,751 & 0.60 & 4,081 & 25,456 & 13.49 \\
\hline 1996 & 46,900 & 910 & 5,979 & 0.63 & 4,340 & 29,796 & 15.79 \\
\hline 1997 & 47,880 & 980 & 6,097 & 0.65 & 4,600 & 34,396 & 18.23 \\
\hline 1998 & 48,790 & 910 & 6,224 & 0.67 & 4,780 & 39,176 & 20.76 \\
\hline 1999 & 49,770 & 980 & 6,343 & 0.69 & 5,053 & 44,229 & 23.44 \\
\hline 2000 & 50,750 & 980 & 6,470 & 0.70 & 5,215 & 49,444 & 26.21 \\
\hline $\begin{array}{l}\text { (a) } \\
\text { (b) } \\
\text { (d) } \\
\text { (e) } \\
\text { (f) }\end{array}$ & \multicolumn{2}{|c|}{ 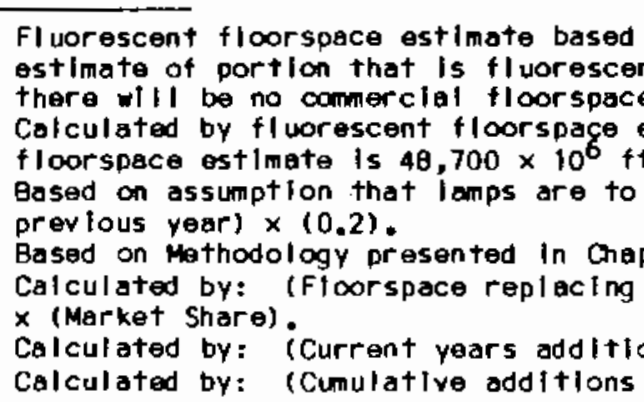 } & $\begin{array}{l}\text { on Ela estimat } \\
\text { ntly llit of } 0.7 \\
\text { e retirements. } \\
\text { estimbte for ch } \\
2 \text { (DOE 1984). } \\
\text { be replaced e } \\
\text { pter } 4.0 \text { ond as } \\
\text { conventional } \\
\text { ons + prevlous } \\
\text { of Ner Technol }\end{array}$ & $\begin{array}{l}\text { s for commerc } \\
\text { (Paclfic Gas } \\
\text { rent year mir } \\
\text { ry flve year } \\
\text { umptions pres } \\
\text { chnology }+F \\
\text { ears cumulat } \\
\text { (y) } \times(0.53\end{array}$ & $\begin{array}{l}\text { Elal floorspace } \\
\text { is and Electric } \\
\text { nus estlimate for } \\
\text { s. Calculated b } \\
\text { sented in this c } \\
\text { loorspace additi } \\
\text { (ive additions). } \\
\text { k(w). }\end{array}$ & $\begin{array}{l}\text { (DOE 1984) mult } \\
982) .1+\text { is ass } \\
\text { prevlous year. } \\
\text { oy: (Estimated } F \\
\text { chapter. } \\
\text { lons employing ne }\end{array}$ & $\begin{array}{l}\text { plled by } \\
\text { ilmed that } \\
1983 \\
\text { loorspace for } \\
\text { technology) }\end{array}$ \\
\hline
\end{tabular}


TABLE 10.19. Lower Usage Scenario Energy Savings Results

$\begin{array}{ccccc}\text { Year } & \begin{array}{c}\text { Electronic } \\ \text { Ballasts } \\ \text { (BkWh) }\end{array} & \begin{array}{c}\text { Energy Saving } \\ \text { Fluorescent Lamps } \\ \text { (BkWh) }\end{array} & \begin{array}{c}\text { Total } \\ \text { for Both } \\ \text { Technologies }\end{array} \\ 1985 & 0.74 & & 0.67 & \frac{1.41}{1990} \\ 1995 & 4.08 & & 4.58 & 8.64 \\ 2000 & 10.83 & 13.49 & 24.32 \\ & 20.69 & 26.21 & 46.90\end{array}$

TABLE 10.20. Cost/kWh for Electronic Ballasts and Energy Efficient Fluorescent Lamps in New and Retirement Situations

\begin{tabular}{|c|c|c|c|c|}
\hline Technology & $\begin{array}{l}\text { Incremental } \\
\text { Capital Costs in } \\
\text { New and Retirement } \\
\text { Applications }(a)\end{array}$ & $\begin{array}{l}\text { Levelized } \\
\text { Capital Cost } \\
\text { (\$/year) }\end{array}$ & $\begin{array}{c}\text { Annual } \\
\text { Energy } \\
\text { Savings } \\
(\mathrm{kWh} / \text { year })(\mathrm{c})\end{array}$ & $\begin{array}{l}\text { Cost Per } \\
\mathrm{kWh} \text { Saveg } \\
(\$ / \mathrm{kWh})\end{array}$ \\
\hline $\begin{array}{r}\text { Electronic } \\
\text { Ballasts }\end{array}$ & $\$ 14.00$ & $\$ 2.09$ & 96 & 2.18 \\
\hline $\begin{array}{l}\text { Energy } \\
\text { Efficient } \\
\text { Fluorescent } \\
\text { Lamps }\end{array}$ & 1.23 & 0.31 & 24 & 1.29 \\
\hline
\end{tabular}

(a) The incremental capital cost in equivalent to the difference between the average cost for the advanced technologies and the base case technologies as cited in this chapter.

(D) The level stream of annual payments, the present value of which would equal the investment's incremental capital costs. This cost was calculated using an 8 percent discount rate and operating lifetimes of 10 years for electronic ballasts and 5 years for energy efficient fluorescent lamps.

(c) Calculated as savings in watts times the assumed 4000 hours of operation a year.

(d) Calculated as the levelized capital cost (\$/year) divided by annual energy savings in $\mathrm{kWh} /$ year and multiplied by 100 .

levelized costs/kWh saved as the undepreciated portion of the equipment being replaced would be added to the incremental capital costs.

The resulting costs/kWh saved with electronic ballasts and energy efficient fluorescent 1 amps is equivatent to 2.184 and 1.294 , respectively. This 
is significantly less than the estimated average generation cost for new coalfired generating plants of $5.21 \% / \mathrm{kWh}$ (presented in Table 4.3 ).

\subsection{REFERENCES FOR CHAPTER 10.0}

Energy User News. Monday, April 9, 1984. "Product Guide: Energy-Efficient Ballasts." p. 10, cols. 1-5.

Energy User News. Monday, May 16, 1983. "Product Guide: Energy-Efficient Fluorescent Lamps." p. 4, cols. 1-5.

Energy User News. Monday, May 28, 1984. "Dimmer Introduced for Fluorescents." p. 3 .

Energy User News. Monday, June 11, 1984. "Two Firms Introduce New Lighting Products." p. 10, cols. 3-5.

Energy User News. Monday, July 2, 1984. "Firm Introduces 2 Efficient Lighting Fixtures." p. 19.

Energy User News. Monday, July 16, 1984. "Electronic Ballast Lamps: New Line, More Debate." p. 1, col. 5.

Barber, Jeff. Monday, June 13, 1983. "Duro Test Lamp Life Claims Based on Easier Testing." Energy User News, p. 1, cols. 1-2.

Barber, Jeff. Monday, April 30, 1984. "EBT's Electronic Ballasts Score Best in AT\&T Test." Energy User News, p. 1, cols. 1-2.

Duffy, Jamie. Monday, September 26, 1983. "Munt Lighting to Market Electronic Ballasts." Energy User News, p. 4, cols. 3-5.

Gardner, Laura. Monday, May 7, 1984. "Hospital Eyes 2-yr Payback on Reballast, Group Relamp." Energy User News, p. 1, col. 1.

Greenstein, Irwin. Monday, September 26, 1983. GTE Carves 2.5 Watts OA Efficient Lamp; Same Lumens." Energy User News, p. 1, col. 1.

Johnson, D. R. et al. 1981. Obstacles and Opportunities in the Commercialization of the Solid State Electronic FTuorescent Lighting Ballast. PNL-4035, Pacific Northwest Laboratory, RichTand, Washington.

Kaufman, John E., ed. 1981. IES Lighting Handbook, Reference Volume. Illuminating Engineering Society of North America, New York.

Pacific Gas and Electric Company. 1981. Commercial Business Energy Use Survey. Energy Forecasting and Analysis Section, Economics and Statistics Department, San Francisco, California. 
Pospicil, Ray. Monday, July 2, 1984. "GE to Market Fluorescent 2 to 3 Watts More Efficient." Energy User News. p. 1, col. 5.

Stevens Luminoptics Corporation. 1978. Energy Efficient Fluorescent Ballasts. LBL-7852, prepared for the U.S. Department of Energy by Lawrence Berkeley Laboratory, Berkeley, California.

U.S. DOE/EIA. 1984. Annual Energy Outlook 1983. Department of Energy/Energy Information Administration, Washington, D.C.

U.S. DOE. 1984. Energy Conservation Multi-Year Plan: FY 1986-FY 1990. Department of Energy, Office of Conservation, Washington, D.C.

U.S. DOE. 1985. National Energy Policy Plan-V. U.S. Department of Energy, Office of Policy, Planning and Analysis, Washington, D.C.

Verderber, R. R. 1980. The "Real" Energy Savings with Electronic Ballasts. LBL-10707, prepared for the U.S. Department of Energy, by Lawrence BerkeTey Laboratory, Berkeley, California.

Warrock, Anna M. Monday, November 12, 1984. "Co. Claims Ballast Giants Hamper Solid State Market." Energy User News, p. 1, cols. 1-2.

Weaver, Mark. Monday, May 23, 1983. "Oregon Govt. Picks Electronic Ba11ast5." Energy User News, p. 6, cols. 1-5. 


\subsection{HEAT AND COOL STORAGE IN COMMERCIAL BUILDINGS}

In this chapter, the potential national electrical energy savings in the years 1990, 1995, and 2000 from heat and cool storage techniques for commercial space conditioning is estimated. The principal objective of any space conditioning system is to maintain the living space temperature within some predetermined "comfort zone." When used in combination with conventional heating and cooling systems, modern thermal storage systems can provide a means of meeting that objective while significantly reducing its cost by using cheaper off-peak rather than peak power.

Section 11.1 is a technical review of how commercial storage systems work. The current level of use of thermal storage systems is discussed in Section 11.2 while Section 11.3 is an analysis of their cost effectiveness and potential for penetrating the commercial space conditioning market. Section 11.4 applies commercial building stock forecasts to the market penetration estimates to approximate future yearly installations of heat and cool storage systems. The potential national electrical energy savings results are presented in Section 11.5. Section 11.6 is an analysis of the sensitivity of the energy savings results to alterations in the market-penetration scenarios. Finally, Section 11.7 presents the estimated cost/kWh saved by thermal storage systems and discusses how those costs compare with the cost/kWh of new electrical generating capacity.

\subsection{TECHNICAL BACKGROUND}

Cool storage, though not a cormion technology, is not new. In the earlier decades of this century, ice was cut from frozen lakes and ponds and then stored in the basements of banks, hotels, department stores, and other commercial buildings. As the ice melted during the hot summer months, the cool water was collected in tanks and pumped to devices called "air washers." These devices forced air over a chilled water spray and circulated the cooled air throughout the building.

By the mid-1930's small air conditioning (AC) units had arrived on the space conditioning market. However, those $A C$ units were not practical for 
every use. For example, some large buildings such as auditoriums and churches required the capacity to produce a lot of cooling for only a few hours a week. In such a case, it would have been difficult to justify the purchase of an $A C$ unit of sufficient size and capacity because it would have been used so infrequently. One solution was to employ a cool storage technique called "ice banking."

The technique of ice banking used modestly sized refrigeration units to produce ice all week long. The ice was collected and stored until it came time for the building to be cooled. Air or water was then chilled over the ice and subsequently blown or pumped throughout the building to effectively provide the necessary cooling. Such systems were common until the 1950s when large AC units became less costly to purchase and to operate.

Modern cool storage systems are used primarily to support the cooling capacity of conventional AC systems. They operate in much the same way as the ice-banking system described above. In addition to a modern version of the ice-storage system (see Figure 11.1), there are also the very similar chilledwater storage systems (see Figure 11.2), and the somewhat different chilled-air storage systems.

Chilled-air storage systems use the infrastructure of the building (i.e., the space between the walls, beneath the floors, above the ceiling panels, and in the hollow cores of concrete pillars and floor slabs) to store a reserve of pre-cooled air. When the time comes to use $i t$, the reserve of cool air is vented into the central duct system and subsequently distributed throughout the building.

One reason why these systems may use less energy than strictly conventional AC systems is because the cooling capacity is produced overnight. Energy is saved because night air is cooler to begin with than mid-day air so it requires less energy input for further cooling to a desired temperature.

Another reason why cool storage systems conserve energy is because they allow the installation of smaller or "downsized" conventional AC systems. That is, because a cool storage system can be held in reserve until the work day's period of peak cooling demand, it can be used as a support system of a 


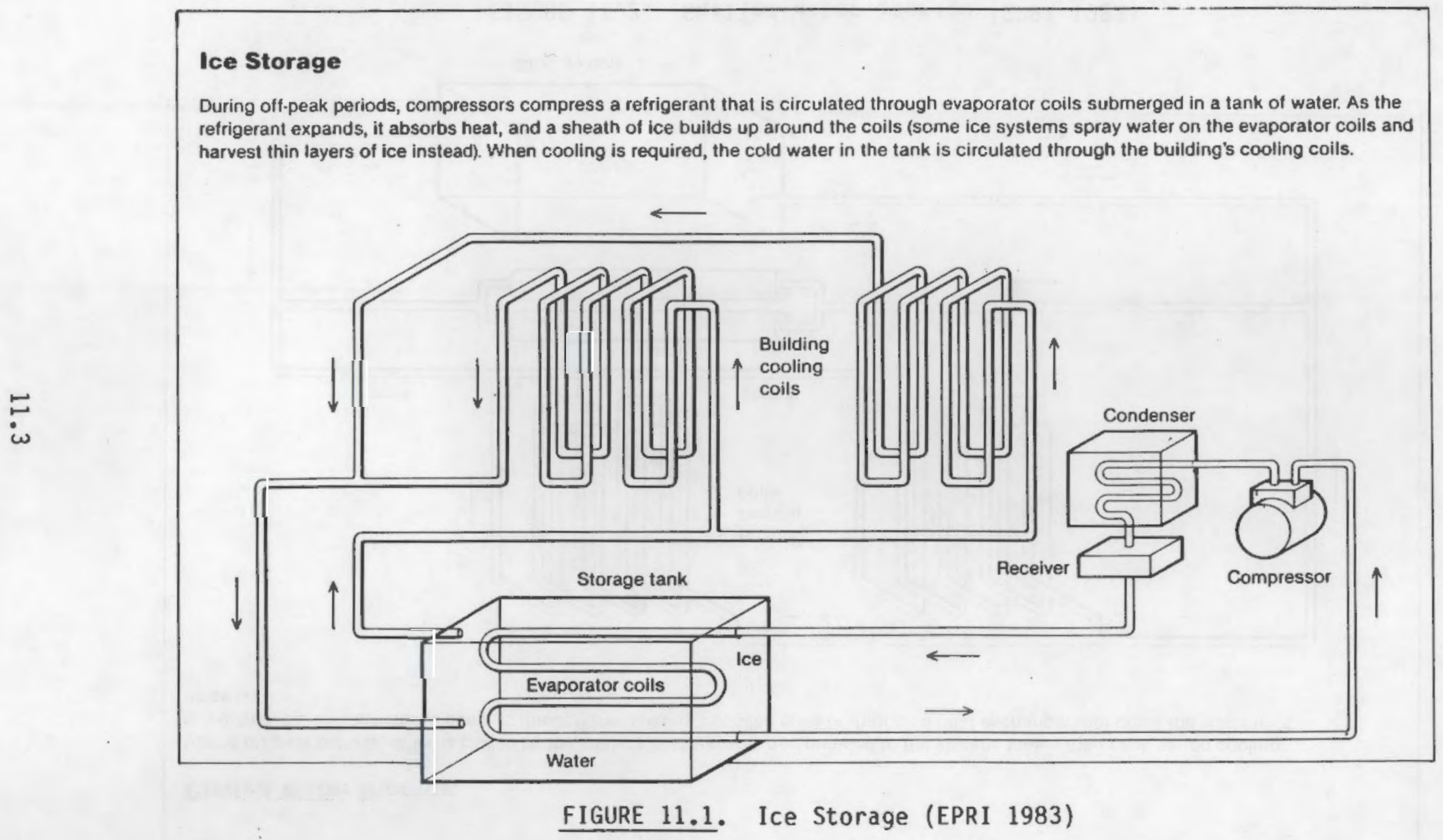




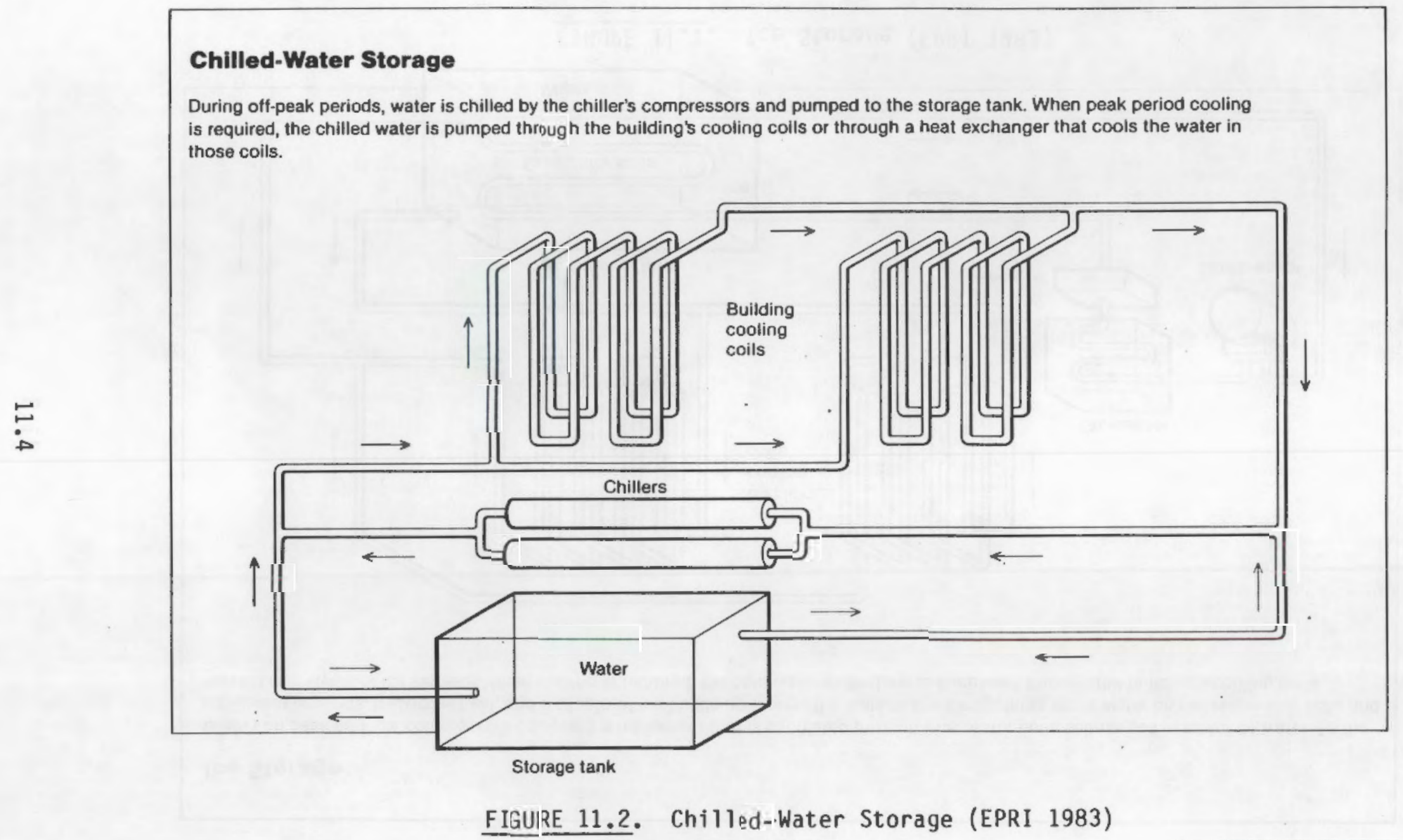


Conventional $A C$ unit. Consequently, the conventional $A C$ unit does not need to be sized to worst-case conditions. Power is conserved because for a given level of cooling, a downsized AC unit operated mostly at full capacity requires less energy input than a larger $A C$ unit operated mostly at less than full capacity.

The primary benefit of a thermal storage system is, however, economy rather than conservation because it uses considerably cheaper off-peak power to operate. This is significant since statistics indicate that space cooling of commercial buildings uses 25 to 40 percent of the summer season's peak load electrical production (EPRI 1983).

It is important to recognize that many types of thermal storage systems can serve the dual purpose of storing heat as well as cool. Under certain conditions, this dual purpose can significantly contribute to the overall economy of such systems (Tamblyn 1982). That is, modern commercial buildings typically require year-round cooling on almost a daily basis so cooling is usually a matter of more serious concern than heating. But even large commercial buildings require some heating on holjdays, weekends, Monday mornings, and during the evenings of the winter. A thermal storage space heating system can usually be employed to meet some of these heating requirements by capturing and storing the excess "waste heat" generated within the building during the active part of the work week.

There are various means of storing the waste heat until it is needed. One such method is to use the heat to warm large tanks of water which, when needed, can be pumped to the peripheral areas of the building. Another method is to use the waste heat to warm a large mass of brick or even the hollow-core concrete of the building structure itself. During the peak heating period a fan can push air through the core of the brick or concrete mass to be warmed and subsequently delivered to the living/working space.

Probably the most common method of heat storage is the heating of a concrete floor slab of a one-story comnercial building. Dften this is accomplished with electrical resistance cable or heating mats placed directly into the concrete. Alternatively, a reservoir of heat can be stored somewhat beneath the concrete floor slab as well as within it. With a layer of sand or 
rock between the heating element and the bottom of the floor slab, the heat storage capacity of the system is effectively increased.

Yet another alternative method is by circulating heated water through pipes that have been embedded in the floor slab. When the water for such a system is heated either with what otherwise would have been waste heat or with heat collected by solar panels, there is more of a potential for energy savings.

Heating with heat that otherwise would have been wasted reduces costs and saves energy directly. In addition, a building with a thermal storage system need not have conventional heating equipment that is sized to worst-case conditions because of the load-leveling capabilities of the thermal storage system. Hence, these systems use somewhat less energy than conventional electric heating, ventilating, and air conditioning (HVAC) systems. They are, however, also primarily designed to shift the heating energy load to the off-peak hours.

\subsection{CURRENT MARKET SITUATION}

Despite the combined incentives of energy savings and off-peak cost of energy savings, thermal storage has not yet become a popular commercial space conditioning option.

According to one report, cool storage technology is presently being used in approximately 100 commercial buildings in the United States, with more under construction (EPRI 1983). However, even with this many cool storage systems presently in operation, there is still surprisingly little information available on their design, performance, economics, operation, and maintenance. Apparently, only a few of the new installations have been monitored for performance in these respects.

It seems that due to the paucity of good information on these systems, the consulting engineers and architects for new commercial buildings still prefer to recommend the installation of conventional HVAC units (EPRI 1983). That is, even though thermal storage systems are not excessively complicated, consulting engineers and building architects are generally unfamiliar with them and regard conventional HVAC units as tried-and-true systems for achieving their design 
objectives. Furthermore, it is likely that this attitude will prevail unless the engineer, architect, or building owner becomes aware of thermal storage space conditioning options (Tamblyn 1982).

The facilities at the Equitec Properties Company's Los Angeles World Trade Center and at the Union 0 il Company of California's Fred L. Hartley Research Center in Brea, California are two notable examples of thermal storage instal1ations. Also, the engineering firms of Engineering Interface, Ltd., Ontario, Canada, and of Thomas Gilbertson and Associates, Moraga, California are two principals in design and installation of thermal storage systems.

An informed estimate of the total number of floor-slab type thermal stor age installations presently in operation could not be found. However, the Mayfran, Inc., building of Cleveland, Ohio is an example of one such installation. Other common trade names for similar systems are Deepheat, Spiroli, Flexicore, Spandeck, Sponcrete, Thermodeck, and Airfloor of California.

\subsection{COST EFFECTIVENESS AND MARKET PENETRATION}

In this section, an example of an assumed prototypical comercial building will be described and analyzed for the potential energy savings and consequent cost savings that could be realized from the installation of a particular thermal storage heating and cooling system. These estimates are then used to calculate the degree to which such systems may penetrate the comercial building space conditioning market by the year 2000 .

\subsubsection{Cost Effectiveness}

Commercial buildings vary a great deal in terms of their physical characteristics (i.e., size, building configuration, and location, etc.) and, consequently, in terms of their heating and cooling load requirements as well. Therefore, for a generalized analysis of this sort, it becomes necessary to establish a benchmark set of characteristics which could conceivably be representative of a typical commercial building in the United States.

Veronika Rab1, manager of cool storage research projects in EPRI's Energy Management and Utilization Division, suggested a hypothetical 100,000-ft ${ }^{2}$ building might be considered appropriate (EPRI 19B3). By her estimate, such a 
conventionally cooled office building would have a load profile that would peak at about $200 \mathrm{~kW}$ during a peak demand period. Alternatively, she suggests, the installation of 1,000 ton-hours of cool storage $(100,000$ gallons of chilled water or about $90,000 \mathrm{lb}$ of ice storage) would reduce the peak of the load profile to less than $100 \mathrm{~kW}$. The cool storage system would likely cost between 20 and 40 thousand dollars more than a conventional full-sized HVAC system. However, such a system would result in about $\$ 7,000$ to $\$ 9,000$ saved annually due to the lower rates for off-peak power. These savings would be in addition to the cost savings due to reduced energy consumption. For this analysis, the higher incremental capital cost figure (i.e., $\$ 40,000)$ is considered to be a more appropriate figure. This is because the higher figure appears to be more representative of cost estimates for similar systems from other sources (see Ayres 1982 and Cassedy 1982).

With regard to cost savings due to an actual reduction of energy consumption, Rabl reports that those are likely to be minimal. (a) Because in the present analysis we are interested in the maximum potential for energy savings, we will use Thomas Gilbertson's estimate that actual electrical power consumption for cooling will be reduced by 5 percent due to nighttime operation and downsized conventional AC units. (b)

The same thermal storage system described above for cooling may be operated in reverse when the heating of the facility is called for. That is, rather than discarding whatever surplus heat a commercial building might generate during an active winter work week, the heat can be collected in the thermal storage system for later redistribution back into the building when the heating of the facility is called for. Using such a system could potentially reduce the electrical heating requirements of the building by up to 20 percent. (c)

\footnotetext{
(a) Personal communication with Veronika Rabl of EPRI on January 17, 1985.

(b) Personal communication with Thomas Gilbertson of Thomas Gilbertson and Associates, Manager, California on January 17, 1985.

(c) Personal communication with Robert Paterson of Cleveland Electrical Illuminating Systems on January 17, 1985.
} 
To determine the actual cost and energy savings contribution of such a system, some other pieces of relevant information must be employed. The estimated average annual electrical energy use $/ \mathrm{ft}^{2}$ of commercial space for 1984 was $36.185 \mathrm{kWh}$ (DOE/EIA 1984). Some 30.3 percent of that electricity is used for cooling and 19.6 percent is used for heating (DDE 1984). Hence, the prototypical 100,000 $\mathrm{ft}^{2}$ commercial building would use an annual average of $1,096,405 \mathrm{kWh}$ for cooling and 528,301 kWh for heating (i.e., total $\mathrm{kWh} / \mathrm{ft}^{2} \mathrm{x}$ percent used for cooling or heating $\times 100,000 \mathrm{ft}^{2} /$ building). Upon the installation and optimal operation of the above described thermal storage system, electrical consumption for cooling could be reduced by $54,820 \mathrm{kWh}$ ( 5 percent of $1,096,405 \mathrm{kWh})$ and for heating by $105,660 \mathrm{kWh}$ (20 percent of $528,301 \mathrm{kWh}$ ). At an average 1983 price of electricity of $7.01 \$ / \mathrm{kWh}$ these energy savings represent reductions in energy expenditures of $\$ 3,892 / \mathrm{yr}$ for cooling and $\$ 7,502 / \mathrm{yr}$ for heating. The reader will recall that these cost savings are in addition to the $\$ 8,000$ reported by Rabl (EPRI 1983) due to the use of cheaper off-peak power. Hence, the total maximum annual energy cost savings would be in the range of $\$ 19,250$. For a system with an incremental capital cost of $\$ 40,000$, these savings represent an approximate two-year payback period.

\subsubsection{Market Penetration}

At present, it appears that the market-penetration potential of thermal storage systems will be moderated by the inherent uncertainties that accompany a new technology. One of the more important questions relates to the appropriate selection of system size and design. This being because commercial buildings vary greatly in their size and function and, consequently, their space conditioning requirements. Other important questions pertain to the operation and the maintenance of such systems which, although not necessarily more complex than conventional HVAC systems, are still far from being widely understood. Basically, the new thermal storage systems are still not well enough understood by building designers to allow proper system fitting and operation for a specific application.

Another serious constraint to the more widespread use of such systems is that in most cases they could not be retrofitted into an existing structure. The tanks of a water or ice storage system are likely to be of such a size as 
to require more space than what could be made available for them and a floor slab system almost certainly would require installation at the time of building construction. Therefore, the market penetration of such systems is restricted to applications in newly constructed buildings.

Keeping these limitations in mind, the reader is referred to Table 4.2 which, for a two year payback, provides an estimate of 65 percent for the maximum percent rate of market penetration. The results of the entire foregoing analysis are presented in Table 11.1.

\subsection{COMMERCIAL BUILDING STOCK AND MARKET SHARE PROJECTIONS}

In this section, a forecast of future additions to total national comercial floor space (DOE/EIA 1984) is employed to estimate the number of square feet of comercial building space likely to be serviced by thermal storage systems in each of the years 1984-2000. Since virtually all commercial space cooling is done with electric power while only about 30 percent of commercial space heating is done with electric power (OOE 1984), it was necessary to perform two separate market-penetration estimations. Table 11.2 presents estimates for the commercial floorspace that is both electrically heated and cooled and Table 11.3 presents estimates for the remainder of the commercial floorspace, which is electrically cooled but not electrically heated. The market share estimates are derived as described in Chapter 4.0 and are based on the payback period and maximum market-penetration estimates presented in Table 11.1 .

These estimates should be regarded as subject to the technical limitations described above. Also, note that a market for the retrofitting of thermal storage units into existing structures is assumed to be nonexistent.

\subsection{NATIONAL ENERGY SAVINGS}

Thermal storage systems can contribute to the reduction of electricity consumption for the purpose of commercial space conditioning. The intent of this section is to use the above per-unit savings estimates and national 
TABLE 11.1. Payback Calculations of a Thermal Storage System for a $100,000 \mathrm{Ft}^{2}$ Commercial Building

\begin{tabular}{|c|c|c|}
\hline & $\begin{array}{l}\text { Base Case } \\
\text { Conventional } \\
\text { HVAC System } \\
\end{array}$ & $\begin{array}{l}\text { New Building with } \\
\text { Built-in Thermal } \\
\text { Storage System } \\
\end{array}$ \\
\hline Incremental Capital Cost $(\$)^{(a)}$ & - & 40,000 \\
\hline $\begin{array}{l}\text { Energy Sayings (Percent) } \\
\text { Heating }(\mathrm{b}) \\
\text { Cooling }(c)\end{array}$ & -- & $\begin{array}{r}20 \\
5\end{array}$ \\
\hline $\begin{array}{l}\text { Annual Energy Consumption } \\
\text { for } 100,000 \text { Square Feet } \\
\text { Heating (kWh) } \\
\text { Cooling (kWh) }\end{array}$ & $\begin{array}{r}528,301 \\
1,096,405 \\
\end{array}$ & $\begin{array}{r}422,641 \\
1,041,585 \\
\end{array}$ \\
\hline Total Heating and Cooling (kWh) & $1,624,706$ & $1,464,226$ \\
\hline $\begin{array}{l}\text { Energy Cost (cents, per kWh) }(e) \\
\text { Annual Fuel Bill } \\
\text { Heating }(\$ / y r) \\
\text { Cooling }(\$ / y r)\end{array}$ & $\begin{array}{l}7.01 \\
37,034 \\
76,858 \\
\end{array}$ & $\begin{array}{l}7.01 \\
29,627 \\
73,015 \\
\end{array}$ \\
\hline $\begin{array}{l}\text { Total Heating and Cooling }(\$ / y r) \\
\text { off-Peak Cost Savings }(\$ / y r)(g)\end{array}$ & $\begin{array}{l}113,892 \\
-- \\
\end{array}$ & $\begin{array}{r}102,642 \\
-8,000 \\
\end{array}$ \\
\hline Total Annual Fuel Bill (\$/yr) & 113,892 & 94,642 \\
\hline Annual Savings on Fuel Bill (\$/yr) & -- & 19,250 \\
\hline Simple Payback Period $(y r)^{(h)}$ & - & 2 \\
\hline Maximum Market Penetration (Percent) $(i)$ & -- & 65 \\
\hline
\end{tabular}

(a) EPRI 1983 (in 1983 dollars).

(b) Personal cormunication with Robert Paterson, Cleveland Electrical Illuminating system, January $17,1985$.

(c) Personal communication with Thomas Gilbertson of Thomas Gilbertson and Associates, Moraga, California on January 17, 1985.

(d) Derived from DOE/EIA 1984 and DOE 1984.

(e) DOE/EIA 1984.

(f) Kilowatt hours times $\$ / \mathrm{kWh}$.

(g) EPRI 1983.

(h) Rounded to nearest complete year.

(i) See Table 4.2. Also, the reader is reminded to consider the market limitations discussed in the above text. Hence, this is a MAXIMUM potential figure. 
TABLE 11.2. Commercial Floorspace Projections and Thermal Storage Market Share Estimates for Electrically Heated and Cooled Buildings

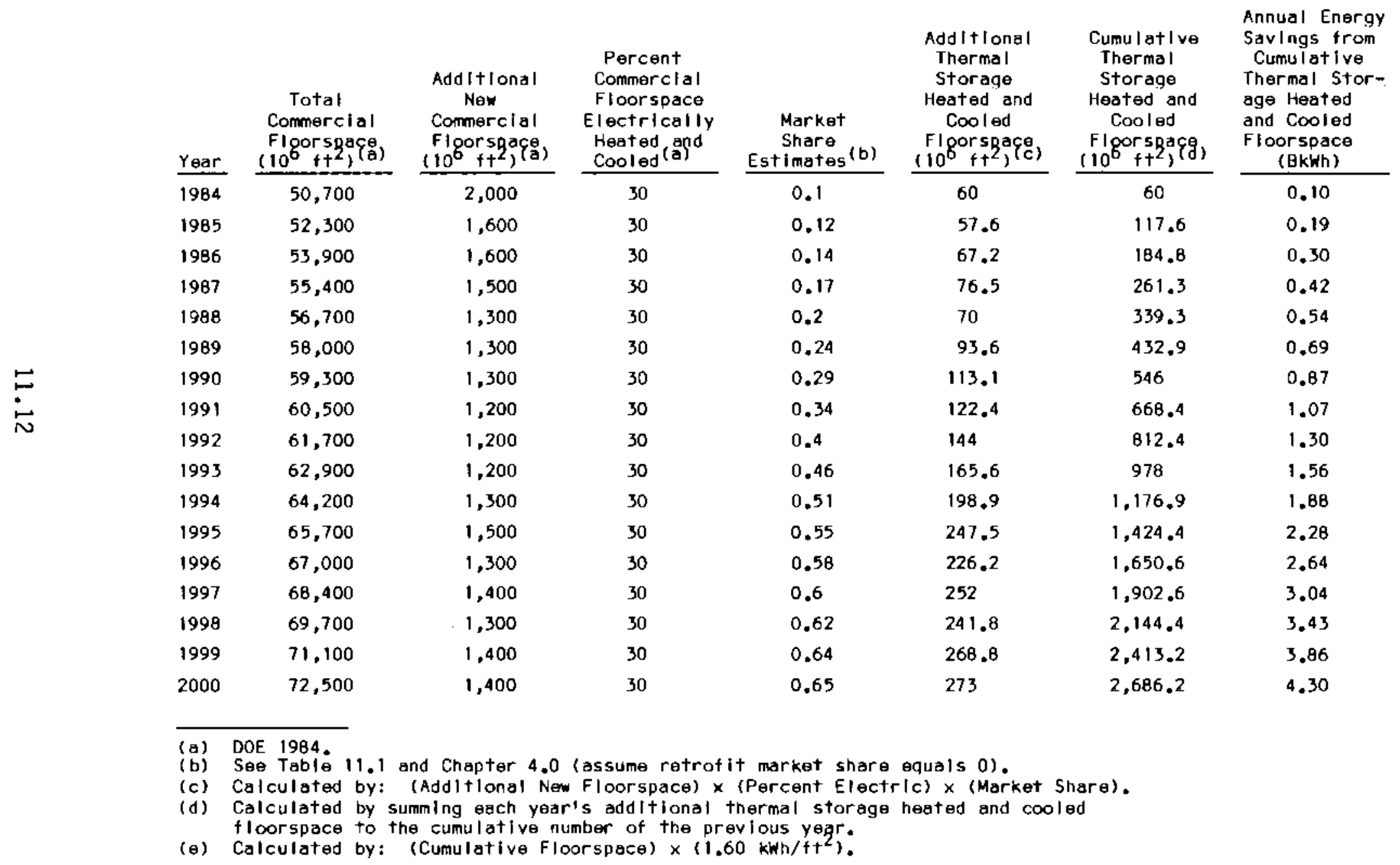


TABLE 11.3. Commercial Floorspace Projections and Themal Storage Market Share Estimates for Electrically Cooled Buildings

\begin{tabular}{|c|c|c|c|c|c|c|c|c|}
\hline & Year & $\begin{array}{c}\text { Total } \\
\text { Commerclal } \\
\text { Flgorspace } \\
\left(10^{8} \mathrm{ft}^{2}\right) \\
\end{array}$ & $\begin{array}{c}\text { Addittonal } \\
\text { New } \\
\text { Commerclal } \\
F 1 \text { gorsgace } \\
\left(10^{8}+t^{2}, \text { a) }\right. \\
\end{array}$ & $\begin{array}{l}\text { Percent } \\
\text { Commerclal } \\
\text { Floorspace } \\
\text { Electrlcal ly } \\
\text { Heated and } \\
\text { Cooled } \\
\end{array}$ & $\begin{array}{c}\text { Market } \\
\text { Share } \\
\text { Estl mates (b) } \\
\end{array}$ & $\begin{array}{l}\text { Addltional } \\
\text { Thermal } \\
\text { Storage } \\
\text { Heated and } \\
\text { Cooled } \\
\text { Floorsgace } \\
\left(10^{6}+t^{2}\right) \text { (c) }\end{array}$ & $\begin{array}{l}\text { Cumulative } \\
\text { Thermal } \\
\text { Storage } \\
\text { Heated and } \\
\text { Cooled } \\
\text { Floorsgaç } \\
\left(10^{6}+\mathrm{t}^{2}\right)(\mathrm{d}) \\
\end{array}$ & $\begin{array}{l}\text { Annual Energy } \\
\text { Savings from } \\
\text { CumulatIve } \\
\text { Thermal Stor- } \\
\text { age Heated } \\
\text { and Cooled } \\
\text { Floorspace } \\
\text { (BkWh) }\end{array}$ \\
\hline & 1984 & 50,700 & 2,000 & 70 & 0.1 & 140 & 140 & 0.08 \\
\hline & 1985 & 52,300 & 1,600 & 70 & 0.12 & 134.4 & 274.4 & 0.15 \\
\hline & 1986 & 53,900 & 1,600 & 70 & 0.14 & 156.8 & 431.2 & 0.24 \\
\hline & 1987 & 55,400 & 1,500 & 70 & 0.17 & 170.5 & 609.7 & 0.34 \\
\hline & 1988 & 56,700 & 1,300 & 70 & 0.2 & 182 & 791.7 & 0.44 \\
\hline & 1989 & 58,000 & 1,300 & 70 & 0.24 & 218.4 & $1,010.1$ & 0.55 \\
\hline ఐ & 1990 & 59,300 & 1,300 & 70 & 0.29 & 260.9 & 1,274 & 0.70 \\
\hline$\dot{-i}$ & 1991 & 60,500 & 1,200 & 70 & 0.34 & 285.6 & $1,559.6$ & 0.85 \\
\hline$\omega$ & 1992 & 61,700 & 1,200 & 70 & 0.4 & 336 & $1,895.6$ & 1.04 \\
\hline & 1993 & 62,900 & 1,200 & 70 & 0.46 & 386.4 & 2,282 & 1.25 \\
\hline & 1994 & 64,200 & 1,300 & 70 & 0.51 & 464.1 & $2,746.1$ & 1.51 \\
\hline & 1995 & 65,700 & 1,500 & 70 & 0.55 & 577.5 & $3,323.6$ & 1.83 \\
\hline & 1996 & 67,000 & 1,300 & 70 & 0.58 & 527.8 & $3,851.4$ & 2.11 \\
\hline & 1997 & 68,400 & 1,400 & 70 & 0.6 & 588 & $4,439.4$ & 2.44 \\
\hline & 1998 & 69,700 & 1,300 & 70 & 0.62 & 364.2 & $5,003,6$ & 2.75 \\
\hline & 1999 & 71,100 & 1,400 & 70 & 0.64 & 627.2 & $3,630.8$ & 3.09 \\
\hline & 2000 & 72,500 & 1,400 & 70 & 0.65 & 637 & $6,267.8$ & 3.45 \\
\hline & $\begin{array}{l}\text { (a) } \\
\text { (b) } \\
\text { (c) } \\
\text { (d) } \\
\text { (e) }\end{array}$ & \multicolumn{7}{|l|}{$\begin{array}{l}\text { DOE 1984. } \\
\text { See Table 11.1 } \\
\text { Calculated by: } \\
\text { Calculated by } \\
\text { flcorspace to t } \\
\text { Calculated by: }\end{array}$} \\
\hline
\end{tabular}


market-penetration projections to assess the degree to which thermal storage could potentially reduce national electrical consumption in each of the years 1984-2000.

The above described representative $100,000 \mathrm{ft}^{2}$ commercial building that employs a thermal storage system would obtain estimated annual savings of $0.5482 \mathrm{kWh} / \mathrm{ft}^{2}$ for cooling services alone and $1.6048 \mathrm{kWh} / \mathrm{ft}^{2}$ for both heating and cooling services combined. Therefore, the national annual electrical savings can be computed by multiplying these savings estimates by the projected number of square feet of commercial space conditioned by a thermal storage system (see the final columns of Tables 11.2 and 11.3).

The dichotomy between the cooled-only and the heated-and-cooled combined categories is because commercial space heating is just 30 percent electric, while space cooling is close to 100 percent electric. Hence, the total annual electrical savings is determined by simply combining the projected savings of the two categories for a given year. These national annual electrical energy savings results are presented in Table 11.4 .

The estimated electrical power savings in the year 2000 due to thermal storage is $7.75 \mathrm{BkWh}$. By comparison, the estimated 1984 national total for commerciat electrical consumption is 680.22 BkWh (DOE/EIA 1984). Hence, the total estimated savings represent approximately 1 percent of the 1984 figure for total consumption. Furthermore, because the above described technical 1 imitations are likely to inhibit the degree of market penetration to less than

TABLE 11.4. Estimated National Annual Electrical Savings from New Commercial Thermal Storage Installations (BKWh)

\begin{tabular}{ccccc} 
Year & $\begin{array}{c}\text { Savings for Commercial } \\
\text { Floorspace Electrically } \\
\text { Heated and Cooled }\end{array}$ & $\begin{array}{c}\text { Savings for Commercial } \\
\text { Floorspace Electrically } \\
\text { Cooled Dnly }\end{array}$ & \multicolumn{2}{c}{$\begin{array}{c}\text { Total Electrical } \\
\text { Savings of Thermal } \\
\text { Storage Systems }\end{array}$} \\
\cline { 2 - 3 } 1985 & 0.19 & & 0.15 & 0.34 \\
1990 & 0.87 & 0.70 & 1.57 \\
1995 & 2.28 & 1.83 & 4.11 \\
2000 & 4.30 & 3.45 & 7.75
\end{tabular}


the estimated maximum of 65 percent, the energy savings are probably overestimated. It is, however, also important not to let these estimates obscure the more meaningful "load-leveling" contribution of thermal storage systems. The potential for such systems to shift power consumption from peak-use periods to off-peak-use periods helps to alleviate the necessity for building new generating capacity by improving load factors.

It is clear that portions of the above analysis were treated in a somewhat simplistic fashion so that the task could be completed within the available resource limitations. Some of the more consequential simplifications include the employment of a specific scenario of assumed future electrical and product prices, assumed market-penetration rates, the abstraction from climatic differences, and assumed "representative" technology-related energy savings. Such simplifications, although appropriate within the scope of this analysis, should be kept in mind when one is determining the level of confidence that these estimates deserve. In that regard, it is appropriate to assess the sensitivity of the above results to alterations in the scenario.

\subsection{SENSITIVITY ANALYSIS}

This section is an assessment of the sensitivity of the aggregate energy savings results presented in Section 11.5 to changes in the thermal storage market-penetration scenarios. Low and high market-penetration scenarios are examined to determine an implied minimum/maximum range of potential future energy savings.

\subsubsection{Low Market-Penetration Scenario}

Thermal storage systems may not penetrate the commercial HVAC market as quickly or as completely as suggested by the above base-case estimates. For example, the previously mentioned technical limitations may inhibit the market penetration of such systems to levels significantly below those that simple cost studies might otherwise imply.

The specific assumption for the low market-penetration scenario is that the maximum potential level of penetration is only half of what it was estimated to be in the base case scenario. That is, the maximum potential market 
share was reduced from a 0.65 market share to a 0.325 market share. Furthermore, the assumed rate of penetration was reduced such that only 75 percent of that new maximum potential market share will be reached by the year 2000 . Tables 11.5 and 11.6 employ that scenario with a forecast of national additions to comercial floorspace to obtain a low penetration estimate of the number of square feet of floorspace that would be space conditioned by a thermal storage system.

\subsubsection{National Annual Electrical Energy Savings Estimates - Low Scenario}

The national annual electrical energy savings estimates for the low market-penetration scenario of thermal storage systems are presented in the final columns of Tables 11.5 and 11.6 and summarized in Table 11.7. The estimates were obtained by multiplying the year's estimated number of square feet of thermal storage, space conditioned buildings from the scenario times the estimates of the per unit annual electrical energy savings. These result could be interpreted as being indicative of a reasonable minimum of the expected electrical energy savings from the new thermal storage systems.

\subsubsection{High Market-Penetration Scenarios}

Under certain conditions, thermal storage systems may penetrate the market more rapidly than Tables 11.2 and 11.3 indicate. For example, if the government or certain utilities should decide that it would be a good investment to subsidize the installation of such measures, then the probable number of such installations would be enhanced. Hence, it is proper that the implications of that possibility be further investigated.

Specifically, the high market penetration scenario assumes that the maximum market share is achieved by 1995 instead of by the year 2000. Tables 11.8 and 11.9 combine that scenario with a forecast of future comercial building space to arrive at high penetration estimates of the future number of square feet of thermal storage, space conditioned buildings.

\subsubsection{National Annual Electrical Energy Savings Estimates - High Scenario}

The national annual electrical energy savings estimates for the high market penetration scenario of the thermal storage systems are displayed in 
TABLE 11.5. Commercial Floorspace Projections and Low Market Share Scenario of Thermal Storage Systems for Electrically Heated and Cooled Buildings

\begin{tabular}{|c|c|c|c|c|c|c|c|}
\hline Year & $\begin{array}{c}\text { Total } \\
\text { Commerclal } \\
\text { FIgorspoc日) } \\
\left(10^{6}+t^{2}\right)\end{array}$ & $\begin{array}{c}\text { Additional } \\
\text { New } \\
\text { Commerclal } \\
\text { Flgorspace } \\
\left(10^{6}+t^{2}\right)(a) \\
\end{array}$ & $\begin{array}{l}\text { Percent } \\
\text { Commerclal } \\
\text { Floorspace } \\
\text { Electrical Iy } \\
\text { Heated and } \\
\text { Cooled } \\
\end{array}$ & $\begin{array}{c}\text { Market } \\
\text { Share } \\
\text { Est1mates } \\
\end{array}$ & $\begin{array}{l}\text { Additlonal } \\
\text { Thermal } \\
\text { Storage } \\
\text { Heated and } \\
\text { Cooled } \\
\text { Flgorspace } \\
\left(10^{6} \mathrm{ft}^{2}\right)(\mathrm{C}) \\
\end{array}$ & $\begin{array}{c}\text { Cumulative } \\
\text { Thermal } \\
\text { Storage } \\
\text { Heated and } \\
\text { Cooled } \\
\text { Floorspace } \\
\left(10^{6} \mathrm{ft}^{2}\right)(\mathrm{g}) \\
\end{array}$ & $\begin{array}{l}\text { Annual Energy } \\
\text { Savings from } \\
\text { Cumulative } \\
\text { Thermal Stor- } \\
\text { age Heated } \\
\text { and Cooled } \\
\text { Floorspace } \\
\text { (BkWh) } \\
\end{array}$ \\
\hline 1984 & 50,700 & 2,000 & 30 & 0.1 & 60 & 60 & 0.1 \\
\hline 1985 & 52,300 & 1,600 & 30 & 0.104 & 49.92 & 109.92 & 0.18 \\
\hline 1986 & 53,900 & 1,600 & 30 & 0.11 & 52.8 & 162.72 & 0.26 \\
\hline 1987 & 55,400 & 1,500 & 30 & 0.12 & 54 & 216.72 & 0.35 \\
\hline 1988 & 56,700 & 1,300 & 30 & 0.13 & 50.7 & 267.42 & 0.43 \\
\hline 1989 & 58,000 & 1,300 & 30 & 0.145 & 56.55 & 323.97 & 0.52 \\
\hline 1990 & 59,300 & 1,300 & 30 & 0.16 & 62.4 & 386.37 & 0.62 \\
\hline 1991 & 60,500 & 1,200 & 30 & 0.18 & 64.8 & 451.17 & 0.72 \\
\hline 1992 & 61,700 & 1,200 & 30 & 0.195 & 70.2 & 521.37 & 0.83 \\
\hline 1993 & 62,900 & 1,200 & 30 & 0.205 & 73.8 & 595.17 & 0.95 \\
\hline 1994 & 64,200 & 1,300 & 30 & 0.212 & 82.68 & 677.85 & 1.08 \\
\hline 1995 & 65,700 & 1,500 & 30 & 0.219 & 98.55 & 776.4 & 1.24 \\
\hline 1996 & 67,000 & 1,300 & 30 & 0.225 & 87.75 & 864.15 & 1.38 \\
\hline 1997 & 68,400 & 1,400 & 30 & 0.23 & 96.6 & 960.75 & 1.54 \\
\hline 1998 & 69,700 & 1,300 & 30 & 0.235 & 91.65 & $1,052.4$ & 1.68 \\
\hline 1999 & 71,100 & 1,400 & 30 & 0.24 & 100.8 & $1,153.2$ & 1.84 \\
\hline 2000 & 72,500 & 1,400 & 30 & 0.244 & 102.48 & $1,255.68$ & 2.01 \\
\hline $\begin{array}{l}\text { (a) } \\
\text { (b) } \\
\text { (c) } \\
\text { (d) }\end{array}$ & \multicolumn{7}{|c|}{$\begin{array}{l}\text { DOE } 1984 . \\
\text { See Table } 11.1 \text { and Chapter } 4.0 \text { (Additional New } \\
\text { Calculated by: (Ading } \\
\text { Calculated by suming esch year' } \\
\text { floorspace to the cumulative num } \\
\text { Calculated by: (Cumulatlve Floo }\end{array}$} \\
\hline
\end{tabular}


TABLE 11.6. Commercial Floorspace Projections and Low Market Share Scenario of Thermal Storage Systems for Electrically Cooled Buildings

\begin{tabular}{|c|c|c|c|c|c|c|c|}
\hline Year & $\begin{array}{c}\text { Total } \\
\text { Commerclal } \\
\text { FIgorsgace } \\
\left(10^{6}+t^{2}\right)(a) \\
\end{array}$ & $\begin{array}{c}\text { Additional } \\
\text { New } \\
\text { Commercial } \\
\text { Floorspaçe } \\
\left(10^{6}+t^{2}\right) \\
\end{array}$ & $\begin{array}{l}\text { Percent } \\
\text { Commercial } \\
\text { Floorspace } \\
\text { Electrlcally } \\
\text { Heated and } \\
\text { Cooled (a) } \\
\end{array}$ & $\begin{array}{c}\text { Market } \\
\text { Share (b) } \\
\text { EstImates } \\
\end{array}$ & $\begin{array}{l}\text { Additional } \\
\text { Thermal } \\
\text { Storage } \\
\text { Heated and } \\
\text { Cooled } \\
\text { Floorspoce } \\
\left(10^{6}+\mathrm{f}^{2}\right)(\mathrm{c}) \\
\end{array}$ & $\begin{array}{c}\text { Cumul atlve } \\
\text { Thermal } \\
\text { Storage } \\
\text { Heated and } \\
\text { Cooled } \\
\text { Floorsgaç, } \\
\left(10^{6}+\mathrm{t}^{2}\right) \text { (g) } \\
\end{array}$ & $\begin{array}{l}\text { Annual Energy } \\
\text { Savings from } \\
\text { Cumulatlve } \\
\text { Thermal Stor- } \\
\text { age Heated } \\
\text { and Cooled } \\
\text { Floorspace } \\
\text { (日kwh) }\end{array}$ \\
\hline 1984 & 50,700 & 2,000 & 70 & 0.1 & 140 & 140 & 0.08 \\
\hline 1985 & 52,300 & 1,600 & 70 & 0.104 & 116.48 & 256.48 & 0.14 \\
\hline 1986 & 53,900 & 1,600 & 70 & 0.11 & 123.2 & 379.68 & 0.21 \\
\hline 1987 & 55,400 & 1,500 & 70 & 0.12 & 126 & 505.68 & 0.27 \\
\hline 1988 & 56,700 & 1,300 & 70 & 0.13 & 118.3 & 623.98 & 0.34 \\
\hline 1989 & 58,000 & 1,300 & 70 & 0.145 & 131.95 & 755.93 & 0.42 \\
\hline 1990 & 59,300 & 1,300 & 70 & 0.16 & 145.6 & 901.53 & 0.50 \\
\hline 1991 & 60,500 & 1,200 & 70 & 0.18 & 151.2 & $1,052.73$ & 0.58 \\
\hline 1992 & 61,700 & 1,200 & 70 & 0.195 & 163.8 & $1,216.53$ & 0.67 \\
\hline 1993 & 62,900 & 1,200 & 70 & 0.205 & 172.2 & $1,388.73$ & 0.76 \\
\hline 1994 & 64,200 & 1,300 & 70 & 0.212 & 192.92 & $1,581.65$ & 0.87 \\
\hline 1995 & 65,700 & 1,500 & 70 & 0.219 & 229.95 & $1,811.6$ & 0.99 \\
\hline 1996 & 67,000 & 1,300 & 70 & 0.225 & 204.75 & $2,016.35$ & 1.11 \\
\hline 1997 & 68,400 & 1,400 & 70 & 0.23 & 225.4 & $2,241,75$ & 1.23 \\
\hline 1998 & 69,700 & 1,300 & 70 & 0.235 & 213.85 & $2,455,6$ & 1.35 \\
\hline 1999 & 71,100 & 1,400 & 70 & 0.24 & 235.2 & $2,690,8$ & 1.48 \\
\hline 2000 & 72,500 & 1,400 & 70 & 0.244 & 239.12 & $2,929,92$ & 1.61 \\
\hline $\begin{array}{l}\text { (a) } \\
\text { (b) } \\
\text { (c) } \\
\text { (d) } \\
\text { (e) }\end{array}$ & $\begin{array}{l}\text { DOE 1984. } \\
\text { See Table } 11.1 \\
\text { Calculated by: } \\
\text { Calculated by } \\
\text { floorspace to } \\
\text { Calculated by: }\end{array}$ & $\begin{array}{l}\text { and Chapter } \\
\text { (Additional } \\
\text { summing each } \\
\text { the cumulativ } \\
\text { (Cumulative }\end{array}$ & $\begin{array}{l}4.0 \text { (assume retr } \\
\text { New Floorspace) } \\
\text { year's add itiona } \\
\text { e number of the } \\
\text { Floorspace) } x\end{array}$ & $\begin{array}{l}\text { it market sha } \\
\text { c (Percent Ele } \\
\text { thermal stora } \\
\text { evilous yegr. } \\
55 \mathrm{kWh} / \mathrm{ft}^{2} \text { ). }\end{array}$ & $\begin{array}{l}\text { equals } 0 \text { ). } \\
\text { ric) } x \text { (Market } \\
\text { heated and co }\end{array}$ & $\begin{array}{l}\text { Share). } \\
\text { oled }\end{array}$ & \\
\hline
\end{tabular}


TABLE 11.7. Estimated National Annual Electrical Savings from New Commercial Thermal Storage Installations - Low Market-Penetration Scenario (BkWh)

\begin{tabular}{ccccc} 
Year & $\begin{array}{c}\text { Savings for Commercial } \\
\text { Floorspace Electrically } \\
\text { Heated and Cooled }\end{array}$ & $\begin{array}{c}\text { Savings for Commercial } \\
\text { Floorspace Electrically } \\
\text { Cooled Only }\end{array}$ & $\begin{array}{c}\text { Total Electrical } \\
\text { Savings of Thermat } \\
\text { Storage Systems }\end{array}$ \\
\cline { 2 - 3 } 1985 & 0.18 & 0.14 & 0.32 \\
1990 & 0.62 & 0.50 & 1.13 \\
1995 & 1.24 & 0.99 & 2.23 \\
2000 & 2.01 & 1.61 & 3.62
\end{tabular}

Tables 11.8 and 11.9 and summarized in Table 11.10. These estimates were arrived at by muttiplying the year's estimated number of square feet of thermal storage, space conditioned buildings from the high scenario times the estimates of the per unit annual electrical energy savings from the thermal storage systems. They are representative of a plausible maximum for the expected future electrical energy savings from those systems.

\subsection{COST/kWh OF ENERGY SAVED CALCULATIONS AND COMPARISONS TO THE COST/KWh OF PROOUCING NEW GENERATION CAPACITY}

The thermal storage systems may be considered as investments the return for which is a reduction in the future amount of energy that must be purchased for a given level of space conditioning. If the cost/kWh of those energy savings is less than the cost/kWh of producing that power, then the undertaking of such investments would contribute to both private and social welfare.

The calculations of the cost/kwh saved for heating, cooling, and heating and cooling combined due to thermal storage systems are presented in Table 11.11. These estimated costs may be compared to the national average cost of about $5.21 \$ / \mathrm{kWh}$ for producing new generating capacity from a new coalfired generating plant (see Table 4.3).

The specific indications are that the costs of new thermal storage installations are significantly less than the cost of new power for the purposes of 
TABLE 11.8. Commercial Floorspace Projections and High Market Share Scenario of Thermal Storage Systems for Electrically Heated and Cooled Buildings

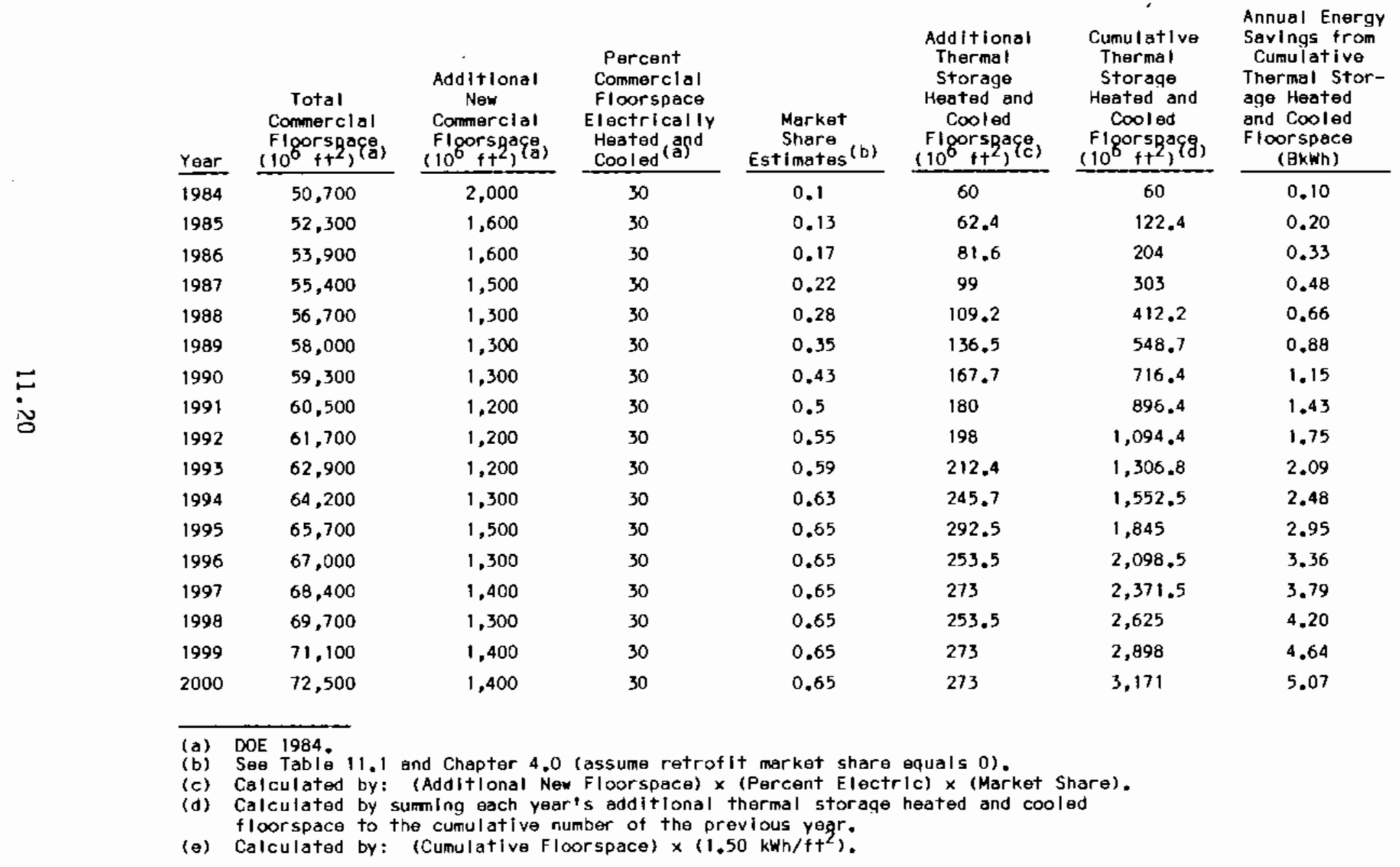


TABLE 11.9. Commercial Floorspace Projections and High Market Share Scenarios of Thermal Storage Systems for Electrically Cooled Buildings

\begin{tabular}{|c|c|c|c|c|c|c|c|c|}
\hline & Year & $\begin{array}{c}\text { Total } \\
\text { Commerciol } \\
\text { Floorspocf) } \\
\left.\left(10^{8}+\mathrm{f}^{2}\right)^{8}\right) \\
\end{array}$ & $\begin{array}{c}\text { Additlonal } \\
\text { New } \\
\text { Commerclal } \\
\text { FIporspac8) } \\
\left(10^{\circ}+f^{2}\right)\end{array}$ & $\begin{array}{c}\text { Percent } \\
\text { Commerclal } \\
\text { Floorspace } \\
\text { Electrically } \\
\text { Heated (and } \\
\text { Cooled } \\
\end{array}$ & $\begin{array}{c}\text { Market } \\
\text { Share } \\
\text { Est1mates (b) } \\
\end{array}$ & 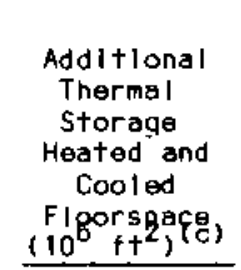 & $\begin{array}{l}\text { Cumulative } \\
\text { Thermal } \\
\text { Storage } \\
\text { Heated and } \\
\text { Cooled } \\
\text { Floorspaç, } \\
\left(10^{8}+\mathrm{f}^{2}\right)(\mathrm{d}) \\
\end{array}$ & $\begin{array}{l}\text { Annual Energy } \\
\text { Savings from } \\
\text { Cumulatlve } \\
\text { Thermal Stor- } \\
\text { age Heated } \\
\text { and Cooled } \\
\text { Floorspace } \\
\text { (BkHh) }\end{array}$ \\
\hline & 1984 & 50,700 & 2,000 & 70 & 0.1 & 140 & 140 & 0.08 \\
\hline & 1985 & 52,300 & 1,600 & 70 & 0.13 & 134.4 & 274.4 & 0.15 \\
\hline & 1987 & 55,400 & 1,500 & 70 & 0.22 & 199.5 & 641.9 & 0.35 \\
\hline & 1988 & 56,700 & 1,300 & 70 & 0.28 & 218.4 & 860.3 & 0.47 \\
\hline & 1989 & 58,000 & 1,300 & 70 & 0.35 & 273 & $1,133.3$ & 0.62 \\
\hline$\sqsubseteq$ & 1990 & 59,300 & 1,300 & 70 & 0.43 & 336.7 & 1,470 & 0.81 \\
\hline & 1991 & 60,500 & 1,200 & 70 & 0.5 & 378 & 1,848 & 1.02 \\
\hline & 1992 & 61,700 & 1,200 & 70 & 0.55 & 436.8 & $2,284,8$ & 1.26 \\
\hline & 1993 & 62,900 & 1,200 & 70 & 0.59 & 487.2 & 2,772 & 1.52 \\
\hline & 1995 & 65,700 & 1,500 & 70 & 0.65 & 682.5 & $4,018.7$ & 2.21 \\
\hline & 1996 & 67,000 & 1,300 & 70 & 0.65 & 591.5 & $4,610.2$ & 2.53 \\
\hline & 1997 & 68,400 & 1,400 & 70 & 0.65 & 637 & $5,247.2$ & 2.89 \\
\hline & 1998 & 69,700 & 1,300 & 70 & 0.65 & 591.5 & $5,838.7$ & 3.21 \\
\hline & 1999 & 71,100 & 1,400 & 70 & 0.65 & 637 & $6,475.7$ & 3.56 \\
\hline & 2000 & 72,500 & 1,400 & 70 & 0.65 & 637 & $7,112.7$ & 3.91 \\
\hline & $\begin{array}{l}\text { (a) } \\
\text { (b) } \\
\text { (c) } \\
\text { (d) } \\
\text { (a) }\end{array}$ & \multicolumn{7}{|l|}{$\begin{array}{l}\text { DOE } 1984 \text {. } \\
\text { See Table } 11.1 \\
\text { Calculated by: } \\
\text { Calculated by } \\
\text { floorspace to } \\
\text { Calculated by: }\end{array}$} \\
\hline
\end{tabular}


TABLE 11.10. Estimated National Annual Electrical Savings from New Commercial Thermal Storage Installations - High Market-Penetration Scenario (BkWh)

\begin{tabular}{ccccc} 
Year & $\begin{array}{c}\text { Savings for Commercial } \\
\text { Floorspace Electrically } \\
\text { Heated and Cooled }\end{array}$ & $\begin{array}{c}\text { Savings for Commercial } \\
\text { Floorspace Electrically } \\
\text { Cooled Only }\end{array}$ & $\begin{array}{c}\text { Total Electrical } \\
\text { Savings of Thermal } \\
\text { Storage Systems }\end{array}$ \\
\cline { 2 - 2 } & 0.20 & 0.15 & 0.35 \\
1990 & 1.15 & & 0.81 & 1.96 \\
1995 & 2.95 & 2.21 & 5.16 \\
2000 & 5.07 & 3.91 & 8.98
\end{tabular}

TABLE 11.11. Cost/kWh Calculations of a Thermal Storage System

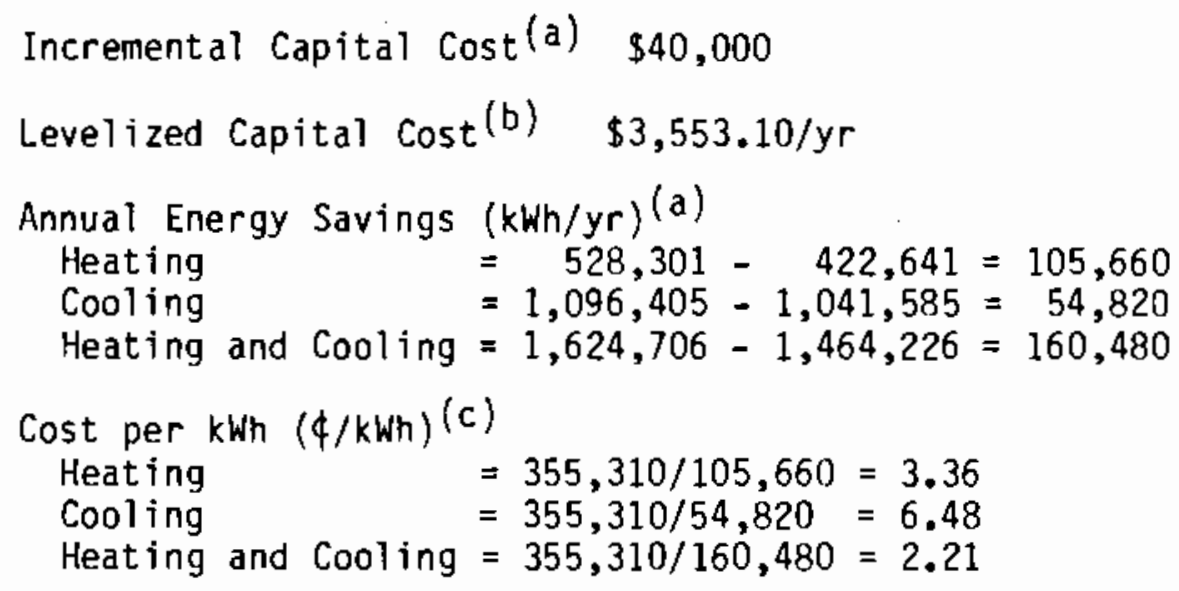

(a) See Table 11.1.

(b) The level stream of annual payments the present value of which would equal the investment's incremental capital cost. Assumes a 30 year useful lifetime of the investment and an 8 percent rate of interest compounded annually.

(c) Levelized Capital Cost $(x 100 \$ / \$) /$ Annual Energy Savings .

heating and for heating and cooling combined. In general, it appears that the advanced thermal efficiency measures are likely to be good investments and deserve more detailed consideration on a more regional basis. 


\subsection{REFERENCES FOR CHAPTER 11.0}

Anderson, L. 0., et a1. 1979. Storage of Heat and Coolth in Hollow-Core Concrete Slabs. Swedish Experience, and Application to Large, American-Style Buildings. [BL-8913. Lawrence Berkeley Laboratory, Berkeley, California.

Ayres, J. M. 1982. "Design and Sizing of Ice and Chilled Water Storage Systems." Seminar proceeding in Thermal Energy Storage: Cooling Commercial Buildings Using off-Peak Energy. Electric Power Research Institute (EPRI), Palo Alto, California. February 1982. Pages 6-1 to 6-17.

Block, D. A. and L. Hodges. 1979. "Use of Concrete Cored Slabs for Passive Cooling in an Iowa Residence." Proceedings of Kansas City ISES Conference. p. 488 .

Cassedy, Edward K. 1982. "Cooling Storage in a Large Department Store - Baltimore Gas and Electric Company." Seminar proceeding in Thermal Energy Storage: Cooling Commercial Buildings Using Off-Peak Energy. Electric Power Research Institute (EPRI), Palo Alto, California. February 1982. Pages 4-1 to $4-10$.

Dean, E. T. and C. F. Barnaby, 1979. "Alternatives for Utilizing the Thermal Mass of Structural Systems for Energy Conservation." Report to the BEV Program, Lawrence Berkeley Laboratory, Berkeley, California.

Electric Power Research Institute (EPRI) Journal. 1983. "Cooling Commercial Buildings with off-peak Power." October 1983.

Electric Power Research Institute (EPRI). 1983. "Opportunities in Thermal Storage R and D." Special Report, July 1983.

Pollack, K. 1983. "Energy Storage, Four Major Alternatives: Heat Storage, Cool Storage, Compressed Air Energy Storage, and Underground Pumped Hydro Storage." Inform, Inc., New York 1983.

Tamblyn, R. T. 1982. "Grappling with the Gremlins for Thermal Storage Applications." Seminar proceedings in Thermal Energy Storage: Cooling Commercial Buildings Using off-Peak Energy. ETectric Power Research Institute (EPRI), Palo Alto, Calffornia. February 1982. pp. 7-1 to 7-30.

DOE/EIA. 1984. Annual Energy Outlook 1983: With Projections to 1995. DOE/EIA-0383(83). U.S. Department of Energy, Energy Information Administration, Washington, D.C. May 1984.

DOE/EIA. 1984. Annual Energy Review 1984. U.S. Department of Energy/Energy Information Administration. Washington, D.C. 
DOE. 1984. Energy Conservation Multi-Year Plan. FY 1986-FY 1990. U.S. Department of Energy, Office of Conservation, Washington, D.C., July 1984.

DOE. 1983. Energy Projections to the Year 2010. Office of Policy, Planning, 


\subsection{HIGH-EFFICIENCY ELECTRIC MOTORS}

High-efficiency electric motors have the potential to produce significant electrical energy savings in the industrial sector by reducing the electrical losses of electric motors. Electric motors are by far the largest end-user of electricity in the industrial sector. In 1980, electric motor drives consumed approximately 63 percent of all electricity used in this sector (EPRI 1984).

Current industrial electric motors are relatively efficient. However, because of the large number and size of electric motors in the industrial sector, even a small increase in efficiency can result in significant electricity savings.

\subsection{TECHNOLOGY DESCRIPTION}

High-efficiency electric motors improve motor efficiency by reducing energy losses that occur internally. In an electric motor (see Figure 12.1), an electromagnetic field is created to produce force that turns a drive shaft. The two components of a motor that produce voltage for the creation of the electromagnetic field are known as the stator and the rotor. Because they are not perfect conductors of electricity, some of the energy supplied to the stator and rotor is lost due to resistance.

The mechanical parts of an electric motor include a frame to hold the stator, a drive shaft, a cooling fan, and end shields with bearings. Friction produced by the actions of these mechanical parts also increases electricity consumption.

Various material and design changes are employed in high-efficiency motors to reduce energy losses. These changes are not standardized across all motors. However, some common design changes employed in high-efficiency motors include (Hunt et al. 1976): 


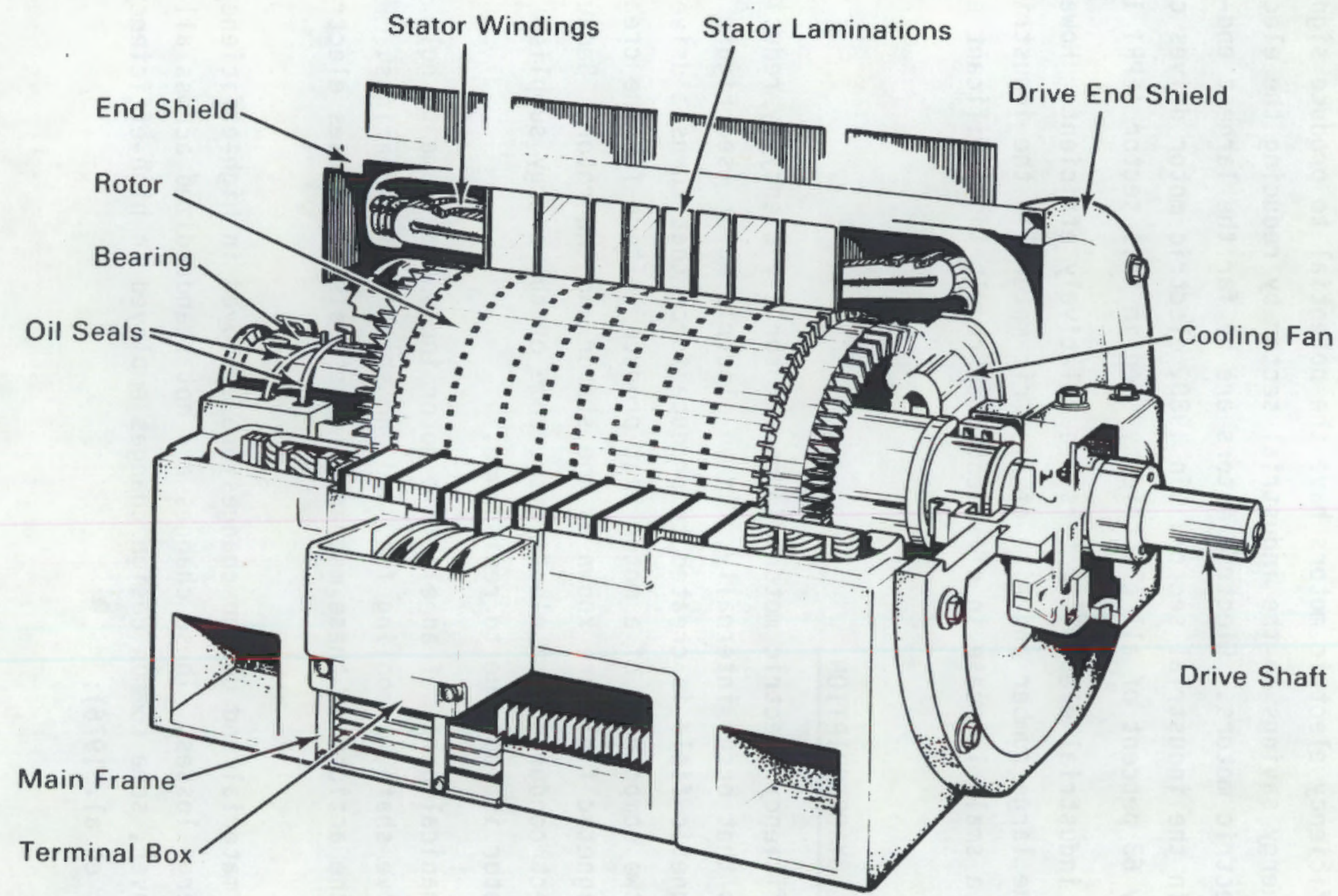

FIGURE 12.1. Large Polyphase AC Industrial Motor 
- longer rotor and stator cores that reduce the density of the electromagnetic field of the motor and increase the conductivity of the rotor and stator to electrical input

- thinner rotor and stator cores that reduce the amount of current lost through the outside of the rotor and stator

- use of silicon steel rather than carbon steel in rotor and stator cores to reduce the amount of energy lost in the creation of the electromagnetic field.

High-efficiency motors can be operated in the same manner as standard electric motors and their expected operating $l i f e t i m e s$ should also be equal to that of standard motors. However, higher cost materials are used in highefficiency motors and this increases their cost (Hane et al. 1983). Thus, a potential purchaser must decide whether the electricity savings of the motor will justify a higher purchase price.

A number of studies (Hane et al. 1983, Hunt et al. 1976, and Argonne National Laboratory 1980) indicate that industrial users of electric motors will generally not replace standard electric motors with high-efficiency motors unless the standard electric motors are no longer operating properly. The costs of motor installation and disrupting industrial operations are perceived to exceed any potential energy cost savings that could result from improving electric motor efficiencies. Thus, this analysis of high-efficiency motors will be limited to new and retirement applications of such motors and will exclude retrofit applications.

The market penetration and energy savings potential of high-efficiency motors will vary substantially depending upon many factors, and one factor that is crucial is motor size. Thus, this analysis is segmented into five motorsize categories: 1 to 5 horsepower (HP) motors, 5 to $20 \mathrm{HP}$ motors, 20 to $50 \mathrm{HP}$ motors, 50 to $125 \mathrm{HP}$ motors and motors larger than $125 \mathrm{HP}$. Motors of less than 1 HP in size were excluded from analysis because of their small potential for energy savings (Argonne National Laboratory 1980). 
Because many factors affect the cost effectiveness of high-efficiency motors, this analysis can only provide an estimation of these motors marketpenetration potential and energy-savings potential. The chapter begins by describing the current market situation.

\subsection{CURRENT MARKET SITUATION}

High-efficiency electric motors have been available for several years (Hunt et al. 1976). However, according to one manufacturer interest in purchases of high-efficiency electric motors has increased dramatically in the last two years. (a)

The rate of market penetration for high-efficiency electric motors has been slow because electricity costs of motors is a small percentage of total manufacturing costs, the costs of retrofitting electric motors is perceived to be high and the rate of retirement of electric motors is slow. (b) However, virtually all electric motor vendors contacted stated that high-efficiency motors are being purchased in increasing numbers in situations where 1) a motor needs replacing because it no longer operates properly, or 2) a completely new motor drive process is being installed.

Many of the major electric motor manufacturers, including General Electric, Century Electric, Emerson Electric, and Siemans-Allis manufacture high-efficiency electric motors. (c) Thus, the comercial availability of this conservation technology is high. Normally, manufacturers offer both standardefficiency and high-efficiency motors for a given application and, in some cases, three efficiency levels are offered.

The electricity savings from the use of high-efficiency electric motors depend on the usage rate and size of the motors, and other factors. Sales of

(a) Personal comnunication with Silby Carroll, Electric Apparatus Company, Howe11, Michigan, November 15, 1984.

(b) Personal communication with Frank Seabury, Arthur D. Little, Cambridge, Massachusetts, November 15, 1984.

(c) Personal communication with John Matthews, a sales representative for K\&N Electric, Spokane, Washington, November 15, 1984. 
high-efficiency motors of less than I HP are significantly lower proportionately than sales of high-efficiency motors in the larger horsepower classes. (a)

Vendors of electric motors that were contacted indicated that the development and marketing of electric motors has been driven by the demand for such motors on the part of motor purchasers. One representative of a custom motor manufacturer stated that it is becoming increasingly cormon for purchasers of electric motors to require in their bid specifications that an electric motor attain a minimum level of efficiency. (b) Motor manufacturers have responded to such demands by developing entire lines of high-efficiency electric motors. (c)

\subsection{COST EFFECTIVENESS AND MARKET PENETRATION}

Evaluations of the cost effectiveness and likely market penetration of high-efficiency electric motors are presented in this section. These evaluations begin with the presentation of information on representative incremental capital costs and payback periods for the various size categories of highefficiency electric motors. These estimates are then integrated with information on technical factors that could inhibit the use of high-efficiency electric motors to derive estimates of the maximum potential market penetration of high-efficiency motors.

\subsubsection{Cost Effectiveness of High-Efficiency Motors}

The cost effectiveness of high-efficiency electric motors, as measured by their incremental capital costs and payback periods, are dependent upon their capital costs, energy savings and dollar savings compared to standard motors. All of these factors are addressed in this section.

(a) Personal communication with John Allen, Emerson Electric Co., St. Louis, Missouri, November 16, 1984.

(b) Personal communication with Silby Carroll, Electric Apparatus Co., Howell, Michigan, November 15, 1984.

(c) Unpublished product Iine catalogue from Century Electric Co., St. Louis, Missouri, November 1984. 
Representative Capital Costs for High-Efficiency and Standard Electric Motors

Product catalogues from two major electric motor manufacturers were used for developing representative estimates of the capital costs of high-efficiency and standard electric motors (Siemans-Allis 1984 and Century Electric 1984). Both manufacturers produce high-efficiency and standard electric motors that are similar in almost all respects except for the level of energy-use.

Several models are produced in various sizes. The list prices for the various models were averaged across models to derive representative estimates of the capital costs for motors within the size classifications selected for use in this study. For example, Siemans-Allis produces four models of electric motors in both one and five HP sizes (i.e., eight motors in the 1 to 5 HP class used in this study). The capital costs of these models were averaged to derive a representative estimate of capital costs for motors in the 1 to $5 \mathrm{HP}$ size classification.

Estimates of the initial costs for high-efficiency and standard electric motors, obtained by averaging the list prices presented in the manufacturers' product catalogues, are shown in Table 12.1. The estimates do not include

TABLE 12.1. Representative Costs for High-Efficiency Electric Motors(a)

\begin{tabular}{|c|c|c|c|c|}
\hline $\begin{array}{c}\text { Motor Size } \\
\text { (HP) } \\
\end{array}$ & $\begin{array}{c}\text { Initial Cost } \\
\text { for High } \\
\text {-Efficiency } \\
\text { Motors (\$1984) } \\
\end{array}$ & $\begin{array}{c}\text { Initial Cost } \\
\text { for Standard- } \\
\text { Efficiency Motors } \\
(\$ 1984)\end{array}$ & $\begin{array}{l}\text { Incremental } \\
\text { Cost }(\$) \\
\end{array}$ & $\begin{array}{c}\text { First Cost } \\
\text { Percentage } \\
\text { Increase (percent) }\end{array}$ \\
\hline 1 to & 324 & 245 & 79 & 32 \\
\hline 5 to 20 & 720 & 545 & 175 & 32 \\
\hline 20 to 50 & 1616 & 1273 & 343 & 27 \\
\hline 50 to 125 & 4712 & 3849 & 863 & 22 \\
\hline$>125$ & 8950 & 7370 & 1580 & 21 \\
\hline
\end{tabular}

(a) Source: Calculated from data presented in Siemans-Allis Selection and Pricing Guide--Integral Horsepower AC Motors, 1984 and Century Electric Product Catalogue, 1984. 
installation costs. In new and retirement applications, the installation costs for high-efficiency motors should not differ from those for standard motors (Hunt et al. 1976). Because retrofit applications are excluded from this analysis, installation costs should have no impact on the cost-effectiveness of high-efficiency motors. Representative estimates of first cost percentage increases for high-efficiency electric motors are shown in the last column of Table 12.1.

Representative Energy-use Efficiency Improvements for High-Efficiency Motors

The energy-use efficiency of an electric motor is the ratio of electric power output from an electric motor to the electricity input to the motor. Estimates of representative efficiencies were obtained by averaging the efficiencies of various models produced by a major electric motor manufacturer (Siemans-Allis 1984) that were within the size classifications selected for use in this study. The representative estimates are shown in Table 12.2.

TABLE 12.2. Representative Efficiency Improvements for High-Efficiency
Electric Motors

\begin{tabular}{|c|c|c|c|}
\hline $\begin{array}{c}\text { Motor } \\
\text { Size (HP) }\end{array}$ & $\begin{array}{c}\text { Representative } \\
\text { Efficiency for High- } \\
\text { Efficiency Motors } \\
\text { (percent) }\end{array}$ & $\begin{array}{l}\text { Representative } \\
\text { Efficiency for } \\
\text { Standard Motors } \\
\text { (percent) } \\
\end{array}$ & $\begin{array}{l}\text { Estimated } \\
\text { Electricity } \\
\text { Savings } \\
\text { (percent) (b) }\end{array}$ \\
\hline 1 to & B4. 67 & 74.25 & 14.0 \\
\hline 5 to 20 & 91.12 & 83.99 & 8.5 \\
\hline 20 to 50 & 93.85 & 88.03 & 6.6 \\
\hline 50 to 125 & 94.59 & 91.42 & 3.5 \\
\hline$>125$ & 94.79 & 93.98 & 0.9 \\
\hline
\end{tabular}

(a) Source: Siemans-Allis Selection and Pricing Guide--Integral Horsepower AC Motors, 1984.

(b) Calculated by dividing the efficiency of high-efficiency motors into the efficiency of standard motors, subtracting one, and multiplying by 100 . 
The last column of Table 12.2 presents estimates of the reductions in electricity use from using high-efficiency motors. These estimates were calculated by dividing the representative efficiencies for high-efficiency motors into the representative efficiencies for standard motors, subtracting one, and multiplying by 100 . Note that the percentage reductions in electricity use for high-efficiency motors decline as motor size is increased. This result was also obtained in other studies of energy-efficient motors (Hane 1983 and Hunt et a . 1976).

\section{Representative Electricity Savings for High-Efficiency Motors}

To estimate electricity savings for high-efficiency electric motors based on savings estimates shown in Table 12.2, we estimated the electricity consumed per unit by standard electric motors in the various size classifications. To make this estimate, data on electricity use for electric motors in industry were collected from the ISTUM model (Carhart et al. 1979). ISTUM results were selected because this model is used for forecast future growth in electric motor populations. The model indicated that industrial electric motors used 632.7 BkWh of electricity in 1978. Data on motors in the five size classes used in this study and the number of motors in each class were obtained from an Argonne National Laboratory (1980) study. The Argonne consumption data were used to calculate the share of total industrial motor electricity use per size classification.

The calculated size shares were multiplied by the ISTUM total use estimate to obtain estimates of the electricity consumption by electric motors in each size classification (second column of Table 12.3). The estimated number of motors in each size class (column three of Table 12.3) was divided into the estimated total annual electricity use for each class to obtain an estimate of the annual electricity use per motor in each size class (column four of Table 12.3).

Once estimates of electricity use per unit for standard electric motors were derived, estimates of the annual kWh savings per motor for high-efficiency electric motors were calculated. These estimates are shown in the last column of Table 12.3. 
TABLE 12.3. Representative Electricity Use Per Motor for Conventional Electric Motors Calculated from a Baseline Electricity Use for Industrial Motor Drives of 632.7 Billion $\mathrm{kwh}(\mathrm{a})$

\begin{tabular}{|c|c|c|c|c|}
\hline $\begin{array}{l}\text { Motor } \\
\text { Size } \\
\text { (HP) }\end{array}$ & $\begin{array}{l}\text { Percent of Total } \\
\text { Electricity } \\
\text { Use in This } \\
\text { HP Classification } \\
\text { (percent) b }\end{array}$ & $\begin{array}{c}\text { Annual } \\
\text { Electricity } \\
\text { Use in This } \\
\text { HP Classification } \\
\text { (Billion } \mathrm{kWh} \text { ) }\end{array}$ & $\begin{array}{c}\text { Estimated Number } \\
\text { of Motors in } \\
\text { This HP Class } \\
(000 s)(b)\end{array}$ & $\begin{array}{l}\text { Annual } \\
\text { Estimated } \\
\text { Electricity } \\
\text { Use Per } \\
\text { Motor (kWh) }\end{array}$ \\
\hline 1 to 5 & 0.9 & 5.69 & 8082 & 704 \\
\hline 5 to 20 & 7.7 & 48.72 & 5191 & 9,385 \\
\hline 20 to 50 & 12.3 & 77.82 & 1973 & 39,442 \\
\hline 50 to 125 & 24.0 & 151.85 & 928 & 163,629 \\
\hline$>125$ & 55.0 & 347.99 & 782 & 444,994 \\
\hline
\end{tabular}
(a) Source: Documentation on the ISTUM forecasting model presented in The Least-Cost Energy Strategy--Technical Appendix, (Carhart et al. 1979).
(b) Source: Calculated from data presented in Classification and Evaluation of Electric Motors and Pumps, (Argonne National Laboratory 1980).

\section{Representative Operating Cost Savings for High-Efficiency Motors}

The reduction in operating costs from the use of high-efficiency motors is a function of electricity savings from these motors and the price charged for electricity. For purposes of this study, an average electricity price of $4.97 \% / \mathrm{kWh}$ was used in a11 cost savings calculations. This figure represents the average price paid by industrial electricity users in 1983.

\section{Representative Payback Periods for High-Efficiency Electric Motors}

Estimates of representative payback periods for high-efficiency electric motors are presented in Table 12.4. These estimates were derived using manufacturers' data on motor costs and efficiencies and a U.S. average industrial electricity price of $4.97 \$ / \mathrm{kWh}$ as inputs to the calculation process. Note that the estimated payback periods for motors in the middle size categories are much shorter than for motors in the smallest and largest size categories. These results are in agreement with results obtained in other studies that found that 
TABLE 12.4. Representative Payback Periods for High-Efficiency Electric Motors

\begin{tabular}{|c|c|c|c|c|c|}
\hline $\begin{array}{c}\text { Motor } \\
\text { Size (HP) }\end{array}$ & $\begin{array}{c}\text { Estimated } \\
\text { Electricity } \\
\text { Savings } \\
\text { for High- } \\
\text { Efficiency } \\
\text { Motors (percent) } \\
\end{array}$ & $\begin{array}{l}\text { Estimated } \\
\text { Electricity } \\
\text { Use for } \\
\text { Convent ional } \\
\text { Motors (kWh) } \\
\end{array}$ & $\begin{array}{c}\text { Estimated } \\
\text { Annual } \\
\text { Electricity } \\
\text { Cost } \\
\text { Savings }(\$) \\
\end{array}$ & $\begin{array}{l}\text { Incremental } \\
\text { Capital } \\
\text { Costs } \\
\text { for High- } \\
\text { Efficiency } \\
\text { Motors }(\$) \\
\end{array}$ & $\begin{array}{l}\text { Estimated } \\
\text { Payback } \\
\text { Period } \\
\text { (Years) } \\
\end{array}$ \\
\hline 1 to 5 & 14.0 & 704 & 4.90 & 79 & 16.1 \\
\hline 5 to 20 & 8.5 & 9,385 & 39.65 & 175 & 4.4 \\
\hline 20 to 50 & 6.6 & 39,442 & 129.38 & 343 & 2.7 \\
\hline 50 to 125 & 3.5 & 163,629 & 284.64 & 863 & 3.0 \\
\hline$>125$ & 0.9 & 444,994 & 199.05 & 1580 & 8.0 \\
\hline
\end{tabular}

the greatest opportunities for cost-effective electricity savings from the use of high-efficiency motors are in the middle motor size ranges (Hane et a). 1983 and Hunt 1976).

\subsubsection{Technical Limits on the Use of High-Efficiency Motors}

No justification was found for applying any technical limits to the use of high-efficiency electric motors. All available information indicated that high-efficiency motors can be used in any situation where standard motors are used.

\subsubsection{Maximum Potential Market of High-Efficiency Motors}

Estimates of the maximum market penetration for high-efficiency electric motors in the industrial sector were obtained by applying representative estimates of the first cost percentage increases for these motors (from Table 12.1) and payback period estimates (from Table 12.4) to data presented previously in Table 4.2. The results of this process are shown in Table 12.5 .

\subsection{POPULATION DATA}

In this section, data on current electric motor populations, growth rates in electric motor populations, and retirement rates for electric motors are presented. The most current data that could be located on electric motor populations in the various size categories were for 1978 (Argonne National Laboratory 1980). These data were presented previously in the fourth column of 
TABLE 12.5. Estimates of the Maximum Market-Penetration Potential (a) of High-Efficiency Electric Motors in New and

Retirement Applications

\begin{tabular}{|c|c|c|c|}
\hline $\begin{array}{c}\text { Motor } \\
\text { Size (HP) } \\
\end{array}$ & $\begin{array}{l}\text { Estimated First } \\
\text { Cost Percentage } \\
\text { Increase (percent) } \\
\end{array}$ & $\begin{array}{c}\text { Estimated } \\
\text { Payback } \\
\text { Period (Years) } \\
\end{array}$ & $\begin{array}{l}\text { Estimated Maximum } \\
\text { Market Penetration } \\
\text { Potential (percent) }\end{array}$ \\
\hline $\begin{array}{rlr}1 & \text { to } & 5 \\
5 & \text { to } & 20 \\
20 & \text { to } & 50 \\
50 & \text { to } 125 \\
>125\end{array}$ & $\begin{array}{l}32 \\
32 \\
27 \\
22 \\
21\end{array}$ & $\begin{array}{r}16.1 \\
4.4 \\
2.7 \\
3.0 \\
8.0\end{array}$ & $\begin{array}{r}5 \\
20 \\
30 \\
40 \\
10\end{array}$ \\
\hline
\end{tabular}

(a) Obtained from information from DOE/BERD presented previously in Table 4.2.

Table 12.3 and will be used to represent the current level of electric motor populations. Data on growth rates in sales of electrical equipinent between 1978 and 1982 indicated that this growth was relatively small (DRI 1982). Thus, the results of our analys is will likely not be affected significantly by the use of 1978 data to represent current motor populations.

The growth in electric motor populations incorporated in this study are intended to be consistent with those assumed in the ISTUM industrial energy use forecasting model. This model assumes that electric equipment sales will increase at an average rate of approximately 7.2 percent in constant dollar terms between 1984 and 200D (EEA 1982). Fluctuations in forecast annual growth rates around the forecast average growth rate of 7.2 percent were generally less than 0.5 percent (EEA 1982). Thus, use of an average growth rate should not significantly affect the results of this study. This growth rate is used to derive the number of potential new applications of high-efficiency motors in all size categories.

Retirement rates for electric motors will vary depending upon the size of the motors, with smaller motors having shorter expected lifetimes and faster retirement rates than larger motors. Motor retirement rates were derived from information on the expected lifetimes of various sizes of motors developed in a comprehensive study of electric motors (Argonne National Laboratory 1980). These retirement rates represent the percent of the current motor stock that 
will be retired in each year from 1984 to 2000. They were calculated by dividing one by the expected lifetimes of motors in the various size classifications.

The current populations, growth rates, and retirement rates assumed for use in this study for the various size classifications of electric motors are summarized in Table 12.6. These numbers were integrated with estimates of the maximum potential market penetration of high-efficiency motors in the various size categories and an S-shaped market adoption rate (see Chapter 4) to develop estimates of the number of high-efficiency motors that will likely be installed between 1984 and 2000. These annual estimates are presented in Tables 12.7 to 12.11 .

\subsection{ENERGY SAVINGS RESULTS}

Estimates of the energy savings that are forecast to result from the use of high-efficiency electric motors in selected years are shown in the last columns of Tables 12.7 to 12.11. Also shown in Table 12.7 to 12.11 are the number

TABLE 12.6. Current Electric Motor Populations, Growth Rates and Retirement Rates Employed in This Study

\begin{tabular}{|c|c|c|c|c|c|}
\hline $\begin{array}{l}\text { Motor } \\
\text { Size } \\
\text { (HP) } \\
\end{array}$ & $\begin{array}{c}\text { Current Motor } \\
\text { Population }(a) \\
(000 s) \\
\end{array}$ & $\begin{array}{c}\text { Future } \\
\text { Annual } \\
\text { Growth Rate } \\
\text { (percent) } \\
\end{array}$ & $\begin{array}{c}\text { Additional } \\
\text { Units Added } \\
\text { Annually (000s) } \\
\end{array}$ & $\begin{array}{c}\text { Annual } \\
\text { Retirement } \\
\text { Rate } \\
\text { (percent) (a) } \\
\end{array}$ & $\begin{array}{l}\text { Units } \\
\text { Retired } \\
\text { Annually } \\
\text { (000s) }\end{array}$ \\
\hline 1 to 5 & 8082 & 7.2 & 582 & 5.8 & 473 \\
\hline 5 to 20 & 5191 & 7.2 & 374 & 5.2 & 268 \\
\hline 20 to 50 & 1973 & 7.2 & 142 & 4.6 & 91 \\
\hline 50 to 125 & 928 & 7.2 & 67 & 3.5 & 32 \\
\hline$>125$ & 782 & 7.2 & 56 & 3.4 & 27 \\
\hline
\end{tabular}

\footnotetext{
(a) Source: Calculated from data presented in Classification and Evaluation of Electric Motors and Pumps, (Argonne National Laboratory 1980).

(b) Source: Documentation on the ISTUM forecasting model presented in Pro-

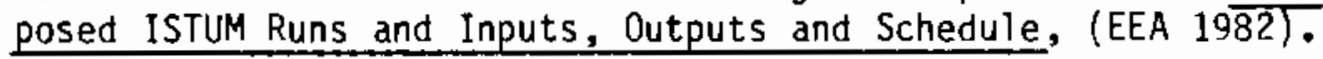


TABLE 12.7. Motor Stock Projections and High-Efficiency Motor Market Share Estimates for 1 to 5 Horsepower Motors

\begin{tabular}{|c|c|c|c|c|c|c|c|c|c|}
\hline & Year & $\begin{array}{c}\text { Retl red } \\
\text { Units } \\
\text { Market(o) } \\
\end{array}$ & $\begin{array}{c}\text { New Market } \\
\text { Add ItIons (b) }\end{array}$ & $\begin{array}{c}\text { Retlred } \\
\text { Units } \\
\text { Market } \\
\text { Share (c) } \\
\end{array}$ & $\begin{array}{c}\text { New } \\
\text { Market } \\
\text { Additions } \\
\text { Share }(e) \\
\end{array}$ & $\begin{array}{l}\text { Additions of } \\
\text { High-Etfliciency } \\
\text { Motors In New } \\
\text { Applications } \\
\end{array}$ & $\begin{array}{c}\text { Addlitions of } \\
\text { Hlgh-Effliclency } \\
\text { Motors in } \\
\text { Retirement } \\
\text { Applicstions } \\
\end{array}$ & $\begin{array}{c}\text { Cumulatlve } \\
\text { UnIts of HIgh- } \\
\text { Efficlency } \\
\text { Electrlc } \\
\text { Motors } \\
\end{array}$ & $\begin{array}{c}\text { Annual } \\
\text { Energy Savl ings } \\
\text { trom Cumulative } \\
\text { Additions of } \\
\text { High-Etficiency } \\
\text { Motors (d) (Bkwh) } \\
\end{array}$ \\
\hline & $\overline{1984}$ & 473,000 & 582,000 & 0.020 & 0.020 & 11,600 & 9,500 & 21,100 & 0.002 \\
\hline & 1985 & 473,000 & 582,000 & 0.021 & 0.021 & 12,200 & 9,900 & 43,200 & 0.004 \\
\hline & 1986 & 473,000 & 582,000 & 0.022 & 0.022 & 12,800 & 10,400 & 66,400 & 0.007 \\
\hline & 1987 & 473,000 & 582,000 & 0,024 & 0.024 & 14,000 & 11,400 & 91,800 & 0.009 \\
\hline & 1988 & 473,000 & 582,000 & 0.026 & 0.026 & 15,100 & 12,300 & 119,200 & 0.012 \\
\hline & $\begin{array}{l}1989 \\
1990\end{array}$ & $\begin{array}{l}473,000 \\
473,000\end{array}$ & $\begin{array}{l}582,000 \\
582,000\end{array}$ & $\begin{array}{l}0.029 \\
0.032\end{array}$ & $\begin{array}{l}0.029 \\
0.032\end{array}$ & $\begin{array}{l}16,900 \\
18,600\end{array}$ & $\begin{array}{l}13,700 \\
15,100\end{array}$ & $\begin{array}{l}149,800 \\
183,500\end{array}$ & $\begin{array}{l}0.015 \\
0.018\end{array}$ \\
\hline & 1991 & 473,000 & 582,000 & 0.035 & 0.035 & 20,400 & 16,600 & 220,500 & 0.022 \\
\hline & 1992 & 473,000 & 582,000 & 0.039 & 0.039 & 22,700 & 18,400 & 261.600 & 0.026 \\
\hline & 1993 & 473,000 & 582,000 & 0.042 & 0.042 & 24,400 & 19,900 & 305,900 & 0.050 \\
\hline & 1994 & 473,000 & 582,000 & 0.044 & 0.044 & 25,600 & 20,800 & 352,300 & 0.035 \\
\hline & 1995 & 473,000 & 582,000 & 0.045 & 0.045 & 26,200 & 21,300 & 399,800 & 0.040 \\
\hline & 1996 & 473,000 & 582,000 & 0.046 & 0.046 & 26,800 & 21,800 & 448,400 & 0.044 \\
\hline & 1997 & 473,000 & 582,000 & 0.047 & 0.047 & 27,400 & 22,200 & 498,000 & 0.049 \\
\hline & 1998 & 473,000 & 582,000 & 0.048 & 0.048 & 27.900 & 22,700 & 548,600 & 0.054 \\
\hline & 1999 & 473,000 & 582,000 & 0.049 & 0.049 & 28,500 & 23,200 & 600,300 & 0.059 \\
\hline & 2000 & 473,000 & 582,000 & 0.050 & 0.050 & 29,100 & 23,600 & 653,000 & 0.065 \\
\hline
\end{tabular}

(a) Current orlginal stack in thls size category of motors Is estimated to be B.082 $\times 10^{6}$ (Argonne Natlonal Laboratory 1980) retlrement assumed to occur at a rate of 5.8 percent annually (Argonne National Laboratory 1980).

(b) Growth in stock assumed to occur at a rate of 7.2 percent annually (EEA 1982).

(c) Function of an estlmated maximum market penetration of 5 percent and an S-shaped adoption curve.

(d) Calculated by: (Cumulative Unlts) $\times(99 \mathrm{kwh} / \mathrm{year}$ ). 
TABLE 12.8. Motor Stock Projections and High-Efficiency Motor Market Share Estimates for 5 to 20 Horsepower Motors

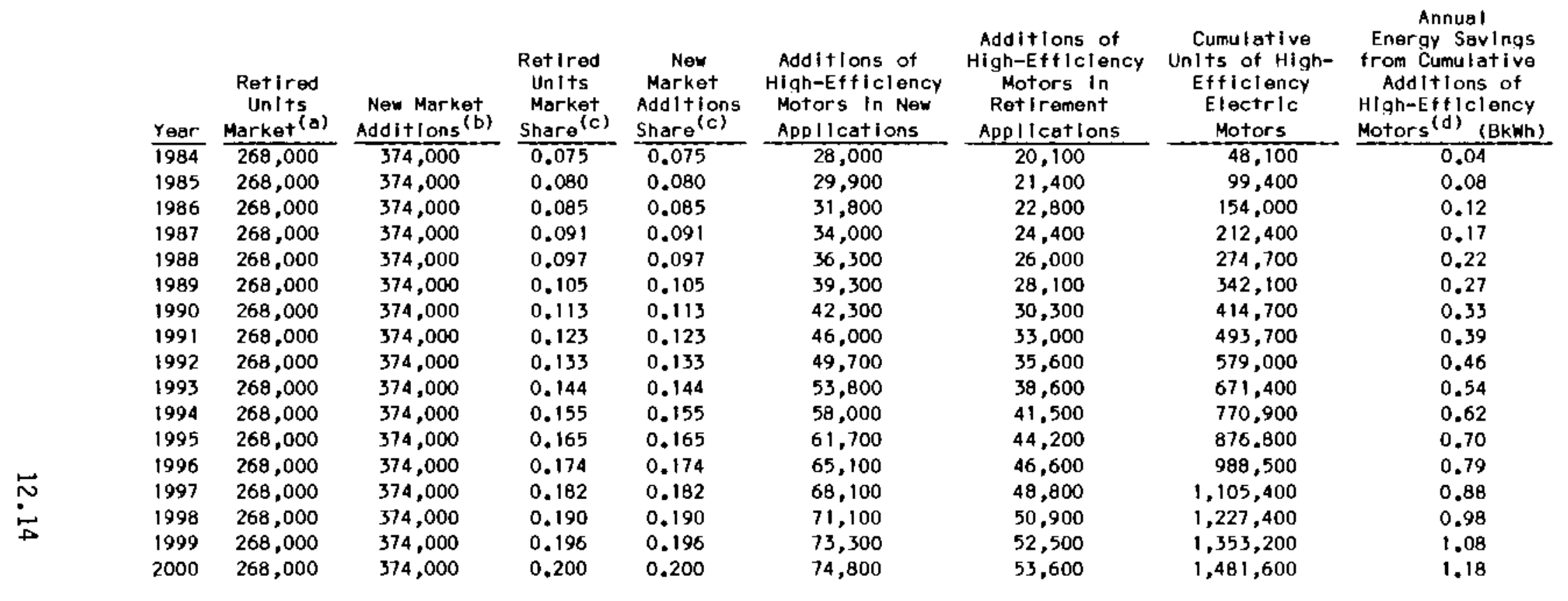

(a) Current or Iglnal stock in this size category of motors is estimated to be $5.191 \times 10^{6}$ (Argonne National Laboratory 1980) retirement assumed to occur at a rate of 5.2 percent annually (Argonne Natlonal Laboratory 1980).

(b) Growth in stock assumed to occur at a rate of 7.2 percent annually (EEA 1982).

(c) Function of an estimated maximum market penetration of 20 percent and an 5-shaped adoptlon curve.

(d) Calculated by: (Cumulative Units) $\times(798 \mathrm{kWh} /$ year). 
TABLE 12.9. Motor Stock Projections and High-Efficiency Motor Market Share Estimates for 20 to 50 Horsepower Motors

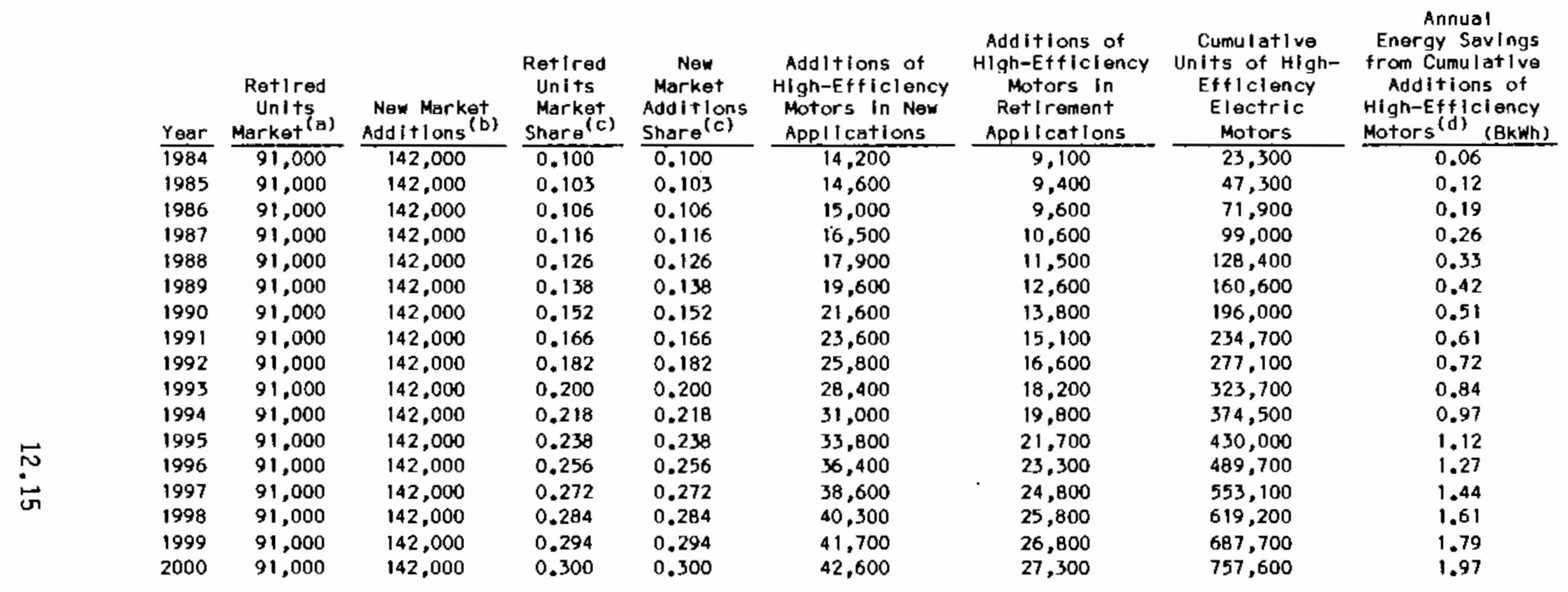

(a) Current orlginal stock in thls slze category of motors is estlmated to be $1.973 \times 10^{6}$ (Argonne National Laboratory 1980) retirement assumed to occur at a rate of 4.6 percent annually (Argonne Nat Tonal Laboratory 1980).

(b) Growth in stock assumed to oecur at a rate of 7.2 percent annually (EEA 1982).

(c) Function of an estlmated maximum market penetratlon of 30 percent and an S-shaped adoption curve.

(d) Calculated by: (Cumulatlve Unlts) $\times(2603 \mathrm{kwh} /$ year). 
TABLE 12.10. Motor Stock Projections and High-Efficiency Motor Market Share Estimates for 50 to 125 Horsepower Motors

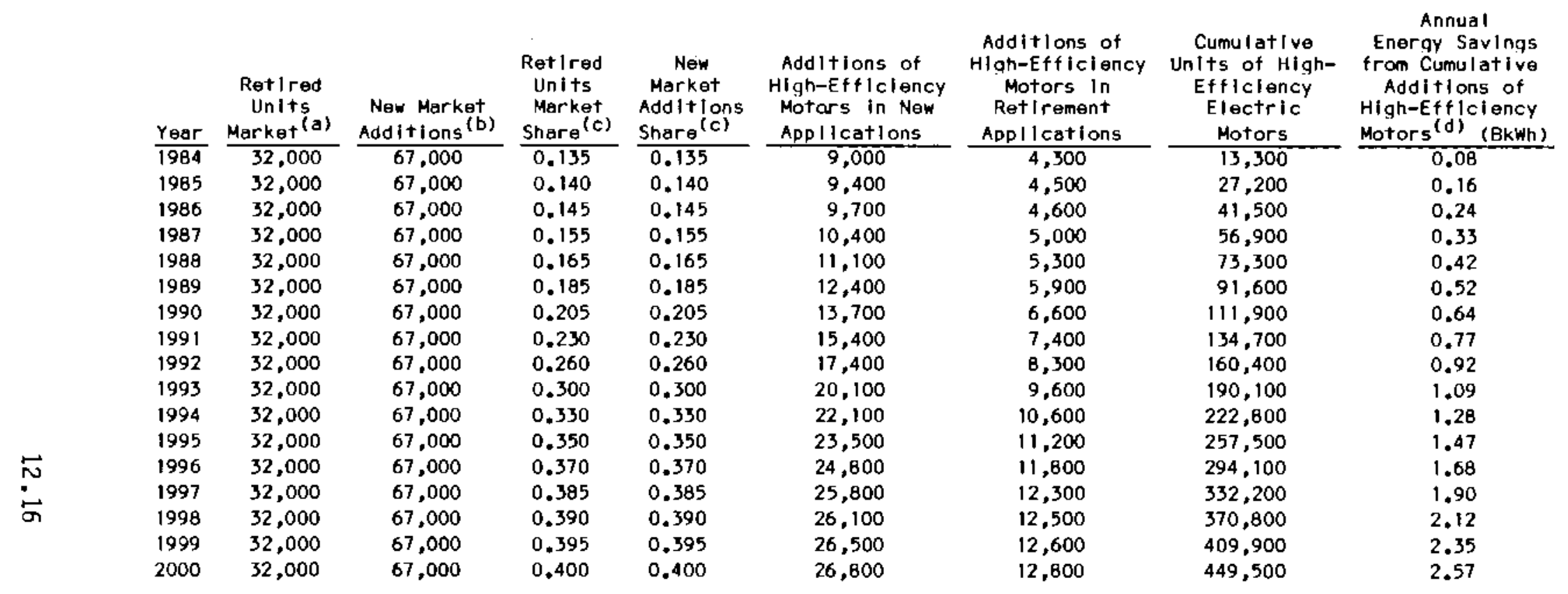

(8) Current original stock in thls slze category of motors is estlmated to be $0.0928 \times 10^{6}$ (Argonne National Laboratory 1980) retirement assumed to occur at a rate of 3.5 percent annually (Argonne National Laboratory 1980).

(b) Growth in stock assumed to occur ot a rate of 7.2 percent annually (EEA 1982).

(c) Function of an estimoted maximum market penetration of 40 percent and an S-shaped adoption curve.

(d) Calculated by: (Cumulative Unlts) $\times(5727 \mathrm{kWh} /$ year). 
TABLE 12.11. Motor Stock Projections and High-Efficiency Motor Market Share Estimates for $>125$ Horsepower Motors

\begin{tabular}{|c|c|c|c|c|c|c|c|c|}
\hline Year & $\begin{array}{c}\text { Retired } \\
\text { Units } \\
\text { Morket (a) }\end{array}$ & $\begin{array}{c}\text { New Market } \\
\text { Add It Ions (b) }\end{array}$ & $\begin{array}{c}\text { Retired } \\
\text { UnIts } \\
\text { Market } \\
\text { Share(c) } \\
\end{array}$ & $\begin{array}{l}\text { New } \\
\text { Market } \\
\text { Additlons } \\
\text { Shara (c) } \\
\end{array}$ & $\begin{array}{l}\text { Additlons of } \\
\text { Hlgh-Etflelency } \\
\text { Motors in New } \\
\text { Applicatlons }\end{array}$ & $\begin{array}{c}\text { Additions of } \\
\text { HIgh-Etfliclency } \\
\text { Motors in } \\
\text { Retirement } \\
\text { Applicotlons } \\
\end{array}$ & $\begin{array}{c}\text { Cumulative } \\
\text { Units of High- } \\
\text { Efticlency } \\
\text { Electrle } \\
\text { Motors } \\
\end{array}$ & $\begin{array}{c}\text { Annual } \\
\text { Energy Savings } \\
\text { trom Cumulative } \\
\text { Add ItIons of } \\
\text { High-Effliclency } \\
\text { Motors (d) (BkWh) }\end{array}$ \\
\hline$\overline{1984}$ & 27,000 & 56,000 & 0.040 & 0.040 & 2,200 & 1,100 & 3,300 & 0.01 \\
\hline $\begin{array}{l}1985 \\
1986\end{array}$ & $\begin{array}{l}27,000 \\
27,000\end{array}$ & $\begin{array}{l}56,000 \\
56,000\end{array}$ & $\begin{array}{l}0.041 \\
0.043\end{array}$ & $\begin{array}{l}0.041 \\
0.043\end{array}$ & $\begin{array}{l}2,300 \\
2,400\end{array}$ & $\begin{array}{l}1,100 \\
1,200\end{array}$ & $\begin{array}{r}6,700 \\
10,300\end{array}$ & $\begin{array}{l}0.03 \\
0.04\end{array}$ \\
\hline 1987 & 27,000 & 56,000 & 0.045 & 0.045 & 2,500 & 1,200 & 14,000 & 0.06 \\
\hline 1988 & 27,000 & 56,000 & 0.049 & 0.049 & 2,700 & 1,300 & 18,000 & 0.07 \\
\hline 1989 & 27,000 & 56,000 & 0.053 & 0.053 & 3,000 & 1,400 & 22,400 & 0.09 \\
\hline 1990 & 27,000 & 56,000 & 0.058 & 0.058 & 3,200 & 1,600 & 27,200 & 0.11 \\
\hline 1991 & 27,000 & 56,000 & 0.063 & 0.063 & 3,500 & 1,700 & 32,400 & 0.13 \\
\hline 1992 & 27,000 & 56,000 & 0.069 & 0.069 & 3,900 & 1,900 & 38,200 & 0.15 \\
\hline 1993 & 27,000 & 56,000 & 0.076 & 0.076 & 4,300 & 2,100 & 44,600 & 0.18 \\
\hline 1994 & 27,000 & 56,000 & 0.083 & 0.083 & 4,600 & 2,200 & 51,400 & 0.21 \\
\hline 1995 & 27,000 & 56,000 & 0.088 & 0.088 & 4,900 & 2,400 & 58,700 & 0.24 \\
\hline 1996 & 27,000 & 56,000 & 0.092 & 0.092 & 5,200 & 2,500 & 66,400 & 0.27 \\
\hline 1997 & 27,000 & 56,000 & 0.095 & 0.095 & 5,300 & 2,600 & 74,300 & 0.30 \\
\hline 1998 & 27,000 & 56,000 & 0.097 & 0.097 & 5,400 & 2,600 & 82,300 & 0.33 \\
\hline $\begin{array}{l}1999 \\
2000\end{array}$ & $\begin{array}{l}27,000 \\
27,000\end{array}$ & $\begin{array}{l}56,000 \\
56,000\end{array}$ & $\begin{array}{l}0.099 \\
0.100\end{array}$ & $\begin{array}{l}0.099 \\
0.100\end{array}$ & $\begin{array}{l}5,500 \\
5,600\end{array}$ & $\begin{array}{l}2,700 \\
2,700\end{array}$ & $\begin{array}{l}90,500 \\
98,800\end{array}$ & $\begin{array}{l}0.36 \\
0.40\end{array}$ \\
\hline
\end{tabular}

(a) Current or lginal stock in this size category of motors Is estimated to be $0.7 a 2 \times 10^{6}$ (Argonne Natlonal Laboratory 1980) retl rement assumed to occur ot a rate of 3.4 percent annually (Argonne Natlonal Laboratory 1980).

(b) Growth in stock assumed to oceur at a rate of 7.2 percent annualiy (EEA 1982).

(c) Function of an estimated maximum market penetration of 10 percent and an S-shaped adoption curve.

(d) Colculated by: (Cumulative Unlts) $\times(4005 \mathrm{kWh} / \mathrm{year})$. 
of units of high-efficiency motors projected to be installed. Note that projected energy savings (in $\mathrm{BkWh}$ ) were obtained by multiplying representative energy savings per unit in each motor size category (in $\mathrm{kWh}$ ) by the projected number of high-efficiency motors that will be installed in each year.

The last column of Table 12.12 presents the likely level of electricity savings for high-efficiency motors in the industrial sector summed across all motor sizes. These estimates are projected to reach approximately $6.19 \mathrm{BkWh}$ by the year 2000 .

\subsection{SENSITIYITY ANALYSIS}

This section presents the results of an analysis of the sensitivity of the energy savings estimates for high-efficiency electric motors to changes in the maximum potential market penetration the technology achieves and the rate at which this maximum is achieved. The sensitivity of the energy savings estimates is evaluated for both a low scenario and a high scenario.

\subsubsection{Low Market-Penetration Scenario}

The maximum potential market-penetration estimates used in the low scenario of the sensitivity analysis are shown in the second column of Table 12.13. These maximum penetration estimates are half as large as those assumed in the baseline analysis. In addition, it was assumed in the low scenario that the rate of market adoption for high-efficiency motors would be slower so that only approximately 75 percent of the assumed maximum potential

TABLE 12.12. Projections of Energy Savings from the Use of High-Efficiency Electricity Motors (BkWh)

\begin{tabular}{|c|c|c|c|c|c|c|}
\hline Year & 1 to $5 \mathrm{HP}$ & 5 to $20 \mathrm{HP}$ & 20 to $50 \mathrm{HP}$ & 50 to 125 & $>125 \mathrm{HP}$ & All Moto \\
\hline 1985 & 0.004 & 0.08 & 0.12 & 0.16 & 0.03 & 0.39 \\
\hline 1990 & 0.018 & 0.33 & 0.51 & 0.64 & 0.11 & 1.61 \\
\hline 1995 & 0.040 & 0.70 & 1.12 & 1.47 & 0.24 & 3.57 \\
\hline 2000 & 0.065 & 1.18 & 1.97 & 2.57 & 0.40 & 6.19 \\
\hline
\end{tabular}


TABLE 12.13. Low Scenario Maximum Market-Penetration Potentials and Market Penetrations Assumed to be Reached in 2000

\begin{tabular}{rrrr}
$\begin{array}{c}\text { Motor } \\
\text { Size (HP) }\end{array}$ & $\begin{array}{c}\text { Estimated Maximum } \\
\text { Market Penetration } \\
\text { Potential (percent) }\end{array}$ & $\begin{array}{c}\text { Market Penetration } \\
\text { Assumed to be }\end{array}$ \\
\cline { 1 - 2 } $\begin{array}{rrr}\text { Reached in 2000 (percent) } \\
\text { to } 5\end{array}$ & 2.5 & 1.9 \\
to 20 & 10.0 & 7.5 \\
20 to 50 & 15.0 & 11.3 \\
50 to 125 & 20.0 & 15.0 \\
$>125$ & 5.0 & & 3.8
\end{tabular}

market penetration would be achieved by the year 2000. Thus, the market penetration levels reached by the year 2000 for high-efficiency motors in the low scenario are those shown in the third column of Table 12.13.

The results of the low-scenario sensitivity analysis as well as input data and assumptions used to obtain the estimates are shown in Tables 12.14 to 12.18 and summarized in Table 12.19. These results indicate that under the conservative market penetration assumptions of the low scenario, a total of $2.84 \mathrm{BkWh}$ of electricity could be saved in 2000 through the use of high-efficiency electric motors. This level of savings is approximately 45 percent of the savings obtained in the baseline estimation. A summary of total energy savings for all size motors for selected years is included in Table 12.19.

\subsubsection{High Market-Penetration Scenario}

The maximum potential market-penetration estimates used in the high scenario of the sensitivity analysis are shown in Table 12.20. These penetration estimates are twice as large as those used in the original baseline estimation. There appeared to be no basis for assuming that the maximum potential market penetration of high-efficiency motors would be limited by technical factors. An additional assumption employed in the high scenario is that a rapid rate of market adoption would cause the maximum potential market penetration for high-efficiency motors to be reached by 1995. The results of the high scenario sensitivity analysis as well as input data and assumption used are shown in Tables 12.21 to 12.25 . 
TABLE 12.14. Low-Scenario Motor Stock Projections and High-Efficiency Motor Market Share Estimates for 1 to 5 Horsepower Motors

\begin{tabular}{|c|c|c|c|c|c|c|c|c|}
\hline Year & $\begin{array}{c}\text { Retired } \\
\text { Units } \\
\text { Market (a) }\end{array}$ & $\begin{array}{l}\text { New Market } \\
\text { Add It tons }(b)\end{array}$ & $\begin{array}{l}\text { Retlred } \\
\text { Units } \\
\text { Market } \\
\text { Share } \\
\text { Sc) }\end{array}$ & $\begin{array}{c}\text { New } \\
\text { Market } \\
\text { Additions } \\
\text { Share (c) }\end{array}$ & $\begin{array}{l}\text { Additlons of } \\
\text { Hlgh-Efficlency } \\
\text { Motors In New } \\
\text { Applications }\end{array}$ & $\begin{array}{c}\text { Additions of } \\
\text { Hlgh-Efficlency } \\
\text { Motors in } \\
\text { RetIrement } \\
\text { AppIlcatlons }\end{array}$ & $\begin{array}{c}\text { Cumulatlve } \\
\text { Units of HIgh- } \\
\text { Efficiency } \\
\text { Electric } \\
\text { Motors }\end{array}$ & $\begin{array}{l}\text { Annual } \\
\text { Energy Savings } \\
\text { from Cumulatlve } \\
\text { Additlons of } \\
\text { High-Efficlency } \\
\text { Motors (d) (Bkwh) }\end{array}$ \\
\hline$\overline{1984}$ & 473,000 & 582,000 & 0.0050 & 0.0050 & 2,900 & 2,400 & $5, \overline{300}$ & 0.001 \\
\hline 1985 & 473,000 & 582,000 & 0.0055 & 0.0055 & 3,200 & 2,600 & 11,100 & 0.001 \\
\hline 1986 & 473,000 & 582,000 & 0.0060 & 0.0060 & 3,500 & 2,800 & 17.400 & 0.002 \\
\hline 1987 & 473,000 & 582,000 & 0.0065 & 0.0065 & 3,600 & 3,100 & 24,300 & 0.002 \\
\hline 1988 & 475,000 & 582,000 & 0.0075 & 0.0075 & 4,400 & 3,500 & 32,200 & 0.003 \\
\hline 1989 & 473,000 & 582,000 & 0.0085 & 0.0085 & 4,900 & 4,000 & 41,100 & 0.004 \\
\hline $\begin{array}{l}1990 \\
1991\end{array}$ & $\begin{array}{l}473,000 \\
473,000\end{array}$ & $\begin{array}{l}582,000 \\
582,000\end{array}$ & $\begin{array}{l}0.0095 \\
0.0110\end{array}$ & $\begin{array}{l}0.0095 \\
0.0110\end{array}$ & $\begin{array}{l}5,500 \\
6,400\end{array}$ & $\begin{array}{l}4,500 \\
5,200\end{array}$ & $\begin{array}{l}51,100 \\
62,700\end{array}$ & $\begin{array}{l}0.005 \\
0.006\end{array}$ \\
\hline 1992 & 473,000 & 582,000 & 0.0125 & 0.0125 & 7,300 & 5,900 & 75,900 & 0.008 \\
\hline 1993 & 473,000 & 582,000 & 0.0135 & 0.0135 & 7,900 & 6,400 & 90,200 & 0.009 \\
\hline 1994 & 473,000 & 582,000 & 0.0145 & 0.0145 & 8,400 & 6,900 & 105,500 & 0.010 \\
\hline 1995 & 473,000 & 582,000 & 0.0155 & 0.0155 & 9,000 & 7,300 & 121,800 & 0.012 \\
\hline 1996 & 473,000 & 582,000 & 0.0165 & 0.0165 & 9,600 & 7,800 & 139,200 & 0.014 \\
\hline 1997 & 473,000 & 582,000 & 0.0175 & 0.0175 & 10,200 & 8,300 & 157,700 & 0.016 \\
\hline 1998 & 473,000 & 582,000 & 0.0180 & 0.0180 & 10,500 & 8,500 & 176,700 & 0.017 \\
\hline 1999 & 473,000 & 582,000 & 0.0185 & 0.0185 & 10,800 & 8,800 & 196,300 & 0.019 \\
\hline 2000 & 473,000 & 582,000 & 0.0190 & 0.0190 & 11,100 & 9,000 & 216,400 & 0.021 \\
\hline
\end{tabular}

(a) Current original stock in this slze category of motors is estimated to be $0.782 \times 10^{6}$ (Argonne Natlonal Laboratory 1980) retlrement assumed to occur at a rate of 3.4 percent annually (Argonne Natlonal Laboratory 1980).

(b) Growth In stock Bssumed to occur at a rate of 7.2 percent annually (EEA 1982 ).

(c) Function of an estlmated maximum market penetration of 1.9 percent assumed to be reached in 2000 and an S-shaped adoption curve.

(d) Calculated by: (Cumulatlve Units) $\times(99 \mathrm{kwh} /$ year). 
TABLE 12.15. Low-Scenario Motor Stock Projections and High-Efficiency Motor Market Share Estimates for 5 to 20 Horsepower Motors

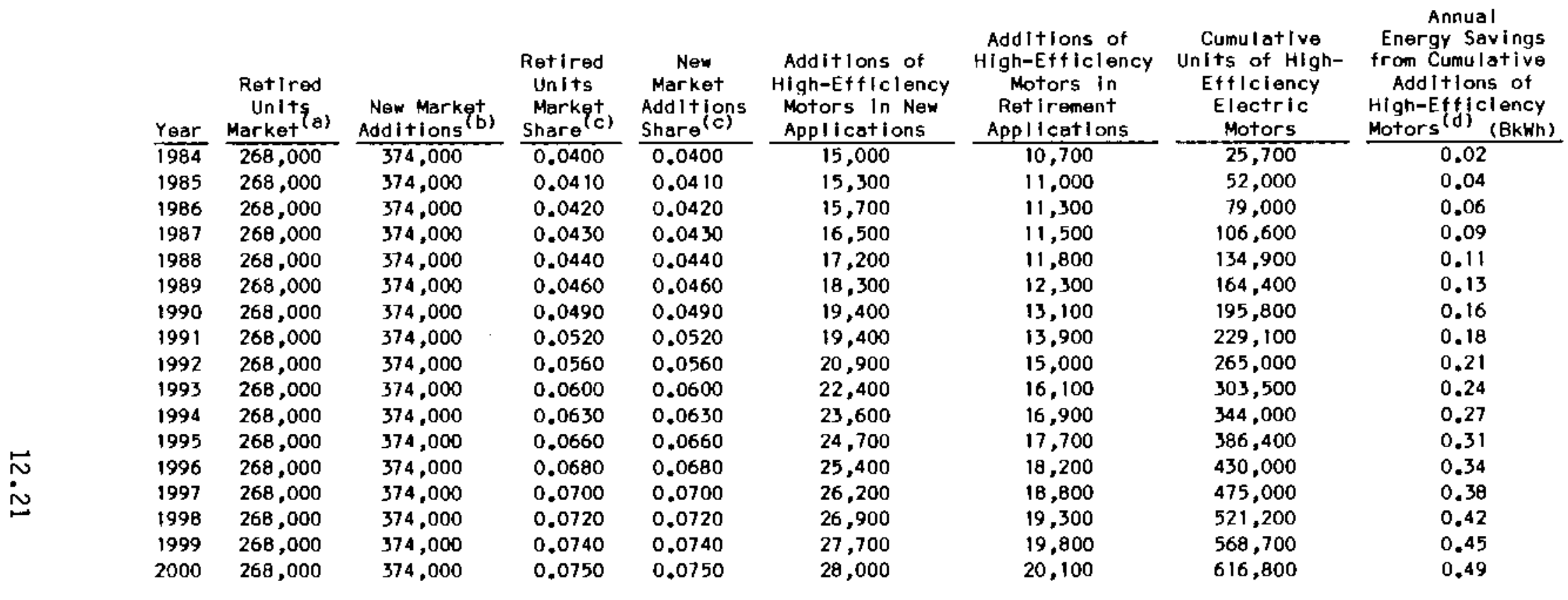

(a) Current orlginal stock in this slze cateqory of motors is estimated to be $0.782 \times 10^{6}$ (Argonne National Laboratory 1980) retIrement assumed to occur at a rate of 3.4 percent annually (Argonne Natlonal Laboratory 1980 ).

(b) Growth In stock assumed to $\infty$ cur at a rate of 7.2 percent annually (EEA 1982).

(c) Function of an estimated maximum market penetration of 7.5 percent assumed to be reached in 2000 , and an S-shaped odoption curve.

(d) Calculated by: (Cumulatlve Units) $\times(798 \mathrm{kWh} /$ year). 
TABLE 12.16. Low-Scenario Motor Stock Projections and High-Efficiency Motor Market Share Estimates for 20 to 50 Horsepower Motors

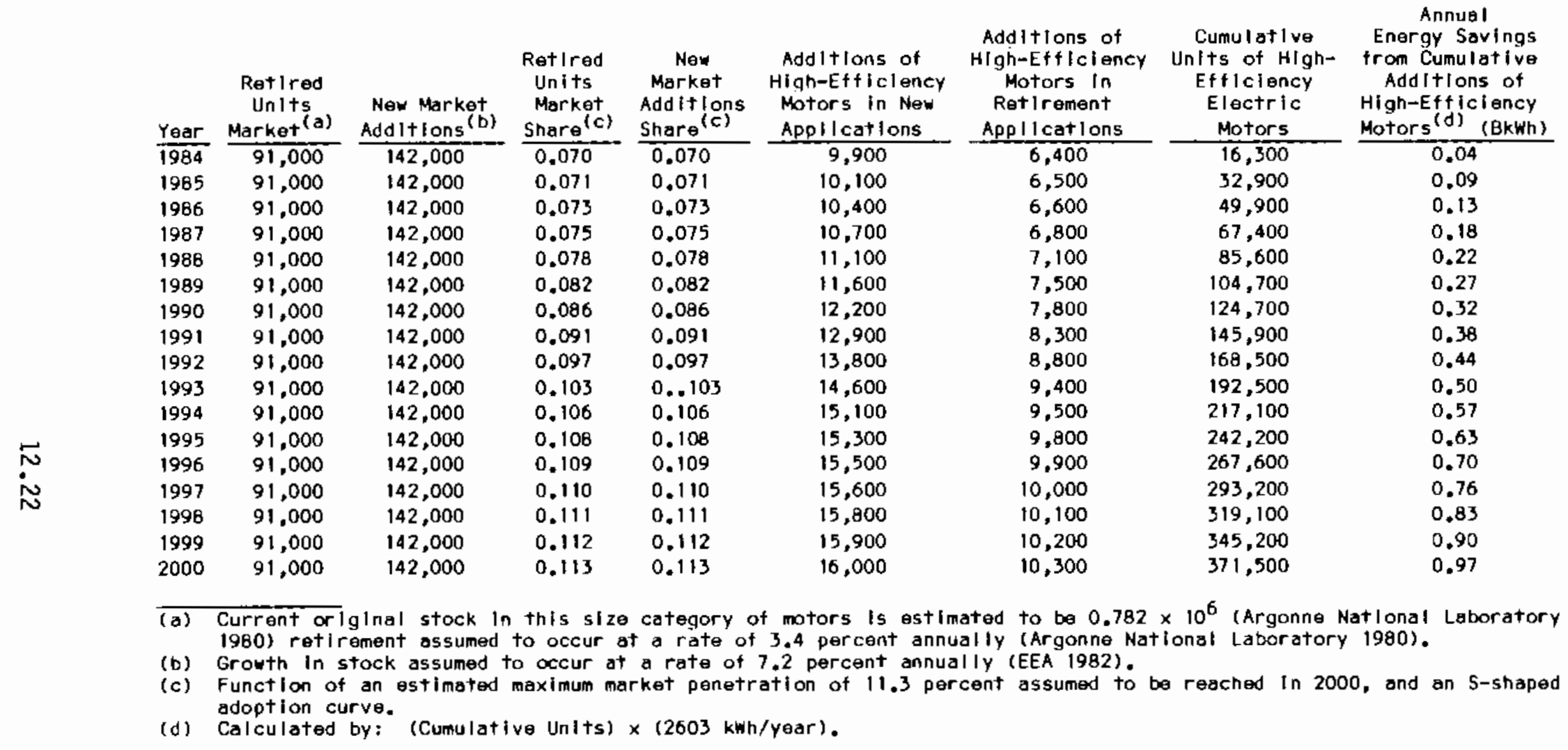


TABLE 12.17. Low-Scenario Motor Stock Projections and High-Efficiency Motor Market Share Estimates for 50 to 125 Horsepower Motors

\begin{tabular}{|c|c|c|c|c|c|c|c|c|}
\hline Year & $\begin{array}{c}\text { Retl red } \\
\text { Un 1ts } \\
\text { Market (a) } \\
\end{array}$ & $\begin{array}{r}\text { New Market } \\
\text { Add Itlons }(b)\end{array}$ & $\begin{array}{c}\text { Ret1red } \\
\text { Units } \\
\text { Market } \\
\text { Share (c) } \\
\end{array}$ & $\begin{array}{c}\text { New } \\
\text { Market } \\
\text { Additions } \\
\text { Share }\end{array}$ & $\begin{array}{l}\text { Additions of } \\
\text { High-Effliciency } \\
\text { Motors in New } \\
\text { Applicatlons } \\
\end{array}$ & $\begin{array}{c}\text { Addltions of } \\
\text { High-Efficlency } \\
\text { Motors In } \\
\text { Retirement } \\
\text { Applications } \\
\end{array}$ & $\begin{array}{c}\text { Cumulative } \\
\text { Unlts of HIgh- } \\
\text { Efflciency } \\
\text { Electrlc } \\
\text { Motors } \\
\end{array}$ & $\begin{array}{c}\text { Annual } \\
\text { Energy Savings } \\
\text { from Cumulative } \\
\text { Additlons of } \\
\text { Hlgh-Efflclency } \\
\text { Motors (d) (Bkwh) }\end{array}$ \\
\hline$\overline{1984}$ & 32,000 & 67,000 & 0.100 & 0.100 & 6,700 & 3,200 & 9,900 & 0.06 \\
\hline 1985 & 32,000 & 67,000 & 0.101 & 0.101 & 6,800 & 3,200 & 19,900 & 0.11 \\
\hline 1986 & 32,000 & 67,000 & 0.103 & 0.103 & 6,900 & 3,300 & 30,100 & 0.17 \\
\hline 1987 & 32,000 & 67,000 & 0.105 & 0.105 & 7,000 & 33,400 & 40,500 & 0.23 \\
\hline 1988 & 32,000 & 67,000 & 0.108 & 0.108 & 7,200 & 3,500 & 51,200 & 0.29 \\
\hline 1989 & 32,000 & 67,000 & 0.112 & 0.112 & 7,500 & 3,600 & 62,300 & 0.36 \\
\hline 1990 & 32,000 & 67,000 & 0.117 & 0.117 & 7,800 & 3,700 & 73,800 & 0.42 \\
\hline 1991 & 32,000 & 67,000 & 0.122 & 0.122 & 8,200 & 3,900 & 85,900 & 0.49 \\
\hline 1992 & 32,000 & 67,000 & 0.128 & 0.128 & 8,600 & 4,100 & 98,600 & 0.56 \\
\hline 1993 & 32,000 & 67,000 & 0.134 & 0.134 & 9,000 & 4,300 & 111,900 & 0.64 \\
\hline 1994 & 32,000 & 67,000 & 0.139 & 0.139 & 9,300 & 4,400 & 125,600 & 0.72 \\
\hline 1995 & 32,000 & 67,000 & 0.143 & 0.143 & 9,600 & 4,600 & 139,800 & 0.80 \\
\hline 1996 & 32,000 & 67,000 & 0.145 & 0.145 & 9,700 & 4,600 & 154,100 & 0.88 \\
\hline 1997 & 32,000 & 67,000 & 0.147 & 0.147 & 9,800 & 4,700 & 58,600 & 0.97 \\
\hline 1998 & 32,000 & 67,000 & 0.148 & 0.148 & 9,900 & 4,700 & 183,200 & 1.05 \\
\hline 1999 & 32,000 & 67,000 & 0.149 & 0.149 & 10,000 & 4,800 & 198,000 & 1.13 \\
\hline 2000 & 32,000 & 67,000 & 0.150 & 0.150 & 10,100 & 4,800 & 212,900 & 1.22 \\
\hline
\end{tabular}

(a) Current origlnal stock in this 51 ze category of motors is estimated to be $8.082 \times 10^{6}$ (Argonne National Laboratory 1980) retlrement assumed to occur at a rate of 5.8 percent annually (Argonne Natlonal Laboratory 1980).

(b) Growth In stock assumed to occur at a rate of 7.2 percent annually (EEA 1982).

(c) Function of on estlmated maximum market penetration of 15 percent assumed to be reached in 2000 , and an S-shaped adoption curve.

(d) Calculated by: (Cumulatlve Unlts) $\times(5727 \mathrm{kWh} /$ year). 
TABLE 12.18. Low-Scenario Motor Stock Projections and High-Efficiency Motor Market Share Estimates for $>125$ Horsepower Motors

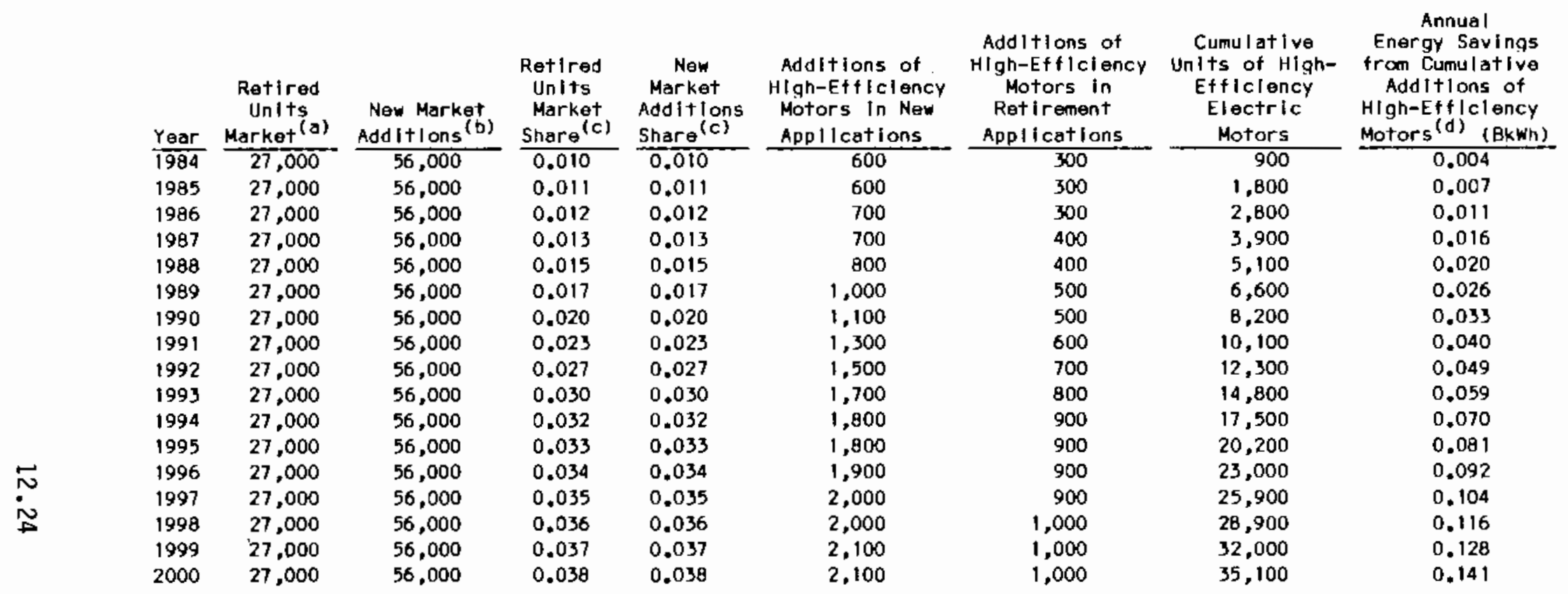

(a) Current orlglnal stock In this slze category of motors is estimated to be $8.082 \times 10^{6}$ (Argonne Natlonal Leboratory $1980)$ ratlrement assumed to occur at a rate of 5.8 percent annually (Argonne Natlonal Laboratory 1980).

(b) Growth in stock assumed to occur at a rate of 7.2 percent annually (EEA 1982).

(c) Function of an estimated maxlmum market penetration of 3.6 percent assumed to be reached In 2000 , and an S-shaped adoption curve.

(d) Calculated by: (Cumulative Unlts) $\times(4005 \mathrm{kwh} / \mathrm{year}$ ). 
TABLE 12.19. Low-Scenario Estimates of Electricity Savings from the Use of Electric Motors (BkWh)

\begin{tabular}{|c|c|c|c|c|c|c|}
\hline Year & 1 to $5 \mathrm{HP}$ & 5 to $20 \mathrm{HP}$ & 20 to $50 \mathrm{HP}$ & 50 to $125 \mathrm{HP}$ & $>125 \mathrm{HP}$ & A11 Motors \\
\hline 1985 & 0.00 & 0.04 & 0.90 & 0.11 & 0.07 & 0.25 \\
\hline 1990 & 0.01 & 0.16 & 0.32 & 0.42 & 0.33 & 0.93 \\
\hline 1995 & 0.01 & 0.31 & 0.63 & 0.80 & 0.81 & 1.83 \\
\hline 2000 & 0.02 & 0.44 & 0.97 & 1.22 & 0.141 & 2.52 \\
\hline
\end{tabular}

IABLE 12.20. High-Scenario Maximum Market Potentials Assumed to be Reached in 1995

\begin{tabular}{|c|c|}
\hline $\begin{array}{c}\text { Motor } \\
\text { Size (HP) }\end{array}$ & $\begin{array}{c}\text { Maximum Market Pene- } \\
\text { tration (assumed to be } \\
\text { reached in 1995), (percent) }\end{array}$ \\
\hline 1 to 5 & 10 \\
\hline 5 to 20 & 40 \\
\hline 20 to 50 & 60 \\
\hline 50 to 125 & 80 \\
\hline$>125$ & 10 \\
\hline
\end{tabular}

The total electricity savings of 12.11 BkWh by 2000 estimated in the high scenario are almost twice as large as those obtained in the baseline estimation. A summary of the results of the high scenario is presented in Table 12.26 .

12.7 COST/KWh OF ENERGY SAVED CALCULATIONS AND COMPARISONS TO THE COST/kWh OF PRODUCING NEW GENERATING CAPACITY

High-efficiency electric motors can potentially be considered as investments which can produce power at costs that are less than the costs of power produced by new generating facilities. If high-efficiency motors can produce power for less than new generating facilities, then benefits can potentially be obtained by utilities and others undertaking investments to promote the use of high-efficiency motors as a means of meeting future power demands. 
TABLE 12.21. High-Scenario Motor Stock Projections and High-Efficiency Motor Market Share Estimates for 1 to 5 Horsepower Motors

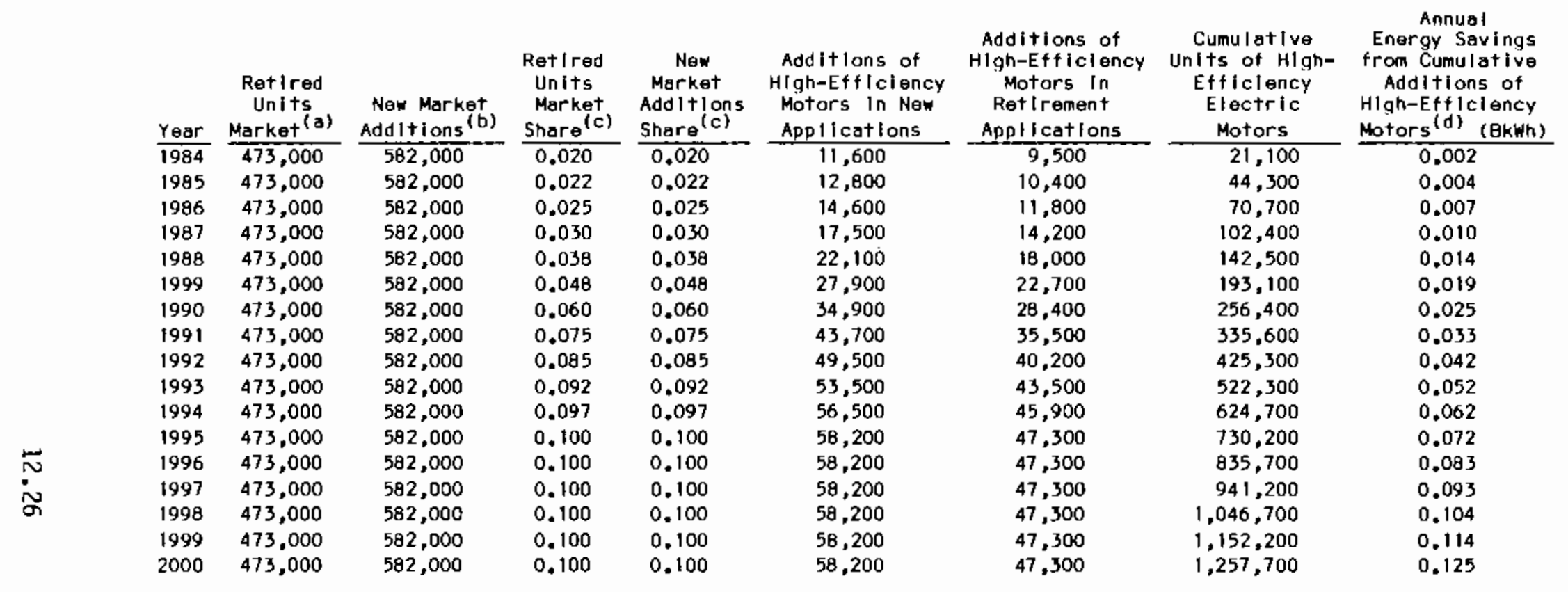

(a) Current orlginal stock in this size category of motors is estimated to be a.082 $\times 10^{6}$ (Argonne National Laboratory 1980) retlrement assumed to occur at a rate of 5.8 percent annually (Argonne Natlonal Laboratory 1980 ).

(b) Growth in stock assumed to occur at a rate of 7.2 percent annually (EEA 1982).

(c) Function of an estlmated maximum market penetration of 10 percent assumed to be reached in 1995, and an S-shaped adoption curve.

(d) Calculated by: (Cumulative Units) $\times(99 \mathrm{kwh} / \mathrm{year})$. 
TABLE 12.22. High-Scenario Motor Stock Projections and High-Efficiency Motor Market Share Estimates for 5 to 20 Horsepower Motors

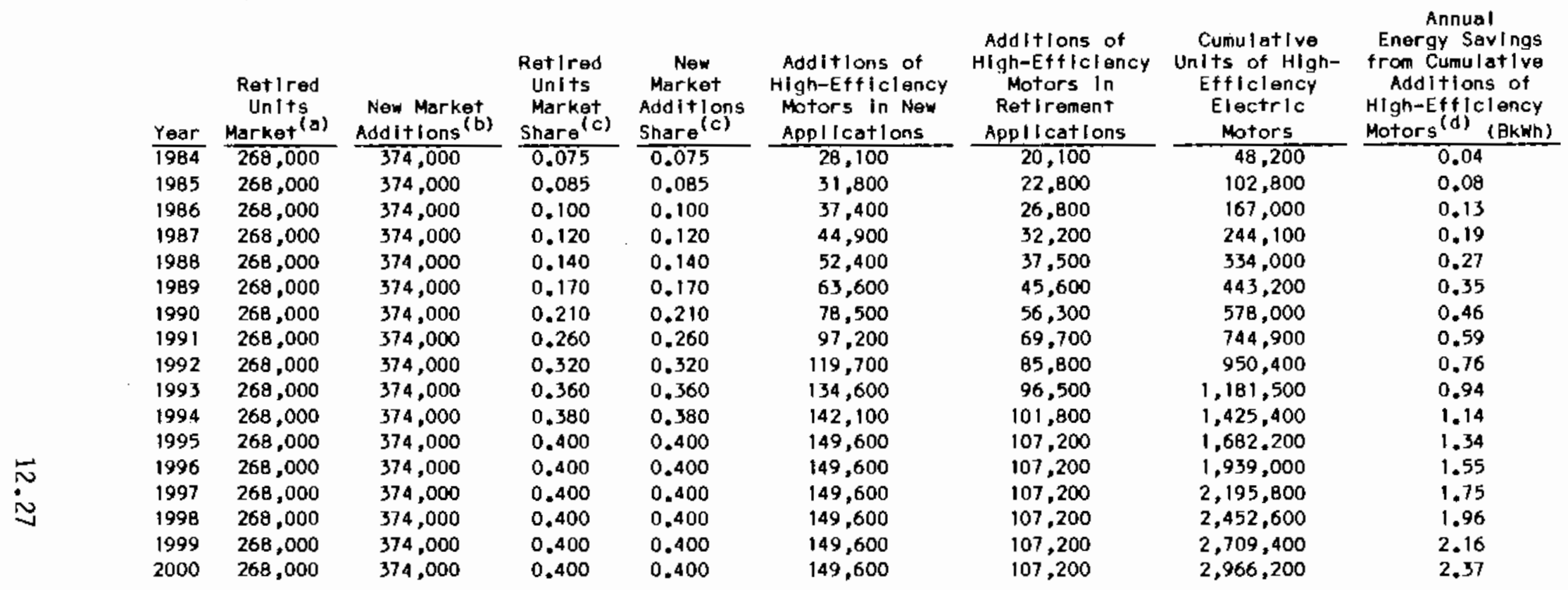

(a) Current origlnal stock in this size category of motors is estlmated to be $8.082 \times 10^{6}$ (Argonne Natlonal Laboratory 1980) retlrement assumed to occur at a rate of 5,8 percent annualiy (Argonne Natlonal Laboratory 1980).

(b) Growth in stock assumed to occur at a rate of 7,2 percent annually (EEA 1982).

(c) Function of an estimated maximum market penetration of 40 percent assumed to be reached in 1995 , and an S-shaped adoption curve.

(d) Colculated by: (Cumulative Unlts) $\times(798 \mathrm{kWh} /$ year). 
TABLE 12.23. High-Scenario Motor Stock Projections and High-Efficiency Motor Market Share Estimates for 20 to 50 Horsepower Motors

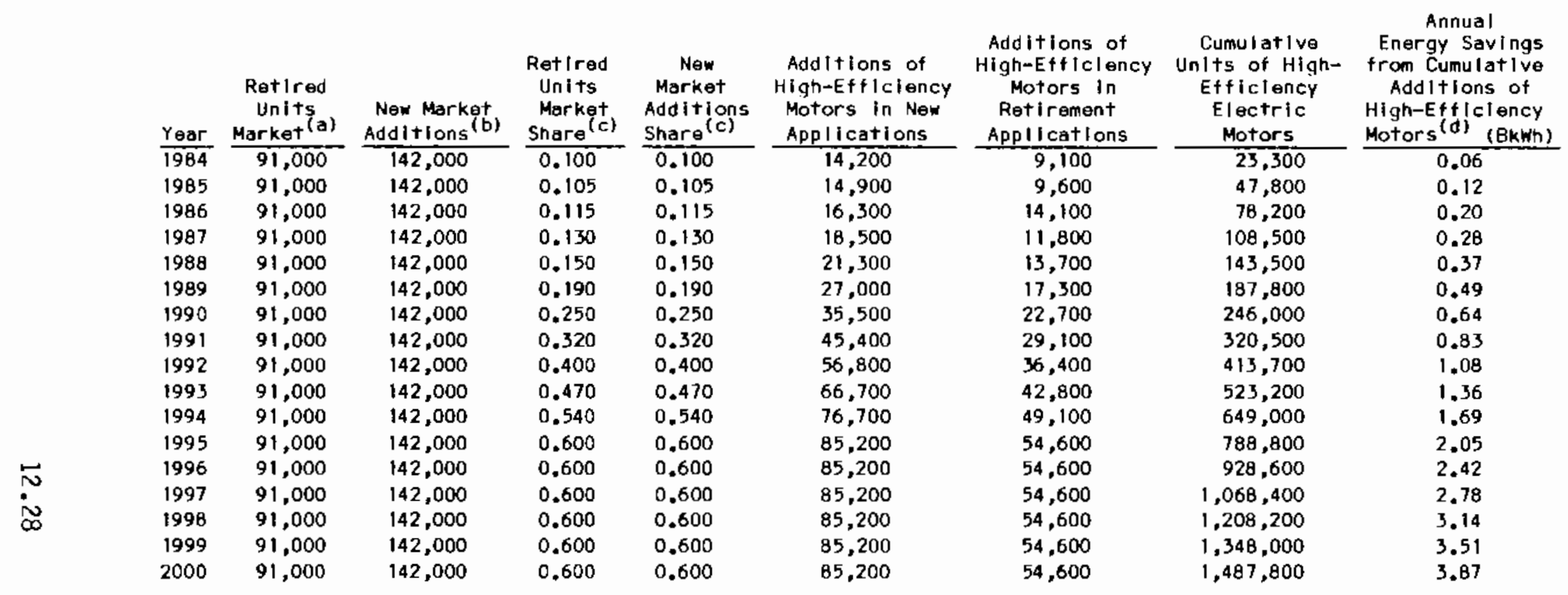

(a) Current origlnal stock in this slze category of motors is estimated to be $8.082 \times 10^{6}$ (Argonne National Laboratory 1980) retirement assumed to Occur at a rate of 5.8 percent annually (Argonne Nationa! Laboratory 1980).

(b) Growth in stock assumed to occur at a rate of 7.2 percent annualiy (EEA 1982).

(c) Function of on estimated maximum market penetration of 60 percent assumed to be reached in 1995 , and an S-shaped adoptlon curve.

(d) Calculated by: (Cumulative units) $\times(2603 \mathrm{kWh} / \mathrm{year})$. 
TABLE 12.24. High-Scenario Motor Stock Projections and High-Efficiency Motor Market Share Estimates for 50 to 125 Horsepower Motors

\begin{tabular}{|c|c|c|c|c|c|c|c|c|c|c|}
\hline & Year & $\begin{array}{c}\text { Retired } \\
\text { Units } \\
\text { Market } \\
\end{array}$ & $\begin{array}{r}\text { New Market, } \\
\text { Additlons (b) }\end{array}$ & $\begin{array}{c}\text { Retired } \\
\text { Unlts } \\
\text { Markg(c) } \\
\text { Share } \\
\end{array}$ & $\begin{array}{c}\text { New } \\
\text { Market } \\
\text { Addit logs } \\
\text { Share } \\
\end{array}$ & $\begin{array}{l}\text { Addlitlons of } \\
\text { High-Efficlency } \\
\text { Motors in Ner } \\
\text { Applicatlons } \\
\end{array}$ & $\begin{array}{l}\text { Additions of } \\
\text { High-Efficiency } \\
\text { Motors in } \\
\text { Retirement } \\
\text { Applications } \\
\end{array}$ & $\begin{array}{c}\text { Cumulative } \\
\text { Units of HIgh- } \\
\text { Efficlency } \\
\text { Electrlc } \\
\text { Motors } \\
\end{array}$ & $\begin{array}{r}\text { Ar } \\
\text { Energy } \\
\text { from Cl } \\
\text { Addit } \\
\text { Hlgh-E } \\
\text { Motors } \\
\end{array}$ & $\begin{array}{l}\text { Annual } \\
\text { gy Savings } \\
\text { Cumulative } \\
\text { itlons of } \\
\text { Effjctency } \\
\text { s.d.) (Bkwh) }\end{array}$ \\
\hline & 1984 & 32,000 & 67,000 & 0.135 & 0.135 & 9,000 & 4,300 & 13,300 & & 0.08 \\
\hline & 1985 & 32,000 & 67,000 & 0.145 & 0.145 & 9,700 & 4,600 & 27,600 & & 0.16 \\
\hline & 1986 & 32,000 & 67,000 & 0.160 & 0.160 & 10,700 & 5,100 & 43,400 & & 0.25 \\
\hline & 1987 & 32,000 & 67,000 & 0.190 & 0.190 & 12,700 & 6,100 & 62,200 & & 0.36 \\
\hline & 1988 & 32,000 & 67,000 & 0.240 & 0.240 & 16,100 & 7,700 & 86,000 & & 0.49 \\
\hline & 1989 & 32,000 & 67,000 & 0.300 & 0.300 & 20,100 & 9,600 & 115,700 & & 0.66 \\
\hline & 1990 & 32,000 & 67,000 & 0.370 & 0.370 & 24,800 & 11,800 & 152,300 & & 0.87 \\
\hline & 1991 & 32,000 & 67,000 & 0.450 & 0.450 & 30,200 & 14,400 & 196,900 & & 1.13 \\
\hline & 1992 & 32,000 & 67,000 & 0.550 & 0.550 & 36,900 & 17,600 & 251,400 & & 1.44 \\
\hline & 1993 & 32,000 & 67,000 & 0.650 & 0.540 & 43,600 & 20,800 & 315,800 & & 1.81 \\
\hline & 1994 & 32,000 & 67,000 & 0.740 & 0.740 & 49,600 & 23,680 & 389,080 & & 2.23 \\
\hline & 1995 & 32,000 & 67,000 & 0.800 & 0.800 & 53,600 & 25,600 & 468,280 & & 2.68 \\
\hline & 1996 & 32,000 & 67,000 & 0.800 & 0.800 & 53,600 & 25,600 & 547,480 & & 3.14 \\
\hline & 1997 & 32,000 & 67,000 & 0.800 & 0.800 & 53,600 & 25,600 & 626,680 & & 3.59 \\
\hline & 1998 & 32,000 & 67,000 & 0.800 & 0.800 & 53,600 & 25,600 & 705,880 & & 4.04 \\
\hline & 1999 & 32,000 & 67,000 & 0.800 & 0.800 & 53,600 & 25,600 & 785,080 & & 4.50 \\
\hline & 2000 & 32,000 & 67,000 & 0.800 & 0.800 & 53,600 & 25,600 & 864,280 & & 4.95 \\
\hline & $\begin{array}{l}\text { (a) } \\
\text { (b) } \\
\text { (c) } \\
\text { (d) }\end{array}$ & $\begin{array}{l}\text { Current ori } \\
\text { 1980) retir } \\
\text { Growth in s } \\
\text { Function of } \\
\text { adoption cu } \\
\text { Calculated }\end{array}$ & \multicolumn{2}{|c|}{$\begin{array}{l}\text { glnal stock in thls size } \\
\text { ement assumed to occur } \\
\text { tock assumed to occur at } \\
\text { an estimated maximum me } \\
\text { rve. } \\
\text { by: (Cumulative Units) }\end{array}$} & \multicolumn{2}{|r|}{$\begin{array}{r}\theta s \\
\text { ta } \\
\text { pe }\end{array}$} & $\begin{array}{l}\text { ted to be } 8.082 \\
\text { ily (Argonne Nat } \\
\text { ly (EEA 1982). } \\
\text { t assumed to be }\end{array}$ & $\begin{array}{l}\times 10^{6} \text { (Argonne } N \\
\text { ional Laboratory } \\
\text { reached in } 1995 .\end{array}$ & $\begin{array}{l}\text { lat lonal } \\
1980 \text { ). } \\
\text { and an }\end{array}$ & $\begin{array}{l}\text { Loboratory } \\
\text { S-shaped }\end{array}$ \\
\hline
\end{tabular}


TABLE 12.25. High-Scenario Motor Stock Projections and High-Efficiency Motor Market Share Estimates for $>125$ Horsepower Motors

\begin{tabular}{|c|c|c|c|c|c|c|c|c|}
\hline Year & $\begin{array}{c}\text { Retlred } \\
\text { Units } \\
\text { Market }\end{array}$ & $\begin{array}{l}\text { New Mark gt } \\
\text { Additlons }\end{array}$ & $\begin{array}{c}\text { Retired } \\
\text { Units } \\
\text { Market } \\
\text { Share }(c) \\
\end{array}$ & $\begin{array}{c}\text { New } \\
\text { Market } \\
\text { Addttlges } \\
\text { Share }\end{array}$ & $\begin{array}{l}\text { Additions of } \\
\text { High-Efficlency } \\
\text { Motors in New } \\
\text { Appllacations } \\
\end{array}$ & $\begin{array}{c}\text { Additlons of } \\
\text { High-Efficiency } \\
\text { Motors in } \\
\text { Retrement } \\
\text { Applifeations } \\
\end{array}$ & $\begin{array}{c}\text { Cumulatlve } \\
\text { Units of High- } \\
\text { Efflelency } \\
\text { Electrlc } \\
\text { Motors } \\
\end{array}$ & 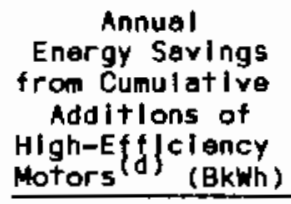 \\
\hline 1984 & 27.000 & 56,000 & 0.040 & 0.040 & 2,200 & 1,100 & 3,300 & 0.01 \\
\hline 1985 & 27,000 & 56,000 & 0.045 & 0.045 & 2,500 & 1,200 & 7,000 & 0.03 \\
\hline 1986 & 27,000 & 56,000 & 0.052 & 0.052 & 2,900 & 1,400 & 11,300 & 0.05 \\
\hline 1987 & 27,000 & 56,000 & 0.062 & 0.062 & 3,500 & 1,700 & 16,500 & 0.07 \\
\hline 1988 & 27,000 & 56,000 & 0.080 & 0.080 & 4,500 & 2,200 & 23,200 & 0.09 \\
\hline 1989 & 27,000 & 56,000 & 0.095 & 0.095 & 5,300 & 2,600 & 31,100 & 0.12 \\
\hline 1990 & 27,000 & 56,000 & 0.115 & 0.115 & 6,400 & 3,100 & 40,600 & 0.16 \\
\hline 1991 & 27,000 & 56,000 & 0.140 & 0.140 & 7,800 & 3,800 & 52,200 & 0.21 \\
\hline 1992 & 27,000 & 56,000 & 0.165 & 0.165 & 9,200 & 4,500 & 65,900 & 0.26 \\
\hline 1993 & 27,000 & 56,000 & 0.180 & 0.180 & 10,100 & 4,900 & 80,900 & 0.32 \\
\hline 1994 & 27,000 & 56,000 & 0.190 & 0.190 & 10,600 & 5,100 & 96,600 & 0.39 \\
\hline 1995 & 27,000 & 56,000 & 0.200 & 0.200 & 11,200 & 5,400 & 113,200 & 0.45 \\
\hline 1996 & 27,000 & 56,000 & 0.200 & 0.200 & 11,200 & 5,400 & 800 129 & 0.52 \\
\hline 1997 & 27,000 & 56,000 & 0.200 & 0.200 & 11,200 & 5,400 & 146,400 & 0.59 \\
\hline 1998 & 27,000 & 56,000 & 0.200 & 0.200 & 11,200 & 5,400 & 163,000 & 0.65 \\
\hline 1999 & 27,000 & 56,000 & 0.200 & 0.200 & 11,200 & 5,400 & 179,600 & 0.72 \\
\hline 2000 & 27,000 & 56,000 & 0.200 & 0.200 & 11,200 & 5,400 & 196,200 & 0.79 \\
\hline
\end{tabular}

(a) Current or iginal stock In this slze category of motors is estimated to be $8.082 \times 10^{6}$ (Argonne Natlonel Laboratory 1980) retirement assumed to occur at a rate of 5.8 percent annually (Argonne Natlonal Laboratory 1980).

(b) Growth In stock assumed to occur at o rate of 7.2 percent annually (EEA 1982).

(c) Function of an estimated maxlmum market penetration of 10 percent assumed to be reached in 1995 , and an S-shaped adoption curve.

(d) Calculated by: (Cumulative Units) $\times(4005 \mathrm{kwh} /$ year). 
TABLE 12.26. High-Scenario Estimates of Electricity Savings from the Use of High-Efficiency Electric Motors

$\begin{array}{cccccccc}\frac{\text { Year }}{1985} & \frac{1 \text { to } 5 \mathrm{HP}}{0.00} & \frac{5 \text { to } 20 \mathrm{HP}}{0.08} & \frac{20 \text { to } 50 \mathrm{HP}}{0.12} & \frac{50 \text { to } 125 \mathrm{HP}}{0.16} & \frac{>125 \mathrm{HP}}{0.03} & \frac{\text { All Motors }}{0.39} \\ 1990 & 0.02 & 0.46 & 0.64 & 0.87 & 0.16 & 2.15 \\ 1995 & 0.07 & 1.34 & 2.05 & 2.68 & 0.45 & 7.24 \\ 2000 & 0.12 & 2.37 & 3.87 & 4.95 & 0.79 & 12.11\end{array}$

Estimates of the levelized costs/kWh saved for high-efficiency electric motors are presented in Table 12.27. Comparing these estimates to an average generation cost for new coal-fired generation plants of $5.21 \% / \mathrm{kWh}$ (presented in Table 4.3) implies that high-efficiency motors would generally be lower cost sources of new electricity than new coal generating units. The only exception

TABLE 12.27. Cost/kWh Saved Calculations for High-Efficiency Electric Motors

Incremental Capital

Cost (1984 \$) in

Motor New and Retirement

$\frac{\text { Size }(H P)}{1 \text { to } 5} \frac{\text { Applications }(a)}{79}$

5 to 20

20 to 50

50 to 125

$>125$
79

175

343

863

1580
Levelized Annual Energy Capital cost Savings (kWh/ $(\$ /$ year $)(\mathrm{b})^{(}$ 8.66 18.22 33.62

77.34

141.60
Cost per kwh Saved in New and Retirement Appl ications $(\$ / \mathrm{kWh})^{(\mathrm{d})}$

8.75 2.28 1.29 1.35 3.54

(a) See Table 12.1.

(b) The level stream of annual payments the present value of which would equal the investment's incremental capital cost. The levelized cost was calculated using an 8 percent discount rate and operating lifetimes of 17 years for 1 to $5 \mathrm{HP}$ motors, 19 years for 5 to $20 \mathrm{HP}, 22$ years for 20 to $50 \mathrm{HP}$, and 29 years for all other motors.

(c) Calculated as the percent electricity savings for high-efficiency motors (from Table 12.4) multiplied by the estimated electricity use in kwh for conventional motors (also from Table 12.4).

(d) Calculated as levelized capital costs (\$/year) divided by annual energy savings (kWh/year) and multiplied by 100 . 
to this finding is for high-efficiency motors of less than 5 HP in size. The estimated costs per $\mathrm{kWh}$ saved for high-efficiency motors larger than 5 HP are significantly less than the regional cost of new power estimates (presented in Table 4.3 ) in all regions of the country.

\subsection{REFERENCES FOR CHAPTER 12.0}

Argonne National Laboratory. 1980. Classification and Evaluation of Electric Motors and Pumps. DOE/TIC-11339. Prepared for the U.S. Department of Energy, Office of Industrial Programs, Washington, D.C.

Carhart, S. C., W. R. King, S. S. Mulherkar, M. H. Ross, and R. H. Shackson. 1979. The Least-Cost Energy Strategy--Technical Appendix. The Energy Productivity Center, MelTon Institute, Arlington, Vírginia.

Century Electric. 1984. Century Electrical Motor Product Catalogue. Century Electric Co., St. Louis, Missouri.

DRI. 1982. U.S. Long-Term Review. Data Resources, Inc. Fal1, 1982.

EEA: 1982. Impacts of Four Legislative Initiatives on Energy Use in the Industrial Sector. Energy and Environmental Analysis, Inc., Arlington, Virginia. Prepared for Battelle Northwest Laboratories, Richland, Washington.

EPRI. 1984. Industrial Electrotechnologies and Electrification (IEE) Program Plan. Electric Power Research Institute, Palo ATto, Californía. May 1984.

Hane, G. J., J. C. King, S. A. Smith, and R. L. Watts. 1983. Assessment of Electric Power Conservation and Supply Resources in the Pacific NorthwestVolume III-Industrial Conservation. Battelle Pacific Northwest Laboratories, Richland, Washington. Prepared for the Pacific Northwest Electric Power and Conservation Planning Council, Portland, Oregon.

Hunt, R. E., F. Seabury; and P. F. Valence. 1976. Energy Efficiency and Electric Motors. PB-259 129. Arthur D. Little, Inc. Cambridge, Massachusetts. Prepared for the Federal Energy Administration, Office of Industrial Programs, Washington, D.C.

Siemans Allis. 1984. Siemans-Allis Selection and Pricing Guide--Integral Horsepower AC Motors. Siemans ATlis Co., Little Rock, Arkansas. 


\subsection{ADJUSTABLE SPEED MOTOR DRIVES}

Adjustable speed electric motor drives (ASDs) can potentially produce electrical energy savings by properly matching electric motor speeds with motor power output requirements. As reported in Chapter 12.0 , electric motors are the largest end user of electricity in the industrial sector, consuming approximately 63 percent of all electricity used in the sector (EPRI 1984a). ASDs can reduce the amount of electricity used by electric motors in any situation where motor power output requirements are not the same at all times. Though ASDs generally cost several times as much as their corresponding motors, they can be quite cost effective due to the magnitude of potential energy savings.

\subsection{TECHNOLOGY DESCRIPTION}

In many applications, the power output required from an electric motor varies significantly over time. An example of such an application is process chemical mixing operations where small chemical flows are required at certain times, while at other times much larger flows are required.

When constant speed motor drives are used in motor drive applications that have variable output requirements, control valves are necessary to limit outputs when full output levels are not required. Significant amounts of energy are wasted as a result of constant speed drives providing full output levels that in turn must be limited by control valves. ASDs reduce this waste by changing motor speeds to match motor output requirements.

An example of a potential application of ASDs is illustrated in Figure 13.1. A constant-speed motor drive is being used in the top and middle segments of Figure 13.1. In the top segment of Figure 13.1, full air flow is required from the motor drive and no energy savings would result from the use of an ASD in this situation. However, in the middle segment of Figure 13.1, the air flow requirements from the fan are reduced and a control valve at the inlet is required to limit air flow. Energy is wasted as air that is not required is deflected from the inlet valve. 


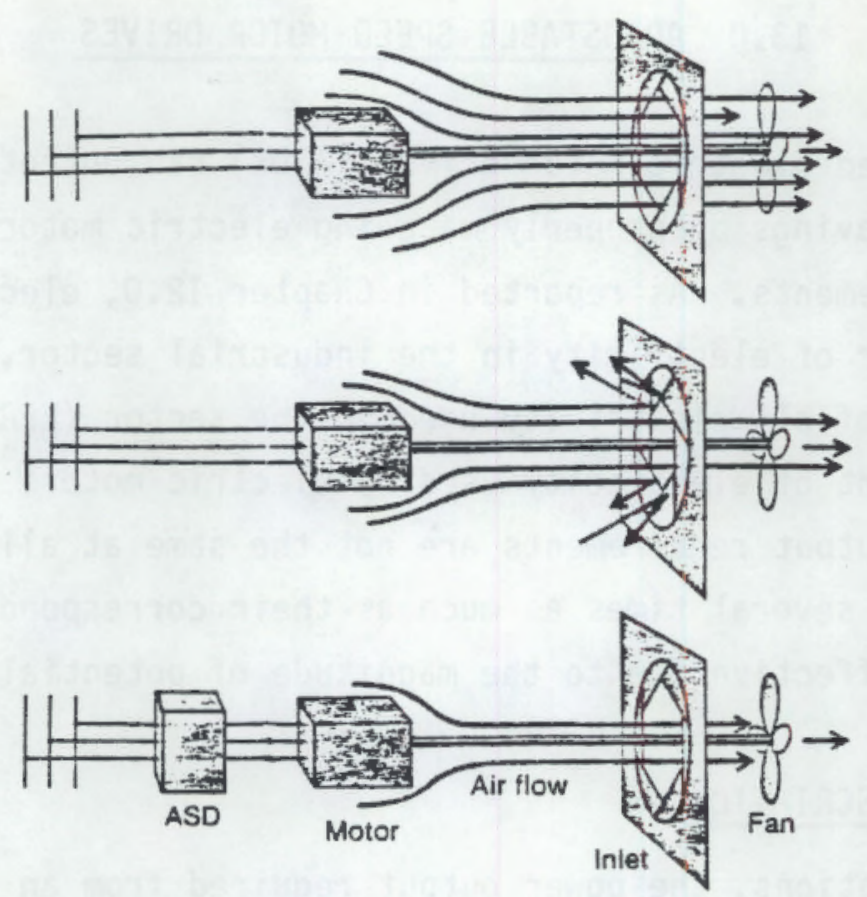

FIGURE 13.1. Illustration of a Potential Application of an Adjustable Speed Motor Drive (EPRI 1984b)

A motor equipped with an ASD is illustrated in the bottom segment of Figure 13.1. The ASD allows for motor speed to be reduced in response to changing flow requirements and energy is no longer wasted against the inlet valve.

There are two primary types of ASDs--mechanical and electronic. Mechanical ASDs, such as those that use hydraulic clutches to change electric motor speeds, have been available for some time. However, several problems, including the difficulty and costs of installing mechanical ASDs, energy losses from friction, and high maintenance costs, have limited the widespread use of mechanical ASDs (EPRI 1984b).

Electronic ASDs appear to offer the most potential for future gains in ASD usage. These ASDs use solid-state electronic hardware and software to control motor speed. The most common type of electronic ASD controls motor speed by changing the frequency of the electric power input pulses provided to the motor (Hane et al. 1983). Electronic ASDs are more compact and easier to install 
than mechanical ASDS. In addition, electronic ASDS, with no moving parts or friction, reduce energy losses and maintenance costs compared to mechanical ASDS.

The benefits of using ASDs often include lower motor wear and tear, as well as energy cost savings. The back pressures produced by the use of control valves with constant speed motors are often considerable, and may quickly wear out component parts. ASDs can eliminate the need for control valves and the back pressures they produce.

A crucial factor in determining the relative benefits of ASDs is the variability in the required outputs of the electric motor drives on which ASDs can be applied. The greater the variation in required outputs, the greater the benefits of using ASDs. In this study, representative estimates of the variability of required outputs for electric motors were used in deriving estimates of energy savings benefits of ASDs.

The market analysis of ASDs was segmented into the same motor size categories used for high-efficiency motors (i.e., l to 5 HP motors, 5 to $20 \mathrm{HP}$ motors, 20 to 50 HP motors, 50 to 125 HP motors, and motors larger than $125 \mathrm{HP})$. The analysis begins with the current market situation.

\subsection{CURRENT MARKET SITUATION}

Both mechanical and electronic ASOs have been used in industrial applications for a number of years. However, the buTkiness of mechanical ASDs and reliability concerns about electronic ASDs limited their market acceptance. In addition, electronic ASDs for alternating current ( $A C$ ) motors have only been available for five years. Thus, a significant number of electric motors could not use ASDs until recently.

ASDs are currently produced and marketed by most of the major electric motor manufacturers, including General Electric, Westinghouse Corporation, and Century Electric. Representatives of these companies report that interest in 
and sales of ASDs have been expanding in recent years. (a,b) This reported growth in ASD sales supports forecasts made by the Electric Power Research Institute (EPRI 1984b) which predict that ASD usage will expand rapidly in the next 10 to 20 years. EPRI also reports that the current market penetration of ASDs is significantly below their potential market penetration.

\subsection{COST EFFECTIVENESS AND MARKET PENETRATION}

Evaluations of the cost effectiveness and likely market penetration of ASDs are presented in this section. The evaluations begin with the presentation of estimates on representative capital costs and payback periods for using ASDs on various sizes of motors. These estimates are then integrated with information on any technical factors that could limit the use of ASDs to derive estimates of the maximum potential market penetration of ASDs.

\subsubsection{Cost Effectiveness of Adjustable Speed Drives}

The cost effectiveness of ASDs for electric motors, as measured by their incremental capital costs and payback periods, depend on the capital costs, the level of energy savings, the dollar value of these energy savings, and the reduction in operating costs from using ASDs. These factors are addressed in this section.

\section{Representative Capital Costs for ASDs}

Price data from electric motor manufacturers were used in developing representative estimates of the capital costs of ASDs (Century Electric 1984 and Westinghouse Corporation 1984). These estimates are shown in Table 13.1 for the five motor size categories specified for use in this study. The estimates presented in Table 13.1 were derived by averaging list prices for ASDs offered by the manufacturers within the various size categories.

(a) Personal communication with Pete Graven, sales representative with General Electric Motor Division, Seattle, Washington, January 11, 1985.

(b) Personal communication with J. L. Sharpe, representative of Westinghouse Electric Corporation Control Division, Asheville, North Carolina, January 11, 1985. 
TABLE 13.1. Representative Estimates of Adjustable Speed Drive Costs, 1984 Dollars $(a)$

\begin{tabular}{|c|c|c|c|}
\hline $\begin{array}{l}\text { Motor Size } \\
\text { (HP) } \\
\end{array}$ & $\begin{array}{l}\text { ASD Purchase } \\
\text { Cost in New } \\
\text { Applications } \\
\text { (1984\$/Motor) } \\
\end{array}$ & $\begin{array}{c}\text { ASD Purchase and } \\
\text { Installation Cost } \\
\text { in Retrofit Applications } \\
\text { (1984\$/Motor) }\end{array}$ & $\begin{array}{c}\text { Initial Cost for } \\
\text { Standard Eff } j \bar{c}\rangle \\
\text { ciency Motors } \\
(\$ 1984) \\
\end{array}$ \\
\hline $1-5$ & 1,490 & 1,860 & 245 \\
\hline $5-20$ & 6,425 & 8,030 & 545 \\
\hline $21-50$ & 13,060 & 16,325 & 1273 \\
\hline $51-125$ & 24,205 & 30,255 & 3849 \\
\hline$>125$ & 49,000 & 61,250 & 7370 \\
\hline
\end{tabular}

(a) Representative estimates derived by averaging estimates provided in Century Electrica] Motor Product Catalogue, 1984 and Westinghouse Electric Corp. Price List 8710, 1984.

(b) Purchase and installation cost calculated as purchase cost multiplied by 1.25. 25 percent cost premium estimate for installation cost obtained from information presented in a previous study (Hane et al. 1983).

(c) Source: Calculated from data presented in Siemans-All is Selection and Pricing Guide--Integral Horsepower AC Motors, 1984 and Century Electric Product Catalogue, 1984.

Estimates shown in the third column of Table 13.1 include the costs of installing ASDs in retrofit and retirement applications. Significant installation costs will often be incurred because of space limitations and other factors. Although these costs will vary widely, representative average cost for installing ASDs in retrofit and retirement applications is 25 percent of the ASD purchase cost (Hane et al. 1983). In new applications, the additional installation costs for incorporating ASDs in a motor drive system should not be significant.

The estimates presented in Table 13.1 imply that the incremental capital costs of ASDs for electric motors are significant. In comparing these estimates to representative costs for electric motors (presented in the fourth column of Table 13.1), it can be seen that the costs for ASDs will generally be five to ten times larger than the costs of the electric motors upon which they are used. 
Representative Percentage Energy Savings for ASDs

As stated previously, the energy savings resulting from using ASDs will vary significantly depending upon the amount of variability in the required output of the motor. However, no information on the relative degree of variability in required output from the various sizes of motors could be obtained within the time frame of this study. Thus, it was necessary to use average estimates of the percentage energy savings that should be expected from the use of ASDs to derive estimates of the kWh savings for ASDs.

EPRI has contracted for extensive field testing of ASDs and analyses of the energy savings that can be obtained from ASD usage. Information published by EPRI (EPRI 1984b) indicates that the percentage energy savings from using ASDs should generally range from 30 to 50 percent. The results of field tests of the use of ASDs in industrial applications ranging from waste water treatment to iron casting indicate that the percentage energy savings from ASDs will generally range from 20 percent to 65 percent (CRS Sirrine 1984). Estimates published in a previous study of ASDs (Hane et al. 1983) place the savings that should be expected from ASDs at a more conservative level of 25 percent to 30 percent.

An estimate of 35 percent will be used in this analysis to represent the average percentage energy savings for implementing ASDs on electric motors. This estimate is well within the range of the results of field tests of ASD effectiveness.

\section{Representative kWh Savings for ASDs}

In this study, representative kWh savings for ASDs are derived simply by multiplying the average estimate of the percentage energy savings for ASDs of 35 percent by representative estimates of the electricity consumed per unit by standard electric motors in the various size classifications. It is recognized that using one estimate of the percentage energy savings from ASDs for all motors ignores the considerable variation in savings that is likely to occur from one ASD motor application to another. However, available information did not permit the development of disaggregate estimates of the percentage energy savings likely to result form the use of ASDs. 
Representative estimates of the electricity consumption of standard electric motors were presented previously in Table 12.3 and are reproduced in Table 13.2. These estimates are used directly in deriving estimates of the $\mathrm{kWh}$ savings for ASDs. The methods used to develop the motor electricity consumption estimates were described in Chapter 12.0, and this description is not repeated here.

\section{Representative Operating Cost Savings for ASDs}

The reduction in operating cost savings from using ASDs will be a function of the energy cost savings that will result from ASD usage, and the reduction in motor-drive equipment repair and replacement costs produced by ASDs. Avai1able evidence indicates that using ASDS will likely reduce motor-drive equipment repair and replacement costs. For example, a number of electric utility users of ASDs state that a major reason for installing ASDs on the drives of their generating plant motors was to reduce costly wear and tear on motor drive parts (EPRI 1984b).

TABLE 13.2. Representative Electricity Use per Motor for Conventional Electric Motors Calculated from a Baseline, Electricity Use for Industrial Motor Drives of 632.7 billion $\mathrm{kWh}(\mathrm{a})$

\begin{tabular}{|c|c|c|c|c|}
\hline $\begin{array}{l}\text { Motor } \\
\text { Size } \\
\text { (HP) }\end{array}$ & $\begin{array}{l}\text { Percent of Total } \\
\text { Electricity } \\
\text { Use in } \\
\text { This HP Classi- } \\
\text { fication }(q)(\mathrm{b}) \\
\end{array}$ & $\begin{array}{l}\text { Annual } \\
\text { Electricity } \\
\text { Use in This } \\
\text { HP Classification } \\
\text { (Billion kWh) } \\
\end{array}$ & $\begin{array}{c}\text { Estimated Number } \\
\text { of Motors in } \\
\text { This HP Class } \\
(000 s) \text { (b) } \\
\end{array}$ & $\begin{array}{l}\text { Annual } \\
\text { Estimated } \\
\text { Electricity } \\
\text { Use Per } \\
\text { Motor (kWh) } \\
\end{array}$ \\
\hline 1 to 5 & 0.9 & 5.69 & 8082 & 704 \\
\hline 5 to 20 & 7.7 & 48.72 & 5191 & 9,385 \\
\hline 20 to 50 & 12.3 & 77.82 & 1973 & 39,442 \\
\hline 50 to 125 & 24.0 & 151.85 & 928 & 163,629 \\
\hline$>125$ & 55.0 & 347.99 & 782 & 444,994 \\
\hline
\end{tabular}
(a) Source: Documentation on the ISTUM forecasting model presented in The Least-Cost Energy Strategy--Technical Appendix, (Carhart et al . 1979).

(b) Source: Calculated from data presented in Classification and Evaluation of Electric Motors and Pumps, (Argonne National Laboratory 1980). 
TABLE 13.3. Representative Payback Periods for Adjustable Speed Drives on Electric Motors in New Applications

\begin{tabular}{|c|c|c|c|c|c|}
\hline $\begin{array}{c}\text { Motor Size } \\
\text { (HP) } \\
\end{array}$ & $\begin{array}{c}\text { Estimated } \\
\text { Electricjty } \\
\text { Use for } \\
\text { Conventional } \\
\text { Motors (kWh) } \\
\end{array}$ & $\begin{array}{l}\text { Estimated } \\
\text { Annual } \\
\text { Electricity } \\
\text { Cost }\{a v- \\
\text { ings (a) (\$) }\end{array}$ & $\begin{array}{c}\text { Estimated } \\
\text { Annual } \\
\text { Equipment } \\
\text { Cost Savings } \\
(\$) \\
\end{array}$ & $\begin{array}{l}\text { Capital } \\
\text { Costs for } \\
\text { ASDs }(\$) \\
\end{array}$ & $\begin{array}{l}\text { Estimated } \\
\text { Payback } \\
\text { Period } \\
\text { (Years) } \\
\end{array}$ \\
\hline 1 to 5 & 704 & 12.25 & 1.37 & 1,490 & 109.4 \\
\hline 6 to 20 & 9,385 & 163.25 & 18.27 & 6,425 & 35.4 \\
\hline 21 to 50 & 39,442 & 686.09 & 76.76 & 13,060 & 17.1 \\
\hline 51 to 125 & 163,629 & $2,846.33$ & 318.42 & 24,205 & 7.7 \\
\hline$>125$ & 444,994 & $7,740.67$ & 865.96 & 49,000 & 5.7 \\
\hline
\end{tabular}

(a) Calculated by multiplying representative percentage electricity savings for ASDs of 35 percent by estimates of electricity use for conventional motors and an average cost for electricity of $4.97 \$$ per $\mathrm{kWh}$.

TABLE 13.4. Representative Payback Periods for Adjustable Speed Drives on Electric Motors in Retirement/Retrofit Applications

\begin{tabular}{|c|c|c|c|c|c|}
\hline $\begin{array}{c}\text { Motor Size } \\
\text { (HP) }\end{array}$ & $\begin{array}{l}\text { Estimated } \\
\text { Electricity } \\
\text { Use for } \\
\text { Conventional } \\
\text { Motors (kWh) }\end{array}$ & $\begin{array}{l}\text { Estimated } \\
\text { Annual } \\
\text { Electricity } \\
\text { Cost \{av- } \\
\text { ings (a) (\$) }\end{array}$ & $\begin{array}{c}\text { Estimated } \\
\text { Annual } \\
\text { Equipment } \\
\text { Cost Savings } \\
(\$) \\
\end{array}$ & $\begin{array}{l}\text { Capital } \\
\text { Costs for } \\
\text { ASDs (\$) }\end{array}$ & $\begin{array}{l}\text { Estimated } \\
\text { Payback } \\
\text { Period } \\
\text { (Years) } \\
\end{array}$ \\
\hline 1 to 5 & 704 & 12.25 & 1.37 & 1,860 & 136.6 \\
\hline 6 to 20 & 9,385 & 163.25 & 18.27 & 8,030 & 44.2 \\
\hline 21 to 50 & 39,442 & 689.09 & 76.76 & 16,325 & 21.4 \\
\hline 51 to 125 & 163,629 & $2,946.33$ & 318.42 & 30,255 & 9.3 \\
\hline$>125$ & 444,994 & $7,740.67$ & 865.96 & 61,250 & 7.1 \\
\hline
\end{tabular}

(a) Calculated by multiplying representative percentage electricity savings for ASDs of 35 percent by estimates of electricity use for conventional motors and an average cost for electricity of $4.97 \$$ per $\mathrm{kWh}$. 
in EPRI sponsored research on ASDs, which is limited to applications on electric motors that are generally greater than $100 \mathrm{HP}$, (a)

\subsubsection{Technical Limits on the Use of ASDS}

No justification was found for applying technical limits to the use of ASDs in any applications where such use is cost effective.

\subsubsection{Maximum Potential Market Penetration of ASDs}

Estimates of the maximum market penetration for adjustable speed drives in the industrial sector are shown in Table 13.5 for motors exceeding $50 \mathrm{HP}$. These estimates were developed by applying the payback period estimates presented in Tables 13.3 and 13.4 to data presented previously in the first row of Table 4.2.

In selecting the appropriate maximum market-penetration estimates for ASDs, the incremental capital costs for ASDs were ignored because incorporating

\section{TABLE 13.5. Estimates of the Maximum Market-Penetration Potential(a) of Adjustable Speed Drives in New and Retirement/Retrofit Applications}

\begin{tabular}{|c|c|c|c|c|}
\hline $\begin{array}{l}\text { Motor } \\
\text { Size } \\
\text { (HP) }\end{array}$ & $\begin{array}{l}\text { Est imated } \\
\text { Payback } \\
\text { (Years) for } \\
\text { ASDs in New } \\
\text { Applications } \\
\end{array}$ & $\begin{array}{l}\text { Estimated Payback } \\
\text { Period (Years) for } \\
\text { ASOs in Retrofit/ } \\
\text { Ret irement } \\
\text { Applications } \\
\end{array}$ & $\begin{array}{l}\text { Estimated Maximum } \\
\text { Market-Penetration } \\
\text { Potential (\%) in } \\
\text { New Applications } \\
\end{array}$ & $\begin{array}{l}\text { Estimated Maximum } \\
\text { Market-Penetration } \\
\text { Potential ( } \% \text { ) in } \\
\text { Retirement/Retrofit } \\
\text { Applications } \\
\end{array}$ \\
\hline 50 to 125 & 6.9 & 9.3 & 20 & 20 \\
\hline$>125$ & 5.1 & 7.1 & 20 & 20 \\
\hline
\end{tabular}

(a) Obtained from information from DOE/BERD presented previously in Table 4.2 penetration of ASDs is zero for all types of motors. Such a conclusion would be inconsistent with current market evidence that ASDs are already being used in some industrial situations and that interest in ASD usage is increasing rapidiy. A maximum potential market penetration of 20 percent for ASDs is consistent with the current market situation for this equipment.

(a) Personal communication with Ralph Ferraro, manager of adjustable-speed drive industrial program, Electric Power Research Institute, Palo Alto, California, January, 1985. 
these costs would have led to the conclusion that the maximum potential market penetration of ASDs is zero for all types of motors. Such a conclusion would be inconsistent with current market evidence that ASDs are already being used in some industrial situations and that interest in ASD usage is increasing rapidly. A maximum potential market penetration of 20 percent for ASDs is consistent with the current market situation for this equipment.

\subsection{POPULATION DATA}

Estimates of current electric motor populations, growth rates in these populations, and retirement rates for electric motors were developed previously in Chapter 12.0 of this paper and are reproduced in Table 13.6. The estimates for motors greater than $50 \mathrm{HP}$ are used as a basis for deriving estimates of the number of potential applications of ASDs and the energy savings that will result from such applications. The method used to derive the estimates presented in Table 13.6 were explained previously in Section 12.4, and this explanation is not repeated here.

TABLE 13.6. Current Electric Motor Populations, Growth Rates and Retirement Rates Employed in This Study

\begin{tabular}{|c|c|c|c|c|c|}
\hline $\begin{array}{l}\text { Motor } \\
\text { Size } \\
\text { (HP) } \\
\end{array}$ & $\begin{array}{c}\text { Current Motor } \\
\text { Population }(a) \\
(000 s) \\
\end{array}$ & $\begin{array}{c}\text { Future } \\
\text { Annua1 } \\
\text { Growth } \\
\text { Rate }^{(b)}(\%)\end{array}$ & $\begin{array}{c}\text { Additional } \\
\text { Units Added } \\
\text { Annually (000s) }\end{array}$ & $\begin{array}{c}\text { Annual } \\
\text { Ret irement } \\
\text { Rate }(\%)(a) \\
\end{array}$ & $\begin{array}{l}\text { Units } \\
\text { Retired } \\
\text { Annually } \\
(000 s) \\
\end{array}$ \\
\hline 1 to 5 & 8082 & 7.2 & 582 & 5.8 & 473 \\
\hline 5 to 20 & 5191 & 7.2 & 374 & 5.2 & 268 \\
\hline 20 to 50 & 1973 & 7.2 & 142 & 4.6 & 91 \\
\hline 50 to 125 & 928 & 7.2 & 67 & 3.5 & 32 \\
\hline$>125$ & 782 & 7.2 & 56 & 3.4 & 27 \\
\hline
\end{tabular}

(a) Source: Calculated from data presented in Classification and Evaluation of Electric Motors and Pumps, (Argonne National Laboratory 1980).

(b) Source: Documentation on the ISTUM forecasting model presented in Proposed ISTUM Runs and Inputs, Outputs and ScheduTe, (EEA 1982). 
The estimates presented in Table 13.6 for motors greater than 50 HP were integrated with estimates of the maximum potential market penetration of ASDs and an S-shaped market adoption rate (see Chapter 4.0) to develop estimates of the number of ASDs that will likely be installed between 1984 and 2000. A faster rate of market adoption was assumed for ASDs on motors greater than $125 \mathrm{HP}$ in size compared to motors from 50 to $125 \mathrm{HP}$ because of the shorter representative payback periods estimated for the larger motors. These annual estimates are presented in Tables 13.7 and 13.8 .

\subsection{ENERGY SAVINGS RESULTS}

Estimates of the potential energy savings that are forecast to result from the implementation of adjustable speed drives on electric motors in selected years are shown in the last columns of Tables 13.7 and 13.8. Table 13.9 shows the energy savings as well as the number of adjustable speed drives projected to be installed on motors in the selected forecast years. The projected energy savings for ASDs (in BkWh) were obtained by multiplying representative estimates of the energy savings per unit (in kWh) for ASDs on motors greater than $50 \mathrm{HP}$ by the projected number of ASDs that will be installed in each year. Representative estimates of the energy savings per unit for ASDs were $57,000 \mathrm{kWh}$ for 50 to $125 \mathrm{HP}$ motors and 156,000 kWh on motors greater than $125 \mathrm{HP}$.

The final column of Table 13.9 presents estimates of the potential electricity savings for ASDs in the industrial sector summed across all motors greater than $5 \mathrm{HP}$. These savings are expected to be approximately $51.2 \mathrm{BkWh}$ in the year 2000 .

\subsection{SENSITIVITY ANALYSIS}

An analysis was performed of the sensitivity of the energy savings estimates for ASDs to changes in the maximum potential market penetration the technology achieves and the rate at which this maximum is achieved. The results of this sensitivity analysis for both a low and a high scenario are presented in this section.

\subsubsection{Low Market-Penetration Scenario}

The maximum potential market penetration assumed in the low scenario of the sensitivity analysis for ASDs was 10 percent for both 50 to $125 \mathrm{HP}$ motors 
TABLE 13.7. Annual Market Share Projections - Adjustable Speed Drives on Industrial Electric Motors of 50 to $125 \mathrm{HP}$

\begin{tabular}{|c|c|c|c|c|c|c|c|c|c|c|c|}
\hline & Year & $\begin{array}{c}\text { Number of } \\
1984 \text { and Pre- } \\
1984 \text { Motors } \\
\text { Not Retired }(a) \\
\end{array}$ & $\begin{array}{c}\text { Number } \\
\text { of New } \\
\text { Motors (b) }\end{array}$ & $\begin{array}{l}\text { Number of } \\
\text { Ret 1 red } \\
\text { Motors (c) } \\
\end{array}$ & $\begin{array}{l}\text { Retrofit } \\
\text { Units } \\
\text { Market } \\
\text { Share (d) } \\
\end{array}$ & $\begin{array}{l}\text { Retired } \\
\text { Units } \\
\text { Market } \\
\text { Share (d) } \\
\end{array}$ & $\begin{array}{l}\text { New } \\
\text { Units } \\
\text { Market } \\
\text { Share (d) } \\
\end{array}$ & $\begin{array}{l}\text { Cumulative } \\
\text { Retrof tted } \\
\text { Units (e) } \\
\end{array}$ & $\begin{array}{c}\text { Annual Additions } \\
\text { and Retirement } \\
\text { ln New } \\
\text { Applications } f \text { ) }\end{array}$ & $\begin{array}{l}\text { Cunmul at ive } \\
\text { Addit ions } \\
\text { of ASD's }(g)\end{array}$ & $\begin{array}{c}\text { Cumulative } \\
\text { Energy Savings } \\
\text { from ASO } \\
\text { Installations }(\mathrm{h}) \\
\text { (Bkwh) } \\
\end{array}$ \\
\hline & 1984 & 928,000 & 67,000 & 32,000 & 0.040 & 0.050 & 0.050 & 37,120 & 4,950 & 42,070 & 2.40 \\
\hline & 1985 & 896,000 & 67,000 & 32,000 & 0.041 & 0.051 & 0.051 & 36.736 & 5.049 & 46,735 & 2.66 \\
\hline & 1986 & 864,000 & 67,000 & 32,000 & 0.043 & 0.053 & 0.053 & 37,152 & 5,247 & 52,398 & 2.99 \\
\hline & 1987 & 832,000 & 67,000 & 32,000 & 0.046 & 0.056 & 0.056 & 38,292 & 5,544 & 59,062 & 3.37 \\
\hline & 1988 & 800,000 & 67.000 & 32,000 & 0.050 & 0,060 & 0.060 & 40,000 & 5,940 & 66.730 & 3.80 \\
\hline & 1989 & 768,000 & 67.000 & 32.000 & 0.055 & 0.065 & 0.065 & 42,240 & 6,435 & 75,405 & 4.30 \\
\hline & 1990 & 736,000 & 67,000 & 32,000 & 0.062 & 0.072 & 0.072 & 95,632 & 7,129 & 85,925 & 4.90 \\
\hline & 1991 & 704,000 & 67,000 & 32,000 & 0.070 & 0.080 & 0.080 & 49,280 & 7,820 & 97,493 & 5.55 \\
\hline & 1992 & 672,000 & 67,000 & 32,000 & 0.070 & 0.090 & 0.090 & 47,040 & 8,910 & 104,163 & 5.94 \\
\hline & 1993 & 640,000 & 67,000 & 32,000 & 0.090 & 0.100 & 0.100 & 57,600 & 9,900 & 124,623 & 7.10 \\
\hline & 1994 & 608,000 & 67,000 & 32,000 & 0.105 & 0.115 & 0.115 & 63,840 & 11,385 & 142,248 & 8.11 \\
\hline$\vec{\omega}$ & 1995 & 576,000 & 67,000 & 32,000 & 0.120 & 0.130 & 0.130 & 69,120 & 12,870 & 160,398 & 9.14 \\
\hline & 1996 & 544,000 & 67,000 & 32,000 & 0.135 & 0.145 & 0.145 & 73,440 & 14,355 & 179,073 & 10.21 \\
\hline & 1997 & 512,000 & 67.000 & 32,000 & 0.150 & 0.160 & 0.160 & 76,800 & 15,840 & 198,273 & 11.30 \\
\hline & $199 R$ & 484,000 & 67,000 & 32,000 & 0.170 & 0.175 & 0.175 & 82,280 & 17,325 & 221.078 & 12.60 \\
\hline & 1999 & 452,000 & 67,000 & 32,000 & 0.190 & 0.190 & 0.190 & 85,880 & 18,810 & 243,488 & 13.88 \\
\hline & 2000 & 420,000 & 67.000 & 32,000 & 0.200 & 0.200 & 0.200 & 84,000 & 19,800 & 261,408 & 14.90 \\
\hline & $\begin{array}{l}\text { (a) } \\
\text { (b) } \\
\text { (c) } \\
\text { (d) } \\
\text { (e) } \\
\text { (f) } \\
\text { (g) } \\
\text { (b) }\end{array}$ & \multicolumn{10}{|c|}{ 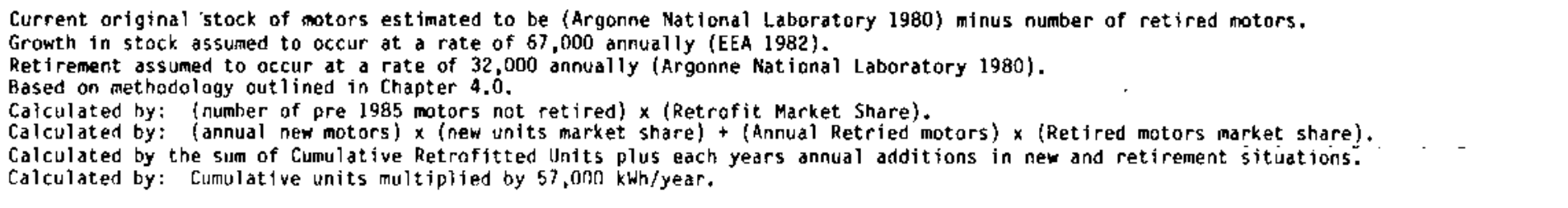 } \\
\hline
\end{tabular}


TABLE 13.8. Annual Market Share Projections - Adjustable Speed Drives on Industrial Electric Motors Greater than $125 \mathrm{HP}$

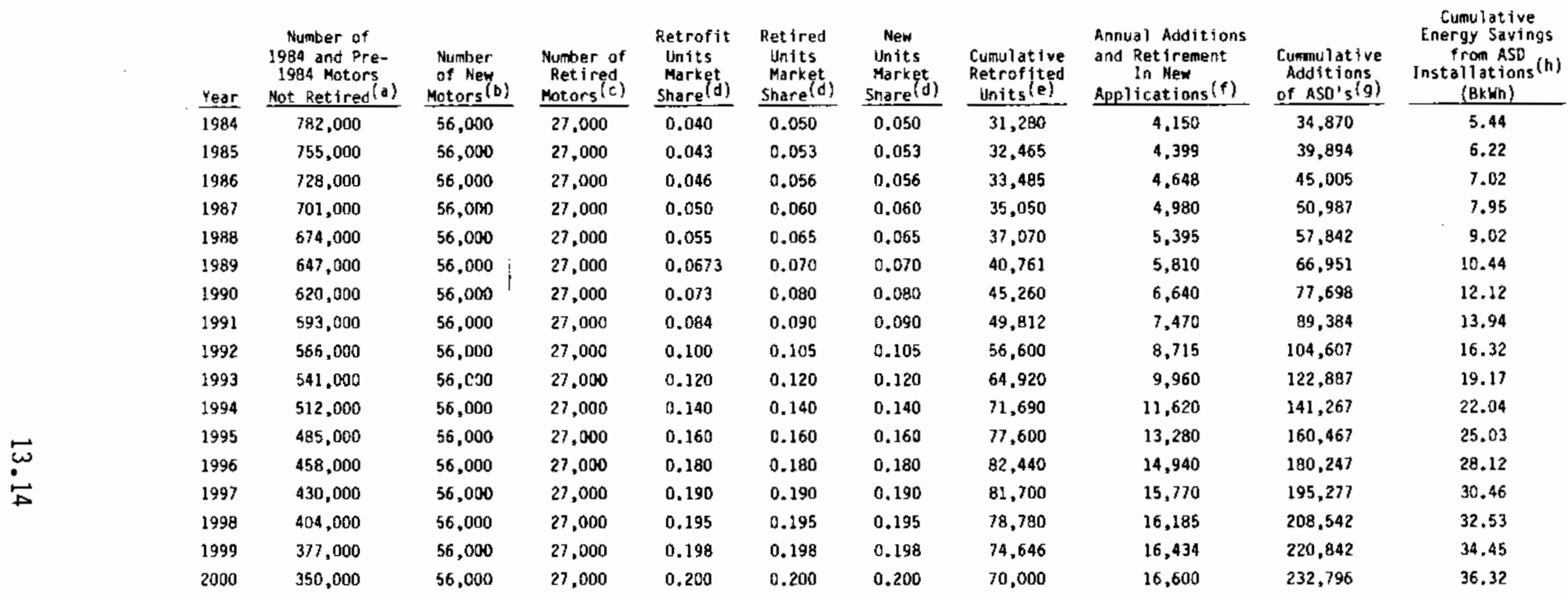

(a) Current origfnal stock of motors estimated to be (Argonne Naticnal Laboratory 1980) minus number of retired motors.

(b) Frowth in stock assumed to occur at a rate of 56,000 annually (EEA 1982).

(c) Ret irement assumed to occur at a rate of 27,000 annually (Argome National Laboratory 1980).

(d) Rased on methodology out lined in chapter 4.0 .

(e) Calculated by: (number of pre 1985 motors not retired) $\times$ (Retrofit Market Share)

(f) Calculaten by: (annual new motors) $x$ (new units market share) + (Annual Retried motors) $x$ (Retired motors market share).

(g) Calculated hy the 54 m of Cumulative Retrofitted Inits plus each years annual additions in new and retirement situations.

(h) Calculated by: Cumulative units multiplied by $156,000 \mathrm{kwh} / \mathrm{year}$. 
TABLE 13.9. Estimated Energy Savings (BkWh) and Number of Units Projected to Be Installed for Adjustable Speed Drives on Industrial Electric Motors

\begin{tabular}{|c|c|c|c|c|c|c|}
\hline \multirow[b]{2}{*}{ Year } & 50 to 125 & & \multicolumn{2}{|c|}{ Motors } & \multicolumn{2}{|c|}{ All Motors $>50 \mathrm{FP}$} \\
\hline & $\begin{array}{l}\text { No. of Motors } \\
\text { Projected to } \\
\text { Be Installed }\end{array}$ & $\begin{array}{l}\text { Estimated } \\
\text { Energy } \\
\text { Savings } \\
\end{array}$ & $\begin{array}{l}\text { No. of Motors } \\
\text { Projected to } \\
\text { Be Installed }\end{array}$ & $\begin{array}{l}\text { Estimated } \\
\text { Energy } \\
\text { Savings } \\
\end{array}$ & $\begin{array}{l}\text { Wo, of Motor } \\
\text { Projected to } \\
\text { Be Installed }\end{array}$ & $\begin{array}{l}\text { Estimafod } \\
\text { Energy } \\
\text { Savings }\end{array}$ \\
\hline 1985 & 46,735 & 2.66 & 39,894 & 6.22 & 86,629 & 8.88 \\
\hline 1990 & 85,925 & 4.40 & 77,698 & 12.12 & 163,623 & 17.02 \\
\hline 1995 & 160,398 & 9.14 & 164,674 & 29.03 & 324,072 & 34.17 \\
\hline 2000 & 261,400 & 14.90 & 232,796 & 36.32 & 494,204 & 51.22 \\
\hline
\end{tabular}

and motors greater than $125 \mathrm{HP}$. This number was half as large as that assumed in the baseline analysis. It was also assumed that only 75 percent of the maximum potential market penetration would be achieved by the year 2000 . These assumptions resulted in the use of an estimate of 7.5 percent market penetration for ASDs by the year 2000 on all motors greater than 50 HP.

The results of using an estimate of 7.5 percent market penetration by 2000 and other low scenario market penetration assumptions are shown in Tables 13.10 and 13.11. The total estimated energy savings for ASDs by 2000 is 34.92 . The results are summarized for selected years in Table 13.12.

13.6.2 High Market Penetration Scenario

The maximum potential market penetration assumed for ASDs in the high scenario was 40 percent for all motors greater than $50 \mathrm{HP}$. It was also assumed that a rapid rate of market adoption would cause this maximum penetration to be reached by 1995 .

The results obtained using the high scenario market-penetration assumptions are shown in Table 13.13 and 13.14. The total estimated energy savings in the year 2000 are $107.46 \mathrm{Bkwh}$. The results are summarized for selected years in Table 13.15 .

13.7 COST/KWh OF ENERGY SAVED CALCULATIONS AND COMPARISONS TO THE COST/KWh OF PRODUCING NEW GENERATING CAPACITY

Comparisons of the estimated levelized costs/kWh for ASDs versus the esti mated costs/kwh for new generating plants are presented in this section. 
TABLE 13.10. Low Scenario Annual Market Share Projections - Adjustable Speed Drives on Industrial Electric Motors of 50 to $125 \mathrm{HP}$

\begin{tabular}{|c|c|c|c|c|c|c|c|c|c|c|}
\hline Year & $\begin{array}{l}\text { Number of } \\
1984 \text { and Pre- } \\
1984 \text { Motars } \\
\text { Not Ret Ired (a) }\end{array}$ & $\begin{array}{l}\text { Number } \\
\text { of New } \\
\text { Motors }(\mathrm{b}) \\
\end{array}$ & $\begin{array}{c}\text { Number of } \\
\text { Ret ired } \\
\text { Motors }(c)\end{array}$ & $\begin{array}{l}\text { Retrofit } \\
\text { Units } \\
\text { Market } \\
\text { Share (d) } \\
\end{array}$ & $\begin{array}{l}\text { Ret ired } \\
\text { Units } \\
\text { Market } \\
\text { Share (d) } \\
\end{array}$ & $\begin{array}{c}\text { New } \\
\text { Units } \\
\text { Market } \\
\text { Share(d) } \\
\end{array}$ & $\begin{array}{l}\text { Cumulative } \\
\text { Retrofited } \\
\text { Units(e) } \\
\end{array}$ & $\begin{array}{l}\text { Annual Additions } \\
\text { and Retirement } \\
\text { In New } \\
\text { Agplications (f) }\end{array}$ & $\begin{array}{l}\text { Cummulative } \\
\text { Additions } \\
\text { of ASD's(g) } \\
\end{array}$ & $\begin{array}{c}\text { Cumulative } \\
\text { Energy Savings } \\
\text { from ASD } \\
\text { Installatians }(\mathrm{h}) \\
\text { (Bkblh) } \\
\end{array}$ \\
\hline 1984 & 928,000 & 67,000 & 32,000 & 0.030 & 0.040 & 0.040 & 27,840 & 3,960 & 31.800 & 1.81 \\
\hline 1985 & 896,000 & 67,000 & 32,000 & 0.041 & 0.041 & 0.041 & 36,736 & 4.059 & 44.755 & 2.55 \\
\hline 1986 & 864,000 & 67,000 & 32,000 & 0.043 & 0.043 & 0.043 & 37.152 & 4,257 & 49,428 & 2.82 \\
\hline 1987 & 832,000 & 67,000 & 32,000 & 0.045 & 0.045 & 0.045 & 37,440 & 4,455 & 54,171 & 3.09 \\
\hline 1988 & 800,000 & 67,000 & 32,000 & 0.049 & 0.049 & 0.049 & 39,200 & 4,851 & 60,782 & 3.46 \\
\hline 1989 & 768,000 & 67,000 & 32,000 & 0.053 & 0.053 & 0.053 & 40,704 & 5,247 & 67,533 & 3.85 \\
\hline 1990 & 736,000 & 67,000 & 32,000 & 0.056 & 0.056 & 0.056 & 41,216 & 5,544 & 73.599 & 4,19 \\
\hline 1991 & 704,000 & 67,000 & 32,000 & 0.061 & 0.061 & 0.061 & 42,944 & 6,039 & 81,356 & 4.64 \\
\hline 1992 & 672,000 & 67,000 & 32,000 & 0.065 & 0.065 & 0.065 & 43,680 & 6,435 & 88,527 & 5.05 \\
\hline 1993 & 540,000 & 67,000 & 32,000 & 0.067 & 0.067 & 0.067 & 42,880 & 6,633 & 94,360 & 5.38 \\
\hline 1994 & 608,000 & 67,000 & 32,000 & 0.069 & 0.069 & 0.069 & 41,952 & 6.831 & 100,263 & 5.71 \\
\hline 1995 & 576,000 & 67,000 & 32,000 & 0.070 & 0.070 & 0.070 & 40,320 & 6,930 & 105,561 & 6.02 \\
\hline 1996 & 544,000 & 67,000 & 32,000 & 0.071 & 0.071 & 0.071 & 38,624 & 7,029 & 110,894 & 6.32 \\
\hline 1997 & 512,000 & 67,000 & 32,000 & 0.072 & 0.072 & 0.072 & 36,864 & 7,128 & 116,262 & 6.63 \\
\hline 1998 & 484,000 & 67,000 & 32,000 & 0.073 & 0.073 & 0.073 & 35,332 & 7,227 & 121,957 & 5.95 \\
\hline 1959 & 452,000 & 67.000 & 32,000 & 0.074 & 0.074 & 0.074 & 33,448 & 7,326 & 127,399 & 7.26 \\
\hline 2000 & 420,000 & 67,000 & 32.000 & 0.075 & 0.075 & 0.075 & 31,500 & 7,425 & 132.876 & 7.57 \\
\hline
\end{tabular}

(a) Current original stock of motors estimated to be (Árgonne Mational Laboratory 1980) minus number of retired motors.

(b) Growth in stock assumed to occur at a rate of 67,000 annually (EEA 1982).

(c) Retírement assumed to occur at a rate of 32,000 annually (Argonne National Laboratory 1980),

(d) Based on methadology out li ned in Chapter 4.00 .

(e) Calculated by: (number of pre 1985 motors not retired) $x$ (Retrof1t Market Share).

(f) Calculated by: (annual new motors) $x$ (new units market share) + (Annual Retried motors) $x$ (Retired motors market share).

(g) Calculated by the sum of Cundative Retrofitted Units plus each years annual additions in new and retirement situations. 
TABLE 13.11. Low Scenario Annual Market Share Projections - Adjustable Speed Drives on Industrial Electric Motors Greater than 125 HP

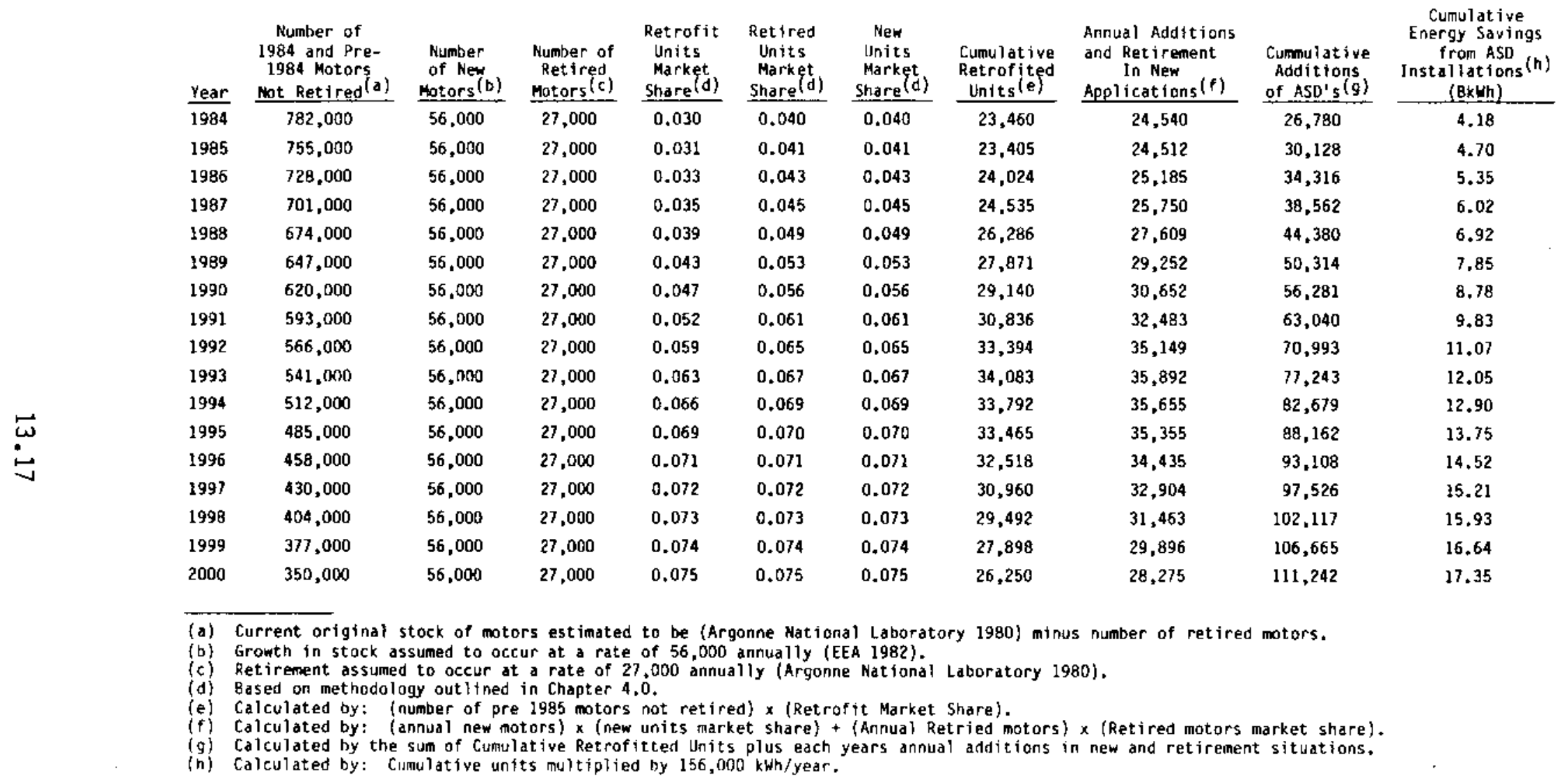


TABLE 13.12. Low Scenario Estimated Energy Savings (BKWh) and Number of Units Projected to Be Installed for Adjustable Speed Drives on Industrial Electric Motors

\begin{tabular}{|c|c|c|}
\hline Year & $\begin{array}{l}50 \text { to } 125 \\
\text { No. of Motors } \\
\text { Projected to } \\
\text { Be Instal led }\end{array}$ & $\begin{array}{l}\text { Motors } \\
\text { Estimeted } \\
\text { Energy } \\
\text { Savings }\end{array}$ \\
\hline 1985 & 44,755 & 2.55 \\
\hline 1990 & 67,533 & 3.85 \\
\hline 1995 & 105,561 & 6.02 \\
\hline 2000 & 132,876 & 7.57 \\
\hline
\end{tabular}

\begin{tabular}{|c|c|}
\hline $\begin{array}{l}\text { P125 HP } \\
\text { No. of Motors } \\
\text { Projected to } \\
\text { Be Instal Ied }\end{array}$ & $\begin{array}{l}\text { Motors } \\
\text { Esfimated } \\
\text { Energy } \\
\text { Savings } \\
\end{array}$ \\
\hline 30,128 & 4.70 \\
\hline 56,281 & 8.78 \\
\hline 88,162 & 13.75 \\
\hline $11 t, 242$ & 17.35 \\
\hline
\end{tabular}

\begin{tabular}{|c|c|}
\hline $\begin{array}{l}\text { All Motors } \\
\text { No. of Motor } \\
\text { Projected to } \\
\text { Be Installed }\end{array}$ & $\begin{array}{c}>50 \mathrm{HP} \\
\text { Estimated } \\
\text { Energy } \\
\text { Savings } \\
\end{array}$ \\
\hline 74,883 & 7.25 \\
\hline 123,814 & 12.65 \\
\hline 193,725 & 19.77 \\
\hline 244,118 & 34.92 \\
\hline
\end{tabular}

Representative estimates of the levelized costs/kWh saved for ASDs on electric motors are presented in Tables 13.16 and 13.17 .

The estimated costs/kWh saved for ASDs in new retirement and retrofit applications on motors less than 50 HP are significantly higher than an estimated average generation cost for new coal-fired generating plants of $5.82 \$ / k$ Wh (presented in Table 4.3). However, the estimated costs/kwh saved for ASDs on motors greater than $50 \mathrm{HP}$ are at or below the estimated average new coal-plant generating cost. The ASD costs/kWh saved on motors greater than 50 HP are also less than the regional cost of new power estimates (presented in Table 4.3) in most regions of the country. 
TABLE 13.13. High Scenario Annual Market Share Projections - Adjustable Speed Drives on Industrial Electric Motors of 50 to $125 \mathrm{HP}$

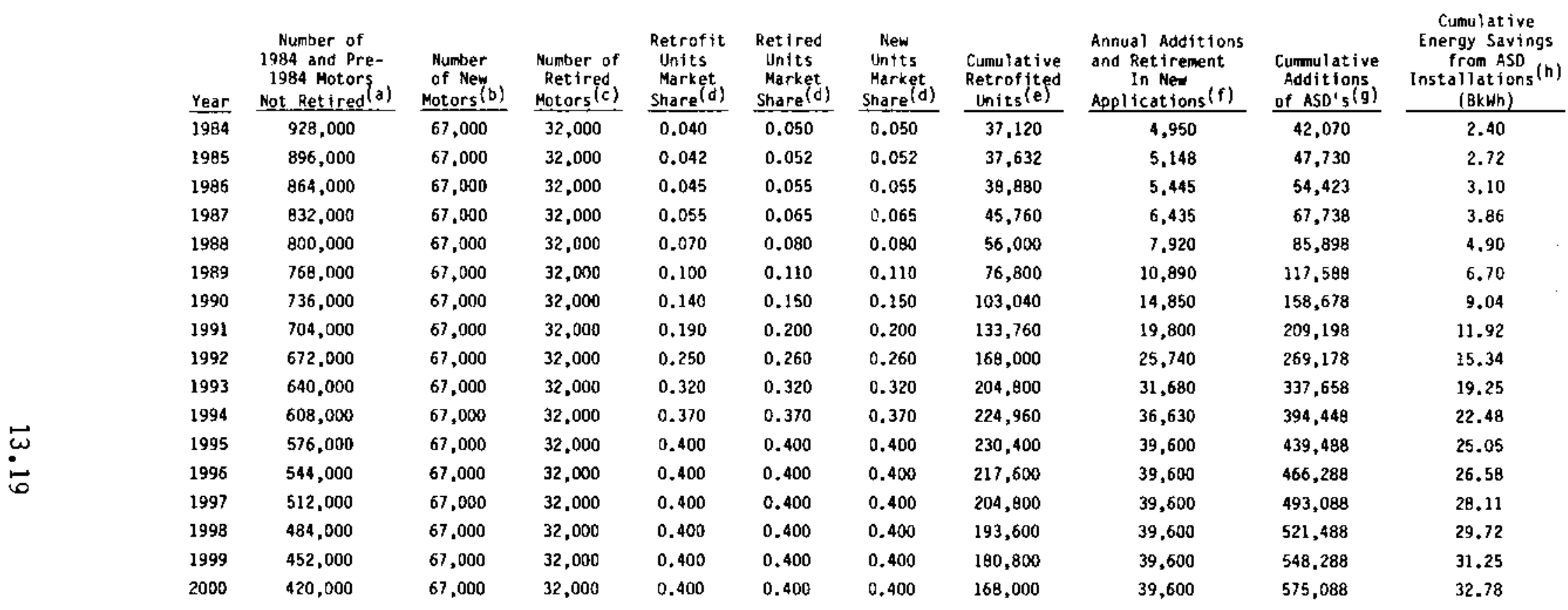

(a) Current original stack of motors estimated to be (Arganne Natlonal Laboratory 1980) minus number of retired motors.

(b) Growth in stock assumed to occur at a rate of 67,000 annually (EEA 1982).

(c) Ret i rement assumed to occur at a rate of 32,000 annually (Argonne National Laboratory 1980).

(d) Based on methodology aut ined in chapter 4.0 .

(f) Calculated by: (nmber of pre 19or) motors not retired) $x$ (Retrofit Market. Share).

Ca

(9) Calculated by the sum of Cumulative Retrofitted Units plus each years annual additions in new and retirement situations. 
TABLE 13.14. High Scenario Annual Market Share Projections - Adjustable Speed Drives on Industria1 Electric Motors Greater than 125 HP

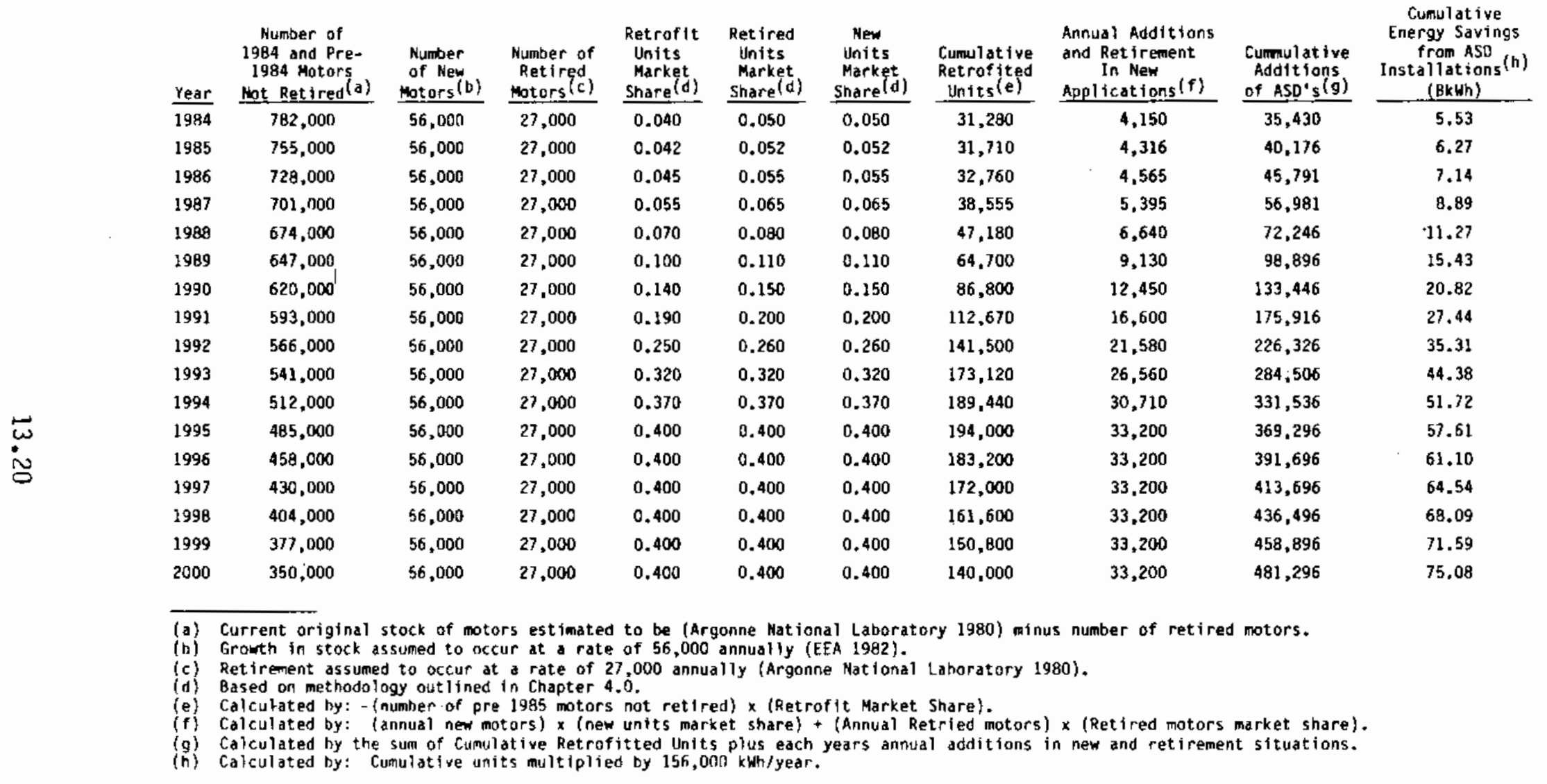


TABLE 13.15. High Scenario Estimated Energy Savings and Number of Units Projected to Be Installed for Adjustable Speed Drives on Industrial Electric Motors

\begin{tabular}{|c|c|c|}
\hline Year & $\begin{array}{l}50 \text { to } 125 \\
\text { No. of Mofors } \\
\text { Projected to } \\
\text { Be Installed }\end{array}$ & $\begin{array}{c}\text { HP Motors } \\
\text { EstTmated } \\
\text { Energy } \\
\text { SavIngs } \\
\end{array}$ \\
\hline 1885 & 47,730 & 2.72 \\
\hline 1990 & 158,678 & 9.04 \\
\hline 1995 & 439,388 & 25.05 \\
\hline 2000 & 575,088 & 32.78 \\
\hline
\end{tabular}

\begin{tabular}{|c|c|}
\hline $\begin{array}{l}\frac{125 \mathrm{HP}}{\text { No, of Motors }} \\
\text { Projected to } \\
\text { Be Instal led }\end{array}$ & $\begin{array}{c}\text { Motors } \\
\text { Estimated } \\
\text { Energy } \\
\text { Savings } \\
\end{array}$ \\
\hline 40,176 & 6.27 \\
\hline 133,446 & 20.82 \\
\hline 369,296 & 57.61 \\
\hline 481,296 & 75.08 \\
\hline
\end{tabular}

\begin{tabular}{|c|c|}
\hline $\begin{array}{l}\text { No. of Mator } \\
\text { Projected to } \\
\text { Be Install ad }\end{array}$ & $\begin{array}{l}\text { Estimated } \\
\text { Energy } \\
\text { Savings }\end{array}$ \\
\hline 87,906 & 8.99 \\
\hline 292,124 & 29.86 \\
\hline 808,684 & 82.66 \\
\hline $7,056,284$ & 107.86 \\
\hline
\end{tabular}

TABLE 13.16. Cost/kWh Saved Calculations for Adjustable Speed Drives on Electric Motors in New and Retirement Applications

Incremental Capita] Cost (1984 \$) in

Motor New and Retirepent

Size (HP) Applications (a)

1 to 5

6 to 20

1,490

6,425

13,060

24,205

49,000
Leverized Capital Cost
(\$1year) 153.95

654.40

$1,330.19$

$2,465.33$

$4,990.76$
Cost per kWh Annual Energy Saved in New and Savings ( $($ Wh) Retirement Applj $\frac{\underset{\text { year })(c)}{246}}{\text { cations }(\$ / \mathrm{kWh})(\overline{\mathrm{d}})}$ 190.92 3,285 9.64 4.30 3.20

(a) See Table 13.1.

(b) The level stream of annual payments the present value of which would equal the investment's incremental capital cost. The levelized cost was calculated using an 8 percent discount rate and operating 1 ifetimes of 20 years for adjustable speed drives.

(c) Calculated as the percent electricity savings for adjustable speed drives (35 percent) multiplied by the estimated electricity use in kWh for conventional motors (from Table 13.2).

(d) Calculated as levelized capital costs (\$/year) divided by annual energy savings (kWh/year) and multiplied by 100 . 
TABLE 13.17. Cost/kWh Saved Calculations for Adjustable Speed Drives on Electric Motors in Retrofit Applications

\begin{tabular}{|c|c|c|c|c|}
\hline $\begin{array}{c}\text { Motor } \\
\text { Size (HP) }\end{array}$ & $\begin{array}{c}\text { Incremental Capital } \\
\text { Cost (1984 } \$) \\
\text { in Retrofit } \\
\text { Applications (a) } \\
\end{array}$ & $\begin{array}{c}\text { Levelized } \\
\text { Capital Cost } \\
\text { (\$/year (b) }\end{array}$ & $\begin{array}{l}\text { Annual Energy } \\
\text { Savings (kwh/ } \\
\text { year) (c) }\end{array}$ & $\begin{array}{l}\text { Cost per kWh } \\
\text { Saved in New and } \\
\text { Retirement Appl ji } \bar{d}) \\
\text { cations }(\$ / \mathrm{kWh})\end{array}$ \\
\hline 1 to 5 & 1,860 & 189.45 & 246 & 77.01 \\
\hline 6 to 20 & 8,030 & 817.87 & 3,285 & 24.90 \\
\hline 21 to 50 & 16,325 & $1,662.74$ & 13,805 & 12.04 \\
\hline 51 to 125 & 30,255 & $3,081.54$ & 57,270 & 5.38 \\
\hline$>125$ & 61,250 & $6,238.45$ & 155,748 & 4.01 \\
\hline
\end{tabular}

(a) See Table 13.1.

(b) The level stream of annual payments the present value of which would equal the investment's incremental capital cost. The levelized cost was calculated using an 8 percent discount rate and operating lifetimes of 20 years for adjustable speed drives.

(c) Calculated as the percent electricity savings for adjustable speed drives (35 percent) multiplied by the estimated electricity use in kWh for conventional motors (from Table 13.2).

(d) Calculated as levelized capital costs (\$/year) divided by annual energy savings (kWh/year) and multiplied by 100 .

\subsection{REFERENCES FOR CHAPTER 13.0}

Argonne National Laboratory. 1980. Classification and Evaluation of Electric Motors and Pumps. DOE/TIC-11339. Prepared for the U.S. Department of Energy, Office of Industrial Programs, Washington, $0 . C$.

Carhart, Steven C., Wn. Raffington King, Shirish S. Mulkerkar, Marc H. Ross, and Richland H. Shackson. 1979. The Least-Cost Energy Strategy--Technical Appendix. The Energy Productivity Center, Mellon Institute, Arlington, Virginia.

Century Electric. 1984. Century Electrical Motor Product Catalogue. Century Electric Co., St. Louis, Missouri.

CRS Sirrine. 1984. Status Report - Industrial Application of Adjustable Speed Drives. EPRI RP1966-4, CRS Sirrine Job. No. R-1891, CRS Sirrine Co., Research Triangle Park, North Carolina. 
EEA. 1982. Impacts of Four Legislative Initiatives on Energy Use in the Industrial Sector. Energy and Environmental Analysis, Inc., Arlington, Virginia. Prepared for Battelle Northwest Laboratories, Richland, Washington.

Electric Power Research Institute. 1984a. Industrial Electrotechnologies and Electrification (IEE) Program Plan. Palo ATto, California.

Electric Power Research Institute. 1984b. "Pacing Plant Motors for Energy Savings." EPRI Journal. Volume 9, Number 2. March, 1984.

Hane, G. J., J. C. King, S. A. Smith, and R. L. Watts. 1983. Assessment of Electric Power Conservation and Supply Resources in the Pacific NorthwestVolume III - Industrial Conservation. Battelle Pacific Northwest Laboratories, Richland, Washington. Prepared for the Pacific Northwest Electric Power and Conservation Planning Council, Portland, Oregon.

Westinghouse Electric Corp. 1984. Price List 8720 - Accutrol 300 Adjustable Frequency Motor Control. Westinghouse Electric Corporation, Vectrol Division, Odsmar, Florida. 


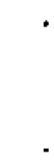




\subsection{ELECTROLYTIC PROCESSES: THE CASE OF ALUMINUM}

This chapter analyzes the impacts on energy use of new conservation technologies for industrial electrolytic processes, processes that use electrical energy to produce chemical changes. In industry, such processes are used to convert raw or only partially refined materials to materials having more useful and valuable properties. Electrolysis is used for the chlor-alkali process, electroplating, electrolytic production of magnesium, manganese, zinc and copper, aluminum production and specialty applications (Beck 1977; Van Nostrands 1983; Jansson 1984). The primary metals industry uses the most energy for electrolytic processes, and aluminum production accounts for almost all of this energy use (Whitaker 1984). Aluminum production is analyzed in detail because only one case study could be performed due to resource constraints, and the electrolytic smelting of aluminum uses more electricity than any other United States industrial electrolytic process.

Section 14.1 provides technical background for the existing smelting process and for potential efficiency improvements. The current and likely future market situation for U.S. aluminum producers is described in Section 14.2. Section 14.3 discusses technologies, estimated costs and energy conservation possibilities of a potential retrofit measures and a potential new process. Technical limits and market-penetration assumptions are also discussed in Section 14.3. Section 14.4 develops values for baseline projections of U.S. aluminum production; the market-penetration estimates developed in Section 14.3 for new technologies are applied to these production estimates. Section 14.5 presents energy savings results and assumptions. Section 14.6 analyzes the sensitivity of the energy savings results to changes in the market-penetration scenario. Section 14.7 concludes the analysis with an estimate of the estimated cost/kWh saved from electrolytic process improvements in aluminum smelting.

\subsection{TECHNICAL BACKGROUND}

Aluminum production is a three stage process. First bauxite, a mined mineral ore containing aluminum oxide $\left(\mathrm{Al}_{2} \mathrm{O}_{3}\right)$, is refined to obtain the aluminum 
oxide. Next, the aluminum oxide (also referred to as alumina) is smelted and chemically changed to pure aluminum metal. This chapter focuses on the conversion from alumina to aluminum, which is an electrolytic process. In the third stage of aluminum production, the aluminum metal is fabricated into foil, sheets and other saleable shapes.

Whenever one substance is oxidized in an electrolytic process, another is reduced. The conversion of alumina to aluminum is a chemical reduction in which the alumina is reduced and carbon is oxidized. In the United States, all but experimental alumina reduction is performed using the Hall-Heroult process, which is explained in the following paragraphs (Pierce et al. 1984).

Alumina reduction occurs in an area called a cell or a pot. The Hall cell is made of steel and has a baked carbon lining. The reduction cell is 10 to 15 feet wide, 20 to 40 feet long, and 3 to 4 feet deep (Berk et al. 1982). It is filled with a medium that conducts electricity (an electrolyte). In HallHeroult cells, molten cryolite $\left(\mathrm{Na}_{3} \mathrm{AlF}_{6}\right)$ serves as a large electrolyte bath.

Electricity is conducted into the cell at a carbon anode; the anode is the cell's negative pole. The electricity is passed through the electrolyte to the cathode, the cell's positive pole. The anode and cathode are referred to collectively as electrodes. The electric current is conducted out of the cell through steel bars (Beck 1977).

The carbon anode is partly consumed in the smelting process and needs regular replacement. The method of anode replacement distinguishes two variants of the Hall process: the Soderberg process and the prebake process. Prebaked anodes are more common in the United States, are replaced less frequently than Soderberg anodes, and are more energy-efficient than Soderberg anodes (Pierce et al. 1984).

The theoretical minimum energy use per pound of aluminum reduced is $2.89 \mathrm{kWh}$, assuming 100 percent efficiency of the overall cell reaction (Beck 
1977). (a) As of October 1983, the industry average Hall-cell energy consumption was $7.5 \mathrm{kWh} / \mathrm{lb}$ of aluminum produced (Aluminum Association 1983). Thus, the industry average efficiency was approximately 39 percent, despite widespread use of prebaked anodes. This is an improvement: the average was $12 \mathrm{kWh} / \mathrm{lb}$ during World War II, and was $8 \mathrm{kWh} / \mathrm{lb}$ as recently as 1980 (Cochran 1981).

Almost 40 percent of Hall-Heroult cell power losses are due to electrolyte resistance between the anode and the cathode. These losses cannot be eliminated using molten cryolite as the electrolyte. However, in a technology for new smelters, molten cryolite is replaced with a chloride bath, and several other changes are made in the smelting process to make the use of a chloride electrolyte feasible. This technology, called the Alcoa process, saves electricity because the chloride bath conducts electricity better than the cryolite medium and has lower resistance losses over equivalent distances. Resistance losses are also dependent on the distance between the electrodes, and decrease as the interelectrode separation decreases. The interelectrode separation in a chloride bath electrolyte can be smaller than in a cryolite electrolyte, again contributing to smaller power losses. The Alcoa process has as much as 30 percent energy savings over the Hall-Heroult cell (Peacey and Davenport 1974; Jarrett 1984; Beck 1977).

A retrofit measure to decrease the interelectrode separation in the HallHeroult cell, and thereby decrease power losses due to resistance, involves the use of a titanium diboride cathode coating. In conventional cells, the cathode is essentially a mass of molten aluminum that is very unstable. A titanium diboride coating would permit the reduction of interelectrode separation by stabilizing the cathode. Aluminum metal would deposit on the titanium diboride plates and drip down into collecting wells. Although early estimates indicated energy savings of 6 to 15 percent over the standard Hall cell, more recent estimates are for about 2 percent energy savings (Beck 1977; Whitaker 1984).

(a) The overall cell reaction is:

$\mathrm{Al}_{2} \mathrm{O}_{3}$ (solid $+1.5 \mathrm{C}$ (solid) $2 \mathrm{Al}$ (molten) $+1.5 \mathrm{CO}_{2}$ (gas).

It takes place at $975^{\circ} \mathrm{C}$ (Beck 1977). 
Some power inefficiency occurs because of an electrolytic reaction between the anode, which is made of carbon, and cathodically deposited aluminum. An inert anode, that is not destroyed by electrolytic action, is another retrofit possibility that might someday decrease electric power consumption of smelters. Some patents for inert anodes using a tin oxide material exist, but to date no commercial development efforts have succeeded (Jarrett 1984). If development efforts are successful, one estimate indicates that such inert anodes have energy savings potential of up to 35 percent (Whitaker 1984).

Potential energy-conserving technologies that are described elsewhere in the literature include carbothermic reduction (Landi, DaRoit and Piras 1984), the Alcan process (Rogers, MacMillan and Wright 1984), and some standard pot modifications to reduce power losses in old plants (Chaudhry 1984). The technologies selected for further analysis in this chapter are the Alcoa process, for new smelters, and the titanium diboride cathode coating, for retrofits of existing smelters. These technologies are not fully developed, and only preliminary cost estimates are available. However, measures that are both technically mature and economically sensible are already adopted by the industry. The industry pays considerable attention to reducing electric power costs for smelting and appears to apply the mix of measures available to it to achieve energy conservation goals.

\subsection{CURRENT MARKET SITUATION}

A11 commercial alumina reduction in the United States is performed using the Hall-Heroult process (Pierce et al. 1984). The industry has experimented with several alternatives to conventional Hall-Heroult smelting, but commercial potential for all these measures appears 1 imited. Unfortunately, power costs for this country are so much higher than at other locations in Canada and overseas (Brazil and Australia, for example), that potential energy conservation measures for U.S. plants are becoming increasingly irrelevant. The very high power rates encourage efficiency, but it may (and often does) cost less to relocate than to undertake the retrofitting that would be needed to obtain an efficient plant (Kennedy 1985). 
Most U.S. aluminum smelters were built when electric power was relatively inexpensive. The plants are relatively old; in 1980 their average age was 20.5 years (Aluminum Association 1980). Most likely, these old plants will not be replaced, and new capacity will be built outside the United States where power rates are much more attractive. The average cost to aluminum smelters for electric power is 23 mills in the United States (1983); the free world average, excluding the United States and some high energy-cost Asian countries, is 12 mills; and in Canada, power can be obtained for approximately 3 mills per kWh. (a) In an industry where electricity costs constitute 19 to 30 percent of all variable cost of production (from bauxite to fabricated products), these power cost differentials are extremely significant (Aluminum Association 1980; Whitaker 1984).

Worldwide demand for aluminum products will likely grow, despite competition from substitute materials (Berk et al. 1982). Aluminum continues to be a versatile material that is reliable and cost effective in numerous applications. However, primary aluminum production is shifting out of the United States. The share of world production capacity accounted for by the United States was 45 percent in 1970; this share has been deciining and is forecast to decrease to 26 percent by 1990 (Kennedy 1985). The U.S. share of world production declined from about a third in 1980-1981 to 24 percent by 1984 (Berk et al. 1982; Jarrett 1984). Capacity is higher than production because plants are operated below capacity.

The commercial development of the Alcoa process has been severely hampered by the current U.S. market situation for producers of primary aluminum. This is because further development is necessary to make the system economical for commercial aluminum production, even though a pilot plant has already demonstrated the potential for large power savings. Joint technology development between Arco and Alcoa seemed likely to produce a more economical system until recently. Now, however, Arco is exiting the primary metals business and the effort that had been planned is unlikely to occur. (b)

\footnotetext{
(a) Conversations with Noel Jarrett, ATcoa, and James S. Kennedy, U.S. Department of Commerce.

(b) Noel Jarrett, Alcoa Laboratories, personal communication.
} 
The titanium diboride cathode coating is used on an experimental basis. Kaiser Aluminum is working with the U.S. Department of Energy on this technology (final report forthcoming). Martin Marietta has developed and tested an effective low cost $\mathrm{TiB}_{2}$ coating, but the material is proprietary (Boxall and Cooke 1984). Thus, the titanium diboride cathode coating is in late stages of development, but no commercial product is generally available.

\subsection{COST EFFECTIVENESS AND MARKET PENETRATION}

In this section, the adoption of the technologies described in Section 14.1 is estimated according to the methodology described in Chapter 4.0. First-cost increases and payback periods for the Alcoa process on new plants and titanium diboride $\left(\mathrm{TiB}_{2}\right)$ cathode coatings on retrofits are presented in Section 14.3.1. The base case is a U.S. Hall-Heroult plant with capacity of 160,000 tons of aluminum annually. Although, given the current market situation, the base case would be more realistic if it represented capital and operating costs of a new plant overseas, resources did not permit such cost comparisons. Technical limits are discussed in Section 14.3.2. Since neither technology is yet used commercially, it is difficult to verify technical limits that may be encountered in commercial operation. Market penetration assumptions are presented in Section 14.3.3.

14.3.1 Simple Payback of Alcoa Process, for New Plants and Titanium Oiboride $\left(\mathrm{TiB}_{2}\right)$ Coating for Retrofit Applications

In the Alcoa plant, overall production costs appear to have been greater than anticipated at earlier research stages despite large power savings. This may be attributable to the need for a different, more expensive feedstock for the Alcoa process as opposed to the Hall-Heroult process. The costs of constructing and operating the pilot plant are not publicly available, and a payback period cannot be calculated without these data. However, payback periods for the Alcoa process are largely irrelevant to the analysis of probable electricity use by electrolytic processes in U.S. aluminum production, since it is unlikely that new aluminum production facilities will be added to existing United States capacity. The process is for new plants, so its commercial prospects in the United States are extremely poor. 
The costs of retrofitting an existing Hall plant with titanium diboride coated cathodes are difficult to confirm, since this technology is not yet available on a general unproprietary basis. A representative payback period of 3 to 4 years is calculated in Table 14.1 from the data that are available. Energy savings are estimated to be about 2 percent (Whitaker 1984).

\subsubsection{Technical Limits}

Several problems are often experienced with $\mathrm{TiB}_{2}$ in aluminum smelting cells. These problems include chemical instability, poor resistance to thermal shock and impact, and/or intergranular penetration (Jarrett 1984; Boxall and Cooke 1984). A proprietary material that Martin Marietta developed may circumvent these problems (Boxall and Cooke 1984). This material would give the retrofit cathodes a 3 to 5 year life. To account for technical problems whose

TABLE 14.1. Simple Payback of Titanium Diboride Cathode Coating for Retrofits of Hall-Heroult Cells

\begin{tabular}{|c|c|c|c|}
\hline & $\begin{array}{l}\text { First cost }(a) \\
\text { (\$/ton of } \\
\text { capacity) }\end{array}$ & $\begin{array}{c}\text { Annual Savings } \\
(\$ / \text { br } \\
\text { of ton } \\
\text { of capacity }\end{array}$ & $\begin{array}{c}\text { Simple } e^{(c)} \\
\text { Payback } \\
(y r)\end{array}$ \\
\hline Hall with $\mathrm{TiB}_{2}$ & 22.95 & 6.90 & $3.3 \mathrm{yr}$ \\
\hline
\end{tabular}

(a) First Cost $=0.9$ percent of fixed capital investment (Skovronek et al. 1976)

$\times \$ 2,550$ capital investment/ton/yr capacity (Castera 1984)

$=\$ 22.95 /$ ton capacity.

(b) Cost Savings/ton $/ \mathrm{yr}$

= 2 percent energy savings (Whitaker 1984)

x $7.5 \mathrm{kWh} / 1 \mathrm{~b}$ (U.S. industry average; Aluminum Association 1983).

$\times 2000 \mathrm{lb} /$ ton.

$\times 23 \mathrm{mi} 11 \mathrm{~s} / \mathrm{kWh}$ (U.S. industry average; Kennedy 1985).

$x \$ 1 / 1000 \mathrm{mills}$

$=\$ 6.90 / \mathrm{yr} /$ ton.

(c) Obtained by dividing first cost by annual savings. 
solutions are not publicly available, retrofitting with $\mathrm{TiB}_{2}$ cathodes is assumed to occur no earlier than the eighth year of the forecast period (i.e., 1991). In addition, a 4-year lifetime is assumed.

\subsubsection{Market Penetration Assumptions}

The process for new plants, i.e. the Alcoa process, is assumed to have no market penetration. The retrofit measure of coating cathodes with $\mathrm{TiB}_{2}$ is estimated to have a maximum market penetration of 50 percent, with no adoption of the technology until 1991. This estimate is based on a payback of 3.3 years, calculated in Section 14.3.1, a first cost increase of less than 10 percent, and technical limits discussed in Section 14.3.2. The maximum market penetration depends on the methodology in Chapter 4.0 (refer to Table 4.2).

\subsection{POPULATION DATA}

This section develops assumptions for primary aluminum production in the United States for the years 1985-2000. Market share estimates for $\mathrm{TiB}_{2}$-retrofitted production capacity are also sumarized. These estimates are based on the market-penetration assumptions discussed in Section 14.3.3.

Industry experts expect that aluminum production will continue to shift away from the developed economies to the bauxite producers (Fitzgerald and Pollio 1982; Berk et al. 1982). No U.S. capacity additions are expected in the projection period, and several plant retirements are likely to occur. Estimates of U.S. aluminum primary capacity and utilization, in 1983 and in 2000, are shown in Table 14.2.

The assumed primary capacity in 2000 was chosen by eliminating all U.S. capacity with less than 50 percent capacity utilization in 1983 from the capacity base, except in the Pacific Northwest where the only smelter assumed to continue operating is Intalco. Data on capacity utilization are summarized in Adams et al. (1983). This process of elimination is intended to select out the least efficient plants, $i . e .$, those that are first to be idled. This scenario eliminates all but 2,749,000 tons/yr primary capacity by the year 2000 . Assumed capacity utilization is 80 percent for all projection years. The 
TABLE 14.2. Estimates of 1983 Capacity Utilization and Primary Aluminum Production, with Assumptions Regarding Capacity and Utilization in 2000

\begin{tabular}{|c|c|c|c|}
\hline & $\begin{array}{c}\text { U.S. Total Estimated } \\
\text { Primary Capacity } \\
\left(10^{3} \text { TPY }\right) \\
\end{array}$ & $\begin{array}{c}\text { U.S. Aluminum } \\
\text { Produçtion } \\
\left(10^{3} \mathrm{~T}\right) \\
\end{array}$ & $\begin{array}{l}\% \text { Capacity } \\
\text { Utilization } \\
(/ 100) \\
\end{array}$ \\
\hline 1983 & 5,526 (a) & $3,640^{(b)}$ & 0.66 \\
\hline 2000 & 2,749 & 2,199 & 0.80 \\
\hline
\end{tabular}

(a) Adams et al. 1983.

(b) Jarrett 1984.

decline in production is assumed to occur at a constant rate of 4.2 percent beginning in 1983 and ending in 2000. Approximately half of the projected decline is estimated to occur in the first 5 years.

Table 14.3 shows results of the market share calculations. The first retrofits occur in 1991; market penetration increases to 50 percent by 2000 . Details of the market share calculation may be found in Table 14.4.

The scenario in Table 14.3 shows U.S. primary aluminum capacity diminishing by approximately 4.2 percent per year. Observations of industry experts lead one to believe that this scenario is optimistic. In contrast, scenarios

TABLE 14.3. Estimates for Cathode Retrofits of Hall Reduction Cells Using a $\mathrm{TiB}_{2}$ Coating $(\mathrm{a})$

U.S. Total Projected Primary Capacity

1985

1990

1995

2000

$\frac{\left(10^{6} \text { TPY }\right)}{5.29}$

4.27

3.45

2.75
U.S. Aluminum Production

$\frac{\left(10^{6} \mathrm{~T}\right)}{4.23}$

3.42

2.76

2.20
Production with $\mathrm{TiB}_{2}$ Retrofit Measure $\left(10^{6} \mathrm{~T}\right)$ $-0-$ $-D-$ 0.57 1.11

(a) Assumptions stated in text. 
TABLE 14.4. Primary Aluminum Industry in the United States: Projected Capacity, $\mathrm{TiB}_{2}$ Retrofits, and Energy Savings by Year, 1985-2000

\begin{tabular}{|c|c|c|c|c|c|c|c|}
\hline & & $\begin{array}{l}\text { Remaining } \\
\text { Productlon } \\
\text { Capacity }\end{array}$ & $\begin{array}{l}\text { Copacity } \\
\text { RetIred }\end{array}$ & $\begin{array}{l}\text { Energy Use } \\
\text { Reductions Due } \\
\text { to Copac Itf } \\
\text { Retirement }\end{array}$ & $\begin{array}{l}\text { Market Shore } \\
\text { of } \mathrm{TiB}_{2}\end{array}$ & $\begin{array}{l}\text { Energy Sovings } \\
\text { Due to TiB } \\
\text { Cooting } 2\end{array}$ & $\begin{array}{l}\text { Total Reduc- } \\
\text { tions In } \\
\text { Annual Elec- } \\
\text { trlcity Use }\end{array}$ \\
\hline & Yeor & $\left(10^{6} \text { Tons }\right)^{(\theta)}$ & $\left(10^{6} \text { rons }\right)^{(\theta)}$ & (Bkwh) & Coating $(c)$ & $(8 k w h)^{(d)}$ & $(B k W h)^{(\theta)}$ \\
\hline & 1985 & 5.29 & 0.22 & 5.45 & $-0-$ & $-0-$ & 5.45 \\
\hline & 1986 & 5.07 & 0.21 & 8.01 & -0 & $-0-$ & 8.01 \\
\hline & 1987 & 4.86 & 0.20 & 10.46 & $-0-$ & $-0-$ & 10.46 \\
\hline & 1988 & 4.66 & 0.20 & 12.80 & $-0-$ & $-0-$ & 12.80 \\
\hline & 1989 & 4.46 & 0.19 & 15.19 & -0 & $-0-$ & 15.19 \\
\hline & 1990 & 4.27 & 0.18 & 17.19 & $-0-$ & $-0-$ & 17.19 \\
\hline$\stackrel{\square}{P}$ & 1991 & 4.09 & 0.17 & 19.25 & 0.03 & 0.03 & 19.28 \\
\hline - & 1992 & 3.92 & 0.17 & 21.24 & 0.07 & 0.06 & 21.30 \\
\hline & 1993 & 3.76 & 0.16 & 23.13 & 0.12 & 0.11 & 23.24 \\
\hline & 1994 & 3.60 & 0.15 & 24.95 & 0.18 & 0.16 & 25.11 \\
\hline & 1995 & 3.45 & 0.15 & 26.69 & 0.26 & 0.21 & 26.90 \\
\hline & 1996 & 3.30 & 0.14 & 28.32 & 0.34 & 0.27 & 28.59 \\
\hline & 1997 & 3.16 & 0.13 & 29.95 & 0.41 & 0.31 & 30.26 \\
\hline & 1998 & 3.03 & 0.13 & 31.48 & 0.44 & 0.32 & 31.00 \\
\hline & 1999 & 2.90 & 0.12 & 32.94 & 0.47 & 0.33 & 33.26 \\
\hline & 2000 & 2.78 & 0.12 & 34.35 & 0.50 & 0.33 & 34.68 \\
\hline
\end{tabular}

(a) Capaclty in 1983 of 5,526,000 tons per year is assumed to decline at a constant rate of approximately 4.2 percent per year. This rate of decline Implles that all U,S. capacity with less than 50 percent capacity utilization in 1983 is el im Inated by the year 2000 .

(b) Colculated by: (Capactity RetIrement) $\times(15,000 \mathrm{kwh} / \mathrm{ton})$.

(c) See Chapter 4.0.

(d) Energy savings are assumed to be 2 percent (300 kwh/ton).

(e) Calculated by: (Energy Reductions due to Capaclty Retirement) + (Energy Savings Due to TiD 2 Coating). 
of a recent Brookhaven study (Pierce et al. 1984) assume that growth in demand for fabricated aluminum products drives growth in United States primary production. The rate of demand growth assumed in the Brookhaven model appears to be reasonable, but the assumptions in that and the present study differ markedly with respect to the amount of U.S. primary capacity that will be employed to meet demand growth.

\subsection{ENERGY SAVINGS RESULTS}

The impacts on electricity use due to the special cathode coating retrofit measure are estimated in this section. Reductions in electricity use due to projected retirements of capacity, without replacement, are also sumarized since these are very significant in the scenario that is analyzed.

Energy savings in primary aluminum production that are attributable to plant retirements and the $\mathrm{TiB}_{2}$ cathode coating are shown in Table 14.4 and summarized in Table 14.5. It is assumed that the $\mathrm{TiB}_{2}$ cathode coating is not installed commercially until 1991, but then penetrates 50 percent of remaining capacity by 2000 (refer to Section 14.4). The delay in the measure's adoption is assumed to occur because a tested coating is not yet generally available.

TABLE 14.5. Estimates and Projections of Annual Energy Savings in Primary Aluminum Due to Declining Production and Adoption of a Special Cathode Coating $(\mathrm{a})$

\begin{tabular}{|c|c|c|c|}
\hline & $\begin{array}{l}\text { Energy Use } \\
\text { Reductions Due } \\
\text { to Capacity } \\
\text { Retirement } \\
\text { (Bkwh) }\end{array}$ & $\begin{array}{c}\text { Energy Savings } \\
\text { Due to } \mathrm{TiB}_{2} \\
\text { Coating } \\
\text { (BkWh) }\end{array}$ & $\begin{array}{c}\text { Remaining } \\
\text { Electricity } \\
\text { Use } \\
\text { (BkWh) } \\
\end{array}$ \\
\hline 1995 & 5.45 & $-0-$ & 63.6 \\
\hline 1990 & 17.19 & -0 & 51.3 \\
\hline 1995 & 26.69 & 0.21 & 41.3 \\
\hline 2000 & 34.35 & 0.33 & 33.4 \\
\hline
\end{tabular}

(a) Assumes 80 percent capacity utilization and $7.5 \mathrm{kWh} / \mathrm{lb}$. 
The energy savings estimates in Table 14.4 show a scenario in which electricity use for primary aluminum smelting falls at approximately the same rate as production for selected years. Electricity use reductions due to decreasing production are much larger (100 times as large) than electricity use reductions from the retrofit measure analyzed.

\subsection{SENSITIVITY OF ENERGY SAVINGS RESULTS TO MARKET-PENETRATION ASSUMPTIONS}

Estimated energy savings from retrofitting aluminum smelters with special titanium diboride $\left(\mathrm{TiB}_{2}\right)$ cathode coatings are small in the base case (Table 14.4). Would these energy savings results be larger if the special coatings were assumed to be introduced earlier and have more rapid market penetration? Alternatively, how much smaller would the results be if market penetration were assumed to occur more slowly? The sensitivity of the energy savings results to variations in the market-penetration assumptions is tested in this section.

\subsubsection{Low Market-Penetration Scenario}

The possibility that market penetration of titanium diboride cathode coatings on existing aluminum smelters will occur less quickly than was assumed in the base case is explored in this section. Maximum market penetration is reduced to 25 percent (from 50 percent in the base case) of remaining capacity by the year 2000. The assumption that the coating is not generally available commercially until 1991 is retained.

Table 14.6 presents the low market-penetration scenario estimates of market shares and energy savings for the titanium diboride coating retrofit measure. Table 14.7 summarizes these projections. It is apparent that the savings are an insignificant fraction of total electricity demand for aluminum production.

\subsubsection{High Market-Penetration Scenario}

This section explores the possibility that market penetration of titanium diboride cathode coatings may be higher than assumed in the base case 
TABLE 14.6. Low Market-Penetration Scenario Estimates of Annual Market Share and Energy Savings for $\mathrm{TiB}_{2}$ Cathode Coating Retrofit Measure

\begin{tabular}{|c|c|c|c|c|c|c|c|c|}
\hline & Year & $\begin{array}{r}\text { Re } \\
\text { Pro } \\
\text { Ca } \\
110^{6} \\
\end{array}$ & $\begin{array}{l}\text { emalnIng } \\
\text { oduction } \\
\text { apacity } \\
\text { Tons) (a) }\end{array}$ & $\begin{array}{c}\text { Capacity } \\
\text { Retired } \\
\left(10^{6} \text { Tons }\right)^{(\Delta)} \\
\end{array}$ & $\begin{array}{c}\text { Electriclty Use } \\
\text { Reductlons Due } \\
\text { to Capacity } \\
\text { Ret Irement } \\
(\text { Bkm (b) } \\
\end{array}$ & $\begin{array}{c}\text { Market Share } \\
\text { of TlB } \\
\text { Coating(E) } \\
\end{array}$ & $\begin{array}{c}\text { Electriclty Sarings } \\
\text { Due to } \mathrm{TIB}_{2} \\
\text { Coating } \\
(\mathrm{gk} h)^{\prime}(\mathrm{d}) \\
\end{array}$ & $\begin{array}{l}\text { Total Reduc- } \\
\text { tlons in } \\
\text { Annual Elec- } \\
\text { tricity Use } \\
\text { (BkWh) }(\theta) \\
\end{array}$ \\
\hline & 1985 & & 5.29 & 0.22 & 5.45 & $-0-$ & -0 & 5.45 \\
\hline & 1986 & & 5.07 & 0.21 & 8.01 & $-0-$ & $-0-$ & 8.01 \\
\hline & 1987 & & 4.86 & 0.20 & 10.40 & $-0-$ & -0 & 10.46 \\
\hline & 1988 & & 4.66 & 0.20 & 12.80 & $-0-$ & $\rightarrow 0-$ & 12.80 \\
\hline & 1989 & & 4.46 & 0.19 & 15.19 & $-0-$ & $-0-$ & 15.19 \\
\hline & 1990 & & 4.27 & 0.18 & 17.19 & $-0-$ & $-0-$ & 17.19 \\
\hline & 1991 & & 4.09 & 0.17 & 19.25 & 0.02 & 0.02 & 19.25 \\
\hline & 1992 & & 3.92 & 0.17 & 21.24 & 0.04 & 0.04 & 21.28 \\
\hline & 1993 & & 3.76 & 0.16 & 23.13 & 0.06 & 0.05 & 23.18 \\
\hline & 1994 & & 3.60 & 0.15 & 24.95 & 0.08 & 0.06 & 25.01 \\
\hline & 1995 & & 3.45 & 0.15 & 26.69 & 0.10 & 0.08 & 26.77 \\
\hline & 1996 & & 3.30 & 0.14 & 28.32 & 0.12 & 0.10 & 29.42 \\
\hline & 1997 & & 3.16 & 0.13 & 29.95 & 0.16 & 0.15 & 30.10 \\
\hline & 1998 & & 3.03 & 0.13 & 31.48 & 0.20 & 0.15 & 31.63 \\
\hline & 1999 & & 2.90 & 0.12 & 32.94 & 0.23 & 0.16 & 33.10 \\
\hline & 2000 & & 2.78 & 0.12 & 34.35 & 0.25 & 0.17 & 39.52 \\
\hline & $\begin{array}{l}\text { (a) } \\
\text { (b) } \\
\text { (c) } \\
\text { (d) } \\
\text { (a) }\end{array}$ & \multicolumn{7}{|c|}{ 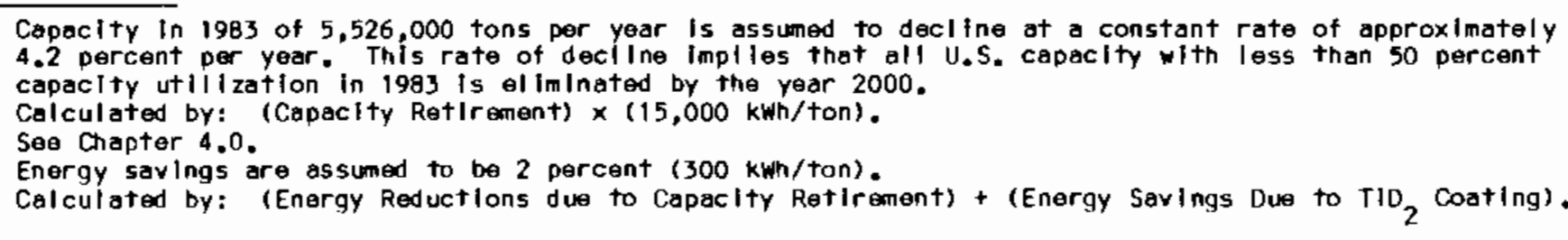 } \\
\hline
\end{tabular}


TABLE 14.7. Estimated National Annual Electricity Savings in Primary Aluminum Production Due to Capacity Retirement and $\mathrm{TiB}_{2}$ Retrofit--Low Market-Penetration Scenario

Energy Use

Reductions Due to Capacity Retirement

$\frac{\text { Year }}{1985}$

1990

1995

2000
(BkWh)
17.19

26.69
Electricity Savings Due to TiB Coating (BkWh)

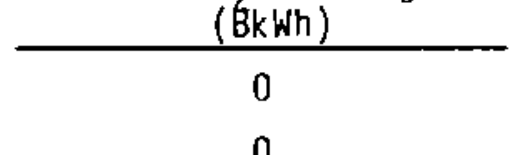

0.08

0.17

(Table 14.4). The measure is assumed to become generally commercially available in 1988, three years sooner than in the base case. Maximum market penetration is increased to include practically all (95 percent) of remaining U.S. aluminum smelting capacity.

Table 14.8 presents the year-by-year estimates of annual market share and electricity savings for titanium diboride cathode coatings in the primary aluminum production industry for the high market-penetration scenario. These projections are summarized in Table 14.9. Even with 95 percent market penetration and comercial adoption beginning in 1988, the expected electricity savings are relatively small.

\subsection{ESTIMATED COST/KWh FOR ENERGY CONSERVEO WITH SPECIAL TITANIUM OIBORIDE CATHODE COATING IN PRIMARY ALUMINUM PRODUCTION}

This section provides an estimate of the cost/kWh for energy conserved by the use of a titanium diboride coating for cathodes in existing U.S. aluminum smelters. The cost of conserved energy may be compared with the cost of new generating capacity to determine which source of energy is cheaper.

Table 14.10 shows the calculation of cost/kWh energy conserved by the primary aluminum production retrofit measure. The calculated cost is $2.3 \$ / \mathrm{kWh}$, and is cheaper than the costs of new generating capacity cited in Chapter 4.0. 
TABLE 14.8. High Market-Penetration Scenario Estimates of Annual Market Share and Energy Savings for $\mathrm{TiB}_{2}$ Cathode Coating Retrofit Measure

\begin{tabular}{|c|c|c|c|c|c|c|}
\hline Year & $\begin{array}{l}\text { Remaining } \\
\text { Production } \\
\text { Capacity } \\
\left(10^{6} \text { Tons) }\right.\end{array}$ & $\begin{array}{l}\text { Copactity } \\
\text { Retired } \\
\left(10^{6} \text { Tons }\right)^{(a)}\end{array}$ & $\begin{array}{l}\text { Electrlcity Use } \\
\text { Reductlons Due } \\
\text { to Capacity } \\
\text { Retirement } \\
\text { (Bkwh) (b) } \\
\end{array}$ & $\begin{array}{l}\text { Market Share } \\
\text { of } \mathrm{Tl}_{\mathrm{B}} \\
\text { Cooting } \\
\text { Cos) }\end{array}$ & $\begin{array}{c}\text { Electricity Sarlings } \\
\text { Due to } \mathrm{THB}_{2} \\
\text { Cooting } \\
\text { (Bkwh) (d) }\end{array}$ & $\begin{array}{c}\text { Total Reduc- } \\
\text { tlons In } \\
\text { Annual Eloc- } \\
\text { tricity Use } \\
\text { (BkWh) (e) } \\
\end{array}$ \\
\hline 1985 & 5.29 & 0.22 & 5.45 & $-0-$ & $-0-$ & 5.45 \\
\hline 1986 & 5.07 & 0.21 & 8.01 & $-0-$ & $-0-$ & 8.01 \\
\hline 1987 & 4.86 & 0.20 & 10.46 & $-0-$ & -0 & 10.46 \\
\hline 1988 & 4.68 & 0.20 & 12.80 & 0.02 & 0.02 & 12.82 \\
\hline 1989 & 4.46 & 0.19 & 15.19 & 0.05 & 0.05 & 15.24 \\
\hline 1990 & 4.27 & 0.18 & 17.19 & 0.09 & 0.09 & 17.28 \\
\hline 1991 & 4.09 & 0.17 & 19.25 & 0.15 & 0.15 & 19.40 \\
\hline 1992 & 3.92 & 0.17 & 21.24 & 0.22 & 0.21 & 21.45 \\
\hline 1993 & 3.76 & 0.16 & 23.13 & 0.30 & 0.27 & 23.40 \\
\hline 1994 & 3.60 & 0.15 & 24.95 & 0.39 & 0.34 & 25.29 \\
\hline 1995 & 3.45 & 0.15 & 26.69 & 0.49 & 0.40 & 27.09 \\
\hline 1996 & 3.30 & 0.14 & 28.32 & 0.60 & 0.47 & 28.79 \\
\hline 1997 & 3.16 & 0.13 & 29.95 & 0.70 & 0.53 & 30.48 \\
\hline 1998 & 3.03 & 0.13 & 31.48 & 0.80 & 0.58 & 32.06 \\
\hline 1999 & 2.90 & 0.12 & 32.94 & 0.89 & 0.62 & 33.06 \\
\hline 2000 & 2.78 & 0.12 & 34.35 & 0.95 & 0.64 & 34.99 \\
\hline
\end{tabular}

(a) Capaclty in 1983 ot 5,526,000 tons per year is assumed to decline at a constant rate of approximately 4.2 percent per year. This rate of deciline Implies that all U.S. capactity ith less than 50 percent capaclty utilization In 1983 Is el imlnated by the year 2000.

(b) Calculated by: (Capacity RetIrement) $\times(15,000 \mathrm{kwh} / \mathrm{ton})$.

(c) See Chapter 4,0 .

(d) Energy sovings are assumed to be 2 percent (300 kwh/ton).

(e) Colculated by: (Energy Reductlons due to Capacity Retirement) + (Energy Sayings Due to TiD 2 Costing). 
The Aluminum Association. 1983. Energy Conservation and the Aluminum Industry. The Aluminum Association, Washington, D.C.

The Aluminum Association. 1984. Aluminum Statistical Review for 1983. The Aluminum Association $/ 94$, Washington, $\bar{D} . \bar{C}$.

Beck, Theodore, R. 1977. Improvements in Energy Efficiency of Industrial Electrochemical Processes. Prepared by the Electrochemical Technology Corporation for Argonne National Laboratory, (ANL/OEPM-77-2). Argonne, Illinois.

Berk, R. et al. 1982. Aluminum: Profile of the Industry. Jeffrey Keefe, Editor-in-Chief. Published by Metals Week, McGraw-HiT1, New York, New York.

Boxal1, Larry G. and A. V. Cooke. 1984. "Use of $\mathrm{TiB}_{2}$ Cathode Material: Application and Benefits in Conventional VSS Cells." Light Metals 1984. J. P. McGeer, editor. American Institute of Mining, Metallurgical and Petroleum Engineers, Inc. (AIME) Warrendale, Pennsylvania. pp. 573-588.

Castera, Michael. 1984. "Movements in Vertical Integration within the Aluminum Industry." Journal of Metals, September, pp. 47-51.

Chaudhry, 0. S. 1984. "Reduction of Power Consumption in 1940/1950 Designed Pots." Light Metals 1984. J. P. McGeer, editor. American Institute of Mining, Metallurgical and Petroleum Engineers, Inc. (AIME) Warrendale, Pennsylvania. pp. 461-473.

Cochran, C. N. 1981. "Energy Balance of Aluminum--From Production to Application." Journal of Metals, July, pp. 45-48.

Fitzgerald, M. D. and G. Pollio. 1982. "Aluminum: The Next Twenty Years." Journal of Metals, December, pp. 37-42.

Jansson, Robert. 1984. "Organic Electrosynthesis." Chemical \& Engineering News, $62(47): 43-57$.

Jarrett, Noel. 1984. "Aluminum Extractive Metallurgy in 1983." Journal of Metals, Apri1, pp. 71-74.

Kennedy, J. S. 1985. "Energy and the Primary Aluminum Industry." Report prepared by the U.S. Dept. of Commerce, International Trade Administration Basic Industries Sector, Nonferrous Metals Divisions, Washington, D.C.

Landi, M. F., S. DaRoit, S. Montesi and L. Piras. 1984. "The Production of Raw Al/Si Alloys from Italian Leucitic Minerals by a Direct Carbothermic Process. Experiments and Results on a Pilot Plant." Light Metals 1984. J. $P$. McGeer, editor. American Institute of Mining, MetaTlurgical and Petroleum Engineers, Inc. (AIME) Warrendale, Pennsylvania. pp. 601-618 
Peacey, J. S. and W. G. Davenport, 1974. "Evaluation of Alternative Methods of Aluminum Production." Journal of Metals, July, pp. 25-28.

Pierce, B. L., et al. 1984. Industrial Process Models of Electricity Demand-Volume 4: The Aluminum Industry. EPRI EA-3507 Vol. 4. Brookhaven National Laboratory, Upton, New York.

Rogers, C. J., D. W. MacMillan and W. J. Wright. 1984. "Development of a High Amperage End-to-End Reduction Cell Design." Light Metals 1984. J. P. McGeer, editor. American Institute of Mining, Metallurgical and Petroleum Engineers, Inc. (AIME) Warrendale, Pennsylvania. pp. 443-453.

Skovronek, H. S., et al. 1976. Environmental Considerations of Selected Energy Conserving Manufacturing Process 0ptions: VoT. VII ATumina/ATuminum Industry Report. EPA-600/7-76-034h, (NTIS: PB-264 274). Arthur D. Little, Cambridge, Massachusetts.

Von Nostrands Scientific Encyclopedia, 1983. Edited by 0. M. Considine, pubTished by Van Nostrand Reinholdt Company, New York, New York.

Whitaker, Ralph. 1984. "Electricity: Lever on Industrial Productivity." EPRI Journal, October, pp. 6-15. 
No. of

Copies

OFFSITE

5 David Meyer

Office of Policy, Planning and Analys is

Mail Stop 7 H085

Forrestal Building

U.S. Department of Energy

Washington, DC 20585

30 DOE Technical Information Center

ONSITE

DOE Richland Operations Office

J. J. Sutey

15 Pacific Northwest Laboratory

R. J. Moe (3)

B. J. Harrer (2)

A. J. Lyke

K. L. Imhoff

Z. J. Fisher

Publishing Coordination (2)

Technical Information (5) 
. 